\title{
Op weg naar een bestuursrechtelijke normering van het gemeentelijk aanbestedingsbeleid in de bouw
}

Citation for published version (APA):

Nijholt, H. (1996). Op weg naar een bestuursrechtelijke normering van het gemeentelijk aanbestedingsbeleid in de bouw. [Doctoral Thesis, Maastricht University]. Universiteit Maastricht. https://doi.org/10.26481/dis.19960202hn

Document status and date:

Published: 01/01/1996

DOI:

10.26481/dis.19960202hn

Document Version:

Publisher's PDF, also known as Version of record

\section{Please check the document version of this publication:}

- A submitted manuscript is the version of the article upon submission and before peer-review. There can be important differences between the submitted version and the official published version of record. People interested in the research are advised to contact the author for the final version of the publication, or visit the DOI to the publisher's website.

- The final author version and the galley proof are versions of the publication after peer review.

- The final published version features the final layout of the paper including the volume, issue and page numbers.

Link to publication

\footnotetext{
General rights rights.

- You may freely distribute the URL identifying the publication in the public portal. please follow below link for the End User Agreement:

www.umlib.nl/taverne-license

Take down policy

If you believe that this document breaches copyright please contact us at:

repository@maastrichtuniversity.nl

providing details and we will investigate your claim.
}

Copyright and moral rights for the publications made accessible in the public portal are retained by the authors and/or other copyright owners and it is a condition of accessing publications that users recognise and abide by the legal requirements associated with these

- Users may download and print one copy of any publication from the public portal for the purpose of private study or research.

- You may not further distribute the material or use it for any profit-making activity or commercial gain

If the publication is distributed under the terms of Article $25 \mathrm{fa}$ of the Dutch Copyright Act, indicated by the "Taverne" license above, 
Op weg naar een bestuursrechtelijke normering van het gemeentelijk aanbestedingsbeleid in de bouw 


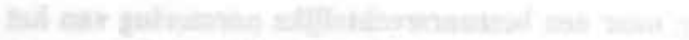

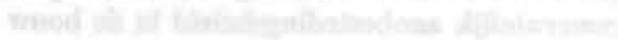




\title{
Op weg naar een bestuursrechtelijke normering van het gemeentelijk aanbestedingsbeleid in de bouw
}

\author{
PROEFSCHRIFT
}

ter verkrijging van de graad van doctor aan de Rijksuniversiteit Limburg te Maastricht op gezag van de Rector Magnificus, prof. mr. M.J. Cohen, volgens het besluit van het College van Dekanen, in het openbaar te verdedigen op vrijdag 2 februari 1996 te 16.00 uur

door

Hylke Nijholt 
Beoordelings-commissie: Prof.mr. A.Q.C. Tak (voorzitter)

Dr.mr. J.J. Goudsmit (voormalig directeur Juridische Zaken Kon. Volker Stevin N.V.)

Prof.mr. H.J. de Kluiver

Prof.dr. B.F.M. de Witte

Van deze dissertatie is een handelseditie verschenen in de Bouwrecht Monografieen, $\mathrm{nr} .14$ (ISBN: 9026828950 )

1996, H. Nijholt, Maastricht

Alle rechten voorbehouden. Niets uit deze opgave mag worden verveelvoudigd, opgeslagen in een geautomatiseerd gegevensbestand, of openbaar gemaakt, in enige vorm of enige wijze, hetzij elektronisch, mechanisch, door fotokopieën, opnamen, of op enige andere manier, zonder voorafgaande schriftelijke toestemming van de uitgever.

Voor zover het maken van kopieen uit deze uitgave is toegestaan op grond van artikel 16B Auteurswet 1912 jo. het Besluit van 20 juni 1974, Stb. 351, zoals gewijzigd bij Besluit van 23 augustus 1985. Stb, 471 en artikel 17 Auteurswet 1912, dient men de daarvoor wettelijk verschuldigde vergoedingen te voldoen aan de Stichting Reprorecht (Postbus 882, 1180 AW Amstelveen). Voor het overnemen van gedeelte( $n$ ) uit deze uitgave in bloemlezingen, readers en andere compilatiewerken (artikel 16 Auteurswet 1912) dient men zich tot de uitgever te wenden. 


\section{Voorwoord}

Een proefschrift schrijven is weliswaar een solistische bezigheid, maar zonder de hulp van anderen is de voltooiing ervan een onmogelijke opgave. Daarom maak ik op deze plaats graag gebruik van de mogelijkheid een ieder te danken die mij heeft bijgestaan bij het tot stand komen van dit boek. In het bijzonder geldt dit voor mijn promotor prof.mr. C.A. Adriaansens. Gedurende de afgelopen jaren heeft hij mijn 'worsteling' met het onderwerp ondersteund met inhoudelijke suggesties en prikkelende opmerkingen. De leden van de beoordelingscommissie, prof.mr. A.Q.C. Tak, prof.mr. H.J. de Kluiver en prof.dr. B.F.M. de Witte zeg ik dank voor hun bereidheid om het lidmaatschap van deze commissie op zich te nemen.

Daarmaast prijs ik me gelukkig met de Engelse 'synopsis' van mijn samenvatting door Caroline J. Forder LL.B. (Nottm.), LL.B. (Cantab.). Verder gaat mijn dank uit naar het secretariaat Privaatrecht waar Margriet van Woerden mijn A4-tjes 'camera ready' heeft gemaakt, en waardoor het onderzoek 'zomaar' een boek werd. De 'lastige figuren' in het laatste hoofdstuk zijn tot leven gekomen door de gezamenlijke 'technische' inspanningen van Ine Corstjens en Paul Adriaans.

Last but not least ben ik veel dank verschuldigd aan mijn vrouw Patty en aan 'the kids', Lieke en Sonja, die er telkens weer begrip voor opbrachten, dat dit onderzoek mijn privétijd vrijwel volledig in beslag nam. Aan hen draag ik dit boek op.

Het onderzoek werd afgesloten op 1 maart 1995. Hetgeen daarna verscheen is niet of slechts mondjesmaat nog verwerkt. Dat geldt ook voor de proefschriften van J.P.L. van Marissing, De regelgeving voor overheidsopdrachten op het niveau van de Europese Gemeenschap en de GATT, alsmede de gevolgen hiervan voor de Nederlandse regelgeving, Europese Monografieën 43, Deventer 1995 en G.W.A. van de Meent, Overheidsaanbestedingen: De EG-rechtelijke context, Bouwrecht Monografieën, Stichting Instituut voor Bouwrecht, Deventer 1995. In mijn boek ligt het accent minder dan bij hen op de analyse van de Europese aanbestedingsrichtlijnen, en in het geheel niet op de ontwikkelingen van het intemationale aanbestedingsrecht. Wat dat betreft volsta ik dan ook graag met te verwijzen naar de beide andere proefschriften.

Maastricht, 16 november 1995 


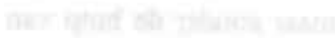

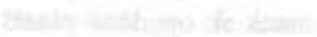

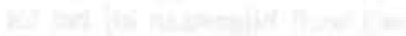




\section{Inhoudsopgave}

Voorwoord

Afkortingenlijst

XIII

Verkorte inhoudsopgave

Hoofdstuk 1. Een juridische topografie 1

1. Wat is aanbesteding?

1

2. Participanten en procedures 5

3. Aanbestedingen en bouwmarkt $\quad 7$

4. Aanbestedingen en Europese integratie 16

5. De aanbestedingsovereenkomst 25

6. Beleidsaspecten van aanbestedingen

7. Probleemstelling 36

Hoofdstuk 2. De bevoegdheid tot aanbesteden 37

1. Het tot aanbesteden bevoegde bestuur

2. Openbare en onderhandse aanbesteding; beleidsgrondslag 47

3. Het repressieve toezicht $\quad 63$

$\begin{array}{ll}\text { 4. Conclusie } & 74\end{array}$

Hoofdstuk 3. (Zelf)regulering van de gemeentelijke overheidsaanbesteding 75

1. Inleiding 75

2. Confrontatie met de regelgeving $\quad 75$

2.1. De aanbestedingsreglementen $\quad 75$

2.2. De Europese richtlijnen $\quad 91$

3. Conclusie 101

Hoofdstuk 4. Eisen aan de beleidsuitgangspunten 103

1. Inleiding 103

2. UAR en financieel doelmatig beleid 103

2.1. Het Uniform Aanbestedingsreglement $1972 \quad 103$

2.2. Het Uniform Aanbestedingsreglement $1986 \quad 104$

2.3. Het Uniform Aanbestedingsreglement-EG 1991

2.4. Conclusie 118

3. Beleidscoördinatie op het Europese niveau 119

3.1. Richtlijn 71/305 119

$\begin{array}{ll}\text { 3.2. Richtlijn } 93 / 37 & 124\end{array}$

3.3. Conclusie 126

4. 'Andere' beleidsuitgangspunten 126

4.1. Aanvullende voorwaarden 126

4.2. Rechtmatige beleidsaspecten 132 
Hoofdstuk 5. Grondslagen van aanbestedingsbeleid

1. Van privaatrecht naar bestuursrecht 151

$\begin{array}{ll}\text { 2. Wat is aanbestedingsbeleid? } & 157\end{array}$

3. (Bestuursrechtelijke) eisen aan het beleid 160 ,

3.1. Het gelijkheidsbeginsel: eis van beleid $\quad 160$

3.2. Het openbaarheidsbeginsel: kenbaarheid van het beleid 171

3.3. Het motiveringsbeginsel: beredeneerd beleid 174

3.4. Het (financiële doelmatigheidsbeginsel: prioriteit van het financiële belang $\quad 174$

$\begin{array}{ll}\text { 4. Vormgeving van het aanbestedingsbeleid } & 175\end{array}$

$\begin{array}{ll}\text { 5. Het besluitvormingsproces; nadere analyse } & 177\end{array}$

6. Besluitvorming en bevoegde rechter 183

6.1. De burgerlijke rechter is compent 183

6.2. Naar een bevoegde administratieve rechter 186

7. Naar een wettelijk kader voor het aanbestedingsbeleid 192. 


\section{Inhoudsopgave}

Hoofdstuk 1. Een juridische topografie

1. Wat is aanbesteding?

Begripsverkenning 1 - Nadere begripsafbakening 3

2. Participanten en procedures

Participanten 5 - UAR-procedures 5

3. Aanbestedingen en bouwmarkt

Conclusie 16

4. Aanbestedingen en Europese integratie

Het streven naar een gemeenschappelijke markt 16 - Tegenvallende resultaten 20 -

Streven naar een interne markt: economische noodzaak 21 - Wijzigingsvoorstellen 23 -

Handhaving 24 - Conclusie 25

5. De aanbestedingsovereenkomst

Privaatrecht ... 25 - ... met een snufje publiekrecht 29 - Conclusie 33

6. Beleidsaspecten van aanbestedingen

7. Probleemstelling

Hoofdstuk 2. De bevoegdheid tot aanbesteden

1. Het tot aanbesteden bevoegde bestuur

De bevoegdheidsverdeling in historisch perspectief 37 - Nieuwe ontwikkelingen 44 - Conclusie 46

2. Openbare en onderhandse aanbesteding; beleidsgrondslag

Periode tot 185147 - Periode na 185150 - Preventief toezicht 52 - 'Ontzuiling

der procedures' 57 - Decentralisatie aanbestedingsbeleid 60 - Dode letter 61 - Conclusie 62

3. Het repressieve toezicht

Repressief toezicht: ultimum remedium 63 - Gevolgen van de vernietiging 67 -

De toetsingspraktijk 68 - Opvattingen in literatuur en rechtspraak 70 - Administratiefrechtelijke rechisbescherming 72

4. Conclusie

Hoofdstuk 3. (Zelf)regulering van de gemeentelijke overheidsaanbesteding

1. Inleiding

2. Confrontatie met de regelgeving

2.1. De aanbestedingsreglementen

Het Uniforme aanbestedingsreglement 1972 (UAR 1972) 77 - Tweesporenbeleid 78 -

Het Uniforme aanbestedingsreglement 1986 (UAR 1986) 80 - De Europese dimensie 87 -

Het Uniforme aanbestedingsteglement-EG 1991 (UAR-EG 1991) 88 - Conclusie 90 
Liberalisatierichtlijn 71/30491 - Coôrdinatierichtlijn 71/305 91 - Inbreuken op de publiciteitseis 95 Wijziging van de richtlijn 97 - Richtlijn 93/37 99 - Conclusie 100

3. Conclusie

Hoofdstuk 4. Eisen aan de beleidsuitgangspunten

1. Inleiding

2. UAR en financieel doelmatig beleid

2.1. Het Uniform Aanbestedingsreglement 1972

'Het oordeel van de opdrachtgever' 103 - Het motiveringsbeginsel 104

\subsection{Het Uniform Aanbestedingsreglement 1986}

Eisen en criteria 104 - Twee (samenhangende) vragen 106 - Uitnodiging na selectie 112 -

De gunning van het werk; gunningsplicht? 112 - Het motiveringsbeginsel 115

\subsection{Het Uniform Aanbestedingsreglement-EG 1991}

Selectie-eisen en gunningscriteria 116 - Het motiveringsbeginsel 117

2.4. Conclusie

3. Beleidscoördinatie op het Europese niveau

3.1. Richtlijn $71 / 305$

Algemene geschiktheidseisen: referenties en criteria 120 - Selectie: referenties en criteria; publikatie 120 - Gunning: criteria; publikatie 122

3.2. Richtlijn $93 / 37$

Selectie-eisen en gunningscriteria 124 - Het motiveringsbeginsel 125

3.3. Conclusie

4. 'Andere' beleidsuitgangspunten

4.1. Aanvullende voorwaarden

4.2. Rechtmatige beleidsaspecten

COM (89) 400 final 132 - Het begrip 'contractuele voorwaarde' 133 - De verenigbaarheid met het vrije werknemersverkeer (artikel 48 EG) 133

4.3. Aanbestedingen en artikel 92 v. EG

Standpunt Europese Commissie 135 - Standpunt Europees Hof 137

4.4. 'Alle relevante bepalingen van gemeenschapsrecht'

Algemene opmerkingen 139 - 'Onderscheid'-maatregelen 140 - 'Zonder onderscheid'maatregelen 142 - Evenredigheid: ja, maar waartussen? 147

5. Conclusie 
1. Van privaatrecht naar bestuursrecht

151

'No nonsense'-recht: instrumentalisme 151 - Bestuursrechtelijke normering 152

2. Wat is aanbestedingsbeleid?

157

Begripsomschrijving 157

3. (Bestuursrechtelijke) eisen aan het beleid

3.1. Het gelijkheidsbeginsel: eis van beleid

Gelijkheid en vertrouwen 161 - Het UAR als gemeentelijke beleidsregel 162 - Het rationele besluitvormingsmodel 164

3.2. Het openbaarheidsbeginsel: kenbaarheid van het beleid

3.3. Het motiveringsbeginsel: beredeneerd beleid

3.4. Het (financiële doelmatigheidsbeginsel: prioriteit van het financiële belang

4. Vormgeving van het aanbestedingsbeleid

5. Het besluitvormingsproces; nadere analyse

Het UAR-besluitvormingsproces 177 - Het bestuurlijke besluitvormingsproces 178 - Een bestuurlijke besluitvormingsparaplu: besluitvormingsmodel 178 - Het rechtskarakter van de aanbestedingsovereenkomst 179 - Conclusie 182

6. Besluitvorming en bevoegde rechter

6.1. De burgerlijke rechter is competent

Onder de wetten-BAB en Arob 183 - Onder de Awb 184

6.2. Naar een bevoegde administratieve rechter

Criterium 186 - Belgisch model 187 - Dubbele competentie 189 - Beter: overheidskamer 190 -

Beleidsfasetoetsing 191

7. Naar een wettelijk kader voor het aanbestedingsbeleid

Korte weergave Euregionaal praktijkonderzoek 1986-1988

Samenvatting

Synopsis 


\section{Lijst van gebruikte afkortingen}

A-G

AA

$\mathrm{AB}$

ac.prft.

Adv.bl

AR

ARB

Arob

art.

AV

AVBB

Awb

$\mathrm{BAB}$

BAW

$\mathrm{Bb}$

$B \& W$

BEUV

BR

BRv

BTW

BW

B. wet

CEM

CMLRev

COM

CPB

DG

EC

ECU

EEG

EG

EK

ELRev

EuGH

EuZW

EVRM

FIDE

GATT

GEA

GS

Gst

GWW

Hand. I

Hand. II

Advocaat-Generaal

Ars Aequi

Administratief-Rechtelijke Beslissingen

proefschrift

Advocatenblad

Afdeling rechtspraak van de Raad van State

Administratieve en Rechterlijke Beslissingen

Wet administratieve rechtspraak overheidsbeschikkingen

artikel

Algemene Voorwaarden

Algemeen Verbond Bouwbedrijf

Algemene wet bestuursrecht

Wet beroep administratieve beschikkingen

Besluit Aanbesteding van Werken

Bedrijfsjuridische berichten

College van Burgemeester en Wethouders

Benelux Economische Unieverdrag

Bouwrecht

Wetboek van Burgerlijke Rechtsvordering

Belasting Toegevoegde Waarde

Burgerlijk Wetboek

Bestuurswetenschappen

Commissie economische mededinging

Common Market Law Review

Document van de Europese Commissie

Centraal Planbureau

Directoraat-Generaal

Europese Commissie

European Currency Unit

Europese Economische Gemeenschap

Europese Gemeenschappen

Eerste Kamer

European Law Review

Europäisches Gerichtshof; zie Hof EG

Europäische Zeitschrift für Wirtschaftsrecht

Europees Verdrag tot bescherming van de Rechten van de Mens

Fédération Internationale de Droit Européen

General Agreement on Tariffs and Trade

Gerecht van Eerste Aanleg

Gedeputeerde Staten

De Gemeentestem

Grond- weg- en waterbouw

Verslag der Handelingen van de Eerste Kamer der Staten-Generaal

Verslag der Handelingen van de Tweede Kamer der Staten-Generaal 


$\begin{array}{ll}\text { HGrG } & \text { Haushaltsgrundsätzegesetz } \\ \text { Hof EG } & \text { Hof van Justitie van de Europese Gemeenschappen } \\ \text { HR } & \text { Hoge Raad } \\ \text { Jb } & \text { Jurisprudentie bestuursrecht } \\ \text { jo } & \text { juncto } \\ \text { Jur. } & \text { Jurisprudentie (van het Hof van Justitie en het Gerecht van Eerste Aanleg } \\ & \text { van de Europese Gemeenschappen) } \\ \text { KB } & \text { Koninklijk Besluit } \\ \text { KG } & \text { Kort Geding } \\ \text { LIEI } & \text { Legal Issues of European Integration } \\ \text { M\&R } & \text { Milieu en Recht } \\ \text { MKB } & \text { Midden- en kleinbedrijf } \\ \text { MLRev } & \text { The Modern Law Review } \\ \text { m.nt } & \text { met noot } \\ \text { MvBZ } & \text { Ministerie van Binnenlandse Zaken } \\ \text { NG } & \text { De Nederlandse Gemeente } \\ \text { NJ } & \text { Nederlandse Jurisprudentie } \\ \text { NJB } & \text { Nederlands Juristenblad } \\ \text { NJV } & \text { Nederlandse Juristenvereniging } \\ \text { N.O.P. } & \text { Niet openbare procedure } \\ \text { nr. } & \text { nummer } \\ \text { NV } & \text { De Naamloze Vennootschap } \\ \text { NTB } & \text { Nederlands Tijdschrift voor Bestuursrecht } \\ \text { NTBR } & \text { Nederlands Tijdschrift voor Burgerlijk Recht } \\ \text { O.P } & \text { Openbare procedure } \\ \text { Pb } & \text { Publikatieblad van de Europese Gemeenschappen } \\ \text { PE DOC } & \text { Document van bet Europees Parlement } \\ \text { PPLRev. } & \text { Public Procurement Law Review } \\ \text { Pres.Rb. } & \text { President van de rechtbank } \\ \text { Rb. } & \text { arrondissementsrechtbank } \\ \text { Rep. } & \text { Repertorium van de Nederlandsche Jurisprudentie en rechtsliteratuur } \\ \text { RM Themis } & \text { Rechtsgeleerd Magazijn Themis } \\ \text { RMC } & \text { Revue du Marché Commun } \\ \text { r.o. } & \text { rechtsoverweging } \\ \text { RO } & \text { Wet op de Rechterlijke Organisatie } \\ \text { RTDE } & \text { Revue Trimestrielle de Droit Européenne } \\ \text { RvA } & \text { Raad van Arbitrage voor de Bouwbedrijven in Nederland } \\ \text { RvdW } & \text { Rechtspraak van de Week } \\ \text { RW } & \text { Rechtskundig Weekblad } \\ \text { S. } & \text { Staatsblad } \\ \text { S\&V } & \text { Stedebouw en Volkshuisvesting } \\ \text { SER } & \text { Sociaal-Economische Raad } \\ \text { SEW } & \text { Sociaal-Economische Wetgeving } \\ \text { SPO } & \text { Vereniging van Samenwerkende Prijsregelende Organisaties in de Bouwnij- } \\ & \text { verheid } \\ \text { Stcrt. } & \text { Staatscourant } \\ \text { TED } & \text { Tenders Electronic Daily } \\ \text { TK } & \text { Tweede Kamer der Staten-Generaal } \\ & \end{array}$


TMA Tijdschrift voor Milieu-aansprakelijkheidsrecht

Trb.

Tractatenblad van het Koninkrijk der Nederlanden

TvA

Tijdschrift voor Arbitrage

TvAan Tijdschrift voor Aannemingsrecht

TvO

TVP

Tijdschrift voor Openbaar bestuur

TVVS

Tijdschrift voor Privaatrecht

UAR

Tijdschrift voor Vennootschappen, Verenigingen en Stichtingen

UAR.EG

Uniform Aanbestedingsreglement

UAV

UCV

UPR

VAR

Vgl.

VNG

VOB/A

Uniform Aanbestedingsreglement voor aanbestedingen op EG-niveau

VROM

$\mathrm{Vz} . \mathrm{Abr}$

W.

Uniforme Administratieve Voorwaarden voor de uitvoering van werken

Uitgebreide commissievergadering

Uniform Prijsregelend Reglement

Vereniging voor Administratief Recht

Vergelijk

Vereniging van Nederlandse Gemeenten

Verdingungsordnung für Bauleistungen/ Teil A - Allgemeine Bestimmungen für die Vergabe von Bauleistungen

WBA

Ministerie van Volkshuisvesting, Ruimtelijke Ordening en Milieubeheer

WEM

WMV

Voorzitter Afdeling bestuursrechtspraak van de Raad van State

Weekblad van het Recht

Weekblad voor de Burgerlijke Administratie

Wonen en Milieu Vakmatig

WPNR Weekblad voor Privaatrecht, Notariaat en Regi 


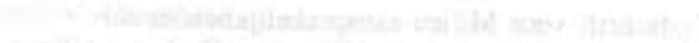

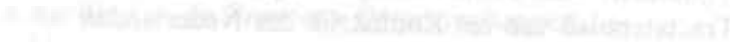

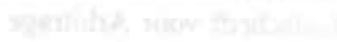

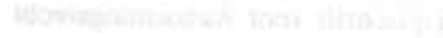

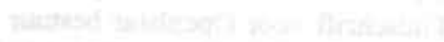

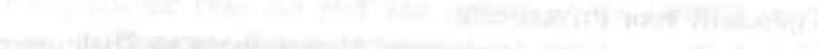

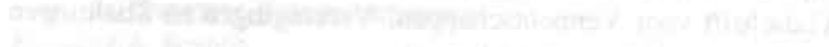

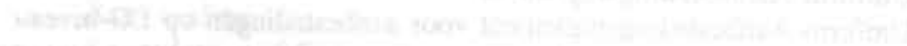

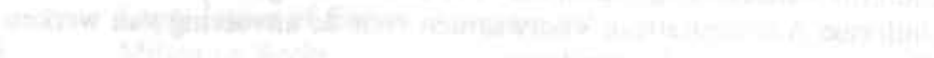

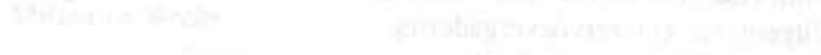

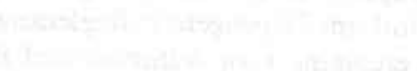

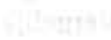

.

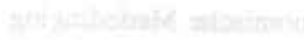

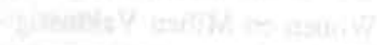

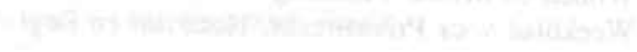




\section{Een juridische topografie}

\section{Wat is aanbesteding?}

\section{Begripsverkenning}

Overheidsaanbestedingen vormen een moeilijk te rubriceren categorie. Het mag dan ook geen wonder heten, dat het begrip aanbesteding tot voor kort nergens in de toepasselijke regelgeving werd omschreven. Dit werd anders met de invoering van het Besluit mededingingsregelingen aanbestedingen ${ }^{1}$. Dit besluit geeft in artikel 1 een omschrijving van het begrip aanbesteding, maar de toelichting haast zich direct om te benadrukken dat het besluit eigenlijk niet over aanbestedingen gaat, maar over met betrekking tot de aanbesteding door de aannemers gemaakte mededingingsbeperkende afspraken ${ }^{2}$. Een poging om aan het begin van het onderzoek het begrip 'overheidsaanbesteding' althans enigszins in kaart te brengen kan daarom niet achterwege blijven.

In de (oudere) literatuur kan men de opvatting tegenkomen waarbij de aanbesteding op één lijn gezet wordt met de opdrachtverlening, dat wil zeggen: het sluiten van het aannemingscontract $^{3}$. Een dergelijke eindterm-omschrijving van het aanbestedingsbegrip leent zich evenwel niet goed voor een onderzoek als het onderhavige, waar het er om gaat het (besluitvormings)proces voorafgaand aan de opdrachtverlening te analyseren. Een praktische omschrijving is dan dat er sprake is van een aanbesteding wanneer een potentiële opdrachtgever ten behoeve van de uitvoering van een bouwwerk bij een al dan niet beperkte groep van ten minste twee aannemers informeert omtrent de daarvoor te stellen prijzen en de daarbij behorende voorwaarden ${ }^{4}$. In civilibus kan een aanbesteding - in verhouding tot de latere aannemingsovereenkomst - worden omschreven als een uitnodiging tot het doen van een aanbod $^{5}$. Dit is althans het geval wanneer het initiatief tot de bouw bij de potentiële opdrachtgever ligt en deze, zoals gebruikelijk, op de aanbesteding voorwaarden toepasselijk heeft verklaard, waarin voor de aanbesteder de vrijheid is voorbehouden, het werk al dan niet

\section{S. 1994,55 .}

2 Toelichting, 25. Art. 1, sub b Besluit: 'de al dan niet gelijktijdige uitnodiging van een aanbesteder aan twee of meer eigenaren van ondernemingen of vrije-beroepsbeocfenaren om een inschrijfcijfer in te dieneu voor de uitvoering van een opdracht tot het leveren van goederen of het verrichten van diensten'.

3 O.m. Gst 1854, 124; Gst 1908, 2971; Gst 1915, 3343. Vergelijk verder Hogerzeil (1982), 124 v., De Haan, Drupsteen, Fernhout (1986 a), 350 en De Vries (1990), 220 die met de term aanbesteder eigenlijk de opdrachigever op het oog hebben. Waarschijnlijk ook Droogleever Fortuyn (1970), 37-39. Deze opdrachtverlening moet niet worden verward met de opdracht in Boek 7.7 BW.

4 Van Loenen (z.j.), 176-3 (losbladige).

s Zie Asser-Hartkamp II (1993), 125 en de daar genoemde literatuur. Voorts Van Nouhuys (1986), 26; Van den Berg (1990), 216; Van Wassenaer (1990), 26. Ook TK 1992-1993, 22 093, nr. 9, 5 (Brief van de staatssecretaris van Economische Zaken). 
te gunnen aan één der inschrijvers ${ }^{6}$. Volgens Rozemond ${ }^{7}$ doet de aanbesteder die een bestek uitgeeft en daarop bepaalde procedureregels (het Uniforme Aanbestedingsreglement; UAR) van toepassing verklaart zelf een algemeen of selectief aanbod aan aannemers om de aanbestedingsprocedure volgens die regels te laten verlopen. Aannemers kunnen dit aanbod al dan niet aanvaarden. Van Nouhuys, en ik ondersteun hem daarin, heeft zich afkerig getoond van de opvatting dat een openbare aanbesteding een volledig openbaar aanbod ${ }^{8}$ zou behelzen. Hij ziet daarvoor alleen ruimte indien de aanbesteder zijn uitnodiging als zodanig formuleert dat daaruit de wil van de aanbesteder kan worden afgeleid dat door aanvaarding een overeenkomst tot stand komt ${ }^{9}$. Alleen voor wat betreft het arbitragebeding in artikel 41 UAR 1986 lijkt Van Nouhuys zijn toevlucht te willen nemen tot de opvatting van Rozemond ${ }^{10}$. Het onderscheid tussen de uitnodiging tot het doen van een aanbod en het aanbod is steeds een kwestie van uitleg, waarbij de persoonlijke wil in belangrijke mate maatschappelijk wordt bepaald ${ }^{1 !}$. Door de uitdrukkelijke verwijzing naar het UAR, zo kan men redeneren, geeft de aanbesteder er blijk van een openbaar aanbod te willen doen. Aanvaarding van het aanbod doet een overeenkomst ontstaan (artikel 6:217 BW). De wetgever heeft in artikel 6:219 (juncto artikel 6:217, lid 2) BW het stelsel aanvaard dat een aanbod steeds herroepelijk is, tenzij het een termijn voor de aanvaarding inhoudt of de onherroepelijkheid ervan op andere wijze uit het aanbod volgt ${ }^{12}$. De opvatting van Rozemond heeft dan tot gevolg dat er sprake is van een onherroepelijk aanbod, nu volgens artikel 6, lid 2, sub j UAR 1986 de bekendmaking van de aanbesteding vermeldt wanneer de inschrijvingsbiljetten moeten worden ingeleverd. Dit zou als een termijn voor de aanvaarding kunnen worden opgevat. Het zal deze consequentie zijn, waardoor de opvatting van Rozemond in de praktijk weinig steun vindt. Adriaansens neemt een tussenpositie in waar hij de aanbesteding omschrijft als de (eenzijdige) rechtshandeling van de aanbesteder, welke in eerste instantie is gericht op bet uitbrengen van een offerte door een aannemer, en uiteindelijk op het tot stand komen van een aannemingsovereenkomst ${ }^{13}$. Iets dergelijks vinden we ook in de Toelichting op het Besluit mededingingsregelingen in de bouwsector ${ }^{14}$. Daar werden de hiervoor gegeven omschrijvingen van het aanbestedingshegrip gecombineerd. Opgemerkt werd, dat onder aanbesteding wordt verstaan zowel het vragen van prijsopgaven aan aannemers door de opdrachtgever (aanbesteder), als het sluiten van een aannemingsovereenkomst tussen opdrachtgever en aannemer ${ }^{15}$. In de Uniforme aanbestedingsreglementen (bij voorbeeld artikel 11, lid 1 UAR

- Daarover bestaat volgens Van den Berg (1990), 217 'vrijwel eenstemmigheid'. Andersom kan ook de aannemer (bouwondernemer) het initiatief tot de bouw nemen, zoals bij het brochureplan. Vgl. Aanbesteding, bouwteam of brochureplan. Wat bepaalt de keuze?, Stichting Bouwresearch, nr. 124, Rotterdam 1985.

7 O.m. Rozemond (1982), 116.

- Hiervan is sprake wanneer het aanbod niet is gericht tot éen of meer bepaalde personen, maar tot een meer of minder uitgebreid publiek, aldus Hartkamp (Asser-Hartkamp II (1993), 124).

- Van Nouhuys (1986), 26. Ook zo Van den Berg (1990), 217.

10 Van Nouhuys (1986), 38-39.

11 HR 19 december 1969, NJ 1970, 154 m.nt. MS, AA 1970, 550 m.nt. G (Lindeboom/ Ansterdam). Volgens annotator Van der Grinten schept het aanbod een wilsrecht voor de wederpartij. Vgl. Van Dunne (1985), $11 \mathrm{en}$ 73, die kiest voor een normatieve uitleg, waarbij er geen ruimte is voor consensualisme. De Raad van Arbiuage volgt de Hoge Raad. Men zie RvA 1 mart 1984, TvA 84/5, nr. 27 m.nt. M.A. van Wijngaarden.

12 Zie over de problematiek van de al dan niet herroepelijkheid Asser-Hartkamp II (1993), 129-131.

13 Adriaansens (1981), $171 \mathrm{v}$.

i4 Besluit van 29 december 1986 (S. 1986, 676).

19. $1986,676,6$ (Nota van Toelichting). 
1986) heeft het aanbestedingsbegrip betrekking op de mogelijkheid voor de gegadigden om in te schrijven. De inschrijver kan tot het tijdstip van de aanbesteding zijn inschrijving intrekken (artikel 11, lid 8 UAR 1986).

De Overleggroep Ordeningsthema's Aanbestedingswezen ${ }^{16}$ had yoorgesteld dat een dergelijk verzoek om intrekking zou kunnen worden ingewilligd, doch uitsluitend na betaling van een redelijke schadevergoeding door de verzoeker. Dit zou alleen uitzondering lijden wanneer er voor beide partijen sprake was van een notoire vergissing, zelfs na het tijdstip van de gunning. Van Wijngaarden heeft er op gewezen, dat ook volgens het UAR 1972 en het voorontwerpUAR 1985, arbiters in zeer bijzondere gevallen konden beslissen dat de aannemer niet aan zijn door de aanbesteder aanvaard aanbod gebonden was ${ }^{17}$.

\section{Nadere begripsafbakening}

Naast de term aanbesteding komt men in de literatuur ook het begrip uitgifle van bouwwerken tegen. Het omvat naast de (eigenlijke) aanbesteding ook de gunning uit de hand. Men spreekt ook wel van het één-één-verkeer, de ondershandse aanbesteding of van de enkelvoudige aanbesteding, hoewel er strikt genomen dan geen sprake van aanbesteding is. Het kenmerk van de aanbesteding, waarbij meerdere aannemers met elkaar in concurrentie treden, is bij de enkelvoudige aanbesteding immers afwezig. Anderzijds moet het verschil met de eigenlijke aanbesteding ook weer niet worden overtrokken: de concurrentie is wel latent aanwezig, doordat de potentiële opdrachtgever, indien hem de prijsopgave te hoog voorkomt, zich tot een andere aannemer kan wenden. Kenmerkend voor de enkelvoudige aanbesteding is de mogelijkheid tot onderhandelen. In de praktijk wordt daarbij vaak gebruik gemaakt van de techniek van de open begroting, waardoor de potentiële opdrachtgever inzicht kan krijgen in de wijze waarop de aannemer aan zijn aanneemsom is gekomen ${ }^{18}$. De potentiële opdrachtgever neemt kennis van de gedetailleerde opbouw van de kostprijsberekening van de aannemer, waardoor het voor de eerste mogelijk wordt de prijs van de verschillende onderdelen in de begroting te beïnvloeden. In de literatuur, en ook in dit onderzoek, wordt de enkelvoudige aanbesteding tot de aanbesteding gerekend ${ }^{19}$.

Nog ruimer dan het begrip uitgifte van werken is het begrip overheidsopdrachten voor de uitvoering van werken. Deze term wordt gebruikt in de Europese coördinatierichtlijn inzake de uitvoering van bouwwerken ${ }^{20}$. Het dient te gaan om schriftelijke overeenkomsten onder bezwarende titel; zoveel staat wel vast! Maar er rijzen al direct problemen bij de omschrijving van de begrippen 'aannemer' en 'aanbestedende dienst'. Blijkens de omschrijving in het Vademecum Overheidsopdrachten in de Gemeenschap ${ }^{21}$ is met de term aannemer ${ }^{22}$ bedoeld

16 Overleggroep Ordeningsthema's Aanbestedingswezen (1982), Deel D, Hoofdstuk 1.03, 3

17 O.m. Van Wijngaarden (1985), 263, noot 11.

18 In het verleden kwam het wel voor dat de overheid de kosten van haar begroting openbaar makte. Dit is later in onbruik geraakt (vgl. Gst 1862, 539).

19 Van Nouhuys (1986), 6; Van den Berg (1990), nr. 352; Asser-Kormann-De Leede-Thunnissen (1994), 537. Anders Van Werven (1992), 217, noot 78.

20 Art. 1.a richulijn 71/305, Pb 16 augustus 1971, L 185/5-14 (cok: de richulijn Werken). Inmiddels onder meer gewijzigd bij richtijn 89/440, Pb 21 juli 1989, L 210/1 v. Zie ook geconsolideerde tekst in richtlijn 93/37, 14 juni 1993, $\mathrm{Pb} 9$ augustus 1993, L 199/54.

${ }^{21} \mathrm{~Pb} \mathrm{C} 358$ van 31 december 1987, 27. Volgens art. 21 richtlijn $93 / 37$ wordt pas een bepaalde rechtsvorm verlangd nadat de opdracht is gegund.

$n$ Dit is niet de in het UAR-EG 1991 bedoelde aannemer: een inschrijver aan wie het werk is opgedragen. 
een natuurlijke of rechtspersoon danwel een combinatie van aannemers. Contracten met anderen, bij voorbeeld met beleggers, vallen er dus buiten ${ }^{23}$. De problemen met het begrip 'aanbestedende dienst' blijven hierna buiten beschouwing: in dit onderzoek is dat steeds de gemeente.

De contractsinhoud wordt in artikel 1.a richtlijn 93/37 als volgt omschreven: schriftelijke overeenkomsten '(..) die betrekking hebben op de uitvoering dan wel het ontwerp alsmede de uitvoering van werken (...) dan wel op het laten uitvoeren met welke middelen dan ook van een werk dat aan de door de aanbestedende dienst vastgestelde eisen voldoet'. Bij 'het laten uitvoeren' moet worden gedacht aan 'alle contractsvormen die zich de afgelopen tien jaar hebben ontwikkeld, en die leiden tot het plaatsen van steeds ruimere opdrachten $(\ldots)^{\prime 24}$. Het Vademecum Overheidsopdrachten voegt daar nog aan toe: 'Daar geen beperkingen zijn opgenomen, is de werkingssfeer van de richtlijn derhalve de ruimst denkbare en vallen alle soorten van overeenkomsten die de contracterende partijen maar kunnen bedenken, eronder.' Op vragen van het Europese Parlement gaf de Commissie te kennen dat bedoeld was 'enkel andere contractsvormen (...) in de mate dat zij verbonden zijn met de uitvoering van werken' 25 . Hieronder vallen alle vormen waarop de uitvoering van bouwwerken aan derden kunnen worden opgedragen, waartoe naast de (enkelvoudige) aanbesteding ook het werken in bouwteamverband (met name in de sociale woningbouw), het turnkey-contract en de verlening van concessies worden gerekend. Maar er kan ook gedacht worden aan projectontwikkelingsovereenkomsten en "management"-overeenkomsten, die niet alleen betrekking hebben op het eigenlijke bouwen maar ook op de financiële aspecten, organisatie en directie van werken $^{26}$. De concessieverlening ${ }^{27}$ en het bouwteam vallen buiten het eerder genoemde aanbestedingsbegrip en komen daarom hierna niet aan de orde. En ook het terrein van de (sociale) woningbouw blijft om die reden verder buiten beschouwing ${ }^{28}$.

Lezers die vermoeden dat in dit boek de direct met de precontractuele verhoudingen samenhangende problemen - zoals de onderbandelingsplicht en het schadevergoedingsvraagstuk - centraal staan, komen bedrogen uit. Ik verwijs wat dit betreft naar de inmiddels omvangrijke literatuur op dat gebied ${ }^{29}$. Dat betekent ook dat de enkelvoudige aanbesteding slechts zijdelings ter sprake komt. Zoals nog zal worden uiteengezet richt dit onderzoek zich op de grondslagen van het gemeentelijk aanbestedingsbeleid in de bouw. De ontwikkeling van

23 In die zin Wedekind (1993), 504. Zie verder over de problematiek van de in de richtlijn gebezigde begrippen Janssen (1993), 493 v.; Bregman (1993), 499 en Van Wassenaer (1993 b), 588.

$24 \mathrm{COM}(86) 679$ def., 23 december 1986, 2 (toelichting).

25 PE DOC A-2 37/88, 5 april 1988, 39 (toelichting).

26 In zijn preadvies wil Goudsmit (1989), 39 onderscheid maken tussen het management-contract op zich en de gunning van aannemingscontracten door de management-contractor. Alleen de laatste typen contracten zouden volgens hem onder de werking van richtlijn 93/37 vallen. Ik ben het eens met Wedekind (BR 1990, 174 en 177). die tijdens de beraadslagingen over dit preadvies, opmerkte, dat dit een creatieve gedachte is, maar dat het de vraag is of de Europese Commissie en her Hof van Justitie dit ook zo zullen willen zien.

27 Art. 3 richtlijn 93/37.

as Art. 9 richtlijn 93/37.

29 Vgl. Contractenrecht (Spier) (losbl.), VII- B (Precontractuele fase), nr. 20 y. Zie nog Santen (1988); Huygen (1991), 39-53, De Kluiver (1992) en Asser-Kortmann-De Leede-Thunnissen (1994), 550-551. 
een dergelijk beleid vindt plaats voorafgaand aan de precontractuele relaties met de aannemers.

\section{Participanten en procedures}

\section{Participanten}

In de diverse opeenvolgende Uniforme aanbestedingsreglementen worden als bouwparticipanten genoemd: de aanbesteder en de opdrachtgever, de gegadigde en de inschrijver, terwijl daarnaast ook het begrip aannemer voorkomt. In het UAR 1972 werd het begrip opdrachtgever omschreven als 'de natuurlijke of rechtspersoon die het werk opdraagt'. In het UAR 1972 werd daarmee gedoeld op degene die voornemens was het werk op te dragen. In overeenstemming met de literatuur ${ }^{30}$ is later in het UAR 1986 de term opdrachtgever gereserveerd voor de aanbesteder, die het werk aan een aannemer heeft opgedragen. De aanbesteder is dan degene die voornemens is het werk op te dragen. Onder een gegadigde wordt verstaan: de natuurlijke of rechtspersoon, die zich bij een aanbesteding met een voorafgaande selectieprocedure heeft aangemeld met het verzoek tot de inschrijving te worden uitgenodigd. Een inschrijver wordt omschreven als de natuurlijke of rechtspersoon, die door middel van een inschrijving aangeboden heeft het werk uit te voeren ${ }^{31}$. En de aannemer is de inschrijver aan wie het werk wordt opgedragen. Voor wat betreft het voor de Europese overheidsaanbestedingen (dat wil zeggen: aanbestedingen met een geraamde waarde van meer dan 5 miljoen $\mathrm{ECU}^{32}$ ) ontworpen UAR-EG 1991 is in de omschrijving van 'gegadigde' rekening gehouden met de 'Europese' onderhandelingsprocedures met en zonder voorafgaande bekendmaking.

\section{UAR-procedures}

In Nederland zijn de aanbestedingsprocedures geregeld in de Uniforme aanbestedingsreglementen. Het doel van het aanbesteden kan worden omschreven als het op basis van selectieen gunningscriteria verlenen van de opdracht aan een aannemer. Bij de kwalitatieve selectiecriteria in de verschillende Uniforme aanbestedingsreglementen gaat het om eisen die de aannemer zelf betreffen (zijn deskundigheid, solvabiliteit en dergelijke). De gunningscriteria hebben betrekking op het bouwwerk (prijsaspecten). Teneinde te komen tot een optimale prijs-kwaliteitsverhouding lokt de aanbesteder concurrentie uit binnen een grotere of kleinere kring van aannemers. Het middel daartoe wordt gevormd door de aanbestedingsprocedure. De UAR-aanbestedingsprocedure kan daarom worden beschouwd als een besluitvormingsproces op basis van vooraf ontwikkelde eisen en criteria die voortvloeien uit het belang van een financieel-doelmatige opdrachtverlening.

30 Asser-Coehorst-De Leede-Thunnissen (1983), 289. Hogerzeil (1982), 126 v. Ten onrechte is in TK 1992-1993, 22 093, nr. 9, 5 (Brief van de staatssecretaris van Economische Zaken) sprake van "opdrachtgever" waar de aanbesteder wordt bedoeld. Ook de artikelen 7A:1640 v. BW over de aanneming van werken hebben betrekking op de aanhesteder als opdrachtgever.

"Blijkens het arrest zaak 389/92 (Ballast Nedam Groep N.V./ België) moet zulks ruim worden opgevat. Ook (rechts)personen die niet zelf de bedoeling hebben om zelf de werken uit te voeren, kunnen niet van deelname aan een aanbestedingsprocedure worden uitgesloten. Zie Pijnacker Hordijk - Bel (1994), 660-662.

52 Art. 1, onder h richtlijn 93/37. 
Het UAR 1972 kende vier wijzen van aanbesteding van werken: de openbare aanbesteding, de aanbesteding met voorafgaande selectie, de onderhandse aanbesteding en de onderhandse aanbesteding na selectie. De openbare aanbesteding was omschreven als een aanbesteding welke algemeen bekend werd gemaakt en waarbij een ieder kon inschrijven (artikel 5 UAR 1972). Een aanbesteding met voorafgaande selectie onderscheidde zich van de openbare aanbesteding, doordat niet alle gegadigden tot de inschrijving werden toegelaten (artikel 24 UAR 1972) ${ }^{33}$. Bij een onderhandse aanbesteding werd door een schriftelijke ${ }^{34}$ uitnodiging tot inschrijving een beperkt aantal van ten minste twee natuurlijke of rechtspersonen uitgenodigd voor de inschrijving (artikel 29 UAR 1972). En bij de onderhandse aanbesteding na selectie werden ten minste twee gegadigden uitgenodigd om deel te nemen aan een selectie, waarna één of meer van hen tot de inschrijving konden worden toegelaten. De uitnodiging tot inschrijving was vormvrij (artikelen 33 en 34 UAR 1972). Het UAR 1972 bevatte geen voorschriften voor de zogenaamde enkelvoudige aanbesteding. Het UAR 1972 is inmiddels vervangen door het UAR 1986. Dit UAR 1986 kent hetzelfde viertal aanbestedingsvormen als het UAR 1972, zij het dat de omschrijving daarvan enigszins is aangescherpt.

Het speciaal voor Europese aanbestedingen ${ }^{35}$ ontwikkelde UAR-EG 1991 voorziet eveneens in vier aanbestedingswijzen. Naast de reeds bekende openbare aanbesteding (artikel 8 UAREG 1991) en de aanbesteding met voorafgaande selectie (artikel 34 UAR-EG 1991) introduceert het reglement in de artikelen 40 en 54 een tweetal onderhandelingsprocedures (met en zonder voorafgaande bekendmaking in het EG-Publikatieblad). Deze voor ons land nieuwe onderhandelingsprocedures mogen slechts in uitzonderlijke gevallen worden gehanteerd (artikelen 41 en 55 UAR-EG 1991).

Gelet op de bezwaren zijdens de aannemers tegen het onderhandelen is daaraan zoveel mogelijk tegemoet gekomen, door het aanbrengen van een scheiding tussen aan de ene kant het overleg over het uit te voeren werk (over de aanpassing van het bestek) en de voorwaarden (overlegfase in artikel 46) en aan de andere kant de gelijktijdige onderhandelingen over de prijs, nadat de prijsaanbiedingen hebben plaatsgevonden (onderhandelingsfase in artikel 50 UAREG 1991) ${ }^{36}$. Een waarborg tegen het oneigenlijk gebruik maken door de aanbesteder van informatie, verkregen van een gegadigde of inschrijver, is gelegen in de verplichting voor de aanbesteder om zowel tijdens de overlegfase als de onderhandelingsfase uitsluitend aan betrokkene daarvan verslag te doen. Zijn de aangepaste bestekken inhoudelijk gelijk, dan is gelijktijdig onderhandelen in verband met het gevaar van leuren niet wegestaan. Onder 'leuren' wordt verstaan dat aannemers tegen elkaar worden uitgespeeld door achtereenvolgens verschillende gegadigden met een verzoek om prijsopgave te benaderen, waarbij de latere gegadigde wordt geïnformeerd over de vertrouwelijke prijsaanbieding van de eerdere met het doel aldus een lagere prijs te verkrijgen ${ }^{37}$. De regeling in het UAR-EG 1991 moet waarborgen dat pas wanneer de besprekingen met de eerste inschrijver mislukken, besprekingen met een ander kunnen worden begonnen.

Wordt aanbesteed volgens de procedure van gunning via onderhandelingen met voorafgaande bekendmaking, dan mag het aantal gegadigden dat tot de onderhandelingen wordt toegelaten niet lager zijn dan drie, op voorwaarde dat er voldoende geschikte gegadigden zijn. Ook ter zake van de aanbesteding met voorafgaande selectie heeft de aanbesteder de mogelijkheid om

33 Vergelijk over de introductie van deze procedure in ons land S. 1973, 202, 3 (Nota van Toelichting op het Besluit Aanbesteding van Werken 1973).

3. Dit volgt uit het woord 'zenden' in art. 30 UAR 1972.

3s D.w.z. voor aanbestedingen met een geraamde bouwsom van meer dan 5 miljoen ECU.

36 Zie Toelichting op art. 40 UAR-EG 1991. Vgl. Pijnacker Hordijk (1992 a), 107-109. Van den Berg (1993 a), 36-37 heeft weinig vertrouwen in de twee-fasenprocedure.

37 Overleggroep Ordeningsthema's Aanbestedingswezen (1982), Deel B, 62. Ook Donders (1991), 754. 
het aantal uit te nodigen gegadigden te limiteren (artikel 34 UAR-EG 1991). Het aantal mag echter niet lager zijn dan vijf. Is het aantal gegadigden, dat aan de eisen voldoet, groter dan het door de aanbesteder gekozen maximum, dan biedt het reglement de mogelijkheid om te loten of iedere andere methode van 'shortlisten ${ }^{38}$ te gebruiken, onder voorwaarde dat zulks op een objectieve en controleerbare wijze gebeurt, zodat willekeur en discriminatie worden voorkomen (artikel 37, lid 4 UAR-EG 1991). De aanbesteder dient de methode die hij zal aanwenden voorafgaand aan de aanbestedingsprocedure te publiceren. Is het aantal geschikte gegadigden kleiner dan het gestelde maximum dan is dat geen bezwaar, zolang het aantal uit te nodigen gegadigden maar voldoende is om van een daadwerkelijke mededinging te kunnen spreken $^{39}$. De procedures worden uitvoeriger besproken in het derde en vierde hoofdstuk.

\section{Aanbestedingen en bouwmarkt}

De ontwikkeling van het aanbestedingsrecht (en het aanbestedingsbeleid) kan niet los worden gezien van de verhoudingen op de bouwmarkt. In beschouwingen over de bouwmarkt wordt er voortdurend op gewezen, dat deze zeer typische kenmerken heeft ${ }^{40}$. De techniek van de aanbesteding brengt de aanbesteder in de unieke positie van enige vrager van een niet-substitueerbaar goed, tegenover een veelheid van gegadigden, die in onderlinge concurrentie naar de gunning van het werk dingen, waarbij de hoogte van de prijs een zeer overheersende rol speelt terwij] er van prijsvergelijking nauwelijks sprake is. Weliswaar zijn er vele aanbesteders, maar deze opereren vaak op deelmarkten, gescheiden naar regio en naar de aard van het werk. In deze situatie geniet de opdrachtgever een belangrijk marktoverwicht en neemt de individuele gegadigde - aangenomen dat tussen de gegadigden geen contacten plaatsvinden - als marktpartij een zwakke positie in. De Commissie economische mededinging heeft de aanbesteding in dit verband ooit 'een in wezen barbaarse methode' genoemd ${ }^{4 !}$. Het ontbreken van pluraliteit aan de vraagzijde van de bouwmarkt, kan het evenwicht in de marktverhoudingen gemakkelijk verstoren, hetgeen een ernstige belemmering vormt voor een effectieve concurrentie (monopsonie). Daar staat dan tegenover dat met name in de GWW-sector

34. 'Shortisten' wil zeggen, dat de aanbesteder een objectieve methode gebruikt om te bepalen wie tot de inschrijving zal worden toegelaten, in het geval dat er zich meer gegadigden aanmelden voor de inschrijving dan het maximum aangegeven aantal zoals dat in de bekendmaking is aangekondigd.

38 Toelichting op art. 34 in Stcrt. 1991, 228.

* Vergelijk 0.a. CEM-rapport (1976), 15-17, 24; Toelichting Erecode voor ondernemers in het bouwbedrijf (Erecode, laatstelijk gewijzigd per l oktober 1980); Overleggroep Ordeningsthema's Aanbestedingswezen (1982), Deel B, par. 3.01, 14 en par. 6.01, 59 en meer recent de conclusies in het evaluatierapport inzake het Besluit mededingingsregelingen in de bouw (Evaluatie besluit mededingingsregelingen in de bouwsector. Eindrapport uitgebracht aan de Directie Mededinging. Directoraat-Generaal voor Diensten, Midden- en Kleinbedrijf van het Ministerie van Economische Zaken, Amsterdam 2 juli 1991). Zeer kritisch is de Europese Commissie blijkens haar beschikking van 5 februari 1992, IV/31.572 en 32.571 - Bouwnijverheid in Nederland, Pb 7 april 1992, Nr. L 92/1 (92/204). Ook opgenomen in BR 1992, 476 v., m.n. 487-495. Zie over de gevolgen van deze beschikking. voor de Nederlandse bouwwereld BR 1993, 1 v. Zie over eigenaardigheden van de bouwmarkt voorts o.m. Slagter (1975 a), 230-257 en Slagter (1975 b), 571-585 alsmede Boonstra (1981), 185-186 en recentelijk Donders (1992), 93-95. Wat de uitvoeringsfase betreft Hogerzeil (1982), 123-165.

- CEM-rapport (1976), 17. 
aannemers heel wel in staat blijken het werk onderling te verdelen ${ }^{42}$. Vanuit de aanbodzijde bezien vertoont de (deel)markt dan een oligopolistisch beeld: dat wil zeggen dat de markt een monopolievorm kent en wordt beheerst door slechts een klein aantal aannemers. Het bestaan van zogenaamde asfaltkartels zou de werkverdeling vooraf in de hand werken. Dergelijke kartels werpen in de praktijk feitelijke barrières op tegen buitenlandse aannemers, aan wie geen asfalt wordt verkocht).

Asfaltkartels zijn exclusief verkeersafspraken tussen asfalpproducenten en aannemers. Minister Smit-Kroes (Verkeer en Waterstaat) zei daarover destijds het volgende ${ }^{3}$ : 'Een zeer groot deel van de wegenbouwaannemers, die zelf asfalt produceren, is aangesloten bij de Wegenbouw Aannemers Combinatie (WAC), één van de in Nederland voorkomende prijsregelende organisaties. (...) Zowel de georganiseerde als de niet georganiseerde aannemers zijn (...), indien zij over slechts tén asfaltmenginstallatie beschikken, voor werken op een afstand van meer dan $50 \mathrm{~km}$ van hun installaties aangewezen op andere producenten van afval'. En: 'Een mogelijk gevolg hiervan, namelijk dat aannemers, die over slechts één (vaste) asfaltmenginstallatie beschikken en voor de levering van asfalt niet samenwerken met andere asfaltproducenten, geen asfaltwerken op grote afstand van hun installatie kunnen aannemen, is (...) onderkend'.

Ook in andere sectoren blijken ongereglementeerde afspraken veelvuldig voor te komen. Het is daarom weinig steekhoudend om te stellen dat de problematische vraag-aanbodverhouding op de bouwmarkt het enkele resultaat is van de macht van de aanbesteder ${ }^{44}$. De oorzaak moet allereerst worden gezocht in de beperkte mogelijkheden tot afstemming tussen vraag en aanbod. Doordat elke opdracht zozeer op zichzelf staat, verloopt de uitwisseling van informatie op de bouwmarkt moeilijk in vergelijking tot markten waar prijsaanbiedingen makkelijker convergeren naar een evenwichtsprijs. Het daarmee samenhangende 'transactievraagstuk' wordt volgens Admiraal op twee manieren gecompliceerd: door het verschijnsel van cyclische concurrentie en door de omstandigheid, dat de transactiekosten relatief hoog zijn. Met cyclische concurrentie wordt het verband bedoeld tussen prijsvorming bij onderbezetting en overspanning: wat aannemers tekort komen in slappe tijden moet in betere tijden weer worden goedgemaakt. Reglementering kan dan al te heftige prijsbewegingen afremmen. Wat dát betreft droegen de door de Europese Commissie vermaledijde Uniforme prijsregelende reglementen (UPR) bij tot de oplossing van deze informatie-uitwisselingsproblematiek, waardoor een te grote neerwaartse druk op de prijzen kon worden voorkomen. En daarnaast is ook de achterblijvende technische innovatie in de bouw er lange tijd de oorzaak van geweest dat het werk een te ambachtelijk karakter behield en niet uitgroeide naar een industriële bedrijfstak. Daardoor treffen de aanbesteder en de aannemer elkaar op een ad hoc markt in plaats van op een genormaliseerde markt, hetgeen kan leiden tot een monopsonie aan de kant van de aanbesteder ten nadele van de aannemer ${ }^{45}$.

42 Evaluatie besluit mededingingsregelingen in de bouwsector. Eindrapport uitgebracht aan de Directie Mededinging, Directoraat-Generaal voor Diensten, Midden- en Kleinbedrijf van het Ministerie van Economische Zaken, Amsterdam 2 juli 1991.

4. Zie het antwoord van minister Smit-Kroes (Verkeer en Waterstaat), dat zij, mede namens staatssecretaris Bolkestein van Economische Zaken, gaf op vragen van de Tweede Kamerleden Hennekam en Van Vlijmen (beiden CDA), Aanhangsel Hand. II 1982-1983, nr. 576.

44 In die zin Admiraal (1993), 584-585.

4s Slagter (1986), 82. 
Door de internationalisering zal naar verwachting het aantal vragers naar gespecialiseerde produkten en diensten toenemen, hetgeen in het voordeel is van de toeleverende bedrijven (mede door de schaalvergroting en hoogwaardige produktie $)^{46}$. De afhankelijkheid van Éen opdrachtgever kan daardoor verminderen. Meer in het algemeen doet zich een verschuiving voor van kwantitatieve bouw naar kwalitatieve bouwbehoefte.

Gegeven deze verhoudingen op de bouwmarkt kunnen (en konden) gemakkelijk tegen elkaar worden uitgespeeld door met het werk te leuren. Volgens Mok kunnen er in concreto bedenkingen rijzen, dat er van leurgedrag sprake kan zijn, bij voorbeeld als gevolg van gehanteerde middelen of doordat een aanbesteder een machtspositie bekleedt. Daarbij komt het zijns inziens niet aan op de machtsverhouding bij een bepaalde aanbesteding, maar op beheersing van bepaalde (deel)markten in het algemeen. Hij lijkt daarbij vooral de overheid op het oog te hebben ${ }^{47}$.

Op de bouwmarkt wordt de vraagzijde in overwegende mate bepaald door de overheidsaanbestedingen. Lagere overheden blijken zelfs de belangrijkste opdrachtgevers; voor de GWW-werken (75\% van alle gemeentelijke opdrachten), hetgeen goed was voor zo'n $f 4,8$ miljard in 1990. De verwachting voor 1996 is dat dit bedrag nog zal oplopen tot $f$ 5,7 miljard ${ }^{4 s}$. De (GWW)markt is zeer conjunetuurgevoelig. De produktie van de bouwnijverheid is sterk afhankelijk van het overheidsbeleid ${ }^{49}$ Deze dominante rol van de overheid stelt haar in staat om de bouwproduktie, đoor het stimuleren of juist afremmen van de vraag als instrument te gebruiken ter beĩnvloeding van de conjunctuur, in de door baar gewenste richting te sturen ${ }^{50}$. Door de aannemersorganisaties is er op gewezen, dat wanneer daarin niet regelend. wordt opgetreden, zulks een sterk discontinu verlopend bouwproces ten gevolge heeft. Dit wordt nog eens beklemtoond doordat er niet op voorraad kan worden gewerkt ${ }^{51}$. Ook het Ordeningsrapport ${ }^{52}$ wijst op het belang van een goede ordening van de bouwmarkt bij het realiseren van continuĩteit van het produktieniveau, omdat er dan rust komt in de verhouding tussen vraag, en aanbod.

Om zich tegen het 'leuren' te wapenen, sloten aannemers in het verleden onderlinge opzetcontracten ${ }^{53}$.

Het opzetcontract, ook wel prijsafspraak of prijsregeling genoemd, beperkt zich tot de afspraken over de hoogte der te bepalen opzetten en moeten worden onderscheiden van mededingingsregelingen in die zin, dat de mededingingsregelingen ${ }^{44}$ een bredere funktie hebben, doordat zij ook de procedure tijdens het vooroverleg regelen. Op daartoe belegde voorvergaderingen vond prijsvergelijking plaats en werden afspraken gemaakt over de bedragen die elke potentiēle inschrijver op zijn aannemingssom moest zetten en bij de gunning moest uitbetalen aan zijn collega-

46 TK 1988-1989, 21 238, nr. 2, 9 (Notitie van de minister van VROM inzake de Nederlandse bouwnijverheid in de Europese Gemeenschap).

47 Mok (1987), 46.

4s TK 1991-1992, 22 360, nr. 2, 18 (laatste Nota Bouwprognoses 1991-1996).

49 COB/SER (1989), 54 v. Dit onderzoek noemt daarnaast nog 11 andere factoren die de concurrentiepositie van de Nederlandse industrie mede bepalen. Geconcludeerd wordt dat er nog slechts in geringe mate sprake van een Eurọpese bouwnoarkt. Mobilisatiekosten en kennis van nationale bouwvoorschriften en produktenspecificaties zijn beperkende factoren voor de activering van de Europese bowwmarkt (t.2.p., 64).

so Zie. over de mogelijkheden van een continu verlopend bouwproces Kindt (1979) en P.G.A. Noordanus, W'. Roest, C.A. Adriaansens, Stagnatic en continuitteit in de bouw, Preadviezen voor de. Vereniging voor Bouwrecht, nr. 10. Deventer 1982.

51 Hierop wordt gewezen in de Toelichting op de: Erecode 1980.

s2 T.a.p., Deel E, hoofdstuk 1 .

53. Laus (1966), 95 noemt bet begrip opzetcontract een verzamelbegrip waar verschillende soorten contracten onder kunnen vallen.

34 Van Wassenaei (1990), 9 noemt dit 'indirecte aanbestedingsregelingen' waarbij het gaat om regelingen die het terrein van vraag en aanbod bestrijken. Zulks in tegenstelling tot de 'directe aanbestedingsregelingen' die zich bewegen op het terrein van aanbod en aagvaarding. 
ontstaan en de problematiek van de prijs- en opzetafspraken, die bij bouwbedrijven gebruikelijk zijn, samenhangt met cen reeks van knelpunten, die zich in verband met de boupproduktie en de verhoudingen op de bouwmarkt voordoen $^{70}$. Het positieve aspect van de aanhestedingsregelingen is volgens hem dat bij het vooroverleg bepaalde procedures en normen in acht worden genomen. Dat wil niet zeggen dat de aanbestedingsregelingen ook rechtstreeks kunnen bijdragen aan een bevredigende oplossing van de meer fundamentele problemen. Daarvoor zijn structurele maatregelen nodig ${ }^{71}$. Ook. Spier staat in beginsel niet afwijzend tegen het opzetstelsel ${ }^{32}$.

De rijksoverheid beperkte zich oorspronkelijk tot het voeren van een misstandenbeleid, door concurrentiebeperkende mededingingsregelingen generiek onverbindend te verklaren (artikel 10 Wet economische mededinging) ${ }^{73}$. Voor het overige wachtte men de resultaten van de in ontwikkeling zijnde private mededingingsregelingen af. Ook het rapport van de Commissie De Vries (ook wel: Commisie Aanbestedingswezen) kon daarin geen verandering brengen.

In 1953 gaven de toenmalige Minister van Economische Zaken en zijn collega van Volkshuisvesting en Bouwnijverheid"4 opdracht aan de Commissie De Vries om een onderzoek te verrichten naar de structuur van het bouwbedrijf, de aanbesteding als vraagtechniek en de prijsvorming op de bouwmarkt. Doel van het onderzoek was om de opzetcontracten en de bij het sluiten daarvan gevolgde procedures kritisch door te lichten. In haar rapport stelde de commissie vast, dat aannemers ten gevolge van structurele factoren (zoals het voorcalculatierisico en produktiediscontinuitteiten) een relatief zwakke positie op de bouwmarkt innamen. Maar dat anderzijds ongereglementeerde opzetcontracten een gezonde prijsvorming in gevaar konden brengen. De oplossing voor deze problemen kon naar de mening van de commissie niet worden gevonden in directe eenzijdige ingrepen in de verhoudingen aan de aanbodzijde. Naast de mogelijkheid van het introduceren van een classificatiesysteem, werd voorgesteld om tot schriftelijke afspraken te komen: de zogenaamde mededingingsregelingen. Dit 'monument in de gedachtenvorming ${ }^{75}$ werd destijds - in 1958 - niet door het kabinet overgenomen.

In de lijn van dit misstandenbeleid paste de beperkte vraagstelling van staatssecretaris Van Son van Economische Zaken aan de Commissie economische mededinging (ook wel Commissie Van der Weijden; hierna: CEM) in $1971^{76}$, De CEM vatte haar taak gelukkig ruim op door de vraag in het bredere beleidskader inzake de techniek van de vraag en de regulering van het aanbod te plaatsen. $\mathrm{Zij}$ concludeerde, dat formele of informele aanbestedingsregelingen inherent waren aan de marktstructuur, zodat een verbod ten principale alleen tot illegale praktijken aanleiding zou geven ${ }^{77}$. En verder, dat het stelsel van (met name de openbare) aanbesteding, zonder contacten tussen de inschrijvers, een duidelijke tendens heeft om het prijspeil te drukken, beneden het niveau dat nodig is om de bedrijfstak van een redelijke rentabiliteit te verzekeren ${ }^{78}$. De CEM bepleitte daarom een tweesporenbeleid. Primair diende een specifiek op de marktstructuur en het aanbestedingswezen gericht over-

\%olshof (1973). 147.

7) Hulshof (1973), 154.

$n$ Spier (1981), 47.

3 Zie daarover kritisch CEM-rapport (1976), 15. Zie over deze praktijk Van der Loo (1969), 658-660.

74 Beschikking van de Ministers van Economische Zaken en van Wederopbouw en Volkshuisvesting van 13 november 1953, no. K 1576 ZK, Directoraat-Generaal van de Handel en Nijverheid/DO, gepubliceerd in Gst 1953, 5255.

7S CEM-rapport (1976), 12. Voor een kritische bespreking van het rapport zie men Zonderland (1959), $66 \mathrm{v}$.

76 Adviesaanvraag van 21 januari 1971, Stert. 25 januari 1971, 16. Zie over de (te) beperkte vraagstelling Jak (1976), 843.

$n$ CEM-rapport (1976), 23-24. Zie ook S. 1986, 676, 13 (Nota vau Toelichring bij Besluit mededingingsregelingen in de bouw).

n CEM-rapport (1976), $16 \mathrm{en} 24$. 
heidsbeleid te worden ontwikkeld, terwijl zij slechts een complementaire rol toedichtte aan het mededingingsbeleid. Voor een generieke onverbindverklaring zou alleen plaats zijn voorzover de mededingingsregelingen verder gingen dan strikt noodzakelijk moest worden geacht voor de correctie van bouwmarktstructurele deficiënties ${ }^{79}$. Doorzichtiger aanbestedingsprocedures en criteria voor de selectie en de gunning zouden het motief voor het instandhouden van onderlinge prijsafspraken zoveel mogelijk moeten wegnemen en omgekeerd werd van beperking en verbetering van die prijsafspraken een positief effect verwacht op de bereidheid van opdrachtgevers om over te gaan tot verbetering en uniformering van de informatie aan het uitvoerend bouwbedrijf ter gelegenheid van een aanbesteding ${ }^{80}$.

In een in juli 1977 aan de bouwministers uitgebracht rapport van een ambtelijke werkgroep werd het advies van de CEM van 1975 ten aanzien van de mededingingspolitieke voorstellen (informatie aan de aanbesteder, rekenvergoeding, prijscorrectie, prijsverbetering, directieleveringen, preferentieverlening, tijdsduur opzetafspraken) nader uitgewerkt. Het zou dan nog tot 1 april 1987 duren voordat de overheid met het Besluit mededingingsregelingen in de

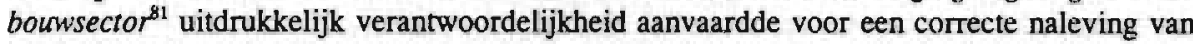
de prijsafspraken. Deze algemene maatregel van bestuur intervenieërde daadwerkelijk (onder andere door het verbod van de contramelding ${ }^{82}$ en het begrenzen van de diverse opzetten ${ }^{83}$ ) in de gereglementeerde prijsregelingen en opzetcontracten, waarbij de deelname aan een inschrijving wordt geregeld. Uitgangspunt vormde de erkenning van specifiek bouwmarktstructurele oorzaken, waardoor de aannemer in een zwakkere positie kan komen te verkeren. Prijsoverleg werd daarom niet a priori onaanvaardbaar geacht, maar omdat zij gemakkelijk zou kunnen ontaarden in het afschermen van de bouwmarkt voor buitenstaanders en daardoor tot vervalste concurrentieverhoudingen zou kunnen leiden, werd reglementering noodzakelijk gevonden $^{84}$. Het Besluit mededingingsregelingen in de bouw had een looptijd van vijf jaar en zou op 1 april 1992 expireren, tenzij bij nadere wet anders zou worden bepaald (artikel 10, lid 4 WEM).

Hoewel in het evaluatierapport ${ }^{85}$ werd geconcludeerd dat het Besluit van kracht moest blijven, lag het blijkens de Memorie van Toelichting bij het wetsvoorstel tot verlenging van de werking van het Besluit mededingingsregelingen in de bouwsector ${ }^{86}$ in het voomemen van staatssecretaris mevrouw Van Rooij om op korte termijn te komen tot regeling van de aanbesteding in een Besluit mededingingsregelingen aanbestedingen, dat qua systematiek

7 CEM-rapport (1976), 16-17. Slagter (1986), 82 spreekt in dit verband van een 'condiriekartel'

* Kritisch over de uitgangspunten van het CEM-rapport Klijn en Koolma (1985), 433.

81 Besluit van 29 december 1986 tot onverbindendverklaring van een aantal bepalingen in mededingingsregelingen aangaande het aannemersoverleg in de bouwsector, S. 1986, 676. Gewijzigd bij S. 1991, 475. Over dit Besluit uitvoering preadvies Slagter (1986).

n Zie art. 10 Besluit. Contramelding kan ertoe kan leiden dat tijdens een voor-voorvergadering aannemers al tot onderlinge afspraken komen. In die zin reeds CEM-rapport (1976), 41-42.

Zie artt. 2, 3 en 5 Besluit. In die zin ook rapport CEM-rapport (1976), 28-35.

S. 1986, 676, 16 (Nota van Toelichring bij Besluit).

ts Aangeboden aan de leden van de Tweede Kamer bij brief van 30 september 1991. TK 1991-1992, 22 093, nr. 3. Evaluatie besluit mededingingsregelingen in de bouwsector. Eindrapport uitgebracht aan de Directie Mededinging Directoraat-Generaal voor Diensten, Midden- en Kleinbedrijf van het Ministerie van Economische Zaken, Amsterdam 2 juli 1991. Zie hierover S. 1994, 55, 9-10.

u TK 1991-1992, 22 406, nr. 3, 2 (Memorie van Toelichting). 
vergelijkbaar is met het Besluit voor de horizontale prijsregeling ${ }^{87}$. Het gaat dan om onverbindendverklaring van alle mededingingsregelingen ter gelegenheid van een aanbesteding met de mogelijkheid van ontheffing en vrijstelling (verbodsregime) ${ }^{88}$. Inmiddels is dit Besluit ${ }^{89}$ in werking getreden en vervangt het sindsdien het Besluit mededingingsregelingen in de bouw. Krachtens het nieuwe besluit zijn onder meer rekenvergoedingen (artikel 3 Besluit) en prijsoverleg ter vaststelling van inschrijfcijfers (artikel 4 Besluit ${ }^{90}$ ) verboden.

Aanvankelijk zou haar beleid, net als dat van haar voorganger oud-staatssecretaris Evenhuis $^{91}$, slechts tenderen in de richting van een verbodstelsel ${ }^{92}$. Alle prijsafspraken zouden in beginsel zijn verboden, tenzij de prijsregelende organisaties zouden bewijzen dat zij aan bepaalde ontheffingseisen voldeden. Evenhuis maakte daarbij onderscheid tussen bestuurlijkformele criteria en materiële ontheffingscriteria ${ }^{93}$. De bestuurlijk-formele criteria hadden onder meer betrekking op de afstemming op de Europese regelgeving (met name artikel 85 EG). De materiële ontheffingscriteria waren gelegen in een evidente onevenwichtigheid in de concurrentieverhoudingen, zoals de aanwezigheid van relatief hoge offertekosten, de aanwezigheid van een relatief groot aantal inschrijvers per werk, waardoor veel kansen op het verwerven van opdrachten worden gemist, de grote concurrentiedruk en de wenselijkheid van een ruim en gedifferentieerd aanbod. Alleen zwaarwegende argumenten zouden uitzonderingen kunnen rechtvaardigen. Dergelijke (materiële) argumenten, zo meende de toenmalige staatssecretaris, waren er voor wat betreft de bouwsector in engere zin: de toeleverings- en nevenbedrijven zouden buiten deze ontheffing vallen. De rekenvergoeding kwam daarmee voor ontheffing in aanmerking. Extra voorwaarde voor ontheffing was dat de vergoedingen niet hoger zouden zijn dan de werkelijk gemaakte kosten ${ }^{94}$. Naderhand ontstonden nieuwe inzichten met betrekking tot de regeling van de mededinging in de bouwsector ${ }^{95}$. Blijkens de parlementaire geschiedenis heeft staatssecretaris Van Rooij zich voor het ontwerpen van de algemene maatregel van bestuur (mede) laten leiden door de uitkomsten van de evaluatie van het Besluit mededingingsregelingen in de bouw en de uitkomsten van een tweetal procedures bij de Europese Commissie ${ }^{\$ 6}$. Met name de gewijzigde systematiek is daarvan een

"7 Zie TK 1990-1991, 22 093, nr. 4, 8 en nr. 9, 6 en TK 1991-1992, 22 406, nr. 6, 2 over de systematische verhouding tot bet Besluit horizontale prijsbinding (Besluit van 4 februari 1993, S. 1993, 80), $13-14$.

TK 1990-1991, 22 093, nr. 1, 9 (Brief van de staatssecretaris van Economische Zaken inzake het mededingingsbeleid).

* Het Besluit houdende onverbindendverklaring van bepalingen in mededingingsregelingen inzake aanbesteding ( $S$. $1994,55)$ trad op 1 juni 1994 in werking. Vgl. Van de Meent (1994), CS143 v.

* Behoudens het bepaalde in artikel 4, lid 2 en de artikelen 5 en 6 Besluit. Zie bierover $\$ .1991,55,16$.

91 TK 1986-1987, 19 700, XIII, nr. 118 (Activiteitenplan mededingingsbeleid).

92 TK 1990-1991, 22 093, nr. 2, 11, 17-18 (UCV Economische Zaken 18 juni 1991 inzake het mededingingsbeleid).

93 TK 1988-1989, 20 800, XIII, nr. 85, 5-6 (Verslag van een mondeling overleg).

4. TK 1988-1989, 20 800, XIII, nr. 85, 7 (Verslag van een mondeling overleg).

95 TK 1991-1992, 22 406, nr. 3, 3 (Memorie van Toelichting inzake de verlenging van de werking van het Besluit mededingingsregelingen in de bouw).

* TK 1991-1992, 22 406, nr. 3, 4 (Memorie van Toelichting). Men zie voorts TK 1991-1992, 22 406, nr. 6, 1 (Nota naar aanleiding van het Verslag) en TK 1991-1992, 22 406, nr. 7, 2 (Brief van de staatssecretaris van Economische Zaken) alsmede Hand. II 27 februari 1992, 58-3713. 
direct gevolg. Bij de toepassing van de ontheffingsgrond werd sindsdien aangesloten bij de algemene ontheffingsbepaling in artikel 85 , lid $3 E G^{97}$.

Wat de beide Europese procedures betreft, was daar allereerst de procedure op grond van artikel 85 EG inzake (onder meer) de vraag of de Uniforme Prijsregelende Reglementen van de Vereniging van Samenwerkende Prijsregelende Organisaties (SPO) waren aan te merken als overeenkomsten of besluiten in de zin van artikel 85, lid $1 \mathrm{EG}^{98}$. En of het UPR en de Erecode in aanmerking kwamen voor ontheffing krachtens artikel 85, lid 3 EG. Volgens de Europese Commissie was het UPR in strijd met de Europese mededingingsregels ${ }^{\text {p }}$. Tegen deze beschikking is op 13 april 1992 door de SPO beroep aangetekend bij de President van het Gerecht van Eerste Aanleg van de Europese Gemeenschappen met de bedoeling de ten uitvoerlegging van de beschikking van de Europese Commissie op te schorten, totdat uitspraak zou zijn gedaan in de bodemprocedure ${ }^{100}$. Een dergelijke beschikking kwam af op 16 juli 1992, waarbij op diverse punten de tenuitvoerlegging van de beschikking werd opgeschort ${ }^{101}$. In het verweer van de Nederlandse aannemers tegen de beschikking van de Europese Commissie speelt het leurargument een belangrijke rol. Admiraal ${ }^{y 2}$ wijst dit leurargument af als oorzaak van de problemen die zich voordoen bij de toepassing van aanbestedingen op de bouwmarkt. Volgens hem wijzen de feitelijke marktresultaten niet in de richting van een systematisch leurgedrag. De naarvoren gebrachte argumenten mochten niet baten: het Gerecht van Eerste Aanleg gaf de Europese Commissie op alle fronten gelijk ${ }^{103}$.

Een tweede procedure op grond van artikel 169 EG liep tegen de Nederlandse Staat. Door het vaststellen van het Besluit mededingingsregelingen in de bouw en enkele bepalingen in het UAR 1986 zou de Nederlandse regering, volgens de Europese Commissie, in strijd met haar verdragsverplichtingen een mededingingsregeling, die in strijd is met de verdragsregels, expliciet toestaan, ondersteunen, respectievelijk bevorderen. De voortgang van deze tweede procedure zou opnieuw worden bezien na afronding van de procedure op grond van artikel 85 EG ${ }^{104}$. Nadat de Europese Commissie de eerder genoemde beschikking met betrekking tot de UPR had vastgesteld, heeft overleg tussen de Nederlandse overheid en de Commissie er toe geleid dat de laatste (nog) geen aanleiding heeft gezien in deze procedure verdere stappen te ondernemen. Aangenomen mag worden dat daarbij met name de voorgenomen en inmiddels gerealiseerde beleidswijzigingen een rol zullen hebben gespeeld.

En ook wat de systematiek in de Wet economisch mededinging (WEM) betreft, (b)lijkt Europa over de langste adem te beschikken. Het wetsvoorstel tot wijziging van de WEM gaat uit van het Europese verbodstelsel en bevat artikelen, die ertoe strekken dat in alle sectoren, dus ook in de bouwsector en aanverwante sectoren, horizontale prijsbinding onverbindend

97 TK 1991-1992, 22 093, nr. 1, 10 (Brief van de staatssecretaris van Economische Zaken). Men zie over de vrijstellingsmogelijkheden TK 1992-1993, 22 093, nr. 9, 6-7 (Brief van de staatssecretaris van Economische Zaken).

98 Zie de daarop betrekking hebbende schriftelijke vraag nr. 2043/88 van Europarlementariër P. Dankert inzake de prijsvormingspraktijken in de Nederlandse bouwwereld en het antwoord van Commissaris Brittan, $\mathrm{Pb} 89 / \mathrm{C}$ 174/37).

99 Beschikking van 5 februari 1992, IV/31.572 en 32.571 - Bouwnijverheid in Nederland, Pb 7 april 1992, Nr. L 92/1 (92/204). Ook opgenomen in BR 1992, 476 v. Zie over de 'Mogelijke gevolgen EC-heschikking mededingingsregelingen in de bouw', het daaraan gewijde themanumner in BR 1993, 1 v. met bijdragen van Braakman (1993), 1-12; Slagter (1993), 13-25; Jacobsen Jensen (1993), 25-32; Van den Berg (1993 a), $32-44$; Van Wassenaer (1993 a), 44-54 en Bleeker (1993), 54-60. De rechtspraak sloot zich snel aan bij het oordeel van de Europese Commissie. Zie Rb Rotterdam 23 okt. 1992, BR 1993, 84.

${ }_{100}$ Zaak T-29/92 R.

${ }^{101}$ Beschikking President GEA 16 juli 1992, BR 1992, 723 v., Jur. 1992, 2161

${ }^{102}$ Admiraal (1993), 584-585. Volgens Admiraal, en ik steun hem daarin, zijn de bezwaren van de Europese Commissie tegen het UPR ideologisch getint. Zie over bet UPR en de daaraan 'gehechte' regelingen, Van den Berg (1991). Rb. Rotterdam, 23 oktober 1992, BR 1993, 84 heeft het systeem van de bescherming van de rechthebbende bij niet gelijktijdige prijsaanbieding en een opzetovereenkomst betreffende een rekenvergoeding en een organisatiebijdrage in strijd geoordeeld met artikel 85 EG en daarmee nietig verklaard. En v.w.b. de rekenvergoedingen in strijd met art. 85, lid 1 EG, zie men Hof 's-Hertogenbosch 19 april 1994, BR 1994, 702.

103 GEA 21 febr. 1995, zaak T-29/92 (SPO/ Commissie), BR 1995, 333, NJ 1995, 546.

104 TK 1991-1992, 22 406, nr. 6, 4 (Nota naar aanleiding van het Verslag). 
is met een mogelijkheid van ontheffing ${ }^{105}$. De meerderheid van de Sociaal-economische raad is inmiddels voorstander van een consequente overstap naar dit verbodstelsel ${ }^{106}$.

\section{Conclusie}

Gebleken is dat de marges voor een nationaal mededingingsbeleid bijzonder smal zijn en de ruimte om te komen tot een 'positieve ordening' uiterst beperkt ${ }^{107}$. Of zoals de staatssecretaris het zegt:

'De ruimte voor ontheffing en vrijstelling wordt in feite bepaald door de uitkomst van het bodemgeschil (geschil tussen SPO en Europese Commissie (zie hiervoor); HN). Als de Europese Commissie in het gelijk wordi gesteld is er de facto weinig ruimte voor ontheffing of vrijstelling. De weg die ons dan rest om toch nog enige ordening in de markt aan te brengen is gelegen in de mogelijkheid dat het Uniforme aaanbestedingsreglement (UAR) voor overheidsaanbesteders een bepaling bevat tegen het leuren' ${ }^{10 \%}$.

Met het nagenoeg wegvallen van het mededingingsspoor komt - nog meer dan voorheen - het accent te liggen op de ordeningsaspecten (dat wil zeggen de gevolgen voor de bouwmarktverhoudingen) van het aanbestedingsbeleid. Met name het grote marktaandeel van de overheid betekent dat haar handelen belangrijke consequenties heeft voor de vraag en aanbodverhoudingen op deze markt en voor de continuïteit van de bouwproduktie. Voor de overheid betekent dit, dat zij alleen al om die reden een doorzichtig aanbestedingsbeleid zou moeten voeren. Aannemers kunnen daardoor inschatten of het zinvol is om min of meer uitgebreid te calculeren, en dus kosten te maken, en al dan niet bedrijfspotentieel vrij te houden voor het geval de opdracht aan hen zal worden verleend. Alleen een vooraf kenbaar beleid zal kunnen bijdragen aan het voorkomen van een 'jungle' van ondoorzichtige opzetregelingen, wat een voorwaarde vormt voor effectieve concurrentie. Een onderzoek naar de grondslagen van het aanbestedingsbeleid zou een bijdrage kunnen leveren aan de verdere ontwikkeling van dit ordeningsaspect van het aanbestedingsbeleid.

\section{Aanbestedingen en Europese integratie}

\section{Het streven naar een gemeenschappelijke markt}

De aanbesteding van werken is niet louter meer een zaak van nationale aard. Integendeel. Met de totstandkoming op 25 maart 1957 te Rome van het Verdrag tot: oprichting van de Europese Economische Gemeenschap ${ }^{109}$ werd een ontwikkeling in gang gezet die moet gaan leiden tot een vergaande marktintegratie van de bij het verdrag aangesloten lidstaten. Daarnaast is de communautaire samenwerking gericht op het geleidelijk nader tot elkaar brengen

${ }^{105}$ TK. 1992-1993, 22 093, nr. 8 (B.rief van de staatssecretaris van Economische Zaken inzake het mededingingsbeleid).

105 Advies nieuwe Mededingingswet 1994, 's-Gravenhage 21 oktober 1994. Vgl. Mok (1994), 467-480, Ottervanger en Nijhuis (1994), 481 v. en Ham (1994), 492 v.

ion Mok (1983), 677.

10 Hand. II 27 febr. 1992, 58-3713. Hierover positief Van den Berg (1993 a), 34.

109 Trb. 1957, 91 (Nederlandse tekst). Het oorspronkelijk EEG-verdrag is laatstelijk gewijzigd bij het Verdrag betreffende de Europese Unie (Verdrag van Mastricht) van 7 februari 1992 (i.w.tr. 1 november 1993). Er is thans sprake van het Verdrag tot oprichting van de Europese Gemeenschap (hierna: EG). 
van het economisch beleid der lidstaten in de mate waarin dit ter bereiking van de doelstellingen van het verdrag noodzakelijk is. Deze twee (intermediaire) doelstellingen zijn op hun beurt middelen om te komen tot het hoogste doel: de ontwikkeling van nauwere betrekkingen tussen de in de Gemeenschap verenigde Staten. Een gemeenschappelijke markt ontstaat echter niet vanzelf: de bestaande coördinatiemechanismen op de nationale markten moet daarvoor worden aangevuld met activiteiten gericht op het doen ontstaan van een dergelijke binnenmarkt. Voorzover zulks nodig is om de instelling en het functioneren van de gemeenschappelijke markt te realiseren, moeten daartoe de wettelijke en bestuursrechtelijke bepalingen der lidstaten op elkaar worden afgestemd.

Formeelrechtelijk behoort het primaire EEG-recht en het daarop gebaseerde secundaire recht (zoals richtlijnen) tot het volkenrecht. Echter, in de loop der tijd heeft het gemeenschapsrecht zich, met name door toedoen van het Europese Hof van Justitie (hierna: het Hof), naar zijn inhoud ontwikkeld tot een binnen het recht der internationale. organisaties op zichzelf staande rechtsorde, ten behoeve waarvan de lidstaten ten dele hun soevereiniteit hebben beperkt. Deze rechtsorde is, volgens constante jurisprudentie ${ }^{110}$, bij de inwerkingtreding van het EEG-verdrag in de afzonderlijke nationale rechtsordes opgenomen: de lidstaten en hun onderdanen moeten deze interne rechtsorde respecteren. Dit omvat tevens het respect voor de (Europese en nationale) grondrechten. Verreweg de belangrijkste consequentie van de aanvaarding van een dergelijke communautaire rechtsorde is dat het verdragsrecht cen van het nationale recht onafhankelijke positie heeft verkregen, zonder dat er nog aan het volkenrecht behoeft te worden gerefereerd $^{\mathrm{II}}$. Deze autonomie van de communautaire rechtsorde uit zich op tweeêrlei wijze: in de voorrangspositie van het gemeenschapsrecht boven nationaal (constitutioneel) recht en in de (verticale) rechtstreekse werking, van de verdragsbepalingen. Het voorrangsbeginsel houdt in dat de lidstaten hebben te aanvaarden dat gemeenschapsrecht steeds voor gaat boven cen regeling van nationale (constitutionele) status en origine. (Verticale) rechtstreekse werking houdt in dat particulieren onder bepaalde voorwaarden rechtstreeks beroep kunnen instellen voor hun nationale rechters, waarbij zij naar de desbetreffende communautaire regelgeving kunnen verwijzen ${ }^{112}$. De toevoeging 'verticaal' betekent dat het gaat om verplichtingen van de Staat in rechtsbetrekkingen tot de burger (de 'particulier') ${ }^{13}$. Ook aanbestedingsrichtlijnen - waarover uitvoeriger in de hoofdstukken drie en vier - kunnen rechtstreekse werking heb$\operatorname{ben}^{114}$.

Het EEG-verdrag omschrijft het begrip gemeenschappelijke markt niet. Volgens artikel 9 EG is de Gemeenschap gegrondvest op een douane-unie welke zich uitstrekt over het gehele goederenverkeer en welke zowel het verbod meebrengt van in- en uitvoerrechten en van alle heffingen van gelijke werking in het verkeer tussen de lidstaten als de invoering van een gemeenschappelijk douanetarief voor hun betrekkingen met derde landen (artikel 18 en volgende EG). De Gemeenschap is echter veel meer dan alleen een douane-unie. Kapteyn en Verloren van Themaat ${ }^{115}$ geven de volgende, zeer algemene, omschrijving: een markt waar iedere marktdeelnemer onder niet kunstmatig vervalste concurrentievoorwaarden vrij is te investeren, te produceren, te werken, te kopen, te verkopen of diensten te verlenen of te betrekken daar waar de economische voorwaarden de gunstigste zijn. De belangrijkste elementen van deze uitgebreide omschrijving zijn terug te vinden in de voortvarende jurisprudentie van het Hof.

${ }^{110}$ Standaardarresten in deze zijn zaak 26/62 (Van Gend \& Loos) en zaak 6/64 (Costa/ENEL).

III Zaken 90 en $91 / 63$ (Zuivelprodukten).

${ }^{112}$ In de literatuur wordt soms onderscheid gemaakt tussen rechtstreekse werking en rechtstreekse toepasselijkheid. Dit laatste begrip betekent dat bet Europese recht zonder tussenkomst ('transformatie') van de nationale wetgever in de nationale rechtsorde wordt opgenomen. Maar dat betekent niet dat de bepalingen vok steeds rechtstreeks werken. Hierover Kapteyn - VerLoren van Themaat (1987), 228.

${ }^{113}$ De horizontale rechtstreekse werking, waarbij uitsluitend particulieren zijn betrokken, bijift in het kader van dit onderzoek naar het overheidsbeleid buiten beschouwing.

114 Kapteyn - VerLoren van Themaat (1989), 468. Zie o.m. zaak 76/81 (Transporoute) en zaak 31/87 (Beentjes).

Its Kapteyn - VerLoren van Themaat (1987), 59. 
Deze coürdinatie van de wettelijke en bestuursrechtelijke bepalingen der lidstaten vormt een overgangsfiguur tussen negatieve integratie ${ }^{116}$ (het opheffen van belemmeringen die bestaan tussen de nationale economieën) en gemeenschappelijk beleid (positieve integratie ${ }^{117}$ ) en kan worden getypeerd als 'harmonisatie ${ }^{118}$. Onderliggend beginsel is het principe van nondiscriminatie naar nationaliteit (artikel $6 \mathrm{EG}^{\mathrm{HS}}$ ). Dit artikel verbiedt niet alleen formele discriminatie, maar - volgens constante jurisprudentie - ook alle vormen van verkapte discriminatie die in feite tot het zelfde resultaat leiden. De verdragsbepalingen inzake de vrijheden op het gebied van het verkeer van personen, goederen, diensten en kapitaal vormen de nadere uitwerking van dit beginsel. Deze bepalingen staan op zichzelf niet in de weg aan de zogenaamde omgekeerde discriminatie, waarbij de lidstaat de eigen onderdanen achterstelt hij de onderdanen uit andere lidstaten. Omgekeerde discriminatie kan door nadere uitvoeringsbepalingen (bijvoorbeeld richtlijnen) worden voorkomen. Artikel $8 \mathrm{EG}$ gaf het oorspronkelijke ontwikkelingstempo aan waarin de gemeenschappelijke markt, na een zekere overgangsperiode, tot stand zou moeten komen.

Voor het doen ontstaan van een gemeenschappelijke markt voor overheidsaanbestedingen zijn met name de activiteiten genoemd in artikel 3, onder $\mathrm{c}$ en $\mathrm{h}$ EG relevant. Volgens artikel 3, onder c EG dienen de lidstaten de hinderpalen voor het vrije verkeer van personen, diensten en kapitaal te verwijderen (negatieve integratie). Deze activiteit is verder uitgewerkt in Titel III van het Tweede Deel van het Verdrag. Daaruit blijkt dat de vestigingsvrijheid (artikel 52 en volgende EG) alsmede de vrijheid van het dienstenverkeer (arikel 59 en volgende EG) behoren tot de grondslagen van het gemeenschapsrecht. De artikelen 54 , lid 2 (vestiging) en 63, lid 2 EG (vrij dienstenverkeer) bevatten in dit verband een opdracht tot het uitvoeren van Algemene Programma's voor de opheffing van de beperkingen van de vrijheid van vestiging $^{120} \mathrm{in}$ de ophetfing van de beperkingen van het vrij verrichten van diensten ${ }^{121}$.

Er zijn geen afzonderlijke verdragsbepalingen met betrekking tot de overheidsaanbesteding. De Algemene Programma's gaven in de overgangsperiode houvast voor een uitwerking van de artikelen 52 v. en 59 v. EG, waardoor de toen bestaande beperkingen op het vrije vestiging en het dienstenverkeer moesten worden opgeheven. De precieze juridische status van de Algemene Programma's uit 1962 is niet eenvoudig te duiden. In de richtlijnen zijn de verboden discriminatoire maatregelen veelal gecatalogiseerd, waardoor zij een beperktere betekenis lijken te hebben dan de catalogus in de Algemene Programma's. Sommige auteurs veronderstellen dat aan deze Algemene Programma's ook nu nog enige juridische waarde toekomt ('soft law'). De arresten Thieffry (zaak 71/76) en Defrenne II (zaak 43/75) lijken tit te bevestigen. Anderen zijn daarentegen van mening dat de rol van de Algemene Programma's is vitgespeeld sinds - na de overgangsperiode (31 december 1969) - de artikelen 52 en 59 EG rechtstreekse werking hebben gekregen.

${ }^{116} \mathrm{Bij}$ voorbeeld art. 12 en $30 \mathrm{EG}$.

$11 \mathrm{Bij}$ voorbeeId ar, $100 \mathrm{~A}$ EG.

${ }^{11}$ In die zin ook TK 1988-1989, 21 238, nr. 2, 2 (Notitie inzake de Nederlandse bouwnijverheid in de Europese gemeenschap). Vgl. Timmermans (1980), 408 en 411 over de integratie gebonden funktie van de harmonisatie. Over dit begrip ook Vignes (1990), 358. McGee - Weatherill (1990), 578 v.: zij gaan in op de problemen rond het harmonisatieproces. Volgens hen moet politieke hesluitvorming het antwoord geven op de vraag welke belemmeringen nog wel en welke niet meer verenigbaar zijn met de interne markt. Zij wijzen daarbij op de rol van de gevestigde belangen die zullen willen vasthcuden aan hun machtspositie.

$" 19$ Met het Verdrag betreffende de Europese Unie is an. 7 EEG-verdrug hernummerd tot art. 6 EG.

$120 \mathrm{~Pb} \mathrm{~L} \mathrm{nr.} \mathrm{2,} 15$ januari 1962, 36-62.

$121 \mathrm{~Pb}$ L nr. 2, 15 januari 1962, 32-62. 
Artikel 60 slot EG maakt het verschil duidelijk tussen de vestigingsvrijheid en het vrij verrichten van diensten: voor de vestigingsvrijheid is blijvende vestiging in een derde-lidstaat nodig om aldaar economisch werkzaam te kunnen zijn, terwijl voor de vrijheid van dienstverlening slechts sprake is van een tijdelijk verblijf in de derde-lidstaat, waar de dienst wordt verleend. Het verschil moet anderzijds ook weer niet worden overtrokken ${ }^{122}$. Uitwerking van dit instrumentarium vindt plaats via de liberalisatierichtlijn (richtlijn $71 / 304^{123}$ ).

Deze richtlijn moet niet alleen door de rijksoverheid worden toegepast, maar onk dour de territoriale fichamen, waartoe de gemeenten worden gerekend. Deze liberalisatierichtlijn is van toepassing op alle overheidsaanbestedingen ongeacht de geraande buuwsom. Hieronder vallen volgens artikel 2 , lid I van de richtlijn alle werkzuamheden die zijn vermeld in Bijlage I van het Algemeen Programma voor de ophefting van de beperkingen van de vrijheid van vestiging, klasse 40 van de systematische indeling van industrietakken in de Europese Gemetenschappen (NICE) ${ }^{124}$. Deze NICE-indeling is inmiddels vervangen door een lijst gebaseerd op de Algemene systematische bedrijtsindeling in de Europese Gemeenschappen (NACE) ${ }^{125}$. Volgens Winter ${ }^{126}$ heeft deze richtlijn vooral hetekenis als 'providing interpretative guidance with regard to the scope ' van de artikelen 54 en $63 \mathrm{EG}$.

Uitgangspunt van de richtlijn (artikel 1) is het beginsel van non-discrininatie naar nationaliteit, hetgeen een uitwerking vormt van het rechtstreeks werkende artikel 6 EG. Iedere aannemer die afkomstig is uit éún der lidstuten dicut in heginsel gelijke kansen te hebben op het verkrijgen van een overheidsopdracht en dient zich daartoe in alle lidstaten vrijelijk te kunnen vestigen. Er dient zo een eind te komen aan juridische en feitelijke barrières ${ }^{127}$ voor het vrij verrichten van diensten op het gebied van de overheidsopdrachten. Na de genoemde afbakening van het toepassingsgebied in het tweede artikel wordt in artikel 3 het non-discriminatiebeginsel verder uitgewerkt. Techuische specificaties mogen geen enkele clausule met een discriminerende uitwerking bevatten ${ }^{12 x}$; zij worden tehter niet geacht deze werking te hebben wanneer zij door het voorwerp van de opdracht worden gerechtvaardigd. Bovertlien moeten alle begunstigden onder dezelfde voorwaarden als de eigen onderdanen kunnen beschikken over de voorzieningsmogelijkheden (kredieten en dergelijke), waarop de Staat controle kan uitoefenen en waarover zij moeten heschikken om hun opdracht te kunnen uitvoeren.

Artikel 3, onder h EG bepaalt dat de nationale wetgevingen - in de mate waarin dit vonr de werking van de gemeenschappelijke markt noodzakelijk is - nader tot elkaar worden gebracht. Artikel 57 EG bevat daartoe een instructienorm voor de Raad en de andere EG-instellingen om te voorzien in richtlijnen inzake de coördinatie van de wettelijke en bestuursrechtelijke bepalingen der lidstaten betreffende de toegang tot werkzaamheden, anders dan in loondienst en de uitoefening daarvan. Doel is om door middel van het recht van vrije vestiging de toegang tot werkzaamheden in andere lidstaten te vergemakkelijken. Artikel $66 \mathrm{EG}$ verklaart artikel 57 EG eveneens van toepassing op het vrije dienstenverkeer. Uitwerking vindt plaats in de coördinatierichtlijn (richtlijn 71/305), waarop in de hoofdstukken 3 en 4 nog uitvoerig zal worden ingegaan.

\footnotetext{
122 Kapteyn - VerLoren van Themaat (1989), 429.

$122 \mathrm{~Pb} \mathrm{~L} \mathrm{nr.} \mathrm{185.} 16$ augustus 1971. 1-4.

134 Zie daarover de preambule bij de richtijn.

123 Zie Bijlage II bij de richtlijn.

Winter (1991), 744.

127 Zie Dijkhuis (1973), 73. Hij wijst op de verschillende aanbestedingsstelsels in Nederland, Belgiê en Frankrijk en de daaruit volgende feitelijke verschillen. Ook de (de)centralisatie speelt daarbij een rol.

${ }^{128} \mathrm{Zie}$ de verwijzing naar de Algemene Programma's in de preambule van richtlijn $71 / 304$. Verder Bijlage II, richtlijn 71/305.
} 


\section{Tegenvallende resultaten}

Blijkens het Witboek ${ }^{129}$ was het anno 1985 met de openstelling van de markt voor overheidsopdrachten, als één van de belangrijke factoren voor het gemeenschappelijke marktbeleid, slecht gesteld. De overheidsopdrachtenmarkt werd in alle Europese landen afgeschermd en er werd in feite vrijwel uitsluitend aan nationale aannemers gegund. De coördinatierichtlijn droeg in de praktijk weinig bij aan het ontstaan van een gemeenschappelijke (bouw)markt en had nauwelijks invloed op de intracommunautaire handel. Volgens statistische gegevens zou er sprake zijn van een minimaal gebruik van de richtlijnen 71/304 en 71/305; nauwelijks $20 \%$ van de totale overheidsuitgaven in het door de richtlijnen bestreken beleidsveld werd in het Europese Publikatieblad bekendgemaakt ${ }^{130}$. Uit het Tweede Rapport van de Commissie aan de Raad en het Europese Parlement over de invoering van het Witboek-beleid inzake de voltooiing van de interne markt blijkt dat in 1986 slechts $2 \%$ van de overheidsopdrachten in de Gemeenschap werd gegund aan bedrijven uit andere lidstaten en plusminus $75 \%$ van de werken aan nationale bedrijven werden opgedragen 'for whom the tenders are tailor-made'131.

Uit resultaten van een onderzoek dat in de periode 1983-1984 werd verricht, worden door de Commissie een aantal corzaken aangewezen, die het falen van richtlijn $71 / 305$ zouden kunnen verklaren ${ }^{132}$.

1. De ongunstige economische omstandigheden als gevolg van recessie op de nationale niveaus, zouden aanbestedende diensten extra gevoelig maken voor de druk vanuit de binnenlandse aamemerswereld. En ook de gebrekkige wijze warop de technische harmonisatie in het verleden had plaatsgevonden speelt een rol bij de geringe marktintegratie. Daamaast werd gewezen op de beperkte mogelijkheden tot samenwerking tussen ondernemingen in de diverse lidstaten ${ }^{133}$;

2. Opdrachten werden vrijwel steeds uitsluitend opgedragen aan binnen de lidstaat gevestigde bedrijven, waardoor er nauwelijks grensoverschrijdend werd aanbesteed. Daarbij wordt aangetekend dat opdrachten wel eens aan plaatselijke dochterondernemingen van ondernemingen uit een derde-lidstaat gegund werden. En ook gunning aan combinaties van nationale aannemers met aannemers uit derde-lidstaten kwam voor;

3. Als derde oorzaak werd gewezen op de extensieve uitleg van hetgeen behoort tot de uitgesloten sectoren, het opzettelijk splitsen van werken orn de richtlijn te ontduiken (hetgeen is verboden in artikel 2 richtlijn 71/305) alsook het bewust onjuist toepassen van de procedures in de richtlijn. Zo werd de niet-openbare procedure vaak gebruikt orn de eigen markt voor aannemers uit derde-lidstaten gesloten te houden, en werd er een ongerechtvaardigd beroep gedaan op uitzonderlijke aanbestedingsprocedures. Verder kwamen er in de aankondiging van de aanbesteding discriminerende administratieve, financiële, economische of technische voorwaarden voor. Gegadigden en inschrijvers werden voorts op onwettige gronden uitgesloten, bij voorbeeld door het vaststellen van discriminerende selectie- en gunningscriteria of door vestiging te eisen in het aanbestedende land. Door een ruime uitleg van de in artikel 9 richtijn $71 / 305$ genoemde uitzonderingsgevallen, werd ongeveer een kwart van alle opdrachten na een onderhandse aanbesteding gegund ${ }^{\text {t3 }}$.

${ }^{129}$ Completing the internal market. White Paper from the Commission to the European Council (Milan, 28 and 29 june 1985), $\operatorname{COM}(85) 310$ tinal, 14 june 1985.

$130 \operatorname{COM}(85) 310$ final, 14 june 1985, 23 en Europese Commissie, Overheidsopdrachten in een ééngemaakte economische ruimte, Europese Documentatie 1988, 10.

131 $\operatorname{COM}(87) 203$ final, 11 mei 1987, 16, alinea 49. Zie voor cijfermateriaal ook TK 1987-1988, 20 596, nrs. 1-3, 5 (Memorie van Toelichting). Het gehruik van de term 'tailor-made' heeft ingang gevonden, vgl. de schriftelijke vraag van Richard Simmonds (ED) aan de Commissie, nr. 2976/90, Pb 18 januari 1991, 91/C 177/31. Antwoord in $\mathrm{Pb} 8$ juli $1991,91 / \mathrm{C} 177 / 15$.

19 Vgl. COM(86) 375 final, 19 juni 1986, 3-5. Zie over deze tekorkomingen Flamme, Flamme (1988), 455 v.

130 Reeds Van Agtmaal (1971), 740.

1.4 Reeds Goudsmit (1973), 70-71. Zie ook Schlangen (1989), 27, noot 52. 
4. De richtiijn schoot verder tekort doordat er onvoldoende waarborgen waren die de gelijkheid tussen de bij de aanbesteding belanghebbende aannemers garandeerden. Er werd vaak niet gepubliceerd wanneer zulks verplicht was, terwijl een adequaat controlemechanisme ontbrak;

5. Als laarste factor werden de uitgesloten sectoren (vervoersector; produktie, distributie en vervoer van water en energie (vergelijk artikel 3, leden 4 en 5 richtlijn 71/305) genoemd. Een belangrijk deel van de overheidsmarkten stond daardoor niet open voor concurrentie op communautair niveau.

\section{Streven naar een interne markt: economische noodzaak}

$\mathrm{Na} 1984$ lijkt er sprake van een kentering. Sindsdien kennen de Europese regeringen hoge. prioriteit toe aan het doen ontstaan van een interne markt, waarbij het openstellen van de markt voor overheidsopdrachten voor de uitvoering van werken als eén der belangrijkste voorwaarden wordt genoemd ${ }^{135}$. De macro-economische betekenis van de markt voor overheidsopdrachten is dan ook zeer aanzienlijk. De effectieve vraag in de periode 1983-1984 in de 10 lidstaten inzake alle overheidsopdrachten werd geschat op ongeveer 200 miljard ECU/ jaar, dit is 8 à $9 \%$ van het communautaire bruto binnenlands produkt. Het grootste deel daarvan was afkomstig van de gedecentraliseerde overheden ${ }^{136}$. In het Tweede Rapport van de Commissie aan de Raad en het Europese Parlement over de invoering van het Witboekbeleid inzake de voltooiing van de interne markt, schatte de Europese Commissie de totale waarde van de overheidsaanbestedingen in de Gemeenschap zelfs op 400 miljard ECU/ jaar $^{137}$. De versplintering van de Europese markt betekende dat de producenten te hoge kosten doorberekenden aan de consument/ belastingbetaler. De Gemeenschap verloor volgens de Cechinni-analyse ${ }^{138}$ daarom steeds meer terrein aan haar voornaamste concurrenten: de Verenigde Staten en Japan. De kosten van deze verspilling, als gevolg van de verbrokkeling van de markt, werden in het rapport voor het gebied van de overheidsopdrachten geraamd op plusminus 21,5 miljard ECU op jaarbasis (uitgedrukt in prijzen van 1988).

In de verschillende studies uit die tijd van de Europese Commissie over het kostenaspect liet de Commissie zich optimistisch uit over de finaneiële voordelen van de marktintegratie. Het Adkins-rapport, dat overigens niet op de Nederlandse markt betrekking heeft, gaf voor de EG5-overheidsaanschaffingenmarkt ${ }^{139}$ in 1984 het cijfer 102 miljard ECU op een totaal van 384 miljard ECU (15\% EG5-bruto nationaal produkt) ${ }^{100}$. Het kostenvoordeel wordt geschat op 0.9 miljard ECU, hetgeen overeenkomt met $0,9 \%$ van de EG5-overheidsaanschaffingen, op een totaal van 12,7 miljoen ECU (prijzen 1984) ${ }^{141}$.

193 Zo in Kopenhagen in 1982 tijdens een bijeenkomst van de Europese Raad, in 1984 in Fontainebleau, in december 1984 in Dublin en in Brussel in maart 1985. Vgl. Swann (1992).

136 Mededeling van de Commissie aan de Raad. De markt voor overheidsopdrachten in de Gemeenschap, COM(86) 375 def., 19 juni 1986, 1.

157 European Commission, Second Report from the Commission to the Council and the European Parliament on the implementation of the Commission's White Paper on completing the internal market, $\mathrm{COM}(87) 203$ final, 11 mei 1987, 16, alinea 49.

${ }^{136}$ Research on the 'Cost on non-Europe'. Basic Findings, Volume V part A en B. Document van de Commissie van de Europese Gemeenschappen, Brussel, Luxemburg 1988 (W.S. Atkins Managment Consultants). Zie ook Europese Commissie. Bureau voor officięle publikaties. Eén grote markt zonder grenzen. Europese documentatie, 4-1987, 12-13 en 3-1988, 14.

${ }^{139}$ Met EGS worden bedoeld Belgie, Frankrijk, Bondsrepubliek Duitsland, Italiê en het Verenigd Koninkrijk.

140 Atkins (1988) weergegeven in CPB (1989), 4.

${ }^{14} \mathrm{I}$ M. Catinat, A. Italianer, Achèvement du marché intérieur - effets primaires microćconomiques et mise en oevre dans les modèles macroéconomiques, Cornmission of the European Communities, Directorate General for Economic and Financial Affairs (Document II/140/88), Brussels 1988, Tabel II.1 weergegeven in CPB (1989), 6. Zie ook kanttekeningen bij deze cijfers op p. 7 van het CPB-rapport. 
Het CPB-rapport uit 1989 schatte de omvang van de Nederlandse overheidsopdrachtenmarkt in 1985 in de bouw op zo'n $f$ 10,7 miljard (op een totaal van $f 50$ miljard). Het kostenvoordeel door de liberalisering van de markt werd door het CPB geschat op ongeveer $f 230$ miljoen, hetgeen overeenkomt met zo'n half percent van de totale omvang van overheidsopdrachten (gegevens 1985) ${ }^{142}$. Toepassing van de Europese modellen (Aukins en Catinat-Italianer) zou voor Nederland uitkomen op een kostenvoordeel van plusminus $f$ 1,7 miljard. Het CPB-rapport verklaarde dit grote verschil, doordat de eigen berekeningswijze corrigeert voor een aantal specifiek Nederlandse karakteristie$\mathbf{k e n}^{143}$. Onbetwist lijkt echter dat openstelling van de nationale markten kostprijsdrukkend zal werken. Bovendien leidt liberalisering tot een groei van de exportmogelijkheden. Voor de bouw werd dit geschat op $f 200$ miljoen $^{144}$. De verwachtingen over een aanzienlijke verhoging van de exportactiviteiten voor het uitvoerend bouwbedrijf moeten blijkens de notitie 'De Nederlandse bouwnijverheid in de Europese Gemeenschap' yan de minister van VROM niet worden overschat ${ }^{145}$. De redenen voor deze terughoudendheid zijn gelegen in de bouwmarktstructuur waarop zeer veel kleine bedrijven werkzaam zijn en de regional gerichte cultuur van de bedrijfstak. Uit de cijfers zoals deze worden gepresenteerd in de studie 'Prospects of the Dutch Construction Sector in the EC Single Market' ${ }^{146}$ lijkt het desondanks te gaan om een potentieel aanzienlijke markt. Geschat wordt dat ten hoogste $5 \%$ van alle Europese bouwactiviteiten zullen worden verricht door niet-nationale bouwbedrijven, hetgeen overeen komt met ongeveer $f$ 50 miljard. Ter vergelijking: de produktiewaarde van in 1988 in Nederland uitgevoerde bouwwerken bedroeg ruim $f 45$ miljard.

Met de verklaringen van de verschillende regeringsleiders ${ }^{147}$ was het klimaat geschapen waarin de Europese Commissie het als haar taak ging beschouwen 'to achieve a single market by 1992 thereby creating a more favourable environment for stimulating enterprise, competition and trade ${ }^{148}$. In het Programma van de Commissie voor 1985 dat op 6 maart 1985 aan het Europese Parlement werd gepresenteerd, stond de doelstelling van 'a fully unified internal market by 1992' centraal. Tijdens de zitting op 29 en 30 maart maakte het Europese Parlement de visie van de Commissie tot de hare. Het eerder in 1984 gedane voorstel van de Commissie ${ }^{149}$ werd breder uitgewerkt en vormde de aanzet tot het Witboek. Het Witboek gaf het voorgenomen interne marktbeleid aan met een daarbij behorend tijdschema om uiterlijk op 1 januari 1993 de voltooiing van de interne markt (artikel 8A $\mathrm{EG}^{1.50}$ ) te kunnen realiseren. Voor de overheidsopdrachten is dan met name het bepaalde in de artikelen 54, lid 2, 57, lid 2, 59 en $63 \mathrm{EG}$ in verband met artikel $8 \mathrm{~A} \mathrm{EG}^{15 !}$ van belang. Met hetrekking tot de toegang tot werkzaamheden, anders dan in loondienst en de uitoefening daarvan, diende de Raad, vóór de afloop van de overgangsperiode, richtlijnen vast te stellen inzake de coördinatie van de wettelijke en bestuursrechtelijke bepalingen der lidstaten. Uit de samenhang met de Europese Akte blijkt dat besluiten hierover met gekwalifi-

${ }^{12} \mathrm{CPB}(1989), 10-11$.

${ }^{143}$ CPB (1989), 10.

i4 CPB (1989), 14.

is TK 1988-1989, 21 238, nr. 2, 8 (Notitie inzake de Nederlandse bouwnijverheid in de Europese Gemeenschap).

tof Dutch export opportunities on EC-markets up to the year 2000. Prospects for the Dutch construction sector. Prognos AG, Basel, january 1989 i.o.v. Exportbevorderings- en voorlichtingsdienst EVD.

${ }^{147} \mathrm{Zo}$ in Kopenhagen in 1982 tijdens een bijeenkomst van de Europese Raad, in 1984 in Fontainebleau, in december 1984 in Dublin en in Brussel in maart 1985.

tos $\operatorname{COM}(85) 310$ final, 14 juni 1985, 1. Dit document staat bekend als het Withoek of ook het Cockfield-rapport. Over de economische en politieke problemen van de interne markt zie men Padoa-Schioppa (1987). Over de juridische aspecten Mattera (1990).

${ }^{149}$ Consolidation Programme, COM(84) 305 final, 13 juni 1984.

${ }_{150}$ Toegevoegd bij art. 13 Europese Akte (Trb. 1986, 63 en Pb EG Supplement 2/86).

151 Artt. 54, lid 2 en 57, leden 1 en 2 EG zijn gewijzigd bij artikel 6 Europese Akte. Art. 57, lid 2, 2e zin EG is gewijzigd bij artikel 16, lid 2 Europese Akte. Art. 59, 2e al., is gewijzigd bij art. 16, lid 3 Europese Akte. 
ceerde meerderheid van stemmen kunnen worden genomen (artikel 100A EG ${ }^{152}$ ). Volgens lid 3 zal de Europese Commissie bij haar in lid 1 bedoelde voorstellen op het gebied van de volksgezondheid, de veiligheid, de milieubescherming en de consumentenbescherming uitgaan van een hoog beschermingsniveau.

\section{Wijzigingsvoorstellen}

In het Aktieprogramma aan het slot van de Mededeling aan de Raad van 19 juni $1986^{153}$ werd voorgesteld om de coördinatierichtlijn te wijzigen. Procedures zouden doorzichtiger moeten worden, procedures voor het plaatsen van overheidsopdrachten in de uitgesloten sectoren moesten worden geharmoniseerd, de bestaande markt voor overheidsopdrachten moest verder worden opengesteld en er diende een verscherpt toezicht te worden ontwikkeld om de naleving van de toen reeds geldende bepalingen te garanderen.

Al in december 1986 deed de Commissie een concreet wijzigingsvoorstel ${ }^{154}$, dat dezelfue aangescherpte maatregelen bevatte als eerder in het voorstel tot wijziging van de leveringenrichtlijn ${ }^{155}$ waren genomen, en toen nog door de Raad waren afgezwakt. Uit het Tweede Rapport van de Commissie aan de Raad en het Europese Parlement over de invoering van het Witboek-beleid inzake de voltooiing van de interne markt ${ }^{156}$, blijkt dat de Europese Commissie ook meer haast wilde maken met de implementatie dan nog was voorzien in het orspronkelijke tijdschema van het Witboek. Toch duurde het nog tot 14 oktober 1988 voordat de Raad met een gemeenschappelijk standpunt kwam ${ }^{157}$. Op 4 april 1989 verscheen het opnieuw behandeld voorstel voor een richtlijn van de Raad, met daarin de opvatting van de Commissie ten aanzien van het gemeenschappelijk standpunt van de Raad en de amendementen die daarop door het Europese Parlement in tweede lezing op 15 februari 1989 waren aangenomen ${ }^{158}$. Deze amendementen werden door de Commissie aanvaard en in het gewijzigde voorstel verwerkt. De inspanningen van de Europese Conmissie resultcerden uiteindelijk in het vaststellen door de Raad van richtlijn $89 / 440$ tot wijziging van richtlijn $71 / 305^{15 \%}$ met als doel de totstandkoming van een interne markt voor overheidsupdrachten

\footnotetext{
152 Toegevoegd bij art. 18 Europese Akte.

${ }^{159}$ COM(86) 375 final, 19 juni 1986, 5 v.. De preambule van richtlijn 71/305 preludeerde reeds op de mogelijke aanpassing van de richtlijn, nadat hiermee enige ervaring zou zijn opgedaan.

is. Voorstel voor een richtlijn van de Raad tot wijziging van Richtlijn 71/305 betreffende de coordinatie van de procedures voor het plaatsen van overheidsopdrachten voor de uitvoering van werken, COM(86) 679 def., 23 december 1986. Vgl. Van Nouhuys (1987), $416 \mathrm{v}$.

iss Zie richtlijn 88/295, $\mathrm{Pb} 20$ juni 1988, nr. L $127 / 1$ v. tot wijziging van richtlijn 77/62 en tot intrekking van sommige bepalingen van richulin 80/767. Zie inmiddels codificatie in richtlijn 93/36, Pb 9 augustus 1993 , rr. L 199/54 v. Over de GATT-achtergronden zie men Bovis; (1993), 83 v.

${ }^{156} \mathrm{COM}(87) 203$ final, 11 mej 1987, 16.

${ }^{157}$ Gemeenschappelijk standpunt bepaald door de Raad op 14 oktober 1988 met het oog op de vaststelling van de richtlijn van de Raad tot wijziging van richtlijn 71/305 betreffende de coördinatie van de procedures voor het plaatsen van overheidsopdrachten voor de vitvoering van werken, Raadsstuk 8970/88, Brussel 31 oktober 1988.

158 COM(89) 141 def. - SYN 71, 4 april 1989.

${ }^{159}$ Richtlijn van 18 juli 1989 , Pb L nr. 210,21 juli $1989,1 \mathrm{v}$
} 
in de loop van de periode eindigend op 31 december $1992^{160}$. Inmiddels zijn de wijzigingen gecodificeerd in richtlijn $93 / 37^{161}$.

\section{Handhaving}

Ingevolge richtlijn $89 / 665^{162}$ dient te worden voorzien in de instelling van doeltreffende rechtsmiddelen om onregelmatigheden te bestraffen en vergoeding van geleden schade als gevolg van schending van de Europese aanbestedingsregelgeving te verkrijgen ${ }^{163}$. Hoewel volgens de preambule van richtlijn $71 / 305$ de gemeenschappelijk toezicht éen van de beginselen is die aan de coördinatie ten grondslag ligt, heeft het tot eind 1989 geduurd voordat een dergelijke richtlijn het licht zag. De handhavingsrichtlijn voorziet in een procedure waardoor op de inachtneming van de aan de coördinatie ten grondslag liggende beginselen gemeenschappelijk toezicht kan worden uitgeoefend. De richtlijn geldt voor alle overheidsopdrachten inzake bouwwerken (en leveranties). Omdat bij aanbestedingsconflicten snelheid van het grootste belang is, legt de richtlijn het accent op doeltreffende en snelle beroepsprocedures, die schendingen van het Europese aanbestedingsrecht, of van de nationale voorschriften waarin dat recht is omgezet, ongedaan maken. Volgens artikel 1 richtlijn $89 / 665$ i.v.m. artikel 2 , lid 7 richtlijn $89 / 665$ dienen de lidstaten voor dergelijke snelle en doeltreffende en voor ieder toegankelijke procedures zorg te dragen. Mogelijke juridische acties van benadeelde ondernemingen zijn: voorlopige maatregelen, inclusief de maatregel ter opschorting van een aanbestedingsprocedure of van de uitvoering van het aanbestedingsbesluit, nietigverklaring van onwettige besluiten, en schadevergoeding. Van de oorspronkelijke mogelijkheid voor de Europese Commissie om te interveniëren in nationale beroepsprocedures als ook om zelf een aanbestedingsbesluit te kunnen opschorten is afgezien. De Europese Commissie kan wel, indien er bij de toewijzing van de opdracht een duidelijke schending van de Europese regels heeft plaatsgehad, de betrokken lidstaat daarover inlichten en vragen om deze onregelmatigheid ongedaan te maken (artikel 3). De lidstaat dient de Europese Commissie te laten weten of ze aan dit verzoek tegemoet komt of in het andere geval de reden geven waarom ze niet aan het verzoek toegeeft ${ }^{164}$.

Het lijkt er voorshands echter nog niet op dat de richtlijnbepalingen steeds nauwlettend worden gevolgd ${ }^{165}$.

100 Zie voor enkele hoofdlijnen Boncompagni (1990), 322 v. en Wedekind (1992), 87-90.

tot Richtlijn van 14 juni $1993, \mathrm{~Pb}$ L $199 / 54$ v., d.d. 9 augustus 1993 . Ook op het terrein van de zogeheten vitgestoten sectoren zijn inmiddels richtlijnen tot stand gekomen. Voor een overzicht van de regelgeving in de diverse richtlijnen zie men: Weiss (1993), Cox (1993), Part B. 75 v., Rees (1994), 169-188, Wedekind (1990 a), 811 en Wedekind (1992), 90.

102 Richtlijn van de Raad van 21 december 1989 houdende de coördinatie van de wettelijke en bestuursrechtelijke bepalingen betreffende de toepassing van de heroepsprocedures inzake het plaatsen van overheidsopdrachten voor leveringen en voor de uitvoering van werken, Richtlijn 89/665, Pb 30 december 1989, nr. L $395 / 33$ v. Over de achtergronden Coleman - Marque (1989), 546-553.

${ }_{163}$ Zie voor precedent richtlijn 64/221 van 25 februari 1964, $\mathrm{Pb} 4$ april 1964, 56, 850/64, m.n. artt. 8 en 9 . Vgl. Toelichting bij COM (86) 679 def., 23 december 1986, 14.

144 Zie artikel 3 richtlijn 89/665. Verder Winter (1991), 750, noot 26.

165 Dat moge blijken uit een chronologisch lijstje van enkele in de vakpers verschenen artikelen: Simon Kooistra, Europese richtlijn met voeten getreden. Overheden vaak niet op de hoogte van aanbestedingsregels, NG 21/28 december 1990, 6 v.; EG-aanbestedingsnorm vele malen overschreden, Cobouw 4 november 1992, nr. 205; Overheid besteedt te weinig Europees asn, Cobouw 5 november 1993, nr. 207; Jos Kuys, Nederlandse overheden 


\section{Conclusie}

De behoefte aan het onderhavige proefschiftonderzoek is ook nog om een andere dan de aan het slot van de vorige paragraaf genoemde reden groot. Het streven naar een interne markt veronderstelt een steeds verdergaande afstemming van het plaatselijke, gedecentraliseerde aanbestedingsbeleid op een bovennationaal en in de toekomst wellicht een regionaal niveau. Daaruit wordt wel de conclusie getrokken dat er dan geen ruimte meer zou zijn voor een eigen aanbestedingsbeleid van de lagere overheden. Dat lijkt me een wat voorbarige schrikreactie, hetgeen ik in de loop van dit onderzoek zal proberen aan te tonen. Wel is zeker dat het overheidsaanbestedingenbeleid steeds vaker met de Europeesrechtelijke normen in aanraking zal komen. In die richting wijst ook het aangekondigde strengere handhavingsbeleid van de Europese Commissie ${ }^{166}$. Bij eventuele geschillen zal de nationale rechter moeten toetsen aan het communautaire recht. Een onderzoek naar de grondslagen van het aanbestedingsbeleid kan behulpzaam zijn bij het toetsen van de rechtmatigheid van de uitgangspunten van het gevoerde beleid.

\section{De aanbestedingsovereenkomst}

\section{Privaatrecht ...}

In literatuur en rechtspraak wordt de vraag of door het toepasselijk worden van het UAR op een aanbesteding enige rechtsverhouding tussen de aanbesteder en de inschrijver ontstaat positief beantwoord. Tot de voorstanders van die opvatting behoren in ieder geval Zonderland $^{167}$, Goudsmit ${ }^{188}$, Spier ${ }^{169}$, Rozemond ${ }^{170}$, Van Werven ${ }^{171}$, Donders ${ }^{172}$, en Van den Berg ${ }^{173}$. Hoewel de schrijvers het erover eens zijn dat er een rechtsverhouding ontstaat,

\section{$165 \rightarrow$}

ontduiken nog steeds massaal aanbestedingsregels, NG 21/28 mei 1993, 16 v. en Elisabetia R. Manumza, Effectiviteit van de communautaire regelgeving inzake overheidsopdrachten voor de uitvoering van werken, VU Amsterdam 1993, waarover in Stcrt. 1994, 12 (Schending EG-richtlijnen aanbestedingen) en met reactie van minister Andriessen (Economische Zaken) op Kamervragen in Stcrt. 1994, 24 (Geen sprake van schending EGaanbestedingsrichtlijnen).

${ }^{166}$ Zie schriftelijke vraag or. 2976/90, Pb 18 januari 1991, 91/C 177/31 van Richard Simmonds (ED) en antwoord van de heer Bangemann in $\mathrm{Pb} 8$ juli 1991, 91/C 177/15 onder verwijzing naar richtlijn 89/665. Zie verder antwoord van de heer Bangemann (Pb 5 nov, 1992, C 92/289/49) op vragen (nr. 1225/92, Pb 21 mei 1992, 92/C 289/97) van Gijs de Vries (CDR). Zie voor de (on)mogelijkheden van de Europese Commissie om een art. 169. zaak aan te spannen tegen een lidstaat Martín (1993 a), 40 v. Zie ook Arrowsmith (1994), CS 130. Verder Coleman en Margue (1989), 546-553. Over dit onderwerp ook Vervaele (1993). Verder Gormley (1994), 158164.

${ }^{167}$ Cremers/ Zonderland, Bouwrecht (losbladige), Deel A-I, nr. 6.

${ }^{16}$ Goudsmit (1974), 231.

${ }^{160}$ Spier (1981), $61 \mathrm{v}$.

170 Reeds Rozemond (1982), 116-117. Recent Rozemond (1987), 94.

17 Van Werven (1985), 44.

in Zie diens noten onder RvA 31 maart 1987, nr. 12.753, BR 1987, 552, nr. 14.011, RvA 1 augustus 1989, BR 1990,65 en RvA 16 januari 1990, nr. 13.665, BR 1990, 646.

${ }^{173}$ Van den Berg (1987 b), 93. Hij spreekt van een voorbereidende hulpovereenkomst vowrafgaand aan het eigenlijke aannemingscontract. Het begrip voorbereidende hulpovereenkomst onderscheidt zich van het pacturn de contrahendo, doordat de aanbesteder niet verplicht is het werk op te dragen (vgl. art. 24, lid 1 UAR 1986). Recentelijk 
verschillen zij in de typering die zij daaraan geven. Zonderland spreekt van een overeenkomst met een tamelijk zwakke werking ${ }^{174}$. Goudsmit acht voldoende dat vastgesteld wordt dat er verbintenissen ontstaan en maakt zich minder druk over de precieze bron. Eis is slechts dat de toepasselijkverklaring van dat reglement een vermogensrechtelijk effect heeft. Spier opperde in zijn proefschrift voorzichtig de mogelijkheid van een 'voorovereenkomstje' ${ }^{175}$. Van Nouhuys ${ }^{176}$ lijkt Spier daarin te willen volgen: tussen partijen, die een privaatrechtelijke overeenkomst willen sluiten is sprake van een door de goede trouw beheerste precontractuele rechtsverhouding, terwijl de overheidsaanbesteder zich daarbij tevens dient te richten naar de algemene beginselen van behoorlijk bestuur. Deze goede trouw houdt in dat partijen zich ten opzichte van elkaar fatsoenlijk moeten gedragen, dat wil zeggen dat zij hun gedrag mede moeten laten bepalen door de gerechtvaardigde belangen van de wederpartij $^{177}$. Dezelfde gedachte komen we ook tegen in het proefschrift van De Jong over de gronduitgifte door de gemeente, een onderwerp dat in zekere opzichten verwantschap vertoont met de gemeentelijke aanbesteding ${ }^{178}$. Ook Van Erp meent dat er sprake is van een door de goede trouw beheerste rechtsverhouding ${ }^{179}$. Rozemond, Van Werven, Donders en Van den Berg spreken van een obligatoire rechtsverhouding ${ }^{180}$. Volgens Van der Vlies heeft het UAR betrekking op privaatrechtelijk (overheids)handelen. Het UAR verleent niet rechtstreeks rechten aan burgers, en zeker geen rechten van publiekrechtelijke aard, aldus Van der Vlies.

Recentelijk heeft Van den Berg gewezen op de meerwaarde die aan het veronderstelien van een obligatoire overeenkomst toekomt boven een door de goede trouw beheerste relatie ${ }^{181}$. Dit is allereerst de directe integrale binding aan het 'uitgesponnen normencomplex' van het UAR. Met name is het voor hem de vraag of de goede trouw de betrokkenen bindt aan de formele voorschriften van het UAR, in gevallen waarin niet tevens een materiële onregelmatigheid kan worden aangetoond. Hij verwees daarbij naar het arrest Staat/ Has$\operatorname{ler}^{182}$. In die zaak oordeelde de Hoge Raad dat het aanbestedingsreglement is aan te merken als een naar buiten werkende, voor de rijksoverheid en de bij de aanbesteding betrokken aannemers bindende regeling, welke is uitgegaan van het openbaar gezag, dat de bevoegdheid daartoe ontleent aan de (Comptabiliteits)wet. Dat betekent dat het UAR als recht in de zin

${ }_{173} \rightarrow$

Van den Berg (1991), 24. De Kluiver en Mac Lean (1987), 6 v. (m.n. 23) wijzen m.i. op goede gronden het pactum de contrahendo als afzonderlijk begrip af. Het begrip voorbereidende overeenkomst benadrukt, dat het gaat om een zelfstandige overeenkomst die in chronologisch verband staan met andere, nl. de uiteindelijk beoogde, definitieve (aannemings)overeenkomst (vgl. t.a.p., 60).

174 Voor de grondslag van de leer van de contractuele normen met zwakkere en sterkere werking zie nen Zonderland (1974). Zie daarover nog Zonderland (1975), 259 waar hij spreekt over diligentiecontracten.

173 Koeman (1982), 396 was nog niet overtuigd van het bestaan van een dergelijk 'voorovereenkomstje'.

196 Van Nouhuys (1986), 15 en 45.

I7 HR 15 november 1957, NJ 1958, 67 m. nt. L.E.H.R. (Baris/ Riezenkamp).

178 De Jong (1984), 179.

179 Van Erp (1990), 298-303.

Zo ook de Raad van Arbitrage blijkens o.m. RvA 17 oktober 1989, nr. 12.930. BR 1990, 228 (als vervolg op RvA 31 maart 1987, nr. 12.753, BR 1987, 550 en RvA 27 juni 1988, nr. 12.930, BR 1989, 71)

181 Van den Berg (1991), 28-31.

18 HR 31 mei 1985, AB 1985, 480 m.nt. FHvdB, BR 1985, 788. Zie m.n. ook de uitvoerige conclusie van A-G Ten Kate. 
van artikel 99 Wet op de rechterlijke organisatie kan worden aangennerkt en dus voor cassatie in aanmerking kan komen. De betekenis daarvan is gelegen in de verhoogde rechtsbescherming van gegadigden en inschrijvers, doordat de uitleg van het reglement en de beoordeling van de juridische kwaliteit aan de Hoge Raad kan worden voorgelegd. Zo achtte de Hoge Raad het strikt vasthouden aan formele voorschriften (artikelen 18 en 19 UAR 1972) noodzakelijk uit een oogpunt van rechtsbescherming van de bij de aanbesteding betrokkenen. In de hier bedoelde zaak had Haarlem BV formeel niet juist ingeschreven en kon zij daarom gepasseerd worden door de hoger inschrijvende Hasler BV, terwijl toch moest worden aangenomen dat Haarlem BV te goeder trouw had gehandeld. Blijkens het arrest Stuyvers' Beheer/ Eugster $^{183}$ kan er een plicht bestaan tot dooronderhandelen op het moment dat partijen erop mochten vertrouwen dat in elk geval enigerlei overeenkomst tot stand zou komen. Dat zou bij de aanbesteding het moment zijn waarop de aanbesteder een inschrijver te kennen heeft gegeven, dat diens prijsaanbieding in principe aanvaardbaar is. Maar ook al eerder! In dat geval kan onmogelijk een onderhandelingsplicht worden gebaseerd op de goede trouw alleen. Volgens Van den Berg brengt een redelijke uitleg van het UAR in dat geval mee, dat het een aanbesteder die ontevreden is over het resultaat der inschrijvingen, niet vrijstaat onmiddellijk met derden in zee te gaan. 'De kennelijke bedoeling van het UAR om leuren te voorkomen vereist', aldus Van den Berg, 'dat de aanbesteder dan eerst op basis van reële onderhandelingen onderzoekt of toch overeenstemming kan worden bereikt met de inschrijver die volgens de toepasselijke eisen en criteria voor opdrachtverlening in aanmerking zou komen'184.

Volgens artikel 3 UAR 1972 gold als voorwaarde voor de toepasselijkheid van het reglement, dat in de algemene bekendmaking van de aanbesteding of in de uitnodiging tot inschrijving was vermeld dat de aanbesteding overeenkomstig het reglement zou moeten geschieden. In dat geval waren de bepalingen van het reglement van toepassing, voorzover daarvan niet uitdrukkelijk in de bekendmaking, de uitnodiging, het bestek, de nota van inlichtingen ${ }^{185}$ of het proces-verbaal van aanwijzing ${ }^{186}$ was afgeweken. Eenzelfde bepaling is opgenomen in artikel 2, lid 1 UAR 1986. Maar er is iets aan toegevoegd. Volgens het tweede lid wordt degene, die tegenover de aanbesteder blijk heeft gegeven voornemens te zijn op het werk in te schrijven of deel te nemen aan de selectie, geacht te hebben ingestemd met toepassing van de regeling in het reglement. Dat wil zeggen dat vanaf dat moment inschrijver en aanbesteder zich jegens elkaar binden tot de toepassing van het UAR 1986. In het voorontwerp-UAR 1985 kwam in artikel 3, lid 2 een vergelijkbare bepaling voor. In de Toelichting op dat artikel werd opgemerkt:

'Met de anpassing van artikel 3 wordt beoogd te voorzien in het tweezijdig van toepassing verklaren van het reglement op de opdrachtgever en anderszins bij de aanbesteding betrokkenen. Immers, het feit dat de apdrachtgever in de bekendmaking of uitnodiging mededeelt dat het U.A.R. van toepassing is, bindt een bij de aanbesteding betrokkene niet zonder meer. De betrokkene zal ermee moeten instemmen dat het U.A.R. zal worden toegepast. Pas

\footnotetext{
${ }^{183}$ HR 15 juni 1981, NJ 1982, 85 (Stuyvers' Beheer/ Eugster). De eis dat partijen 'over en weer mochten vertrouwen dat enigerlei contract in ieder geval uit de onderhandelingen zou resulteren' wordt in het arrest VSH/ Shell(NJ 1988, 1017) op twee manieren genuanceerd. Zie noot C.J.H. Brunner onder het arrest.

13 Van den Berg (1991), 31 onder verwijzing naar nr. 12. Zie ook a.w., 21.

Iss Eén of meer nota's, die van de zijdens de aanbesteder verstrekte inlichtingen zijn opgemaakt (art. 1 UAR: 1972).

is Het verslag waarin de bij de aanwijzing verstrekte gegevens zijn vastgelegd (ant. 1 UAR 1972).
} 


\section{Hoofdstuk 1}

nadat hij uitdrukkelijk of stilzwijgend heeft ingestemd met de toepassing van het reglement is hij jegens de opdrachtgever gebonden. (...) Met de in het tweede lid geformuleerde fictie wordt bereikt dat enigerlei handeling van de betrokkene jegens de opdrachtgever verricht in het kader van de desbetreffende aanbesteding na het moment van de bekendmaking of van de uitnodiging zal gelden als een al dan niet stilzwijgende toestemming van de betrokkene'.

Consequentie van de fictie in het tweede lid is dat het moment waarop partijen in de precontractuele fase jegens elkaar gebonden raken niet het moment van de inschrijving behoeft te zijn, maar daar vóor kan liggen ${ }^{187}$. Met Slagter en Van den Berg ${ }^{188}$ ben ik van mening dat pas kan worden aangenomen dat een gegadigde de toepasselijkheid van het UAR 1986 heeft aanvaard als zulks uit een concrete gedraging van zijn kant valt af te leiden. Van den Berg noemt als voorbeelden dat de gegadigde zich zonder protest tegen het van toepassing zijn van het UAR 1986 heeft aangemeld om deel te nemen aan de selectieprocedure of doordat een gegadigde zonder verdere bezwaren heeft ingeschreven. Door de aanvaarding van het aanbod ontstaat dan een (zelfstandige) aanbestedingsovereenkomst (artikel 6:217, lid $1 \mathrm{BW}$ ). Het is met de grondslag voor deze gebondenheid wonderlijk gesteld. Wanneer de rijksoverheid of een door het Rijk gesubsidieerde privaatrechtelijke instelling optreedt als aanbesteedster, geldt het UAR 1986 krachtens wettelijk voorschrift automatisch tussen de bij de aanbesteding betrokkenen.

Deze toepasselijkheid berust op het op artikel 34 Comptabiliteitswet gebaseerde Besluit aanbesteding van werken (BAW) van 6 april 1973, houdende regelen voor het plaatsen van opdrachten tot de uitvoering van werken (S. 1973, 202). Dit Besluit is laatstelijk gewijzigd bij Besluit van 30 mei 1994, S. 1994, 379 houdende wijziging van het Besluit overheidsaanbestedingen (overheidsopdrachten voor de uitvoering van werken en voor leveringen) ${ }^{193}$. Door deze wijziging vormt de Raamwet EEG-voorschriften aanbestedingen (S. 1993, 212) thans de basis voor de zgn. 'Europese aanbestedingen' op het gebied van de levering van goederen, de uitvoering van werken en het verrichten van diensten. Het BAW is nog slechts de grondslag voor de 'nationale' rijksaanbestedingen. Lange tijd vormde de Wet aanbesteding van werken lagere publiekrechtelijke lichamen de grondslag voor de 'Europese' aanbestedingen van de gemeenten. Deze wet werd ingetrokken op het moment van inwerkingtreding van de Raamwet ${ }^{(9)}$. Voor de liberalisatierichtlijn werd geen aanpassing van de nationale regelgeving noodzakelijk geacht ${ }^{19 !}$.

Treedt de gemeente op als aanbesteder dan zal het UAR 1986 pas gaan gelden als voldaan is aan de eisen die het UAR 1986 zelf stelt aan zijn toepasselijkheid: toepasselijkverklaring van het UAR 1986 door middel van een verklaring van de aanbesteder en instemming zijdens de gegadigde(n). In de woorden van Van den Berg: 'Afhankelijk van de hoedanigheid van de aanbesteder bindt dit reglement hetzij ipso iure, hetzij op grond van een afspraak daartoe van de bij een aanbesteding betrokkenen'192. Het UAR-EG 1991 kent een met artikel 3, lid 2 UAR 1986 vergelijkbare bepaling: ook het UAR-EG 1991 is toepasselijk in het geval de

${ }^{67}$ Van Nouhuys (1986), 38: 'kunstgreep;' Slagter (1986), 133: 'niet ontoelaatbare kunstgreep'; Van den Berg (1987 b), 92: 'misgreep'.

Is. Slagter (1987), 106; Van den Berg (1991), 25.

1*9 Gecodificeerd bij beschikking van 31 mei 1994, S. 1994, 380.

(wij Men zie Pijnacker Hordijk (1992 a), 100 over de Wet aanbesteding werken lagere publiekrechtelijke lichamen en Pijnacker Hordijk (1992 b), 678-680 over de Raamwet. Vgl. ook Van de Meent (1993), CS136. Zie over de implementatie van bindende EG-besluiten art. 1:7 v. Awb. Blijkens de parlementaire behandeling geldt deze regelgeving (ook) voor ricbtlijnen.

191 Aanhangsel Handelingen II, zitting 1972, 31 .

in Van den Berg (1991), 23. 
aannemer er tegenover de aanbesteder blijk van heeft gegeven te willen deelnemen aan het overleg over het werk en de voorwaarden ter gelegenheid van een onderhandelingsprocedure (artikel 3).

\section{... met een 'snufje' publiekrecht}

Volgens De Haan, Drupsteen en Fernhout behoort de aanbesteding van werken tot de categorie van de privaatrechtelijke overeenkomsten zonder meer ${ }^{193}$. Dat genoemde auteurs de aanbestedingsovereenkomst niet rekenen tot de categorie der beleidsovereenkomsten, kan mijns inziens hieruit worden verklaard, dat zij bij de aanbesteding het oog hebben op het resultaat van de aanbestedingsprocedure: de opdrachtverlening. Hun kan worden toegegeven dat het feit, dat de algemene beginselen van behoorlijk bestuur op deze overeenkomst van toepassing zijn, niet betekent dat er dáárom reeds sprake zou zijn van een privaatrechtelijke beleidsovereenkomst. Aan de opvatting dat er geen sprake is van een beleidsovereenkomst wordt evenwel later terecht door De Haan c.s. nog iets toegevoegd. Bij de aanbesteding van werken kunnen problemen ontstaan in verband met het beginsel van de rechtsgelijkheid, dat speciaal de overheid bij de opdrachtverlening in acht zou moeten nemen. In verband daarmee bestaat er toch 'zoiets als een aanbestedingsbeleid, hoewel dit in Nederland minder aan regeling is onderworpen dan bij voorbeeld in België en Frankrijk'. Kennelijk is dan de aanbesteding van werken niet alleen maar privaatrecht, en wordt de rechtsgelijkheid mede bepaald door 'zoiets als een aanbestedingsbeleid'. In de feestbundel ter gelegenheid van het afscheid van De Haan geeft ook Lubach ${ }^{194}$ als zijn mening te kennen, dat de aanbesteding valt onder de overeenkomsten over privaatrechtelijke bevoegdheden zonder beleidsaspecten. Ook Bloembergen ${ }^{195}$ gaat uit van een privaatrechtelijke verhouding. In overeenstemming met de opvatting in de literatuur, dat de aanbestedingsovereenkomst een gewone privaatrechtelijke overeenkomst is, wordt de aanbestedende overheid traditioneel beschouwd als een privaatrechtelijk handelend rechtspersoon, die een puur privaatrechtelijke rechtshandeling verricht $^{196}$. Het enige publiekrechtelijke aspect is de gedachte dat de overheid in beginsel steeds openbaar zou moeten aanbesteden. Dat wil zeggen dat de overheid in beginsel iedereen tot de inschrijving moet toelaten, enkele bijzondere gevallen daargelaten ${ }^{197}$. Achtergrond voor dit standpunt vormt de opvatting dat het openbaar aanbesteden het meest zuinige gebruik van overheidsmiddelen met zich meebrengt, dat de overheid daardoor aan een ieder gelijke kansen op de inschrijving biedt, dan wel dat daarmee de openbaarheid van de overheidsaanbesteding het best is gewaarborgd. Ook combinaties van deze opvattingen komen voor.

De Haan, Drupsteen en Fernhout ${ }^{198}$ geven drie oorzaken die deze privaatrechtelijke benadering zouden kunnen verklaren. Ten eerste is het privaatrecht het oudste ontwikkelde deel van het recht. In de tweede plaats ontbreekt er (nog) een algemene regeling van de over-

\footnotetext{
193 De Haan, Drupsteen, Fernhout (1986 a), 350.

19. Lubach (1989), 41-42.

198 Bloembergen (1992), 951 .

196 Volgens deze schrijver (t.a.p., 951) wordt in ons land niet gesproken over iets als cen marche des travaux publics, maar dat moet ik toch tegenspreken.

197 Zo Spier (1981), 26. Zie de mijns inziens terechte kritiek hierop van Van den Berg (1986), 32. Volgens Adriaansens (1981), 171 is sprake van de 'heersende gedachte'.

19 De Haan, Drupsteen, Fernhout (1986 b), 80.
} 
eenkomst in het bestuursrecht. En ten slotte is er geen algemene administratieve rechtspraak in geschillen betreffende de overheidseigendom en het overheidsovereenkomstenrecht. Het bestuursrecht heeft zich op deze punten nooit los kunnen maken van het privaatrecht. Toch is er wel wat gebeurd.

Tot yoor kort toetste de burgerlijke rechter het overheidsoptreden alleen direct asn het verbod van détournement de pouvoir $^{19}$ en aan het verbod van willekeui ${ }^{200}$. De overige algemene beginselen speelderi bij de beoordeling alleên een indirecte rol ${ }^{201}$. In het UAR 1972 was het bovendien aan het subjectieve ourdeel van de aanbestedter overgelaten welke aannemers werden geselecteerd en wie van hen voor de gunning van de opdracht in aanunerking kwam. Het bewijs van cen onredelijke belangenafweging was in de prakrijk dan ook niet eenvoudig te leveren, hetgeen mogelijk verklaart waarom er niet of nauwelijks geschillen aan de rechter werden voorgelegde?. Inschrijvers die het gevoel hadden dat zij tijdens de aanbesteding ongelijk waren behandeld, konden op grond van artikel $1401 \mathrm{BW}$ (oud) (thans art. 6:162 BW) schadevergoeding eisen ${ }^{203}$. Deze vergoeding kon bestaan in de kosten van onnodig onderzoek, winstderving en de kosten van de procedure ${ }^{204}$. De rechter kon ook de gunning verhinderen en/ of het werk doen uitstellen totdat een besiissing genomen was ${ }^{205}$, en de eis toekennen dat een gegadigde alsnog ten bestek zou worden gegeven ${ }^{206}$.

Algemeen wordt aangenomen dat sinds het arrest Amsterdam/ IKON ${ }^{207}$ sprake is van rechtstreekse toetsing aan de algemene beginselen van behoorlijk bestuur van door de overheid verrichte burgerrechtelijke rechtshandelingen. Ook zonder dat het gaat om 'typische' overheidscontracten ${ }^{208}$. Men zie thans artikel 3:14 BW en het complement in artikel 3:1, lid $2 \mathrm{Awb}$. Dat heeft bij voorbeeld tot gevolg dat de overheid niet steeds gebruik mag maken van de (burgerlijke) vrijheid om met anderen contracten te sluiten ${ }^{269}$. Daarop sluit ook de opvatting van Huygen aan. Deze beweert dat waar het gaat om privaatrechtelijk handelen het publiekrechtelijk tintje met zich mee kan brengen dat de overheid in de precontractuele fase minder vrijheid heeft bij de keuze van haar contractspartij ${ }^{210}$. Geconcludeerd moet worden dat waar aan de zijde van de overheid sprake is van contractsvrijheid, deze niet dezelfde betekenis heeft als die daaraan in het privaatrecht wordt gehecht.

Over de wijze waarop en de mate waarin de algemene beginselen van behoorlijk bestuur in de privatrechtelijke verhouding doorwerken bestaat in de literatuur overigens geen eensgezindheid $^{211}$. Droogleever Fortuyn ${ }^{212}$ is niet overtuigd van de extra betekenis die van toet-

\footnotetext{
19e HR 14 januari 1949, NJ 1949, 557 (Zandvoortse woonnimtevordering).

${ }^{204}$ HR 25 februari 1949, NJ 1949, $558 \mathrm{~m} . \mathrm{nt}$. Vesgens (Doetinchemse woonruimtevordering).

2m HR 4 januari 1963, NJ 1964, 202-204 m.nt. Beekhuis, ARB $596 \mathrm{~m} . \mathrm{nt}$. Stellinga, AA 1962/63, $138 \mathrm{~m} . \mathrm{nt}$. Van der Grinten (Landsmeer).

202 Toelichting op het UAR 1986, 23.

${ }^{203}$ Slagter (1987), 108. HR 16 januari 1981, NJ 1981, 426 en HR 18 juni 1982. NJ 1983, 723 (Plas/ Valiburg).

${ }^{204}$ Hof Arnhem 16 januari 1984, BR 1984, 357.

${ }^{204}$ Pres. Rb. Den Haag 26 januari 1983, BR 1986, 788 m.nt. J. Rozemond.

206 Pres. Rb.Roermond 18 augustus 1983, BR 1984, 162.

${ }^{207}$ HR 27 matart 1987, AB 1987, 273 m. nt. FHvdB, NJ 727 m.nt. Scheltema, Gst 6840 m.nt. De Moor-Van Vugt en Kobussen, BR 1987, 533 m.nt. P. de Haan en AA 1988, 111 v. m.nt. A.

${ }^{206}$ HR 15 maart 1991, NJ 1991, 399 (Körfer/ Heerlen).

209 Bij voorbeeld HR 12 januari 1990, NJ 1990, 766 (Staat/ Appels). Zie voor de overvloedige literatuur over de contractsvrijheid van de overheid Contractenrecht VIII (Spier), nr. 22 v.

${ }^{210}$ Huygen (1991), 15 ea 53.

211 Vgl. onder meer Verhey (1987), 1310-1311.

21 Droogleever Fortuyn (1970), 36 en Droogleever Fortuyn (1979), 39 v.
} 
sing aan de algemene beginselen van behoorlijk bestuur uitgaat bij privaatrechtelijke verhoudingen tussen overheid en burger. Volgens Bloembergen spelen de publiekrechtelijke en privaatrechtelijke beginselen een gelijkwaardige rol. Hij verwacht overigens meer heil van geschreven spelregels, zoals het $\mathrm{UAR}^{213}$. Spier wil de algemene beginselen steeds bij elk overheidshandelen een rol laten spelen ${ }^{214}$. Lubach acht de toetsing aan de algemene beginselen van behoorlijk bestuur juist bij de contractsweigering van bijzonder belang ${ }^{215}$. Nieskens-Isphording wil de betekenis van de publiekrechtelijke en privaatrechtelijke normen steeds opnieuw vaststellen aan de hand van de feitelijke casus. De specifieke invulling van de zorgvuldigheidsnorm kan, zo begrijp ik haar, dan meebrengen met name in onderhandelingsrelaties met de overheid, deze tot verder onderhandelen kan worden gedwongen ${ }^{216}$. Snijders ${ }^{217}$ houdt er een praktische opvatting op na: de algemene beginselen van behoorlijk bestuur bepalen, waar zij gelet op de aard van de rechtsverhouding van toepassing zijn, de inhoud van de eisen die volgen uit de privaatrechtelijke rechtsbeginselen. Diverse schrijvers $^{218}$ zijn van mening dat de publiekrechtelijke normen vooralsnog stringenter zijn dan de privaatrechtelijke. Kobussen ${ }^{219}$ bepleit dat de rechter bij de toetsing van de uitoefening van zowel privaatrechtelijke als bestuursrechtelijke bevoegdheden dezelfde maatstaven aanlegt, hetgeen zou betekenen dat het bestuur ook bij haar privaatrechtelijk optreden materieel aan het legaliteitsbeginsel wordt gebonden. Voor Van der Does ${ }^{220}$ is rechtstreekse toetsing aan de algemene beginselen vooral een terminologische kwestie. Voorheen plaatste de Hoge Raad de beginselen in de sleutel van het redelijkheidsbegrip. Op het moment dat dit wordt vervangen door een meer beperkt willekeurbegrip, moet het gelijkheidsbeginsel als afzonderlijke norm worden toegevoegd. De winst zit er volgens hem in, dat het misverstand wordt weggenomen als zou de civiele rechter de overheid meer ruimte laten dan de administratieve rechter.

Omstreden was verder of ook in de precontractuele fase de algemene beginselen van behoorlijk bestuur een rol kunnen spelen. Bekend was al dat ook precontractuele verhoudingen worden beheerst door wat destijds de goede trouw werd genoemd ${ }^{221}$. Recente rechtspraak lijkt wat dit betreft de grenzen ruim te willen trekken, getuige het arrest Zeeland/ Hoondert $^{222}$, ongeacht of de rechtsverhouding ook wordt beheerst door de redelijkheid en billijk-

${ }^{213}$ Bloembergen (1976), 6-7 en 22. Men zie ook Bloembergen (1992), 951.

${ }^{214}$ Spier (1981), 62-64.

${ }^{215}$ Recentelijk Lubach (1988), 424-425.

${ }_{216}$ Nieskens-Isphording (1986), 331-332. Zie wat dit onderhandelingsaspect betreft nog De: Kluiver (1992), nrs. 105 e.v. en nr. 159. Naast het bevel tot dooronderhandelen, kan z.i. worden gedacht aan het bevel aan bijvoorbeeld cen gemeente om in het licht van nieuwe gegevens tot hernieuwde besluitvorming over te gaan.

${ }^{217}$ Snijders (1988), 49 v. Met instemming geciteerd door Ackermans-Wijn (1989), 63.

${ }^{218}$ Simon (1988), 2; Lubach (1986), 16, die verwijst naar Van Buuren, in: Administratieve rechtsgangen (losbladige), par. 1.8.4.1.

${ }^{219}$ Kobussen (1989), 105-107.

220 Van der Does (1987), 1701.

21 NJ 1958, 67 LEHR (Baris/ Riezenkamp).

$m$ HR 24 april 1992, NJ 1993, 232 MS, AB 1992, 542, Gst 6950 (1992) HH, Bb 1992, p. 139 (Spier), NTBR 1993, p. 125 (Spier). Eveneens positief zijn de uitspraken van het Haagse Hof 19 juni 1991, BR 1991, 406 en Pres. Rb.Middelburg 8 nov. 1990, BR 1991, 408 in de zelfde zaak. Aarzelend nog HR 13 maart 1981, NJ 1981, 346 m.nt. Brunner, AB 396 m.nt. Van der Veen (Den Haag/ Van Beveren). 
heid. Geconcludeerd kan worden dat pas met het Körfer-arrest ${ }^{223}$ in combinatie met het hiervoor genoemde arrest Zeeland/ Hoondert de algemene beginselen van behoorlijk bestuur van toepassing worden op de privaatrechtelijke aanbestedingsovereenkomst tussen overheid en burger. Illustratief is wat dit betreft hetgeen Lubach $^{224}$ nog in 1989 schreef, namelijk dat wat het aangaan van de overeenkomst betreft 'ook wanneer men van mening zou zijn dat ook op dat soort overeenkomsten de algemene beginselen van behoorlijk bestuur van toepassing zouden zijn', er geen behoefte is aan een regeling naast 3:14 BW en 3:1, lid 2 Awb. De toepasselijkheid van de algemene beginselen was, voor wat betreft de overheidsaanbesteding, kennelijk allesbehalve een vanzelfsprekendheid!

Om welke beginselen gaat het dan? Van der Burg ${ }^{225}$ ziet, gegeven de uitsluitend privaatrechtelijke aanbestedingsverhouding, ruimte voor het gelijkheidsbeginsel (artikel 1 Grondwet) en het vertrouwensbeginsel. In zijn noot onder het Amsterdam/IKON-arrest was hij van oordeel dat uit de combinatie van dit arrest met het KB van 9 januari 1987 inzake het Arnhemse boycotbesluit ${ }^{226}$ kon worden afgeleid dat de overheid ook bij het aangaan van de overeenkomst aan het gelijkheidsbeginsel is gebonden. Ook Spier ${ }^{227}$ gaat er in zijn dissertatie van uit dat aanbesteding een specialis is van het leerstuk van de overheidsovereenkomst, waarbij in de precontractuele fase met name het gelijkheidsbeginsel in samenhang met het motiveringsbeginsel en het fair play-beginsel een rol spelen. Ook in meer recente proefschriften komt met wat dit betreft geen andere opvatting tegen ${ }^{228}$. Adriaansens ${ }^{229}$ daarentegen heeft er destijds op gewezen dat het gelijkheidsbeginsel weliswaar betekenis heeft voor de tot de procedure toe te laten aannemers, maar dat in de praktijk bij de gunning ook heel andere, respectabele motieven een rol kunnen spelen, waarvoor hij onder meer verwees naar beoogde lokale werkgelegenheidseffecten. Lubach ${ }^{230}$ is van oordeel dat de werking van het gelijkheidsbeginsel op zichzelf niet behoeft te betekenen dat er geen beleid zou mogen worden gevoerd door middel van het vaststellen van selectiecriteria. Dat bracht hem tot de vraag welke grenzen er moeten worden gesteld aan de redengeving van contractsweigering. Net als Spier wijzen Lubach en De Jong ${ }^{231}$ daarvoor op de samenhang tussen het gelijkheidsbeginsel en het motiveringsbeginsel. Deze samenhang bestaat er volgens Lubach in dat de eis van gelijke behandeling in gelijke gevallen zwaardere eisen stelt aan de motivering van verschillen in behandeling ${ }^{232}$. Daarnaast acht Lubach ook ruimte aanwezig voor het vertrouwensbeginsel en het (formele) zorgvuldigheidsbeginsel ${ }^{233}$. In zijn bijdrage aan de Osmosebundel $^{234}$ herhaalt Lubach zijn eerder genoemde standpunt. Hij wijst Adriaansens' opvatting

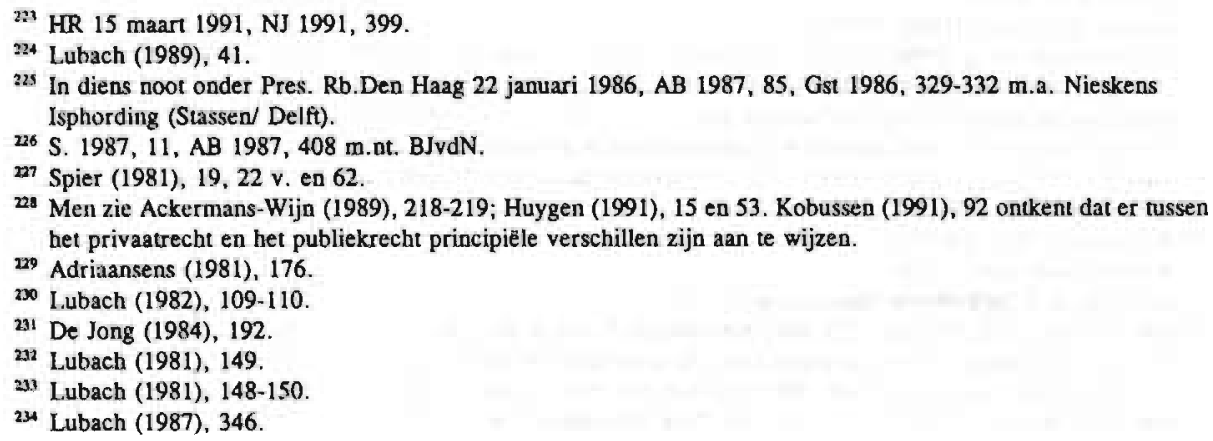


van de hand. De rechtsgelijkheid zou in gevaar komen: het niet-gunnen op grond van - op zichzelf mogelijk respectabele - politieke motieven betekent volgens Lubach in feite hetzelfde als beperkingen op de inschrijvingsmogelijkheid. Hij concludeert dat 'zolang geen wettelijke voorschriften zoals bij voorbeeld een boycotmaatregel worden overtreden, dergelijke motieven alleen geen reden mogen zijn voor contractsweigering'. Een beetje zuur voegt hij daaraan toe, dat '[men] in de praktijk overigens wel argumenten [zal] kunnen vinden om dergelijke bedrijven buiten de deur te houden wanneer men dat persé wil'. Van der $\mathrm{Ner}^{235}$ is aanmerkelijk positiever. Hij wijst op de mogelijk zuiver matschappelijke en ethische oogmerken van gemeenten om een halt toe te roepen aan leven- en vredebedreigende ontwikkelingen van uitbouw van nucleaire oorlogsmiddelen. Hij concludeert dat het terugbrengen van de drijfveren van het gemeentebesturur tot het zich niet neerleggen bij een "niet relevante omstandigheid" van een "politiek onwelgevallig geacht project" een te flauwe aftekening van de bredere werkelijkheid (is) welke de gemeentelijke overheid kan bewegen. Ook Holterman ${ }^{236}$ is van mening dat gemeenten een taak hebben op het gebied van het vredesbeleid en dat zulks gevolgen kan hebben voor de selectieprocedure.

\section{Conclusie}

In literatuur en rechtspraak wordt er in overwegende mate van uitgegaan dat de aanbestedingsovereenkomst met de overheid een gewone privaatrechtelijke overeenkomst is, zij het met een 'snufje' publiekrecht. Dit kan tot gevolg hebben dat de 'contractsvrijheid' van de overheid kan worden beperkt, wanneer de overheid 'typische' overheidshandelingen verricht.

Uit de osmose van publiekrechtelijke en privaatrechtelijke normen mag mijns inziens niet de conclusie worden getrokken, dat het er niet langer meer toe doet of het de overheid is die contracteert of dat het gaat om een contract tussen burgers onderling. Verschil blijft dat het wezenskenmerk van de overheid de publieke belangenbehartiging is. Dit doet de vraag rijzen, of de in beginsel privaatrechtelijke benadering (dogmatisch) wel de meest correcte is. Anders gezegd: is het wenselijk de pragmatische keuze voor het (overheids)privaatrecht in te wisselen voor een principiëler bestuursrechtelijke benadering van het overheidsoptreden? Het is deze - vooralsnog in algemene termen geformuleerde - vraag, die hierna verder zal worden toegespitst op de overheidsaanbesteding.

\section{Beleidsaspecten van aanbestedingen}

Al naargelang de gekozen procedure nodigt de aanbesteder meer of minder aannemers uit om op de aanbesteding in te schrijven, en ontstaan er tussen de aanbesteder en de inschrijvers precontractuele relaties. Op basis van (financiële) doelmatigheidsoverwegingen zullen aannemers - afhankelijk van de gekozen aanbestedingsprocedure - eerst worden geselecteerd, waarna aan één van hen het werk kan worden gegund. Het aanbestedingsrecht zal de normen moeten bevatten, die hebben te gelden bij de afweging tussen de rechtmatigheid en de

\footnotetext{
${ }^{233}$ In diens noot onder KB 9 januari 1987, S. 1987, 11, AB 1989, 408 m.nt. BJvdN (Arnhem).

${ }^{26}$ Holterman (1987 a), 335-337 spreekt van 'politieke ruimte om op politieke wijze lokale sturing van centrale waarden te bedrijven".
} 
doelmatigheid van de selectie- en gunningsbeslissing: het normatieve karakter van het aanbestedingsrecht.

Maar daar houdt het verhaal niet op. In de praktijk blijken gemeenten ook andere beleidsuitgangspunten te betrekken bij de beslissingen die voorafgaan aan de opdrachtverlening. Als voorbeelden van een dergelijk instrumenteel gebruik van de aanbesteding door de plaatselijke overheid in het kader van een te voeren aanbestedingsbeleid noem ik:

- het Utrechtse en Rotterdamse sociale vestigingsbeleid ${ }^{237}$;

- het Deventer anti-fraudebeleid ${ }^{238}$;

- het Groningse anti-Chileense dictatuurbeleid ${ }^{239}$;

- het Amsterdamse werkgelegenheidsbeleid ${ }^{240}$;

- het Zaanstadse anti-kruisrakettenbeleid ${ }^{241}$;

- de Woensdrechtse boycotacties ${ }^{242}$.

En ook uit een eigen praktijkonderzoek onder de gemeenten in de Euregio Maas-Rijn blijkt dat de gemeentebesturen ter gelegenheid van een aanbesteding allerlei overwegingen een rol laten spelen, die weinig tot niets te maken hebben met prijs- en kwaliteitsoverwegingen (de resultaten van dit praktijkonderzoek zijn in verkorte vorm weergegeven in een bijlage bij dit onderzoek) ${ }^{243}$. Deze bevindingen sluiten aan op de opmerkingen van De Haan c.s. en Adriaansens, waaruit naarvoren komt, dat er in de praktijk op lokaal niveau kennelijk een zekere behoefte bestaat om in de beslissing tot opdrachtverlening ook 'andere' belangen mee te wegen dan uitsluitend het belang van een maximale mededinging (op basis van financiële doelmatigheidscriteria) en rechtsgelijkheid. Er is met andere woorden behoefte aan 'zoiets als een aanbestedingsbeleid', waarbij de gemeente een zekere ordening aanbrengt in het scala van beleidsuitgangspunten ter gelegenheid van een aanbesteding. Een dergelijk aanbestedingsbeleid zou moeten bestaan in de afwegingen tussen de mogelijke verschillende bij de aanbesteding betrokken eisen met als sequeel de keuze van een bepaalde aanbestedingsprocedure.

Het is allesbehalve uitgesloten dat de gereleveerde privaatrechtelijke benadering wel eens tekort zou kunnen schieten in het scheppen van een bevredigende regeling van de beleidsaspecten van de aanbesteding waarbij de rechtsgelijkheid is gewaarborgd. Het aanbestedingsrecht zal mijns inziens een normatief kader moeten vormen voor de afweging tussen de diverse bij de aanbesteding betrokken belangen mede in relatie tot de rechtsgelijkheid van de

${ }^{237}$ Aanhangsel Hand. I 1976-1977, nr. 22 over het Rotterdamse sociale vestigingsbeleid. Zie voor een pleidooi voor een dergelijk beleid door Van Schaick (1980), 1-2 en eerder kritisch Gst 1973, 6270. En Aanhangsel Hand. II 1978-1979, $\mathrm{nr}$. 1050, 2103-2104 over het Utrechtse sociale vestigingsbeleid.

$238 \mathrm{Vgl}$. Adriaansens (1981), 176 onder verwijzing naar Cobouw 9 januari 1980, 1. Het beleid bestond erin dat de gemeente toetste of de voor de gemeente werkzame aannemers hun verplichtingen ten aanzien van de inhouding en afdracht van belastingen en sociale premies nakwamen. Daarnaast diende de aannemer - om voor gunning in aanmerking te komen - bewijs te leveren dat was ingeschreven in het Handelsregister en bij de Bedrijfsvereniging voor de Bouwnijverheid. Voorts moest er een vestigingsvergunning zijn.

236 Hierover Adriaansens (1981), 176.

240 Aanhangsel Hand. II 1983-1984, nr. 142, 297.

211 Aanhangsel Hand. II 1983-1984, nr. 794, 1605-1606.

242 Aanhangsel Hand. II 1986-1987, nr. 350. 697-698. Het ging toen om een boycot van bedrijven die contacten onderhielden met het (toenmalige) Zuidatrikaanse apartheidsbewind.

${ }^{2+3}$ Zie voor de volledige rapportage Nijholt (1987), Verjans (1987), Nijholt (1988). 
gegadigden en inschrijvers. Deze complexe afweging noem ik het aanbestedingsbeleid. Hoogerwerf omschrijft beleid als het streven naar het bereiken van bepaalde doeleinden met bepaalde middelen en bepaalde tijdskeuzen ${ }^{244}$. Beleid ziet in deze politicologische optiek op het maken van keuzes: een bepaald antwoord op een bepaald probleem ${ }^{245}$. Dit beleid kan het resultaat zijn van planning. Deze doel-middelenstructuur komen we eveneens tegen in de zogenaamde 'orthodoxe visie op planning': het gaat dan om een weloverwogen, bewust, systematisch en doelgericht handelen ${ }^{246}$. Een minder rigide vorm van planning zou zijn, wanneer minder wordt vastgelegd voor een niet te overziene toekomst: 'van de planning wordt dan niet verwacht dat ze de toekomst bepaalt, maar veeleer dat ze het mogelijk maakt steeds opnieuw zo verantwoord mogelijk te kiezen, ${ }^{247}$. Naast deze bestuurskundige/ politicologische invalshoek kan een bestuursrechtelijke opvatting van beleid worden geplaatst. Beleid is volgens Duk een bepaalde wijze van bevoegdheidsuitoefening: het stelselmatig gebruik van een bevoegdheid, volgens normen die autonoom zijn vastgesteld of (uitdrukkelijk dan wel stilzwijgend) aanvaard door degene aan wie die bevoegdheid toekomt ${ }^{248}$. De eis van stelselmatigheid vloeit voort uit de algemene beginselen van behoorlijk bestuur, met name het verbod van willekeur, het gelijkheidsbeginsel en het rechtszekerheidsbeginsel ${ }^{249}$.

Hoe verhouden de beide omschrijvingen van beleid zich tot elkaar? Duidelijk is dat enerzijds het bestuur niet meer ruimte krijgt dan de wetgever haar toemeet (eisen van rechtsstatelijkheid en demokratie), terwijl anderzijds wordt erkend dat het beleid effectief en efficiënt moet zijn. Het legaliteitsbeginsel eist dat de overheid zich bij haar taak, die een beperking van de burgerlijke vrijheid met zich meebrengt, gebonden weet door de wet. Dat wil niet zeggen, dat het noodzakelijk is dat elk bestuurlijk handelen in de wet moet zijn terug te vinden, maar dat dat handelen door de wet wordt genormeerd. Daarnaast volgt uit de wetmatigheidseis dat het bestuurshandelen in overeenstemming moet zijn met de wettelijk voorschriften. De wettelijke voorschriften inzake overheidsaanbestedingen zouden in ieder geval bepalingen moeten inhouden over de te hanteren procedures, waarborgen voor belanghebbenden en over de beleidsrapportage aan het vertegenwoordigend orgaan ${ }^{250}$. In deze zin verschilt mijn opvatting van de opvatting die aan De Haan c.s. wordt toegeschreven ${ }^{251}$, waarbij het bestuursrecht niet alleen de instrumenten voor overheidsbeleid aanreikt, maar ook zelf een instrument is. Deze laatste opvatting stuit bij velen op verzet, omdat in die benadering het

\footnotetext{
${ }^{244}$ Hoogerwerf (1989), 20.

245 Hoogerwerf (1989), 21.

${ }^{246}$ Term ontleend aan Van Wijk - Konijnenbelt - Van Male (1993), 283. Een vergelijkbare omschrijving is te vinden in Commissie Wetgevingsvraagstukken (1985), 29

${ }^{247}$ Van Wijk - Konijnenbelt - Van Male (1993), 284.

24. Duk (1978), 574.

${ }^{200}$ Duk spreekt dan van de 'eis van beleid', die voorafgaat aan de algemene beginselen van behoorlijk bestuur. Van Kreveld (1983), 188-189 noemt dit het consistentiebeginsel. Dit beginsel vormt de grondslag voor de gebonden. heid van het bestuur aan beleidsregels.

200 Vgl. Wessel (1977), $249 \mathrm{v}$.

${ }^{251}$ Kritisch o.m. Scheltema (1982), 131 y, en Stroink (1987), 280-282. Van Wijk - Konijnenbelt - Van Male (1993), 59 relativeren mijns inziens terecht (een deel van) de kritiek op De Haan c.s. Over de aanvankelijke 'schrikreacties' op de instrumentele benadering ook Fernhout (1989), 23.
} 
bestuur zelf zou kunnen beschikken over het recht, dat nu juist haar handelen zou dienen te normeren ${ }^{252}$.

\section{Probleemstelling}

Ik betwijfel of het privaatrechtelijke instrumentarium geschikt is om de ingewikkelde belangenafweging die het aanbestedingsbeleid kenmerkt, op bevredigende wijze te maken. Het is deze twijfel die de voortdurende drijfveer vormt achter het onderzoek. Deze twijfel leidt tot de volgende probleemstelling:

\section{Welke eisen moeten worden gesteld aan een gemeentelijk aanbestedingsbeleid?}

Achterliggende gedachte is dat door een dergelijk onderzoek bovendien meer inzicht kan worden verkregen in het aanbestedingsbegrip (vergelijk hierover eerder paragraaf 1). Alvorens deze probleemstelling te lijf te kunnen gaan, wordt onderzocht hoe de bevoegdheid tot het aanbesteden van werken over de gemeentelijke bestuursorganen is verdeeld. Daarbij wordt tevens de vraag betrokken hoe deze regelgeving de aanbestedingsbevoegdheid normeert. Daarvoor moet dan met name worden gedacht aan de Gemeentewet en het daarin voorziene toezichtsinstrumentarium (tweede hoofdstuk). Normen zijn ook te vinden in de vele procedurevoorschriften zoals het UAR en de Europese aanbestedingsrichtlijnen. Ook daarvan wordt, in het derde hoofdstuk, onderzocht of zij in voldoende mate in staat kunnen worden geacht om de aanbestedingsbevoegdheid van gemeenten te normeren. Met andere woorden: heeft het uitgangspunt, dat de overheid in beginsel steeds iedere gegadigde tot de inschrijving moet toelaten, uitdrukking gevonden in de regelingen waaraan de overheid bij het aanbesteden is gebonden? In het vierde hoofdstuk worden de eisen onder de loupe genomen waaraan de door het gemeentebestuur gekozen beleidsuitgangspunten zouden moeten voldoen. Of anders gezegd: onder welke voorwaarden is het rechtens toelaatbaar dat het gelijke kansenbeginsel wordt beperkt omwille van het nastreven van andere algemene belangen, dan uitsluitend het belang van de financiële doelmatigheid. Zijn deze grenzen verkend, dan staat in elk geval vast dat er zoiets is als een aanbestedingsbeleid. In het vijfde en laatste hoofdstuk zal dan een begin worden gemaakt met het leggen van een juridisch fundament onder dit beleid. Aan het eind van dit eerste hoofdstuk gekomen spreek ik de hoop uit, dat dusdoende enige voorzichtige aanbevelingen voor een op gemeentelijk niveau te ontwikkelen aanbestedingsbeleid kunnen worden gedaan.

\footnotetext{
${ }^{252}$ De Haan, Drupsteen, Fernhout (1986 a), 29 relativeren hun omstreden uitgangspunt overigens cok zelf, door er op te wijzen dat het een kwestie is van 'verschil in niveau' waarop beide uitgangspunten kunnen worden geëxpliciteerd en bestudeerd. Konijnenbelt en Van Male (Van Wijk - Konijnenbelt - Van Male (1993), 41-42) zijn beducht voor wat zij blanketwetgeving noemen; ze biedt nauwelijks waarborgen voor de burgers en legitimeert het bestuursoptreden alleen formeel. Vgl. ook Konijnenbelt (1989 b), 496 v. De Haan (1990), 344 is inmiddels van mening dat Van der Hoeven het dilemma oplost door in plaats van de normatieve de legitimerende funktic als eerste dimensie van het bestuursrecht te onderscheiden.
} 


\section{De bevoegdheid tot aanbesteden}

\section{Het tot aanbesteden bevoegde bestuur}

Sinds de inwerkingtreding van de (nieuwe) Gemeentewet per 1 januari 1994 is er op het punt van de bevoegdheidsverdeling het een en ander gewijzigd!. Maar voordat we daaraan toekomen, volgt hieronder eerst een historisch overzicht van de ontwikkeling van de bevoegdheden ter zake van het aanbesteden van werken. Mijns inziens heeft deze 'oude' taakverdeling ook voor de toekomst nog betekenis, doordat daaraan rechtshistorische argumenten kunnen worden ontleend voor het geval zich conflicten in de bevoegdheidsuitoefening zouden voordoen. $\mathrm{Na}$ dit historische overzicht volgt een weergave van de bevoegdheidsverdeling in de (nieuwe) Gemeentewet van 1994. Het overzicht geeft inzicht in een ontwikkeling waarbij de wetgever de oorspronkelijke bevoegdheidsverdeling - gedwongen door de praktijk - heeft losgelaten, en het thans aan de gemeente overlaat de bevoegdheid inzake de aanbesteding van werken te verdelen over de bestuursorganen. Bij het onderzoek is onder meer gebruik gemaakt van redactionele commentaren en door gemeentebesturen en anderen ingezonden brieven en de beantwoording van de daarin gestelde vragen door de redacties van de Gemeentestem en het Weekblad voor de Burgerlijke Administratie. Tezamen geven deze vragen en antwoorden een beeld van de (oplossing van) problemen die gemeenten in hun aanbestedingspraktijk tegenkwamen ${ }^{2}$.

\section{De bevoegdheidsverdeling in historisch perspectief}

Krachtens de regeling in Titel II, Eerste Hoofdstuk van de gemeentewet 1851 betreffende de regeling en het bestuur van de huishouding van de gemeente was de aanbesteding van werken een autonome bestuursbevoegdheid. Beginsel in deze wet was dat alle bevoegdheid tot regeling en bestuur van de huishouding der gemeente aan de raad behoorde. Bij het tot stand komen van de gemeentewet in 1851 rees in dit verband de vraag of de Grondwet van 1848 de mogelijkheid bood om bepaalde bestuursbevoegdheden op te dragen aan andere gemeentelijke colleges. Hierbij wordt aangetekend, dat de Grondwet van 1848 alleen de raad als gemeentelijk orgaan kende en niet ook B\&W of de burgemeester. Thorbecke loste dit vraagstuk op door het beginsel van artikel 140 Grondwet van 1848 als volgt in artikel 134 gemeentewet van 1851 uit te werken: alle bevoegdheden met betrekking tot de regeling en het bestuur van de huishouding der gemeente werden toebedeeld aan de raad, tenzij een uitdrukkelijk wetsvoorschrift $B \& W$ of de burgemeester bevoegd zou verklaren. Deze takverdeling week geheel af van die in de vroegere rijksreglementen ${ }^{3}$ (waarover hierna) waar

\footnotetext{
Ter onderscheiding van de oude gemeentewet, wordt de nieuwe Gemeentewet met cen kapitaal begonnien.

Vergelijk in dit verband de opmerkingen van Randeraat (1994), 480 over de betekenis van bestuurshistorisch onderzoek op basis van deze beide tijdschriften.

3 Respectievelijk art. 88 Stadsreglement 1824 en art. 57 Plattelandsreglement 1825.
} 
burgemeester en wethouders, respectievelijk de burgemeester al of niet met assesoren, het bestuur en het oppertoezicht hadden over 'alles, hetgeen bij die reglementen niet bijzonderlijk aan de raad was opgedragen"4. In de Memorie van Toelichting bij de artikel 134 gemeentewet van 1851 (artikel 167 gemeentewet (oud)) viel hierover te lezen:

'Het artikel dient gelijk art. 94 der provinciale wet, tot wegneming van twist en twijfel over den persoon, die in huishoudelijke zaken der gemeente tot regeling en bestuur bevoegd is'.

Aldus was de hoofdregel inzake de attributie en distributie van gemeentelijke bestuursbevoegdheden gegeven: de raad was het centrale bestuursorgaan in zaken die de gemeentelijke huishouding betroffen. De raad was derhalve het tot aanbesteden bevoegde lichaam, voorzover deze bevoegdheid niet uitdrukkelijk aan hem was onttrokken.

De Belgische wet eo ook het ontwerp-De Kempenaer waren op het punt van de algemene bevoegdheidsverdeling minder duidelijk dan de gemeentewet van $1851^{5}$.

Direct na invoering van de gemeentewet in 1851 bleken er evenwel ter zake van de verdeling van de aanbestedingsbevoegdheid over de gemeentelijke organen evenwel onduidelijkheden te bestaan ${ }^{6}$. Deze problemen vloeiden voort uit onenigheid over de (veronderstelde) verhouding tussen de artikelen $70^{7}, 134^{8}, 142^{9}$ en 179 , sub a en 179 , sub $i^{10}$ gemeentewet 1851 . Of, zoals het in de Gemeentestem ${ }^{11}$ werd verwoord:

'Het zal altijd een der moeilijkst op te lossen vraagstukken blijven, de grenzen der bevoegdheid russchen de verschillende machten, die samen de gemeente besturen, scherp af te bakenen. Kan men in bet algemeen zeggen, dat de wetgever ook hierin tamelijk wel is geslaagd, - op het punt van de aanbestedingen en vaststelling van plannen en voorwaarden daarvan zijn nog altijd verschillende meeningen gangbaar.'

Volgens artikel 70 gemeentewet van 1851 was de burgemeester bevoegd om op te treden ter uitvoering van de besluiten van de gemeentebesturen. In artikel 179 gemeentewet van 1851 werden bepaalde bevoegdheden die tot het dagelijks bestuur behoorden opgedragen aan B\&W. Het begrip 'dagelijks bestuur' kwam niet voor in de Grondwet en evenmin in de

4 Kocken (1973), 513. De Belgische gemeentewet van 1836 en het ontwerp-gemeentewet van De Kempenaei hadden eveneens de bedoeling de raad de eerste macht te doen zijn.

5 Kocken (1973), 521.

6 Oppenheim (1928 a), 169. Meer recent heeft o.m. Elzinga (1979) er op gewezen, dat door allerlei oorzaken de verhouding tussen de raad en B\&W is scheefgegroeid.

7. Vigl. art. 76, eerste alinea gemeentewet (oud): Als hoofd van den raad en van het college van burgemeester en wethouders is hij, behoudens de bepaling van artikel 209, onder a, met de uirvoering hunner besluiten belast.

- Vgl. art. 167 gemeentewet (oud): Aan den raad behoort, met betrekking tot de regeling en het bestuur van de huishouding der gemeente, alle bevoegdheid die niet bij deze of eenige andere wet aan den burgemeester, of aan burgemeester en wethouders is opgedragen.

- Vgl. art. 176 gemeentewet (oud): Hij kan zich de vaststelling der plannen en voorwaarden van aanbesteding der werken en leverantiën, ten behoeve der gemeente te doen, voorbehouden.

$10 \mathrm{Vgl}$. art. 209 gemeentewet (oud), voor zover relevant, Tot het dagelijksch bestuur der gemeente, aan burgemeester en wethouders opgedragen, behoort:

a. het uitvoeren der besluiten van den raad;

i. het vaststellen der plans en voorwaarden van aanbesteding der werken en leverantiên, ten behoeve der gemeente te doen, wier vaststelling de raad niet aan zich voorbehield.

11 Gst 1892,2105 
reglementen ${ }^{12}$. Tot deze limitatieve lijst van bevoegdheden behoorde het uitvoeren van de raadsbesluiten (sub a) en het vaststellen 'der plans en voorwaarden' van aanbesteding van werken ten behoeve der gemeente te doen, wier vaststelling de raad niet aan zich had voorbehouden (sub i). Hierna wordt de ontwikkeling geschetst die de bevoegdheidsverdeling tussen de gemeentelijke organen in de loop der tijd heeft doorgemaakt. Daarbij wordt onderscheid gemaakt tussen een vijftal beslissingen.

\section{Het vaststellen van plannen en administratieve voorwaarden}

Er bestond onduidelijkheid over de vraag welk orgaan bevoegd was tot het maken van de plannen en het vaststellen van de voorwaarden. Het kwam veelvuldig voor dat de raad de plannen en voorwaarden vaststelde, hoewel dit steeds vaker aan B\&W of een commissie voor de plaatselijke werken werd overgelaten ${ }^{13}$. Over de precieze taakverdeling ontstond onenigheid toen op 19 mei 1868 de Leidse gemeenteraad weigerde om een door B\&W voorgesteld bestek vast te stellen ${ }^{14}$. Deze gang van zaken werd in de Gemeentestem hevig bekritiseerd. De Leidse gemeenteraad verwees voor zijn optreden naar het bepaalde in artikel 72 van het rijksreglement voor de steden van 1824 . Volgens dat artikel stelde de raad de voorwaarden van aanbesteding vast. In de Gemeentestem werd er op gewezen dat de systematiek van de gemeentewet 1851 op dit punt anders was. Artikel 142, lid 1 gemeentewet 1851 bepaalde:

Hij [đe raad; $H N$ ] kan zich de vaststelling der plannen en voorwaarden van aanbesteding der werken en leverantiēn, ten behoeve der gemeente te doen, voorbehouden.

Hoewel dus naar haar aard de vaststelling van plannen en voorwaarden tot de bevoegdheid van de raad behoorde, introduceerde de gemeentewet van 1851 op dit punt de figuur der omgekeerde delegatie. Of zoals Van Baren het uitdrukte: het vaststellen van plans en voorwaarden is een zaak die in principe aan de raad toebehoort. Deze bevoegdheid kan niet worden gedelegeerd, wel worden voorbehouden ${ }^{15}$. Zou de raad van zijn bevoegdheid tot vaststelling van de plannen en voorwaarden geen gebruik maken, dan trad automatisch artikel 179, sub i gemeentewet 1851 (later artikel 209, sub i gemeentewet (oud)) in werking, waardoor het college van burgemeester en wethouders in staat werden gesteld deze taak uit te voeren. B\&W waren belast met de dagelijkse uitvoering van de raadsbesluiten. De rechtbank in Middelburg ${ }^{16}$ had op 29 februari 1888 in dit verband overwogen, dat:

'(..) art. 142 der gem.wet aan den gem.raad wel de bevoegdheid geeft zich de vaststelling der plannen en voorwaarden van aanbesteding voor te behouden, maar dat daardoor aan Burgemeester en Wethouders die bevoegdheid niet wordt ontnomen om door middel van aanbesteding, zonder vitdrukkelijke goedkeuring van den Raad datgene te doen uitvoeren, wat hen opgedragen is bij art. 179 voornoemd.'

${ }^{12}$ Ook de Provinciewet (S. 6 juli 1850,39$)$ kende het algemeen bestuur toe aan de raad en het dagelijks bestuur aan $B \& W$.

13 Blijkens o.a. Rb.Heerenveen 26 juni 1861, W. 1861, 2309. Gst 1861, 514. Gst 1861, 523; Gst 1861, 1504; WBA 1861, 645; WBA 1862, 703: de handelingen van de commissie werden beschouwd als daden van het gemeentebestuur.

it Gst 1868, 863 en 872 .

is Van Baren (1977), 1093.

I6 Zie Gsi 1888, 1935, W. 1888, 5614. WBA 1888, 2054. 
De redactie van de Gemeentestem ${ }^{17}$ - onder verwijzing naar voornoemd vonnis van Rb.Middelburg - was van oordeel dat het recht van de raad om zelf plannen en voorwaarden vast te stellen beperkt zou moeten blijven tot het aanleggen of verbeteren der in artikel 141 gemeentewet 1851 (artikel 175 gemeentewet (oud)) bedoelde werken. De redactie ging er kennelijk vanuit dat er een relatie bestond tussen de aanbestedingsbevoegdheid van de raad en het aanleggen of verbeteren van gemeentewegen, waterleidingen, straten, pleinen, grachten, gebouwen, werken en inrichtingen. Maar zou het werken betreffen als bedoeld in artikel 179, sub h gemeentewet 1851 (artikel 209, sub h gemeentewet (oud)), dan was het volgens de Gemeentestem raadzaam het vaststellen van de bestekken over te laten aan B\&W. Deze opvatting was waarschijnlijk gebaseerd op de redactie van artikel 142 ontwerp-gemeentewet van Thorbecke, waarin de latere afzonderlijke artikelen 141 en 142 gemeentewet 1851 nog gezamenlijk figureerden ${ }^{18}$. Deze werkverdeling werd in de Gemeentestem zelfs doorgetrokken naar de uitvoering van werk in eigen beheer. Deze zienswijze ligt vermoedelijk ook ten grondslag aan de opvatting van B\&W van Groningen. Zij achtten een besluit van de raad nodig om het onderhoud van schoolgebouwen in eigen beheer te doen uitvoeren. De raad zou zich in beginsel evenwel moeten beperken tot het beoordelen van de vraag of de plannen zouden moeten worden gefinancierd. Terwijl de plannen daarnaast de toetsstenen vormden voor de beoordeling der uitvoering. Alleen het bestuursorgaan dat de voorwaarden had vastgesteld, zou deze ook kunnen veranderen ${ }^{19}$.

Wilde de raad zelf de plannen en voorwaarden voor aanbesteding vaststellen, dan diende hij het daartoe strekkende voorbehoud steeds opnieuw te maken. Dat was althans de opvatting die door de redactie van de Gemeentestem naarvoren werd gebracht, naar aanleiding van een Leids raadsbesluit, dat de strekking van een algemeen voorbehoud had ${ }^{20}$. De raad diende elk plan op zichzelf vast te stellen, om daarna de uitvoering en uitwerking aan B\&W te kunnen opdragen, zo werd geredeneerd. Daar werd later anders over gedacht: de raad behoefde een dergelijk voorbehoud niet voor elke afzonderlijke aanbesteding opnieuw te maken. Als de raad voor aanbestedingen van dezelfde soort, waarvoor dezelfde bijzondere redenen golden, éénzelfde besluit zou nemen, was dit niet in strijd met de eisen van artikel 50 , lid 2 sub e gemeentewet (oud) (eerder artikel 44 gemeentewet 1851) ${ }^{21}$. Volgens artikel 44 gemeentewet 1851 kon in een besloten vergadering niet beraadslaagd, noch een besluit genomen worden over het onderhands aanbesteden van werken ${ }^{22}$. Later, na de wetswijziging van 15 december 1966, S. 1966, 564 bepaalde artikel 50 gemeentewet (oud) dat er in besloten vergadering geen besluit kon worden genomen over het onderhands aanbesteden van werken. De wetswijziging maakt het anderzijds wel mogelijk dat in besloten raadsvergadering zou kunnen worden beraadslaagd (het openbaarheidsvereiste).

19 Gst $1892,2105$.

18 Kocken (1973), 487 v. Ontkennend Oppenheim (1928 b), 170.

19 Gst 1905,2105 . Gst 1895, 2274 (verlenging van de opleveringstermijn).

20 Verslag Leidse gemeenteraad 2 april 1868 , Gst 1868,863 en 872.

21 Oud (1959), 372.

22 Over de openbare raadsvergadering: Gst 1880, 1505, Gst 1890, 2022 en WBA 1865, 814. 


\section{Het besluit tot openbare c.q. onderhandse aanbesteding op basis van (selectie-eisen en) gunningscriteria}

Hoewel de algemene bevoegdheid van de raad tot aanbesteden reeds voortvloeide uit artikel 134 gemeentewet 1851 , werd deze bevoegdheid voor de aanbesteding nog eens herhaald in artikel 142 gemeentewet 1851 . Dat valt hieruit te verklaren, dat de gemeentewetgever buiten twijfel heeft willen stellen welk orgaan ter zake van de aanbesteding bevoegd was ${ }^{23}$. Bovendien, waar ter zake van de aanbesteding een, van de algemene bepalingen der autonomie, afwijkende competentieverdeling was gekozen (omgekeerde delegatie aan B\&W van de bevoegdheid tot het vaststellen van de plannen en voorwaarden), maakte een dergelijke wettelijke bepaling nog eens duidelijk dat de aanbesteding behoorde tot de gemeentelijke autonome bevoegdheden en de raad het bevoegde orgaan was. De opvatting dat de bevoegdheid tot het besluiten tot aanbesteden exclusief toebehoorde aan de raad treffen we ook aan in het Handboek over gemeenterecht van Oud. Terecht, aldus Oud, verwees artikel 212 gemeentewet (oud) niet ook naar artikel 176, eerste alinea gemeentewet (oud), zodat vaststond dat de raad de beslissing tot openbare c.q. onderhandse aanbesteding ook niet aan B\&W zou kunnen delegeren.

Artikel 212 gemeentewet (oud) was bij de wijziging van de gemeentewet in 1931 opgenomen, nadat bij de grondwetswijziging in 1922 delegatie van bestuursbevoegdheden mogelijk was gemaaka. Het oorspronkelijke regeringsvoor * stel om aan de raad voortaan uitsluitend de regeling en niet langer ook het bestuur der gemeentelijke huishouding op te dragen, was eerder door de Tweede Kamer verworpen. In artikel 212 gemeentewet (oud) werd de delegatiebepaling aldus uitgewerkt dat B\&W, indien de raad daartoe besloot en volgens de door de raad te stellen regelen, de in de artikelen 171-175 en 177, eerste en tweede lid gemeentewet (oud) bedoelde macht van de raad konden uitoefenen. De raad kon overigens alle bestuursbeslissingen overdragen aan commissies, behordens, het bepaalde in artikel 63 gemeentewet (oud), waaronder het vaststellen van de begroting.

Volgens Oud ${ }^{24}$, die daarvoor wijst op de samenhang met de openbaarheid van de besluitvorraing:

'zou [er] van de waarborg, die dit voorschrift (art. 50, lid 2, sub e gemeentewet (oud): HN) beoogt, niet veel terecht komen, indien de beslissing zou mogen vallen in een vergadering van her College'.

\section{De aanbesteding}

De (openbare) aanbesteding was de feitelijke uitvoering van het raadsbesluit en moest ten overstaan van $B \& W$ geschieden ${ }^{2 s}$. De raad kon zich de aanbesteding dus niet voorbehouden of aan een commissie delegeren ${ }^{26}$; de aanbesteding geschiedde krachtens besluit van $\mathrm{B} \& \mathrm{~W}$ (artikel 179, sub a gemeentewet 1851). En ook de gunning (als onderdeel van de aanbesteding) was als onderdeel van de uitvoering van het raadsbesluit aan B\&W, zonder dat daarvoor nadere goedkeuring van de raad werd vereist, en ongeacht of het daarbij ging om

23 De Memerie van Toeliehting bij de arth. 136 v. gemeentewet van 1851 luidđe: 'De wetgever, ofschoon buiten magte, alles te vermelden, wat onder huishoudelijke gemeente-aangelegenheden is te rangschikken, zal wel doen, het voomaamste te noemen, opdat althans te dien aanzien geen twijfel ontsta, en daaruit ten aanzien van het overige een besluit kunne worden afgeleid' (Staten-Generaal, 1850-51, III, 377 ч.).

24 Oud (1959), 372.

29 Gst 1851, 3; Gst 1851, 6; Gst 1853, 88; Gst 1856, 273. Verslag Zeeland 1863 (blijkens Boissevain (1867), 901) en 1864, Gst 1878, 1419; Gst 1882, 1580.

26 Gst 1862,565 onder verwijzing naar een missive van de minister van Binneniandse Zaken. 
onderhoud of de aanleg- c.q. verbeteringsactiviteiten ${ }^{27}$. In overeenstemming met deze wetsuitleg sloot de Minister van Binnenlandse Zaken zich in 1890 aan bij het oordeel van Gedeputeerde Staten van Friesland, dat de raad zich de bevoegdheid om tot gunning over te gaan nitt zou mogen voorbehouden, behoudens de bevoegdheid van de raad om ten dien aanzien regelen te stellen ${ }^{28}$. Een raadsbesluit, waarbij werd bepaald, dat de raad zich de beslissing tot het gunnen voorbehield, kon daarom voor vemietiging worden voorgedragen ${ }^{29}$. Zo had in 1892 de Minister van Binnenlandse Zaken bedenkingen tegen een besluit, waarbij de Winschoter gemeenteraad zich de gunning voorbehield ${ }^{30}$. De raad gaf aan diens wenk gehoor, dour vervolgens de bevoegdheid van B\&W niet meer te bestrijden.

Het feit dat de gemeentebegroting was goedgekeurd, betekende niet dat B\&W al tot optreden bevoegd waren ${ }^{31}$. Het op de begroting uitgetrokken bedrag gaf enkel het bedrag aan, dat voor een bepaalde begrotingspost mocht worden besteed, maar dat nam niet weg dat de raad diende te besluiten of, en zo ja op welke wijze, enig werk zou worden uitgevoerd. Zou het bedrag waarvoor een werk zou worden gegund hoger uitvallen dan het op de begroting uitgetrokken bedrag, dan diende eerst de begroting te worden gewijzigd en goedgekeurd door Gedeputeerde Staten ${ }^{32}$. Pas daarna zouden B\&W - en volgens het Weekblad voor de Burgerlijke Administratie ook de raad - tot aanbesteding en gunning van het werk kunnen overgaan. In de Gemeentestem van $1872^{33}$ kon men de opvatting tegenkomen, dat, indien de gemeenteraad zich de vaststelling der plannen en voorwaarden niet had voorbehouden, het dagelijks bestuur zonder voorafgaande machtiging van de raad de voorkomende werken in de gemeente, die niet publiek waren aanbesteed, kon doen uitvoeren, indien de begrotingspost niet werd overschreden.

Ongeacht of de raad al dan niet gebruik had gemaakt van het voorbehoud in artikel 142 gemeentewet 1851 stond het $\mathrm{B} \& W$ vrij het werk te gunnen aan een inschrijver, die niet als laagste had ingeschreven ${ }^{34}$. $B \& W$ behoefden deze beslissing niet jegens de raad te motiveren, behoudens hun verantwoordelijkheid voor het uitgavenbeleid ${ }^{35}$. De raad kon

${ }^{37}$ Gst 1852, 49; Gst 1875, 1265; Gst 1877, 1318. Anders WBA 1893, 2323: de gunning behoort aan de raad, tenzij het bestek inhoudt, dat aan de laagste inschrijver kan worden gegund. Ook zo Gst 1892, 2105; Gst 1892, 2134. Gst 1893, 2167 (goedkeuring vereist van de raad).

28 Gst 1890, 2116. Ook zo Gst 1892, 2134. In die lijn ook WBA 1891, 2205. Gst 1903, 2718. Deze opvarting ook 20 bij Schroot (1979), 259. Kritisch Oppenheim (1928 b), 172.

29 Gst 1884, 1707.

30 Gst $1892,2134$.

31 Gst 1881, 1557; Gst 1904, 2745; Gst 1907, 2889.

32 WBA $1896,2433$.

33 Gst 1872, 1086.

34 Gst 1885, 1737; Gst 1898, 2462. Blijkens het verslag van de algemene vergadering van de Maatschappij ter bevordering der Bouwkunst in juli 1856 te Amsterdam werd voor de onderhoudswerken in de praktijk gebruik gemaaki van een viertal aanbestedingsstelsels: 1 . in massa vonr een overeen te komen som; 2 . volgens tarief, door of vanwege de aanbesteders opgemaakt en ingevuld, waarbij het werk worot gegund aan de laagste inschrijver, percentsgewijs gerckend; 3 . volgens tarief, door of vanwege de aanbesteder opgemaakt en door de inschrijvers zelf in te vullen, en 4 . door een combinatie van enige werkzaamheden in massa en een tarief. Eis is een duidelijk bestek, met een uitvoerige lijst van werkzaamheden, duidelijke afmetingen etc. (Gst 1857, 285. Vgl. ook Gst 1857,287 en Gst 1857, 289).

3s Artikelen 183 jo 172 , sub i gemeentewet 1851 . 
derhalve niet bepalen dat het werk aan de laagste inschrijver zou moeten worden gegund. Dit zou de bevoegdheid van artikel 142 gemeentewet 1851 te boven gaan: de gunning der openbare aanbesteding was geheel en al overgelaten aan de beslissing van $B \& W^{36}$. De opvattingen daarover waren trouwens niet eensluidend. Volgens het Weekblad voor de Burgerlijke Administratie was de raad steeds tot gunning bevoegd. Het was daarbij niet van belang of hij zich de vaststelling van de plans en voorwaarden had voorbehouden ${ }^{3 ?}$. Dit zou alleen anders zijn indien de raad in de voorwaarden zou bepalen dat het werk aan de laagste inschrijver zou moeten worden gegund. Dan zou de gunning aan B\&W moeten worden overgelaten. De gebruikelijke wetsinterpretatie hield in dat de burgemeester de dag en de plaats bepaalde waarop de aanbesteding zou worden gehouden.

\section{Het besluit tot opdrachtverlening}

B\&W waren steeds bevoegd te besluiten tot opdrachtverlening. Naar aanleiding van de hiervoor genoemde Winschoter affaire, waar de raad zich ten onrechte de beslissing tot gunnen had voorbehouden, werd in de Gemeentestem de vraag aan de orde gesteld of het juist was, dat de raad, ingeval van een onderhandse aanbesteding, het werk zou moeten opdragen. Daarbij werd verwezen naar het bepaalde in artikel 44, sub i gemeentewet 1851 . Daar werd bepaald dat in een besloten raadsvergadering niet beraadslaagd en niet besloten zou kunnen worden over het onderhands aanbesteden van werken. Daaruit zou kunnen worden afgeleid dat de raad, en niet B\&W, bevoegd was tot gunning na een onderhandse aanbesteding. De redactie concludeerde dat de gemeentewetgever zich hier aan een inconsequentie had schuldig gemaakt, 'door de besluiten tot onderhandsche aanbesteding tot de attributen van den Raad te brengen'. Immers, de aanbesteding en de gunning behoorden tot de bevoegdheid van B\&W. De volgende oplossing, passend in het stelsel der wet, werd voorgesteld. De raad zou kunnen besluiten tot onderhandse aanbesteding; daarna zouden B\&W het werk onderhands kunnen aanbesteden, om vervolgens beide besluiten, èn dat van de raad èn van $B \& W$, aan het preventieve toezicht van Gedeputeerde Staten te onderwerpen. Maar erkend werd dat tegen deze interpretatie wel iets viel aan te voeren. Het was immers zo, zo werd geconcludeerd, dat de raad het besluit behoorde te nemen, dat de onderhandse aanbesteding in haar geheel regelde ${ }^{38}$.

\section{De feitelijke opdrachtverlening (de contractssluiting)}

Omtrent de vraag welk orgaan uiteindelijk bevoegd was tot de feitelijke uitvoering van het raadsbesluit waarbij de opdracht werd gegund, bestond enige onduidelijkheid. Deze onduidelijkheid sproot voort uit de verhouding tussen de artikelen 167 gemeentewet en 209, onder a gemeentewet (oud). Volgens artikel 167 gemeentewet (oud) was de raad steeds het bevoegde orgaan in zaken die de autonomie van de gemeente betroffen. En in artikel 209 , onder a gemeentewet (oud) werd B\&W opgedragen om in het kader van het dagelijks bestuur de raadsbesluiten uit te voeren. De vraag was dan of de feitelijke opdrachtverlening, zijnde de uitvoering van een raadsbesluit, al dan niet uitsluitend aan $B \& W$ behoorde. Deze discussie werd nog gecompliceerd doordat de burgemeester als voorzitter van de raad en $B \& W$

\footnotetext{
3 Gst 1885,1739

WBA 1893, 2323; WBA 1896, 2433.

- Gst 1892, 2134.
} 
eveneens terzake van de uitvoering van raadsbesluiten een taak had. Ingevolge artikel 76 gemeentewet (oud) werd deze bevoegdheid echter beperkt in het geval dat artikel 209, onder a gemeentewet (oud) van toepassing was, en $B \& W$ bevoegd waren ${ }^{39}$. In de literatuur werd voor mogelijke conflicten tussen de competentie van B\&W en de burgemeester, die hiervan het gevolg zouden kunnen zijn, de volgende oplossing gegeven. Wanneer voor de uitvoering nadere maatregelen noodzakelijk zouden zijn, dan was dat een taak voor B\&W. Men spreekt hier van exécution délibérative. In het andere geval was de burgemeester bevoegd (exécution active). Deze verhouding tussen de beide artikelen werd door de minister van Binnenlandse Zaken en Landbouw bevestigd tijdens de behandeling van de wet tot wijziging van de gemeentewet van $1931^{40}$. In de praktijk geschiedde de feitelijke opdrachtverlening vrijwel steeds door $B \& W^{41}$. De scherpe kantjes waren intussen wat van de problematiek afgehaald, nadat artikel 169 gemeentewet (oud) was gewijzigd ${ }^{42}$. Dit artikel bepaalde dat de raad in verordeningen $\mathrm{B} \& \mathrm{~W}$ bevoegd kon verklaren om 'nadere regels' te stellen nopens bepaalde, in die verordening aangewezen onderwerpen.

De beoogde scherpe scheiding van bevoegdheden inzake aanbesteding in de verhouding tussen raad, B\&W en burgemeester is in de loop der tijd verlaten. Dit vond zijn oorzaak in het feit dat het vaak niet was uit te maken wanneer sprake was van 'regeling' dan wel van 'uitvoering'. Bovendien was de raad binnen de gemeentelijke huishouding de eerst aangewezene om de grenzen te bepalen van haar bestuursbevoegdheid. De raad kon dus bepalen wat nog wel en wat niet meer viel onder de regeling van artikel 209 , sub a gemeentewet (oud). Het verbaast dan ook niet dat Oppenheim ${ }^{43}$ en Oud $^{44}$ meenden, dat de raad bevoegd zou kunnen zijn om zijn eigen besluiten uit te voeren. Oud ${ }^{45}$ liet het antwoord op deze vraag afhangen van de inhoud der voorwaarden en wie zich daarbij de gunning hadden voorbehou$\operatorname{den}^{46}$. Anders Schroot ${ }^{47}$ : hij was van opvatting dat de bevoegdheid tot het uitvoeren van raadsbesluiten uitsluitend toekwam aan $B \& W$.

\section{Nieuwe ontwikkelingen}

Bij de bestudering van het nieuwe gemeenterecht zoals dat na 1 januari 1994 in werking is getreden, valt op dat er geen afzonderlijke regels zijn opgenomen ter zake van de aanbeste-

39 Eerder KB 25 aug. 1881, S. 152, Gst 1881, 1563, WBA 1881, 1683. Hierop zal Oud (1959), 375 hebben gedoeld met zijn opmerking dat nog nooit iemand de consequentie had getrokken dat de gunning aan de burgemeester, als uitwoerder van de besluiten van $B \& W$, toebehoorde.

40 Hand. I 30 jan. 1931, 201 v. (m.n. 203).

4 In meer algemene zin: TK 1985-1986, 19 403, nr. 3, 136 (Memorie van Toelichting). Blijkens de toelichting op art. 152 ontwerp-Gemeentewet was de uitvoering voornamelijk beperkt tot het rerrein van de openbare orde. Daarom was oorspronkelijk niet beroep opengesteld tegen besluiten die waren genomen door de burgemeester. Zie echter art. 153 Gemeentewet. Zie over deze taakverdeling tussen het college van B\&W en de burgemeester ook art. 161 Gemeentewet en de Memorie van Toelichting, t.a.p., 142.

4 Wet van 9 juli 1964 , S. 256.

43 Oppenheim (1928 a), 403 en Oppenheim (1928 b), 93.

4 Oud (1959), 331 en 427.

4 Oud (1959), 374-375.

46. Voor nog andere opvatcingen Van Loenen (z.j.), commentaar op artt. 176 en 209 gemeentewet: Gst 1901, 2582; Gst 1903, 2718; Gst 1904, 2776; Gst 1907, 2916; Gst 1909, 3012; Gst 1913, 3233; Gst 1925, 3823 en ook Schroot (1979), 260 hield vast aan het strikte onderscheid tussen de bevoegdheid inzake het besluit tot aanbesteden en de virvoering van dit besluit. En Oppenheim (1928 b), 171.

\$7 Schroot (1979), 260. 
ding. Verder kan worden vastgesteld, dat tijdens de parlementaire behandeling, op geen enkel moment het opnemen van (afzonderlijke) aanbestedingsbepalingen zelfs maar is overwogen. Dit heeft tot gevolg dat de bijzondere aanbestedingsbevoegdheidsverdeling tot het verleden is gaan behoren. Voor de verdeling van aanbestedingsbevoegdheden geldt datgene, dat ook voor de overige gemeentelijke bestuursbevoegdheden wordt bepaald. Daarmee is de oorspronkelijk - in 1851 - specifiek bedoelde bevoegdheidsverdeling inzake de aanbesteding verdwenen, hetgeen een bevestiging vormt van de ontwikkelingen nadien. Maar de Gemeentewet 1994 gaat verder: door de globale regeling wordt het aan het gemeentebestuur overgelaten om te komen tot een op de lokale situatie toegesneden bevoegdheidsverdeling. Volgens artikel 108 Gemeentewet 1994 (juncto artikel 124, lid 1 Grondwet) komt de bevoegdheid tot regeling en bestuur inzake de huishouding van de gemeente toe aan het gemeentebestuur. Het wordt aan de raad overgelaten te bepalen of en in hoeverre hij gebruik wil maken van zijn beleidsbepalende taken ${ }^{48}$. Dit geldt eveneens voor de mate waarin hij gebruik wenst te maken van zijn controlerende bevoegdheden. Er wordt met andere woorden niet vastgehouden aan een gemeentelijk monisme; door al of niet geclausuleerd beleidsbepalende bevoegdheden over te dragen kan de raad ook een keuze voor een (meer) dualistische structuur bevorderen.

De bevoegdheid van de raad wordt uitgewerkt in artikel 147 Gemeentewet 1994. In beginsel zijn alle bevoegdheden toebedeeld aan dit hoogste gemeentelijke orgaan (artikel 125 Grondwet). Deze bevoegdheden zijn niet alleen van regelgevende aard; ook planning en bestuur behoren ertoe ${ }^{49}$. Anders dan in de gemeentewet is afgezien van het opnemen van een opsomming van beyoegdheden. Daarmee wordt tevens duidelijk dat de raad op het gehele terrein van de gemeentelijke werkzaamheden, ook waar het gaat om medebewindswerkzaamheden, in beginsel aan het hoofd van de gemeente staat. Blijkens de Memorie van Toelichting ${ }^{50}$ is overwogen om een aantal raadsbevoegdheden (waaronder bestuursbeslissingen inzake burgerrechtelijke rechtshandelingen) toe te kennen aan B\&W onder de toevoeging dat de raad de bevoegdheden aan zich zou kunnen trekken of voorbehouden. Gewezen werd op de mogelijkheid dat spoed geboden kan zijn bij het nemen van een beslissing, zodat niet steeds gewacht kan worden op een raadsvergadering. De wetgever heeft evenwel van een dergelijke regeling afgezien, onder meer omdat dit als te bevoogdend jegens de rasd werd gezien. Blijkens artikel 156 Gemeentewet 1994 is gekozen voor een verniming van de delegatiemogelijkheden, waarbij de raad in even ruime mate als bij de commissies bevoegdheden aan B\&W kan delegeren". In artikel 160 Gemeentewet 1994 wordt vervolgens bepaald dat het dagellijks bestuur van de gemeente berust bij B\&W, voorzover niet bij of krachtens de wet de burgemeester hiermee is belast. Iedere enumeratie van hetgeen tot het dagelijks bestuur behoort, ontbreekt. Slechts aan de belangrijkste elementen van de bevoegdheden is nog een afzonderlijke bepaling gewijd, zoals de voorbereiding en uitvoering van raadsbesluiten (artikelen 161 en 162 Gemeentewet 1994). Laatstgenoemde bepaling dient niet als een regel van relatieve competentie te worden beschouwd, maar vooral als een plicht te zorgen voor een adequat uirvoeren van de bestuurs- en beheerstaken ${ }^{52}$. De bevoegdheden van B\&W kunnen door de wethouder in mandaat worden uitgeoefend (artikel 168, lid 1 Gemeentewet 1994) ${ }^{53}$, met als gevolg dat B\&W als geheel verantwoordelijk blijven (artikel 168, lid 2 Gemeente-

4 TK 1988-1989, 19 403, nr. 6, 52 (Memorie van Antwoord).

4 TK 1985-1986, 19403 , nr. 3, 131 (Memorie van Toelichting).

so TK 1985-1986, 19 403, nr. 3, 38-39 (Memorie van Toelichting).

s1 TK 1985-1986, 19 403, nr. 3, 58 en 138-139 (Memorie van Toelichting).

s2 TK 1985-1986, 19403 , nr. 3, 141 (Memorie van Toelichting)

53 TK 1985-1986, 19403 , ar. 3, 43 en 57-58 en 145 (Memorie van Toelichting bij art. 170 Gemeentewet) en TK 1988-1989, 19 403, nr. 10, 72 (Memorie van Antwoord). Mandaat kan worden uitgeoefend zonder wettelijke basis, tenzij een uitdrukkelijke wetsbepaling zich ertegen verzet (o.m. ABAR-rapport (19184), 46). Dat hicr toch in een bepaling wordt voorzien hangt samen met het feit dat de ondergeschiktheidsrelatie in de verhouding tot het college ontbreekt. 


\section{Hoofdstuk 2}

wet 1994$)^{54}$. Blijkens artikel 165 Gemeentewet $1994 \mathrm{kan}$ de raad, op voorstel van het college, aan een commissie bevoegdheden van B\&W toekennen. Het leggen van een wettelijke basis voor mandaat door B\&W aan ambtenaren wordt onnodig geachts ${ }^{35}$. Delegatie aan ambtenaren komt slechts in enkele bijzondere gevallen voor (artikel 166 Gemeentewet 1994). Gedacht zou kunneu worden aan de overdracht van de bevoegdheid aan een Directeur Publieke Werken om tot een bepaalde som ter uitvoering, van het raadsbesluit e.q. het besluit van B\&W een aanbesteding te houden. Volgens de Memorie van Toelichting ${ }^{56}$ moet de term uitvoering in dit artikel worden uitgelegd als vooral een technische uitvoering van besluiten, waarbij van een reële politieke verantwoordelijkheid van $B \& W$ nauwelijks meer sprake kan zijn. Van dergelijke delegatiebesluiten staat beroep open op B\&W, tenzij bij of krachtens de wet beroep op een ander orgaan is opengesteld dan wel de raad heeft bepaald dat beroep op hem openstaat (artikel 166, lid 2 Gemeentewet 1994) ${ }^{57}$.

De burgemeester wordt niet meer met zoveel woorden belast met de uitvoering van raadsbesluiten en collegebesluiten. Blijkens de Memorie van Antwoord ${ }^{\text {se }}$ is van het opnemen van een bepaling als voorheen in artikel 76, lid 1 gemeentewet (oud) afgezien, omdat de praktijk inmiddels anders is. De uitvoering van besluiten van de raad en B\&W geschiedt nu reeds door anderen, bijvoorbeeld door een commissie of door een ambtenaar, aldus de Memorie van Antwoord. Wel kunnen de gemeente-grootte en plaatselijke politieke verhoudingen aan de burgemeester meer taken doen toebedelen dan de wetgever heeft gedaan ${ }^{50}$. In het algemeen zal de raad in zijn besluiten omtrent het verrichten van rechtshandelingen bepalen in hoeverre er naast de bevoegdheid van de burgemeester, als hier bedoeld, plaats is voor uitvoering door B\&W (artikel 147 Gemeentewet 1994) ${ }^{60}$. Dat wil zeggen in boeverre B\&W nog nadere beslissingen moeten nemen ter uitvoering van het raadsbesluit. Het kan dan ook niet zo zijn dat de burgemeester na een raadsbesluit omtrent het verrichten van een publiek- of privaatrechtelijke rechtshandeling direct een kan beginnen met het namens de gemeente verrichten van de rechtshandeling ${ }^{61}$. De raad kan, op voorstel van de burgemeester, diens bevoegdheden toekennen aan een commissie, behoudens enkele nader genoemde bevoegdheden (artikel 178 Gemeentewet 1994$)^{62}$. Het is voorts mogelijk dat de burgemeester met instemming van de raad de uitvoering van raadsbesluiten, de genoemde uitzonderingen daargelaten, overdraagt aan een gemeenteambtenaar (artikel 177 Gemeentewet 1994). Van de besluiten van de ambtenaar staat beroep open op de burgemeester. De raad kan echter bepalen dat beroep openstaat op de raad ${ }^{63}$. Artikel 179 bepaalt dat de voorschriften inzake de uitoefening en het toezicht op de overgedragen bevoegdheden van overeenkomstige toepassing zijn.

\section{Conclusie}

In tegenstelling tot de oorspronkelijke opzet van de gemeentewetgever in 1851 is de wijze waarop de aanbestedingsbevoegdheid over de verschillende bestuursorganen wordt verdeeld, thans nagenoeg geheel overgelaten aan het bestuur. De Gemeentewetgever heeft zich kennelijk willen aansluiten bij de alledaagse praktijk, er wellicht in berustend dat alle zegen van de in de volgende hoofdstukken te bespreken aanhestedingsreglementering zal moeten komen.

$34 \mathrm{Bij}$ het amendement-Stoffelen, TK 1989-1990, $19403, \mathrm{nr}, 43$ was voorgesteld om in het toenmalige art. 171, lid 1 'door het college' te vervangen door 'door hen'. Zie TK 1989-1990, 19 403, nr. 16, 29 (Nota naar aanleiding van het Eindverslag). Het amendement werd later ingetrokken, blijkens Hand. II 26 sept. 1990, 4-160

ss TK 1985-1986, 19 403, nr. 3, 56 (Memorie van Toelichting).

s6 TK 1985-1986, 19 403, nr. 3, 144 (Memorie van Toelichting).

57 In verband met de hier bedoelde overdracht van collegiale bevoegdheden is het bepaalde in artikel $167 \mathrm{Gemeen-}$ tewet relevant: de bepalingen betreffende de uitoefening van en het toezicht op de collegiale bevoegulteden is van overeenkomstige toepassing op de gedelegeerde bevoegdheden, behoudens de voorschriften betreffende vergaderingen.

58 TK 1985-1986, 19 403, nr. 3, 107 (Memoric van Toelichting).

59 TK 1985-1986, 19 403, nr. 3, 146 (Memorie van Toelichting bij art. 169 ontwerp).

so TK 1985-1986, 19 403, nr. 3, 147 (Memorie van Toelichting).

61 EK 1990-1991, 19 403, nr. 64b, 6 (Memorie van Antwoord) onder verwijzing naar Van Stegeren (1991), 6916, 89-95 en. Gsi (1991). 6917, 125-128.

22 Zie omtrent mogelijkheid zijn bevoegdheden te delegeren aan commissies TK 1985-1986, 19 403, ar. 3, 58 (Memorie van Toelichting) en art. 180 Gemeentewet.

63 Kritisch Brederveld (1990), 417. Het destijds voorgestelde beroep op ook B\&W is vervallen. 
Het is thans nog te vroeg om hierover al een oordeel te vellen. De vrees wordt hier geuit, dat de bevoegdheidsverdeling gevolgen kan hebben voor de openbaarheid van de besluitvorming, in die gevallen dat $B \& W$ in gesloten vergadering het aanbestedingsbeleid gaan bepalen. Daarmee zijn we dicht bij hetgeen Thorbecke - door ervaring als Leids raadslid wijs geworden - destijds heeft willen vermijden.

\section{Openbare en onderhandse aanbesteding; beleidsgrondslag}

\section{Periode tot 1851}

Hierna wordt de ontwikkeling geschetst die het aanbestedingsbegrip in de gemeentewet in de loop der tijd heeft doorgemaakt. Daarbij wordt, waar nodig, verwezen naar het ontwerpgemeentewet van Thorbecke ${ }^{64}$. Thorbecke heeft zich bij het ontwerpen van het gemeenterecht laten inspireren door het buitenlandse (met name het Belgische, Franse, Pruisische en Oostenrijkse ${ }^{65}$ ) recht. Thorbecke's gemeentewet wijkt evenwel op belangrijke punten af van de Belgische wet van $1836^{66}$.

Het blijkt moeilijk materiaal over het ontwerp-Thorbecke te achterhalen. In de dossiers van het ministerie van Binnenlandse Zaken is het oorspronkelijk ontwerp van oktober 1850 niet teruggevonden. Dit ontwerp is door het kabinet aan de Koning Willem III aangeboden. Er zijn alleen 'schoone exemplaren' aangetroffen, de hand van Thorbecke ontbreekt. 'Verdere naspeuringen om het geschreven exemplaar zelf terug te vinden, bleven vruchteloos ${ }^{\circ 7}$. De Raad van State maakte geen opmerkingen betreffende de aanbesteding ${ }^{s}$.

In de achttiende eeuw werden vrijwel alle werken in de grote steden onder eigen beheer uitgevoerd door het stedelijk fabriekambt, de timmer- en metseltuinen, de werkplaatsen en dergelijke ${ }^{69}$. Slechts de uitvoering van enkele werken, zoals dijken, werd aanbesteed. Ten tijde van de Franse overheersing werden publieke werken meer algemeen en werd het maken van straatwegen, vestingswerken (forteressen) en gebouwen openbaar aanbesteed ${ }^{70}$. In dat verband zijn twee wetten van betekenis. In de eerste plaats is dat de Wet van 28 Pluviose an VIII (1800), volgens welke de na een gehouden aanbesteding (la conclusion des marchés publics) af te sluiten overeenkomsten van administratiefrechtelijke aard (contrats administratifs) waren. Ten tijde van de inlijving bij Frankrijk in 1810 was deze wet in ons land van kracht. En daarnaast de Wet van 19 Ventôse an IX (1801)). Deze wet kende twee aanbestedingsprocedures: de openbare aanbesteding ('adjudication ouverte', waarbij het gunningsproces goeddeels in het openbaar geschiedde en waarbij de opdracht moest: worden gegund aan de laagste inschrijver, en de onderhandse aanbesteding ('marché négociés', ook: 'entente directe'). Spier wijst nog op de wet van 10 mei 1829 waarin dit onderscheid eveneens

64 De Vries (1931), 102 v. resp. 142 v.; Vis (1980), 333 v.

ds De Vries (1931), VII.

* Over die wet zie men De Vries (1931), 19-20, 24 en 41; Kocken (1973), 460 v, en 483-485.

67 De Vries (1931), p. LX.

* Advies van den Raad van State 17 december 1850, no. 3 op het ontwerp-gemeentewet van Thorbecke 1851. Zie De Vries (1931), $90 \mathrm{v}$.

Zie over deze periode ook Van den Berg (1990), 215-216.

70 Gst 1891, 2066; Gst 1891, 2067. 
voorkwam. In 1836 werd hieraan de aanbesteding met voorafgaande selectie toegevoegd ('adjudication restreinte') ${ }^{71}$.

Aan de adjudication liggen de beginselen: 'la concurrence', 'T'égalité entre concurrents' en 'la publicite' ten grondslag. Het gaat hier kennelijk om algemene erkende grondslagen, die men ook kan tegenkomen in het Belgische en het Duitse recht. De basis voor de diverse aanbestedingswijzen ligt in de negentiende eeuw. Oorspronkelijk lag het accent op het financiële belang dat met de aanbesteding was gemoeid. Dit heeft tot gevolg gehad dat bij de adjudication de laagste prijs dwingend was. Later is de wetgever wat van dit rigoureuze standpunt teruggekomen en wordt de aanbestedende overheid wat meer vrijheid gelaten bij de keuze van de aannemer. Een belangrijke overweging daarbij is dat 'les marchés publics sont apparus de plus en plus comme réalisant le plus souvent une collaboration plus ou moins étroite du cocontractant à un service public, et justifiant de ce fait une prise en considération très élargie de l'intuitis personae ${ }^{72}$. Decreten, die sinds die tijd zijn uitgevaardigd, laten in veel gevallen de keuze over voor tén der andere procedures.

Hoewel, na het vertrek van de Fransen, onder Willem I openbare aanbesteding wel voorkwam, keerde het onderscheid tussen de openbare en onderhandse aanbesteding niet terug in de latere stedelijke en plattelandsreglementen. Volgens de Grondwetten van 1814 en 1815 moesten er reglementen tot stand komen, die de inrichting van de plaatselijke regering voor zowel de stad als voor het platteland zouden regelen ${ }^{73}$.

De stedelijke reglementen, welke door de stedelijke regeringen waren gemaakt stonden onder preventief toezicht van de Staten en hadden koninklijke bekrachtiging nodig (artikel 154 Grondwet van 1815). De Staten waren voorts belast met het financiële toezicht op de plaatselijke besturen. Deze dienden hun begrotingen te overleggen en zich te gedragen naar hetgeen dienaangaande door de Staten nodig werd geoordeeld. Verder waren in de bestuursreglementen verschillende burgerrechtelijke rechtshandelingen aan voorafgaande goedkeuring onderworpen. De reglementen voor het platteland werden op last van de Staten gemaakt, eveneens onder bekrachtiging van de Kroon (artikel 132 Grondwet van 1815). Bij de regeling van het plattelandsbestuur werd gekozen yoor én algemeen reglement per provincie, met de mogelijkheid om daarvan af te wijken, gelet op de 'verschillende toestanden' per provincie. De provinciale reglementen konden onderling dus nog aanzienlijk verschillen, ook al waren zij op dezelfde leest geschoeid $^{74}$. Met name door gebruikmaking van 'het algemeen model', dat was ontworpen door de minister van Binnenlandse Zaken, kon een zekere gelijkenis tussen de plattelandsreglementen worden bereikt ${ }^{75}$. En ook de overeenkomst met de reglementen der steden was nadien veel groter dan in de jaren tot $1815^{76}$.

Kocken ${ }^{n}$ bespreekt de regeling der Groningse stadsregering van $1815^{78}$. De raad oefende onder meer verschillende burgerrechtelijke rechtshandelingen uit. Voor de meeste dezer rechtshandelingen behoefde de raad goedkeuring van hogerhand". Deze goedkeuringsvoorschriften, nodig met het oog op de belangen van de Staat en de plaatselijke gemeenschap, waren ontleend aan de Franse wetgeving. Voor de aanbesteding bestond een dergelijk toezicht overigens niet ${ }^{50}$. Volgens artikel 16 moest de raad de voorwaarden van aanbesteding goedkeuren. Van de

2) Spier (1981), 67.

De Laubadere (1990), 631. Ook Spier (1981), nrs. 30-34.

n Uitgebreid Kocken (1973), 239 v.

74 Kocken (1973), 245 v.

7s Over de diverse reglementen zie nesı Kocken (1973), $249 \mathrm{v}$.

76. Kocken (1973), 297.

77 Kocken (1973), 265.

78 Het Reglement voor de Regering der Stad Graningen geapprobeerd bij KB 5 nov. 1815, nr. 60. Opgenomen in Kocken (1973), Bijlage II, 627 v. Ook Vis (1980), 155 v.

Kocken (1973), 268.

Thorbecke (1843), $136 \mathrm{v}$. 
plattelandsgemeenten bespreekt Kocken het provinciale reglement van Utrecht van $1816^{11}$. Dit week, slechts weinig af van de andere reglementen. (Alle) aanbestedingen van werken, die uit de plaatselijke kas betaald werden, konden niet anders geschieden dan ten overstaan van twee leden van de gemeenteraad, en onder goedkeuring van de Staten $^{82}$. Later, volgens artikel 42 van het plattelandsreglement van 1825 stelde de gencenteraad de voorwaarden van aanbesteding vast. De processen-verbaal van aanbesteding moesten, met al de daarop betrekking hebbende stukken aan de Staten worden gezonden. De aanbestedingscontracten konden dus, behalve in bijzonder spoedeisende gevallen, slechts onder voorwaarde ('provisioneel') worden aangegaan, en pas definitief door de raad worden goedgekeurd, na ontvangst van de stukken van de Staten, 'voor zoo verre er door denzelven in de zaak geene andere instructien mogten zijn gegeven'. De burgemeester was belast met de zorg voor de uitvoering van alles waartoe de raad zou besluiten (artikel 57).

Toch begon reeds vóór de invoering der gemeentewet hier en daar openbare aanbesteding van het onderhoud der gemeentewerken tot regel te worden. Waar het eigen beheer nog bestond, bleef dit beperkt tot herstelwerkzaambeden die niet voor onderhandse of openbare aanbesteding vatbaar waren, zoals kleine werken of (dringende) spoedgevallen. In het ontwerp-De Kempenaer van $1849^{83}$ keert het onderscheid tussen openbare en onderhandse aanbesteding voor het eerst weer terug.

De grondwetsherziening van 1848 maakte een eind aan het onderscheid tussen stedelijke en platrelandsgemeenten en vorderde een wettelijke grondslag voor de samenstelling, inrichting en bevoegdheid van de gemeentebesturen. Het ontwerp-gemeentewet van de minister van Binnenlandse Zaken $\mathbf{M}$. de Kempenaer sloot nauw aan bij de Belgische gemeentewet van 30 maart 1836 en bij de stedelijke reglementen. De Belgische gemeentewet van 1836 was zelf voor een deel de voortzetring van de plaatselijke bestuursreglementen van 1824 en 1825 , terwijl zij voor een ander deel berustte op de beginselen van bet Franse gemeenterecht vit de periode 1795-1815. Zij putte derhalve ten dele uit dezelfde bronnen als het Nederlandse gemeenterecht. De Belgische wet was Nederland echter op verschillende punten vooruit, zij het niet op alle punten. De gemeenten waren bij voorbeeld in hun autonomie meer beperkt dan de Nederlandse gemeenten volgens het ontwerp-De Kempenaer zouden zijn geweest ${ }^{34}$. Pas na de afscheiding in 1839 ontstonden er meer verschillen tussen het Belgische en Nederlandse gemeenterecht ${ }^{83}$.

Volgens artikel 97 ontwerp-De Kempenaer werden de daar genoemde besluiten van de raad onderworpen aan de goedkeuring van Gedeputeerde Staten. Anders dan later in het ontwerpThorbecke had deze goedkeuring geen betrekking op het besluit tot onderhands aanbesteding. Blijkens artikel 102 ontwerp-De Kempenaer werd de goedkeuring van de voorwaarden van aanbesteding alleen voorgeschreven voor gemeenten, welker bevolking niet meer dan drie duizend zielen bedroeg. Artikel 102 ontwerp-De Kempenaer bepaalde verder dat aanbestedingen in het openbaar geschieden. 'Om bijzondere redenen kunnen zij, met goedvinden van Gedeputeerde Staten, onder 's hands plaats hebben'. Een toelichting ontbreekt. Blijkens het advies van de Raad van State van 4 juni 1849 , no. 10 op het ontwerpgemeentewet-De Kempenaer $1849^{86}$ rees de vraag of in de ontwerp-bepaling lag besloten, dat aanbestedingen in het openbaar zullen moeten geschieden dan wel of de gemeentebesturen

6. Reglement voor de plattelandse gemeenten in de provincie Utrecht van 1816, gearresteerd bij KB 29 juni 1816 , nr. 9. Hierover Kocken (1973), 273 en afgedrukt in Bijlage II, 640 v.

- lets dergelijks in het Reglement van besnur voor het planteland der provincie Graningen, gearresteerd bij KB 7 mei 1819, opgenomen in Vis (1980), 207 v., zij het dat de goedkeuring der Staten ontbrak.

* Ontwerp van wet omtrent de zamenstelling, inrigting en bevoegdheid der gemeentebesturen, in De Vries (1931), 70 v. Over het wetsontwerp o.m. Oppenheim (1928 a), 38.

Kocken (1973), 482.

- De Vries (1931), 21.

to De Vries (1931), 58 v. 
ten deze de vrije hand hadden. In dit verband werd nog opgemerkt dat de stedelijke raden volgens een mededeling van de minister van Binnenlandse Zaken aan Gedeputeerde Staten van Zeeland van 19 december 1836, No. 91, als niet onbevoegd te beschouwen waren, om, daartoe termen vindende, de verpachting van stedelijke eigendommen niet publiek, maar, mits in geschrift gesteld, onder de hand te doen plaats hebben ${ }^{87}$. Van beaniwoording der vraag is het - belaas - niet meer mogen komen. Voordat kon worden toegekomen aan de schriftelijke behandeling van het ontwerp-De Kempenaer in de Kamer trad het kabinet af.

\section{Periode na 1851}

Het duurt dan nog tot 1851 , ter gelegenheid van de invoering van de gemeentewet ${ }^{88}$, eer het onderscheid tussen de openbare en onderhandse aanbesteding werkelijk herleeft. Het toenmalige artikel 142, lid 2 gemeentewet van 1851 luidde:

'De aanbesteding geschiedt in het openbaar, behoudens de gevallen, waarin om bijzondere redenen, onderhandse aanbesteding in het belang der gemeente ware ${ }^{20}$.

In het verleden is uit deze bepaling ten onrechte wel afgeleid dat er steeds zou moeten worden aanbesteed, en het uitvoeren van werken (zoals de aanleg of het onderhoud van gemeentewerken) in eigen beheer zou zijn uitgesloten. Het uitvoeren van werken in eigen beheer druist evenwel niet in tegen het stelsel der wet: deze laat zich over de verhouding tot het aanbesteden niet uit ${ }^{90}$. De redactie van de Gemeentestem bleek overigens wel een duidelijke voorkeur te hebben voor de aanbesteding ${ }^{91}$.

In de Gemeentestem werd daarover het volgende opgemerki". De $17 \mathrm{e}$ eeuwse gilden (bv. de stadswerven) stonden aan de noodzakelijke concurrentie in de weg. De gemeentewetgever begreep dat voor de gemeentebesturen openbare aanbesteding tot de aanleg en het onderhoud van gemeentewerken als regel en onderhandse aanbesteding als uitzondering moest gelden. Toen de gilden werden opgeheven, en ieder zich vrijelijk kon vestigen, bracht de verhouding van de gemeentehesturen tot de ingezetenen (belastingbetalers) mee, dat zij voortaan gebruik zou maken van deskundigen, onder behoorlijk toezicht en na voorafgaande openbare aanbesteding. Het verrichten van werken in

7 Kocken (1973), 353-354.

s De benaming "gemeentewet" wordt pas officieel bij de wet 28 april 1897, S. 10. Zie over de totstandkoming van de gemeentewet De Vries (1931). Het ontwerp is bij KB 3 maart 1851 aan de Tweede Kamer aangeboden. Zie "Bijlagen tot het verslag van de Tweede Kamer van de Staten Generaal", 1850-1851, 377 v. In de Bijlagen treft men het Verslag van de Commissie van Rapporteurs (443 v.) en de Memorie van Antwoord aan, alsmede de Nota van Wijzigingen. $(513 \mathrm{v}$.) Voor de beraadslagingen over het wetsontwerp die op 12 mei 1851 in de Tweede Kamer zijn begonnen, wordt verwezen naar Hand. II, 714-851, 854, 856-1030. Op 4 juni 1851 is bet ontwerp door de Tweede Kamer aangenomen. Voor de behandeling in de Hand. I, zitting 1850 - 1851, 149 v. Op 27 juni 1851 is het ontwerp door de Eerste Kamer aanvaard. Met betrekking tot de totstandkoming van de gemeentewet kan worden opgemerkt, dat deze in beide Kamers met weinig amendementen werd aangenomen. Vgl. Boissevain (1867), 5 v. en Oud (1970), 587.

89 Oud (1959), 372 heeft terecht opgemerkt, dat het vanzelfsprekend was, dat het in het tweede lid bepaalde gold voor alle aanbestedingen, ongeacht of de plannen en voorwaarden door de raad of door B\&W waren vastgesteld.

D Blijkens o.m. Gst 1857, 285; Gst 1871, 1032; Gst 1876, 1301; Gst 1876, 1303; Gst 1876, 1317 en Gst 1896 , 2335. Zie onk Ministeriêle Beslissing, in: Gst 1898, 2432. Verder Van Loenen (z.j.), commentaar op art. 176 gententewet; Oud (1959), 374, Schroot (1979), 259 en Burger (1983), 225. Anders Oppenheim (1928 a), 742. In zijn hewerking verzet Van der Pot zich overigens tegen de opvatting van Oppenheim.

91 Zie bijv. Gst 1854, 168; Gst 1855, 170; Gst 1857, 291; Gst 1891, 2066; Gst 1891, 2067. Anders WBA 1893, 2315.

93 Gst 1891, 2066; Gst 1891, 2067. 
eigen beheer was een overgangsmaatregel, om te voorkomen dat men zou zijn overgeleverd aan onbillijke eisen of gebrekkige uitvoering van de werkzaamheden. Aanbesteding bleek in de praktijk veelal goedkoper. Ein hoewel het weekloon van de 'gemeentelijke bouwvakker' billijk was, werd opgemerkt, dat de werktijd niet in verhouding stond tot de werktijd bij een gewone werkbaas. Daarop duidde ook het spreekwoord: 'dat het werkzweet van een stadswerkman niet te verkrijgen was, noch in de apotheek, noch elders, voor hoogen prijs zelfs niet'. Langzamerhand begon dan ook reeds voor de invoering der gemeentewet hier en daar openbare aanbesteding van het onderhoud der gemeentewerken tot regel te worden. Waar het eigen beheer nog bestond, bleef het beperkt tot die herstelwerkzaamheden die niet voor onderhandse of openbare aanbesteding vatbaar waren. Het ging dan om kleine werken of om dringende spoed.

Met het stelsel der openbare aanbesteding moest het gesloten gildesysteem (zoals de stadswerven) worden doorbroken, waardoor er niet alleen uitzicht kwam op economische groei door vrije concurrentie, maar waardoor het ook mogelijk zou worden om zich vrijelijk te vestigen ('liberalisme'). Let op de frappante parallel met de grondgedachten van de Europese interne markt! Om oneigenlijke aanbestedingspraktijken te weren, werd bepaald dat raadsleden zich volstrekt dienden te 'onthouden van aannemingen, hetzij die in 't openbaar of onder de hand mochten worden aanbesteed' (artikel 24 gemeentewet van 1851$)^{93}$.

In artikel 142, lid 2 gemeentewet van 1851 stond de openbare aanbesteding tegenover de onderhandse $\mathrm{e}^{\mathrm{s}}$. Het stelde de openbare aanbesteding als regel, en gedoogde de onderhandse alleen dan, wanneer die om bijzondere redenen in het belang der gemeente zou zijn. Deze 'bijzondere redenen' moesten expliciet worden geformuleerd en blijken uit een met stukken gestaafde toelichting95. Alleen wanneer naar de aard van het besluit (tot onderhandse aanbesteding) klaarblijkelijk in het algemeen geformuleerde bepalingen onontbeerlijk waren, zou goedkeuring van de onderhandse aanbesteding kunnen worden verkregen. Wat verstond men nu onder een openbare en een onderhandse aanbesteding? In de Gemeentestem werd alleen een zodanige aanbesteding openbaar genoemd, waarbij een ieder die aan de gestelde voorwaarden kon voldoen tot inschrijving werd toegelaten ${ }^{*}$. Openbare aanbesteding betekende dus niet slechts dat het feit van aanbesteding openbaar moest worden gemaakt. Deze wijze van aanbesteden had de voorkeur van de wetgever en werd ook zijdens het hogere bestuur meermalen aanbevolen ${ }^{97}$. Analyse van de betrokken wetsbepalingen maakt duidelijk dat het uitgangspunt van de openbare aanbesteding is gebaseerd op een viertal beginselen: het gelijkheidsbeginsel en het openbaarheidsbeginsel (met name artikelen 142 en 44 gemeentewet van 1851), het motiveringsbeginsel (artikel $142 \mathrm{j}^{\circ}$ artikel 194 gemeentewet 1851) en het financieel-doelmatigheidsbeginsel. Deze beginselen zouden, gezamenlijk danwel afzon-

${ }^{93}$ Zie art. 24 Ontwerp-Thorbecke 1850. Vgl. Lion (1851), 40-41. Ook reeds de stedelijke reglementen (art. 8 Reglement 1815 en art. 51 Reglement 1824), het ontwerp-De Kempenaer (art. 92) en de Belgische wet (art. 68). Vgl. Boissevain (1867), 120.

3uriks (1955), 370-373.

s5 Zo GS Overijssel 20 juni 1903, Gst 1903, 2702.

* Gsi 1888, 1928; Gst 1906, 2859; Gst 1906, 2873. Ook Oud (1959), 373.

97 Circulaires van de Minister van Binnenlandse Zaken 24 februari 1881, nr. 669, Afd. O, Gst 1904, 2728 en 28 april 1936, no. 11650, Afd. B.B. waarbaar wordt verwezen in een missive van GS Groningen 28 mei 1948, Gst 1948, 4966 (tegen plaatselijke protectie in de provincie). Zie ook circulaire van de Minister van Wederopbouw en Volkshuisvesting 1 maart 1950, Gst 1950, 5064 (aanbesteding niet beperken tot stadsgenoten of aamemers, die een bepaalde staatkundige of religieuze richting aanhangen). Anders missive van de Minister van Wederopbouw en Volkshuisvesting van 26 mei 1948, waarover in Gst 1948, 4972. Zie verder Rondschrijven GS ZuidHolland 18 juli 1960 aan gemeentebesturen, Gst 1960, 5599 en het Rondschrijven GS Utrecht 4 september 1961, Gst 1961,5662 . 
derlijk, de beste verzekering vormen voor een algemene mededinging onder de belanghebbende aannemers ${ }^{98}$. Zou de raad daarentegen beslissen dat het werk zou worden aanbesteed bij één of enkele door hem aangewezen aannemer(s), dan was dit te beschouwen als een onderhandse aanbesteding: de opdracht van een werk aan één aannemer voor een vooraf bepaalde prijs ${ }^{99}$.

\section{Preventief toezicht}

Aan de ene kant liet artikel 142 gemeentewet van 1851 de getneentebesturen de van oudsher bestaande zelfstandigheid tot het aanbesteden van werken. Blijkens de regeling in Titel II, Eerste Hoofdstuk van de gemeentewet van 1851 betreffende de regeling en het bestuur van de huishouding van de gemeente is de aanbesteding van werken een autonome bestuursbevoegdheid. Anderzijds moest worden gewaakt tegen een plaatselijk financieel wanbeleid ${ }^{100}$. De bevoegdheid van de gemeentebesturen tot het zelfstandig regelen en besturen van de eigen huishouding was daarom op grond van artikel 141 Grondwet van 1848 afhankelijk gesteld van het preventieve toezicht, in casu de goedkeuring ${ }^{101}$ door Provinciale Staten. Artikel 141 Grondwet 1848 schreef deze goedkeuring expliciet voor met betrekking tot alle beschikkingen over het gemeentelijke eigendom. Voor wat betreft andere burgerrechtelijke rechtshandelingen liet de grondwetgever het aan de gewone wetgever over om daarover te beslissen. De gemeentewetgever heeft daarvan in 1851 gebruik gemaakt en in artikel 194 gemeentewet $^{102}$ een verdergaand onderscheid geïntroduceerd, waarin werd bepaald dat het toezicht alleen gold voor de daar limitatief genoemde rechtshandelingen, zoals voor het beschikken met betrekking tot onroerend goed en een aantal onlichamelijke zaken ${ }^{103}$. Bovendien droeg de gemeentewet van 1851 , in overeenstemming met het toenmalige artikel 161 Provinciewet, het toezicht op aan de Gedeputeerde Staten. In 1887 werd de Grondwet in dit opzicht aan de gemeentewet van 1851 aangepast (artikel 146 Grondwet van 1887). Voor het verdere onderzoek naar de betekenis van het in de gemeentewet gehanteerde aanbestedingsbegrip, is met name het bepaalde in artikel 194, onder f gemeentewet van 1851 van betekenis. Daar werd geregeld, dat:

'Aan de goedkeuring der Gedeputeerde Staten worden onderworpen de besluiten der gemeentehesturen betreffende: $f$. het onderhands aanbesteden van werken of leverantèn.'

Het bepaalde in artikel 194 gemeentewet 1851 was niet alleen afwijkend van de toenmalige rijksreglementen ${ }^{104}$, maar evenzeer van artikel 81 Belgische gemeentewet 1836 en qua systematiek van het ontwerp-De Kempenaer ${ }^{105}$.

* Zie de eerder genoemde Memorie van Toelichting bij art. 194, sub f gemeentewet van 1851.

* Gst 1890, 2009; Gst 1893, 2186; Gst 1906, 2859 en Gst 1915, 3343.

100 Over deze en andere 'vage' grondslagen Tak en Kuizinga (1975), 375, noten 2-6.

iot Tot het preventieve toezicht kunnen verder onder meer worden gerekend de toestemming, de ontheffing, de machtiging en de verklaring van geen bezwaar.

102 Artikel 228 gemeentewet (oud).

103 Poortinga (1987), 200.

104 Ingevolge art. 141 Grondwet van 1848 verving art. 194 gemeentewet van 1851 de desbetreffende bepalingen in de artt. $71 \mathrm{Vm} 74$, resp. $35,41 \mathrm{t} / \mathrm{m} 44$ van de reglementen, benevens de diverse Koninklijke Besluiten, waarmee de reglementen waren aangevuld. Vgl. Kocken (1973), 319 v. en 488.

105 Kocken (1973), $526 \mathrm{v}$. 
Anders dan in Belgiê - waar zonder dat er daarvoor naar nadere wettelijke voorschriften werd gewezen - koninklijke goedkeuring werd geẻist, werd in ons land de goedkeuring afhankelijk gesteld van de desbetreffende bepalingen in de gemeentewet ${ }^{106}$. Artikel 81 Belgische gemeentewet 1836 bepaalde, dat: 'Ntanmoins, pour les communes plactes sous les attributions des commissionaires d'arrondissement, les actes de locations et adjudications seront soumis, avec les cahiers des charges, à l'approbation de la députation permanente du conseil provincial. Il en sera de même, dans les autres communes, pour les actes d'adjudications, lorsque ces actes auront pour objet une valeur de plus de 10,000 fr.'.

Doordat het toezicht op de onderhandse aanbesteding niet afzonderlijk bij de aanbestedingsbevoegdheid van de raad wordt geregeld, maar deel uitmaakt van een algemene toezichtsbepaling was Thorbecke's systematiek inzake de goedkeuring door Gedeputeerde Staten daarnaast coherenter dan het ontwerp-De Kempenaer.

Besluiten tot openbare aanbesteding vielen buiten het preventieve toezicht ${ }^{107}$. Anders dan in het Franse recht inzake het contrat administratif was in ons land alleen de onderhandse aanbesteding onderworpen aan preventief toezicht. Over de achtergrond van deze goedkeuringseis wordt in de Memorie van Toelichting bij dit artikel de volgende passage gewijd:

'Volgens art. 141 der Grondwet moeten besluiten der gemeentebesturen omtrent de beschikking over gemeenteeigendom en sommige andere burgerrechtelijke rechtshandelingen, aan de goedkeuring der Staten, naar art. 161 der provinciale wet Gedeputeerde Staten, worden onderworpen. De Grondwet wil, dat het vermogen der gemeente tegen onbedachtzaamheid, verzuim of misbruik van het besturend personeel worde beschermd. Vandaar een hoger toezicht, gelijk op den voogd van de minderjarige, op zoodanige handelingen van den raad, waardoor de gemeente soms voor een lange toekomst wordt verbonden, of haar belang, ten gevolge eener oogenblikkelijke willekeur of ontevredenheid van een niet altijd even gelukkig zamengesteld collegie, kan worden benadeeld ${ }^{100}$.

In deze classe worden ook onderhandsche verhuringen, verpachtingen en aanbestedingen gerangschikt. De gemeentebesturen kunnen deze handelingen, volgens het ontwerp, in het openbaar verrigten, zonder enige goedkeuring van hooger gezag te behoeven. Maar verlangen zij die met bepaalde personen onderhands te sluiten, dan komt de waarborg van zoodanige goedkeuring in de plaats van dien eener algemeene mededinging'.

Tak en Kuizinga ${ }^{109}$ onderscheiden in het denken over de betekenis van het preventieve toezicht drie opvattingen. De oudste opvatting is die van de Grondwetgever van 1848 , volgens welke de goedkeuring een daad van medewetgeving was. Dat had tot gevolg, dat het goedgekeurde besluit alleen zou kunnen worden ingetrokken door een gezamenlijk wilsbesluit van de instantie die het besluit in eerste aanleg had genomen en Gedeputeerde Staten ${ }^{110}$. Een andere opvatting was die, welke in de goedkeuring een daad van voortdurende werking wilde zien. Dit betekende dat de goedkeuring steeds (stilzwijgend) aanwezig diende te zijn, en dat intrekking het lagere besluit krachteloos zou maken. Deze beide opvattingen zijn thans verlaten. Volgens Tak en Kuizinga wordt de goedkeuring na de Grondwetswijziging van 1887 'vrijwel algemeen gezien als een voorwaarde die vervuld moet zijn, wil een rechtsgeldig genomen besluit juridische werking kunnen krijgen. Is eenmaal goedkeuring verleend, dan is a.h.w. de "slagboom" opgeheven: intrekking van het goedkeuringsbesluit (...) kan geen invloed meer hebben op het rechtsgeldig voortbestaan en werken van dit besluit"1!.

\footnotetext{
${ }^{106}$ Kocken (1973), 469-470.

107 Kocken (1973), 353-354, die wijst op de ten deze gevestigde prakiijk.

$10 *$ Poortinga (1987), 199 heeft er op gewezen dat de vergelijking met de minderjarige minder juist is.

${ }^{109}$ Tak en Kuizinga (1975), 376. Zie daarover ook De Monchy (1947), 204-213.

${ }^{110}$ De schrijvers verwijzen nog naar Buys (1887), 90, die daarover opmerkt dat velen van oordeel zijn, dat de regering haar "mandaat" het best vervult als zij zich zoveel mogelijk "plaatst op de zetel van de (lagere) macht". Buys keurt dit af, maar erkent dat deze "staatsvoogdij" overeenstemt met de bedoelingen van de grondwetgever. III Vgl. Tak en Kuizinga (1975), 376 en de daar genoemde literatuur.
} 
Artikel 194, sub f gemeentewet van 1851 werd zo ruim mogelijk ${ }^{112}$ opgevat: op alle onderhandse aanbestedingen werd het preventieve toezicht van Gedeputeerde Staten gevorderd. Het toezicht strekte zich niet alleen uit tot raadsbesluiten, waarbij voor één concreet geval tot het verrichten van een rechtshandeling werd besloten, maar ook tot algemene regelingen, behelzende voorwaarden, waaronder de burgerrechtelijke rechtshandelingen door de gemeente zouden worden aangegaan, delegatiebesluiten en besluiten van $B \& W$ houdende de uitvoering van deze besluiten ${ }^{113}$. Het maakte verder niet uit of het werken 'en bloc' of werken op tarief betrof ${ }^{114}$. Of dat het om zeer kleine werken ging ${ }^{115}$. Zo hadden Gedeputeerde Staten van Overijssel bezwaar tegen het raadsbesluit waarbij aan B\&W het onderhands drukken van stukken ten behoeve van de secretarie werd overgelaten (dit viel eveneens onder artikel 176 gemeentewet (oud)). Gedeputeerde Staten wensten telkens, voorafgaand aan iedere opdrachtverlening, de naam van de persoon, met wie men onderhandelde, de voorwaarden, het tarief en de prijs te kennen ${ }^{116}$. En ook als het aanbestede werk deel uitmaakte van een groter werk dat de gemeente onder eigen beheer liet uitvoeren, bleef artikel 194, sub f gemeentewet van 1851 van toepassing. In een artikel in de Gemeentestem durfden de schrijvers de veronderstelling aan, dat het toezicht in de praktijk veel minder strikt was, dan uit het Overijsselse besluit naar voren kwam. Zij wezen daarbij op de bestaande praktijk waarbij uit elke gemeenterekening voorbeelden konden worden geput van de aanbesteding van werken die waren gedaan zonder dat er sprake was geweest van concurrentie of goedkeuring door Gedeputeerde Staten ${ }^{117}$.

Uit het eerder genoemde Overijsselse besluit blijkt waarover het preventieve toezicht zich naar het oordeel van de wetgever uitstrekte. Artikel 194 gemeentewet van 1851 had ten doel het uitoefenen van preventief toezicht op de burgerrechtelijke rechtshandelingen als zodanig, die door de raad gesloten werden, al was de feitelijke uitvoering aan B\&W opgedragen. De voorbereidingsbesluiten, die aan deze burgerrechtelijke rechtshandelingen voorafgingen, waren derhalve niet aan afzonderlijk toezicht onderworpen. Pas wanneer B\&W (na onderhandelingen) met één aannemer tot een akkoord waren gekomen omtrent de voorwaarden, het tarief en de prijs (= de gunning), kwam, voorafgaand aan de opdrachtverlening (dus preventief) goedkeuring van Gedeputeerde Staten aan de orde ${ }^{118}$. Door het preventieve toezicht

112 Dit volgde uit het woordje 'betreffende' in art. 194 gemeentewet van 1851 . Ter gelegenheid van de wetswijziging van 15 december 1966, S. 564 is overwogen de term te vervangen, doch de minister van Binnenlandse Zaken vreesde dat de wijziging nieuwe vragen zou oproepen. Vgl. TK 1963-1964, 7685, nr. 3, 10 (Memorie van Toelichting). Zie ook kritiek Schroot (1980), 228-229.

113 Sinds de wetswijzing van 1966 vielen loutere uitvoeringsbesluiten van B\&W buiten het toezicht.

134 Gst $1871,1035$.

119 Bij de behandeling van de gemeentewet was zijdens de Tweede Kamer bezwaar geuit tegen de eis dat ook voor de aanbesteding van roerende goederen van geringe waarde goedkeuring voorgeschreven was. De minister was daarentegen van oordeel dat er geen geschikte gronden waren om een onderscheid te maken. Vgl. Boissevain (1867), 249.

${ }^{116}$ Gst 1868, 894 en Gst 1868, 896. Het preventieve toezicht strekte zich ingevolge art. 142 gemeentewet 1851 ook uit over leveringen. Het raadslid Boissevain vond het 'nietig' tegenover de Arnhemse raad, maar erkende dat Gedeputeerde Staten zulks konden eisen. Het besluit werd in WBA 1868, 1014 verdedigd.

11 Gst 1869, 907. Andere voorbeelden in Gst 1873, 1124 en Gst 1893, 2193 (Geen verandering van een openbare in een onderhandse aanbesteding door $\mathrm{B} \& \mathrm{~W}$ ).

118 Oud (1959), 373. 
leek de onderhandse aanbesteding in artikel 142 gemeentewet van 1851 oorspronkelijk veel op de thans in België bekende onderhandse opdracht en de Duitse Freihändige Vergabe.

Bij de Belgische onderhandse opdracht is de overheid vrij de opdracht toe te wijzen aan een door hatar uitgekozen aannemer, zij het dat de overheid zo mogelijk meerdere aannemers uitnodigt. De onmogelijkheid om andere aannemers bij de aanbesteding te betrekken moet worden gemotiveerd"'. Freihändige Vergahe komt - evenals de onderluandse opdracht - slechts in uitdrukkelijk bepaalde gevallen als gunningsprocedure in aanmerking. De Freihändige Vergabe is slechts mogelijk als er ến of hooguit twee aannemers voor opdrachtverlening in aammerking kunnen komen ${ }^{i 20}$.

De opvatting die ten grondslag ligt aan het Overijsselse besluit blijkt eveneens ten grondslag te liggen aan de weigering van Gedeputeerde Staten van Zuid-Holland in 1890 om hun goedkeuring te hechten aan een besluit tot onderhandse aanbesteding van de restauratie van de vestibule van het Haagse gemeentehuis ${ }^{121}$. Dit raadsbesluit had de strekking van een machtiging aan B\&W zonder dat er sprake was van een ondubbelzinnige aanduiding van het onderwerp, van de aannemer en van de prijs. Deze machtiging was volgens Gedeputeerde Staten dan ook niet meer dan een bestuurlijke handeling, zonder dat daardoor bet gemeentelijke belang zou kunnen worden geschaad. De machtiging was dus niet een besluit dat aan goedkeuring was onderworpen; dat was alleen het besluit tot rechtstreekse onderhandse aanbesteding van een werk ${ }^{122}$. Bij KB 2 juli 1890 werd dit besluit van Gedeputeerde Staten van Zuid-Holland gehandhaafd ${ }^{123}$. Een beoordeling zijdens Gedeputeerde Staten werd pas mogelijk geacht wanneer vaststond welke gedeelten van het te verrichten werk ondershands aanbesteed werden en dus aan welke aannemer en tot welke prijs het werk zou worden opgedragen ${ }^{124}$. Ook het feit dat $B \& W$ de op de begroting gestelde som niet zouden overschrijden kon daaraan niet afdoen.

Een ander geval is het volgende. De gemeenteraad van Beemster besloot in 1900 tot de aanbesteding van een bouwwerk onder de ingezetenen van de gemeente. Dit raadsbesluit werd aan de goedkeuring van Gedeputeerde Staten van Noord-Holland onderworpen. Inmiddels gaven $B \& W$ uitvoering aan het besiuit. De gunning van het werk geschiedde, onder voorwaarde dat Gedeputeerde Staten de aanbesteding zouden goedkeuren, zonder welke de aanbesteding en gunning geacht werden niet te zijn gedaan. Gedeputeerde Staten oordeelden dat het niet het raadsbesluit was, dat aan goedkeuring onderhevig was, maar dat de goedkeuring moest worden gevraagd op het besluit tot gunning van het werk onder overlegging van het proces-verbaal van aanbesteding ${ }^{125}$.

119 Over het Belgische recht inzake overheidsopdrachten zie rnen M.-A. Flamme, Ph. Mathei, Ph. Flanme, Praktisch Kommentaar bij de reglementering van de Overheidsopdrachten, Brussel 1986 en recentelijk D'Hooghe (1993). Zie ook nog Flamme (1990), 332 v.

130 Voor het Duitse recht raadplege men Ingenstau - Korbion (1989) Zie over gevolgen van wijzigingsrichtlijn voor de regeling in de Verdingungsordnung für Bauleistungen/ Teil A (VOB/A) van richtlijn 89/440 Heierman (1990), $325 \mathrm{v}$.

(21 Raadsbesluit d.d. 26 november 1889 en beschikking GS Zuid-Holland van 7/14 januari 1890, nr. 30. Hierover Gst 1890, 2001, 2002 en 2003.

12. In diezelfde zin blijkens besluit GS Overijssel 5 februari 1903, WBA 1905, 2902.

123 WBA I890, 2154. Zie verder Gst 1890, 2034.

i2. In de Gemeentestem wordt in dit verband gewezen op KB 9 sept. 1881, S. 154 (Veere).

ix Gst 1902, 2624. 
Totdat goedkeuring was verleend hadden de in artikel 194 gemeentewet van 1851 genoemde besluiten van het gemeentebestuur geen rechtskracht. Gedeputeerde Staten moesten binnen dertig dagen na ontvangst van de besluiten beslissen $^{126}$. Deze termijn was blijkens artikel 197 gemeentewet 1851 fataal: het besluit werd geacht te zijn goedgekeurd. ${ }^{17}$; een later besluit van Gedeputeerde Staten tot afkeuring van het raadsbesluit deed daaraan niets af. Dit was alleen anders als Gedeputeerde Staten de gemeenteraad hadden bericht dat zij de beslissing hadden verdaagd. Bovendien moest de strekking der verdaging duidelijk blijken uit de brief of de beschikking ${ }^{12 s}$. Het onthouden van goedkeuring kon leiden tot onthouding van đe goedkeuring aan de betrokken begrotingsposten (artikel 226 gemeentewet van 1851$)^{129}$. De raad kon van de weigering om de onderhandse aanbesteding goed te keuren binnen dertig dagen na de beslissing van Gedeputeerde Staten bij de Kroon vooziening vragen. (artikel 200 gemeentewet van 1851). Beziet men artikel 141 Grondwet van 1848 naar de letter, dan kan men zich afvragen of de Grondwet wel ruinte liet voor dit Kroonberoep. In de Grondwet van 1848 werd voor wat het goedkeuringsrecht van Gedeputeerde Staten betreft niet van enige bevoegdheid van de Kroon gerept, voor het geval Gedeputeerde Staten de goedkeuring aan het besluit zou onthouden. Wel kon de Kroon aan een reeds goedgekeurd besluit de rechtskracht achteraf nog ontnemen door het alsnog te vernietigen. Deze bevoegdheid berustte echter op een zelfstandig recht van de Kroon om besluiten van Gedeputeerde Staten te vernietigen. De gemeentewettelijke regeling vond derhalve geen steun in de Grondwet.

Goedkeuring van een besluit tot het onderhands aanbesteden van werken krachtens artikel 194 gemeentewet van 1851 (artikel 228 gemeentewet (oud)) verleend, verplichtte niet tot uitvoering van het besluit, althans voorzover de gemeente daartoe niet uit anderen hoofde verplicht zou zijn ${ }^{130}$.

De invoering van het preventieve toezicht op de onderhandse aanbesteding had tot gevolg dat de beleidsvrijheid van de plaatselijke besturen afnam. Door het toezicht op de feitelijke beslissing tot opdrachtverlening na een onderhandse aanbesteding kon op dat moment het gehele voorafgaande besluitvormingsproces door Gedeputeerde Staten worden getoetst. De Memorie van Toelichting bij artikel 194, sub $\mathrm{f}$ gemeentewet van 1851 wierp in dit verband de vraag op waar de gemeentelijke autonomie ophield en de correctie door het hogere bestuursorgaan begon. Uitgangspunt vormde de opvatting dat Gedeputeerde Staten zich bij de beoordeling van het gemeentelijke besluit terughoudend, marginaal, dienden op te stellen en er voor moesten waken dat zij bij het uitoefenen van het goedkeuringsrecht niet zouden treden in hetgeen door de gemeente als haar belang werd opgevat ${ }^{131}$. Gedeputeerde Staten kwam terzake van het gemeentelijk belang geen eigen discretionaire bevoegdheid toe ${ }^{132}$. Goedkeuring diende alleen dan te worden onthouden, wanneer kenbaar was, dat de algemene gemeentelijke vermogenssituatie door het desbetreffende raadsbesluit op onevenredige wijze zou worden geschaad. Tot omstreeks het begin van deze eeuw was dit financiële belang der gemeente de enige grond waaraan de in artikel 194 gemeentewet van 1851 genoemde rechtshandelingen door het hogere bestuur mochten worden getoetst, hetgeen in overeenstemming is met de Memorie van Toelichting op dit wetsartikel ${ }^{133}$. Aan het begin van

126 Gst 1893, 2158.

in $\mathrm{Rb}$. 's-Hertogenbosch 29 januari 1892, W. 1892, 6141; WBA 1892, 2231; Rep. 1892, 9617.

12: KB 13 juni 1891, 25; WBA 1891, 2210.

129 Zie uitleg circulaire GS Zuid-Holland 12 januari 1915 (H.G.S. no. 4/3, Prov.blad no.5), in Gst 1915, 3305.

13) Vgl. KB 6 nov. 1882, 17; WBA 1883, 1758. Betrof de vraag of de raad verplicht was uitvoering te geven aan het oorspronkelijke besluit om een nieuw schoolgebouw te bouwen, of kon volstaan met verbouwen van het oude gebouw.

i3 Kocken (1973), 526 v.

19: Zie Oud (1959), 374.

13 KB 4 aug. 1886, 16, geciteerd bij Kan (1951), 173. 
deze eeuw werd de toetsingspraktijk geleidelijk aan vernuimd; ook andere gemeentelijke belangen deden, naast het louter financiële belang, hun intrede als toetssteen ${ }^{134}$. Weer later wordt het toezicht opnieuw verruimd en konden de besluiten ook worden getoetst aan strijd met de wet en het algemeen belang. Deze voortgaande verruiming van de goedkeuringspraktijk betekende tegelijk een steeds verdergaande beperking van de beleidsvrijheid van de gemeenten. Tot aan de wetswijziging in 1966 (zie hierna) was het vaste Kroon-jurisprudentie, dat aan besluiten bedoeld in artikel 228 gemeentewet (oud), niet alleen goedkeuring kon worden onthouden wegens strijd met het financiële belang der gemeente, maar ook om 'andere dringende redenen', waaronder was begrepen het geval dat door het raadsbesluit het regeringsbeleid in een bepaalde sector zou worden doorkruist ${ }^{135}$.

Op 9 februari 1966 werd door het Tweede Kamerlid Van Helvoort bij amendement ${ }^{136}$ voorgesteld om ter gelegenheid van de voorgenomen herziening van de gemeentewet een artikel op te nemen waardoor aan deze steeds ruimer wordende toetsingspraktijk een halt zou kunnen worden toegeroepen. 'Niemand weet exact wat dringende redenen zijn; er is geen enkel houvast te vinden, noch voor de gemeentebesturen noch voor derden, die bij de besluiten inzake burgerlijke handelingen van de gemeente zijn betrokken', aldus Van Helvoort ${ }^{13}$. Er werd in dit verband gewezen op de voorstellen over de toetsingsgronden door de Commissie-Oud inzake de herziening van de gemeentewet ${ }^{138}$. De regering verzette zich echter tegen dit amendement. Het werd bezwaarlijk gevonden, dat ten gevolge van een codificatie van de toetsingsgronden de ontwikkeling van het toezicht in de praktijk zou worden beperkt, doordat dit zou leiden tot 'een zekere verstarring van de jurisprudentie' ${ }^{\text {'39 }}$. Ondanks dit verzet werd het amendement-Van Helvoort aangenomen. Bij wetswijziging in $1966^{100}$ werden de in de praktijk ontwikkelde criteria inzake de omvang van het goedkeuringsrecht van Gedeputeerde Staten gecodificeerd in artikel 228a gemeentewet $^{10 !}$.

\section{'Ontzuiling der procedures'}

Hoewel er, mede door het preventieve toezicht, oorspronkelijk (door de wetgever van 1851) een strikte scheiding was bedoeld tussen de openbare en onderhandse aanbesteding met een daaraan gekoppelde strikte scheiding tussen de aanbestedingsbevoegdheden, bleken er in de praktijk niet alleen veel verschillende opvattingen te bestaan omtrent hetgeen openbaar c.q. onderhands was, maar was er cok steeds minder sprake van een duidelijke scheiding der bevoegdheden. Wat de procedures betreft, verdient in dat verband met name de ontwikkeling

134 KB 26 mei 1909, Gst 1909, 3013: Het toezicht van GS strekte ertoe te beourdelen of een besluit van de gemeenteraad overeen te brengen was met een redelijke behartiging van het gemeentebelang. Zie ook KB 22 april 1924, Gst 1924, 3795. In het onderhavige geval was er sprake van een werkgelegenheidsheleid.

${ }^{134}$ Over de oruvang van het toezicht o.m. Schroot (1980), 233 v.

136 TK 1965-1966, 7865, nr. 11.

17 Handelingen II, 1965-1966, 1290.

130 TK 1964-1965, 7865, ar. 4, 1 (Voorlopig Verslag). Rapport Commissie-Oud, Herziening van de gemeentewet, rapport uitgebracht aan het bestuur van de V.N.G., Blauwe Reeks nr. 28, 1959, 143 v. Schroot (1980), 236 wijst erop dat noch de voorstellen van de Commissie-Oud, noch het amendement-Van Helvoort bedocld waren om het toezicht inhoudelijk te beperken.

${ }^{139}$ TK 1964-1965, 7865, nr. 6, 1-2 (Memorie van Antwoord).

100 Wet van 15 december 1966 , S. 564 .

${ }^{141}$ In dit verband is het curieus de wetsingsgrond 'andere dringende redenen' in an. 156 Gemeentewet weer tegen te komen. Volgens TK 1985-1986, nr. 3, p. 138 is deze grond ontleend aan de jurisprudentie op artikel 245a gemeentewet. 
van de beperkte aanbesteding aandacht, waarbij de uitnodigingen werden beperkt tot de plaatselijke aannemers.

Op deze ontwikkeling duiden o.m. MvBZ 24 februari 1881, nr. 669, Afd. O, Gst. 1904, 2728 en 28 april 1936 , no. 11650, Afd. B.B.; GS Groningen 28 mei 1948, Gst 1948, 4966 (tegen de plaatselijke protectie in de provincie) en de circulaire van de Minister van Wederopbouw en Volkshuisvesting 1 maart 1950, Gst 1950, 5064 (aanbesteding niet beperken tot stadgenoten of aannemers, die een bepaalde staatkundige of religieuze richting aanhangen). Een eerdere missive van de Minister van Wederopbouw en Volkshuisvesting van 26 mei 1948 (waarover Gst 1948, 4972) liet wel een heel ander geluid horen: er werd een beroep gedaan op de medewerking van gemeentebestuurders om bij de aanbesteding van woningen na te gaan of de uitgifte daarvan wellicht in kleinere complexen kon plaatsvinden, zodat meerdere plaatselijke gevestigde aannemers daarop konden inschrijven. De reden daarvoor was gelegen in het feit, dat kleine aannemers gedwongen werden hun bestaan te zoeken in minder urgente onderhouds- en uitbreidingswerkzaamheden, of hun toevlucht zochten tot de zgn. zwarte bouw.

Door de beperkte aanbesteding ontstond een tussenvorm die de wetgever oorspronkelijk niet had bedoeld. Het was geen openbare aanbesteding en evenmin een opdrachtverlening aan één aannemer, waarvoor vooraf goedkeuring moest worden verkregen. Het was daardoor omstreden of deze beperkte aanbesteding was onderworpen aan preventief toezicht.

Zo verzette de redactie van de Gemeentestem zich tégen de idee đat een openbare aanbesteding zou kunnen worden beperkt tot alleen de plaatselijke ingezetenen. Door een beperking tot alleen die aannemers die binnen de gemeente woonachtig waren, zou de aanbesteding haar openbare karakter verliezen ${ }^{142}$. In 1901 werd deze zogenoemde beperkte aanbesteding nog zonder meer als een onderhandse beschouwd ${ }^{13}$. Wilde de raad de aanbesteding beperken tot de ingezetenen, dan moest ter gelegenheid van het preventieve toezicht het daarbij betrokken belang der gemeente blijken $^{14}$. Later koos de redactie een andere constructie: een gemeentelijke aanbesteding welke uitsluitend gehouden werd onder de eigen ingezetenen kon noch als onderhands noch als openbaar worden beschouwd, zodat een dergelijke handelwijze van de raad in strijd was met de gemeentewet ${ }^{\text {las }}$. Wilden B\&W, als uitvoerders van het raadsbesluit tot openbare aanbesteding (artikel 179, sub a gemeentewet van 1851) de inschrijving tot bepaalde personen beperken, dan was een afzonderlijk raadsbesluit noodzakelijk, dat door Gedeputeerde Staten was goedgekeurd $^{145}$. In het Weekblad voor de Burgerlijke Administratie kan men wat dit betreft een andere opvatting tegen komen. Volgens het Weekblad ${ }^{147}$ was een onderhandse aanbesteding die aanbesteding, waarbij (openbare) mededinging werd uitgesloten. De consequentie daarvan was dat ook wanneer de mededinging werd beperkt tot bepaalde personen, de aanbesteding daardoor nog niet onderhands werd.

De hiervoor gereleveerde recht-toe-recht-aan opvatting van Gedeputeerde Staten van Overijssel en Noord- en Zuid-Holland, dat alleen de burgerrechtelijke rechtshandeling voorwerp van preventieve toetsing was, bleek niet opgewassen tegen de voortgaande grensvervaging tussen de aanbestedingsprocedures. Zo deed zich blijkens een rondschrijven van Gedeputeerde Staten van Zuid-Holland ${ }^{148}$ en Utrecht ${ }^{149}$ inzake de preventieve toetsing (goedkeuring ex artikel 228 gemeentewet (oud)) zich in de praktijk de vraag voor, in welk stadium van de aanbesteding een besluit ter goedkeuring moest worden ingezonden. De vraag

\footnotetext{
142 Gst 1896, 2349; Gst 1932, 4206; Gst 1932, 4232.

143 Gst 1901, 2622.

14 Gst 1904, 2728. En ook blijkens het eerder genoemde KB 22 april 1924, Gst 1924, 3795.

14s Gist 1906, 2859; Gst 1907, 2916; Gst 1908, 2937; Gst 1912, 3117.

ito Gst 1908, 2937.

(4) WBA 1901, 2741.

148 Rondschrijven van 18 juli 1960 aan gemeentebesturen, in: Gst 1960, 5599.

149 In dezelfde zin het Rondschrijven GS Utrecht van 4 september 1961, in: Gst 1961, 5662.
} 
werd gesteld of dit het raadsbesluit ex artikel 167 gemeentewet (oud) was, waarbij werd vastgesteld dat onderhandse aanbesteding de voorkeur verdiende boven de openbare, en waarbij gewoonlijk de wijze van aanbesteding nader werd geregeld (aantal personen of bedrijven aan wie prijsopgaaf zal worden gevraagd etc.). Of betrof de goedkeuring het besluit dat strekte tot opdrachtverlening aan de aannemer, wiens aanbieding het meest aanvaardbaar werd geacht. Dit besluit kon, als strekkende tot uitvoering van het eerste besluit, door B\&W worden genomen, tenzij de raad zich bij het eerste besluit de bevoegdheid tot het nemen van het tweede had voorbehouden. Tot dan toe hielden Gedeputeerde Staten van Zuid-Holland de beslissing aan totdat het tweede besluit was genomen.

De Kroon was van oordeel dat een raadsbesluit tot onderhandse aanbesteding van een werk onder de plaatselijke bonafide aannemers, waarin de naam en prijs niet waren vermeld, maar waarbij tegen de aanbesteding (lees: opdrachtverlening) als zodanig geen bezwaar bestond, onderworpen was aan het preventieve toezicht door Gedeputeerde Staten.

Dit oordeel kon met zich meebrengen, dat wanneer er uiteindelijk geen goedkeuring werd verkregen, het gemeentebestuur in een moeilijke situatie kwam te verkeren. Het was dan in verband met de in aannemerskringen bestaande 'bescherming' onmogelijk om op korte termijn tot een openbare aanbesteding van het 'besmette werk' over te gaan. Artikel 194 gemeentewet van 1851 sloot volgens het (eerder genoemde) KB van 26 oktober 1951, ARB 1952, p. 152 overigens niet uit dat de béide besluiten (ex artikel 167 en artikel 209, sub a) aan het toezicht onderworpen waren ${ }^{150}$.

In 1960 komt daarin verandering. Gedeputeerde Staten waren blijkens het genoemde Rondschrijven van 18 juli 1960 tot de gevolgtrekking gekomen, dat de tot dan toe gevolgde gedragslijn niet met de wet in overeenstemming was! Vervolgens concludeerden zij, op grond van de nauwe relatie tussen de artikelen 228 , sub $\mathrm{g}$ (het preventieve toezicht op de onderhandse aanbesteding) en 176, lid 2 gemeentewet (oud), dat de wetgever uitsluitend had bedoeld om de keuze tussen openbare en onderbandse aanbesteding aan het toezicht van Gedeputeerde Staten te onderwerpen. Dit had tot gevolg dat wanneer het eerstbedoelde raadsbesluit was genomen, dat besluit terstond, onder mededeling van de gronden waarop het steunde ter goedkeuring moest worden ingezonden en de beslissing moest worden afgewacht alvorens kon worden overgegaan tot het vragen van prijsopgaven. Blijkens het Rondschrijven van Gedeputeerde Staten van Utrecht van 4 september 1961 werd daar nog aan toegevoegd, dat het begrijpelijk was, dat 'onder de huidige economische omstandigheden vele malen voldoende bijzondere redenen voor het houden van een onderhandse aanbesteding kunnen worden aangevoerd"151. In deze benadering stond niet langer het besluit tot de burgerrechtelijke rechtshandeling onder preventief toezicht, maar was het toezicht beperkt tot het raadsbesluit tot onderhandse aanbesteding ex artikel 167 gemeentewet (oud). Deze uitleg is mijns inziens minder in overeenstemming met de oorspronkelijke bedoelingen van de wetgever, maar sloot waarschijnlijk wel meer aan op de door de gemeenten in de praktijk gevoelde behoefte aan beleidsvrijheid.

\footnotetext{
$150 \mathrm{Vgl}$. Oud (1959), 603-604.

is! Gst 1961, 5662 .
} 


\section{Decentralisatie aanbestedingsbeleid}

Sinds de wijziging van de gemeentewet in 1966 speelt de preventieve toetsingsproblematiek voor de aanbestedingspraktijk overigens geen rol meer, doordat het preventieve toezicht door Gedeputeerde Staten op de gemeentelijke onderhandse aanbestedingen bij deze gelegenheid werd afgeschaft.

Strekking van de wetswijziging was onder meer de herziening van het toezicht op de gemeentebesturen, waarbij de regering zich voor wat betreft de gemeentelijke aanbestedingen oorspronkelijk aansloot bij de vergaande voorstellen van de Commissie Territoriale Decentralisatie $^{152}$. Maar de regering ging zelfs nog een stap verder. Het standpunt van de regering luidde dat het toezicht van Gedeputeerde Staten op de burgerrechtelijke rechtshandelingen van de gemeente nog extra verminderd zou kunnen worden ${ }^{153}$, waardoor een nog verdergaande decentralisatie mogelijk zou worden. De regering stelde zich daarbij op het ruimhartige standpunt, dat het toezicht beperkt zou dienen te blijven tot die onderwerpen waar 'hoger toezicht bepaald onmisbaar geacht moest worden'. Ondanks dit toch zeer liberale standpunt van de regering inzake het decentralisatiestreven, werd ten aanzien van de onderhandse aanbestedingen niettemin overwogen, dat het preventieve toezicht van Gedeputeerde Staten bezwaarlijk zou kunnen worden gemist 'zulks vanwege de belangrijkheid van de desbetreffende besluiten'.

Uit het Voorlopig Verslag van de Tweede Kamer ${ }^{154}$ blijkt daarentegen dat vele Kamerleden een andere mening waren toegedaan. De Kamercommissie, die met het decentralisatievraagstuk was belast, meende dat het preventieve toezicht op de onderhandse aanbesteding wel degelijk zou kunnen worden gemist. De Kamercommissie stelde daaromtrent:

\footnotetext{
'Afgezien van de provinciaal uiteenlopende opvattingen omtrent de inhoud van het begrip 'openbare aanbesteding' zijn de motieven om tot onderhandse aanbesteding over te gaan in de loop der tijden zodanig gewijzigd, dat huns inziens het voorkomen van misbruik op dit gebied aan de gemeenteraden ware over te laten. Andere leden der commissie (...) vestigden er nog de aandacht op dat onder de invloed van het E.E.G.-verdrag de onderhandse aanbesteding dikwerf een semi-openbaar karakter zal krijgen, ten gevolge van voorafgaande publikatie van de onderhandse aanbesteding'.
}

In zijn antwoord ging de Minister van Binnenlandse Zaken in op de opmerkingen van de commissie $^{155}$. Hij bleek (opeens?!) met de commissie van oordeel:

'dat goedkeuring op onderhandse aanbesteding van werken of leveranties beter kan vervallen. Stemmen uit de praktijk hebben hem ervan overtuigd, dat aanbestedingen een materie vormen, waarbij plaatselijke, aan bet gerneentebestuur het best bekende, omstandigheden een dusdanig grote rol spelen, dat speciaal bij deze materie veel aan het plaatselijk beleid dient te worden overgelaten'.

Deze laatste zin moet worden geproefd. En verder:

'De ondergetekende heeft zich ten deze voorts mede laten leiden door de overweging, dat bij een juiste toepassing van het non-discriminatiebeginsel bij het aanbestedings- en aankoopbeleid conform bet Benelux Unie-verdrag en zijn

\footnotetext{
152 TK 1963-1964, 7865, nr. 3, 5 (Memorie van Toelichting).

is TK 1963-1964, 7865, nr. 3, 8-9 (Memorie van Toelichting)

154 TK 1964-1965, 7865, nr. 4, 2 (Voorlopig Verslag).

iss TK 1964-1965, 7865, ar. 6, 3 (Memorie van Antwoord).
} 
uitvoeringsbepalingen alsmede voor soortgelijke regelingen in E.E.G.-verband voor een zuivere onderhandse aanbesteding minder plaats is'.

Door het afschaffen van het preventieve toezicht op besluiten tot onderhandse aanbestedingen, werd een einde gemaakt aan de voortschrijdende centralisatie bij het aanbesteden van werken. Hoewel de besluiten tot onderhandse aanbesteding dus niet meer preventief worden getoetst aan strijd met de wet of strijd met het algemeen belang, bleef het oorspronkelijke toetsingscriterium van het gemeentelijk financiële belang echter - via een omweg - bestaan. Uit de parlementaire geschiedenis blijkt namelijk dat de minister van Binnenlandse Zaken van opvatting was dat het Rijk via het begrotingstoezicht (artikel 132 Grondwet; artikel 242 gemeentewet (oud)), de Wet kapitaaluitgaven publiekrechtelijke lichamen en de Financiële Verhoudingswet voldoende toezicht op de gemeentelijke aanbestedingspraktijk zou kunnen uitoefenen ${ }^{156}$. En ook meer recent heeft de regering er op gewezen dat de privaatrechtelijke besluiten praktisch vrijwel steeds via de autorisatie van de begroting of een begrotingswijziging aan Gedeputeerde Staten bekend zijn ${ }^{157}$. Daardoor heeft dit college tijdig de beschikking over informatie betreffende de financiële risico's van de betrokken privaatrechtelijke besluiten. Thans is de regeling aldus, dat volgens artikel 259 Gemeentewet 1994 besluiten van gemeentebesturen, op de voet van artikel 132, lid 3 Grondwet, slechts aan voorafgaand toezicht worden onderworpen in de bij de wet of krachtens de wet bij provinciale verordening bepaalde gevallen.

\section{Dode letter}

Het preventieve toezicht op de gemeentelijke onderhandse aanbestedingen heeft niet kunnen verhinderen, dat het oorspronkelijk scherpe onderscheid tussen de openbare en onderhandse aanbesteding gaandeweg verdween. De opkomst van de beperkte aanbesteding is wat dat aangaat zeker een saillante ontwikkeling. Hierop duidt ook het Voorlopig Verslag ${ }^{158}$ bij het wetsontwerp tot wijziging van de gemeentewet, waar wordt opgemerkt dat de gemeentelijke aanbestedingspraktijk weerbarstiger bleek, dan bet nauwkeurige onderscheid tussen de omschrijving van de openbare en onderhandse aanbesteding zou doen vermoeden. En ook op provinciaal niveau bestonden daarover uiteenlopende opvattingen, hetgeen zeker niet zonder gevolgen zal zijn gebleven voor de gemeentelijke aanbestedingspraktijk.

Het afschaffen van het preventieve toezicht in 1966 bezegelde de op plaatselijk niveau reeds bestaande verschillen in opvatting over wat onder een openbare en een onderhandse aanbesteding moest worden verstaan. Hoewel het primaat van de openbare aanbesteding dan nog onverkort in de gemeentewet overeind staat, is artikel 176 gemeentewet (oud) dan praktisch al een dode letter. Het afschaffen van het preventieve toezicht betekende dat het sindsdien

156 TK 1963-1964, 7865, nr. 3, 5 (Memorie van Toelichting); TK 1964-1965, 7865, nr. 6, 3 (Memorie van Antwoord). Schroot (1980), 233-235. Sommige schrijvers spreken in dit verband wat smalend over deconcentratie in plaats van decentralisatie. Boeiend zijn in dit verband de persoonlijke herinneringen van Kan (1986), 185, die er op wijst dat zijn oud-collega op Binnenlandse Zaken Nap van oordeel was dat de gemeente, wanneer zij bij het aangaan van privaatrechtelijke rechtshandelingen onderworpen zou zijn aan het algemene repressieve toezicht van de Kroon, zij er in bet algemeen op achteruit zou gaan.

157 TK 1988-1989, 19 403, nr. 6, 39-40 (Memorie van Antwoord). Vgl. over de wijziging van het corspronkelijk voorgestelde an. 253 Gemeentewet, TK 1988-1989. 19 403, nr. 6. 37-38 (Memorie van Antwoord)

us TK 1964-1965, 7865, nr. 4, 2 (Voorlopig Verslag). 
aan de discretionaire (bestuurs)bevoegdheid der gemeentebesturen overgelaten werd wat onder de 'bijzondere redenen' in artikel 176, lid 2 gemeentewet (oud) moest worden verstaan. En daarmee was de facto de keuze voor de ene of de andere procedure als ook welk orgaan tot die keuze bevoegd was, aan de gemeentebesturen overgelaten, waarbij veel afhing van de 'plaatselijke omstandigheden'.

Zo is er reeds sprake van een openbare aanbesteding wanneer alleen de ingezetenen der gemeente de mogelijkheid wordt geboden om op de opdracht in te schrijven of wanneer er andere beperkingen van algemene aard worden aangelegd ${ }^{159}$. Als een onderhandse aanbesteding wordt in de praktijk aangemerkt een handelwijze, waarbij met name genoemde gegadigden tot inschrijving worden uitgenodigd. Van Baren heeft getracht om aan te geven, waar de openbare aanbesteding overgat in de onderhandse ${ }^{160}$. De enkele beperking van het aantal gegadigden die tot de inschrijving worden toegelaten, is volgens hem op zich onvoldoende reden om van een onderhandse aanbesteding te kunnen spreken. Naar zijn mening is steeds sprake van een openbare aanbesteding wanneer: $1^{\circ}$. een ieder zich kan aanmelden voor het uitvoeren van de te houden aanbesteding; $2^{\circ}$. slechts diegenen zich voor de te houden aanbesteding kunnen melden, die voldoen aan de gestelde eisen van vakbekwaamheid en solventie alsmede aan speciale eisen, verband houdende met de te verrichten levering of het uit te voeren werk, en $3^{\circ}$. slechts daartoe geselecteerden kunnen deelnemen aan de te houden aambesteding. Alle andere vormen van aanbesteding vallen daarmee in de restgroep der onderhandse aanbesteding. In het bijzonder geldt als een onderhandse aanbesteding het informeren naar de prijs, voorwaarden e.d. bij slechts tén aanbieder.

Deze ontwikkelingen hebben inmiddels hun beslag gekregen in de Gemeentewet $1994^{161}$. Deze wet laat het in belangrijke mate aan de gemeentebesturen over zelf te bepalen welk orgaan waartoe bevoegd is. Artikel 108 Gemeentewet 1994 bepaalt dat de bevoegdheid tot regeling en bestuur inzake de huishouding van de gemeente aan het gemeentebestuur wordt overgelaten. En blijkens artikel 147, lid 2 Gemeentewet 1994 berusten de (overige, zie in dit verband lid 1) bevoegdheden bij de raad voorzover deze niet bij of krachtens de wet aan het college van burgemeester en wethouders is toegekend. Het dagelijks bestuur van de gemeente berust bij dit college voorzover niet bij of krachtens de wet de burgemeester hiermee is belast (artikel 160 Gemeentewet 1994).

\section{Conclusie}

Gaandeweg is het onderscheid tussen de begrippen openbaar en onderhands in de gemeentewet vervaagd. Strikt genomen gold in de gemeentewet nog wel het uitgangspunt van de openbare aanbesteding, waarbij iedereen zou kunnen inschrijven. Maar de keuze tussen de beide procedures werd overgelaten aan de gemeentebesturen. Daardoor werd artikel 176, lid 2 gemeentewet (oud) praktisch een dode letter. De Gemeentewet 1994 maakt ook formeel een einde aan het primaat van de openbare aanbesteding, overigens zonder dat er is voorzien in een kader op basis waarvan tot de keuze van een procedure uit de aanbestedingsreglementen moet worden gekomen. De regeling van de overheidsaanbesteding wordt overgelaten aan de veel gedetailleerder aanbestedingsreglementen (UAR-en). In zijn dissertatie kon Spier nog een 'jubelklank' uitten aan het adres van artikel 176, lid 2 gemeentewet (oud); dat is thans

\footnotetext{
159 Burger (1983), 225.

เ的 Van Baren (1977), 1093 en 1095.

161 Wet van 14 februari, S. 1952, 96. Inwerkingtreding 1 januari 1994. Bij beschilking van de Minister van Justitie van 21 oktober 1994 is de tekst van de Gemeentewet in het Staatsblad geplaatst, zoals deze laatstelijk is gewijzigd bij wet van 22 juni 1994, S. 573, in: S. 1994, 762.
} 
verleden tijd! Met Spier moet thans ook voor de Gemeentewet 1994 worden herhaald, dat:

'Het (..) natuurlijk heel mooi [is] om tal van procedures te schetsen, waartussen een keuze kan worden gemaakt, doch het is, m.i., bepaald onbegrijpelijk en zeer ongelukkig om niet te regelen hoe die keuze moet worden gemaakt. 162

\section{Het repressieve toezicht}

\section{Repressief toezicht: ultimum remedium}

Na een lange periode waarin het overheidsbestuur steeds verder was gecentraliseerd, kreeg in het revolutiejaar 1848 het streven naar vernieuwing van de maatschappelijke verhoudingen, welke werd ingegeven door de ideeën der Verlichting, de invloed die het verdiende. In dat jaar droeg Koning Willem II aan een commissie van vijf leden, onder Thorbecke's leiding, op de Grondwet verregaand te herzien ${ }^{163}$. Na een zeer snelle parlementaire behandeling werd de Grondwet nog in oktober van dat jaar door de Koning bekrachtigd ${ }^{164}$. In de Grondwet van 1848 formuleerde Thorbecke het wankele evenwicht tussen het beginsel van de eenheidsstaat en het beginsel van de gemeentelijke zelfstandigheid ${ }^{165}$. Het juridische onderscheid tussen stad en platteland verdween en maakte plaats voor demokratie op basis van rechtssoevereiniteit. Het bestuurlijke model dat werd geintroduceerd gaf uiting aan het besef dat de lagere overheden in de bestuursstructuur een eigen, zelfstandige plaats toekomt.

Ook thans vermeldt de Grondwet in artikel 124, lid 1 dat voor gemeenten de bevoegdheid tot regeling en bestuur inzake de eigen huishouding aan hun besturen is overgelaten. Er is sprake van gemeentelijke autonomie; dit is de bevoegdheid van de gemeente om verordenend en besturend op te treden in de eigen aangelegenheden (artikel 108 Gemeentewet 1994). In beginsel mogen gemeenten zich op het aan hen toegewezen gebied inlaten met alles wat hun nuttig en doelmatig voorkomt (territoriale decentralisatie) ${ }^{166}$. Lokale autonomie houdt volgens het daarvoor geschreven Europese Handvest in: het recht en het vermogen van lokale autoriteiten om binnen de grenzen van de wet een belangrijk deel van de openbare aangelegenheden krachtens de eigen verantwoordelijkheid en in het belang van de plaatselijke bevolking te regelen en te beheren. Of zoals de regering het in haar toelichting op artikel 124 Grondwet 1983 zei:

'(...) dat bij elke inbreuk van hoger gezag op de zelfwerkzaamheid van deze lichamen (gemeenten; HN) op dit gezag de volle bewijslast van de gerechtvaardigdheid van de inbreuk rust. Men mag deze norm ongetwijfeld een rechtsinorin noemen, ook al is het een norm die in ons bestel niet door een rechterlijk orgaan maat door politieke organen gehandhaafd moet worden'.

Daarnaast kan het hogere bestuur bij of krachtens de wet vorderen, dat de gemeente bepaalde regelingen treft of bepaalde bestuursdaden verricht (artikel 124, lid 2 Grondwet). In dat geval

\footnotetext{
102 Spier (1981), nr. 26, noot 146.

16. Over de eerdere voorstellen van de Negen Mannen zie men Kocken (1973), 421 v.

16 Over deze grondwetsherziening uitvoerig in Kocken (1973), $441 \mathrm{v}$.

${ }^{165}$ Over de voorstellen van de staatscommissie o.m. Oud (1956), 17 v.

${ }^{166}$ Sikkes (1967), 12. Boissevain (1867), $16 v$.
} 
spreekt men van medebewind of zelfbestuur. De (boven)grens van hetgeen tot de huishouding der gemeente behoort kan dus niet los gezien worden van de vraag wat de hogere bestuurslagen aan zich hebben getrokken. De ondergrens is dat de gemeente bij de inrichting van haar huishouding niet treedt in de belangen van de particuliere huishoudens ${ }^{167}$. Het weinig scherpe begrip 'huishouding' beoogt enerzijds waarborgen te bieden tegen onrechtmatige ingrepen door het hogere bestuur, en anderzijds te voorkomen dat wordt getreden in de bijzondere belangen der ingezetenen.

Naast de negatieve vormen van (repressief en preventief) toezicht introduceert de Gemeentewet 1994 vormen van positief toezicht, "opdat de hogere overheid niet dan in zeer bijzondere gevallen in de gemeentelijke beleidsvrijheid kan treden'168. Niet het ongedaan maken van bepaald gemeentelijk handelen maar het positief beinvloeden staat voorop bij de mededelingsplicht, het verplichte overleg, het verplichte advies, de aanwijzing, de uitnodiging een besluit te nemen en het opleggen van samenwerking. Hoewel de term 'positief toezicht' de indruk wekt dat het gaat orn een vorm van toezicht, is er in werkelijkheid sprake van medebewind. In de Memorie van Antwoord wordt er op gewezen dat het derhalve onjuist is om op dit positieve toezicht het toezichtsartikel uit de Grondwet (artikel 132) toepasselijk te achten. Voorgesteld wordt om te spreken van 'medebewind gevorderd door concreet werkende besluiten'16. Dergelijke besluiten vallen onder artikel 124, lid 2 Grondwet en artikel 108 Gemeentewet 1994. Ondat de aanbestedingsbevoegdheid behoort tot de autonome bestuursbevoegdheden van bet gemeentebestuur blijft het medebewind hierna zonder bespreking.

Als ratio voor het repressieve toezicht geldt dat dit ten doel heeft de eenheid van het bestuur te bewerken. Door de gemeentelijke besluiten te onderwerpen aan repressief toezicht wordt centrale sturing van de oorspronkelijk autonome, lokale bevoegdheid mogelijk (eenheid van bestuur). Dit repressieve toezicht (het spontane vernietigingsrecht, dat wil zeggen vernietigingsbevoegdheid ${ }^{170}$ ) betreft derhalve alle aanbestedingsbesluiten en niet - zoals bij het preventieve toezicht - enkel de besluiten tot onderhandse aanbesteding. Besluiten van het gemeentebestuur kunnen worden vernietigd wegens strijd met het recht of het algemeen be$\operatorname{lang}^{171}$.

Voor de grondslag van bet repressieve toezicht van de Kroon moet terug worden gegaan naar artikel 140 Grondwet van 1848. Dat artikel bepaalde dat, op de verordeningen welke de raad met betrekking tot de huishouding der gemeente maakte en aan Provinciale Staten moest mededelen, artikel 133 Grondwet van 1848 van toepassing was. Dit grondwettelijke schorsings- en vernietigingsrecht werd uitgewerkt in artikel 153 gemeentewet van 1851 . Volgens deze bepaling konden gemeentelijke verordeningen ${ }^{17}$, voorzover zij met de wetten of het algemeen belang ${ }^{173}$ strijdig

167 Zie reeds Gst 1856, 396; HR 14 mei 1856, W. 1857, 1871.

16 TK 1988-1989, 19 403, nr. 10, 32-33 (Memorie van Antwoord).

${ }^{169}$ TK 1988-1989, 19403 , ar. 10, 33 (Memorie van Antwoord).

${ }^{170}$ Dat het om een bevoegdheid gaat blijkt uit Handelingen TK 25 september 1990, 4-143 (Gemeentewet). Vgl. over diverse opvattingen Burger (1971), \$ 14.3.2.5 en de daar genoemde auteurs. Zie voor een kwantitatief onderzoek naar de vernietigingsbesluiten van de Kroon Nijenhuis en Boland-de Vries (1977), 392. De algemene beginselen van behoorlijk bestuur en andere publiekrechtelijke normen kunnen meebrengen dat de Kroon ingrijpt. De bevoegdheid kan nooit naar vrij believen al dan niet worden gehanteerd.

${ }^{171}$ Dit is in overeenstemming met het ABAR-rapport (1984), 288 terzake.

${ }^{172}$ Het verordeningshegrip, dat aanleiding had gegeven tot een zeer gekunstelde interpretatie van dit begrip in art. 153 gemeentewet van 1851, werd bij de wijziging van de gemeentewet in 1931 (S. 1931, 41) omgezet in "besiujten van gemeentebesturen'. Men zie het latere art. 185, lid 1 gemeentewet (oud). Zie over het begrip 'verordening' Kranenburg (1951), 556-562 en 567. En Gst 1880, 1504 en 1505.

${ }^{17}$ Dit is niet: 'strijd met het gemeentebelang'; men zie Gst 1862, 548. 
waren door de Kroon worden geschorst of vernietigd. Het gaat hier om een ultimum remedium ${ }^{174}$ : eerst wordt de weg van het overleg geprobeerd, zoals in het geval van het Utrechtse sociale vestigingsheleid en het Amsterdamsc werkgelegenheidsbeleid ${ }^{17 s}$. Het mag niet zo zijn dat de autonome bevoegdheden van de gemeente zijn overgeleverd aan de politieke inzichten en doelstellingen van hogere bestuursniveau's ${ }^{176}$. Gemeentewettelijk uitgangspunt was dat de toetsing aan strijd met de wet vooraf ging aan de toetsing van bestuurlijk handelen aan het algemeen belang. De grens tussen beide criteria is trouwens niet erg scherp. Onder meer bij de algehele grondwetsherziening ${ }^{17}$ is zijdens de regering uitgesproken dat gemeentebesturen binnen de grenzen van de huishouding van de gemecnte zouden blijven, als er een relatie bestond tussen de gemeentelijke activiteit en de lokale gemeenschap. Dat heeft tot gevolg dat slechts op grond van artikel 124, lid 1 Grondwet kan worden vernietigd, indien zou komen vast te staan dat deze relatie ontbreekt. Overigens blijkt in de praktijk dat - ook al blijven de gemeentelijke activiteiten binnen de eigen huishouding - zulks niet steeds betekent dat beshiten dan niet zouden kunnen worden vernietigd. Zij kunnen namelijk in strijd zijn met andere rechtsregels dan artikel 124, lid 1 Grondwet of met het algeneen belang.

De Memorie van Toelichting bij de Gemeentewet $1994^{178}$ releveert dat het criterium 'strijd met de wet' in artikel 185 gemeentewet (oud) steeds in formele zin werd opgevat. Strijd met andere dan formeelwettelijke voorschriften werd in de regel herleid tot strijd met het algemeen belang (waaronder strijd met de algemene beginselen van behoorlijk bestuur). Dit werd als onwenselijk gezien: de onjuistheid van een gemeentelijk besluit is immers evidenter, waar duidelijk strijdigheid met een algemeen verbindend voorschrift kan worden aangetoond, dan wanneer de motivering moet zijn, dat het besluit indruist tegen het - onvermijdelijk een vagere inhoud hebbende - algemeen belang. Kortmann ${ }^{179}$ wijst er overigens op dat - sinds in 1983 in artikel 132, lid 4 Grondwet als vernietigingsgronden strijd met het recht of het algemeen belang worden genoemd - de Kron gemeentelijke besluiten reeds op deze gronden vernierigde. Thans bepaalt artikel 268, lid 1 Gemeentewet 1994 dat de besluiten van het gemeentebestuur, waaronder thans ook besluiten van de burgemeester, kunnen worden vernietigd wegens strijd met het recht of het algemeen belang ${ }^{180}$. Onder de gemeentewet 1851 bestond er geen vernietigingsrecht van de uitvoeringsbesluiten van de burgemeester. Dit werd overbodig geacht vanwege het intensieve contact tussen de regering en de burgemeester ${ }^{181}$. Bedacht moet worden dat oorspronkelijk de burgemeester (ook) optrad als plaatselijke rijkstoezichthouder (vergelijk artikelen $59-78$ gemeentewet 1851$)^{1: 52}$.

Waren aan een commissie als bedoeld in artikel 61 gemeentewet (oud) aanbestedingsbevoegdheden toegekend van de raad c.q. van B\&W, dan waren ingevolge artikel 64b gemeentewet (oud) ten aanzien van deze bevoegdheden de toezichtshepalingen van overeenkomstige toepassing ${ }^{123}$. Ingevolge artikel 212 , lid 2 gemeentewet (oud) waren ook bestuiten van ambtenaren, aan wie de vitvoering van raadsbesluiten was gedelegeerd, onderworpen aan het repressieve toezicht ${ }^{184}$.

De Gemeentewet 1994 beoogt een verschuiving van preventief (meer structureel) toezicht naar repressief (incidenteel) toezicht.

174 TK 1965-1966, 7865, nr. 3 (Memorie van Toelichting op art. 185a gemeentewet). Zie recenter parlementaire geschiedenis van art. $132 \mathrm{GW}$. Hierover Konijnenbelt (1989 a) 212. En TK 1985-1986, 19 403, ar. 3, 14 en 19 (Mernorie van Toelichting).

${ }^{175}$ Zie daarover eerder Hoofdstuk 1, paragraaf 6.

${ }^{176}$ Visser (1986), 33 spreekt in dit verband van het 'evenredigheidsbeginsel': het toezicht mag niet umvangrijker en ingrijpender zijn dan noodzakelijk voor het beoogde doel.

ith Naar een nieuwe Grondwet. Algehele grondwetsherziening VIla (eerste lezing) (Provincies, gemeenten, waterschappen en andere openbare lichamen), 's-Gravenhage 1980, m.n. 11, 71 en 101.

17s TK 1985-1986, $19403, \mathrm{nr} .3,181$.

${ }^{17}$ Kortmann (1987), 362-363. Onder de term 'recht' vallen zowel de algemeen verbindende voorschriften als ook de algemene beginselen van behoorlijk bestuur. Vgl. Heringa - Zwart (1983), 142. Zie voor de oudere toetsingspraktijk Crince le Roy (1975), 397 v.

$100 \mathrm{Zie}$ omtrent de overwegingen om ook de besluiten van de burgemeester eronder te brengen TK 1985-1986, 19 403, nr. 3, 180 v. (Memorie van Toelichting bij art. 261 Ontwerp).

121 Gst 1893, 2166.

Zie De Laat de Kanter (1892) en bespreking daarvan in Gst 1892, 2133.

${ }^{183}$ Arrt. $61 \mathrm{Vm} 64$ f gemeentewet zijn ingevoegd bij de wet van 9 juli 1964, S. 256.

18 Wetswijziging 15 dec. 1966, S. 564. 
Slechts op grond van krachtige argumenten kumen andere dan repressieve toezichtsvormen worden geaccepteerd. De Memorie van Teelichting ${ }^{115}$ op het ontwerp-Gemeentewet gaat in dit verband in op de mogelijke motieven voor het invoeren van toezicht. Geinoemd worden: het coördinatiemotief (voorkomen/ oplossen van belangenconflicten tussen gemeenten), beleidsbewaking (afstemming van het beleid van de gemeente op dat van de hogere overheid), kwaliteitsbewaking (controle op de deugdelijkheid, de technische kwaliteit van het besluit), financiële motieven (bevordering van een gezond en evenwichtig financieel beleid van de gemeente) en rechts- en belangenbescherming van de burger ${ }^{126}$.

Deze verschuiving wordt ingegeven door het streven naar decentralisatie, waardoor de plaatselijke beleidsvrijheid kan worden vergroot (art. 117 Gemeentewet 1994). Gekozen wordt voor een terughoudende vorm van repressief toezicht, dat met name niet zou moeten worden gebruikt ten behoeve van toezicht op het gemeentelijk beleid in algemene zin. Sturing van het algemene beleid dient te gebeuren via wettelijke normstelling.

Gedeputeerde Staten $^{187}$ en de burgemeester ${ }^{188}$ zijn (als voorheen) de wettelijk ingestelde sondes: zij berichten de Kroon wanneer zij vermoeden, dat een besluit onwettig is danwel in strijd met het algemeen belang. Schorsing en vernietiging zijn echter niet afhankelijk van het initiatief van Gedeputeerde Staten ${ }^{189}$ of de burgemeester ${ }^{190}$. Ook burgers kunnen zich op grond van hun petitierecht tot de verantwoordelijke minister wenden, met het verzoek om tot schorsing en vernietiging van het besluit over te gaan (artikel 5 Grondwet).

De schorsingsbevoegdheid is thans afzonderlijk geregeld in artikel 268, lid 2 Gemeentewet 1994. De Memorie van Toelichting bij dit artikel merkt op dat de redactie in artikel 185, lid 1 gemeentewet (oud) ten onrechte de indruk wekte, dat voorwaarde voor schorsing zou zijn, dat het desbetreffende besluit in strijd was met de wet of het algemeen belang. Schorsing beoogt daarentegen juist het onderzoek mogelijk te maken naar de vraag of er aanleiding voor vernietiging is. Artikel 270 Gemeentewet 1994 is behoudens een redactionele wijziging gelijkluidend aan artikel 185a gemeentewet (oud) ${ }^{191}$. Blijkens artikel 272 Gemeentewet 1994 kan een besluit tot het verrichten van een privaatrechtelijke rechtshandeling niet worden geschorst of vernietigd, indien drie maanden zijn verstreken na de dag waarop het is genomen. Indien binnen deze termijn schorsing heeft plaatsgevonden, blijft vernietiging binnen de duur van de schorsing mogelijk.

Deze regeling is - anders dan in de oude gemeentewet (artikel 230 van die wet) - niet beperkt tot besluiten betreffende privaatrechtelijke rechtshandelingen die zijn onderworpen aan het preventieve toezicht door Gedeputeerde Staten. Voorts is niet meer sprake van besluiten 'betreffende privaatrechtelijke rechtshandelingen' maar van besluiten 'tot het verrichten van privaatrechtelijke rechtshandelingen'. Volgens de Toelichting ${ }^{192}$ impliceert zulks dat

185 TK 1985-1986, 19403 , nr. 3, 15 (Memorie van Toelichting).

196 Over deze motieven Kraan (1990), 105.

in Voorheen art. 184 gemeentewet jo art. 120 Provinciewet. Thans art. 173 Provinciewet.

${ }^{12 \mathrm{~A}} \mathrm{Zie}$ art. 76 (oud) gemeentewet en thans art. 273 Gemeentewet.

184 J.R. Thorbecke. Parlementaire redevoeringen II, I november 1849-september 1850, Deventer 1859, 220.

190 MvBZ 16 febr. 1857, WBA 1857, 409. Zie eerder KB 1 okt. 1856, S. 91, WBA 1856, 383. HR 7 juni 1864, W. 1864, 2599, Gst 1864, 673; WBA 1864, 793. Ook De Laat de Kanter (1892).

191 Art. 185 a gemeentewet (oud) luidde: Een besluit dat nog goedkeuring behoeft kan niet worden geschorst of vernietigd. Een besluit, ten aanzien waarvan een verzoek om een administratiefrechtelijke voorziening aanhangig of nog mogelijk is, wordt niet vernietigd.

${ }^{152}$ TK 1985-1986, 19403 , nr. 3, 182-183 (Memorie van Toelichting). 
besluiten, houdende algemene regels inzake het verrichten van een bepaalde rechtshandeling en besluiten tot delegatie buiten het artikel vallen.

Een besluit dat geschorst is, kan, nadat de schorsing is geëindigd, niet meer worden vernietigd (artikel 275 Gemeentewet 1994). Dit is een eis van rechtszekerheid ${ }^{193}$.

\section{Gevolgen van de vernietiging}

Omdat gemeentelijke besluiten tot het moment van schorsing c.q. vernietiging volkomen rechtsgeldig bestaan, kunnen zij mogelijk reeds tot rechtsgevolgen hebben geleid. In dat verband deed zich de vraag voor naar de uitleg van de artikelen 190 en 191 gemeentewet (oud). Volgens het eerstgenoemde artikel bracht de vernietiging door de Kroon de vernietiging mee van alle daarvoor vatbare gevolgen der vernietigde bepalingen, althans voorzover de Kroon niet anders had bepaald. De beide artikelen lieten onduidelijkheid bestaan over de vraag of de vernietiging alleen zag op de rechtsgevolgen of ook op de feitelijke gevolgen. In het arrest Parochiehuis Woerden oordeelde de Hoge Raad ${ }^{194}$ dat artikel 190 gemeentewet (oud) aldus moest worden uitgelegd, dat alleen de inmiddels ingetreden rechtsgevolgen zouden kunnen worden teruggedraaid, wanneer het besluit naderhand zou worden vernietigd. Dus niet de feitelijke gevolgen. In beginsel heeft vernietiging dus terugwerkende kracht (tot het tijdstip waarop het besluit is tot stand gekomen), zij het dat de Kroon het in haar macht heeft om bepaalde voor vernietiging vatbare (rechts)gevolgen aan deze consequentie te onttrekken. Deze rechtsopvatting is gecodificeerd in artikel 280 , lid 1 Gemeentewet $1994^{195}$. Volgens Brederveld kon artikel 190 gemeentewet (oud) dus niets zeggen over de gevolgen van de vernietiging voor de overeenkomst (als feitelijke handeling) ${ }^{196}$.

Brederveld vindt het KB van 3 maart 1992, S. 122 (Herten) daarom onjuist. Met dit KB vernietigde de Kroon het raadsbesluit van de gemeente Herten tot het aangaan van een realiseringsovereenkomst (dat is een projectontwikkelingsovereenkomst) met Herten Maasdorp BV wegens strijd met het algemeen belang. Bovendien besloot de Kroon dat de gemeente Roermond, waarin Herten kort na de besluitvorming is opgegaan, vanaf het tijdstip van de vernietiging en met terugwerkende kracht tot aan het tijdstip van de schorsing van het raadsbesluit geen uitvoering geeft: aan de met Herten Maasdorp gesloten overeenkomst. Brederveld is, met de Raad van State, van oordeel dat het aangaan van de overeenkomst niet een rechtsgevolg is van het besluit dat daaraan voorafgaat, maar slechts een feitelijk gevolg. Van Buuren ${ }^{197}$ heeft wel begrip voor het betoog van de staatssecretaris, die er daarentegen van uit gaat dat de overeenkomst juist wel bezien moet worden als een rechtsgevolg van het daaraan voorafgaande besluit. Maar dit betekent naar de mening van Van Buuren evenmin dat de vernietiging van het besluit tot vernietiging van de overeenkomst zou moeten leiden, zoals de staassecretaris wil.

Uitgangspunt is dat de vernietiging van het besluit de overeenkomst onaangetast laat ${ }^{198}$. De Toelichting op dit artikel 280, lid 2 Gemeentewet $1994^{199}$ zegt hierover:

\footnotetext{
${ }^{19}$ TK 1988-1989, 19 403, nr. 6, 40 (Memorie van Antwoord).

194 HR 28 febr. 1975, AB 128 m.nt. J.R. Stellinga, BR 1975, 455 m.nt. R. Crince le Roy, AA 1975, 561 v. (J. Wessel) (Parochiehuis Woerden). Zie ABAR (1984), 302-304.

${ }^{195}$ TK 1988-1989, 19403 , nr. 6, 31 (Memorie van Antwoord).

190 Brederveld (1992), 6944, 289

${ }^{197} \mathrm{AB} 1992,466$ mo.nt. P. van Buuren (KB Herten).

19. Anders Steenbeek (1958), 111-112 die meent dat door het vernietigen van het beshit de titel voo: het slutten van de overcenkomst (achteraf bezien) daaraan komt te ontvallen.

190 TK 1985-1986, 19403 , nr. 3, 185 (Memorie van Toelichting).
} 
'Het aangaan van een overeenkomst, hoewel zelf een rechtshandeling, is in relatie tot het vernietigde besluit tot het aangaan van die overeenkomst een uitvoeringshandeling. Vernietiging van het besluit tot aangaan van de overeenkomst zal niet altijd zonder meer hoeven te betekenen dat de gemeente niet meer is gebonden aan die overeenkomst. Niettemin zal de vernietiging, qua strekking veelal gericht zijn op bet niet of - indien al een begin is gemaakt met de uitvoering - niet verder tot uitwoering komen van de overeenkomst. Daarom is het gewenst uitdrukkelijk te bepalen dat de gemeente, temzij de Kroon anders beslist, de overeenkomst niet of niet verder uitvoert. Dat betekent dat de verplichting tot nakoming jegens de wederparij wegvalt.'

De staatssecretaris anticipeerde daarom op een onjuiste manier op het (toen nog) ontwerpartikel 280, lid 2 Gemeentewet 1994. Dit artikel geeft zonneklaar aan dat de Kroon de hoofdregel - dat er geen verdere uitvoering aan de overeenkomst zal worden gegeven - kan beperken. Zij kan daarentegen aan deze hoofdregel geen uitbreiding geven, door te bepalen dat met terugwerkende kracht tot aan het tijdstip van schorsing van het raadsbesluit geen uitvoering aan de overeenkomst meer wordt gegeven. De Kroon eigent zich hiermee een bevoegdheid toe die zij noch onder de oude, noch onder de nieuwe Gemeentewet 1994 bezit200 .

Ongedaanmaking van de overeenkomst veronderstelt een nader besluit van het gemeentebestuur. Volgens artikel 281 Gemeentewet 1994 is het gemeentebestuur verplicht om een nieuw besluit te nemen omtrent het onderwerp van het vernietigde besluit, waarbij met het Koninklijk Besluit rekening wordt gehouden. Het wordt namelijk als wenselijk gezien - ook tegenover de burger - dat de gemeente zich opnieuw uitspreekt over de vraag of, en zo ja op welke wijze, opnieuw wordt voorzien in het onderwerp van het vernietigde besluit, mede in het licht van de vernietiging. Er zal dan een nieuwe belangenafweging moeten plaatsvinden in het kader van de eventuele ongedaanmaking van de feitelijke gevolgen (de overeenkomst). $\mathrm{Er}$ is echter geen plicht tot ongedaanmaking, omdat ook dan met de algemene beginselen van behoorlijk bestuur moet worden gerekend. Het 'tweede' besluit blijft aan het repressieve toezicht onderworpen.

Artikel 280, lid 2 Gemeentewet 1994 geeft de wederpartij van de gemeente een recht op schadevergoeding. Daarvoor is dan wel vereist dat het optreden van een gemeentelijk orgaan (zowel van de raad, B\&W als van de burgemeester) is te kwalificeren als een onrechtmatige daad (artikel 6:162 BW). Schuld is bij overheidsoptreden in strijd met de wet in beginsel steeds gegeven ${ }^{201}$.

\section{De toetsingspraktijk}

Een onderzoek naar de beslissingen van de Kroon inzake besluiten van gemeentebesturen met betrekking tot de aanbesteding van werken geeft het volgende resultaat ${ }^{202}$.

Een besluit dat veel aandacht heeft getrokken, betreft het KB 9 januari $1987^{213}$ inhoudende de vernietiging van een raadsbesluit van de gemeente Amhem. De raad had op 9 juni 1986

200 In die zin Van der Tang-van Loenen (1993), 282

201 TK 1988-1989, 19 403, nr. 6, 190 (Memorie van Antwoord) en TK 1989-1990, 19 403, nr. 16, 15 (Nota naar aanleiding van het Eindverslag). Over de hiermee samenhangende onduidelijkheden De Groot - Van der Meulen Van Rossum (1994), 1200.

200 Voor de antwoorden van de verantwoordelijke ministers op vragen van leden van de Tweede Kamer verwijs ik de lezer terug naar het slot van het vorige hoofdstuk.

${ }^{203}$ S. 1987,11, AB 1987, 408 m.nt. BJvdN, NG 6 febr. 1987, 111. 
besloten geen nieuwe opdrachten meer te verstrekken aan bedrijven die rechtstreeks betrokken waren bij de aanleg en (nieuw)bouw van de kruisrakettenbasis Woensdrecht. Dit besluit werd door de minister van Binnenlandse Zaken vernietigd wegens strijd met het gelijkheidsbeginsel, bedoeld in artikel 1 Grondwet. Volgens de toelichting bij het besluit, die daarvoor verwijst naar de grondwetsherziening ${ }^{204}$, dient de gemeente bij haar beleid dit rechtsbeginsel niet alleen in publiekrechtelijke verhoudingen in acht te nemen, maar ook in privaatrechtelijke relaties, zoals bij het sluiten van contracten en de aanbestedingen van opdrachten. Het gaat hier om de bescherming van grondrechten van organisaties. In dit verband is bij de grondwetsherziening ${ }^{205}$ opgemerkt dat niet alleen natuurlijke personen, maar ook rechtspersonen en groepen en organisaties zonder rechtspersoonlijkheid, beroep kunnen doen op de bescherming van grondrechten, voorzover dat naar de aard van het desbetreffende grondrecht zin kan hebben. Volgens de minister dient de overheid bij het verlenen van opdrachten redelijke en objectieve criteria aan te leggen, waarbij het gaat om de kwaliteit van het te leveren produkt, de prijs, de kredietwaardigheid van het bedrijf en dergelijke. En daarom:

'zal een gemeente geen acht mogen slaan op voor een goede uitvoering van de opdracht niet relevante aspecten als de politieke overtuiging van de aannemer of deelname aan voor die overheid onwelgevallige projecten. Zou dat het geval zijn, dan is er sprake van een ingevolge artikel 1 Grondwet ontoelaatbare ongelijke behandeling bij de aanbesteding'.

Naast ingrepen in besluiten die strijdig zijn met de wet (zoals bij het Arnhemse boycotbesluit in strijd met artikel 1 Grondwet), wordt strijd met het algemeen belang aangenomen, als het gemeentelijk beleid het op het nationale niveau gevoerde beleid doorkruist. Blijkens het KB 22 december 1988 , S. $675^{206}$ had de gemeente Hilversum geweigerd produkten af te nemen van bedrijven (in casu: Shell Nederland Verkoopmaatschappij B.V.) die blijk hadden gegeven handel te drijven met Zuid-Afrika. Naar het oordeel van de betrokken minister en staatssecretaris vormde het besluit een onaanvaardbare doorkruising van het buitenlands beleid, dat tot de verantwoordelijkheid behoort van de regering, zodat het besluit van B\&W niet in stand kon blijven. Het regeringsbeleid was neergelegd in een aan de gemeentebesturen gerichte circulaire en was gericht op beëindiging van het Zuidafrikaanse apartheidsregime langs vreedzame weg, met als doel de totstandkoming van een demokratische en non-discriminatoire samenleving. De regering had hierover afspraken gemaakt met de andere EG-lidstaten. Daarbij waren een aantal selectieve maatregelen genomen en uitgevoerd, waaronder een beperkte boycot (zie daarover verder de Nota van Toelichting). Het gemeentelijke antiapartheidsbeleid was niet in overeenstemming met deze afspraken.

Ook later, in de loop van 1990 en 1991, werd een groot aantal raadsbesluiten geschorst wegens het voeren van een economisch apartheidsbeleid ${ }^{207}$. De LOTA-gemeenten (Lagere Overheden Tegen Apartheid) hadden zich verenigd met het doel geen zaken te doen met ondernemingen die connecties hadden met het Zuidafrikaanse apartheidsregime. Deze negatieve omschrijving werd naderhand vervangen door een positief voorkeursbeleid: naast

\footnotetext{
204 TK 1975-1976, 13 872, nrs. 1-5, 15 (Memorie van Toelichting).

205 t.a.p., 11.

2006 AB 1989, 490 m.n. BJvdN, Gst 1989, 6871 (Hilversum).

${ }_{207}$ S. 1990 , nrs. $65-78$ en nrs. 309-314, S. 1991 , nrs. 23 en 24
} 
prijs- en kwaliteitscriteria werd ook het al dan niet hebben van relaties met het apartheidsregiem in Zuid-Afrika betrokken bij de gunningsbeslissing. Dit nam niet weg dat deze raadsbesluiten vernietigd op gronden aan het algemeen belang ontleend: het gemeentelijke beleid doorkruiste het regeringsbeleid ter zake ${ }^{208}$.

Een algemener overzicht van de toetsingspraktijk geeft Van der Tang-van Loenen ${ }^{20 *}$. Haar eerste conclusie is dat de Kroon een terughoudend gebruik makt yan de schorsings- en vernietigingsbevoegdheid. In de tweede onderzoeksperiode tot en met 1992 zorgde vooral de besluiten tot vernietiging van het grote aantal (gelijkluidende) anti-apartheidsbesluiten voor een beperkte stijging ${ }^{210}$. Het merendeel van de vernietigingsbesluiten wordt genomen wegens strijd met de wet. De tweede conclusie is, dat de Kroon bij politiek gevoelige onderwerpen, zoals het antiapartheidsbeleid en het beleid inzake de stationering van kernwapens, de gemeentelijke standpunten totaal ondergeschikt maakt aan het regeringsbeleid.

\section{Opvattingen in de literatuur en rechtspraak}

Gemeenten hebben in het verleden meermalen de vrijheid genomen om tot een zelfstandig aanbestedingsbeleid over te gaan. De meningen over wat tot de gemeentelijke autonomie behoort c.q. zou behoren wordt evenwel niet door iedereen op dezelfde wijze beantwoord (vergelijk artikel 124 Grondwet en artikel 108 Gemeentewet 1994).

Ackermans-Wijn ${ }^{211}$ toont zich, met een beroep op artikel 1 Grondwet, een verklaard tegenstandster van de mogelijkheden van een gemeentelijk sociaal vestigingsbeleid of (kruisraketten)boycotbeleid. Een dergelijke 'harde' stellingname is vrij uitzonderlijk. Van der Burg merkt in zijn noot onder Amsterdam/ IKON op, dat het er om gaat, of de ongelijkheid van de behandeling gerechtvaardigd wordt door de mate van ongelijkheid der gevallen. Wanneer de overheid op grond van een door haar gekozen relevantiecriterium aanneemt of bepaalt dat sommige gevallen gelijk zijn aan elkaar, en dat andere gevallen ongelijk zijn, dan zal de rechter dit relevantiecriterium niet zomaar aan de kant mogen schuiven ${ }^{212}$. Van der Burg ${ }^{213}$ sprekend over criteria die niet 'sachfremd' mogen zijn, wijst er op dat:

'zij hun rechtvaardiging (moeten) kunnen vinden in de aard van de materie. Echter hoe en door wie wordt dat beourdeeld? Is de praktijk van vele gemeenten om bij het sluiten van contracten voorrang te geven aan ter plaatse gevestigde ondernemingen 'sachfremd' en derhalve in strijd met art. $1 \mathrm{Gr}$.w? Strikt genomen wel, maar de gedachte dat de werkgelegenheid in de gemeente een 'ter zake dienende' factor is, klinkt plausibel' 214

${ }^{20}$ Blijkens Hand. II 25 september 1990, 4-143. Zie voor bet rijksbeleid inzake Zuid-Afrika TK 17895 (m.n. TK 1986-1987, nr. 53, 6). Winter (1991), 775, noot 69 en ook Kortmann (1990), 71 merken terecht op dat de Europese (en Benelux) regelgeving inzake aanbesteding niet in de weg staan aan het overheidsbeleid van de LOTAgemeenten. In die zin B.C. Vis, waarnaar Kortmann verwijst.

309 Van der Tang-van Loenen (1990), 528 en Van der Tang-van Loenen (1993), 277.

$210 \mathrm{~KB}$ 's 28 december 1990, S. 1991, ars. 25-37.

211 Ackermans-Wijn (1989), 216 v. In die zin eerder Slagter (1986), 135-136

${ }^{312}$ In die zin Spier (1981), 23, noot 3 onder verwijzing naar Mendel's relevantiebeginsel. Ook Akkermans (1988), 113.

213 Noot onder AB 1987, 273 (Amsterdam/ IKON).

${ }^{214}$ Dergelijke raadsbesluiten zijn niet eerder vernietigd, vgl. Aanhangsel Hand. II 1978-1979, Kamervragen nr. 1050 door Kamerleden Keja en Braams over het werkgelegenheidsheleid van Utrecht (beiden VVD), en in het Amsterdamse geval, Aanhangsel Hand. II 1983-1984, Kamervragen nr. 142 door Kamerleden Beer en Tripels (beiden VVD). 
Voorafgaand aan het KB 9 januari 1987, S. 11 (Amhem) gaat Stam ${ }^{215}$ na waar de grenzen van het gemeentelijk aanbestedingsbeleid liggen. Volgens Stam is uitsluiting op zuiver politieke gronden in strijd met de Europese aanbestedingsrichtlijnen. Wat betreft strijd met artikel 1 Grondwet is Stam terughoudender. Blijkens de behandeling van artikel 1 Grondwet in de Tweede Kamer werd het begrip 'discriminatie' bepaald door 'het ongerechtvaardigde onderscheid van personen'. Of hieronder ook bedrijven vallen was zijns inziens op voorhand niet duidelijk. Anders dan Stam is Van Vugt ${ }^{216}$ van oordeel dat het Zaanstadse antikruisrakettenbesluit verder nog in strijd is met artikel 19, (lid 2) Grondwet (vrijheid van arbeidskeuze). Ook Verplanke ${ }^{217}$ is van oordeel dat gemeenten bij de aanbesteding niet op politieke gronden een opdracht aan een gegadigde mogen weigeren. Hij is het evenwel niet eens met de motivering van het besluit tot vernietiging van het Arnhemse raadsbesluit; hij acht een dergelijk aanbestedingsbeleid strijdig met artikel 124 Grondwet (dan wel artikel 167 gemeentewet (oud), thans artikel 108 Gemeentewet 1994), in welk geval men aan toetsing aan artikel 1 Grondwet niet meer toekomt. Een dergelijk besluit mag zijns inziens het karakter van een intentieverklaring (zonder aanwijsbare rechtsgevolgen) niet overschrijden. Ook Hennekens ${ }^{218}$ meent dat artikel 1 Grondwet geen goede basis is voor het vernietigingsbesluit. De juridische merites van het Arnhemse KB vragen aandacht omdat hier het criterium van discriminatie 'op welke grond dan ook' uit artikel 1 Grondwet werd gehanteerd om een (gemeentelijk) besluit van civielrechtelijke aard te vemietigen. Het zou volgens hem wel eens richtingbepalend kunnen zijn voor een nieuwe ontwikkeling ${ }^{219}$. Holterman ${ }^{220}$ meent dat er voor gemeenten in elk geval juridische ruimte bestaat om politieke uitspraken te doen en beslissingen te nemen ter bevordering van 'centrale waarden' (vredesbeleid ex artikel 90 Grondwet). Een andere vraag is of er ook politieke ruimte is om 'lokale sturing van centrale waarden' te bevorderen? Hij vindt dat het gelijkheidsbeginsel geen goede maatstaf is voor de vraag hoever een gemeente kan gaan bij haar aanbestedingsbeleid. Met name niet als het gaat om politiek onwelgevallige projecten. De Kroon moet de vernietiging dan ook niet op artikel 1 Grondwet baseren, maar aangeven dat er politieke verschillen van opvatting bestaan tussen het hogere en lagere bestuur. Holterman en Vis ${ }^{221}$ zouden het Arnhemse boycot-besluit in stand willen laten. Holterman verwijt de regering 'argumentatieve willekeur': door een politiek besluit in een juridische jasje te steken, kan het politieke onwelgevallige raadsbesluit worden aangemerkt als een vorm van 'doorkruisen van het rijksbeleid'. Volgens Kortmann ${ }^{222}$ kan uit artikel 90 Grondwet alsmede de systematiek van deze wet worden afgeleid dat de regering de eerst aangewezene is om een buitenlands beleid te voeren. Daarmee wil niet gezegd zijn dat er op dat punt geen ruimte zou zijn voor gemeentelijk beleid $^{223}$. Voorkeursbesluiten zijn volgens hem niet zonder meer in strijd met artikel 90 Grondwet. In de praktijk komt van een gemeentelijk buitenlands beleid echter weinig terecht,

\footnotetext{
${ }^{215} \operatorname{Stan}(1986), 734$.

116 Van Vugt (1984), 27.

${ }^{317}$ Verplanke (1987), 72-73. In die zin ook Kortmann (1990), 72

${ }^{118}$ Hennekens (1987), 201-202.

${ }^{219} \mathrm{Hij}$ wijst daarvoor naar artikel 115 ontwerp-Gemeentewet waarin gemeenten volgens hem in veel opzichten gelijk zijn aan gedeconcentreerde diensten.

2200 Holterman (1987 a), 335-337.

21 Holterman (1987 b), 451-452. Zie ook naschrift redactie, AA 1987, 453 en eerder 130.

mortmann (1990), 71.

20 Vgl. Wijzenbroek (1988), 52.
} 
doordat het Rijk het beleid volledig aan zich trekt. Toch ziet Akkermans wel enig licht. Een pluriform buitenlands beleid op onderdelen lijkt hem geen bezwaar. Aangegeven zou dan moeten worden aan welk dwingend beleid gemeenten zich niet zouden mogen onttrekken en daarnaast zouden aanbevelingen moeten worden gegeven omtrent het door de gemeenten te voeren beleid. Een anti-apartheidsbeleid behoort wat hem betreft tot de mogelijkheden: het probleem schuilt in de grondslag voor zo'n beleid 224 .

\section{Administratiefrechtelijke rechtshescherming}

In de Grondwet van 1848 was slechts het regelen van de gevolgen van de vernietiging aan de wetgever overgelaten ${ }^{225}$. Maar doordat er geen enkel rechtsmiddel openstond tegen het grondwettelijke schorsings- c.q. vernietigingsbesluit van de Koning, kon deze een onbeperkt repressief toezicht uitoefenen op de raadsverordeningen en besluiten. De Koning kon daardoor beslissingen nemen die diep ingrepen in de gemeentelijke autonomie ${ }^{226}$. Daarin kwam in 1887 in zoverre verandering, dat na de grondwetsherziening ook het vernietigingsrecht zèlf door de wet werd beperkt, zij het met één uitzondering: ten aanzien van de besluiten van de gemeentebesturen bleef het oude regime gehandhaafd. Deze beperking van het Koninklijk vernietigingsrecht door de Grondwet maakte, zo was de gedachte, de weg vrij voor een zelfstandige en onafhankelijke administratieve rechtspraak. Op het moment dat een administratiefrechtelijk college in het leven zou worden geroepen, zou dan geregeld moeten worden, dat in bepaalde gevallen van de schorsings- en vernietigingsbesluiten van de Kroon voorziening bij dat rechtscollege open zou staan. Bij de Grondwetswijziging van 1922 werd de eerder nog gemaakte uitzondering voor de gemeentelijke besluiten opgeheven ${ }^{227}$.

De artikelen 184-191 gemeentewet (oud), die het schorsings- en vernietigingsrecht regelden, vormden tot voor kort nog steeds de grondslag voor een vernietigingsrecht van de Kroon, dat zich uitstrekte tot àlle besluiten van de raad en van B\&W, zij het dat bij wet van 15 december 1966, S. 564 in de regeling inzake de schorsings- en vernietigingsbevoegdheid enkele wijzigingen zijn aangebracht, welke in hoofdzaak zijn ontleend aan rapport van de Commissie-De Monchy inzake de verhoging van de rechtsbescherming. Het gaat dan om het bepaalde in de artikelen 185 , lid $2,185 \mathrm{a}$ en $185 \mathrm{~b}$ gemeentewet (oud). De wetgever merkte hierover op:

\footnotetext{
'Daar vernietiging een uiterste middel is, waarvan geen gebruik dient te worden gemaakt zolang nog andere wegen openstaan, is in artikel $185 \mathrm{a}$, in overeenstemming met de bestaande praktijk, schorsing en vernietiging van een besluit dat nog goedkeuring behoeft, alsmede vernietiging van een besluit waartegen beroep aanhangig is of opea staat, uitgesloten. Schorsing van de in het tweede lid genoemde besluiten blijft wel mogelijk, omdat de beroepsmogelijkheid de uitvoering van het besluit niet steeds opschort. $\mathrm{Na}$ het verstrijken van de beroepstermijn c.q. na de definitieve uitspraak in beroep kan vernietiging alsnog plaatsvinden'.
}

en met betrekking tot artikel $185 \mathrm{~b}$ :

\footnotetext{
23. Akkermans (1987), 190.

223 Boissevain (1867), 32.

20. Sikkes (1967), 30.

27. Een lacune in de gemeentewet was, dat in de arm. $184 \mathrm{v}$. alleen werd gesproken over besluiten van de raad en van B\&W en niet ook van de Burgemeester, terwijl art. 145 Grondwet van 1887 sprak van besluiten van de gemeentebesturen. Zic ook Oud (1956), 25.
} 
'Artikel 185 b heeft ten doel conflicten tussen de Kroon en de onafhankelijke rechter terzake van de hantering van het vernietigingsrecht zoveel mogelijk te voorkomen ${ }^{.228}$.

Hierdoor verkreeg het rechtsoordeel van de rechter voorrang boven dat van de Kroon. De artikelen 185a en $185 \mathrm{~b}$ zijn opnieuw vastgesteld bij wet van 1 mei $1975, \mathrm{~S} .283$ in verband met de arob-bezwaarschriftenprocedure. Door de wijziging moest nog beter tot uitdrukking komen dat het rechtsoordeel prevaleerde boven dat van de Kroon.

Tot veor kort kwijtte de burgerlijke rechter zich ook op dit terrein nog van zijn taak als aanvullende rechter. Ik doel hier op de rechispraak inzake de eerder genoemde 'decentralisatie-overeenkomst'. Toen de gemeente Rotterdam bepaalde bezuinigingsbesluiten nam, werden die door de Kroon vernietigd, omdat ze in strijd zouden zijn met de financieringsafspraken. De gemeente wendde zich vervolgens tot de burgerlijke rechter, die zich bevoegd verklaarde: de gemeente legde aan haar vordering wanprestatie respectievelijk onrechtmatige daad ten grondslag en daarmee een schuldvordering in de zin van artikel 2 RO (vervallen) en artikel 112 Grondwet. Daaraan deed niet af dat het om een geschil uit een publiekrechtelijke overeenkomst gaat en de burgerlijke rechter zo krijgt te oordelen over de wijze warop de Kroon van haar in artikel 185 gemeentewet (oud) gegeven bevoegdheid tot vernietiging gebruik makt ${ }^{23}$.

Inmiddels heeft de wetgever de mogelijkheid geschapen om bij de Afdeling bestuursrechtspraak van de Raad van State in beroep te komen tegen besluiten, inhoudende schorsing of vernietiging door de Kroon. Op grond van artikel 281 a Gemeentewet $1994^{230}$ staat beroep open voor belanghebbenden, waartoe zijn te rekenen de in hun belang getroffen bestuursorganen, maar ook derden. Geen beroep is mogelijk tegen een weigering om schorsing of vernietiging van een gemeentelijk besluit te bevorderen: 'een administratieve rechtsgang tegen een negatieve beslissing op een verzoek tot schorsing of vemietiging zou niet verenigbaar zijn met het algemeen-bestuurlijke karakter van het schorsings- en vernietigingsinstrument en wordt derhalve uitgesloten ${ }^{23 !}$.

(Al) in 1990 had het Tweede Kamerlid Van den Berg (SGP) ${ }^{232}$ hierover vragen gesteld aan de staatssecretaris van Binnenlandse Zaken. De staatssecretaris antwoordde dat de mogelijkheden om bestuursgeschillen voortvloeicud uit (repressief) toezicht te onderwerpen aan rechterlijke toetsing uitvoerig aan de orde zouden komen tijdens de behandeling van het betrokken wetsontwerp ${ }^{233}$. En ook meer recent, blijkens de toelichting op het wetsvoorstel eerste fase herziening rechterlijke organisatie ${ }^{234}$ op artikel 8:5 Awb, was de regering voornemens om het spontane schorsingsen vernietigingsrecht op een andere leest te schoeien en te gelegener tijd te voorzien in de mogelijkheid van bestuursrechtelijke rechtsbescherming tegen schorsings- en vernietigingsbesluiten.

De regels, zoals deze in Titel V van de Gemeentewet 1994 zijn neergelegd, hebben onder meer betrekking op de motivering van de toezichtsbeslissingen, de mogelijkheid om voorafgaand te overleggen, het recht van beroep tegen het besluit van het toezichthoudend orgaan en op de termijnen die door de toezichthouder in acht moeten worden genomen. Goorden

TK 1963-1964, 7685, nr. 3, 7 (Memorie van Toelichting).

29 HR 5 febr. 1993, AB 1993, 239.

20 S. 1993,650 (i.w. $x .1$ januari 1994). Hierover Hennekens, Gst 1994 (6991), 350 v.

21 TK 1992-1993, 22 495, nr. 12, 74 (Tweede nots van wijzigingen).

27. Hand. II 19 september $1990,2-44$.

${ }^{23}$ Hand. II 25 september $1990,4-141$.

24 Vergelijk TK 1991-1992, 22 495, nr, 3, 104 (Memorie van Toelichting): TK 1992-1993, 22 495, nr. 6, 50 (Memorie van Antwoord bij art. 8.1.1.5 Awb); TK 1992-1993, 22 495, ar. 10. 40 (Nota n.a.v. het Eindverslag). Zie verder over beroep tegen vernietigingsbesluiten titel 1A.2.2 Awb. En TK 1991-1992, 21 427, nr. $21,14$. 
acht het denkbaar dat op termijn dergelijke algemene onderwerpen, die het gemeentelijk belang kunnen overstijgen, zullen worden geregeld in de Awb. De gemeentewetgever zal dan de vraag moeten beantwoorden in hoeverre er in de Gemeentewet aanvullende of afwijkende regels zouden moeten worden gesteld ${ }^{235}$. Dit zal naar mijn mening overigens niet al te snel moeten worden aangenomen. Ik laat deze verhouding tussen de regeling van het toezicht in de Gemeentewet en handhavingsafdeling 1A.2.2 Awb hier verder rusten.

\section{Conclusie}

De Gemeentewet 1994 staat aan het eind van een ontwikkeling waarbij de bevoegdheidsverdeling thans wordt overgelaten aan het plaatselijke bestuur. Een wettelijke grondslag voor de ontwikkeling van een aanbestedingsbeleid ontbreekt, als gevolg van het ontbreken van een met het oude artikel 176 gemeentewet overeenstemmende bepaling. Daarmee heeft de praktijk gezegevierd, waarin dit gemeentewetsartikel al tot een dode letter was geworden. Gemeenten kunnen hiermee zeer wel uit de voeten: het geeft hen het privaatrechtelijke instrumentarium waarmee zij wenselijk geachte beleidsdoelstellingen kunnen realiseren. De decentralisatiegolf in 1966 en de opkomst van Europese procedureregelgeving op het gebied van de aanbesteding van werken lijkt de wetgever blind te hebben gemaakt voor de (oorspronkelijk) bestuurlijk-normatieve betekenis van artikel 176 gemeentewet (oud) waar het ging om de voorafgaande explicitering van beleidsuitgangspunten in verband met het preventieve toezicht door Gedeputeerde Staten ${ }^{236}$. Met het verdwijnen van een zelfstandige grondslag in de Gemeentewet 1994, werd en wordt het accent eenzijdig gelegd op het (pre)-contractuele aspect van de aanbesteding. Daarmee wordt het uitgangspunt, dat de overheid in beginsel steeds iedere gegadigde tot de inschrijving moet toelaten, overgelaten aan de reglementering van de aanbestedingsprocedures (UAR en Europese richtlijnen). De vraag of de aanbestedingsreglementering een toereikend normatief kader biedt voor 'zoiets als een gemeentelijk aanbestedingsbeleid', komt in het volgende hoofdstuk aan de orde.

\footnotetext{
230 Goorden (1990), 308.
}

236 Het repressieve toezicht, waardoor als ultimun remedium achteraf het besluit kan worden geschorst en vernietigd, is geen geschikt middel on deze openbaarheid voorafgaand aan de uitvoering van bet beleid te bewerkstelligen. 


\section{(Zelf)regulering van de gemeentelijke overheidsaanbesteding}

\section{Inleiding}

In het eerste hoofdstuk (paragraaf 5) is aangegeven dat in de literatuur wel wordt aangenomen dat er zoiets is als een primaat van de openbare aanbesteding, waarmee dan wordt bedoeld dat elke (belangstellende) aannemer op de in het openbaar bekend gemaakte aanbesteding kan inschrijven. We zagen al dat hiervoor de wettelijke grondslag is komen te ontbreken. De vraag die hierna moet worden beantwoord is of de gedachte dat de gemeente als regel openbaar zou moeten aanbesteden uitdrukking heeft gevonden in de regelgeving waaraan de gemeentelijke overheid bij het aanbesteden van bouwwerken is gebonden. Achtereenvolgens gaat het dan om bepalingen in de (nationale) aanbestedingsreglementen en de Europese coördinatierichtlijn 71/305. Hierna zal telkens worden onderzocht welke beginselen aan de regelgeving ten grondslag liggen, en of deze afzonderlijk dan wel gezamenlijk de gedachte van het 'primaat van de openbaar aanbesteding' kunnen dragen.

De Benelux-aanbestedingsregelgeving blijft buiten beschouwing'. Deze heeft, als veeI minder uitgewerki, naast de EEG-regelgeving, voor de gemeentelijke praktijk hoegenaamd geen betekenis, met name niet wanneer wordt gelet op de aan de regelgeving ten grondslag liggende beginselen. Zo blijken aan de Benelux-regelgeving niet alleen geen andere beginselen ten grondslag te liggen dan aan de actuele EEG-regelgeving, maar wordt er ook op verschillende plaatsen aanshiting gezocht bij de Europese aanbestedingsregelgeving.

\section{Confrontatie met de regelgeving}

\subsection{De aanbestedingsreglementen}

Hoewel daarvoor geen (wettelijke) verplichting bestaat, maken gemeenten gewoonlijk gebruik van het voor rijksaanbestedingen ontwikkelde Uniforme aanbestedingsreglement (UAR). Dit gold al voor het UAR $1972^{2}$, en geldt eveneens voor het latere UAR 1986 en het UAR-EG 1991. De Vereniging Nederlandse Gemeenten (VNG) en de prijsregelende organisaties (aan aannemerszijde) verenigd in de Vereniging van Samenwerkende Prijsregelende Organisaties in de Bouw (SPO) zijn destijds overeengekomen dat de VNG de toepassing van het UAR 1986 door gemeenten zou bevorderen waar tegenover de SPO heeft toegezegd bepaalde informatie uit de voorvergadering ${ }^{3}$ (met name over opslagen, rekenvergoedingentotaal en organisa-

I Benelux Economische Unieverdrag. Trb. 1958, 18 en 1960, 124 (BEUV). Eerder, op 15 oktober 1949, was al een Voor-Unie Acccord ondertekend. Zie verder de op art. 62 en 63 BEUV gebaseerde uitvoeringsprotocollen.

2 TK 1976-1977, 14 404, nrs. 1-3, 4 (Memorie van Toelichting). En Toelichting voorontwerp-UAR 1985, 'sGravenhage, 18 december 1984, 22.

3 Dit is de vergadering voorafgaand aan de eigenlijke aanbestedingsvergadering. 


\section{Hoofdstuk 3}

tiebijdragen) desgevraagd openbaar te maken ${ }^{4}$. En ook wat betreft het nog jonge UAR-EG 1991 heeft de VNG zich - zij het onder voorwaarden - bereid verklaard de toepassing daarvan onder gemeenten te stimuleren ${ }^{5}$. Om die reden worden deze aanbestedingsreglementen in de beschouwingen over het primaat van de openbare aanbesteding betrokken.

Het UAR 1972 dat tot stand kwam in nauw overleg tussen de drie bouwministeries ${ }^{6}$ en de Stichting Raad van Bestuur Bouwbedrijf verving en uniformeerde een aantal per departement verschillende aanbestedingsreglementen ${ }^{7}$.

Tot de inwerkingtreding van het Uniforme aanbestedingsreglement $1972^{8}$ werd de precontractuele verhouding tussen de rijksoverheidsaanbesteder en de mogelijke gegadigden c.q. inschrijvers geregeld door het Reglement Openbare Aanbestedingen van Rijkswaterstaat 1932 dat met name betrekking had op de weg- en waterbouw en gedeeltelijk ook op de utiliteitsbouw. Later nog gevolgd door het Aanbestedingsreglement W.B. van 1945 dat speciaal was bestemd voor aanbestedingen voor de gesubsidieerde woningbouw'. Volgens deze reglementen was de aanbesteder bij de gunning van een werk geen enkele uitleg aan de overige inschrijvers verschuldigd ${ }^{10}$. In de periode daaraan voorafgaand werd gebruik gemaakt van het Reglement op het houden van aanbestedingen ${ }^{11}$, de Algemeene bepalingen voor 's-Rijkswerken ${ }^{12}$, de 'Algemeene Voorschriften' vastgesteld bij beschikking van de Minister van Binnenlandse Zaken $^{13}$ en het Aanbestedingsreglement $1919^{14}$. De grote opdrachtgevers, Waterstaat en Defensie, maakten in de eerste helft van de vorige eeuw veelvuldig gebruik van de licitatie, een aanbestedingswijze waarbij na de inschrijving werd gemijnd onder de gegadigden, met de laagste inschrijving als hoogste inzet. De licitatie die (daarom) veel weerstand opriep werd naderhand vervangen door de openbare aanbesteding ${ }^{15}$. Met hun grote zeggensehap hebben deze opdrachtgevers dan ook een belangrijke invloed uitgecofend op de vormgeving van het aanbestedingswezen in ons land.

Met deze uniformering van de aanbestedingsprocedures werd beoogd om, zowel in het belang van de concurrerende bedrijven als van de opdrachtgever, tot een zoveel mogelijk eerlijke

4 VNG-circulaire 'Voorlichting over de praktische toepassing van het UAR [986', bij]lage 5, 25 april 1988, nr. ROVUB/22 267, 55-56. Beroep op deze overeenkomst is mogelijk als de opdrachtgever twijfelt aan de juistheid van de vastgestelde rekenvergoeding of organisatiebijdrage. De prijsregelende organisatie is dan verplicht mededeling te doen van de hoogte van de vastgestelde vergoedingen en of er een organisatiebijdrage in rekening is gebracht.

3 Blijkens Gemeenten en UAR-EG, WMV 3(1992) 1, 6-7. In die zin brief d.d. 15 juli 1991 (MCB03791010) van Minister Alders (VROM) aan de staatssecretaris van Binnenlandse Zaken. En Toelichting UAR-EG 1991.

- Dit zijn thans de ministeries van Verkeer en Waterstaat, van Volkshuisvesting, Ruimtelijke Ordening en Milieubeheer en van Defensie.

7 Cremers - Zonderland, Bouwrecht (losbladige), deel A-I, no. 35

- Ministeriele Beschikking van 21 december 1971, no. U82233, Stcrt. 17 maart 1972, 55. In werking getreden per 1 juli 1972.

- Beide reglementen in Cremers - Zonderland, Bouwrecht (losbladige), deel A-I, nrs. 4 en 5.

$10 \mathrm{Cf}$. art. 11, lid 1 Reglement Openbare Aanbestedingen van Rijkswaterstaat en art. 9, lid 1 Aanbestedingsreglement W.B. 1945.

"I S. 1870, 39. Vgl. hierover Van Oppen - Van Oppen (1895), Eerste vervolgdeel, 1, nr. 93.

12 Over dit reglement zie men Van Oppen - Van Oppen (1895), 8, nr. 21.

13 Beschikking van 22 mei $1876,3^{\circ}$ Afdeling, nr. 31, Gst 1882, 1580.

14 Inwerkingtreding bij KB 8 maart 1919, 27.

is Hulshof (1973), 10. Voor het overige wordt hier volstaan met een verwijzing naar Cremers - Zonderland, Bouwrecht (losbladige), deel A-1, nr. 3. 
en open gunning te geraken. Reden waarom de wijze waarop de overheid tot de gunning van een werk kon komen sterk werd geformaliseerd ${ }^{16}$.

\section{Het Uniforme Aanbestedingsreglement 1972 (UAR 1972)}

De gedetailleerdheid van de procedurevoorschriften in het UAR 1972 was bedoeld om de controleerbaarheid van de aanbesteding te waarborgen ten behoeve van diegenen die daaraan deelnamen. Deze regels dienden volgens de Hoge Raad $^{17}$ strikt in acht te worden genomen. Door onder andere te garanderen dat de ingediende offertes geheim zouden zijn tot het moment waarop de inschrijvingsbiljetten werden geopend en te voorkomen dat daarna nog inschrijvingsbiljetten konden worden ingeleverd, zou het leuren door de opdrachtgever moeten worden voorkomen ${ }^{18}$. Aan het UAR 1972 lagen een aantal beginselen ten grondslag. Ik behandel deze kort.

- Het GeluJkHEIDSBEgINSEL. De rol van het gelijkheidsbeginsel bleek uit begrippen zoals 'een ieder' en 'gelijktijdig'. Daarmee werd bereikt dat de procedurevoorschriften voor alle gegadigden en inschrijvers gelijkelijk en op het hetzelfde moment van kracht waren. Uitwerkingen van het gelijkheidsbeginsel waren te vinden in artikel 5 (omschrijving van de openbare aanbesteding ${ }^{19}$ ), artikel 7 (ter inzage legging van het bestek ${ }^{20}$ ), artikel 8 en dan met name de leden 5 en 6 (nota van inlichtingen en p.v. van aanbesteding ${ }^{21}$ ), artikel 9 (details en monsters ${ }^{22}$ ), artikel 10 , lid 3 (indiening inschrijvingsbiljet ${ }^{23}$ ) en lid 7 (intrekking daarvan ${ }^{24}$ ), artikel 25 (bekendmaking aanbesteding met voorafgaande

I6 Zie TK 1979-1980, 15 800, XII, nr. 82 (Verslag van het mondeling overleg tussen de Vaste Commissie voor Verkeer en Waterstaat en de betrokken minister).

17 HR 31 mei 1985, BR 1985, 788, NJ 1985, 648, AB 1985, 480 m.nt. FHvdB (Staat Hasler).

14 Zie over dit waarborg-aspect Van den Berg (1991), 3. Anders destijds blijkens Gst 1900, 2541.

t9 Art. 5 UAR 1972 luidde: Een openbare aanbesteding is een aanbesteding, welke algemeen bekend wordt gemaakt en waarbij een ieder kan inschrijven.

20 Art. 7, lid 2 UAR 1972 luidde: Het bestek dient tenminste een en twintig dagen voor de dag van aanbesteding verkrijgbaar te zijn. Een exemplaar van het bestek ligt gedurende deze een en twintig dagen voor een ieder ter inzage.

21 Art. 8, lid 5 UAR 1972 luidde: Door of namens de opdrachtgever wordt een ieder, die jegens de opdrachtgever kennelijk blijk heeft gegeven voornemens te zijn op het werk in te schrijven of bij dit werk belang te hebben, afschrift van de nota van inlichtingen en van het eventuele proces-verbaal van aanwijzing verstrekt dan wel op diens verzoek toegezonden.

En lid 6: Alle verstrekte inlichtingen of gegeven aanwijzingen hiervoor bedoeld zijn voor iedere inschrijver verbindend, doch alleen voor zover deze inlichtingen of aanwijzingen zijn opgenomen in de nota van inlichtingen of in het proces-verbaal van aanwijzing.

22 Art. 9 UAR 1972 luidde: Aan hen, die voornemens zijn op het werk in te schrijven of die bij dit werk belang hebben, wordt zoveel mogelijk de gelegenheid geboden kennis te nemen van details van hoofdconstructies en onderdelen, alsmede van monsters, het algemene karakter der leveringen aangevende. Van een en ander wordt in de nota van inlichtingen dan wel in het proces-verbaal van aanwijzing melding gemaakt. Het staat de hiervoor genoemden vrij die details en monsters te wasmerken.

23 Art. 10, lid 3 UAR 1972 luidde: Iedere inschrijver is gerechtigd op het in de bekendmaking vermelde adres zelf het biljet in de daarvoor bestemde gesloten en verzegelde bus te steken.

24 Art. 10, lid 7 UAR 1972 luidde: Iedere inschrijver kan tot het tijdstip van de aanbesteding door middel van een duidelijke, ondertekende verklaring, waarmee op dezelfde wijze gehandeld dient te worden als met het inschrijvingsbiljet, zijn inschrijving intrekken. 
selectie $^{25}$ ), artikel 27 , lid 1 en artikel 31 , lid 1 (gelijktijdige verzending van de uitnodigingen tot inschrijving ${ }^{26}$ ). Zie ook artikel 32, sub a $j^{\circ}$ artikel 8 , leden 5 en 6 als ook artikel 32, sub b $\mathrm{j}^{\circ}$ artikel 9 UAR 1972 alsmede artikel 35. Deze artikelen verklaren de desbetreffende bepalingen van overeenkomstige toepassing voor de onderhandse aanbesteding (na selectie).

- Het openBaARHEIDSBEginsel. Het openbaarheidsbeginsel kwam tot uitdrukking in de bepalingen met betrekking tot de bekendmaking van de aanbesteding (artikel $6^{27}$ ). Bij de openbare aanbesteding en de aanbesteding met voorafgaande selectie ging een openbare aankondiging aan de inschrijving vooraf, zodat ieder bouwbedrijf van de voorgenomen aanbesteding op de hoogte kon zijn (artikel 25). Deze openbaarheid moest bijdragen aan de kansgelijkheid bij de inschrijving. Verder kan worden gewezen op artikel $18\left(j^{\circ}\right.$ artikel 32 , sub $\mathrm{d}^{28}$ ) waar de procedure ter aanbestedingsvergadering werd geregeld. De uitnodiging tot de beide vormen van onderhandse aanbesteding werd vanzelfsprekend niet algemeen bekendgemaakt. $\mathrm{Bij}$ de onderhandse aanbesteding werden twee of meer natuurlijke of rechtspersonen uitgenodigd om in te schrijven (artikel 30, lid 1). Deze uitnodiging ging volgens lid 2 vergezeld van alle gegevens, bedoeld in artikel 6 , tweede lid, die nodig waren om tot inschrijving op het werk te kunnen komen. Bij de onderhandse aanbesteding na selectie gaf de aanbesteder op een door hem te bepalen wijze aan twee of meer natuurlijke of rechtspersonen kennis van zijn voornemen een werk aan te besteden (artikel 34). Daarbij vermeldde hij aan welke eisen moest worden voldaan en welke gegevens moesten worden overgelegd om voor een uitnodiging tot inschrijving in aanmerking te kunnen komen. Na ontvangst van de aanmeldingen en de daarbij verstrekte gegevens bepaalde de aanbesteder wie hij zou uitnodigen om op het werk in te schrijven.

\section{Tweesporenbeleid}

Als bekend (zie reeds hiervoor Hoofdstuk 1, par. 3) heeft de Commissie economische mededinging (CEM) in 1975 voorgesteld te komen tot een tweesporenbeleid, waarbij naast het ordeningsbeleid slechts een complementaire rol toeviel aan het mededingingsbeleid. Dit CEM-rapport leidde op 20 juli 1979 tot de instelling van de Overleggroep Ordeningsthema's Aanbestedingswezen (hierna: Overleggroep), die als taak kreeg de advisering inzake de techniek van de vraag (waaronder de afstandsverklaring, het leuren en de partiële aanbesteding), de regulering van het aanbod en de verbetering van de gegevens, die bepalend zijn

2s Art. 25, lid I UAR 1972 luidde: De opdrachtgever maakt zijn voornemen om een werk aan te besteden bekend in de Staatscourant of in een landelijk vakblad en eventueel op andere wijze; in deze bekendmaking deelt de opdrachtgever mede, dat een ieder schriftelijk een verzoek kan indienen om voor de inschrijving te worden uitgenodigd.

26 Art. 27, lid I UAR 1972 luidde: De opdrachtgever verzendt de uitnodigingen tot inschrijving gelijktijdig aan de daartoe door hem uitgekozen gegadigden.

Art. 31, lid 1 UAR 1972 luidde: De opdrachtgever verzendt de uitnodigingen tot inschrijving gelijktijdig aan de daartoe door hem uitgekozen natuurlijke of rechtspersonen.

37 Art. 6, lid 1 UAR 1972 luidde: De openbare aanbesteding wordt ten minste zes en dertig dagen tevoren in de Staatscourant of in een landelijk vakblad en eventueel op andere wijze bekendgemaakt. Lid 2 bepaalde wat er ten minste in de bekendmaking moest worden vermeld.

2I Art. 18, lid 1 UAR 1972 luidde: Degene, die de aanbesteding houdt, opent de inschrijvingsbiljetten in het openbaar op de plaats en op het tijdstip van de aanbesteding zoals deze in de bekendmaking zijn vermeld. 
voor de inhoud van de aannemingsovereenkomst ter zake van werken waarvoor prijsaanbiedingen worden gedaan. In de marge van haar onderzoek besteedde de Overleggroep ook aandacht aan een aantal 'losse' onderwerpen, te weten: de mogelijkheden tot beinvloeding door de overheid van fluctuaties op de bouwmarkt, het aspect van concurrentievervalsende steunverlening, de risicoverdeling tussen opdrachtgever en aannemers en het kostendeskundigheidsvraagstuk. Op 23 juni 1982 bracht deze Overleggroep haar rapport 'Naar een ordening op de bouwmarkt' uit, waarin een groot aantal aanbevelingen werden gedaan om tot verbetering van de bouwmarktstructuur te geraken. Naar aanleiding van dit rapport werd op 2 augustus 1983 een Stuurgroep 'Ordening op de bouwmarkt' ingesteld ${ }^{29}$, waarin naast de drie bouwdepartementen en het Ministerie van Economische Zaken ook afgevaardigden van het bedrijfsleven zitting hadden. De Stuurgroep werd belast met de concretisering van de ordeningsvoorstellen ${ }^{30}$, die uiteindelijk leidden tot het vaststellen van het Uniforme aanbestedingsreglement 1986, dat per 1 november 1986 in werking trad ${ }^{31}$. Dit reglement dient een bijdrage te leveren aan een betere marktordening, onder meer door het leuren tegen te gaan. Afzonderlijke vermelding verdient in dit verband artikel 3 UAR 1986. Volgens dit artikel is het aan de aanbesteder verboden om, behoudens in het één-één verkeer, van de aannemer te verlangen dat hij afstand doet van zijn rechten en plichten uit de mededingingsregelingen.

Met het vragen van een afstandsverklaring beoogt de opdrachtgever de laagste aanbieder of de eerder gevraagde enige aanbieder - over te halen afstand te doen van diens rechten uit het lidmaatschap van een maatschappelijke en/of prijsregelende organisatie. Zou de gunning aan deze niet slagen, dan kan de aanbesteder zich zonder meer tot een andere aannemer wenden, zonder dat hij de bescherming van de rechthebbende behoeft te respecteren. De praktijk van de afstandsverklaring is ontstaan in de sfeer van het bouwteam. In dit specifieke samenwerkingsverband ontstond gaandeweg behoefte, zowel bij de opdrachtgevers als bij de aannemers, aan een regeling ter beëindiging van die relatie, wanneer zich in hun contacten bepaalde nader omschreven situaties zouden voordoen. Toen de afstandsverklaring eenmaal was geïntroduceerd in de én-én-situatie kwam het steeds vaker voor, dat opdrachtgevers ook in andere prijsvormingssituaties een dergelijke afstandsverklaring van de aannemers vroegen. Geleidelijk aan werd de afstandsverklaring ook gebruikt om onderwerpen te regelen, die gelet op het doel van de afstandsverklaring daarin niet thuishoorden. Er ontstond zo een ware wildgroei, zowel ten aanzien van het gebruik als ook van de inhoud ${ }^{32}$. Dit gebruik van de afstandsverklaring door de opdrachtgever vormt een reactie op de geinstitutionaliseerde bescherming aan de kant van de aannemers, terwijl deze weer haar oorsprong vindt in de zwakke marktpositie bij de aanbesteding van de aannemers ten opzichte van de aanbesteder ${ }^{33}$. Artikel 3 UAR 1986, dat op grote bezwaren van de opdracht-

Stcrt. $1983,150$.

to Zie over de gevolgde werkwijze Toelichting voorontwerp-UAR 1985, 24 en Balk (1985), 99 v.

31 Gemeenschappelijke beschikking van de bouwministeries, d.d. 2 juni 1986, MJZ 0266001 , Stcrt. 24 juli 1986, 118. En S. 1987, 226. De inwerkingtreding van het nieuwe reglement leidde tot wijziging van art. 6 BAW (Besluit van 6 april 1973, S. 1973, 202). Zie over verschillen tussen UAR 1972 en UAR 1986 o.m. Van Werven (1986), 658.

32 Voor een aantal voorbeelden zie men Overleggroep Ordeningsthema's Aanbestedingswezen (1982), Hoofdstuk 6 (Overige onderwerpen), Bijlage I. Ik noem er één: de aanbesteder behoudt zich het recht voor bij overtreding van een of meer bepalingen van de afstandsverklaring de betrokken gegadigden van inschrijving op toekomstige werken uit te sluiten, respectievelijk van hen een (meestal zeer hoge) boete te vorderen.

${ }^{33}$ Overleggroep Ordeningsthema's Aanbestedingswezen (1982), Deel B, 59. 
gevers stuitte ${ }^{4}$, beoogt tot uitdrukking te brengen dat het leuren met het werk in strijd wordt geacht met een goede ordening op de bouwmarkt ${ }^{33}$.

\section{Het Uniforme Aanbestedingsreglement 1986 (UAR 1986)}

Hierna wordt aan de hand van de onderscheiden beginselen ingegaan op de voorschriften in het UAR 1986. Daarbij kon gebruik worden gemaakt van uitspraken van de Raad van Arbitrage voor de Bouwbedrijven in Nederland (hierna: de Raad), doordat sinds het in werking treden van het nieuwe reglement arbiters op grond van artikel 41 UAR 1986 bevoegd zijn om aanbestedingsgeschillen tussen de bij de aanbesteding betrokkenen te beslechten $^{36}$. Één der belangrijkste overwegingen die aan de bevoegdheid van de arbiters ten grondslag ligt is de specifieke branchegerichte deskundigheid ${ }^{37}$. En daarnaast het feit dat de samenhang tussen de precontractuele en contractuele fase er mee is gediend dat er slechts eén college is belast met de geschillenbeslechting in beide fasen ${ }^{38}$. Vór de introductie van artikel 41 UAR 1986 was de aannemer met name aangewezen op de rechtsbescherming door de burgerlijke rechter ${ }^{39}$. Van Wijngaarden heeft er overigens op gewezen dat arbiters in het verleden ook wel geschillen beslechtte, die waren terug te voeren op geschillen in de precontractuele verhoudinge ${ }^{40}$. Doordat de Raad in de praktijk alle aanbestedingsgedingen desgevraagd opvat als spoedgeschillen, is hij in staat om zeer snel tot uitspraken te komen ${ }^{41}$. In artikel 23, lid 5 Statuten voor de Raad is voorzien in de mogelijkheid van arbitraal hoger beroep ${ }^{42}$.

34 Zoals de niet in het Breed Overleg vertegenwoordigde Nationale Woningraad en de VNG. Zie bij voorbeele bijdragen van Pelganta (1981), 9, Dijksma (1981), 9 en Vreugdenhil (1982), 203-204. En ook later, tijdens het Breed Overleg over het UAR-EG 1991, ontstond hierover opnieuw een verhitte discussie.

3s Toelichting op art. 3 UAR 1986.

36 In het CEM-rapport (1976), 19 is sprake van beroep op een neutrale instantie. In het rapport van de Overleggroep Ordeningsthema's Aanbestedingswezen (1982), Deel D, 10-11 werd gekozen voor het bindend advies. Arbitrage werd bepleit door o.m. Rozemond (1982), 120 en Thunnissen (1982), 471. Reserves, bij Van Werven (1985), 4647.

37 Toelichting voorontwerp-UAR 1985, 23

s8 Toelichting voorontwerp-UAR 1985, 31 .

39 Zie naast de reeds hiervoor genoemde rechterlijke uitspraken nog Contractenrecht (losbl.) VIII (Spier), nrs. 20 tot en met 23. Zie ook Van der Riet (1992), 117-123.

* Zie verwijzing Van Wijngaarden (1985), 267 naar RvA 25 oktober 1973, BR 1973, 124-126. Zie ook RvA I maar 1984, BR 1989, 859. Zie verder Van Werven (1985), 45.

4 Vgl. artt. 20, I(c) en 5 Statuten van de Raad van Arbitrage d.d. 1 juni 1987. Vgl. Van den Berg (1987 a), 719. Zie ook Reactie op het artikel van A.J. van den Berg "De gewijzigde Statuten (1987) van de Raad van Arbitrage voor de Bouwbedrijven in Nederland" door het secretariaat van de Raad van Arbitrage voor de Bouwbedrijven in Nederland, met naschrift door A.J. van den Berg. BR 1988, 23-26. Zie over (de wijziging van) deze Statuten eerder Van Wijngaarden (1986), $728 \mathrm{v}$.

4 Vór hoger beroep pleitten 0.a. Smit (1977), 15; Van de Laken (1985), 1 en het rapport van de Werkgroep Standaardregelingen in de Bouw, Harmonisatievoorwaarden in de Bouw, Bouwrecht Monografieën, nr. 5 , Deventer/ Alphen aan den Rijn 1981, 214. Tegen was Rozemond (1976), 93 [meer recent Rozemond (1984), 129]. Over de te lange appeltermijn Van Werven (1992), 226, noot 120. In gelijke zin Van Wijngaarden (1989), 9. 
Volgens de Toelichting op het UAR 1986 behoren in elk geval de gegadigden, de inschrijvers en de aanbesteder tot de 'betrokkenen' bedoeld in artikel 41, lid 1 UAR $1986^{43}$. Het eerste lid van artikel 41 moet volgens de Raad in strikte zin worden uitgelegd, zodat bij voorbeeld een prijsregelings-bv zich daarop niet kan beroepen ${ }^{44}$. Donders ${ }^{45}$ merkt naar mijn mening terecht op, dat de inschrijver die buiten de aanbestedingsprocedure om zijn inschrijvingsbiljet heeft ingeleverd evenmin beroep op artikel 41, lid 1 UAR 1986 toekomt. Het tweede lid moet in samenhang worden gezien met het eerste lid. Tot de 'betrokkenen' van het eerste lid wordt tevens gerekend een vereniging van aannemers met volledige rechtsbevoegdheid die zich tot doel stelt zowel de collectieve als de individuele belangen van haar leden te behartigen (artikel 41, lid 2 UAR 1986). Van Nouhuys ${ }^{46}$ beschouwt artikel 41 , lid 2 als een verklaring van de aanbesteder dat hij zich niet op onbevoegdheid van arbiters zal beroepen als een vereniging van aannemers een aanbestedingsarbitrage aanhangig maakt. Dit tweede lid komt tegemoet aan het verlangen aan aannemerszijde: gesteld werd dat een aannemer niet snel geneigd zal zijn zelf een aanbestedingsgeschil aanhangig te maken, omdat dit zijn relatie met de aanbesteder zou kunnen verstoren ${ }^{47}$. De aannemersvereniging zou de belangen van haar individuele leden kunnen overnemen.

De Raad heeft haar bevoegdheid inmiddels gebruikt om zeer uiteenlopende vorderingen te beoordelen. Onder meer: de eis te verbieclen dat het werk aan de laagste wordt gegund ${ }^{\text {st }}$, de eis van derden tot beëindiging van een reeds gesloten overeenkomst tussen aanbesteder en inschrijver ${ }^{99}$, de eis tot schadevergoeding ${ }^{30}$, de eis van de laagste inschrijver te verbieden dat het werk aan een derde wordt opgedragen ${ }^{51}$ c.q. de eis het werk aan de laagste inschrijver op te dragen?

Blijkens de Toelichting op artikel 41 UAR 1986 is het de bedoeling van de ontwerpers van het reglement geweest, dat dit artikel het mogelijk zou maken dat naast geschillen tussen de aanbesteder en mede-inschrijvers ook aanbestedingsgeschillen tussen gegadigden en/of

43 Art. 41, lid I UAR 1986 luidt: Een geschil russen de bij de aanbesteding betrokkenen - daaronder een geschil dat slechts door een van de betrokkenen als zodanig wordt beschouwd -, dat ontstat naar aanleiding van een aanbesteding waarop deze regeling van toepassing is, wordt beslecht door arbitrage overeenkomstig de regelen bedoeld in de statuten van de Raad van Arbitrage voor de Bouwbedrijven in Nederland, zoals deze drie maanden voor de dag van de algemene bekendmaking van de aanbesteding of van de uitnodiging tot inschrijving luiden. En lid 2: Onder betrokkenen, bedoeld in het eerste lid, wordt tevens verstaan een vereniging van aannemers met volledige rechtsbevoegdheid, die zich tot doel stelt zowel de collectieve als de individuele belangen van haar leden te behartigen.

4 In die zin, maar principiẻler, Van Werven in diens (gast)noot onder RvA 28 juli 1987, nr. 12.927, BR 1987, 793. Hij wijst in dat verband op het karakter van het aanbestedingsreglement. Over prijsregelings-bv zie men $0 . \mathrm{m}$. Slagter (1986), hoofdstuk 4.

4s Diens noot onder RvA 3 maart 1989, nr. 13.774, BR 1989, 717.

4. Van Nouhuys (1986), 41.

"Zie Toelichting art. 41 UAR 1986. Vgl. Van Nouhuys (1986), 40; Rozemond (1987), 95.

4 Rva 5 juli 1990, nr. 14.563, BR 1991, 238; RvA 12 februari 1991, nr. 14.876, BR 1991, 499. RvA 17 augustus 1993, nr. 16.696, BR 1993, 1009.

4 RvA 27 juni 1988, nr. 12.930, BR 1989, 71; RvA 9 januari 1989, nr. 13.693, BR 1989, 550 en als vervolg op deze uitspraak RvA 26 januari 1989, nr. 13.704 en 13.713 (gevoegd), BR 1989, 552 m.nt. Donders.

so Laatstelijk RvA 16 januari 1990, nr. 13.665, BR 1990, 644 m.nt. Donders.

st O.v.a. RvA 1 februari 1991, nr. 70.023, BR 1991, 495 m.nt. Donders en RvA 2 juni 1992, nr. 15.780, BR 1992, 794. RvA 12 augustus 1993, nr. 16.695, BR 1993, 929.

5. Laatstelijk RvA 1 februari 1991, nr. 70.023, BR 1991, 495 m.nt. Donders. 
inschrijvers onderling aan de Raad zouden kunnen worden voorgelegd ${ }^{53}$. De Raad heeft dienovereenkomstig haar bevoegdheid tot het beslechten van dergelijke geschillen uitdrukkelijk aanvaard. Men zie: RvA 26 januari 1989, nrs. 13.704 en 13.713 (gevoegd), BR 1989, 552 m.nt. Donders en RvA 1 augustus 1989, nr. 14.011, BR 1990, 63 m.nt. Donders. Desondanks is er op dit punt geen eenstemmigheid in de literatuur.

Strikt genomen vallen geschillen tussen gegadigden en inschrijvers buiten het onderzoek, dat alleen betrekking heeft op hun relatie met de aanbesteder. Zonder op dit punt volledig te willen zijn, wil ik de lezer de brandende kwesties die de gemoederen bezig houden, niet onthouden. Het gaat om drie vragen. Allereerst de vraag of er op grond van het UAR 1986 rechtsrelaties bestaan tussen inschrijvers onderling. Rozemond ${ }^{\text {s4 }}$ acht de inschrijvers contractueel jegens elkaar gehouden om het UAR 1986 na te leven. Ook de Raad is deze mening toegedaan blijkens de beide hierboven genoemde uitspraken. Van den Bergss vindt het verdedigbaar het voorstel van de aanbesteder om de aanbesteding te doen verlopen volgens het UAR 1986 mede te kwalificeren als een derdenbeding ten gunste van degenen die een gegadigde als mede-gegadigden bij de aanbesteding zal aantreffen. Een tweede aspect is of de Raad in geschillen tussen inschrijvers onderling bevoegd is. De Raad heeft zich als gezegd bevoegd verklaard ${ }^{56}$. Donders oppert in zijn noten onder de beide uitspraken het aannemen van een derdenbeding; anders dan bij Van den Berg en Rozemond beperkt hij dit tot de geschillenregeling in artikel 41 UAR $1986^{57}$. Van Nouhuys ${ }^{38}$ en Slagter ${ }^{59}$ willen niet verder gaan dan het aannemen van bilaterale UAR-overeenkomsten tussen elke inschrijver en de aanbesteder: zij achten artikel 41 UAR 1986 onvoldoende grondslag voor rechtsverhoudingen tussen de inschrijvers onderling. En ook Glazener, Pijnacker Hordijk en Van der Riet ${ }^{60}$ hebben er op gewezen dat een dergelijke bevoegdheid van de Raad zich moeilijk laat verenigen met artikel $1020 \mathrm{BRv}$ : er ontbreekt een arbitrage-overeenkomst tussen de inschrijvers onderling. In die zin AG ten Kate in zijn van uitgebreide literatuurverwijzingen voorziene conclusie bij het arrest Staat/ Hasler (BR 1985, 792). Een laatste heikel punt betreft de vraag of de Raad bevoegd is kennis te nemen van geschillen op basis van het hierna te bespreken UAR-EG 1991. In beginsel bevestigend Thunnissen ${ }^{61}$ en Pijnacker Hordijk $k^{62}$. Ontkennend Kapteyn en VerLoren van Themaat ${ }^{63}$ en zeer waarschijnlijk ook Van Werven $^{64}$. Glazener ${ }^{65}$ en Van der Riet ${ }^{66}$ hebben er op gewezen dat de Raad niet voldoet aan de eisen van artikel 2 , lid 8 richtlijn 89/665, maar dat is dan volgens hen ook niet de bedoeling geweest van de opstellers van de richtlijn. Volgens dit richtlijnartikel moet er van de instanties die geen gerechten zijn in de zin van artikel 177 EG beroep kunnen worden ingesteld bij een onafhankelijke rechter. Ook Sanders ${ }^{67}$ is van oordeel dat de Raad van Arbitrage niet voor een onafhankelijk gerecht in de zin van artikel 177 EG kan doorgaan. Hij (a.w., 202) stelt voor om aansluiting te: zoeken bij artikel $1044 \mathrm{BRv}$ : de Raad zou prejudiciële vragen moeten kunnen stellen door tussenkomst van de President van de Rechtbank Amsterdam. Van de Meent acht het in beginsel mogelijk dat ook de Raad van Arbitrage zelf prejudiciele vragen aan het Europese Hof zou kunnen voorleggen: daarvoor is slechts een beperkte wijziging in het UAR noodzakelijk ${ }^{68}$. Hij stelt voor om aan artikel 41 UAR 1986 een bepaling toe te voegen, welke inhoudt dat de Raad van Arbitrage enkel bevoegd is een aanbestedingsgeschil te beslechten naar de regelen des

33 Tot dan toe werd door aannemers veelal overeengekomen om geschillen voor de Commissie van Toezicht en in heruep voor het College van Beroep voor de Erecode te brengen.

st Rozemond (1987), 94.

ss Van den Berg (1987 b), 93. Ontkennend Thunnissen, men zie Asser-Kortmana-De Leede-Thunnissen (1994), 544.

36 Van den Berg (1991), 27.

\$7 Ook Donders (1992), 98.

s8 Van Nouhuys (1986), 38-40, 49.

so Slagter (1986), 141-142.

60 Glazener, Pijnacker Hordijk en Van der Riet (1990), 210-211.

6! Thunnissen (1982), 468.

62 Pijlacker Hordijk (1992), 113 v.

6. Kapteyn - VerLoren van Themaat (1987), 223.

4. Van Werven (1985), $42 \mathrm{v}$.

is Glazener (1990), 616.

no Van der Riet (1992), 122-123.

67) Sanders (1991), 203.

s Van de Meent (1991), 123 v. 
rechts. In dat geval zou de procedure voor de Raad zijns inziens in belangrijke mate voldoen aan de door richtlijn 89/665 gestelde criteria. De Raad heeft inmiddels van zijn bevoegdheid gebruik gemaakı om op grond van het UAREG 1991 vonnis te wijzen, nu deze bevoegdheid niet door de verweerder - de Staat - werd betwist ${ }^{69}$. Bovendien heeft de President van de Rb.'s-Gravenhage zich onbevoegd geacht te oordelen over een geschil tussen de Staat, als aanbesteder, en een inschrijver onder toepasselijkheid van het UAR-EG $1991^{70}$. Geoordeeld werd dat de Raad van Arbitrage bij uitstek geêquipeerd is om middels een arbitraal kort geding op korte termijn een adequate voorziening te verkrijgen.

Past de gemeente het UAR niet toe dan zullen partijen voor hun aanbestedingsgeschil terechtkomen bij de gewone rechtbank, net zoals dit het geval was onder het UAR 1972, dat geen arbitrageregeling kende. Net als eerder bij het UAR 1972 sta ik hierna stil bij een tweetal beginselen die ten grondslag liggen aan het UAR 1986.

- HET GeLUKHeIDSBEgINSEL. Evenals in het UAR 1972 komt dit beginsel tot uitdrukking door de verwijzing in diverse bepalingen naar de begrippen 'een ieder' en 'gelijktijdig'. Deze kansgelijkheid is blijkens tal van bepalingen in het nieuwe reglement verder uitgewerkt dan in het UAR $1972^{71}$. Zo geeft artikel 9, lid $1 \mathrm{j}^{\circ}$ lid 6 UAR $1986^{72}$ duidelijker dan voorheen de betekenis weer van de antwoorden van de aanbesteder op door de aannemer gestelde vragen: deze staan in een, voor iedere gegadigde bindende, nota van inlichtingen. Hierdoor kan elke aannemer aantonen, dat een vraag reeds in de aanbestedingsfase aan de orde is geweest. Daaraan ligt tevens de gedachte ten grondslag, dat zo geschillen in de uitvoeringsfase kunnen worden voorkomen ${ }^{73}$. De nota van inlichtingen ligt tesamen met het proces-verbaal van aanwijzing gedurende ten minste zeven dagen voorafgaand aan de dag van aanbesteding ter inzage ${ }^{74}$. Alle verstrekte inlichtingen of gegeven aanwijzingen zijn voor elke inschrijver bindend, voorzover die inlichtingen of aanwijzingen zijn opgenomen in de nota van inlichtingen of het proces-verbaal van aanwijzing. Van Wijngaarden wijst er op dat dit artikel - dat al voorkwam in het UAR 1972 en was overgenomen in het voorontwerp-UAR 1985 - in de UAV-jurisprudentie van de Raad veel minder stringent werd toegepast dan de absolute formulering zou doen vermoeden. Reeds in 1933 oordeelde de Raad dat uit de gelijkluidende par. 446 der AV Waterstaat 1901 geenszins volgde, dat niet in het proces-verbaal van aanwijzingen of in de nota opgenomen in-

- RvA 12 mei 1992, nr. 15.775, BR 1992, 944 m.nt. Donders en de daar genoemde literatuur.

to Pres. Rb.'s-Gravenhage, 16 juli 1993, BR 1993, 928.

$7 \mathrm{Vgl}$. over de zgn. pariteitseis Donders in diens noot onder RvA 3 maar 1989, מr. 13.774, BR 1989, 715.

$n$ Art. 9, lid 1 UAR 1986 luidt: Van de verstrekte inlichtingen - voor zover die strekken ter aanvulling of wijziging van het bestek dan wel de kosten, de duur of de wijze van de uitvoering van het werk kunnen beïnvloeden - en de door de inschrijvers schriftelijk gestelde vragen wordt door of namens de aanbesteder een nota van inlichtingen opgemaakt.

En lid 6: Alle verstrekte inlichtingen of gegeven aanwijzingen als bedoeld in dit artikel zijn, voor zover die inlichtingen of aanwijzingen zijn opgenomen in de nota van inlichtingen of in het proces-verbaal van aanwijzing, voor elke inschrijver bindend.

$n$ Toelichting op art. 9 UAR 1986.

74 Artikel 9, lid 3 UAR 1986 luidt: De nota van inlichtingen en het proces-verbaal van aanwijzing worden door of namens de aanbesteder ondertekend en liggen gedurende ten minste zeven dagen voorafgaand aan de dag van aanbesteding op de aangegeven plaats of plaatsen, bedoeld in artikel 6, tweede lid, onder $\mathrm{i}$, ter inzage.

Artikel 6, lid 2, aanhef en onder i UAR 1986 luidt: De bekendmaking, bedoeld in het eerste lid, vermeldt in elk geval: $i$. waar en op welke data het bestek, de nota van inlichtingen en het proces-verbaal van aanwijzing ter inzage liggen. 
lichtingen iedere betekenis misten ${ }^{75}$. Een beroep van de aanbesteder op het ontbreken van deze gegevens werd beschouwd als strijdig met de goede trouw. De Raad heeft zich tot nog toe niet over de UAR-bepaling hoeven uitlaten. Ook artikel 10 UAR 1986 (details en monsters ${ }^{76}$ ) waarborgt dat door de aanbesteder tijdens de aanbesteding verschafte informatie voor een ieder gelijkelijk beschikbaar is. Voorts kan worden gewezen op artikel 11 $\mathrm{j}^{\circ}$ artikelen 21-23 UAR 1986. Artikel 11, lid 1 bepaalt dat de aanbesteding geschiedt bij inschrijving. Artikel 23 herhaalt artikel 20 UAR 1972 in iets andere bewoordingen, maar de strekking is dezelfde: inschrijvingen die niet aan de in het UAR gestelde eisen voldoen zijn ongeldig. Dit is ten opzichte van artikel 20 UAR 1972 meer geobjectiveerd. Rozemond heeft echter terecht opgemerkt, dat deze regeling desondanks niet toereikend is. De bereikte objectivering wordt weer onderuit gehaald, door in de slotzin van het artikel te bepalen dat de eisen vervallen als er bij de aanbesteder voldoende zekerheid over aanbieding en de persoon zou bestaan ${ }^{\pi}$.

Blijkens RvA 20 juni 1994, nr. 17.264, BR 1994, 1046 m.nt. Donders waren arbiters van oordeel, dat de toezegging van de aanbesteder aan de vertraagde gegadigde, dat de aanbesteding zou worden uitgesteld totdat deze gegadigde gearriveerd was, niet zonder meer bindende kracht heeft, omdat daarbij ook belangen van derden zijn betrokken. De mogelijkheid dat, nadat alle inschrijvingen moeten zijn gedaan, nog een geldige inschrijving plaatsvindt, staat haaks op de eis dat gegadigden en inschrijvers gelijk worden behandeld. Dat zou alleen anders zijn., als de overige bij de aanbesteding betrokkenen met de door de 'verlate' inschrijver hadden ingestemd ${ }^{73}$.

Volgens de Overleggroep Ordeningsthema's Aanbestedingswezen ${ }^{79}$ kon de in het UAR opgenomen regeling over de verlenging van de gestanddoeningstermijn in de praktijk concurrentievervalsend werken ${ }^{80}$. Het kwam namelijk voor dat opdrachtgevers de termijn van gestanddoening verlengden uitsluitend om één aanbieder in de gelegenheid te stellen alsnog aan de bij de aanbesteding gestelde eisen te voldoen. Door dan de gestanddoeningstermijn te verlengen werd de aannemer, die niet voldeed aan de bij de aanbesteding gestelde eisen, in de gelegenheid gesteld om alsnog aan de inschrijvingseisen te voldoen. Hierdoor werd deze aannemer onredelijk bevoordeeld ten opzichte van zijn mede-inschrijvers. Deze praktijk was overigens al voor de inwerkingtreding van het UAR 1986 door de rechtspraak veroordeeld ${ }^{81}$.

7 Van Wijngaarden (1985), 262, die hiervoor verwijst naar de uitspraken in geschillen, die zijn opgenomen in de Jaarverslagen van de Raad van Arbitrage van 1933, nr. 975, 58; 1938, nr. 1168, 42 en 1957, nr. 2486, 43.

76 Art. 10 UAR 1986 luidt: Aan hen die blijk hebben gegeven of voomemens zijn op het werk in te schrijven of die bij dit werk belang hebben, wordt zoveel nogelijk de gelegenheid geboden kennis te nemen van details van hor) fdconstructies en onderdelen, alsmede van monsters die het algemene karakter der leveringen aangeven. Van een en ander wordt in de nota van inlichtingen dan wel in het proces-verbaal van aanwijzing melding gemaakt. Het staat de hiervoor genoemden vrij die details en monsters te waarmerken.

$n$ Pres. Rb. 's-Gravenhage 26 januari 1983, BR 1986, 788-791, i.h.b. 790 m.nt. J. Rozemond. Aan deze slozzin werd overigens geen betekenis gehecht in RvA 9 april 1991, ar. 15.008, BR 1991, 798.

7: Vergelịjk artikel 11, lid 6 en 7 UAR 1986.

* Overleggroep Ordeningsthema's Aanbestedingswezen (1982), Deel D, 3.06, 14 sub C.

* Art. 17 UAR 1972 luidde: De inschrijver moet zijn aanbieding gestand doen gedurende dertig dagen na de dag. warrop de aanbesteding plaats heeft, tenzij in de bekendmaking, het bestek of de nota van inlichtingen een andere termijn is gesteld.

I Blijkens het arrest HR 31 mei 1985, NJ 1985, 648 (Staad Hasler). Zie Van den Berg (1991), 1-3. Het arrest vormt een bevestiging van het arrest Hof Arnhem 16 januari 1984, BR 1984, 357. Zie onk Toelichting op art. 17, lid 2 voorontwerp-UAR 1985. 
Svortgelijke rechtspraak in België blijkens Raad van State 1 oktober $1991^{\text {v }}$ waur in het kader van een algemene offerti-aanvraag ${ }^{*}$ gecordeeld werd, dat het gelijkheidsheginsel emstig werd geschunden wanneer aan Je concurtenten, wiens offerte hij de eerste offerte-aanvraag onregelmatig werd hevonden, een kans werd geboden om de onregelmatigheden van hun eerste offerte te regulariseren en de opdracht in de wacht te slepen. Iin ook blijkens de uitspraak van de Belgische Raad van State 19 mei $1992^{2}$, waar geonrdeeld werd dat de Regie der Posterijen het gelijkheidsbeginsel had geschonden door zonder enige vitleg of verwijzing in het dussier het voornaamste keuzecriterium weg te laten, blijkbaar met geen ander motief dan de concurrenten te hevoordelen.

Artikel 19 UAR 1986 moet aan deze praktijk een einde maken. Bepaald wordt dat de inschrijver zijn aanbieding gedurende 30 dagen na de dag waarop de aanbesteding plaats heeft gestand moet doen, tenzij in de bekendmaking, het bestek of de nota van inlichtingen een andere termijn is bepaald. De opdrachtgever kan volgens het tweede lid slechts verzoeken om verlenging van de termijn van gestanddoening. Het oordeel daarover is aan de inschrijver. Aan het verzoek tot verlenging van de gestanddoeningstermijn kan de inschrijver geen aanspraak ontlenen op de opdracht ${ }^{35}$.

Nieuw is artikel 20 UAR 1986 waar bepaald wordt dat een inschrijver zijn aanbieding na het tijdstip van de aanbesteding niet kan wijzigen of aanvullen, tenzij het de inschrijver betreft aan wie de aanbesteder overweegt het werk overeenkomstig artikel 24, lid 3 UAR $1986^{86}$ op te dragen en de aanbesteder aan deze inschrijver een verzoek tot wijziging of aanvulling heeft gedaan. Dit verzoek betekent niet dat de inschrijver aanspraak op de opdracht heeft. Daarmee wordt enerzijds voorkomen dat aanbieders tussentijds op oneigenlijke wijze de opdracht trachten te verwerven, en dat anderzijds de opdrachtgever wordt beperkt in zijn handelingsvrijheid doordat hij slechts de meest aannemelijke aanbieder aan wie hij in beginsel de opdracht wil gunnen - kan verzoeken om zijn aanbieding te wijzigen of aan te vullen ${ }^{87}$.

Het gelijkheidsbeginsel komt ook tot uitdrukking in artikel 31 UAR 1986 in geval van een aanbesteding met voorafgaande selectie. Daar wordt bepaald dat de aanbesteder gelijktijdig de uitnodigingen tot inschrijving verzendt (lid 1). Bovendien verzendt hij gelijktijdig met deze uitnodigingen aan hen die niet worden uitgenodigd een bericht daarvan. Vergelijk in die zin ook de artikelen 35 en 40 UAR 1986 voor de onderhandse aanbesteding (na selectie).

: TvAan. 1992, 236.

83 Dat wil zeggen dat er openbaar wordt aanbesteed, waarbij het laagste prijscriterium niet het enigste gunningscriterium is. Naar Belgisch recht veronderstelt een aanbesteding bet automatisme van de laagste prijs.

4vAan. 1992, 242.

soelichting voorontwerp-UAR 1985, 29.

2s An. 24, lid 3 UAR 1986 luidt:Onverminderd het rweede lid geschiedt de opdracht van het werk aan: a. de inschrijver die de laagste prijs heeft aangeboden;

b. de inschrijver met de economisch meest voordelige aanbieding, indien het een alternatieve aanbieding betreft die door de aanbesteder in beschouwing is genomen;

c. de inschrijver met de economisch meest voordelige aanbieding, indien in de bekendmaking of het bestek overeenkomstig artikel 7, vierde lid, een of meer gunningscriteria zijn vermeld die anders zijn dan alleen de laagste prijs.

87 Vgl. Toelichting voorontwerp-UAR 1985, 30. Zo bijv. RvA 16 januari 1990, nr. 13.665, BR 1990, $644 \mathrm{~m} . \mathrm{nt}$. Donders. Zie ook RvA 15 juli 1992, nr. 15.798, BR 1993, 157. 
- Het openbaARHEmSBeginsel. De Commissie economische mededinging had in zijn rapport van 1975 bepleit, dat zowel de aanbesteding als de selectievoorwaarden door middel van een openbare aankondiging zouden moeten worden bekendgemaakt. En dat zulks zeker voor overheidsaanbestedingen zou moeten gelden. Het wekt dan ook geen verbazing, dat juist met betrekking tot de publikatievoorschriften in het UAR 1986 enkele belangrijke wijzigingen zijn opgetreden ten opzichte van het UAR 1972. Het gaat daarbij steeds om een samenspel tussen hetgeen in de aankondiging c.q. de uitnodiging, het bestek en de nota van inlichtingen wordt gepubliceerd. Het bestek vermeldt thans, volgens artikel 7, lid 3 UAR 1986, alle maatschappelijke, technische, organisatorische en financieeleconomische (geschiktheids)eisen waaraan de inschrijver, zowel op de dag van de openbare aanbesteding als van opdrachtverlening, moet voldoen. En verder, indien de aanbesteder zich het recht voorbehoudt het werk op te dragen aan de inschrijver met de economisch meest voordelige aanbieding, bedoeld in artikel 24, lid 3 onder c UAR 1986, alle gunningscriteria die anders zijn dan het gunningscriterium van de laagste prijs. Deze andere gunningscriteria kunnen blijkens artikel 8, lid 2 UAR 1986 variëren naar de aard van de opdracht zoals prijs, verrekenprijs of -prijzen, gebruikskosten, rentabiliteit, uitvoeringstermijn en technische waarde, doch mogen niet de begroting van de inschrijver betreffen. De aanbesteder vermeldt de gunningscriteria zo mogelijk in afnemende volgorde van het belang dat hij er aan hecht (artikel 7, lid 4) ${ }^{88}$. Gegevens die moeten worden overgelegd om in aanmerking te komen voor de opdracht van het werk moeten in het bestek worden vermeld. Dit is alleen anders als volgens de bekendmaking de daarin gegeven opsommingen van eisen en over te leggen gegevens uitputtend zijn. Artikel 28, lid 2, onder $\mathrm{j}$ en k UAR 1986 over de bekendmaking van de aanbesteding met voorafgaande selectie is nieuw. Bepaald wordt, dat het maximale aantal gegadigden, waaraan een uitnodiging tot inschrijving zal worden verzonden, bekend wordt gemaakt (sub j) ${ }^{89}$. Hetzelfde geldt voor de wijze waarop de keuze tot uitnodiging wordt bepaald (sub $\mathrm{k}$ ). Ook hier geldt een soortgelijke overweging als bij de artikelen 6 en 7 UAR 1986: het in een zo vroeg mogelijk stadium informeren van gegadigden. In artikel 28 , lid 2 , onder $f$ wordt het bepaalde in artikel 7, lid 3 UAR 1986 herhaald, zij het dat deze gegevens dan reeds in de bekendmaking van de aanbesteding worden vermeld. Alsdan is de aanbesteder gebonden aan deze eisen en kan hij deze later niet aanscherpen of uitbreiden. Doordat in artikel 28 UAR 1986 soortgelijke bepalingen als in artikel 6, lid 2, onder m UAR 1986 missen, behoeven de belangrijkste gunningscriteria en gegevens dus niet al bij de bekendmaking te worden gepubliceerd. Anders dan in het UAR 1972 (artikel 26) wordt thans in artikel 30, lid 2, onder i UAR 1986 bepaald, dat de belangrijkste van de in artikel 7, vierde lid UAR 1986 bedoelde gunningscriteria en gegevens in de uitnodiging worden vermeld. Bij de onderhandse aanbesteding gaat de uitnodiging tot inschrijving vergezeld van de gegevens bedoeld in artikel 6, tweede lid, onder a $\mathrm{U} / \mathrm{m} \mathrm{k}$ en m UAR 1986, die nodig zijn om tot inschrijving op het werk te kunnen komen. Anders dan bij de openbare aanbesteding vermeldt de uitnodiging dus niet de selectiecriteria van artikel 7, derde lid UAR 1986, en slechts de belangrijkste van de in artikel 7, lid 4 bedoelde gunningscriteria en

solgens de Toelichting is met de laatste volzin van het vierde lid aansluiting gezecht bij art. 29, lid 2 richtlijn $71 / 305$.

37. 26 voorontwerp-UAR 1985 bepaalde dat het aantal uitnodigingen was beperkt tot ten hoogste tien. Ratio: kostenaspect en grotere gunningskans inschrijvers (zie Toelichting op het voorontwerp-UAR 1985, 30). 
gegevens, die niet noodzakelijk in een afnemende volgorde van het belang dat de aanbesteder er aan hecht behoeven te staan. De regeling der selectie en uitnodiging ter gelegenheid van een onderhandse aanbesteding na selectie in artikel 39 UAR 1986, is ongewijzigd (vgl. artikel 34 UAR 1972).

In RvA 25 april 1994, nr. 17.113, BR 1994, 707 m.nt. Donders deed zich de vraag voor of de gemeente zich op aanvullende eisen mocht beroepen. Een gemeente wilde in afwijking van het bestek, naast de constructieve en economische aspecten, naderhand een alternatieve aanbieding ook nog toetsen op milieu-aspecten. De arbiters oordeelden hierover negatief: de aanbesteder had bij de alternatieve aanbieder het vertrouwen gewekt dat milieuaspecten bij de beoordeling geen rol zouden spelen. Donders tekent daarbij aan dat arbiters in het algemeen terughoudend dienen te zijn met het honoreren van door een aanbesteder bij een bepaalde inschrijver opgewekt vertrouwen. Dat kan ik onderschrijven: derden kunnen daar de dupe van worden. Een beroep op het ontbreken van de voorafgaande publikatie was daarom mijns inziens verstandiger geweest.

\section{De Europese dimensie}

Pas met het UAR-EG $1991^{90}$ wordt in de aanbestedingsreglementering voor het eerst uitdrukkelijk aansluiting gezocht met het Europese aanbestedingsrecht en de, inmiddels gewijzigde, coördinatierichtlijn voor de procedures inzake overheidsopdrachten (richtlijn 71/305). Op basis van een tweetal voorstudies werd gekozen voor het scenario, waarbij er een afzonderlijk aanbestedingsreglement voor Europese aanbestedingen zou worden vastgesteld ${ }^{91}$. Het voorontwerp ${ }^{92}$ zoals dit door VROM/Directie Coördinatie Bouwbeleid namens de drie bouwministeries in juni 1990 werd gepresenteerd vormde het startsignaal voor een nieuw Breed Overleg. Naast het voorstel van de bouwministeries werd zijdens het AVBB en de SPO een eigen voorstel ontwikkeld en ingediend ${ }^{93}$. Op 6 september werd het resultaat van het Breed Overleg aan Minister Alders (VROM) aangeboden, zonder dat over het punt van de, in de wijzigingsrichtlijn geïntroduceerde, onderhandelingsprocedures overeenstemming was bereikt ${ }^{94}$. Op enkele ondergeschikte punten na, is de eindtekst zoals deze op 15 november 1991 door de verantwoordelijke bewindslieden uiteindelijk werd vastgesteld, gelijk aan het concept UAR-EG 1991. Op 22 november 1991 verscheen de eindtekst in de Staatscourant ${ }^{95}$. Op 1 januari 1992 trad het reglement in werking.

Geschillen die voortvloeien uit het UAR-EG 1991 zullen, net als bij het UAR 1986 het geval is, worden beslecht door de Raad voor de Bouwbedrijven in Nederland. Hiervoor geldt dezelfde regeling als in het UAR 1986. Het is als bekend (zie eerder) - vooralsnog omstreden of de Raad al dan niet een gerecht is in de zin van artikel 177 EG.

Inhoud en systematiek van dit (voorontwerp) UAR-EG 1991 zijn zoveel mogelijk gelijk aan het UAR 1986, zij het, dat daarin de aanpassingen voortvloeiend uit de wijzigingsrichtlijn

* Over het voorontwerp UAR-EG zie men Nijholt (1991), 594. Uitvoerige bespreking van bet reglement Pijnacker Hordijk (1992), $106 \mathrm{v}$.

9. Nijholt (1989) en Nijholt (1990).

92 Ministerie van Volkshuisvesting, Ruimtelijke Ordening en Milieuheheer, Centrale Directie Juridische Zaken, uitgegeven door Directie Coördinatie Bouwbeleid, Den Haag, juni 1990.

93 De voorstellen en de commentaren zijn bijeengebracht in de bundel 'Voorontwerp Uniform Aanbestedingsreglement op EG-niveau', VROM/ Directie Coördinatie Bouwbeleid, Den Haag, november 1990.

Zie over de onderhandelingsprocedures o.m. Pijnacker Hordijk (1992), 102-106.

9s Stcrt. 1991, 228, 12-20 
$89 / 440$ zijn verwerkt ${ }^{96}$. De VNG heeft laten weten dat de gemeenten zullen worden geadviseerd zich in de toekomst te houden aan het bepaalde in het UAR-EG 1991. Daarbij past echter de volgende kanttekening. Gemeenten wordt aangeraden om geen gebruik te maken van de in het reglement opgenomen onderhandelingsprocedures, maar daarvoor rechtstreeks de onderhandelingsprocedures uit de richtlijn te hanteren. In verband met de strijdigheid van het bepaalde in artikel 4 UAR-EG 1991 (over de afstandsverklaring; vergelijk artikel 3 UAR 1986) met het Europese recht is dit artikel inmiddels geschrapt uit het UAR-EG $1991^{97}$. Het verbod op het vragen van een afstandsverklaring vormde de (impliciete) medewerking door de overheid aan het bestaan van mededingingsregelingen aan de kant van de aannemers, waartegen de Europese Commissie zich inmiddels met succes heeft verzet (zie hierover eerder Hoofdstuk 1, paragraaf 3).

\section{Het Uniform Aanbestedingsreglement-EG 1991 (UAR-EG 1991)}

Evenals bij de beide vorige reglementen sta ik hierna stil bij het gelijkheidsbeginsel en het openbaarheidsbeginsel die beide ook aan het UAR-EG 1991 ten grondslag liggen.

- Het GeliJKhemsbeginsel. Het UAR-EG 1991 is niet alleen de Europese pendant van het UAR 1986, maar is bovendien een modernere versie van dat reglement. Het wekt dan ook geen verbazing dat de beginselen die aan het UAR 1986 ten grondslag liggen, nog evidenter zijn uitgewerkt in het UAR-EG 1991. Voorbeelden van het gelijkheidsbeginsel zijn te vinden in de artikelen 10, lid 2 (ter inzage legging van bestek), 11 (nota van inlichtingen en het p.v. van aanbesteding), artikel 17 (details en monsters), artikel 18 (de inschrijving ${ }^{98}$, artikel 35 (bekendmaking aanbesteding met voorafgaande selectie), artikel 37 tot en met 39 (uitnodigingen tot inschrijving), artikel 44 (aanmelding als gegadigde bij onderhandelingsprocedure met voorafgaande bekendmaking) en in de daarop volgende inschrijvingsprocedure. De Toelichting op artikel 45 UAR-EG 1991 merkt in verband met deze procedure nog op dat na afloop van de overlegperiode ingediende voorstellen niet meer door de aanbesteder in aanmerking mogen worden genomen. Deze bepaling beoogt uitdrukkelijk de gelijke behandeling van de uitgenodigde gegadigden. Voor wat betreft de onderhandelingsprocedure zonder voorafgaande bekendmaking zie men de artikelen 56 en 57, waar de hiervoor genoemde bepalingen van overeenkomstige toepassing worden verklaard. Bij deze opsomming moet worden bedacht dat veel bepalingen zowel een uitwerking vormen van het gelijkheidsbeginsel als van het openbaarheidsbeginsel, zodat met andere woorden - de betekenis van deze beginselen ten dele ook moet worden gezocht in de combinatie van beide.

* Het UAR-EG $1991 \mathrm{mag}$ niet tot een regime leiden dat beperkter is of meer gedetailleerd is dan de richtlijn. Dit geldt ook wanneer de harmonisatierichtlijn stelt dát de lidstaten verdergaande bepalingen kunnen op̣nemen. Zie zaak 148/78 (Ratti).

n Besluit van 26 februari 1993, Stert. 8 maart 1993, 46, 10 met toelichting.

* Zie over de uitleg van art. 21, lid 3 UAR 1986: RvA 29 oktober 1993, BR 1994, 83. Deze bepaling treedt eerst in werking indien onduidelijkheid bestaat en ook redelijkerwijs kan bestaan over het aanbod van een inschrijver. De verschillende soorten inschrijvingen worden uitgewerkt in de arrikelen 20 tot en met 25 . Het gaat dan achtereenvolgens om de insehrijving op werk verdeeld in percelen (art. 20), op werk van op te geven omvang (art. 21), gezamenlijke inschrijving (art. 22), insehrijving onder voorwaarden (art. 23), alternatieve inschrijvingen (art. 24) en inschrijving op varianten in het bestek (art. 25). 
Door AVBB en SPO is tijdens het Breed Overleg uitdrukkelijk verzocht om een toelichting op het in Hoofdstuk II (Openbare aanbesteding) bepaalde inzake de wijziging van de aanbieding (artikel 27 UAR-EG 1991). Dit artikel komt overeen met artikel 20 UAR 1986 en geeft aan in welke gevallen een inschrijver de mogelijkheid heeft om, na het tijdstip van de aanbesteding, zijn aanbieding te wijzigen. Dit is alleen dan mogelijk indien de aanbesteder aan de inschrijver, aan wie hij voomemens is het werk op te dragen, een daartoe strekkend verzoek heeft gedaan. De Toelichting op het UAR-EG 1991 wijst daarbij op de beperking welke is gelegen in de bij artikel 5 , lid 4 richtlijn $89 / 440$ behorende verklaring. Deze luidt:

'dat bij openbare en niet-openbare procedures, onderhandelingen met gegadigden of inschrijvers over fundamentele punten van de opdrachten waarvan de wijziging de mededinging kan vervalsen, en met name over de prijzen, uitgesloten zijn; wel mogen er besprekingen met gegadigden of inschrijvers platatsvinden, maar alleen inet het oog op een verduidelijking of aanvulling van de inhoud van hun offerte, alsmede van de eisen van de aanbestedende diensten, en voorzover zulks geen discriminatie veroorzaakt'.

Dit sluit aan op het bepaalde in $\$ 24 \mathrm{VOB} / \mathrm{A}, \mathrm{nr}$. 1, Absatz 1. Daar wordt bepaald dat in een limitatief aantal gevallen onderhandelingen met de aannemer mogelijk zijn ná opening der offerte en voorafgaand aan de gunning. Deze onderhandelingen kunnen uitsluitend plaatsvinden binnen het enge kader van een reeds vaststaande rechtsverhouding en mogen niet ten doel hebben om 'den feststehenden Sachverhalt zu ändern' ${ }^{99}$. Het gaat dan om onderhandelingen in verband met het nader onderzoeken van de geschiktheid van de inschrijver of ter opheldering van onduidelijkheden (bij prestatiebestekken). Bij alternatieve aanbiedingen kan het nog gaan om vast te stellen waar bepaalde bouwstoffen c.g. bouwonderdelen vandaan komen (in verband met daaraan te stellen kwaliteitseisen) ${ }^{100}$ of om meer inzicht te krijgen in de gemaakte berekeningen.

- Het openBaARHEIDSBEgINSEL. De aan de inschrijvers of gegadigden te stellen eisen dienen in de aankondiging, de bekendmaking of het bestek te worden vermeld (artikelen 9, 10 en 61 en Model B). Ook eventuele andere gunningscriteria dan dat van de laagste prijs moeten in de aankondiging, de bekendmaking of het bestek worden vermeld (artikel 11, lid 2 UAR-EG 1991). Het bepaalde over het bestek komt grotendeels overeen met het bepaalde in artikel 7 UAR 1986. Er zijn twee leden aan toegevoegd: in artikel 10, leden 5 en 6 is uitwerking gegeven aan het sociaal amendement in artikel 22bis richtlijn 89/440. Hierdoor wordt bereikt dat de inschrijvers op de hoogte (kunnen) zijn van de wettelijke regelingen ter zake van de arbeidsvoorwaarden en arbeidsbescherming die gelden op de bouwplek.

De aankondiging dient zo spoedig mogelijk en langs de meest passende kanalen te worden toegezonden aan het Bureau voor officiële publikaties van de Europese Gemeenschappen. Dit Bureau draagt er zorg voor dat de aankondiging uiterlijk 12 dagen na toezending in extenso in de Nederlandse taal in het EG-Publikatieblad en via de TED-databank bekend wordt gemaakt. De aanbesteder moet verder de gegevens, zoals vermeld in de aankondi-

\footnotetext{
m) Ingenstau - Kurbion (1989), \$24 VOB/A, rdn $15 \mathrm{v}$.

110 Zoals in RvA 29 juni 1988, nr. 13.092, BR 1989, 862.
} 
ging, in de Nederlandse Staatscourant of in een Nederlands vakblad bekend maken. Deze bekendmaking mag niet plaatsvinden vóór de verzending van de aankondiging. Artikel 61 bepaalt in dit verband dat deze bekendmaking uiterlijk binnen vier dagen na de datum van verzending dient plaats te vinden. Het behoeft geen betoog dat de nationale bekendmaking geen andere gegevens mag bevatten dan die welke verschijnen in het EG-Publikatieblad. Voor de procedure met voorafgaande selectie wordt de wijze van bekendmaking van de aankondiging geregeld in artikel 35 . Wat betreft de onderhandelingsprocedure met voorafgaande bekendmaking wordt deze bekendmaking geregeld in artikel 42 .

Een novum is de introductie van de voorinformatieprocedure bij de openbare aanbesteding en de aanbesteding met voorafgaande selectie. De aanbesteder dient van zijn jaarlijkse bouwvoornemen, waarvan de geschatte bouwsom meer dan 5 miljoen ECU bedraagt, zo snel mogelijk nadat deze zijn goedgekeurd via een aankondiging van de hoofdkenmerken daarvan mededeling te doen aan het Bureau voor officiële publikaties der Europese Gemeenschappen in Luxemburg. Dit Bureau draagt dan de zorg voor de verdere bekendmaking. De aanbesteder moet ervoor zorgen dat deze vooraankondiging ook bekend wordt gemaakt in de Nederlandse Staatscourant of in een landelijk verspreid vakblad, zij het dat deze bekendmaking niet vóór de datum van verzending van de vooraankondiging aan het Bureau voor officiële publikaties mag plaatsvinden. Hiermee wordt voorkomen dat de aankondiging op het nationale niveau eerder plaatsvindt dan op het Europese, hetgeen strijdig zou zijn met het gelijkheidsbeginsel. Alsdan kunnen in geval van een openbare aanbesteding of een aanbesteding met voorafgaande selectie de termijnen voor aanbesteding (respectievelijk 52 en 40 dagen) worden verkort tot ten minste 36 c.q. 26 dagen (artikel 9, lid 2 en 38, lid 1). Deze termijnen zijn niet gerelateerd aan het tijdstip van bekendmaking, maar aan de datum van verzending van de aankondiging.

Anders dan de richtlijn, die daaromtrent geen regeling bevat, kent artikel 16 UAR-EG 1991 een met artikel 9, lid 3 UAR 1986 overeenkomstige bepaling. Volgens artikel 16, lid 3 UAR-EG 1991 liggen de nota van inlichtingen en het p.v. van aanwijzing gedurende ten minste 7 dagen voorafgaand aan de aanbesteding ter inzage. Deze termijn kan worden verlengd: artikel 16, lid 4 UAR-EG 1991. Bovendien dienen deze stukken tegen betaling verkrijgbaar te zijn.

\section{Conclusie}

De aan het begin van dit hoofdstuk gestelde vraag is: komt het primaat van de openbare aanbesteding, waarbij een ieder kan inschrijven, tot uitdrukking in deze aanbestedingsreglementen. Gelet op het voorafgaande moet worden geconstateerd dat de reglementering uitgaat van de openbare aanbesteding(sprocedure). De vraag is wat de betekenis daarvan is, zolang de gemeente de vrijheid wordt gelaten voor een andere procedure te kiezen. Daarover houden de UAR-en echter geen bepaling in. Daarmee heeft de in het vorige hoofdstuk vermelde hartekreet van Spier alleen nog maar aan betekenis gewonnen. Met het weglaten van een expliciete grondslag voor het uitgangspunt van de openbare aanbesteding in de Gemeentewet 1994 laat de wetgever ten onrechte na duidelijk aan te geven 'hoe' er moet worden aanbesteed. Die keuze wordt overgelaten aan de gemeentebesturen. Zij kunnen - in hun precontractuele verhoudingen met de inschrijvers - vrijelijk gebruik maken van die UAR-procedure die hun - als marktpartij - het beste uitkomt. 


\subsection{De Europese richtlijnen}

\section{Liberalisatierichtlijn 71/304}

Op het gebied van de overheidsaanbesteding zijn in het verleden een tweetal richtlijnen vastgesteld: een liberalisatierichtlijn (71/304) en een coördinatierichtlijn (71/305). Het doel van de liberalisatierichtlijn is de opheffing van de beperkingen van het verrichten van diensten op het gebied van overheidsopdrachten voor de uitvoering van werken. Het breekijzer om dergelijke beperkingen te lijf te gaan wordt gevormd door het verbod om aannemers te discrimineren op basis van nationaliteit (artikel 1). Artikel 2 richtlijn 71/304 noemt in het tweede lid een aantal werkzaamheden, die niet onder de werking van de richtlijn vallen. In artikel 3 wordt het non-discriminatiebeginsel verder uitgewerkt. Artikel 3, lid 1 . sub $c$ richtlijn $71 / 304$ breidt de werking van de richtlijn bovendien nog uit naar die gevallen waarin er geen sprake is van onderscheid naar nationaliteit (de 'zonder onderscheid'-maatregelen). Bepaald wordt dat de beperkingen moeten worden opgeheven, welke voortvloeien uit bepalingen of praktijken die, hoewel van toepassing zonder onderscheid naar nationaliteit, niettemin uitsluitend of in hoofdzaak de beroepswerkzaamheid van de onderdanen van de andere lidstaten belemmeren. Technische specificaties die een discriminerende werking hebben behoren met name tot de op te heffen beperkingen. Deze specificaties worden echter niet geacht discriminatoir te werken wanneer zij door het voorwerp van de opdracht worden gerechtvaardigd. Niet discriminerende technische specificaties zouden bij de aankoop van bouwmaterialen, machines of ander materiaal daarom in acht moeten worden genomen, voor zover zij geen verkapte beperking van de handel tussen de lidstaten vormen ${ }^{101}$.

\section{Coördinatierichtlijn 71/305}

Op het communautaire vlak wordt het nationale aanbestedingsbeleid der lidstaten gecoördineerd, voorzover dat is gericht op de optimalisering van de prijs/ kwaliteitverhouding, door de harmonisatie van de nationale aanbestedingsprocedures op basis van de non-discriminatiebeginsel en het openbaarheidsbeginsel. Het eerste ontwerp van een coördinatierichtlijn werd reeds in 1964 door de Commissie bij de Raad ingediend. In 1966 102 vond de indiening van het definitieve voorstel plaats. Door de ingewikkeldheid van de materie duurde het nog tot 1971, eer, na eenparige besluitvorming, richtlijn $71 / 305^{103}$ werd vastgesteld.

Door verbetering van de informatievoorziening (transparantie) zou de doelmatigheid van de aanbesteding kunnen worden vergroot. De richtlijn kende daartoe twee procedures. De openbare procedure (O.P.) waarbij alle belanghebbenden konden inschrijven. En de nietopenbare procedure (N.O.P.) waarbij alleen de door de overheid toegelaten belanghebbenden mochten inschrijven ${ }^{104}$. Overheden dienden hun opdrachten te plaatsen op voet van nationale procedures, die aan deze richtlijnprocedures moesten zijn aangepast, zij het dat de in de

\footnotetext{
tol In die zin Verloren van Themaat (1975), 265. Zie verder het antwoord van de minister van Economische Zaken op vtagen van het Kamerlid Vredeling, Aanhangsel Hand. II, 1971- 1972, 1007.

100 Ik herinner eraan dat in dat jaar onder verwijzing naar deze Europese regelgeving het preventieve toezicht op de onderhandse aanbesteding werd afgeschaft. Zie uitvoeriger Hoofdstuk 2.

103 Zie artikelen 100, 101 en 102 EG over de wijze van besluitvorming. Richtlijn van de Raad 71/305, 26 juli 1971 , $\mathrm{Pb} 1971$, d.d. 16 augustus 1971, L 185/1 v. Zie over de totstandkoming Van Agtmaal (1970), 796-799.

${ }^{104}$ Art. 5 richtlijn 71/305.
} 
lidstaten bestaande procedures en praktijken zoveel mogelijk werden gerespecteerd ${ }^{105}$. Richtlijn 71/305 beperkte deze doelstelling overigens tot opdrachten met een geraamde bouwsom (inclusief directieleveringen en exclusief BTW) van meer dan 1 miljoen ECU en behoudens de gevallen genoemd in artikel 9 van de richtlijn ${ }^{106}$. De richtlijn was evenmin van toepassing op overheidsopdrachten voor de uitvoering van werken die werden geplaatst door publiekrechtelijke lichamen die vervoersdiensten beheren en opdrachten door diensten voor de produktie, de distributie en het vervoer van water en energie (artikel 3, leden 4 en 5): de zogeheten uitgesloten sectoren. De vrijstellingen van de richtlijn waren daarin uitputtend geregeld ${ }^{107}$.

Wat betreft de verhouding tot de leveringen-richtlijn ${ }^{108}$ : in grensgevallen waar het voor de uitvoering van werken noodzakelijk is om bepaalde guederen aan te schaffen, zal gekeken moeten worden naar de relatieve verhoudingen tussen de waarde van de diensten en produkten om uit te maken welke richtlijn van toepassing is. Als de overheidsopdracht slechts, een bijkomstig karakter heeft ten opzichte van andere aspecten van de overeenkomst, dan is de werkenrichtlijn niet van toepassing ${ }^{10 s}$. En, ook al is een overheidsopdracht voor de uitvoering van werken als een dienst aan te merken, het daarbij aan te wenden materiaal valt onder het bereik van artikel $30 \mathrm{EG}^{110}$.

De coördinatie werd, volgens de Preambule - die daarvoor verwijst naar de Algemene Programma's - nagestreefd door de invoering van algemene voorschriften op basis van de volgende beginselen:

- het verbod van technische specificaties met een discriminerende werking. Dit werd uitgewerkt in de artikelen 10 en 11 van de richtlijn op basis van het gelijkheidsbeginsel $^{111}$. Deze bepalingen sluiten aan bij de volgens artikel 3 , lid 1 , onder $c$ richtlijn $71 / 304$ (liberalisatierichtlijn) op te heffen beperkingen. Een afwijkende methode voor de berekening van het werk mocht op zichzelf geen reden vormen om ingediende ontwerpen of varianten te verwerpen. De inschrijver moest dan wel alle bewijsstukken bijvoegen, die nodig waren voor de verificatie van het project, en elke nadere toelichting verschaffen, die door de aanbesteder noodzakelijk werd geacht (artikel 11);

- een voldoende bekendmaking van de opdrachten op basis van het openbaarheidsbeginsel. Deze bekendmaking werd uitgewerkt in Titel III (artikelen 12-19) van de richtlijn over de gemeenschappelijke regels voor de bekendmaking;

- het opstellen van objectieve deelnemingscriteria. Daarbij speelde het economisch doelmatigheidsbeginsel een centrale rol. De bepalingen inzake selectie en gunning werden uitgewerkt in de artikelen 20-29 van de richtlijn (waarover hierna: hoofdstuk vier).

- het vereiste van een procedure, waardoor op de inachtneming van deze beginselen gemeenschappelijk toezicht kan worden uitgeoefend. Deze eis is reeds aan de orde geweest in het eerste hoofdstuk (in verband met richtlijn 89/665) en blijft hierna verder buiten be-

105 Preambule en art. 2 richtlijn 71/305.

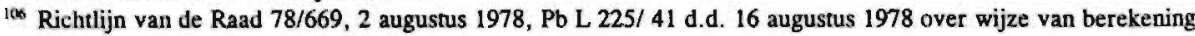
en de bekendmaking van de ECU.

107 Zaak C-71/92, r.o. 24, 37, 42, 46, 50, 52 en 59 (Commissie v. Spanje), PPLRev. 1994, CS73 (Jose M. Fernàndez Martin).

105 Richtlijn 93/36, Pb 9 augustus 1993, nr. L. 199/54 v.

109 Vgl, zaak $331 / 92$ (Gestión Hotelera Internacional SA v. Communidad Autónoma de Canarias c.s.). Vgl. PPL.Rev. 1994, CS200 (Jose M. Fermandez Marin).

${ }^{110}$ Zaak 45/87, r.o. 17 (Dundalk).

111 Bijlage II richtlijn 71/305. 
schouwing. Opvallend is wel dat het tot 1989 heeft geduurd vooraleer er een dergelijke handhavingsrichtlijn afgekondigd werd.

Evenals bij de nationale aanbestedingsreglementen liggen ook aan de coördinatierichtlijn een aantal beginselen ten grondslag. Ik behandel hierna kort het beginsel van non-discriminatie naar nationaliteit en het openbaarheidsbeginsel.

- HET BEgINSEl VAN NON-DISCRIMINATIE NAAR NATIONALITEIT. Het beginsel van nondiscriminatie naar nationaliteit is een herhaling van datzelfde beginsel in de liberalisatierichtlijn. Door de rechtstreekse werking van artikel 6 EG geldt het non-disrciminatiebeginsel overigens ongeacht de aanbestedingssom. Het beginsel vereist dat alle inschrijvingen moeten overeenkomen met de voorwaarden en omschrijvingen zoals neergelegd in de aanbestedingsdocumenten, zodat een objectieve vergelijking mogelijk wordt. Voorbehouden en wijzigingen van de algemene voorwaarden zijn alleen mogelijk als die voorwaarden dat zelf toestaan ${ }^{112}$. Het beginsel moet er aldus toe leiden dat alle gegadigden gelijke kansen hebben op de inschrijving ongeacht hun nationaliteit. Deze kansengelijkheid werd onder meer gewaarborgd door de termijnen voor de inzending van de offertes ruim en voor iedere aannemer gelijk te houden en door de eis gegadigden gelijktijdig uit te nodigen tot het doen van een inschrijving (artikelen 13 en 14 richtlijn 71/305). Wanneer het in dringende gevallen onmogelijk was de termijnen van artikel 14 (voor de niet openbare procedure) in acht te nemen, kon de overheidsaanbesteder ook de verkorte termijnen zoals bedoeld in artikel 15 toepassen. Daarnaast werd gelijke behandeling van ondernemingen uit de lidstaten gewaarborgd doordat elke lidstaat er zorg voor droeg dat de aanbestedende overheid zich onder dezelfde voorwaarden als zij aan de nationale gegadigden stelden wendden tot ondernemingen van de overige lidstaten, die aan de vereisten voldeden. En voorts doordat de selectie plaatsvond op grond van objectieve gegevens (artikelen 22, 2e alinea en 23 en volgende richtlijn 71/305). Één van de zaken die een Nederlandse aanbestedende overheid kon eisen was dat de aannemer aantoonde dat hij was ingeschreven in het beroepsregister volgens de eisen van het land van de Gemeenschap waar hij gevestigd is (artikel 24). De richtlijn bevatte verder voorschriften inzake technische specificaties (artikelen 10 en 11), waaronder het verbod van specificaties met een discriminerende werking. Deze technische voorschriften waren overigens niet in de eerste plaats gericht aan de overheden, maar aan het bouwbedrijfsleven. Voor de overheid had de regeling onder meer tot gevolg dat zij in het bestek geen bepaald fabrikaat mocht voorschrijven maar uitsluitend een kwaliteitsaanduiding ${ }^{113}$.

$" 12$ Zaak C-243/89, r.o. 40 (Commissie v. Denemarken) in verband met het Storebaelt-bruggencomplex. Vgl. Wedekind (1990 b), 14-17, Pijnacker Hordijk - Bel (1994), 656-657 en Martin (1993 b), CS153.

${ }^{11} \mathrm{Zie}$ art. 10, lid 2 richtijn $71 / 305$. De vraag of het voorschrijven van het fabrikaat $\mathrm{X}$ moet worden gezien als een kwaliteitsaanduiding, danwel een met artikel 10, lid 2 richtiijn 71/305 strijdige eis, vormt de inzet van de rechtstrijd tussen de gemeente Meerssen en Kunicon. Men zie Rb.Maastricht 24 december 1987, BR 1988, 389 v. met vervolg in Hof Den Bosch 26 november 1990, BR 1991, 641. Zie over deze problematiek in samenhang met art. 30 EG: zaak 45/87 (Dundalk). 
- HET OPENBAARHEIDSBEgINSEL. In de preambule van richtlijn 71/305 wordt over het openbaarheidsbeginsel opgemerkt, dat het:

'voor de ontwikkeling van een daadwerkelijke mededinging op het gebied van overheidsopdrachten noodzakelijk is (...) dat de door de aanbestedende diensten van de Lid-Staten opgestelde aankondigingen op communautair niveau bekend worden gemaakt; dat het doel van de in deze aankondigingen voorkomende inlichtingen is de aannemers van de Gemeenschap in staat te stellen uit te maken of de voorgenomen opdrachten voor ben van belang zijn; dat zij ten dien einde voldoende ingelicht dienen te worden over de te leveren prestaties en de bijbehorende voorwaarden; dat in het bijzonder in de niet-openbare procedure de bekendmaking ten doel heeft aan de ondernemers van de Lid-Staten de mogelijkheid te verschaffen hun belangstelling te tonen voor deze opdrachten, door de aanbestedende diensten te verzoeken hen uit te nodigen voor een inschrijving onder de vereiste voorwaarden".

Uitgangspunt voor de bekendmaking was dat voor alle aanbestedingen waarop deze richtlijn van toepassing was, gold dat zij moesten worden aangekondigd in het (Supplement van het) Publikatieblad van de Europese Gemeenschappen ${ }^{114}$. In het geval van een nietopenbare procedure diende een aankondiging te worden geplaatst, waarin gegadigden, die aan bepaalde in de aankondiging omschreven eisen moesten voldoen, werden opgeroepen zich te melden. Was de richtlijn niet van toepassing, maar werd er toch gepubliceerd, dan betekende zulks volgens het Hof niet dat dan de richtlijn wel van toepassing zou worden ${ }^{115}$.

De bekendmaking op nationaal niveau in de Nederlandse Staatscourant en de gespecialiseerde pers mocht niet voor de datum van verzending van de aankondiging genoemd in artikel 12, lid 4 richtlijn 71/305 plaatsvinden en diende deze datum te vermelden. De aankondiging op nationaal niveau mocht bovendien geen andere - extra - informatie bevatten. De aanbestedende overheidsdiensten moesten de datum van verzending kunnen aantonen (artikel 12, vijfde alinea). De achtergrond van deze regeling was evident: het gelijkheidsbeginsel mocht niet in gevaar komen, doordat aannemers uit derde-lidstaten pas later van een aanbesteding op de hoogte konden zijn. Het openbaarheidsbeginsel was daarnaast uitgewerkt in de regeling inzake de aanvullende inlichtingen. De preambule merkte daarover op, dat deze inlichtingen - nadat de bekendmaking dus reeds had plaatsgehad - inzake de opdracht, zoals in de lidstaten gebruikelijk was, in het bestek voor elke opdracht of in enig ander gelijkwaardig document moesten voorkomen. Wat in de aankondiging moest staan bleek uit de artikelen 16 (O.P.) en 17 (N.O.P.) van de richtlijn. De uitnodiging tot inschrijving bevatte de gegevens bedoeld in artikel 18 (N.O.P.). Wanneer het in dringende gevallen onmogelijk was deze aankondiging te doen, dan kon worden volstaan met het

${ }^{14}$ Cf. arte, $12 \mathrm{vm} 19$ richtlijn 71/305. Verder richtlijn 72/277 (richtlijn van 26 juli 1972, Pb 3 augustus 1972 , nr. L 176/12) waarin nadere voorschriften met betrekking tot de wijze van bekendmaking van de aankondigingen van overheidsopdrachten voor de uirvoering van werken in het EG-Publikatieblad. In de bijlage van deze richtlijn waren aankondigingsmodellen opgenomen. De publikatierichtijn werd per circulaire onder de aandacht der gemeenten gebracht (circulaire nr. F.V.73/U 116 van 19 februari 1973). Zie ook Aanbeveling van de Commissie van 24 oktober 1991 inzake de standaardisatie van de bekendmakingen van overheidsopdrachten $(91 / 561, \mathrm{~Pb} 6$ nov. 1991, L 305/19. Als gevolg van het in werking treden van de wijzigingsrichtlijn $89 / 440$ werd richtlijn $72 / 277$ ingetrokken.

${ }^{115}$ Zaak 45/87, r.o. 10 (Dundalk). De Europese Commissie had dit anders gezien. Zie Gormley (1992), 86. In lijn met deze uitspraak is zaak C-87/94-R (Commissie v. België), waarover kritisch Pijnacker Hordijk - Bel (1994), 662. 
bekendmaken van de aankondiging in de oorspronkelijke taal in de vier uitgaven van het EG-Publikatieblad (de zgn. versnelde procedure van artikel 15 richtlijn 71/305).

Zoals hiervoor al bleek vormen het gelijkheids- en het openbaarheidsbeginsel twee zijden van eenzelfde munt: het gelijke kansenbeginsel. Richtlijn 71/305 beperkte de beleidsvrijheid van de lidstaten om de enkelvoudige procedure te gebruiken tot de uitputtende lijst van artikel 9. Dit artikel maakt duidelijk dat de richtlijn een afweging maakt tussen het belang van mededinging en een nader te duiden algemeen belang. In bijzondere gevallen kan, gelet op het daarbij betrokken algemene belang, een beperking plaatsvinden van het gelijke kansenbeginsel.

\section{Inbreuken op de publiciteitseis}

De eisen die de richtlijn stelde aan de bekendmaking van overheidsaanbestedingen werden niet steeds nageleefd. In dit verband mocht met name artikel 9 , sub d richtlijn 71/305 zich in een grote populariteit verheugen. Bepaald wordt dat een overheidsopdracht kan worden geplaatst zonder de bepalingen van deze richtlijn toe te passen (met uitzondering van artikel 10 over de technische specificaties)

'in strikt noodzakelijke gevallen waarin de bij de uitvoering van een werk te betrachten dringende spoed, voortvloeiende uit voor de aanbestedende diensten onvoorziene gebeurtenissen, onverenigbaar is met de inachtneming van de termijnen behorende bij andere procedures'.

Uit de jurisprudentie van het Europese Hof van Justitie met betrekking tot artikel 9, sub d richtlijn $71 / 305$ valt het volgende strenge beoordelingsmodel af te leiden ${ }^{116}$.

1. Afwijkingen van de richtlijn moeten strikt worden geïnterpreteerd (zaken 199/85 en C24/91). Het wekt dan ook geen verbazing dat een beroep op artikel 9 richlijn 71/305 weinig kans van slagen bood.

2. Ten bewijze van de spoedeisendheid dient de lidstaat alle eisen die artikel 9 , sub d richtlijn 71/305 stelde, aan te tonen (zie ook reeds zaak 199/85). Deze drie, cumulatieve, eisen zijn:

a. onvoorziene omstandigheden (reeds zaak C-24/91);

b. dringende spoed welke onverenigbaar is met de in het kader van andere procedures gestelde termijnen (reeds zaak C-24/91).

c. causaliteit tussen beiden (zaak C-107/92, r.o. 12).

Een voorbeeld van een dergelijke toets is 's Hofs oordeel in zaak C-24/91"17?. Het College van Bestuur van de Universidad Complutense te Madrid had besloten tot de uitvoering van werkzaamheden in verband met de

116 Zaak 199/85 (Commissie v. Italië) had betrekking op zowel art. 9, sub b als suh d. Verder zaak 194/88-R (Commissie v. Italiê, cok La Spezia); zaak C-24/91 (Conmissie v. Spanje). Vgl. Pijnacker Hordijk - Bel (1993), 691 v. Voorts PPLRev. 1992, 320 (Martin); zaak C-107/92 (Commissie v. Italie). Vgl. Pijnacker Hordijk - Be! (1994), 657. En PPLRev. 1994, CS13 (Martin). Zaak C-296/92 (Commissie v. Italie) stuitte af op de nictonrvankelijkheid van de Europese Commissie.

117 Zaak C-24/91 (Commissie v. Spanje). Vgl. Pijnacker Hordijk - Bel (1993), 691 v. Voorts PPLRev. 1992, 320 (Martin). 


\section{Hoofdstuk 3}

uitbreiding en verbotuwing, van de Faculteit Politieke Wetenschappen en Sociologie en de School voor Maatschappelijk werk. De universiteit had nagelaten zen aankondiging te doen in het Publikatieblad, terwijl het om een bedrag van ruim Ptas 430 miljoen (ongeveer 3 miljoen ECU) ging. Gedaagd voor hei Hof beriep Spanje zich op de spoedeisendheid vun de te verrichten werkzaamheden (artikel 9, sub d richuijn 71/305), die erin bestond dat de universiteit het noodzakelijk achtte dat de werkzaamheden voor het begin van het nieuwe academische jaar werden beëindigd. Gunning vond onderhands plats. Het Hof oordeelde dat de universiteit volgens de verkorte procedure van artikel 15 had kunnen aanbesteden zonder in tijdnood te geraken. Het grociend aantal studenten was een probleem dat al jaren bestond zodat de komst van een nieuwe lichting studenten in oktober 1989 niet kan worden gezien als een onvoorziene gebeurtenis die een geval van dringende spoed ex art. 9, sub d oplevert (r.o. 10).

Een soortgelijke beslissing volgde in zaak C-107/92:18. Op 18 juni 1988 deed het 'Office du génie civil de Bolzano', een uitvoeringsinstantie van het Ministerie van Openbare Werken, een aanhesteding voor de ontwikkeling van een lawineval in de gemeente Colle Isarco/ Brennero en meer in het bijzonder in de regio Alpe Gallina (Hühnerspiel). De werken, met een waarde 10,5 miljard LIT (ongeveer 7 miljoen ECU), werden uitgevoerd in het kader van het beleid ter bescherming tegen lawinegevaar in de regio sinds in 1975 vier mensen omkwamen door etn lawine. Het werk werd gegund aan de Italiaanse onderneming Colline e Rabbiosi SpA. Deze aanbesteding was niet bekendgemaakt via het Publikatieblad, waarvoor Italie zich beriep op de spoedeisendheid van het project. De Europese Commissie wees er op dat het lawinegevaar al sinds 1975 bekend was. Italie had daarom, net als in zaak C-24/91, de versnelde procedure van artikel 15 richtijn $71 / 305$ kunnen volgen. En ook de Advocaat-Generaal Gulmann ging nauwgezet de chronologie der gebeurtenissen na. Het Hof nam de conclusies van Gulmann over: Italie is niet geslaagd in het bewijs dat er sprake was van dringende spoed nu niet was komen vast te staan dat het niet mogelijk was geweest de versnelde procedure toe te passen (r.o. 13 en 14). De beide andere eisen werden niet onderzocht, waaruit kan worden afgeleid dat er kennelijk geen volgorde tussen de drie vereisten bestaat.

3. De lidstaat die zich op de afwijking beroept zal moeten bewijzen dat de uitzonderlijke omstandigheden die een afwijking rechtvaardigen daadwerkelijk bestaan. In dit verband wordt steeds nauwkeurig de chronologie der feiten nagegaan. Op zichzelf zwaarwegende belangen (zoals volksgezondheid, milieu, onderwijs, bescherming tegen lawinegevaar) die zijn ontstaan doordat de lidstaat zelf de spoedeisendheid van de desbetreffende situatie heeft veroorzaakt worden niet (snel ${ }^{119}$ ) gehonoreerd. Slaagt de lidstaat niet in het bewijs, dan wordt de publikatiefout toegerekend aan de Staat.

Deze rechtspraak overziende kan gesproken worden van een consistente lijn. Een lidstaat kan geen beroep doen op 'dringende spoed' als uit de chronologie der feiten blijkt dat de versnelde procedure van artikel 15 richtlijn 71/305 had kunnen worden gebruikt. Daarbij geeft het Hof geen theoretische beschouwingen over onvoorzienbaarheid of over extreme spoed, maar kiest het Hof voor een praktische oplossing ${ }^{120}$. Artikel 9, sub d is bij de wijziging van richtlijn 71/305 vervangen door een in essentie gelijkluidend artikel 7 , lid 3 , sub c richtlijn 93/37. Aangenomen mag worden dat de jurisprudentie inzake arikel 9, sub d richtlijn 71/305 (oud) onverkort van toepassing zal zijn op het nieuwe artikel ${ }^{121}$.

${ }^{118}$ Zaak C-107/92 (Commissie v. Italië). Vgl. Pijnacker Hordijk - Bel (1994), 657.

119 Zie zaak 45/87-R, 1369 (Dundalk) dat wat meer ruimte lijkt te bieden. De President kwam tot het oordeel dat hoewel art. $30 \mathrm{EC}$ was geschonden, de spoed warmee het waterleidingnet moest worden vervangen, gelet op de veiligheid en gezondheid van de gebruikers, onverenigbaar was met de door de Europese Commissie gevraagde schorsing van de aanbestedingsprocedure. Volgens D.J. Keur (SEW 1990, 30) staat daarmee de deur op een kier om het EG-Verdrag te overtreden.

13i In die zin PPLRev 1994, CS13 (José Maria Femandez Martin).

121 In die zin Pijnacker Hordijk - Bel (1993), 691 


\section{Wijziging van de richtlijn}

In het eerste hoofdstuk bleek al dat de coördinatierichtlijn niet het gewenste effect had, en dat in het kader van de interne marktdoelstelling een wijziging van de richtlijn werd voorgenomen $^{122}$. De gewijzigde richtlijn is gebaseerd op de eveneens gewijzigde artikelen 57, lid 2 en artikel 66 en het nieuwe artikel 100A van het EG-verdrag. Op 21 juli 1989 verscheen richtlijn $89 / 440^{123}$ in het EG-Publikatieblad.

Deze (wijzigings)richtlijn $89 / 440$ beoogt de in de praktijk geconstateerde tekortkomingen van richtlijn $71 / 305$ te redresseren. Inmiddels zijn deze wijzigingen geconsolideerd in richtlijn $93 / 37$. Uitgangspunt van de gewijzigde richtlijn is de uitbreiding van het toepassingsgebied van de richtlijn (artikel 1, sub a richtlijn 93/37). Niet alleen het eigenlijke bouwen, maar ook daarmee samenhangende activiteiten, zoals het ontwerp, de financiering en het management vallen voortaan onder haar bereik. De financiële ('Europese') drempel voor de toepassing van de richtlijn is opgetrokken tot aanbestedingen met een geraamde bouwsom van meer dan 5 miljoen $\mathrm{ECU}^{124}$. De betekenis van deze drempelverhoging moet overigens niet worden overtrokken. $\mathrm{Zij}$ is deels het gevolg van de inflatie sinds 1971 en de daarmee samenhangende verhoging van de bouwkosten en bovendien is het toepassingsgebied ruimer, doordat er meer contractsvormen onder het aanbestedingsbegrip vallen dan voorheen. De verhoging wordt daarnaast gerechtvaardigd met een beroep op het belang dat het midden- en kleinbedrijf erbij heeft om aan opdrachten van middelgrote omvang te kunnen deelnemen ${ }^{125}$. Een voorbeeld daarvan is artikel 17 richtlijn 93/37. Dit artikel laat de mogelijkheid open dat de aanbesteder ook aankondigingen plaatst in het Publikatieblad, waarvoor de bekendmaking niet verplicht is voorgeschreven. Nieuw daarbij is dat de ondergrens van 500.000 ECU (ex BTW) is weggelaten, met de bedoeling om de aanbestedingen toegankelijker te maken voor het middenen kleinbedrijf ${ }^{126}$.

Uit de preambule blijkt de hoofdopzet van de wijziging van richtlijn 71/305: het verbeteren van de waarborgen in de richtlijnen inzake de doorzichtigheid van de procedures ${ }^{127}$ en praktijken voor de uitvoering van werken en het aanscherpen c.q. uitbreiden van de bestaande verplichtingen teneinde een beter toezicht te kunnen uitoefenen op de naleving van het verbod op beperkingen en het tegelijkertijd verminderen van de onderlinge verschillen in de

\footnotetext{
123 Het begrip 'interne markt' wordt omschreven in art. 7A, tweede alinea EG.

123 Richtlijn van de Raad 89/440, 18 juli 1989 tot wijziging van richtlijn 71/305, Pb 1989, d.d. 21 juli 1989, L $210 / 1$ v. Zie voor een overvloedige bronvermelding Wedekind (1990 a), 812-813.

124 Art. 6, lid 1 richtlijn 93/37. Het gaat hier om bet geraamde bedrag inclusief directieleveringen en exclusief BTW. De tegenwaarde wordt tweejaarlijks herzien, te rekenen vanaf 1 januari 1992, en in november bekendgemaakt in het Publikatieblad van de EG (art. 6, lid 2.a richtlijn 93/37).

125 Preambule richtlijn 89/440. Het 'MKB-argument' lijkt juist te wijzen op een lage(re) drempel: dan is de deelname van het midden- en kleinbedrijf bij overheidsopdrachten immers het best verzekerd. De 'rechtvaardiging' waarvan in de preambule sprake is, moet daarom naar alle waarschijnlijkheid worden gezocht in het feit dat de verhoging omwille van dit 'MKB-belang' beperkt is gehouden. Vergelijk wat dit betreft het eerdere voorstel om de drempel te verhogen tot 7 miljoen ECU (COM(86) 679 def., 23 december 1986).

${ }_{126}$ Toelichting in COM (86) 679 def., 12. Zie over dit wijzigingsvoorstel Van Nouhuys (1987), 416-420. Zie voor het MKB-beleid COM (89) 400 def., C 311/14-16.

${ }^{127}$ Art. 2 richtlijn 71/305 bepaalde dat de aanbestedende diensten aan de richtijn aangepaste nationale procedures zouden toepassen. Dit artikel is vervallen in de gewijzigde richtijn. Art. 7 richtlijn 93/37 verklaart thans de in art. 1, sub e, $\mathrm{f}$ en g genoemde procedures van toepassing.
} 
mededingingsvoorwaarden tussen de onderdanen van de lidstaten ${ }^{128}$. Dit wordt noodzakelijk geacht voor de verwezenlijking van een daadwerkelijke vrijheid van vestiging alsook voor het vrij verrichten van diensten op het gebied van de overheidsopdrachten voor de uitvoering van werken ${ }^{129}$. De verbetering van de doorzichtigheid komt met name tot uitdrukking in de bepalingen betreffende de uitbreiding van de werkingssfeer van de richtiijn, in verbeteringen van de toegankelijkheid van de aanbestedingsprocedures (waaronder de voorinformatieprocedure en de verlenging van diverse termijnen) en in extra mogelijkheden tot het doen van voorstellen voor ontwerpvarianten (artikel 19 richtlijn 93/37). Uit de laatstgenoemde aanscherping blijkt dat de richtlijn tevens is gericht op het stimuleren van projecten waardoor de overdracht van technologieën en know how tussen de lidstaten mogelijk wordt, hetgeen, volgens de Preambule, niet alleen ten goede komt aan de gezamenlijke gebruikers, maar ook van de bedrijfstak als zodanig. Overwogen werd dat het in het algemeen belang is om de technische vooruitgang in de bouwsector en de sector openbare werken aan te moedigen. In dit verband verdient vermelding dat de richtlijn thans het primaat van de Europese (technische) norm introduceert ${ }^{130}$. Verwacht wordt dat dit innoverend $z a l$ werken waardoor de kwaliteit van de bouwwerken zal toenemen, met een gelijktijdige daling van de kostprijs.

De uitbreiding van de verplichtingen moet vooral worden gezocht in bepalingen over de beperking van het aantal uitzonderingsgevallen ex artikel 9 (oud) richtlijn 71/305 en het daarvoor in de plaats treden van twee onderhandelingsprocedures (artikel 7, lid 2 en 3 richtlijn $93 / 37^{131}$ ) en in de introductie van diverse motiveringsverplichtingen van de aanbesteder en de inschrijvers (waarover in hoofdstuk 4). Bovendien dient de aanbesteder er zorg voor te dragen dat de richtlijn ook toepassing vindt in het geval dat hij rechtstreeks aan aanbestedende derden voor meer dan 50\% subsidie verstrekt. Volgens artikel 2, lid 2 richtlijn 93/37 is dit voorschrift overigens beperkt tot een bepaald type opdrachten ${ }^{132}$.

12a Vergelijk wat dit betreft artikel 22, lid 4 richtlijn 93/37: 'Elke Lid-Staat draagt er zorg voor dat de aanbestedende diensten zich zonder discriminatie en onder dezelfde voorwaarden als die welke zij voor hun eigen onderdanen stellen, tot aannemers van de andere Lid-Staten wenden die aan de vereisten voldoen'. Ook reeds art. 22, lid 2 richtlijn $71 / 305$.

15. Overheidsopdrachten in de 'uitgesloten sectoren' zijn inmiddels afzonderlijk geregeld in Richuijn 93/38, Ricbtlijn van de Raad van 14 juni 1993 betreffende de procedures voor het plaatsen van opdrachten in de sectoren wateren energievoorziening, vervoer en telecommunicatie, $\mathrm{Pb} \mathrm{L} \mathrm{199/84).} \mathrm{Tot} \mathrm{de} \mathrm{totstandkoming} \mathrm{van} \mathrm{de} \mathrm{richtlijn}$ uitgesioten sectoren viel de telecommunicatiesector, voor wat betreft 'werken' onder richtlijn $71 / 305$. Vgl. Wedekind (1992), 90-93. Zie verder Winter (1991), 763-764.

${ }^{130} \mathrm{Vgl}$. Winter (1991), 749.

131 Gebleven is de uitzonderingsmogelijkheid ex art. 9, sub e richtlijn 71/305: zie art. 4, lid 1, sub b richtlijn 93/37.

13. Het gaat dan om opdrachten die vallen onder klasse 50, groep 502 van de NACE-nomenclatuur (zie bijlage Il bij richtlijn 93/37) en opdrachten betreffende bouwwerken voor ziekenhuizen, inrichtingen voor sportheoefening. recreatie en vrijetijdsbesteding, school-en universiteitsgebouwen en gebouwen met een administratieve bestemming. Volgens art. 1 bis van het gemeenschappelijk standpunt van de raad (bepaald op 4 november 1988, Brussel 31 oktober 1988, 8970/88) had dit subsidievoorschrif betrekking op opdrachten inzake infrastructuurwerken waarmee een doel van algemeen belang werd nagestreefd. In de Toelichting op COM (89) 141 def. (4 april 1989) wordt opgemerkt dat, gegeven de nauwkeurige omschrijving in lid 2, de tekst van het eerste lid ditzelfde cok na weglating van deze zinsnede voldoende duidelijk maakte. 
Richtlijn 93/37

Hierna wordt kort ingegaan op de wijze waarop de beide beginselen in de gewijzigde richtlijn zijn uitgewerkt, een en ander in aanvulling c.q. wijziging op hetgeen daarover eerder bij de beschrijving van richtlijn $71 / 305$ al aan de orde is geweest.

- Het begINSEl VAN NON-DISCRIMINATIE NAAR NATIONALITEIT. Het wordt van belang geacht voor werken van enige omvang die over het algemeen zowel technisch als ook organisatorisch zeer ingewikkeld zijn voor alle procedures de termijnen voor ontvangst van aanvragen tot deelneming, inschrijvingen en aanvullende inlichtingen te verlengen. De verwachting is dat er daardoor meer bouwbedrijven zullen inschrijven. Naast regels op het gebied van de in acht te nemen termijnen heeft ook de normalisering en standaardisering van regels op technisch gebied (het genoemde primaat van de Europese norm) een pregnante plaats in de richtlijn gekregen ${ }^{133}$.

In het voorstel $\operatorname{COM}(86) 679$ def. werd in art. 22 , lid 4 een vermoeden van non-discriminatie aangenomen wanneer onder de gegadigden die door de aanbestedende diensten werden toegelaten tot de inschrijving of tot de onderhandelingen dezelfde verhouding tussen eigen onderdanen en onderdanen van de overige lidstaten bestond als onder de gegadigden die aan de vereiste voorwaarden voldeden, of wanneer deze verhouding niet dezelfde was, indien de aanbestedende diensten er zorg voor zouden dragen dat de onderdanen van de overige lidstaten die aan de gestelde voorwaarden voldeden, in voldoende mate vertegenwoordigd zouden zijn. Deze bepaling ontbreekt in de latere richtlijn.

- Het OPENBAARHEIDSBEginsel. Een nieuw middel om de procedures, die de vrije mededinging tussen de aannemers moeten waarborgen, doorzichtiger te maken, is de voorinformatieprocedure. Dat wil zeggen dat de aanbesteder zijn plannen voor toekomstige aanbestedingen van werken met een geraamde bouwsom van meer dan vijf miljoen ECU (half)jaarlijks door middel van een voorinformatieronde op communautair niveau bekend dient te maken, behoudens de gevallen waarin zulks onmogelijk is (artikel 11, lid 1 richtlijn 93/37) $)^{134}$. Gedachte achter deze procedure is dat het voor een werkelijke mededinging op Gemeenschapsniveau noodzakelijk is dat bedrijven uit andere lidstaten onder vergelijkbare voorwaarden kunnen reageren op de aanbestedingen als de nationale bedrijven. De voorinformatieprocedure moet bij een groter aantal aannemers belangstelling wekken. Artikel 11 legt de aanbesteder de verplichting op via een enuntiatieve aankondiging de hoofdkenmerken bekend te maken van de belangrijkste opdrachten voor werken die hij voomemens is het komende (half)jaar te plaatsen. Het is dus geen definitief bericht ${ }^{135}$. Aldus stelt de voorinformatieprocedure aannemers - en met name ook buitenlandse aannemers - in de gelegenheid om al in een vroeg stadium met de voor hun van belang zijnde opdrachten in hun bedrijfsvoering rekening te houden.

${ }^{133}$ Zie over de voortgang op dit punt de schriftelijke vraag van R. Simmonds (ED), nr. 2977/90, 18 jan. 1991 aan de Europese Commissie en de beantwoording door Bangemann op 14 maart 1991, Pb 31 aug. 1991, Pb C227/7.

134 Toelichting COM (86) 679 def., 3: 'de voornaamste kenmerken van voorgenomen werken die in de loop van het komende jaar of halfjaar zullen worden aanbesteed'. Ook Toelichting, 10: 'belangrijkste gegevens over de verschillende volgens de richtlijn geplaatste opdrachten'. Het gaat om een plicht, vgl. zaak C-272/91, r.0. 34 (Commissie v. Italiè).

${ }^{135}$ Blijkens Toelichting bij opnieuw behandeld voorstel COM (89) 141 def. - SYN 71. 
Naast de introductie van de voorinformatieprocedure worden de artikelen inzake de gemeenschappelijke regels voor de wijze van bekendmaking, de bijbehorende termijnbepalingen en de bepalingen over de inhoud van de bekendmaking vervangen door nieuwe bepalingen. Deze wijzigingen zijn van beperkte aard. De termijnen kunnen worden verkort door gebruik te maken van de voorinformatieprocedure. Gehandhaafd blijft het beginsel dat alle aanbestedingen boven de Europese drempelwaarde bekend worden gemaakt in het Publikatieblad (artikel 11, lid 2 richtlijn 93/37). Dit is alleen anders in die gevallen waarin de nieuwe onderhandelingsprocedure zonder voorafgaande bekendmaking kan worden toegepast. De bekendmaking in de Nederlandse Staatscourant of in de Nederlandse vakpers mag, als voorheen, niet plaatsvinden voor de eerdergenoemde datum van verzending van de aankondiging aan het Bureau voor officiële publikaties van de Europese Gemeenschappen die erin moet worden vermeld.

Uit het (gecombineerde) antwoord (2 juli 1992) van Bangemann namens de EC op de schriftelijke van de heer Llewellyn (nrs 802/92-805/92, dd. 14 april 1992, 92/C269/96-99) blijkt dat er geen nadere regels zijn vastgesteld voor de wijze waarop de aanbestedende diensten moeten aantonen dat zij de aankondigingen tijdig hebben toegezonden aan het Bureau voor officiele publikaties ( $\mathrm{Pb} \mathrm{C269/52,} \mathrm{19.10.92).}$

Deze bekendmaking mag geen andere gegevens bevatten dan die welke verschijnen in het Publikatieblad. De aanbestedende gemeente moet de datum van verzending kunnen aantonen (artikel 11, leden 11 en 12 richtlijn 93/37). Hierbij passen twee kanttekeningen:

a. nieuw is dat wanneer de aanbesteder een opdracht plaatst volgens een niet-openbare procedure, hij in de aankondiging een minimum en een maximum mag aangeven waartussen het aantal bedrijven zich zal situeren dat hij voornemens is aan te zoeken (artikel 22, lid 2 richtlijn 93/37). De hoogte van deze aantallen hangt af van de aard van het uit te voeren werk. Het minimumaantal mag niet minder bedragen dan vijf. Het maximum kan worden vastgesteld op twintig. Het aantal gegadigden ${ }^{136}$ moet in ieder geval groot genoeg zijn om een daadwerkelijke mededinging te waarborgen;

b. ook nieuw is dat wanneer aanbesteder een opdracht plaatst volgens de onderhandelingsprocedure met voorafgaande bekendmaking (artikel 7, lid 2 richtlijn 93/37) het aantal gegadigden dat tot de onderhandelingen wordt toegelaten niet lager mag zijn dan drie, op voorwaarde dat er voldoende geschikte gegadigden zijn (artikel 22, lid 3 richtlijn 93/37). De vraag is dan natuurlijk of daarvoor objectieve maatstaven zijn aan te wijzen? In de richtijin zijn daarvoor geen nadere criteria te vinden.

\section{Conclusie}

In het voorafgaande is de vraag onder ogen gezien of het Europese aanbestedingsrecht de keuze van de aanbestedingsprocedure regelt. Het antwoord luidt ontkennend. Op het communautaire vlak wordt het nationale aanbestedingsbeleid der lidstaten gecoördineerd, voorzover dat is gericht op de optimalisering van de prijs/ kwaliteit-verhouding, door de harmonisatie van de nationale aanbestedingsprocedures op basis van de non-discriminatiebeginsel en het openbaarheidsbeginsel. Voor de keuze van een bepaalde aanbestedingsprocedure

${ }^{136}$ De introductie van het begrip 'inschrijvingsgegadigden' in richtlijn 89/440 was onnodig: het gaat hier om gegadigden in de zin van art. 1, sub h richtlijn 89/440. Onder 'gegadigde' wordt verstaan: degene die heeft verzocht om een uitnodiging tot deelneming aan een niet-openbare procedure of aan een procedure van gunning via onderhandelingen. In richtlijn $93 / 37$ is dit begrip terecht geschrapt. 
is het nationale recht bepalend ${ }^{137}$. Alleen voor de onderhandelingsprocedures geldt dat deze slechts in uitdrukkelijk genoemde gevallen mogen worden gehanteerd.

\section{Conclusie}

De aan het eind van het vorige hoofdstuk gestelde vraag of de aanbestedingsreglementering een toereikend normatief kader biedt voor het gemeentelijk aanbestedingsbeleid, moet gelet op het voorafgaande ontkennend worden beantwoord. Op het communautaire vlak wordt het nationale aanbestedingsbeleid der lidstaten gecoördineerd, voorzover dat is gericht op de optimalisering van de prijs/ kwaliteitverhouding, door de harmonisatie van de nationale aanbestedingsprocedures op basis van de non-discriminatiebeginsel en het openbaarheidsbeginsel. Voor de keuze van een bepaalde aanbestedingsprocedure is echter het nationale recht bepalend ${ }^{138}$. De nationale aanbestedingsreglementen gaan er van uit dat de overheid in beginsel openbaar zou moeten aanbesteden. Maar zolang de wetgever verzuimt aan te geven 'hoe' er moet worden aanbesteed, wordt die keuze overgelaten aan de contractsvrijheid van gemeenten. Het mag dan geen verrassing heten, als de aanbesteding in de rechtswetenschappelijke literatuur en in de praktijk als een 'zuiver' privaatrechtelijk handelen wordt getypeerd. Consequentie van die opvatting is intussen wel, dat er nauwelijks zicht is op de gemeentelijke aanbestedingspraktijk; alleen wanneer het echt mis gaat, wordt er, achteraf, repressief ingegrepen. Anders gezegd: de privaatrechtelijke benadering ontbeert een normatief kader aan de hand waarvan het in de praktijk gevoerde gemeentelijk aanbestedingsbeleid op zijn juridische merites kan worden beoordeeld.

17 TK 1976-1977, 14 404, nrs. 1-3, 4 (Memorie van Toelichting).

14. TK 1976-1977, 14 404, nrs. 1-3, 4 (Memorie van Toelichting). 


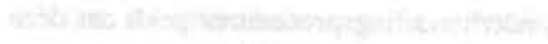


Hoofdstuk 4

\section{Eisen aan de beleidsuitgangspunten}

\section{Inleiding}

Het doel van de aanbesteding is eerder omschreven als het op basis van (selectie- en) gunningscriteria verlenen van een opdracht aan een aannemer. In dit hoofdstuk wordt onderzocht welke eisen de nationale en Europese aanbestedingsregelgeving stellen aan de selectie- en gunningscriteria. Ook wordt onderzocht of, en zo ja, op welke wijze de door het gemeentebestuur gemaakte beleidskeuzes moeten worden gemotiveerd. Een kwestie die met name aandacht verdient is of bij de selectie en gunning alleen overwegingen van prijs en kwaliteit een rol (mogen) spelen, of dat er ook ruimte is voor andere beleidsuitgangspunten. Voor dit laatste zou gedacht kunnen worden aan het lokale werkgelegenheidsbeleid. Mag een dergelijke overweging worden meegewogen in de uiteindelijke opdrachtverlening?

\section{UAR en financieel doelmatig beleid}

\subsection{Het Uniform Aanbestedingsreglement 1972}

'Het oordeel van de opdrachtgever'

In het UAR 1972 was het financieel-doelmatigheidsbeginsel uitgewerkt in bepalingen over de selectie van de gegadigden en de gunning van de opdracht aan één van hen. De afwegingen die moesten worden gemaakt, waren afhankelijk van het subjectieve oordeel van de aanbesteder, waardoor ook het onderscheid tussen de selectie- en de gunningsbeslissing niet steeds helder bleef. In dit verband kan worden gewezen op artikel 20 UAR 1972 waar werd bepaald dat inschrijvingen die niet voldeden aan de gestelde eisen in het reglement, bestek of de nota van inlichtingen ongeldig waren, tenzij de inschrijvingen naar 'het oordeel van de opdrachtgever' voldoende zekerheid verschaften omtrent de aanbieding en de persoon van de inschrijver. Voor de opdracht kwamen volgens artikel 21, lid 2 UAR 1972 uitsluitend inschrijvers in aanmerking omtrent wier geschiktheid om het werk uit te voeren naar het oordeel van de opdrachtgever zowel in technisch, financieel-economisch als in organisatorisch opzicht geen twijfel bestond. Gunning vond plaats aan de inschrijver, wiens aanbieding de opdrachtgever het meest aannemelijk voorkwam (artikel 21, lid 3 UAR 1972) ${ }^{1}$. Altematieve aanbiedingen konden bij de gunning zonder meer door de opdrachtgever buiten beschouwing worden gelaten (artikel 16 UAR 1972). De opdrachtgever was verder niet verplicht om het werk op te dragen (artikel 21, lid 1 UAR 1972). Inschrijven voor de laagste prijs betekende

Zie voor kritiek hierop Cremers - Zonderland, Bouwrecht (losbladige), deel A-I, nr. 6; Goudsmit (1973), 71-72; VerLoren van Themaat (1975), 268; Spier (1981), 52-53; Rozemond (1982), 116-120. 
dus niet dat de inschrijver dan ook het werk gegund zou (moeten) krijgen. Rozemond merkt evenwel terecht op dat moet worden aangenomen dat bij een aanbesteding met voorafgaande selectie de vrijheid van de aanbesteder om niet tot gunning over te gaan beperkter was dan bij openbare aanbesteding. Door een bepaalde inschrijver te accepteren (dat wil zeggen: selecteren) gaf de aanbesteder in elk geval te kennen dat deze in principe voor gunning in aanmerking kwam, zodat alleen het prijsverschil nog een rol zou kunnen spelen ${ }^{2}$. Feit blijft natuurlijk dat de beslissing uiteindelijk aan het subjectieve oordeel van de aanbesteder was overgelaten.

\section{Het motiveringsbeginsel}

Het UAR 1972 kende geen motiveringsplicht. De aanbesteder hoefde de door hem gemaakte beleidskeuzes op geen enkele wijze toe te lichten. Dat betekende dat noch de gekozen wijze van aanbesteding, noch de gemaakte selectie- en gunningsbeslissingen behoefden te worden gemotiveerd. De gevolgen voor de verhoudingen op de bouwmarkt zijn in het eerste hoofdstuk aan de orde geweest, waar ook is ingegaan op de beperkte mogelijkheden tot rechtsbescherming aan de kant van de aannemer.

\subsection{Het Uniform Aanbestedingsreglement 1986}

\section{Eisen en criteria}

De eerder genoemde Overleggroep Ordeningsthema's Aanbestedingswezen nam voor haar onderzoek de vrijheid van de aanbesteder om te selecteren als uitgangspunt. De Overleggroep was er echter niet blind voor, dat het ontbreken van richtlijnen tot gevolg had, dat van de gegadigden vaak teveel gegevens werden gevraagd - wat voor hen veel nodeloos werk betekende - terwijl zij hoegenaamd geen zicht hadden op het verloop van de selectieprocedure. De Overleggroep stelde in dit verband voor te komen tot objectivering en normering van de aanbestedingsverhouding, waardoor de doorzichtigheid van de procedures zou kunnen worden verbeterd. Door de objectivering van de selectie- en gunningscriteria moest worden bereikt dat beoordelingsvrijheid van de aanbesteder werd gerelateerd aan de in het bestek of in de bekendmaking vermelde eisen en criteria. Daarmee werd de eens zo vrije positie van de aanbesteder voor een belangrijk deel aan banden gelegd. De standaardisering van het bestek vormt een zeer belangrijk instrument om deze objectivering kracht bij te zetten ${ }^{3}$. Deze objectivering is overigens beperkt tot de openbare aanbesteding en de aanbesteding met voorafgaande selectie ${ }^{4}$. Dit hangt samen met de opvatting van de verantwoordelijke bewindslieden, dat deze procedures voornamelijk worden gehanteerd door ervaren en deskundige aanbesteders, in het bijzonder door de overheid. Om te bevorderen dat ook particuliere aanbesteders het UAR 1986 zouden (blijven) toepassen is er bij het ontwerp van de regeling voor gekozen om de onderhandse aanbesteding en de onderhandse aanbesteding na selectie (vooralsnog) niet te binden aan de geobjectiveerde eisen en criterias.

Diens noot onder Pres. Rb. 's-Graveñage, 26 januari 1983, BR 1986, 788.

Zie asmbevelingen Overleggroep Ordeningsthema's Aanbestedingswezen (1982). Deel A, Hoofdstuk 11, $32-34$.

- Slagter (1986), 136 en Van den Berg (1991), 11 bepleiten de objectivering van alle, ook onderhandse, procedures. Ook zo Van Werven (1992), 227, noot 121.

5 Toelichting op het UAR 1986 (Algemeen). Vgl. Van den Berg (1991), 8 en Van Nouhuys (1986), 35. 
Selectie-eisen zijn specifieke geschiktheidseisen, die betrekking hebben op de kwaliteiten waaraan de gegadigden moeten voldoen. Volgens artikel 7, lid 3 UAR 1986 moeten alle technische, organisatorische en financieel-economische eisen waaraan de inschrijver moet voldoen in het bestek worden vermeld. Bij een openbare aanbesteding worden blijkens artikel 6 , lid 2 , sub 1 de belangrijkste van de in artikel 7 , derde lid bedoelde eisen vermeld in de bekendmaking van de aanbesteding. Bedacht moet worden dat bij een openbare aanbesteding de technische, organisatorische en financieel-economische geschiktheid pas aan de orde konnt na de inschrijving op een gehouden aanbesteding. Bij de aanbesteding met voorafgaande selectie zijn de selectie en gunning duidelijker te onderscheiden; de specifieke geschiktheidseisen fungeren dan als selectie-eisen voorafgaand aan de inschrijving.

Naast deze selectie-eisen kent het UAR 1986 nog de zogenaamde maatschappelijke eisen: ten slotte wil geen enkele aanbesteder graag met een beunhaas te maken krijgen! De inschrijver die voor een opdracht in aanmerking wil komen, zal moeten voldoen aan de in de bekendmaking en het bestek vermelde maatschappelijke eisen ${ }^{6}$. Deze maatschappelijke eisen beogen de concurrentie te beperken tot de wettig gevestigde aannerners. Dergelijke maatschappelijke eisen vormen met andere woorden een middel om onrechtmatige bedrijfsuitoefening te voorkomen, waarbij gedacht kan worden aan malafiditeitsbestrijding. De Toelichting op het UAR 1986 noemt het bezit van de vestigingsvergunning en het ingeschreven zijn bij de Kamer van Koophandel en Fabrieken als voorbeelden van dergelijke maatschappelijke eisen ${ }^{7}$. Donders ${ }^{8}$ voegt daar de inschrijving bij de bedrijfsvereniging voor de bouw aan toe.

De gunningscriteria betreffen de aan het werk te stellen eisen. In beginsel geldt het criterium van de laagste prijs. Maar er kunnen ook andere gunningscriteria worden gehanteerd. Volgens artikel 7, lid 4 UAR 1986 vermeldt het bestek in dat geval alle gunningscriteria die anders zijn dan het gunningscriterium van de laagste prijs (zo mogelijk in afnemende volgorde van het belang dat de aanbesteder er aan hecht). De belangrijkste van de in artikel 7 , lid 4 genoemde criteria worden in de bekendmaking vermeldt ${ }^{10}$. Dit geldt ook voor de aanbesteding met voorafgaande selectie ${ }^{11}$. De in het bestek of de bekendmaking vermelde gunningscriteria die anders zijn dan het gunningscriterium van de laagste prijs kunnen variëren naar de aard van de opdracht zoals prijs, verrekenprijs of -prijzen, gebruikskosten, rentabiliteit, uitvoeringstermijn en technische waarde doch mogen niet de begroting van de inschrijver betreffen ${ }^{12}$.

Met dit onderscheid tussen eisen voor de selectie en de criteria voor de gunning is aansluiting gezocht bij de Europese coördinatierichtlijn, waarin dat onderscheid prominent aanwezig is.

Artikel 6, lid 2, sub $1 j^{\circ}$ artikel 7, lid 3 UAR 1986.

Bij voorbeeld RvA 2 juni 1992, nr. 15.780, BR 1992, 794.

Diens noot onder RvA 20 november 1987, nr. 13.079, BR 1989 i.h.b. 486.

Artikel 24, lid 3, sub a c.q. artikel $32 \mathrm{j}^{\circ}$ artikel 24, lid 3, sub a UAR 1986.

Artikel 6, lid 2, sub m UAR 1986.

Zie artikel 32 UAR 1986.

12 Artikel 8, lid 2 c.q. artikel $32 \mathrm{j}^{\circ}$ artikel 8, lid 2 UAR 1986. 
Twee (samenhangende) vragen

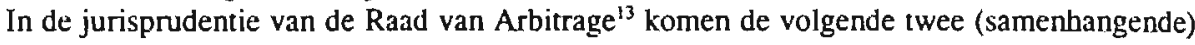
vragen vaak terug:

1. Voldoet(n) de door de aanbesteder gestelde geschiktheidseis(en) ex artikel 7, lid 3 UAR 1986 aan de criteria van artikel 8, lid 1 UAR 1986 ?

2. Voldoet de inschrijver aan de gestelde geschiktheidseis(en) (artikel 24, lid 2 UAR 1986)?

Samen met art. 8, lid 1 vormt art. 24, lid 2 UAR 1986 het fundament van het UARkwalificatiesysteem. Bij de beantwoording van de beide vragen, speelt steeds een rol of arbiters vol dan wel marginaal zouden moeten toetsen. Volle toetsing betekent dat de arbiters zich een zo compleet mogelijk beeld van het onderwerp van het geschil trachten te verschaffen met alle bijkomende omstandigheden en daarover, alle aspecten meewegend, in principe zonder enige reserve, hun oordeel geven. Van een marginale toetsing is sprake als de arbiters niet zozeer het geschilpunt zelf beoordelen, maar de redelijkheid van het standpunt, dat de aanbesteder ten aanzien van het punt in geschil heeft ingenomen ${ }^{14}$. In de praktijk doen zich overigens vele nuances voor in de benadering van de arbiters. Hierna volgt een overzicht van arbitrale uitspraken waarbij de beide, hiervoor genoemde, samenhangende vragen aan de orde waren.

- DE EERSTE VRAAG. De geschiktheidseisen in artikel 7, lid 3 UAR 1986 dienen volgens artikel 8, lid I UAR 1986 objectief en eenduidig te zijn, alsmede in redelijke verhouding te staan tot aard en omvang van het werk (het evenredigheidsbeginsel) ${ }^{15}$. IJkdata voor het aantonen van het voldoen aan de geschiktheidseisen zijn zowel de dag van de aanbesteding als ook de dag van de opdrachtverlening (artikel 24, lid 2 UAR 1986),

Het objectiviteits-en eenduidigheidsvereiste hebben tot doel de aspirant-inschrijver een zo duidelijk mogelijk beeld te geven van het soor bedrijf dat de aanbesteder zoekt. De eisen van objectiviteit en eenduidigheid beogen anders gezegd de transparantie van de bouwmarkt te vergroten. Het moet de gegadigde mogelijk worden gemaakt te beoordelen of zijn onderneming voor gunning in aanmerking komt. Als zodanig dienen deze eisen het belang van de inschrijver, en hebben zij niet ten doel de aanbesteder de vrije hand te geven bij het verruimen of juist beperken van de kring van gegadigden. Het is daarom van belang dat de aanbesteder de geschiktheidseisen als bedoeld in artikel 7, lid 3 UAR 1986 nauwkeurig omschrijft. Veel geschiktheidseisen blijken in te houden dat een inschrijver in een zeker tijdsbestek, werken van een bepaalde aard en/ of omvang moet hebben uitgevoerd $^{16}$. Er rijst dan nogal eens de vraag of een inschrijver aan die eis kan voldoen wanneer hij niet het gehele tijdsbestek heeft bestaan ${ }^{17}$. Een soortgelijk probleem doet zich

13 De Raad van Arbitrage is bevoegd in aanbestedingsgeschillen op grond van artikel 41 UAR 1986.

14 In die zin Donders (1994), 115.

15 Zie voor de aanbesteding met voorafgaande selectie: art. 29 UAR 1986.

I6 O.v.a. RvA 22 januari 1992, nrs. 70.030 en 70.032, BR 1992, 422 m.nt. Donders; RvA 12 mei 1992 , nr. 15.775, BR 1992, 944 m.nt. Donders en laatstelijk RvA 8 juli 1992, nr. 15.881. BR 1993, 156. RvA 6 juli 1993, nr. 16.599, BR 1994, 155. Over deze jurisprudentie uitvoerig Donders (1994), $114 \mathrm{v}$.

17 RvA 23 maart 1989, nr. 13.509, BR 1989, 718; RvA 2 juni 1989, nr. 13.359. BR 1989, 865. 
voor ten aanzien van werken die zijn uitgevoerd in combinaties ${ }^{18}$, of met inschakeling van onderaannemers ${ }^{19}$.

Het is overigens niet eenvoudig aan te geven hoever de aanbesteder in zijn profielschets van de door hem gewenste aannemer dient te gaan, maar het lijkt niet onredelijk als uitgangspunt te nemen, dat de gestelde geschiktheidscriteria een (potentiële) inschrijver in redelijke mate een inzicht moeten geven of hij voor het werk in aanmerking kom $\mathrm{t}^{20}$. Is de geschiktheidseis onduidelijk geformuleerd of voor meerdere uitleg vatbaar dan wordt deze bij twijfel niet in het nadeel van de inschrijver uitgelegd ${ }^{21}$.

Anderzijds moet de aanbesteder een zekere beleidsvrijheid worden gelaten bij de bepaling van de nodige kwalificaties die de inschrijver moet bezitten (de profielschets). Daarbij past een marginale arbitrale toets.

Ook arbiters lijken dat standpunt in te nemen. Men zie (onder meer) de volgende uitspraken.

In RvA 14 juli 1988, nr. 13.444, BR 1988, 790 overwogen arbiters, dat het de aanbesteder in beginsel vrij staat om voorwaarden te stellen waaraan een inschrijver moet voldoen, zij het, dat overeenkomstig artikel 8 UAR 1986 de in het bestek of de bekendmaking vermelde eisen objectief en eenduidig dienen te zijn, alsmede in redelijke verhouding dienen te staan tot aard en omvang van het werk.

RvA 8 nov. 1989, nr. 13.743, BR 1990, 314 m.nt. Donders: dat ook nu de door de aanbesteder gestelde geschiktheidseis niet tot in detail is geformuleerd, niet zonder meer kan worden gesproken van een eis die niet objectref en eenduidig is.

RvA 4 maart 1992, nr. 14.940, BR 1993, 152: dat het door de aanbesteder gehanteerde criterium niet zozeer afwijkt van de in het algemeen geldende maatstaven dat dit onredelijk zou zijn.

De (andere) eis, dat de geschiktheidseisen in een redelijke verhouding moeten staan tot aard en omvang van het werk (evenredigheid), beoogt de bevordering van een gezonde en eerlijke concurrentie door het aantal aspirant-inschrijvers tot min of meer gelijkwaardige bedrijven te beperken. De aanbesteder mag zijn profielschets dus niet te exclusief formuleren, waardoor op zich geschikte bedrijven uit de boot vallen. Terwijl aan de andere kant de eisen ook weer niet te laag mogen zijn ${ }^{22}$. Het gaat hier om het marktbeleid van de aanbesteder ${ }^{23}$. Daarbij past een wat terughoudender toetsing ${ }^{24}$.

18 O.a. RvA 18 april 1991, nr. 15,045, BR 1991, 564 en de appèlzaak RvA 23 januari 1992, nr. 70.038, BR 1992, 881 m.nt. Donders. Recent RvA 11 februari 1991, nrs. 14.903 en 14.904, BR 1991, 644 en appèlzaak RvA 22 januari 1992, nrs. 70.030 en 70.032, BR 1992, 422 m.nt. Donders met vervolg in RvA 7 april 1993, nr. 15.982. BR 1993, 1006. RvA 16 juli 1993, nr. 16.549, BR 1993, 1007. RvA 10 augustus 1993, nr. 16.686, BR 1994, 1044 m.nt. Donders (waarbij het ging om een een moeder- en een dochteronderneming).

19 RvA 14 maart 1990, nr. 14.377, BR 1990, 566 m.nt. Donders. RvA 17 augustus 1993, nr. 16.696, BR 1993, 1009 .

20 In die zin Donders in diens noot onder RvA 2 mei 1990, 14.468, BR 1990, 783.

${ }^{21}$ RvA 26 mei 1987, nr. 12.820, BR 1987, 623 m.nt. Donders.

22 In die zin Donders (1994), 115.

22 Reden waarom Donders (1994), 115 van oordeel is, dat de Raad van Arbitrage geen geschikt instituut is om de normen van art. 8. lid 1 UAR 1986 te handhaven. Arbiters hollen dit (keuze en selectie)regime steeds meer uit, waardoor de marktordenende funktie verloren gaat.

24 Aldus ook Donders (1992), 97. En Donders (1994), 115. 
Aanvankelijk kozen arbiters voor een volle toets ${ }^{25}$. Daar is overigens wel wat voor te zeggen. Zo geeft artike] 41. UAR 1986 op zich geen aanleiding tot een andere opvatting. En verder past een volle toets bij de beoogde: verkleining van de beleidsvrijheid, wat bij de vaststelling van het UAR 1986 juist de bedoeling was. Aan de andere kant moet de aanbesteder een zekere beleidsvrijheid worden gelaten bij de bepaling van de nodige kwalificaties die de inschrijver moet bezitten (hiervoor: de profielschets).

Een overzicht van uitspraken van de Raad van Arbitrage op dit punt levert het volgende beeld op.

RvA 11 februari 1991, nrs. 14.903 en 14.904, BR 1991, 644: 'Aanbesteder heeft het werk voldoende relevant gevonden (...). Hoewel er (...) verschillen in aard en omvang zijn aangewezen, kan niet gesteld worden dat aanbesteder in redelijkheid niet tot deze beslissing heeft kunnen komen'.

RvA 8 jan 1992, nr. 15.419, BR 1992, 879 waar overwogen werd 'dat juist bij een werk als het onderhavige, dat wordt getypeerd door een zeer technisch en specialisrisch karakter, moet worden vastgesteld, dat het stellen van een op de coördinatiecapaciteit gerichte ervaringseis niet onredelijk is en dat deze eis in een redelijke verhouding staat tot de aard en omvang van het werk'.

RvA 4 maart 1992, nr. 14.940, BR 1993, 152: de inschrijver beriep zich er op, dat 'in het algemeen' ervaringseisen worden gesteld op 30 tot $60 \%$ van de raming. Overwogen wordt, dat enerzijds juist is, dat de genoemde ervaringseisen 'in het algemeen' als maatstaf worden aanvaard, waarvan niet willekeurig kan worden afgeweken. Anderzijds is een afwijking wel degelijk mogelijk op grond van de bijzondere eisen, die aan het werk en de uirvoering daarvan gesteld behoren te worden. De vraag, of zich in concreto een siruatie voordoet, die een afwijking van de algemeen aanvaarde maatstaf rechtvaardigt, staat primair ter beoordeling van de aanbesteder.

RvA 11 febr. 1992, nr. 14.857, BR 1992, 887. Gevraagd naar de ruimte die een aanbesteder heeft bij het stellen van een omzeteis, stellen arbiters voorop dat het aanbesteders in het algemeen vrij staat om een omzeteis te hanteren, mits daarbij niet de grenzen van het redelijke kennelijk overschreden worden.

In dic zin RvA 28 april 1994, nr. 17.106, BR 1994, 710 m.nt. Donders.

Een uitzondering op deze marginale toetsingsjurisprudentie is RvA 13 juli 1993, nr. 16.472, BR 1994, 157. Zonder veel omhaal van woorden kozen arbiters voor een volle toetsing. 'Arbiters dienen op de vordering van gegadigde de vraag, of de door de aanbesteder aan toelating tot inschrijving gestelde eis in strijd komt met het daaromtrent in artikel 8 lid 1 U.A.R. 1986 bepaalde volledig te toetsen'.

In RvA 28 april 1994, nr. 17.106, BR 1994, $710 \mathrm{~m}$.nt. Donders keerden arbiters op hun schreden terug en kozen zij voor een veel marginalere beoordeling. Maar ook dan blijken arbiters heel wel in staat corrigerend op te treden als de aanbesteder wat 'al te vrijmoedig omspringt met de beperkingen die deze norm aan zijn vrijheid stelt'. Volgens de arbiters was de aanbesteder er niet in geslaagd aannemelijk te maken dat het werk bijzonder complex was. De in het bestek gestelde omzeteis was daarom onredelijk in bet licht van artikel 8 , lid 1 UAR 1986.

RvA 10 okt. 1994, nr. 17.458, BR 1995, 166. Arbiters zijn van oordeel dat de aanbesteder belang had bij het stellen van bijzondere eisen aan gegadigden. Aanbesteder is in beginsel vrij in de wijze, waarop zij deze bijzondere eisen vertaalt naar criteria om in aanmerking te komen voor een uitnodiging tot inschrijving. (.) niet van oordeel dat (..) gestelde ervaringseis niet in een redelijke verhouding staat tot de aard en de omvang van het werk. (..) Dit is niet anders, nu aanbesteder afwijkt van haar gebruikelijke beleid bij aanbestedingen, nu eerder was overwogen dat het om een ongebruikelijk werk ging.

25 RvA 20 nov. 1987, nr. 13.079, BR 1989, 483 m.nt. Donders en RvA 14 juli 1988, nr. 13.444, BR 1988, 790. 
RvA 16 maart 1995, nr. 17.776 (Gesloten schildboringen), BR 1995, 796 m.nt. Donders. Volgens arbiters mogen de eisen in art. 8, lid 1 in beginsel niet voor meerdere uitleg vatbaar zijn. De toetsing van de geschiktheid van de inschrijvers aan die eisen dient op geobjectiveerde wijze plaats te vinden terwijl anderzijds die eisen niet een onevenredig grote ervaring of geschiktheid van de inschrijvers mogen vergen, dan in verband met de uitvoering van het werk redelijk is.

- DE TWEEDE VRAAG. Wat betreft de (tweede) vraag of de inschrijver voor gunning in aanmerking komt, maakt artikel 24, lid 2 UAR 1986 onderscheid tussen twee toetsingsmomenten. Allereerst dient de inschrijver te voldoen aan de in de bestek en bekendmaking gestelde (geschiktheids)eisen. En daarnaast moet hij 'redelijkerwijs in staat (...) worden geacht het werk vakkundig en op regelmatige wijze uit te voeren' (hierna: 'slotzin'). Pas als de inschrijver aan de volledige profielschets voldoet, komt hij voor de opdracht in aanmerking, (artikel 24, lid 2 c.q. artikel $32 \mathrm{j}^{\circ}$ artikel 24, lid 2).

Betekenis vangnet. De slotzin van artikel 24, lid 2 UAR 1986 laat de gemeente een zeker Freies Ermessen, welke zich slecht verdraagt met de gedachte die aan het UAR 1986 ten grondslag ligt en welke juist uitgaat van een openbare, objectieve en toetsbare aanbestedingsprocedure. Via deze achterdeur krijgt de aanbesteder toch weer de gelegenheid om op grond van subjectieve en niet vooraf gepubliceerde gronden te selecteren. Deze slotzin is dan ook het voorwerp van verscheidene arbitrale uitspraken. In het allereerste UAR-geschil schuiven de arbiters de eerste zin en de slotzin van artikel 24, lid 2 UAR 1986 als het ware in elkaar. Voldoet de inschrijver aan de geschiktheideisen, dan voldoet hij ook aan de eis dat hij redelijkerwijze in staat moet worden geacht het werk vakkundig en op regelmatige wijze uit te voeren.

Bedoeld wordt RvA $31 \mathrm{mrt}$. 1987, nr. 12.753, BR 1987, $550 \mathrm{~m}$. nt. Donders. Arbiters cordeelden dat de in het bestek gestelde voorwaarden een objectivering behelsden ten behoeve van de beoordeling of een inschrijver redelijkerwijs in staat moet worden geacht het werk vakkundig en op regelmatige wijze uit te voeren.

In latere uitspraken geven de arbiters aan deze slotzin een veel zelfstandiger uitleg. Dat wil zeggen dat bij gebreke van vooraf gepubliceerde geschiktheidseisen de geschiktheid van de inschrijver kon worden getoetst aan het criterium in de slotzin van artikel 24 , lid 2 UAR 1986. Dit sluit aan op de opvatting van Van Nouhuys ${ }^{26}$ die eerder het aannemen van twee zelfstandige, aan elkaar nevengeschikte, criteria had bepleit.

Vergelijk RvA 7 november 1989, nr. 13.932, BR 1990, 312 m.nt. Donders, in welk geval bij een openbare aanbesteding geen geschiktheidseisen waren gesteld. Desondanks oordeelden arbiters dat het de aanbesteder vrij. stond de geschiktheid van de laagste inschrijver te toetsen door het achteraf inwinnen van referenties. Nu deze negatief bleken, achtten de arbiters de aanbesteder vrij om met een beroep op de slotzin van artikel 24 , lid 2 UAR 1986 de laagste inschrijver te passeren.

In RvA 2 mei 1990, nr. 14.468, BR 1990, 783 werd overwogen, dat de aanbesteder de ingewonnen informatic zo heeft geinterpreteerd, dat daaruit niet bleek dat de gegadigde geacht moest worden het werk vakkundig en op regelmatige wijze uit te voeren. 
Deze slotzin van het tweede lid van artikel 24 UAR 1986 heeft in de literatuur inmiddels bekendheid verworven als het 'vangnet' ${ }^{27}$. Volgens Van Nouhuys dient het vangnet een mogelijk te rigide werking van het eerste criterium van art. 24 , lid 2 te verzachten. Maar, aldus Donders, dit dient niet ruim te worden opgevat. Hij noemt daarvoor twee redenen: a. de bedoeling van het UAR om de beleidsvrijheid op dit punt te verkleinen, en $b$. mogelijke strijd met art. 25 en 26 richtlijn $71 / 305^{28}$. Volgens Donders kan aan de slotzin van artikel 24, lid 2 UAR 1986 hoogstens de betekenis van correctiefactor toekomen, voor het geval de aanbesteder - hoewel de laagste inschrijver voldoet aan de gestelde geschiktheidseisen - toch goede gronden kan aanvoeren om het werk niet te gunnen. Zo kan een inschrijver formeel aan de eisen voldoen, maar kan dit materieel anders zijn. Te denken ware aan gevallen van 'oneigenlijke aanneming'. Daarvan is sprake als een hoofdaannemer een qua aard en omvang belangrijk en dominant onderdeel van het werk in onderaanneming uitbesteedt, omdat hij zelf niet tot een goede uitvoering daarvan in staat is. Donders wijst er op, dat via deze oneigenlijke onderaanneming in het curriculum vitae van een bouwbedrijf één of meer werken kunnen voorkomen die een vertekend beeld geven van het prestatievermogen van zo'n bedrij $\mathrm{f}^{39}$. Ook Van den Berg ${ }^{30}$ heeft gewezen op de mogelijke gevaren van de slotzin voor de objectiviteit van de geschiktheidseisen. Hij is van oordeel dat er ruimte is voor het vangnet, voor het geval de aanbesteder bij het stellen van geschiktheidseisen een elementair aspect over het hoofd heeft gezien.

Donders' bezorgdheid kan worden nagevoeld na lezing van RvA 2 mei 1990, nr. 14.468, BR 1990, 783 m.nt. Donders. De gemeente had de gestelde geschiktheidseisen zo ruim en vaag mogelijk geformuleerd om vervolgens aan de hand van het tweede criterium van artikel 24 UAR 1986 een onwelgevallige laagste inschrijver te kunnen passeren.

In RvA 10 nov. 1993, nr. 15.674, BR 1994, 354 m.nt. Donders is de betekenis van bet vangnet in lid 2 opnieuw aan de orde. Deze uitspraak komt tegemoet aan de opvatting van Donders: het vangnet kan alleen als correctief functioneren voor het geval een te strikte toepassing van het objectief criterium tot onaanvaardbare gevolgen zou leiden ${ }^{31}$.

Arbiters overwegen dat de twee in artikel 24, lid 2 UAR 1986 genoemde criteria meebrengen dat, indien een inschrijver (...) voldoet aan de eisen die in het bestek en de bekendmaking zijn vermeld, die inschrijver in beginsel redelijkerwijs in staat moet worden geacht het werk vakkundig en op regelmatige wijze uit te voeren, tenzij de aanbesteder op objectieve en zwaarwegende gronden aantoont dat de betreffende inschrijver daar redelijkerwijs niet toe in staat moet worden geacht, behoudens door die insehrijver te leveren tegenbewijs.

Toetsing. De vraag of een inschrijver voldoet aan de gestelde geschiktheidseisen voldoet, dient in beginsel 'vol' te worden getoetst. Het gaat erom, of de inschrijver in principe in aanmerking komt voor gunning, waarbij de beleidsvrijheid van de aanbesteder klein moet worden geacht. De vraag of de inschrijver aan de eisen voldoet raakt direct de onderlinge concurrentie tussen de inschrijvers: arbiters behoren zich dan ook een zelfstandig oordeel te vormen over het standpunt dat de aanbesteder met betrekking tot deze vraag inneemt.

\footnotetext{
Van Nouhuys (1986), 25.

Onder meer diens noot onder RvA 10 november 1993, 15.674, BR 1994, 359

Vgl. RvA 14 mrt 1990, nr. 14.377, BR 1990, 566 m.nt. Donders.

Van den Berg (1991), 7.

"Donders in diens noot onder deze uitspraak (BR 1994, 359).
} 
De toetsingspraktijk kent wat dit betreft een wat grillig verloop. Met name in de beginperiode leek volle toetsing van het voldoen aan de geschiktheidseisen regel ${ }^{32}$. Naderhand zetten de arbiters een wat marginaler koers in $^{33}$. In RvA 1 februari 1991, nr. 70.023, BR 1991, 495 zijn arbiters er - volgens Donders - in geslaagd om een juiste, terughoudende, afstemming te bereiken tussen het principe van volle toetsing en de behoefte aan enige beleidsvrijheid zijdens de aanbesteder ${ }^{34}$. Uitgangspunt is een volle toetsing, met een zeker respect voor de beleidsvrijheid van de aanbesteder.

Vraag was of het door de laagste inschrijver genoemde referentiewerk kon worden aangemerkt als 'een vergelijkbaar werk' (geschiktheidseis). Overwogen wordt, dat een gunningseis in principe eenduidig moet zijn, zodat er geen nuimte is voor een marginale toetsing van de door de aanbesteder gegeven uitleg. Dit neemt echter volgens arbiters niet weg, dat nu er in het onderhavige geschiktheidsvereiste een zekere beoordelingsnuimte is, arbiters zich de vraag hebben te stellen, of een aanbesteder die meent dat aan het vereiste is voldaan of niet, in redelijkheid tot die beslissing kon komen.

$\mathrm{Na}$ nog wat heen en weer geslinger tussen vol $^{35}$ en marginaal ${ }^{36}$, lijken arbiters thans weer op de wat terughoudende koers van RvA 1 februari 1991, nr. 70.023, BR 1991, 495. In RvA 10 november 1993, nr. 15.674, BR 1994, 354 m.nt. Donders wordt overwogen, dat:

'Indien een inschrijver op zowel de dag van aanbesteding als op de dag van opdrachtverlening voldoet aan de eisen die in het bestek en de bekendmaking zijn vermeld, die inschrijver in beginsel redelijkerwijs in staat moet worden geacht het werk op vakkundig en op regelmatige wijze uit te voeren, tenzij de aanbesteder op objectieve en zwaarwegende gronden aantoont dat de betreffende inschrijver daar redelijkerwijs niet toe in staat moet worden geacht, behoudens door die inschrijver te leveren tegenbewijs'.

In RvA 31 juli 1990, nr. 14.615, BR 1991, 314 blijkt dat bij een onderhandse aambesteding de arbiters de gunningsbeslissing van de aanbesteder slechts marginaal willen toetsen: dat wil zeggen dat alleen in geval van kennelijke onjuistheid of kennelijke onredelijkheid van het gebezigde argument daaraan geen kracht kan worden toegekend. Dit hangt naar ik aanneem samen met het ontbreken van geobjectiveerde en eenduidige eisen als grondslag voor de keuze van de aannemer ${ }^{37}$.

32 Men zie RvA 26 mei 1987, nr. 12.820, BR 1987, 623 m.nt. Donders; RvA 11 maar 1988, nr. 13.221, BR 1988, 787; RvA 26 januari 1989, nrs. 13.704 en 13.713, BR 1989, 552 m.nt. Donders; RvA 23 maart 1989, nr. 13.509, BR 1989, 718 en RvA 2 juni 1989, nr. 13.359, BR 1989, 865. Een afwijking van die 'volle' toetsingspraktijk in RvA 9 januari 1989, or. 13.693, BR 1989, 550 waar marginaal wordt getoetst.

3) Gewezen kan worden op de volgende vitspraken: RvA 7 november 1989, nr. 13.932, BR 1990, 312 m.nt. Donders; RvA 8 nov. 1989, nr. 13.743, BR 1990, 314 m.nt. Donders; RvA 2 mei 1990, nr. 14.468, BR 1990. 783 m.nt. Donders en RvA 25 oktober 1990, nr. 13.540, BR 1991, 316.

4. Vgl. uitwoerig Donders (1994), 114 v. Zie cok RvA 19 juli 1991, nr. 15.201, BR 1991, 804.

35 RvA 8 augustus 1991, nr. 15.215, BR 1992, 243; RvA 22 januari 1992, nrs. 70.030 en 70.032, BR 1992,422 m.nt. Donders.

s6 RvA 15 oktuber 1991, or. 70.029, BR 1992, 160 (hoger beroep van RvA 11 januari 1991, nr. 14.786, BR 1991, $561)$.

37 Zie wat dit betreft artikel 37 UAR 1986 (onderhandse aanbesteding) en artikel $40 \mathrm{j}^{*}$ artikel 37 UAR 1986 (onderhandse aanbesteding na selectie). 


\section{Uitnodiging na selectie}

Voldoet een gegadigde bij een aanbesteding na selectie aan de gestelde geschiktheidseisen, dan komt hij in aanmerking voor een uitnodiging tot inschrijving. Volgens artikel 30 , lid 1 UAR 1986 heeft de aanbesteder echter de vrijheid te bepalen wie van de gegadigden hij voor de inschrijving uitnodigt, met dien verstande dat hij alleen die gegadigden mag uitnodigen die aan de selectie-eisen voldoen. Hij hoeft echter niet al deze gegadigden de kans te geven om in te schrijven. De aanbesteder behoeft slechts het maximum-aantal gegadigden dat tot de inschrijving zal worden uitgenodigd in de bekendmaking aan te geven (artikel 28, lid 2 sub f UAR 1986). Gegadigden die voldoen aan de selectie-eisen kunnen dus zonder meer worden gepasseerd, zij het dat deze beslissing dient te worden gemotiveerd (artikel 31, lid 4 UAR 1986). De betekenis van deze motivering is gering, gelet op het vrijblijvende karakter van artikel 30, lid 1 UAR 1986. Dit artikel oogst weinig sympathie, getuige ook haar bijnaam 'het zwarte gat'. Het is 'het moment waarop de aanbesteder een nagenoeg onbeperkte en oncontroleerbare discretionaire bevoegdheid kan uitoefenen. Het is met name hier waar ruimte bestaat voor toepassing van subjectieve en/of discriminatoire preferenties ${ }^{38}$. Donders $^{39}$ merkt hierover op:

'(...) deze aan de aanbesteder gelaten keuzevrijheid [vormt] een vreemd element in het systeem van het UAR 1986 waarbij iedere insclarijver die aan de gestelde eisen voldoet de gelegenheid moet krijgen om mee te dingen naar het werk. We hebben hier te maken met een hinderlijke lacune in de rechtsbescherming van gegadigden bij een aanbesteding met voorselectie die dringend om een oplossing vraagt'.

\section{Waarvan akte!}

De gunning van het werk; gunningsplicht?

Nadat is komen vast te staan dat de aannemer in aanmerking komt voor het werk, moet worden bepaald aan wie van de inschrijvers de opdracht zal worden gegund. Uitgangspunt van het UAR is dat de aanbesteder op grond van art. 24, lid 1 UAR 1986 niet verplicht is om het werk op te dragen ${ }^{40}$. Doch zulks betreft niet één inschrijver, doch alle inschrijvers. Dit betekent in elk geval dat de aanbesteder van deze bevoegdheid om niet te gunnen gebruik mag maken in die gevallen waarin hij besluit het werk in zijn geheel niet te laten uityoe$\operatorname{ren}^{41}$.

In zijn noot onder RvA 26 mei 1987, nr. 12.820, BR 1987, 623 v. wijst Donders er op dat de laagste inschrijver er belang bij kan hebben dat hij tijdig weet dat hij zal worden gepasseerd. Het UAR 1986 kent daarvoor geen regeling. Met Donders en Van Werven ${ }^{42}$ zou ik alsdan het bestaan van een wasschuwingsplicht willen aannemen.

Maar, hoe moet worden geoordeeld als de aanbesteder de procedure eindigt met een nietgunningsverklaring, om dan vervolgens (met alle informatie) met een derde te gaan

3* Pijnacker-Hordijk (1992 a), 109 en in gelijke zin Van den Berg, (1993), 32 v. Winter (1992), 29 ziet hier mogelijkheden voor "creatief aanbesteden.

39 Donders (1994), 118.

* RvA 26 nuei 1987, nr. 12.820 , BR 1987, 623.

4 RvA 27 juni 1988, nr. 12.930, BR 1989, 71 v. Van Werven (1992), 229-230. Volgens Rozemond (1989), 236 sloot deze bevoegdheid aan bij het recht dat de opdrachtgever had op grond van art. 1647 (oud) BW om te allen tijde de aaunemingsovereenkomst op te zeggen.

4. Van Werven (1985), 43. 
onderhandelen. Ontstaat dan praktisch niet eenzelfde situatie als wanneer de aanbesteder hangende een aanbestedingsprocedure een offerte van een derde vraagt?

Een dergelijk geval deed zich voor in RvA 3 maart 1989, nr. 13.774, BR 1989, 715 m.nt. Donders. Arbiters oordeelden dat sprake was van strijd met de geest van het UAR 1986. De aanbesteder die met het werk leurt pleegt naar het oordeel van de arbiters wanprestatie tegenover zijn inschrijvers, omdat hij de uit het UAR voortvloeiende pariteit tussen de inschrijvers miskent. Hierdoor kan een achteraf gevraagde derde zich bij zijn prijsopgave bedienen van de kennis en inschrijfcijfers van zijn voorgangers hetgeen hem ten onrechte in een voordeliger positie zou brengen.

Is de aanbesteder met andere woorden verplicht het werk te gunnen aan één der inschrijvers? De uitspraken op dit terrein overziende lijken de arbiters de vrijheid van de aanbesteder om het werk niet op te dragen te willen clausuleren, zij het niet steeds op dezelfde manier. Aanvankelijk leken de arbiters de aanbesteder weinig in de weg te willen leggen om van zijn bevoegdheid om niet te gunnen gebruik maken, als hij, na een gehouden aanbesteding, besloot het werk slechts gedeeltelijk te laten uitvoeren, in eigen beheer uit te voeren of met inschakeling van derden te doen uitvoeren, zoals de laagste inschrijver op de aanbesteding ${ }^{43}$. Volgens arbiters - onder verwijzing naar artikel 24, lid 1 UAR 1986 - is het niet opdragen van het werk niet in strijd was met de goede trouw ${ }^{44}$.

Vergelijk RvA 9 november 1989 , nr. 14.077, BR 1990, 230; na een aanbesteding met voorafgaancle selectie vindt de aanbesteder laagste prijs onaanvaardbaar. Ook na onderhandelingen zag de inschrijver geen mogelijkheid tot een substantiële verlaging van zijn inschrijfcijfer, waarop de aanbesteder besloot het werk niet aan én der inschrijvers gunnen. De aan arbiters voorgelegde vraag was: of de aanbesteder gerechtigd was om het werk na een gehouden aanbesteding, welke niet tot gunning had geleid, aan een derde op te dragen. Overwogen werd, dat artikel 24, lid 2 UAR 1986 in zijn algemeenheid niet verbiedt dat, indien de aanbesteder het werk niet aan een inschrijver opdraagt, het werk aan een derde niet-inschrijver kan worden opgedragen. Artikel 24, lid 2 beoogt alleen een regeling te geven voor de wijze van opdragen van het werk in de onderlinge relatie tussen de inschrijvers en heeft geen betrekking op de situatie dat de aanbesteder het werk aan geen van de inschrijvers wenst op te dragen. Een ander oordeel verdraagt zich volgens arbiters niet met artikel 3 UAR.

Van deze uitspraak werd hoger beroep ingesteld. In de appèlzaak RvA 16 mei 1991, nr. 70.010, BR 1991, 799 m.nt. Donders kozen arbiters voor een andere benadering.

Overwogen werd, dat in beginsel de aanbesteder moet gunnen aan de inschrijver die daarvoor volgens de bepalingen van het UAR 1986 in aanmerking komt. Dit beginsel lijdt uitzondering als de aanbesteder in redelijkheid van oordeel is dat bij de inschrijving geen passend aanbod is gedaan, bijvoorbeeld omdat de laagste inschrijving aanmerkelijk hoger ligt dan de prijs die de aanbesteder mocht verwachten en omdat nader overleg niet tot een oplossing leidt. Dusdoende kwamen arbiters tot hetzelfde resultaat, zij het langs een andere weg. In beginsel bestaat er een 'gunningsplicht'. Dit lijdt onder genoemde omstandigheden vitzondering, waardoor er in feite niet veel meer dan lippendienst wordt bewezen aan het beginsel.

Met deze uitspraak zijn arbiters de weg opgegaan die ook in het Duitse VOB/A wordt gebruikt, en waarbij er slechts expliciete uitzonderingen op het beginsel bestaan dat steeds

43 Voorbeelden hiervan zijn de volgende uitspraken: RvA 26 mei 1989, nr. 13.900, BR 1989, 720 en RvA 26 mei 1989 , nr. 13.902, BR 1989, 722. De enige beperking is gelegen in het bepaalde in artikel 3 UAR 1986 (verbod van het vragen van een afstandsverklaring).

4 Kritiek op deze uitspraak van Van den Berg (1991), 12 v. omdat de vrijheid van de aanbesteder tot leuren aanleiding zou kunnen geven. 
gegund dient te worden ${ }^{45}$. Deze redenen dient de aanbesteder aannemelijk te maken. Consequentie van deze uitspraak is volgens Donders, dat wanneer de aanbesteder geen geschiktheidseisen formuleert, hij in beginsel aan de laagste inschrijver dient te gunnen ${ }^{46}$.

Later in RvA 21 mei 1991, nr. 14.661, BR 1991, 802, waar het ging om een onderhandse aambesteding, deed zich wederom de vraag voor: of, en zo ja, onder welke omstandigheden de aanbesteder mag besluiten het werk niet op te dragen aan één der inschrijvers. In casu had overleg met laagste inschrijver niet tot de gewenste prijsverlaging geleid. Overwogen wordt, dat een aanbesteder niet verplicht is om het werk op te dragen en na aanbesteding kan overgaan tot heraanbesteding, danwel opdrachtverlening aan een derde, indien de aanbesteder beschikt over concrete gegevens op grond waarvan aannemelijk is dat het werk, zoals aanbesteed, voor een lagere aannemelijke prijs te realiseren valt.

Bleeker $^{47}$ wil, zo begrijp ik hem, bij alle aanbestedingsvormen de benadering 'gunnen is

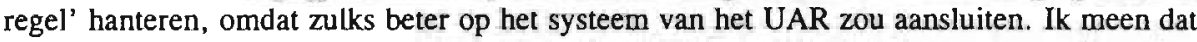
er niet van een dergelijke hoofdregel sprake is. Het komt mij voor, dat naarmate de aanbesteder meer invloed uitoefent op de samenstelling van de inschrijvers, door het stellen van deelnemingseisen, een dergelijke gunningsregel meer voor de hand ligt, dan wanneer dat niet het geval is ${ }^{48}$. Dat betekent dat daarvan bij een openbare aanbesteding geen sprake kan zijn. Bij de aanbesteding met voorafgaande selectie, zo bleek in de appèlzaak RvA 16 mei 1991, nr. 70.010, BR 1991, 799 m.nt. Donders, onder omstandigheden wel. Bij onderhandse aanbestedingen is de band tussen gegadigden en aanbesteder nog sterker dan bij de aanbesteding met voorafgaande selectie, zodat een gunningsplicht geïndiceerd lijkt. Daar staat dan tegenover dat de selectie-eisen en gunningscriteria niet zijn geobjectiveerd, waardoor de aanbesteder in de praktijk meer vrijheid heeft om tot zijn 'subjectieve oordeel' te komen om geen enkele inschrijver het werk op te dragen. Ik kan me overigens voorstellen dat een gunning,splicht ook snel(ler) kan worden aangenomen bij een groot project (zoals boven de Europese drempel). Ten slotte gaat de aanbesteder bij dergelijke werken niet over één nacht ijs. In elk geval zou ik ervan willen uitgegaan dat de weg naar de derde pas open staat, indien de aanbesteder serieus heeft getracht om via onderhandelingen tot overeenstemming te geraken met de aannemer die het meest voor het werk in aanmerking komt ${ }^{49}$.

Ten slotte dient hier nog te worden vermeld het bepaalde in artikel 24, lid 5 UAR 1986. Volgens deze bepaling is de aanbesteder niet gehouden het werk op te dragen aan de daarvoor in aanmerking komende inschrijver indien deze inschrijver bij de aanbesteding of bij een aanbesteding die minder dan vijf jaar geleden heeft plaatsgevonden, in strijd met de waarheid de verklaring, bedoeld in artikel 11 , tweede lid, heeft ondertekend en afgegeven. Het gaat hier om een bevoegdheid van de aanbesteder, niet om een verplichting ${ }^{50}$. Met de

4 Vgl. par. $26 \mathrm{VOB} / \mathrm{A}$ (Aufhebung der Ausschreibung).

4 Donders (1992), 96.

4 Bleeker (1993), 56.

4. Sluit m.i. aan op de eerder genoernde opvatting van Rozemond in diens noot onder Pres. Rb 's-Gravenhage, 26 januari 1983, RR 1986, 788.

49 In die zin Van den Berg (1991), 13.

so RvA 5 juli 1990, nr. 14.563, BR 1991, 238. 
(al dan niet) gunning van de opdracht aan een aannemer eindigt de UAR-aanbestedingsprocedure $^{51}$.

\section{Het motiveringsbeginsel}

$\mathrm{Al}$ in 1980 had het VVD-Kamerlid De Beer voorgesteld om het UAR 1972 in die zin aan te passen, dat het passeren van de laagste inschrijver schriftelijk medegedeeld moest worden aan de betrokkene, onder opgaaf van redenen ${ }^{52}$. Dat voorstel werd door de Minister overgenomen, maar bleef op dat moment zonder zichtbaar resultaat. Hoewel het UAR 1972 een dergelijke bepaling dus niet kende, werd in 1983 het recht van de laagste inschrijver, op het ontvangen van een toelichting waarom hij bij de gunning werd gepasseerd, door de lagere rechtspraak toch reeds erkend ${ }^{53}$. Ook in de literatuur werd wel bepleit dat de aanbesteder in bepaalde gevallen zijn beslissing moest motiveren ${ }^{54}$.

Naast de objectivering van de deelnemingscriteria introduceerde het UAR 1986 een motiveringsplicht voor de aanbesteder. Deze motiveringsplicht houdt bij openbare aanbesteding in dat de aanbesteder de verzoeker desgevraagd in kennis stelt van de redenen die ertoe hebben geleid dat het werk niet aan hem is opgedragen (artikel 24, lid 6 UAR 1986) ${ }^{55}$. In artikel 32, aanhef UAR 1986 wordt artikel 24, lid 6 UAR 1986 voor de aanbesteding met voorafgaande selectie van overeenkomstige toepassing verklaard: de aanbesteder moet toelichten waarom een gegadigde niet tot de inschrijving is toegelaten. Voor de beide onderhandse procedures gelden de motiveringsplichten eveneens: men vergelijke artikel 36 aanhef (onderhandse aanbesteding) en artikel 40 aanhef (onderhandse aanbesteding na selectie). De motivering heeft daarmee zowel betrekking op de selectie- als op de gunaingsbeslissing. In artikel 17, lid 2 UAR 1986 wordt bepaald dat alternatieve aanbiedingen ${ }^{56}$ door de aanbesteder bij de opdracht buiten beschouwing kunnen worden gelaten. Van een alternatief is sprake als de inschrijving betrekking heeft op een wezenlijke wijziging van de vourgeschreven constructie, de bouwstoffen, de werkwijze of de hulpmiddelen. Ook de 'alternatieve' inschrijver kan evenwel op de voet van artikel 24, lid 6 UAR 1986 verzoeken te worden ingelicht omtrent de redenen die tot zijn eventuele afwijzing hebben geleid.

De motiveringsplicht moet ertoe bijdragen dat de gepasseerde inschrijver begrijpt waarom hem het werk niet is opgedragen, zodat hij inzicht kan krijgen in zijn marktpositie. Er is geen termijn aangegeven waarbinnen de laagste inschrijver zijn verzoek moet doen ${ }^{57}$. Van Wijngaarden had zulks bepleit, zich daarbij aansluitend bij het voorstel-De Beer, om het passeren vór de gunning schriftelijk mee te delen ${ }^{58}$. Dit zou bovendien goed aansluiten op de systematiek van artikel 31, leden 3 en 4 UAR 1986. Volgens dit artikel verzendt de aanbesteder

s1 RvA 3 maart 1989, nr. 13.774, BR 1989, 715.

s2 TK 1979-1980, XII, 15 800, nr. 82 (Verslag van het mondeling overleg op 17 juni 1980 russen de Vaste Commissie voor Verkeer en Waterstaat en de Minister).

53 Pres.Rb. Leeuwarden 5 oktober 1983, BR 1984, 74.

s4 Cremers - Zonderland, Bouwrecht (losbladige), deel A-I, nr. 6; Asset-Coehorst-De Leede-Thunnissen (1983), 407: Spier (1981), 54. Ook Rozemond (1982), 118.

ss Over de mótiveringsplicht kritisch Van Werven (1985), 43.

s6 Geen alternatieven in de zin van art. 17, lid 3 UAR 1986 in RvA 2 juni 1992, nr. 15.782, BR 1992, 796.

s Toelichting voorontwerp-UAR 1985, 30: er is geen objectief vast te stellen moment waarop de termijn zou kunnen beginnen.

st Van Wijngaarden (1985), 266 en 270. Ook zo Van Werven (1985), 44 
ter gelegenheid van een aanbesteding met voorafgaande selectie, gelijktijdig met de uitnodigingen, aan een door hem niet gekozen gegadigde bericht, dat hij niet wordt uitgenodigd. Deze kan dan binnen tien dagen na ontvangst van het bericht om een schriftelijke motivering verzoeken van de redenen die ertoe heblen geleid dat hij niet is uitgenodigd (lid 4). De aanbesteder moet in dat geval binnen 14 dagen na ontvangst van het verzoek aan de verzoeker schriftelijk deze redenen mededelen.

De negatief geformuleerde motiveringsplicht gaat niet erg ver. De niet uitverkoren gegadigde of inschrijver heeft slechts recht op informatie waarom hij is gepasseerd. De aanbesteder is niet verplicht om een toe te lichten waarom hij aan een andere inschrijver de voorkeur heeft gegeven. Bovendien is er sprake van een motivering achteraf. Een nadere motivering ligt wel in de rede, indien de op één na laagste inschrijver gemotiveerd aangeeft aan welk inschrijvingsvereiste de laagste inschrijver niet heeft voldaan ${ }^{59}$. Blijkens RvA 4 december 1991, nr. 15.494, BR 1992, 341 m.nt. Donders kan de aanbesteder dan niet volstaan met de enkele mededeling dat het werk aan een ander wordt opgedragen. Het oordeel luidde verder, dat:

'[I]ndien een opvolgend inschrijver twijfel heeft en mag hebben omtrent de vraag of de inschrijver aan wie de aanbesteder voornemens is het werk op te dragen aan de gestelde criteria voldoet, (...) aan deze inschrijver informatie verstrekt [dient] te worden waarmee deze twijfel weggenomen kan worden; het systeem van het UAR brengt met zich mee dat niet alleen voor de aanbesteder en de laagste inschrijver, doch ook voor de overige betrokkenen controleerbaar moet zijn of de aanbesteding reglementair verloopt'.

Een overweging die past in de opvatting van de Raad dat er ook rechtsbetrekkingen bestaan tussen de inschrijvers en gegadigden onderling.

Het is nog maar de vraag of een motiveringsplicht in deze vorm de (afgewezen) inschrijver veel helpt. Donders gaat zelfs zover te veronderstellen, dat het voor gegadigden en inschrijvers wellicht beter ware indien er maar helemaal geen motiveringsplicht in het UAR 1986 was opgenomen ${ }^{60}$. Hij doelt daarmee op verdergaande betekenis van het motiveringsbeginsel als een algemeen beginsel van behoorlijk bestuur, waaraan in het UAR een beperkende uitwerking is gegeven. Dat kan ik meevoelen, al lijkt die veronderstelling (gelukkig) toch wat te 'somber'. Ik acht de gemeente steeds gebonden aan het motiveringsbeginsel als algemeen beginsel van behoorlijk bestuur, ook wanneer daarvan een species is geregeld in - bij voorbeeld - het Uniforme Aanbestedingsreglement ${ }^{61}$.

\subsection{Het Uniform Aanbestedingsreglement-EG 1991 (UAR-EG 1991)}

\section{Selectie-eisen en gunningscriteria}

De in het UAR-EG 1991 opgenomen procedures zijn volgens de Toelichting verdergaand geobjectiveerd, dan die in het UAR 1986. In overeenstemming met artikel 23 richtlijn 89/440 is in artikel 7 UAR-EG 1991 een bepaling opgenomen op grond waarvan aannemers, ongeacht de procedure, kunnen worden uitgesloten van deelneming aan een aanbesteding.

59 RvA 23 maart 1989, nr. 13.509, BR 1989, 718.

6 Donders (1992), 95.

61 In die zin ook Spier (1981), 54. Het gaat om de verantwoording van het beleid. Niet om de motivering van éen beslissing ter uitvoering daarvan. Pront-van Bommel (1993), 956 v. en Lubach (1988) achten de Raad tot toetsing aan de algemene beginselen van behoorlijk bestuur in staat. Anders Adriaansens (1988), 352. 
Vervolgens moet worden nagegaan of de gegadigde voldoet aan de financiële, economische en technische eisen, die in het reglement zijn opgenomen (artikelen 12 en 13 UAR-EG 1991). Binnen de grenzen van de genoemde artikelen kan de aanbesteder verlangen dat de in schrijver de overgelegde getuigschriften en bescheiden aanvult of nader toelicht (artikel 14 UAR-EG 1991). Daarnaast kan de aanbesteder bewijs vragen van inschrijving op een lijst van erkende aannemingsbedrijven (artikel 15 UAR-EG 1991) ${ }^{62}$. Net als in het UAR 1986 dienen de eisen objectief en eenduidig te zijn alsmede in een redelijke verhouding te staan tot aard en onvang van het werk ${ }^{63}$. De aanbesteder kan niet meer van de eenmaal gepubliceerde selectie-eisen en gunningscriteria afwijken. Tenzij andere gunningscriteria zijn vermeld, geldt als criterium voor de gunning dat van de laagste prijs. De mogelijkheid om alternatieve aanbiedingen te doen is zoals steeds beperkt tot aanbestedingen waarbij uitsluitend het criterium van de economisch meest voordelige aanbieding wordt gehanteerd ${ }^{\mathrm{t}}$. Wanneer het werk is opgedragen stelt de opdrachtgever daarvan een proces-verbaal op (artikel 64 UAREG 1991). Bovendien dient de aanbesteder die een opdracht heeft verleend het resultaat door middel van een aankondiging op Europees en nationaal niveau bekend te maken (artikel 65, leden 1 en 4 UAR-EG 1991).

Een met artikel 24, lid 2 UAR 1986 overeenkomstig 'vangnet' ontbreekt in het UAR-EG 1991. De Toelichting zegt hierover dat aan dit criterium geen behoefte bestaat 'aangezien deze eis al ligt besloten in artikel 13, eerste lid onder b'. Volgens deze bepaling kan een inschrijver ten bewijze van zijn technisch kunnen alleen refereren aan werken indien vaststaat dat deze werken vakkundig en op regelmatige wijze zijn uitgevoerd. Daardoor is in het begrip referentiewerk als het ware het vereiste van een goede uitvoering verdisconteerd, en bestaat er aan een afzonderlijke 'vangnet'-toets geen behoefte.

In RvA 6 juli 1993, nr. 16.599, BR 1994, 155 wordt uitgesproken marginaal getoetst of het aan te hesteden werk vergelijkbaar is met het referentiewerk. Volgens Donders (1994), 119 is dit te afstandelijk. Vergelijk op dit punt het jurisprudentie-overzicht inzake art. 24, lid 2 UAR 1986 (boofdstuk 4, paragraaf 2.2).

\section{Het motiveringsbeginsel}

Het reglement kent een tweetal extra motiveringsplichten aan de kant van de aanbesteder. Naast de reeds bestaande motiveringsplicht, die ook al in het UAR 1986 voorkwam ${ }^{65}$, is dit allereerst de motivering van het niet uitnodigen van gegadigden voor het overleg bij een onderhandelingsprocedure. De aanbesteder kan blijkens artikel 45, lid 1 naar eigen inzicht gegadigden, die aan de in artikel 43 bedoelde eisen voldoen, uitnodigen tot het voeren van overleg. Niet tot dit overleg uitgenodigde gegadigden moeten daarvan op de hoogte worden gebracht (artikel 45, lid 4 UAR-EG 1991). En verder dient ook het niet-plaatsen van de

Q. Een dergelijk erkenningssysteem kent men bij voorbeeld in Belgiē.

a Zie art. 11, lid 1 UAR-EG 1991. Zie voor de procedure met voorafgaande selectie: art. 36 UAR-EG 1991. Yoor de onderhandelingsprocedure met voorafgaande bekendmaking: art. 43 UAR-EG 1991. In RvA 23 sepi. 1994. nr. 17.422, BR 1995, $622 \mathrm{~m} . n \mathrm{n}$. Donders verschillen parijen van mening over de uitleg van de gestelde ervaringseis. Nu er geen sprake was van een eenduidige eis (vergelijk arukel 11, lid 1 UAR-EG 1991), geven arbiters daaraan de betekenis die door een redelijke inschrijver aan de eis gegeven zal moeten zijn. Terecht kozen arbiters in dat geval geen marginale opstelling.

4 Zie voor de keuze van de aannemer verder het bepaalde in de artikelen 31, 39, 51 en 57 UAR-EG 1991.

s Vgl. art. 31, lid 6, 38, lid 5 en art. 39 UAR-EG 1991. 
opdracht of het herbeginnen van de aanbesteding te worden gemotiveerd (artikel 63 UAR-EG 1991).

Ook aan de kant van de inschrijvers introduceert het reglement een aantal motiverings- c.q. inlichtingenplichten. In verband met het bepaalde in artikel 10, lid 6 kunnen inschrijvers worden verplicht om bij hun inschrijving aan te geven of zij bij de voorbereiding van hun inschrijving rekening hebben gehouden met de verplichtingen ingevolge de regelingen inzake arbeidsbescherming en arbeidsvoorwaarden die op de bouwplek gelden. Dit vormt geen beletsel voor de toepassing van artikel 63 UAR-EG 1991 inzake de verificatie van abnormaal lage prijzen. Wanneer een abnormaal lage inschrijving wordt gedaan kan de aanbesteder aan de inschrijver schriftelijke preciseringen verzoeken over de samenstelling van de inschrijving. De aanbesteder kan de inschrijver daarnaast om inlichtingen vragen over het gedeelte van de opdracht dat de inschrijver eventueel door derden in onderaanneming wil laten uitvoeren (artikel 66 UAR-EG 1991).

\subsection{Conclusie}

In tegenstelling tot de aanvankelijke subjectieve beoordeling door de aanbesteder zijn in het UAR 1986 de selectie- en gunningscriteria verregaand geobjectiveerd. Naast de algemene maatschappelijke geschiktheidseisen, kan de aanbesteder het bewijs vragen van de financiële, economische en technische capaciteit van de aannemer. Geëist wordt dat de eisen objectief en eenduidig zijn, alsmede in redelijke verhouding staan tot het werk (evenredigheidsbeginsel). Deze eisen beogen de transparantie van de bouwmarkt te vergroten en de concurrentie te beperken tot min of meer gelijkwaardige bedrijven. Ten dele dienen zij het belang van de inschrijver. Anderzijds moet het ontwerpen van een profielschets, waaraan de inschrijver moet voldoen, worden overgelaten aan het beleid van de aanbesteder. Arbiters toetsen de voorwaarden die aan de geschiktheidseisen worden gesteld daarom terecht marginaal. Wat de gunningscriteria betreft: de aanbesteder heeft de keuze tussen het laagste prijscriterium en het criterium van de economisch meest voordelige aanbieding.

Of de aannemer voor gunning in aanmerking komt is van twee vragen afhankelijk. Ten eerste dient hij aan de bekendgemaakte geschiktheidseisen te voldoen, en verder moet hij redelijkerwijs in staat worden geacht het werk vakkundig en op regelmatige wijze uit te voeren. Met name deze tweede toets bedreigt de objectiviteit. Arbiters toetsen thans terughoudend waardoor een juiste afstemming wordt bereikt tussen de beide toetsingsmomenten. Toch is daarmee het systeem niet waterdicht: het 'zwarte gat' van artikel 30, lid 1 UAR 1986 geeft de aanbesteder een 'nagenoeg onbeperkte en oncontroleerbare discretionaire bevoegdheid. In enkele gevallen moet een gunningsplicht worden aangenomen. De regeling van de alternatieve inschrijving laat de aanbesteder zeer veel vrijheid om deze al dan niet in beschouwing te nemen.

Naast de objectivering van de criteria introduceerde het UAR 1986 een bescheiden motiveringsplicht: de aanbesteder moet achteraf begrijpelijk maken waarom de gegadigde niet tot de inschrijving is toegelaten c.q. waarom het werk hem niet is opgedragen. Alleen voor wat betreft de onderhandse procedures is alles bij het oude gebleven, zij het dat ook hier de aanbesteder zijn beslissingen moet motiveren. Bij de onderhandse procedures zal deze motivering, gelet op de subjectiviteit van de beslissingen, weinig om het lijf hebben. Door deze objectivering en motivering van de selectie- en gunningsbeslissingen leveren de 
aanbestedingsreglementen een bijdrage aan de transparantie van de bouwmarkt. Ook de standaardisatie van het bestek vervult daarin een cruciale rol. Het UAR-EG 1991 trekt de in het UAR 1986 uitgezette lijnen door. Het 'zwarte gat' lijkt geëlimineerd, doordat een andere systematiek is gekozen. En bovendien zijn er motiveringsplichten bij gekomen; ook voor de aannemer.

\section{Beleidscoördinatie op het Europese niveau}

Het op het nationale niveau gevoerde prijs/ kwaliteitsbeleid wordt op Europees niveau gecoördineerd. Een van de coördinatiegrondslagen is - als gezegd - het opstellen van objectieve deelnemingscriteria. In richtlijn $71 / 305$ wordt onderscheid gemaakt tussen de algemene en specifieke geschiktheidscriteria en de gunningscriteria. De gemeenschappelijke regels inzake de deelneming staan in titel IV (artikel 20 tot en met 29) van de richtlijn. Er kunnen problemen bij het interpreteren van deze artikelen ontstaan, omdat de kwalitatieve criteria niet steeds duidelijk gescheiden zijn van de mogelijke referenties waarmee de inschrijvers kunnen bewijzen dat zij aan de door de aanbesteder gestelde eisen voldoen ${ }^{66}$. Op dit punt zijn inmiddels enkele verduidelijkende arresten gewezen.

\subsection{Richtlijn 71/305}

De hoofdregel inzake de deelneming aan een overheidsaanbesteding is neergelegd in artikel 20 richtlijn 71/305. Er valt te lezen:

'De gunning vindt plaats op basis van de criteria die in hoofdstuk 2 van deze titel worden vermeld, nadat de geschiktheid van de aannemers die niet uit hoofde van artikel 23 zijn uitgesloten, door de aanbestedende diensten is nagegaan overeenkomstig de in de artikelen 25 tot en met 28 vermelde criteria betreffende de economische, financiêle en technische capaciteit'.

In het arrest-Beentjes wordt in dit verband overwogen, dat de bepalingen van de richtlijn inzake de deelneming en bekendmaking tot doel hebben, de inschrijver te beschermen tegen willekeur van de aanbestedende dienst ${ }^{67}$.

De structuur van artikel 20 richtlijn $71 / 305$ is bepalend voor de opzet van deze paragraaf, waarbij eerst de algemene geschiktheidseisen (artikel 23) aan bod komen, en vervolgens de selectiecriteria (artikelen 25 tot en met 28) en gunningscriteria ('hoofdstuk 2 van deze titel'). De richtlijn sluit niet uit dat het onderzoek naar de geschiktheid van de inschrijvers en de gunning gelijktijdig plaatsvinden, maar zij bevat voor die twee verrichtingen wel verschillende regels ${ }^{68}$.

\footnotetext{
Zo was de vraag van de Belgische Raad van State, die de aanleiding vormde voor een procedure ex art. 177 EG (zaak 27-29/86 (CEI en Bellini)), onjuist gesteld. De Raad van State was er vanuit gegaan dat de waarde van het totale onderhanden werk een referentie is, terwijl het in werkelijkheid een (financieel en economisch) beoordelingscriterium betrefi.

67 Zaak 31/87, r.0. 42.

Zaak 31/87 (Beentjes), r.o. 16.
} 


\section{Algemene geschiktheid: referenties en criteria}

Artikel 23 noemt een aantal inhoudelijke criteria waaraan de aannemers ten minste moeten voldoen. Zo wordt bij voorbeeld bepaald dat een aannemer kan worden uitgesloten van deelneming aan een overheidsaanbesteding, wanneer hij in staat van faillissement of liquidatie verkeert. Daarnaast geeft het artikel aan wat moet worden beschouwd als 'voldoende bewijs', wanneer de aanbesteder van de aannemer verlangt, dat hij aantoont niet in dergelijke (in artikel 23 , sub a-f genoemde) omstandigheden te verkeren ${ }^{69}$. Daarnaast verschaft artikel 24 de grondslag voor het verzoek van de aanbesteder aan de aannemer om aan te tonen dat hij is ingeschreven in het beroepsregister volgens de eisen van het land van de Gemeenschap waar hij is gevestigd. Voor Nederland is dat het Handelsregister. Enerzijds geeft dit artikel (registratie) criteria aan op basis waarvan de gegadigde kan worden uitgesloten. Anderzijds wordt aangegeven op welke manier de aannemer het bewijs kan leveren, dat hij voldoet aan de eisen die worden gesteld voor registratie.

\section{Selectie: referenties en criteria; publikatie}

Artikel 25 bevat een lijst met mogelijke referenties waarmee de aannemer zijn financiële en economische capaciteiten kan aantonen. De aanbesteder dient deze referenties in de aankondiging of in de uitnodiging tot inschrijving aan te geven. Artikel 26 geeft een lijst met mogelijke referenties (diploma's en dergelijke) waarmee de aannemer zijn technische bekwaamheid kan aantonen. Artikel 27 bepaalt vervolgens dat de aanbesteder, binnen de grenzen gesteld in de artikelen 23 tot en met 26 , kan verlangen dat de aannemer de overgelegde getuigschriften en bescheiden aanvult of nader toelicht. Blijkens het Transporoute-arrest mag de aanbesteder, slechts andere dan de uitdrukkelijk in de richtlijn vermelde referenties vragen bij de beoordeling van de financiële en economische capaciteit van de aannemer waarvan sprake is in artikel 25 van de richtlijn. Maar daar staat tegenover dat een aannemer die om gegronde redenen niet in staat is de door de aanbesteder gevraagde referenties te verschaffen, moet worden toegelaten zijn capaciteiten door andere documenten, die de aanbesteder geschikt acht, te bewijzen ${ }^{70}$. Wat betreft de technische kwaliteiten is de richtlijn op het punt van de te verlangen referenties 'uitputtend'.

De inhoud van de geschiktheidseisen wordt door de bestuurlijke autoriteiten, in casu de gemeente, bepaald. De gemeente zal voorafgaand aan een aanbesteding moeten beoordelen welke referenties worden verlangd. Deze beoordeling vindt plaats op basis van het nationale recht der lidstaten en niet op grond van de richtlijn ${ }^{71}$.

'Niettemin volgt uit deze bepalingen (artikelen 23 tot en met 26 richtlijn 71/305; HN) dat de aanbestedende diensten de geschiktheid van de aannemers enkel kunnen theoordelen op basis van criteria die verband houden met hun economische en financiele draagkracht en technische bekwaamheid'.

* Alleen voor de situatie sub g. geeft de richtlijin geen bewijsmiddelen aan. Daar wordt bepaald dat van deelneming wordt vitgesloten, iedere aannemer die zich in ernstige mate schuldig heeft gemaakt aan de afgifte van valse verklaringen bij het verstrekken van inlichtingen die volgens de richtlijn kunnen worden gevragad.

to Zaak 76/81 (Transporoute), r.o. 10. Ook zo zaak 27-29/86 (CEI-Bellini), r.0. 9. Vgl. Winter (i991), 768-770. Zie ook zaak C-71/92 (Commissie v. Spanje), PPLRev. 1994, CS73 (José M. Fernảndez Martin).

7) Zaak 27-29/86, r.o. 11-18 (i.h.b. r.o. 13). 
Aldus (ook) het Hof in het arrest-Beentjes ${ }^{n}$.

Zo verzet de richtlijn zich er niet tegen dat een lidstaat bepaalt voor welk maximumbedrag een onderneming tegelijkertijd werken mag uitvoeren. Zie wat dat betreft het arrest-CEI en Bellini (gevoegde zaken).

7aak 27/86 (CEI) betreft een openbare aanbesteding voor de aanleg van een gedeclte van de 'Autoruute des Ardennes'. Bij onderzoek van de inschrijvingen bleek dat S.A. Constructions et entreprises industrielles (CFI) voor liet lagaste bedrag had ingeschreven. De aanbesteder verzocht vervolgens de drie best gerangschikte inschrijvers om aan te geven voor welk bedrag zij op het tijdstip van het sluiten van het contract werk in uitvuering hadden. Dit selectiecriterium beoogt, aldus de Belgische Raad van State, monopolievorming op het gebied van overheidsopdrachten te voorkomen, een eerlijke werkverdeling te verzekeren en te verhinderen, dat de concurrentie uit de hand loopt of de ondernemingen gaan speculeren en verplichtingen aangaan die bun capaciteiten te boven gaan. Toen CEI bleck meer werken in uitvoering te hebben dan de greaswaarde van 1200 miljoen Bfrs, werd zij gepasseerd, Volgens CEI was haar uitsluiting strijdig met artikel 25 richilijn 71/305.

Het Hof $^{73}$ oordeelde, dat waar het de bedoeling van deze grens is om te voorkomen dat individuele ondernemingen te grote risico's zouden aangaan, zulks een aanvaardbaar financieel en economisch selectiecriterium is. Als afdoende referentie in de zin van artikel $25 \mathrm{kan}$ daarom aan de inschrijver worden gevraagd om het totale bedrag van de hem opgedragen werken aan te geven.

Met het oog op de technische bekwaamheid (artikel 26) van de aannemer is het criterium 'specifieke ervaring voor het uit te voeren werk' een wettig criterium ${ }^{74}$, aldus het Hof in het arrest-Beentjes. Eerder had het $\mathrm{Hof}^{75}$ al geoordeeld dat de nationale wetgever ook eisen kan stellen met betrekking tot het minimumbedrag aan eigen middelen en het minimum aantal werknemers en stafleden. Ook dit worden in de regel beschouwd als eisen die betrekking hebben op de technische capaciteiten van de aannemer.

Artikel 28 heeft betrekking op die lidstaten, waar officiële lijsten van erkende aannemers bestaan. Volgens het Hof biedt dit artikel uitsluitend de aannemer de mogelijkheid om in plaats van de door de aanbesteder gevraagde referenties, binnen de grenzen van het artikel, andere bewijsmiddelen over te leggen ${ }^{76}$. Dat betekent dat de referenties, bedoeld in artikel 28 , feitelijk alleen bruikbaar zijn in het kader van de in artikel 25 bedoelde financiële en economische capaciteiten van de aannemer. Aangenomen mag worden dat geregistreerde aannemers ook andere bewijsmiddelen mogen gebruiken, wanneer daarvoor 'gegronde redenen' $z_{i j n}{ }^{77}$. De aanbestedende diensten mogen de informatie die uit de inschrijving op een officiële lijst voortvloeit, niet in twijfel trekken. Maar de artikelen 25, 26 en 28 verzetten zich er niet tegen, dat een aanbesteder van een in een andere lidstaat erkende aannemer het

${ }^{n}$ Zaak 31/87, (r.o. 17). Ook reeds CEI-Bellini (vwb. de financiee! ten economische kwaliteiten) en voorondersteft in Bellini (vwb. de technische kwaliteiten).

7 CEI-Bellini, r.o. 12-18.

74 In een andere zaak (zaak C-362/90, (Commissie v. Italie), 2353 v.) stuitte het bercep tegen een technische minimumeis af op de niet-ontvankelijkheid van de Europese Commissie.

7 Zie zaak 28-29/86 (Bellini).

75 Transporoute, r.o. 11-13. En CEI-Bellini, r.o. 24. Ook zaak C-71/92 (Commissie r. Spanje), r.o. 45, PPLRev. 1994, CS73 (José M. Fernàndez Maruin).

$n$ Arrowsmith, 29-30. 


\section{Hoofdstuk 4}

bewijs verlangt, dat hij wat betreft zijn financiële en economische draagkracht en technische bekwaamheid aan bepaalde door de nationale wetgeving gestelde eisen voldoet, ook indien die aannemer in de lidstaat van vestiging is erkend in een klasse welke overeenkomt met die welke wegens de omvang van de aan te besteden werken door bedoelde nationale wetgeving wordt verlangd, behoudens wanneer in de twee betrokken lidstaten de classificatie van de ondernemingen op gelijkwaardige criteria met betrekking tot het vereiste geschiktheidsniveau berust $^{78}$.

Ook wat de publikatie van de geschiktheidseisen betreft, werkt het onderscheid tussen de referenties en criteria door: de openbaarheid van de selectiecriteria is niet in de richtlijn geregeld. Daar gaat het alleen om de publikatie van de gewenste referenties. Het Hof oordeelde in het arrest-Beentjes, dat wanneer een selectiecriterium voortvloeide uit een bepaling van nationaal recht (in casu: het UAR) waarnaar de aankondiging van de opdracht verwees, het criterium niet behoefde te voldoen aan de bijzondere eisen van de richtlijn inzake bekendmaking in de aankondiging of in het bestek. Waar het in het Beentjes-arrest ging het om het criterium 'specifieke ervaring voor het uit te voeren werk' (als bekend een technische geschiktheidseis als bedoeld in artikel 26 richtlijn 71/305) kon de gemeente voor de te hanteren beoordelingsmaatstaven volstaan met te verwijzen naar het UAR. Dit mag onbegrijpelijk worden genoemd: het zal niet eenvoudig zijn voor buitenlandse aannemers de desbetreffende nationale regelingen te doorgronden. Bepaald onduidelijk is ook de daaraan ten grondslag liggende rechtsoverweging (r.o. 34):

'Willen de aannemers in de Gemeenschap echter in staat zijn te beoordelen of een opdracht voor hen van belang is, dan dient de aankondiging een - desnoods beknopte - vermelding te bevanten van de bijzondere voorwaarden waaraan zij moeten voldoen om geschikt te worden geacht als inschrijver voor de betrokken opdracht. Die vermelding kan echter niet worden verlangd wanneer het, gelijk in casu, niet gaat om een bijzondere geschiktheidsvoorwaarde, maar om een criterium dat juist niet te scheiden valt van het onderzoek naar de geschiktheid'.

Hier heeft mogelijk een rol gespeeld, dat het in casu een openbare aanbesteding betrof, waarbij voorafgaand aan de inschrijving geen specifieke geschiktheidseisen worden gesteld $^{79}$. Maar ook dan zou ik ervoor willen pleiten dat deze criteria door de aanbesteder bekend worden gemaakt. Het Hof zij toegegeven, dat de richtlijn daarover geen bepaling bevat. De vereiste referenties dienen daarentegen wel steeds te worden aangekondigd ${ }^{80}$.

\section{Gunning: criteria; publikatie}

De - limitatief opgesomde - gunningscriteria zijn (artikel 29, lid 1):

- hetzij alleen de laagste prijs;

- hetzij indien de gunning aan de inschrijver met de economisch voordeligste aanbieding plaatsvindt, verschillende criteria die variëren naar gelang van de aard van de opdracht, zoals prijs, uitvoeringstermijn, gebruikskosten, rentabiliteit en technische waarde.

73 Zaak 27-29/86, r.o. 26 en 28 (CEI-Bellini). Deze overweging past in 's Hofs opvatting inzake artikel 59 EG dat 'onnodige herlaling' moet worden voorkomen. Arrowsmith (1992), 53: 'This clearly seems correct.'

79 Wellicht in antwoord op de vraag van Arrowsmith (1992), 80, die zich terecht afvraagt wat bedoeld wordt met het onderscheid tussen de 'bijzondere geschiktheidsvoorwaarde' en het 'criterium dat niet te scheiden valt van het onderzoek naar de geschiktheid'.

Zaak 31/87 (Beentjes), r.o. 33. 
De gunningscriteria moeten objectief zijn en strikt relevant met betrekking tot het desbetreffende project en gelden voor alle aannemers ongeacht hun nationaliteit ${ }^{81}$.

Wat het eerste gunningscriterium betreft, heeft het Hof in het Transporoute-arrest geoordeeld, dat wanneer de aanbestedende dienst de offerte van een inschrijver in verhouding tot het uit te voeren werk duidelijk abnormaal laag acht, artikel 29, lid 5 richtlijn 71/305 hem verplicht, alvorens tot gunning van de opdracht over te gaan, de inschrijver om motivering van zijn inschrijvingen te verzoeken of hem mee te delen welke inschrijvingen abnormaal laag zijn, en hem een redelijke termijn te gunnen om aanvullende inlichtingen te verschaffen (r.o. $18)^{82}$. Van het doel van het bepaalde in dat artikel - de inschrijver tegen willekeur van de aanbesteder te beschermen - zou weinig overblijven wanneer het aan de aanbesteder zou zijn overgelaten te beoordelen of een verzoek om motiveringen dienstig is (r.o. 17).

Wat een abnormaal lage inschrijving is blijkt niet uit de richulijn, zodat hier zeker ruimte is voor concretiseringen door nationale omzettingsbepalingen. Bij de omzetting van richtlijn 71/305 in nationaal recht mogen de lidstaten echter niet wezenlijk afwijken van het bepaalde in art. 29, lid 5 van de richtlijn. Zo kan de contradictoire verificatieprocedure niet worden vervangen door een regeling die inhoudt dat bepaalde inschrijvers ambtshalve worden uitgesloten waarbij die uitsluiting geschiedt aan de hand van een mathematisch criterium ${ }^{80}$.

Het Hof komt de aanbesteder in zoverre tegemoet, dat de verificatieprocedure kan worden gestart zodra de offerte abnormaal laag lijkt te zijn, en niet pas wanneer zij duidelijk abnormaal laag is. Indien in de stukken is bepaald dat de opdracht aan de laagste inschrijver zou worden gegund, dan is de aanbestedende overheid verplicht het Raadgevend Comité inzake overheidsopdrachten ${ }^{84}$ mede te delen dat de te laag beoordeelde inschrijvingen zijn afgewezen.

M.-A. Flamme en $\mathrm{Ph}$. Flammess beschrijven het probleem dat overheidsbesturen er veelal voor terugdeinzen om hun verantwoordelijkheid te nemen bij het beoordelen van een abnormaal lage offerte. Gewoonlijk kiest men 'maar' voor de laagste prijs, met het gevaar van prijsdumping. De Nederlandse privaatrechtelijke benadering belet volgens hen een doelmatige administratiefrechtelijke controle op de regelmatigheid van het overheidsoptreden ${ }^{86}$. Hoewel artikel 29, lid 5 richtlijn 71/305 in ons land is geimplementeerd, wordt het nimmer toegepast!

Blijkens het arrest Commissie v. Italie ${ }^{87}$ heeft de overheid bij de gunning op basis van de economisch voordeligste aanbieding een discretionaire beslissingsruimte. Ge:oordeeld werd, dat de aanbestedende overheid een beslissing kon nemen op basis van variabele, op de ontwikkeling van de markt afgestemde kwalitatieve en kwantitatieve criteria. De aanbesteder

Bi $\mathrm{Pb}$ 1987, C 358, 36.

4. Daaraan had het blijkens Belg. Raad van State 4 juni 1986, TvAan. 1989, 143 ontbroken in de verhouding tussen de BeIgische Staat en N.V. Orbetra.

4 Zaak 103/88 (Fratelli Costanzo) en zaak 295/89 (Impresa Dona Alfonso \& Figli s.n.c.t. Corsorcione per lo sviluppo industrale del Commune di Malfacone (CSI) e.a.). Zie ook Belg. RvSt 4 juni 1986, TvAan 1989, 143.

84 Besluit van de Raad 26 juli 1971, 71/306, $\mathrm{Pb} \mathrm{L} 185 / 15$ van 16 augusus 1971, m.n. preambule en art. 1. Dit besluit is gewijzigd bij Besluit van de Raad 77/63 van 21 december 1976, Pb L 13/15, d.d. 15 januari 1977.

ss Flamme - Flamme (1986), 717-728.

86 'Gelukkig klagen steeds meer Nederlandse juristen deze ouderwetse zienswijze aan en wensen zij dat m:n $z i=:$. zou spiegelen aan het Franse en Belgische recht' (t.a.p. 721).

B7 Zaak 274/83, 1077. 
kan, zo bleek uit het arrest, dus niet gebonden worden aan een kwantitatief criterium ontleend aan het gemiddelde der geboden prijzen.

Wat betreft de publikatie van de gunningscriteria: wanneer gegund werd aan de inschrijver met de economisch voordeligste aanbieding, diende de overheidsaanbesteder in het bestek of in de aankondiging van de opdracht alle gunningscriteria te vermelden die, naar hij voorzag, zouden worden gehanteerd, zo mogelijk in afnemende volgorde van het belang dat er aan werd gehecht (artikel 29, lid 2). Een algemene verwijzing naar een bepaling van nationale recht, zoals het UAR, is daarvoor onvoldoende ${ }^{88}$. Naar ik aanneem omdat het anders voor (buitenlandse) inschrijvers te lastig zou worden om ze te achterhalen. Goudsmit merkte reeds lang geleden op, dat wanneer men rekening wilde houden met alternatieven (artikel 16 UAR 1972), ook dan eventuele gunningscriteria uitdrukkelijk zouden moeten worden vermeld. Hij kwam tot zijn opvatting met het oog op de non-discriminatiedoelstelling van de richtlijn ${ }^{89}$.

\subsection{Richtlijn 93/37}

Hierna wordt kort ingegaan op de wijze waarop de gemeenschappelijke regels inzake de deelneming in de gewijzigde richtlijn zijn uitgewerkt, in aanvulling op hetgeen daarover eerder bij de beschrijving van richtlijn 71/305 (oud) al aan de orde is geweest.

\section{Selectie-eisen en gunningscriteria}

De selectie-eisen en gunningscriteria zijn ten opzichte van richtlijn 71/305 niet gewijzigd. $\mathrm{Zij}$ spelen thans ook bij de beide onderhandelingsprocedures een rol (artikel 11, lid 6, tweede alinea richtlijn 93/37). Hoofdbeginsel is en blijft dat elke lidstaat er zorg voor draagt dat de aanbestedende diensten zich zonder discriminatie onder dezelfde voorwaarden als die welke zij aan nationale gegadigden stellen, wenden tot ondernemingen van de overige lidstaten die aan de vereisten voldoen (artikel 22, lid 4 richtlijn 93/37).

Nieuw is het bepaalde in artikel 30 , leden 3 en 4 richtlijn $93 / 37$. Het is de aanbesteder volgens artikel 30 , lid 3 richtlijn 93/37 alleen toegestaan andere gunningscriteria dan de in het eerste lid vermelde te hanteren, wanneer in een lidstaat reeds ten tijde van het vaststellen van de onderhavige richtlijn een bepaalde preferentiële regeling ${ }^{90}$ van toepassing was, en deze verenigbaar is met het verdrag.

In verband hiermee bepaalt het ingevoegde artikel 32 dat de lidstaten verplicht zijn de Europese Commissie van dergelijke nationale voorschriften als bedoeld in artikel 30, lid 3 richtlijn $93 / 37$ op de hoogte te stellen, als ook van de wijze waarop zij worden toegepast. Verder dienen de lidstaten de Europese Commissie jaarlijks een verslag te doen toekomen over de toepassing van deze maatregelen. De Europese Commissie legt deze verslagen vervolgens voor aan het Raadgevend Comite inzake overheidsopdrachten ${ }^{91}$.

De richtlijn kent verder een breder uitgewerkte regeling met betrekking tot de abnormaal lage prijzen. Volgens artikel 30 , lid 4 richtlijn $93 / 37$ kan de aanbesteder bij het onderzoek motiveringen inzake de zuinigheid van het bouwprocédé, de gekozen technische oplossingen of de

\footnotetext{
Zaak $31 / 87$ (Beentjes), r.o. 35.

Goudsmit (1973), 71 .

50 Dit was in art. 29, lid 4 richtijn 71/305 beperkt tot preferentie uit hoofde van steun.

9 Besluit van de Commissie van 26 mei 1987. Pb L 152, 12 juni 1987, 32 (87/305).
} 
uitzonderlijk gunstige omstandigheden waarvan de inschrijver kan profiteren voor de uitvoering van de werken of de originaliteit van zijn ontwerp, in aanmerking nemen. Indien in de stukken is bepaald dat de opdracht aan de laagste inschrijver wordt gegund, is de aanbesteder verplicht de Europese Commissie (was: Raadgevend Comité) mede te delen dat de te laag beoordeelde inschrijvingen zijn afgewezen. Niet bepaald is dat ook de redenen voor de afwijzing zouden moeten worden medegedeeld ${ }^{92}$.

Bij wijze van overgangsregeling kon tot eind 1992, wanneer de geldende nationale wetgeving zulks mogelijk maakte, de aanbesteder bij uitzondering en met uitsluiting van elke discriminatie op grond van nationaliteit inschrijvingen die in verhouding tot de prestatie abnormaal laag zijn afwijzen zonder de in de eerste alinea van artikel 30 , lid 4 , 1e alinea richtlijn 93/37 vermelde verificatieprocedure te moeten volgen, wanneer het aantal dergelijke inschrijvingen voor een bepaalde opdracht zo groot was dat de tenuitvoerlegging van deze procedure een aanzienlijke vertraging zou veroorzaken en het met de uitvoering van de betrokken opdracht samenhangende openbare belang zou worden geschaad. De in artikel 11 , lid 5 richtlijn $93 / 37$ bedoelde aankondiging diende een vermelding betreffende het gebruik van deze uitzonderingsprocedure te bevatten.

\section{Het motiveringsbeginsel}

Met de gewijzigde richtlijn wordt op communautair niveau het motiveringsbeginsel geïntroduceerd in de relatie tussen aanbesteder en gegadigden c.q. inschrijvers: de aanbesteder zal meer dan voorheen zijn handelen moeten motiveren. Zo moet de aanbesteder binnen 15 dagen na de datum van ontvangst van een verzoek daartoe aan iedere afgewezen gegadigde of inschrijver de redenen mededelen die hebben geleid tot de afwijzing van hun aanvraag tot deelneming of hun inschrijving op een aanbesteding (artikel 8, lid 1 richtlijn 93/37). In dit laatste geval moet aan de inschrijver ook de naam van de begunstigde worden medegedeeld. De aanbesteder moet voortaan ook aan alle inschrijvers en gegadigden desgevraagd mededelen, om welke redenen is besloten een aanbestede opdracht niet te plaatsen dan wel de procedure opnieuw te starten. Hij dient hiervan ook het Bureau voor officiële publikaties van de Europese Gemeenschappen in kennis te stellen (artikel 8, lid 2 richtlijn 93/37). En ten slotte moet de aanbesteder die een opdracht heeft gegund alle dienstige informatie betreffende de omstandigheden waaronder de diverse opdrachten zijn gegund (het resultaat) in een aankondiging bekendmaken.

De overheidsaanbesteder moet daantoe over elke gegunde opdracht cen proces-verbaal opmaken dat tenminste de in artikel 8 , lid 3 richtlijn 93/37 genoemde gegevens bevat. Dit procesverbaal, of de hoofdpunten hieruit, wordt door de overheidsaanbesteder op verzoek aan de Europese Commissie toegezonden. In bepaalde gevallen behoeven echter sommige gegevens betreffende de gunning niet te worden bekend gemaakt. Namelijk indien de openbaarmaking daarvan toepassing van de wet in de weg zou staan, dan wel in strijd zou zijn met het openbaar belang of de rechtmatige commerciële belangen van bepaalde overheids- of particuliere ondernemingen zou kunnen schaden, dan wel aan de eerlijke concurrentie tussen aannemers afbreuk zou kunnen doen (artikel 11, lid 5 richtlijn 93/37). De aankondiging dient zo snel mogelijk en langs de meest passende kanalen te worden toegezonden aan het Bureau voor officiële publikaties der Europese Gemeenschappen (artikel 11, lid 6 en lid 7, eerste en derde alinea richtlijn 93/37). Deze aankondiging wordt in extenso in het Publikatieblad en via de TED-databank bekend genaakt in de officiele talen, waarbij alleen de tekst in de corspronkelijke taal authentiek is (artikel 11, lid 8 richtijn 93/37).

Maar ook de aannemer dient meer openheid te verschaffen. De aanbesteder kan hem inlichtingen vragen over het gedeelte van de opdracht dat door de inschrijver eventueel aan

92 Art. 30, lid 4, derde alinea richtlijn 93/37. Vgl. anders art. 24, lid 3 COM (86) 679 def. 
derden wordt onderaanbesteed (artikel 20 richtlijn 93/37). Eenzelfde bepaling was opgenomen in artikel 22 COM (86) 679 def. (ter invoeging van artikel 20 ter richtlijn 89/440). De toelichting (t.a.p., 12) merkte daarover op dat:

"het (d.i. artikel 20 ter richtlijn 89//440; HN) mogelijk moet maken te weten te komen welk gedeelte van de opdrachten eventueel aan kleine of middelgrote bedrijven (het MKB) in onderaanbesteding wordt gegeven, een en ander om de taakverdeling messen de algemene aannemers en het MKB bij de uitvoering van overheidsopdrachten doorzichuger te maken'.

In het bestek kan de overheidsaanbesteder de inschrijver verzoeken in diens offerte aan te geven welk gedeelte van de opdracht hij eventueel voomemens is aan derden in onderaanneming te geven.

\subsection{Conclusie}

De coördinatierichtlijn onderscheidt tussen algemene geschiktheidseisen, selectie-eisen (dat wil zeggen: bijzondere geschiktheidseisen) en gunningscriteria. De publikatievoorschriften hebben betrekking op de te verlangen referenties. Door de aanbesteder te verplichten voorafgaand aan de aanbestedingsprocedure de deelnemingscriteria bekend te maken wordt de transparantie van de bouwmarkt bevorderd. Hetgeen nog wordt versterkt door de in de gewijzigde richtlijn opgenomen wederzijdse motiveringsplichten. De inhoud van de selectieeisen wordt bepaald op basis van het nationale recht: het UAR. De overheid heeft bij de gunning op basis van de economisch voordeligste aanbieding een discretionaire beslissingsruimte, zij het dat de gunningscriteria objectief en strikt relevant moeten zijn met betrekking tot het werk en uniform van toepassing voor alle aannemers. Uit 's Hofs jurisprudentie komt naar voren, dat de bepalingen inzake de deelneming tot doel hebben te voorkomen dat de gegadigden zijn uvergeleverd aan de willekeur van de aanbesteder. In dat verband is gewezen op de beperkingen waaraan het vragen van referenties is onderworpen, op de mogelijkheid voor de aannemer om zich op het bepaalde in artikel 28 richtlijn 71/305 te beroepen en de verplichte verificatieprocedure bij abnormaal lage inschrijvingen. Afwijkingen van richtlijnbepalingen worden strikt uitgelegd.

\section{4. 'Andere' beleidsuitgangspunten}

\subsection{Aanvullende voorwaarden}

Naast de algemene geschiktheidseisen, selectie- en gunningseisen onderscheidt het Hof van Justitie nog 'aanvullende bijzondere voorwaarden'. In dat verband is het arrest-Beentjes van grote betekenis. Tijdens een openbare aanbesteding, op basis van het UAR 1972, door een plaatselijke ruilverkavelingscommissie was de laagste inschrijver BV Gebroeders Beentjes (hicrna: Beentjes) gepasseerd omdat het haar zou ontbreken aan specifieke ervaring voor het uit te voeren werk (selectiecriterium), omdat haar aanbieding volgens de aanbesteder niet de meest aannemelijke zou zijn (gunningscriterium) en omdat zij niet in staat zou zijn om langdurig werklozen in te zetten. Wat dit laatste betreft: voorwaarde was dat het bouwbedrijf aan welke de opdracht zou worden gegund in staat moest zijn om ten minste $70 \%$ langdurig 
werklozen in dienst te nemen, die door bemiddeling van het gewestelijk arbeidsbureau zouden worden aangetrokken ${ }^{93}$. Hoewel een dergelijke bijzondere aanvullende voorwaarde niet in de richtlijn voorkomt, oordeelde het Hof, onder verwijzing naar zijn arrest in de gevoegde zaken CEI en Bellini, dat de eis tot het inzetten van langdurig werklozen verenigbaar is met de richtlijn, "indien zij alle relevante bepalingen van het gemeenschapsrecht eerbiedigt en met name de verboden die voortvloeien uit de in het Verdrag neergelegde beginselen inzake het recht van vrije vestiging en het vrij verrichten van diensten' (r.o. 20 en 29). Maar dit mag zoals steeds - niet leiden tot discriminatie. In de woorden van het Hof:

'Het vereiste om langdurig werklozen in te zetten, zou met name inbreuk kunnen maken op het in artikel 7, tweede alinea, EEG-Verdrag neergelegde verbod van discriminatie op grond van nationaliteit, indien mocht blijken dat alleen binnenlandse inschrijvers aan die voorwaarde kunnen voldoen dan wel dat inschrijvers uit andere Lid-Staten er moeilijker aan kunnen voldoen. (....)' (r.o. 30).

In zijn noot merkte Fierstra" op dat de erkenning door het Hof van 'bijzondere aanvullende voorwaarden' niet voor de hand lag, nu de Europese Commissie er in het Vademecum Overheidsopdrachten ( $\mathrm{Pb}$ 1987, C 358) van uit ging dat de in de richtlijn genoemde voorwaarden wel limitatief zijn.

Blijkens het opnieuw behandelde voorstel tot wijziging van richtlijn 71/305 heeft de Europese Commissie naar aanleiding van de uitspraak in de zaak-Beentjes haar beleid aangepast. In COM(89) 141 def. - SYN 71 (4 april 1989) werd voorgesteld om een artikel 22 bis in het ontwerp-richtlijn Werken op te nemen. De nieuwe bepaling betrof de mogelijkheid voor de aanbestedende diensten om voorwaarden op te leggen die ten doel hebben de langdurige werkloosheid te bestrijden en bij te dragen tot de opneming van jongeren in het arbeidsproces (p. 3). Verder merkte de Europese Commissie op dat daarvoor aansluiting was gezocht bij het Beentjes-arrest. Volgens de Europese Commissie zullen dergelijke aanvullende voorwaarden slechts kumen worden opgelegd in de context van operationele programma's die door haar zouden zijn goedgekeurd. Deze maatregel beoogde een grotere rechtszekerheid voor zowel aanbestedende diensten als belangstellende aannemers, doordat de Europese Commissie de gelegenheid werd geboden na te gaan of de voorgestelde voorwaarden verenigbaar waren met het Verdrag, voordat een uitnodiging tot inschrijving was gedaan. De Europese Commissie benadrukte dat het ontbreken van een dergelijke bepaling rechtsonzekerheid teweeg bracht en aanleiding zou kunnen geven tot het stellen van voorwaarden die indruisen tegen het verdrag. Toch heeft het er niet van mogen komen! Een dergelijke regeling ontbreekt in richtijn 93/37.

Maar ook afgezien van Fierstra's opmerking spreekt de verwijzing naar CEI en Bellini in het arrest-Beentjes minder vanzelf dan het Hof ons wil doen geloven. Bij het eerstgenoemde arrest is bet geschiktheidscriterium een selectiecriterium: de aannemer mag ten hoogste voor een bepaald bedrag tegelijkertijd werken uitvoeren. Dit criterium heeft ten doel te beoordelen of de aannemer financieel en economisch voldoende draagkrachtig is. Artikel 25 richtlijn $71 / 305$ beoogt immers niet de bevoegdheid van de lidstaten af te bakenen met betrekking tot de bepaling van de omvang van de voor deelneming aan een overheidsaanbesteding vereiste financiële en economische draagkracht. Het betoog van CEI dat het selectiecriterium 'ook andere oogmerken dient' die niets met het eigen potentieel van de ondememing van doen hebben, kan Advocaat-Generaal Mischo niet vermurwen. Erkend moet worden, aldus de

${ }^{93}$ Later in het rapport van de SER, Commissie Internationale Soeiaal-Economische Aangelegenheden. Advies overheidsopdrachten in de interne markt EG, publikatie nr. 10, 28 april 1990, 93 wordt dit werkgelegenheidsbeleid genoemd als én der matstaven ter beoordeling van de voorstellen van de Europese Commissie.

9. SEW 1990, 74-79 (M.A. Fierstra). 
Advocaat-Generaal, "dat de andere doelen die ermee (het selectiecriterium; HN) worden beoogd, niet in strijd zijn met de bepalingen van het EEG-Verdrag en beleidsaspecten betreffen die buiten het bestek van richtlijn $71 / 305$ vallen' ${ }^{\prime 95}$ (cursief van mij). Maar zo ver hoefde Mischo niet te gaan, waar hij stelde dat zo de Belgische overheid zich heeft laten leiden door het streven te voorkomen dat de ondernemingen te zware verplichtingen aangaan, het criterium verenigbaar is met artikel 25 richtlijn 71/305. Het Hof sluit zich bij deze terughoudende conclusie aan. Hij oordeelde:

'De richtlijn behelst dus niet een eenvormige, volledig communautaire regeling. Binnen (cursief van mij) het kader van de gemeenschappelijke regels die zij (de richtlijn; HN) bevat, blijven de Lid-Staten vrij om materiële en procedureregels inzake de aanbesteding van openbare werken te handhaven of vast te stellen, mits zij daarbij alle relevante bepalingen van het gemeenschapsrecht eerbiedigen en met name de verboden die voortvloeien uit de in het Verdrag neergelegde beginselen inzake het recht van vestiging en het vrij verrichten van diensten' (r.o. 15).

Het voorafgaande betekent dat zowel Advocaat-Generaal Mischo als het Hof de 'andere oogmerken' (de beleidsaspecten) hebben opgevat als bijkomende bedoelingen van een selectiecriterium (ex artikel 25 richtlijn Werken) ter beoordeling van de financiële en economische draagkracht van de aannemer. De voor dit onderzoek relevante prejudiciële vraag of de beoordelingscriteria in de richtlijn ook andere oogmerken (d.w.z. oogmerken die niet verband houden met de primaire doelstelling van de aanbesteding om de diensten onder de beste voorwaarden te verkrijgen) mocht dienen, liet het Hof enigszins in het midden ${ }^{\text {\%6 }}$.

\section{Dat is anders bij het arrest-Beentjes.}

In rechtsoverweging 28 stelt het Hof (terecht) vast dat het niet in staat zijn om langdurig werklozen in te zetten een voorwaarde is, die geen verband houdt met de toetsing van de geschiktheid van de aannemers aan de hand van hun economische, financiële en technische capaciteit, noch met de gunningscriteria. Het Hof kiest vervolgens voor het principe, dat (overigens wel) reeds besloten lag in het arrest-CEI en Bellini: ook een op zichzelf staande voorwaarde, niet zijnde een selectie- of gunningscriterium, kan verenigbaar zijn met het gemeenschapsrecht. En dit is niets anders dan de opvatting van Advocaat-Generaal Mischo die voor het arrest CEI-Bellini immers geconcludeerd had dat er in verband met een overheidsaanbesteding beleidsaspecten konden bestaan die buiten het bestek van richtlijn 71/305 vallen en die met het gemeenschapsrecht verenigbaar zouden kunnen zijn.

In zijn conclusie van 4 mei 1988 (punt 30) geeft Advocaat-Generaal Darmon als zijn mening te kennen, dat het bepaalde in de artikelen 23 tot 26 richtlijn 71/305 een verbod voor de aanbestedende dienst inhoudt om een ondernemer uit te sluiten op grond van kwalitatieve factoren waaromtrent in de aankondiging geen referenties waren gevraagd. Bovendien zijn andere dan de in de richtlijn genoemde kwalitatieve selectiecriteria (financiële, economische en technische) ontoelaatbaar, waarbij de Advocaat-Generaal verwijst naar artikel 16, sub 1 richtlijn 71/305. Dit artikel luidt:

T Zaken 27-29/86, 3364 .

* Vgl. Arrowsmith (1992), 51 . 
In de openbare procedures bevat de aankondiging ten minste de volgende gegevens:

(....)

1. de economische en technische minimumeisen die de aanbestedende diensten aan de aannemers stellen voor hun selectie; deze eisen kunnen geen andere zijn dan die der artikelen 25 en 26.

Een tegenovergestelde oplossing zou volgens hem het gevaar in zich bergen dat het beslissingsmodel van artikel 20 richtlijn $71 / 305$ als een kaartenhuis in elkaar zou storten, terwijl het bovendien een miskenning zou inhouden van de wederzijdse informatieverschaffing door de aanbestedende diensten en de ondernemers. Net als eerder Advocaat-Generaal Reisch ${ }^{97}$ gaat ook Darmon er van uit dat het kwalificatiesysteem van de richtlijn Werken gesloten is, en dat dús alleen de criteria in artikel 23-29 bepalend konden zijn voor de opdrachtverlening. In de woorden van Winter:

'According to Advocate-General Darmon, while it is true that the authorities are left a certain leeway with regard to the minimum standards which they may require of tenderers, those requirements may not concern elements of qualitative assesment other than those contemplated by those references (for instance work carried out previously, tools, average manpower). The aim of Articles 25 and 26 of the Directive is not solely to standardize the documents which may be required in applying criteria of qualitative selection. They also fix these criteria, as is shown by Article $20^{\circ}$.

De gedachte dat het beslismodel van artikel 20 richtlijn 71/305 in elkaar valt, is een bezwaar dat mijns inziens vaak ten onrechte wordt gemaakt ${ }^{99}$. Een beroep op de verenigbaarheid van een geschiktheidscriterium met de richtlijnbepalingen heeft alleen betekenis voorzover de daarmee beoogde beleidsaspecten binnen het kader van de richtlijn vallen. De conclusie van Advocaat-Generaal Darmon kon dus geen doel treffen, omdat de aanvullende voorwaarde niet valt in de termen van de artikelen 25 en 26 richtlijn 71/305. Of anders: aan het limitatieve karakter van de selectiecriteria in de richtlijn staat niet in de weg, dat er ook buiten de richtlijn 'geschiktheidscriteria' kunnen bestaan, die op andere beleidsaspecten betrekking hebben dan op het door de richtlijn gecoördineerde prijs/ kwaliteit-beleid. En daarbij past vanzelfsprekend het principiële onderscheid dat het Hof maakt tussen aanvullende voorwaarden en selectie-eisen. Dat dit principiële onderscheid niet eerder naar voren is gekomen, duidt er (hooguit) op dat het Hof niet snel aanneemt dat er sprake is van een (rechtens aanvaardbare) aanvullende voorwaarde. Wel dient nog de vraag te worden beantwoord aan welke eisen de aanvullende voonwaarden moeten voldoen. Daarvoor verwijs ik de lezer naar paragraaf 4.4 van dit hoofdstuk over de 'relevante bepalingen van gemeenschapsrecht'.

Een volgende zaak die licht werpt op de vraag naar de beleidsruimte van nationale overheden is een procedure tussen de Commissie en Italiaanse republiek ${ }^{100}$. In artikel 2, lid 1 van de Italiaanse Aanbestedingswet van 17 februari 1987 (nr. 80/87) (hierna: Aanbestedingswet) was bepaald dat de aanbestedende diensten in hun aankondiging als eis moesten opnemen dat 15 tot 30 percent van de werken zou zijn voorbehouden aan lokale onderaannemers, dat wil

9 Zaak 76/81 (Transporoute), 433-434.

Winter (1991), 769.

99 In die zin Winter (1991), 769; Arrowsmith (1992), 79 en PPLRev. 1994, CS89 (Martin) in diens nout onder zaak C-71/92 (Commissie v. Spanje). Anders Fierstra in zijn eerder aangehaalde noot in SEW 1990, 74 v. onder het arrest-Beentjes.

100 Zaak C-360/89. 
zeggen aan onderaannemers die hun maatschappelijke zetel hadden in het gebied waar de werkzaamheden zouden worden uitgevoerd. En in artikel 3, lid 3 Aanbestedingswet werd bepaald dat bij de keuze van de tot inschrijving uitgenodigde ondernemingen voorkeur bestond voor tijdelijke verenigingen en consortia waaraan ondernemingen deelnamen die hun hoofdbedrijf uitoefenden in het gebied waar de werken zouden worden uitgevoerd.

Met de Europese Commissie en de Advocaat-Generaal was het Hof terecht van oordeel dat dergelijke bepalingen in strijd zijn met artikel $59 \mathrm{EG}$, doordat zij een potentiële belemmering vormen van het vrij verrichten van diensten. Ook een beroep op de artikelen 66 juncto 56 EG bracht Italië geen soelaas. De uitspraak past in de lijn van het arrest Du Pont de Nemours $^{101}$. Aanvullende voorwaarden kunnen inbreuk maken op het ruime beginsel van non-discriminatie indien mocht blijken dat alleen binnenlandse inschrijvers aan die voorwaarden kunnen voldoen dan wel dat inschrijvers uit andere lidstaten er moeilijker aan kunnen voldoen.

Daarnaast diende het Hof zich uit te spreken over de vraag of het bepaalde in artikel 3, lid 3 Aanbestedingswet in strijd was met de artikelen 23 tot en met 26 richtlijn $71 / 305^{102}$. In de woorden van het Hof is de in artikel 3, lid 3 genoemde 'préference (...) aux associations temporaires ou consortiums auxquels participent des entreprises qui exercent leur activité principale dans la région où sont effectués les travaux' te beschouwen als 'un critère de sélection qui n'est pas mentionné aux articles 23 à 26 (...)' (r.o. 19 en 20). Bedoelde (Aanbestedings)wetsbepalingen waren derhalve strijdig met richtlijn 71/305. Het Hof volgde daarmee opnieuw de benadering van de Europese Commissie en de Advocaat-Generaal. Het is de benadering waarvoor de Europese Commissie gekozen had in haar Mededeling van 22 september $1989^{103}$. Daarin wordt streng opgetreden aangekondigd tegen als aanvullende voorwaarden vermomde selectie- of gunningscriteria. Ik citeer (voorzover relevant) punt 48 van de Mededeling:

'In sommige gevallen zulten contractuele voorwaarden (...) betrekking hebben op zaken die onk verband hnuden met de selectiecriteria of de gunningscriteria. Indien bij voorbeeld de mate waarin de inschrijvers langdurig werklozen aantrekken tot cen van de criteria wordt gemaakt voor het bepalen van wat de economisch voordeligste aanhieding (een gunningscriterium; HN) is, zou dit aanleiding geven to moeilijkheden met artikel 29 van de richtlijn inzake overheidsopdrachten voor de uitvoering van werken, zelfs indien de verplichting om het in de offerte opgegeven aantal langdurig werklozen in dienst te nemen zou worden uitgedrukt als een contractuele voorwaarde'.

Hetzelfde heeft te gelden wanneer het gaat om een selectiecriterium: dan zou strijd met artikel 25 en 26 richtlijn 71/305 voor de hand hebben gelegen. En thans: strijd met artikel 26 en 27 richtlijn 93/37.

Aandacht verdient dat de Europese Commissie, de Advocaat-Generaal en het Hof, alleen strijdigheid met de richtlijn hebben aangenomen voor wat betreft het bepaalde in artikel 3, lid 3 Aanbestedingswet. Kennelijk hebben $\mathrm{zij}$ het bepaalde in artikel 2, lid 1 Aanbestedingswet niet opgevat als een selectiecriterium. Het ligt voor de hand om te veronderstellen, dat het in het laatstgenoemde artikel gaat om een "aanvullende voorwaarde", die (terecht) niet door de beugel van artikel 59 EG kon.

\footnotetext{
101 Zaak C-21/88, 889.

102 Ik wijs er - wellicht ten overvloede - op dat de toets aan artikel 59 EG (het primaire verdragsrecht) steeds vooraf gaat aan de toets aan richtijnbepalingen.

103 Zie hierna COM (89) 400 def., d.d. 24 juli 1989.
} 
Verder heeft het Hof niet willen volstaan met het dictum dat artikel 3 , lid 3 uitsluitend strijdig was met artikel 59 EG. 's Hofs toetsing van artikel 3, lid 3 Aanbestedingswet aan de richtlijn moet daarom worden opgevat als een niet mis te verstaan signaal aan de aanbestedende overheden, dat aanvullende voorwaarden principieel moeten worden onderscheiden van geschiktheidseisen en gunningscriteria. Vermommingen zijn terecht kansloos! Of zoals de Europese Commissie het formuleert:

'Behalve in het zeer bijzondere geval dat het aantrekken van langdurig werklozen het contract voor de aanbestedende dienst economisch voordeliger zou maken, zou dit criterium niet verenigbaar zijn met de richtlijn. Hetzelfde geldt voor andere criteria die niets van doen hebben met het voorwerp van een bepaalde opdracht' ${ }^{\prime \prime}$.

Anders gezegd: het mag niet zo zijn dat de aanvullende voorwaarde gaat functioneren als een selectie- of een gunningscriterium. Advocaat-Generaal Lenz liet in zijn conclusie ruimte voor de opvatting dat lidstaten een discretionaire bevoegdheid hebben om andere selectiecriteria dan die genoemd in de artikelen 23 tot 26 richtlijn 71/305 toe te passen. Zijn redenering is de volgende: zelfs als artikel 22, alinea 1 richtlijn 71/305 'une marge de manoevre pour appliquer des critères supplémentaires, inspirés par example, par des motifs de politique économique' (p. 3413) laat, stuit het in artikel 3, lid 3 Aanbestedingswet genoemde criterium af op artikel 22, alinea 2 richtlijn. Daar staat: 'Elke lidstaat draagt er zorg voor dat de aanbestedende diensten zich onder dezelfde voorwaarden als zij aan nationale gegadigden stellen, wenden tot ondernemingen van de overige Lid-Staten die aan de vereisten voldoen'. Als dan vervolgens het Hof het selectiecriterium afwijst op grond van de eerste alinea van artikel 22 richtlijn 71/305 lijkt het er op dat het Hof terugkeert op zijn 'Beentjes-leer', althans een (veel?) minder ruimhartig standpunt inneemt als het gaat om de erkenning van de in het Beentjes-arrest bedoelde aanvullende voorwaarden. Ten onrechte. Aanvullende voorwaarden moeten principieel worden onderscheiden van selectie- en gunningscriteria in de richtlijn, die uitsluitend betrekking hebben op (de coördinatie van) het prijs/ kwaliteitsbeleid. Consequentie daarvan is dat dergelijke aanvullende voorwaarden niet onder de bepalingen van de richtlijn kúnnen vallen. En met name niet onder het bepaalde in artikel 22, lid 1.

De benadering van de Advocaat-Generaal lijkt door te klinken in het betoog van Pijnacker Hordijk en Bel ${ }^{105}$. Zij zijn blijkens hun commentaar naar aanleiding van zaak C-360/89 van opvatting dat dit arrest niet strookt met de eerdere uitspraak in de Beentjes-zaak. Met zijn uitspraak benadrukte het Hof dat selectie van aannemers uitsluitend mocht plaatshebben binnen het gesloten systeem van selectiecriteria zoals dit is neergelegd in de artikelen 23 tot 26 richtlijn 71/305. Zij willen er niet aan de verklaring voor het verschil met het Beentjesarrest te zoeken in het verschil tussen selectiecriteria en aanvullende voorwaarden. Dit leidt hen tot de conclusie dat in Beentjes meer ruimte bestond voor aanvullende nationaalrechtelijke bepalingen.

Wat het vereiste van publikatie betreft. In het Beentjes-arrest overwoog het Hof dat een dergelijke aanvullende voorwaarde moet worden toegepast met inachtneming van alle procedurevoorschriften van de richtlijn. Dat betekent dat een dergelijke uitsluitingsgrond in de aankondiging van de opdracht moet worden vermeld, opdat de aannemers van het bestaan

\footnotetext{
${ }^{104}$ COM (89) 400 def., punt 48.

los Pijnacker Hordijk - Bel (1993), 693-694.
} 
ervan kennis kunnen nemen (r.o. 36). De motivering van de voorwaarde is een zaak van nationaal recht, waarvoor ik de lezer verwijs naar het tweede hoofdstuk over de (ontbrekende) wettelijke grondslag voor het gemeentelijke aanbestedingsheleid.

\title{
4.2 Rechtmatige beleidsaspecten
}

COM(89) 400 final $^{106}$

Op 24 juli 1989 verscheen, (mede) naar aanleiding van het Beentjes-arrest, de zeer boeiende Mededeling van de Commissie over de regionale en sociale aspecten van overheidsaanbestedingen. Volgens de Europese Commissie 'is er geen enkele reden om te veronderstellen dat de beoordelingsvrijheid van de Lid-Staten in het kader van de Richtlijn 71/305/EEG zich niet zou uitstrekken tot andere doelstellingen dan de bestrijding van de langdurige werkloosheid'. Ik citeer de Europese Commissie:

\begin{abstract}
'Andere types van bescrijding van de werkloosheid bij voorbeeld van de werkloosheid onder jongeren, vormen een even rechtmatig streven. Hetzelfde geldt vermoedelijk voor een groot aantal sociale aangelegenheden, zoals bij voorbeeld beroepsopleiding, veiligheid en gezondheid, arbeidsbetrekkingen en de bestrijding van discriminatie op grond van ras, godsdienst of geslacht. Ook op deze gebieden bevatten de richtlijnen inzake overheidsopdrachten geen uitdrukkelijk verbod en evenmin een uitdrukkelijke toestemming voor de Lid-Staten om de zaak te regelen. Derhalve staat het de Lid-Staten en de aanbestedende diensten op grond van het Gemeenschapsrecht vrij dergelijke doelstellingen na te streven, op voorwaarde dat zij daarbij de bepalingen van de richtlijnen en van het Verdrag in aclit nemen. Hieruit volgt tevens dat het de Lid-Staten overeenkomstig het Gemeenschapsrecht vrijstaat de mogelijkheid van de aanbestedende diensten om dergelijke doelstellingen na te streven, te beperken' (punt 46).
\end{abstract}

Wat de aanvaardbaarheid van 'contractuele' voorwaarden betreft hangt daarbij volgens de Europese Commissie veel af van de precieze inhoud van de opgelegde voorwaarde en van de praktische gevolgen ervan voor inschrijvers uit andere lidstaten. Het komt er dus op aan steeds opnieuw de verenigbaarheid van de contractuele voorwaarden met het gemeenschapsrecht af te wegen ${ }^{107}$. Zo lijkt het aanvaardbaar, dat bij de uitvoering van een werk op een bepaalde plaats bepaalde arbeidsomstandigheden in acht worden genomen, bij voorbeeld die welke in het betrokken gebied over het algemeen worden toegepast (punt 64).

Het gebruikmaken van de door het arrest-Beentjes geboden mogelijkheden om dergelijke rechtmatige beleidsaspecten bij de aanbesteding te betrekken wordt volgens de Europese Commissie in de praktijk evenwel op drieërlei wijze beperkt. Allereerst zijn de toepassingsmogelijkheden van de contractuele voorwaarde bij leveringen kleiner dan bij de openbare werken. De betekenis van het beleidsinstrument wordt verder beperkt door het hoofddoel van de opdracht zelf. En ten slotte is de noodzaak om in elk geval afzonderlijk te onderzoeken of de contractuele voorwaarde verenigbaar is met de omstandigheden van een bepaalde opdracht, niet bevorderlijk voor het vertrouwen waarmee dergelijke voorwaarden kunnen worden opgelegd, aldus de Europese Commissie (punt 61-63) ${ }^{108}$.

\footnotetext{
${ }^{106}$ Public Procurement, Regional and Social aspects, COM (89) 400 def., d.d. 24 juli 1989.

iot Zie m.n. COM(89) 400 def., punten 51-59.

In die zin Winter (1991), 773-775.
} 
Het begrip 'contractuele voorwaarde'

Waar het Hof in het Beentjes arrest sprak van een 'aanvullende voorwaarde', maakt de Europese Commissie gewag van 'rechtmatige doelstellingen die met contractuele voorwaarden kunnen worden nagestreefd' (punt 45). Zij omschrijft de 'contractuele voorwaarde' als 'gewoon een verplichting die door de onderneming die de opdracht in de wacht sleept moet worden nagekomen' (punt 47). Wat de Europese Commissie hier 'gewoon' noemt, is wezenlijk iets anders dan wat het Hof in het Beentjes-arrest beeft bedoeld. Daar was sprake van het feit dat de gunning van de opdracht voor de uitvoering van een werk afhankelijk werd gemaakt van de voorwaarde dat de aannemer een bepaald aantal bij een gewestelijk arbeidsbureau ingeschreven langdurig werklozen zou aantrekken. Daaruit volgt dat, indien de aannemer niet aan die voorwaarde voldoet, de opdracht aan zijn neus voorbij gaat. De opvatting van de Europese Commissie gaat er daarentegen van uit dat de aannemer de opdracht al in de wacht heeft gesleept, waama hij contractueel gebonden wordt aan de nakoming van de voorwaarde. Dat is begrijpelijk wanneer wordt bedacht dat het niet zo mag zijn dat de aanvullende voorwaarden 'betrekking hebben op zaken die ook verband houden met de selectiecriteria of de gunningscriteria' (punt 48). Dat was nu precies waar AdvocaatGeneraal Darmon voor terugschrok in zijn conclusie; hij vreesde dat het beslissingsmodel van artikel 20 richtlijn 71/305 dan als een kaartenhuis in elkaar zou storten ${ }^{109}$. Problemen rijzen intussen wel indien de aannemer die de opdracht heeft verworven de voorwaarde niet kan of niet wil nakomen. De wanprestatie zit dan als het ware in de systematiek van de opdrachtverlening ingebakken. Beter is het om in de hier bedoelde gevallen na gunning te spreken van een voorwaardelijke opdrachtverlening. Kan of wil de aannemer de aanvullende voorwaarde niet nakomen dan kan hij worden gepasseerd en komt de eerstvolgende aannemer voor de opdracht in aanmerking. De gemeente zou door onderhandelingen met de betrokken aannemer te voeren voldoende zekerheid moeten krijgen dat deze inderdaad tot een dergelijke aanvullende prestatie in staat en bereid zal zijn. Deze onderhandelingen mogen vanzelfsprekend geen betrekking hebben op het prijs/ kwaliteits-aspect van de aanbesteding. Zie over dit onderhandelingsaspect Hoofdstuk 5, paragraaf 3.

\section{De verenigbaarheid met het vrije werknemersverkeer (artikel 48 EG)}

De Europese Commissie ${ }^{110}$ wijst er terecht op dat naast de mogelijkheid dat de aanvullende voorwaarden discriminerend kunnen zijn jegens buitenlandse aannemers, er ook sprake kan zijn van discriminatie jegens werknemers uit andere lidstaten van de Gemeenschap ${ }^{111}$. Ook dit aspect zal van geval tot geval moeten worden beoordeeld.

Een tour d'horizon geeft het volgende (onvolledige) beeld van de vrijheid van het werknemersverkeer. In negatieve zin betekent een vrij werknemersverkeer dat iedere discriminatie naar nationaliteit moet worden afgeschaft voor zover deze betrekking heeft op de

${ }^{100}$ Zie diens conclusie bij zaak 31/87, Beentjes. Vgl. ook Slagter (1986), 135 die verwijst naar de "maatschappelijke. eisen' in art. 7, lid 3 UAR 1986.

${ }^{110} \mathrm{COM}(89) 400$ def., punt 54.

11 Het begrip werknemer is in tal van uitspraken van het Hof nader uitgewerkı. Zie bijv. zaak 75/63 (Hoekstra), Jur. 1964, 177. Verwezen wordt verder naar de handboeken: Kapteyn - VerLoren van Themaat (1989); Wyan Dashwood (1993) en Smit - Herzog (losbl.). 
werkgelegenheid, de beloning en andere arbeidsvoorwaarden (artikel 48, lid 2 EG) ${ }^{112}$. In positieve zin impliceert het dat de onderdanen van de lidstaten het recht hebben om zich binnen het grondgebied van de andere lidstaat vrij te verplaatsen en daar te verblijven om binnen een redelijke termijn - werk te zoeken (artikel 48, lid 3 EG). Artikel 48, lid 3 EG geeft een niet-limitatieve opsomming van de rechten waarvan de onderdanen van de lidstaten in het kader van het vrije werknemersverkeer profiteren. Terwijl er anderzijds geen afwijkingen van de hoofdregel van artikel 48, lid 1 EG mogelijk zijn, anders dan genoemd in lid 3. Het gaat dan om beperkingen die uit hoofde van openbare orde, openbare veiligheid en volksgezondheid gerechtvaardigd zijn. Gelet op de omvangrijke jurisprudentie kan zonder meer worden gesteld dat het hierbij gaat om communautaire begrippen ${ }^{113}$ Deze beperkingen hebben betrekking op het recht om een lidstaat te kunnen binnengaan, en zien niet op de situatie waarin reeds in deze lidstaat wordt gewerkt.

Richtlijn 64/221 ${ }^{114}$ coördineert de nationale regelingen met betrekking tot de in het derde lid genoemde beperkingen. Deze richtlijn vormt een verduidelijking van de marges waarbinnen lidstaten een gerechtvaardigd beroep kunnen doen op de beperkingen van artikel 48 , lid 3 EG. Deze restricties mogen met name niet worden ingeroepen om economische doelstellingen te bereiken ${ }^{115}$. Maatregelen gebaseerd op de begrippen openbare orde en openbare veiligheid moeten uitsluitend zijn gebaseerd op het individuele gedrag van de betrokkene. Artikel 48, lid 3 EG ziet niet op zuiver interne situaties, dat wil zeggen situaties die geheel binnen de interne sfeer van een lidstaat zijn gelegen ${ }^{116}$.

De marge waarover nationale overheden, gegeven de strikte uitleg van artikel 48, lid 3 EG beschikken, is onderwerp geweest van een aantal arresten van het Europese Hof van Justitie. In het Van Duyn-arrest ${ }^{17}$ overwoog het Hof dat het begrip 'openbare orde' in communautair verband in relatie tot de beperking op het uitgangspunt in artikel 48, lid 1 EG strikt moet worden opgevat, zodat de strekking ervan niet eenzijdig door elk der lidstaten kan worden bepaald. Niettemin kunnen de specifieke omstandigheden die een beroep op het begrip openbare orde rechtvaardigen naar land en tijd verschillen en mitsdien moet aan de bevoegde nationale autoriteiten een beoordelingsmarge, binnen de door het verdrag gestelde grenzen, worden toegekend. Volgens het Hof ${ }^{18}$ mogen deze beperkingen slechts worden gesteld wanneer de onderdanen van andere lidstaten door hun aanwezigheid of door hun gedrag een werkelijke en genoegzaam ernstige bedreiging voor de openbare orde oplevert. Daarvan is geen sprake als het gastland wegens diezelfde gedragingen, door eigen onderdanen begaan, geen repressieve maatregelen neemt, noch ook andere daadwerkelijke, op bestrijding van zulke gedragingen gerichte maatregelen ${ }^{119}$. Inbreuken op fundamentele rechten zoals deze zijn neergelegd in het Europees verdrag tot bescherming van de rechten van de mens en de fundamentele vrijheden (Trb. 1951, 154) mogen niet verder gaan dan in een demokratische samenleving noodzakelijk is ${ }^{120}$. Het moet derhalve gaan om een noodzakelijk en passend midde $l^{121}$.

\footnotetext{
$1{ }^{2}$ Pickup (1986), 135 v. Zie verder Johnson - O'Keeffe (1994), 1313 v., m.n. 1334-1340.

i1) In die zin Kapteyn - VerLoren van Themaat (1989), 418.

116 Richtlijn 64/221, Pb L 56/850 (4 april 1964).

is Vgl. art. 2, lid 2 richtiijn $64 / 221$.

${ }^{116}$ Bijv. zaak 298/84, r.o. 17 (lorio Paolo v. Azienda Autonome della Ferrovie dello Stato)

i1) Zaak $41 / 74$, r.o. 18.

th Zaak $36 / 75$, r.o. 28.

119 Zaak 115-116/81, r.o. 8 (Adoui).

120 Zaak 36/75, r.0. 32.

(3) Vgl. zaak 11/70, r.o. 12 (Internationale Handelsgesellschaft). Het Bouchereau-arrest (zaak 30/77, r.o. 35) bevestigt dit.
} 
Blijkens het arrest Rush Portuguesa ${ }^{122}$ hebben de uit de lidstaten afkomstige werknemers van de aannemer eveneens een beroep op de vrijheid van dienstverlening, voorzover de aannemer/ werkgever zelf rechten kan ontlenen aan artikel $59 \mathrm{EG}$. Met andere woorden: beperkingen op het gebied van het vrije werknemersverkeer (zoals destijds in verband met de Toetredingsakte) kunnen geen beperkingen vormen op bet vrije dienstenverkeer ${ }^{123}$. Of zulks ook heeft te gelden voor werknemers die geen onderdaan zijn van één van de lidstaten lijkt aannemelijk ${ }^{124}$.

De Porrugese vennootschap Rush Portuguesa Lda is een bedrijf dat werkzaam is in de sector bouwnijverheid en openbare werken. Rush Portuguesa sloot met een Franse onderneming een onderaannemingsovereenkomst voor werkzaamheden aan de TGV-Atlantique in Frankrijk. Voor de uitvoering van de werkzaamheden liet Rush Portuguesa Portugese werknemers overkomen. Bij controle door de Franse arbeidsinspectie bleek dat de werknemers niet in het bezit waren van de voorgeschreven werkvergunning, voor onderdanen van derde-landen die in Frankrijk in loondienst zijn. Bovendien waren zij niet aangeworven door het Office national d'immigration. Verder is van betekenis dat de artikelen 215 tot en met 232 van de Toetredingsakte voor Spanje en Porugal wat betreft het vrije werknemersverkeer een overgangsperiode voorziet, tot, in beginsel, 1 januari 1993. Behoudens enkele specifieke uitzonderingen, die hier niet relevant zijn, zijn verder de artikelen inzake de vrijheid van vestiging en dienstverlening zonder overgangsperiode van toepassing. Rush Portuguesa bestrijdt de bijzondere heffing van FFrs. 1,5 miljoen met een beroep op de artikelen 59 en 60 en artikel 2 Toetredingsakte. Volgens het Hof is het opleggen van de vergunningsvoorwaarde materieel discriminerend (r.o. 12). De oplegging van dergelijke voorwaarden aan de in een andere lidstaat gevestigde dienstverrichter discrimineert deze ten opzichte van zijn in het land van ontvangst gevestigde concurrenten. Het beroep op de in artikel 216 Toetredingsakte voorziene mogelijkheid om op nationaal niveau een vergunning te verlangen faalde, nu er in casu slechts sprake was van een tijdelijke verplaatsing. De in artikel 216 Toetredingsakte voorziene vergunningseis had alleen betrekking op Porngese werknemers die blijvend op de arbeidsmarkt van één der lidstaten vraagt te worden toegelaten. De ratio daarvan was dat zo een verstoring van de arbeidsmarkt(en) kon worden voorkomen.

Later, in de toeristengidsarresten ${ }^{125}$ past het Hof de Rush Portuguesa-redenering toe op dienstverrichters die gebruik maken van anderen dan werknemers, voorzover deze niet zijn gevestigd in de lidstaat waar de dienst moet worden verricht. Hier zou gedacht kunnen worden aan in het buitenland gevestigde onderaannemers, die door de hoofdaannemer in het gastland aan wie het werk is opgedragen, bij de uitvoering daarvan worden ingeschakeld.

In de hierbedoelde arresten stelde het Hof vast dat Frankrijk, Italië en Griekenland in strijd met artikel 59 EG handelden door de dienstverrichtingen van toeristengidsen (vgl. de onderaannemers), die een groep toeristen uit een andere lidstaat begeleidden aflankelijk te stellen van het bezit van een beroepskaart c.q. van een vergunning ten bewijze van een bepaalde professionele kwalificatie.

\subsection{Aanbestedingen en artikel 92 v. EG}

\section{Standpunt Europese Commissie}

Een terrein dat zich niet leent voor 'aanvullende voorwaarden' is de voorkeursbehandeling bij overheidsopdrachten. Dit moge blijken uit het navolgende.

12 Zask 113/89, 1417, NJ 1991, 703.

${ }^{123}$ In die zin Jalles (1990), 310. Zie ook RTDE 1990, 635 v. (Rodière).

124 Vgl. (in bevestigende zin) SEW 1991, 197 (M.A. Fiersira). Zie ook zaak C-43/93, 9 aug. 1994, NJB-rechtspraakkatem 1994, 587 (Vander Elsı v. Office des migrations internationales).

123 Zaak C-154/89 (Europese Commissie v. Frankrijk), zaak C-180/89 (Europese Commissie v. Italie) en zaak C198/89 (Europese Commissie v. Griekenland). Vgl. SEW 1992, 821 v. (M.A. Fierstra). 


\section{Hoofdstuk 4}

'Als de overheid een opdracht om andere dan commerciele redenen niet gunt aan de inschrijver die de laagste prijs bedingt, kan de boveelheid koopkracht die zij afstaat boven het bedrag dat de laagste bieder bereid is te accepteren, gezien worden als een subsidie aan de onderneming waaraan de opdracht is gegund'.

Aldus Winter ${ }^{126}$. Daartue behoort ook de voorkeursbehandeling bij overheidsopdrachten $^{127}$. Daarover merkte destijds hij op, dat de Europese Commissie er van leek uit te gaan dat de met een voorkeursbehandeling gepaard gaande discriminatie van buitenlandse ondernemingen inbreuk maakte op de regels inzake de vrijheid van vestiging en dienstverlening. ter concretisering waarvan richtlijnen zijn ontworpen ${ }^{128}$. Er waren naar zijn mening geen aanwijzingen dat de Europese Commissie de artikelen 92 en volgende EG toepaste op gevallen waarin nationale ondememingen bij de plaatsing van overheidsopdrachten voor de uitvoering van werken een voorkeursbehandeling genoten. Anderzijds sloot de Gemeenschapswetgever niet uit dat de lidstaten steun verleenden, die verenigbaar was met de eisen van art. 92 v. EG (artikel 29, tid 4 richtlijn 71/305). Dit artikel luidde:

'Lid 1 (over de gurumigscriteria; HN) is niet van toepassing wanneer een Lid-Staat in het kader van voorschriften welke aan bepaalde inschrijvers uit hoofde van steun, preferentie verlenen, voor de gunning van opdrachten van andere criteria uitgaat, mits de aangehaalde regeling verenigbaar is met het Verdrag en in het bijzonder de arrikelen 92 en volgende'.

Dit artikel werd blijkens het Gemeenschappelijk Standpunt van de Raad (d.d. 4 november $1988,8970 / 88)$ als volgt gewijzigd:

'Lid 1 is niet van toepassing wanneer een lidstaat in het kader van bij de vaststelling van deze richtlijn geldende voorschriften waarbij aan bepaalde inschrijvers preferentie wordt verleend, voor de gunning van opdrachten van andere criteria uitgaat, mits de desbetreffende voorschriften verenigbaar zijn met het Verdrag'.

Een toelichting ontbreckt helaas. Deze bepaling is overgenomen in COM(89) 141 def. - SYN 71 ) en in art. 29, lid 4 richtlijn $89 / 440$. Zie thans materieel hetzelfde artikel 30 , lid 3 richtlijn $93 / 37$. Naar mijn mening kan uit het verschil in redactie (verenigbaar met het verdrag in plaats van verenigbaar met artikel 92) worden afgeleid dat de toetsing aan artikel 92 en volgende EG zo mogelijk nog minder snel aan de orde is als voorbeen. Een zelfde redenering kan worden gevolgd voor artikel 31 richtlijn 93/37.

Een met dit artikel materieel vergelijkbare bepaling werd ingevoegd in COM(89) 141 def. - SYN $71^{129}$. Het toenmalige artikel 29 bis., lid 1 luidde:

126 Winter (1981), 90-91. Zie verder staatssteun en aanbestedingen Dennis Swana, Standards, procurement, mergers and state aids, in: The Single European Market and Beyond. A Study of the Wider Implications of the Single European Act (Dennis Swann ed.), London 1992, 53-80.

127 Anders Martin en Stehmann (1991), 231-239. Zie voor het begrip overheidssteun i.v.m. EG-controle SER-advies 91/04, Advies EG-controle op nationale steun aan ondernemingen, SER-ISEA, publikatienr. 4, 22 februari 1991. 11 v. Maatregelen die staatssteun inhouden dienen op groad van artikel 93, lid 3 EG bij de Europese Commissie te worden aangemeld. Over de wijze waarop art. $92 \mathrm{EG}$ bij regionale steunnaatregelen dient te worden toegepast, zie men de Mededeling van de Commissie in $\mathrm{Pb}$ C $212 / 2,12$ augustus 1988. Zie eerder $\mathrm{Pb}$ C 31/9, 3 februari 1979. Zie ook Niemeyer (1993), 273 v.

128 Winter (1981), 167-169.

${ }^{129}$ Ook zo art. 29 bis richdijn $89 / 440$. 
'Deze richtlijn vormt tot en met 31 december 1992 geen beletsel voor de toepassing van de bestaande nationale voorschriften betreffende het plaatsen van overheidsopdrachten voor de uitvoering van werken die de vermindering van de regionale ongelijkheden en de bevordering van de werkgelegenheid in minder begunstigde regio's en in door de achteruitgang van de industrie getroffen gebieden beogen, mits deze voorschriften verenigbaar zijn met het Verdrag. met name met de beginselen van uitsluiting van elke discriminatie op grond van nationaliteit, van de vrijheid van vestiging en het vrij verrichten van diensten en met de internationale verplichtingen van de Gemeenschap'.

Volgens het tweede lid geldt zulks onverminderd artikel 29 , lid 4.

Het huidige beleid van de Europese Commissie wordt aangegeven in de punten 93 en 94 van de Mededeling ${ }^{130}$. Dit komt er op neer, dat preferenties alleen worden toegestaan in gevallen waarin de lidstaat kan aantonen dat dergelijke steunmaatregelen onder de gegeven omstandigheden economisch niet van betekenis zijn. Voorwaarde is dan wel dat de regeling doorzichtig is. Aanbestedingsregelingen waarin overheidsbestellingen zonder meer voor nationale bedrijven worden gereserveerd worden niet beschouwd als doorzichtig. Wanneer een regeling evenwel gebaseerd is op een doorzichtig systeem, zoals een aanvaardbare prijspreferentie in de orde van 5 tot $10 \%$, moet het mogelijk zijn het bovengenoemde bewijs te leveren ('de minimis'-uitzondering). De Commissie zal systemen die worden toegepast beneden de drempel onderzoeken met inachtneming van de doorzichtigheid van het aanbestedingssysteem en van de invloed op het handelsverkeer, en op grond daarvan de passende beslissing nemen $^{\text {t3! }}$

Kennelijk vormt het bepaalde in artikel 59 juncto richtlijn Werken ook thans bij uitstek de weg waarlangs de Commissie preferentiële systemen voor overheidsopdrachten wil aanpakken. Alleen wanneer er geen richtlijnen zijn vastgesteld, zoals (destijds) op het gebied van de energievoorziening, kiest de Europese Commissie de weg van artikel 92 EG.

Gewezen wordı op een beschikking van de Europese Commissie van 27 juni $1984^{132}$ inzake het voomemen van de Franse regering tot toekenning van een speciale koersgarantie aan Franse exporteurs met betrekking tot de aanbesteding van een electrische centrale in Griekenland. Volgens vast beleid van de Europese Commissie is exportsteun in het intracommunautaire handelsverkeer onverenigbaar met de gemeenschappelijke markt in de zin van artikel 92 , lid 1 EG. Dergelijke maatregelen komen niet in aanmerking voor één der in artikel 92, lid 3 genoemde uitzonderingen. Dit standpunt vond steun in de arresten van het Hof (gevoegde zaken 6 en 11/69, Frans preferentieel herdiscontotarief).

\section{Standpunt Europees Hof}

Ook het Europese Hof heeft zich meermalen over preferentiële systemen uitgelaten. In zaak 103/84 (Commissie v. Italië) oordeelde het Hof dat de verdragsbepalingen betreffende steunmaatregelen in geen geval kunnen worden benut om afbreuk te doen aan de verdragsbepalingen betreffende het vrije goederenverkeer. Het feit dat een nationale maatregel eventueel als een steunmaatregel in de zin van artikel 92 EG kan worden aangemerkt, is onvoldoende grond om hem aan het verbod van artikel 30 EG te onttrekken.

De opvarting als zou deze uitspraken betekenen dat ook als artikel 92 EG van toepassing, dan ook artikel 30 EG geldt, zou weinig overlaten van de steunmaatregelen, als deze steeds zou moeten worden afgewogen, tegen het vrije

\footnotetext{
${ }^{10}$ COM (89) 400 def.

131 $\mathrm{COM}(89) 400$ def., nr. 41 en 42.

13. Beschikking ar. 84/416, Pb L 230/25, 28 augustus 1984.
} 
verkeer van goederen. Minder restrictief is de opvatting dat artikel 30 EG van toepassing als de steunmaatregelen verder gaan dan nodig is ${ }^{13}$.

Vervolgens stelde het Hof vast, dat Italië, door van de gemeentelijke bedrijven voor openbaar vervoer te verlangen dat $\mathrm{zij}$, om krachtens een wettelijke regeling in aanmerking te komen voor financiële steun, in het binnenland vervaardigde voertuigen moesten kopen, in strijd had gehandeld met artikel $30 \mathrm{EG}$.

De vraag die dan nog open staat is of een regeling die (een percentage van de) overheidsopdrachten voorbehoudt aan ondernemingen, die in bepaalde delen van het nationale grondgebied zijn gevestigd al of niet in strijd is met artikel $30 \mathrm{EG}$, ervan uitgaande dat een dergelijk preferentieel systeem 'eventueel als een steunmaatregel in de zin van artikel 92 kan worden aangemerkt'. Deze vraag werd beslist in de zaak die bekendheid verwierf onder de naam Du Pont de Nemours ${ }^{134}$ en heeft betrekking op een regionale voorkeur bij overheidsaanbestedingen op het gebied van leveringen. Vraag was of de Italiaanse overheid in strijd met het Europese recht had gehandeld, door $30 \%$ van de overheidsopdrachten voor de levering van röntgenfilm en -vloeistof ${ }^{135}$ te reserveren ten gunste van in Zuid-Italië (Mezzogiomo) gevestigde ondernemingen. Naar het oordeel van het Hof verzerte artikel $30 \mathrm{EG}$ zich tegen een dergelijke preferentiële nationale regeling. Het Hof wees bij haar prejudiciële beslissing op constante jurisprudentie op grond waarvan maatregelen van gelijke werking als kwantitatieve invoerbeperkingen zijn verboden, en overwoog dat deze rechtspraak van toepassing is op iedere handelsregeling die de intracommunautaire handel al dan niet rechtstreeks, daadwerkelijk of potentieel kan belemmeren ${ }^{136}$. Aan deze conclusie deed (dus) niet af dat de beperkende gevolgen van het voorkeursregime verhoudingsgewijs even groot waren voor produkten vervaardigd door ondernemingen van de betrokken lidstaat die niet in de desbetreffende streek zijn gevestigd als voor de produkten die zijn vervaardigd door in andere lidstaten gevestigde ondernemingen.

Winter ${ }^{137}$ wijst er in dit verband op dat de 'de minimis'-vitzondering in COM (89) 400 def., nr. 41 en 42 voor wat betreft de aanvaardbaarheid van prijspreferentie vermoedelijk op gespannen voet staat met de opvatting van het Hof in de Du Pont-rechtspraak. Volgens vaste rechtspraak van het Hof kan een nationale maatregel niet aan de toepassing van artikel 30 EG ontsnappen om de eenvoudige reden, dat het effect ervan op de interstatelijke handel gering is ${ }^{13 t}$.

Dit oordeel werd naderhand bevestigd in het arrest-Laboratori Bruneau Srl t. Unità Sanataria Locale RM/24 de Monterotondo ${ }^{139}$. Tot dusverre ging het steeds om de verhouding tussen artikel 30 en $92 \mathrm{EG}$, hetgeen te verklaren is uit de beperkte betekenis van het vrije

133 In die zin Arrowsmith (1992), 100-102.

13. Zaak C-21/88, Jur. 1990, 889. Vgl. SEW 1991, 137 (Peter Jacob) en Arrowsmith (1992), 95 v.

ts Richtlijn $88 / 295$ van 22 maart 1988 wt wijziging van richtlijn $77 / 62$ en van sommige bepalingen van richtlijn $80 / 767, \mathrm{~Pb} 1988, \mathrm{~L} 127 / 1$.

136 Zaak $8 / 74,837$ v. (Dassonville).

137 Winter (1991), 781.

138 Gevoegde zaken 177-178/82 (Van de Haar), Jur. 1984, 1797: zaak 269/83 (Commissit v. Frankrijk), Jur. 1985. 837, zaak 103/84 (Commissic v. Italie), Jur. 1986, $1759 \mathrm{cn}$ zaak 45/87 Dundalk, waarover Arrowsmith (1992). 67. In dezelfde zin Hancher - Ottervanger - Slot (1993), 188, nr. 13.54.

139 Zaak C-351/88, Jur. 1991, I-3641. 
dienstenverkeer in het recente verleden. Mijns inziens zal het voorafgaande ook hehben te gelden in de verhouding tussen art. 59 en art. 92 EG.

\section{4 'Alle relevante bepalingen van het gemeenschapsrecht'}

\section{Algemene opmerkingen}

Aanvullende voorwaarden mogen voor inschrijvers uit andere lidstaten geen direct of indirect discriminerende werking hebben. Maar daarbij moet worden aangetekend dat met name indirecte discriminatie als gevolg van een aanvullende voorwaarde door een nationale rechter niet eenvoudig zal zijn vast te stellen. De eis van non-discriminatie (artikel $6 \mathrm{EG}$ ) zal daarom waarschijnlijk vooral indirect aan de orde komen, namelijk wanneer komt vast te staan dat gemeentelijke overheden niet alle relevante bepalingen van het gemeenschapsrecht eerbiedigen en met name de verboden die voortvloeien uit de in het verdrag neergelegde beginselen inzake het recht van vestiging (artikel $52 \mathrm{v}$. EG) en het vrij verrichten van

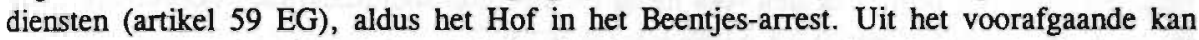
worden geconcludeerd dat de artikelen inzake steunmaatregelen buiten de 'relevante' gemeenschapsrechtelijke bepalingen vallen.

Hierna zal worden onderzocht aan welke criteria de aanvullende voorwaarden moeten voldoen, gelet op de beide vrijheden, die door het EG-verdrag worden gegarandeerd. Vaste rechtspraak is dat de artikelen $52^{140}, 59$ en $60 \mathrm{EG}^{141}$ na het verstrijken van de overgangsperiode rechtstreeks toepasselijk geworden zijn en dat hun toepasselijkheid niet afhangt van de harmonisatie of de coördinatie van de wetgevingen der lidstaten. Uitgangspunt van het EG-verdrag is dat er een verbod bestaat op beperkingen van de vrijheid van vestiging en het vrije verkeer van diensten. dat wil echter niet zeggen dat elke maatregel door de artikelen 52 en 59 EG-verdrag volstrekt verboden wordt. Soms zijn bepaalde beperkingen toegelaten, doordat er dwingende redenen van algemeen belang bestaan die zulks rechtvaardigen. Wat deze dwingende redenen betreft, maakt het Hof verschil tussen 'onderscheid'- maatregelen en 'zonder onderscheid'-maatregelen. Dat onderscheid wordt hierna aangehouden.

Het eerder genoemde vrije werknemersverkeer, de vestigingsvrijheid en het vrije dienstenverkeer, hangen nauw met elkaar samen. Zo kunnen de voorwaarden, die een lidstaat waar de diensten worden verricht, stelt, met betrekking tot de werknemers waarvan de aannemer gebruik maakt, een beperking betekenen van het vrije dienstenverkeer. Gormley ${ }^{142}$ zet op dit punt het Beentjes-arrest af tegen een, naar zijn zeggen, meer 'communautaire' visic in de zaak Rush Portugesa. Volgens deze auteur heeft laatstgenoemde uitspraak meer te bieden voor ondernemingen die gebruik willen maken van de door het EG-Verdrag gewaarborgde vrijheden. Ik ben het met Gormley eens, waar hij de beide uitspraken niet inconsistent noemt. In 'Beentjes' ging bet primair over de reikwijdte van de plicht om niet te discrimineren op grond van nationaliteit; 'Rush Portuguesa' betrof het de spanning tussen het vrije dienstenverkeer en het vrije werknemersverkeer. Of Beentjes inderdaad 'minder communautair' is, hangt mijns inziens in belangrijke mate af van de appreciatie van de rol, die eventuele andere beleidsaspecten spelen, ter gelegenheid van de opdrachtverlening.

Maar niet alleen het vrije verkeer van werknemers en het vrije dienstenverkeer hangen nauw samen. Hetzelfde geldt voor de vestigingsvrijheid en de vrijheid van het dienstenverkeer, hetgeen onder meer blijkt uit de overeenstemmende systematiek van de artikelen 52-58 en 59-66 EG. In de praktijk is sprake van een vloeiende overgang tussen de vrij-

\footnotetext{
${ }^{140}$ Zaak $2 / 74$ (Reyners).

${ }^{141}$ Zaak $33 / 74$ (Van Binsbergen).

${ }^{142}$ Gormley (1992), 86: 'in feite het aanvaarden van lokale voorkeur'.
} 
heid van vestiging en dienstverrichting ${ }^{143}$. Dat wil natuurlijk niet zeggen dat er geen onderscheid zou kunnen worden gemaakt. Zo verklaarde het Hof in zijn arrest U. Steymann v. Staatssecretaris van Justitie ${ }^{14}$ voor recht dat artikel 59 en 60 niet van toepassing zijn op het geval waarin een onderdaan van een lidstaat zich naar het grondgebied van een andere lidstaat begeeft en er zijn hoofdverblijf vestigl om er gedurende onbepaalde tijd diensten te verrichten of te ontvangen. Naar gelang het geval kan de verrichte werkzaamheid wel onder de werkingssfeer van de artikelen 48 tot en met 51 en 52 tot en met 58 EG vallen. In meer recente literatuur en rechtspraak wordt nog de relatie tussen de vrijheid van het goederenverkeer en de dienstenvrijheid benadruki ${ }^{145}$. Dit laatste blijkt hierna van grote betekenis.

\section{'Onderscheid'-maatregelen}

BEGINSEL VAN NON-DISCRIMINATIE NAAR NATIONALITEIT. Blijkens de rechtspraak van het Hof wordt er van uitgegaan, dat voor wat betreft de vestigingsvrijheid (artikel 52 EG) niet alleen formele discriminatie naar nationaliteit ('overeenkomstig de bepalingen welke door de wetgever van het land van vestiging voor de eigen onderdanen zijn vastgesteld') is verboden, maar dat zulks ook heeft te gelden voor materiële discriminatie. Materiële discriminatie werd bij voorbeeld aangenomen in het Vlassopoulou-arrest ${ }^{146}$.

Irene Vlassopoulou is een Griekse advocate, toegelaten tot de Griekse balie, woonachtig en werkzaam in Duitsland. Zij was in Duitsland gepromoveerd op een Duitsrechtelijk onderwerp, werkzaam bij een Duits advocatenkantoor etc. De Duitse regering weigerde haar de toetreding tot de Duitse balie, omdat zij niet de Duitse examens had afgelegd.

Het Hof verklaarde voor recht, dat artikel 52 EG (vestigingsvrijheid) zo moet worden uitgelegd dat de nationale autoriteiten van een lidstaat dienen te onderzoeken in hoeverre de kennis en kwalificaties, zoals deze blijken uit het door de belanghebbende in zijn land van herkomst behaalde diploma, overeenkomen met die welke door de wettelijke regeling van het gastland worden vereist. Wanneer bij vergelijking van de diploma's blijkt dat de kennis en kwalificaties overeenkomen met hetgeen door de nationale bepalingen wordt verlangd, dan is de lidstaat gehouden te aanvaarden dat dit diploma voldoet aan de gestelde voorwaarden (r.o. 19).

Het Hof ging niet in op de vraag of de voorwaarden voor toegang tot het beroep (van advocaat) een objectieve rechtvaardiging zou behoeven. Tegen het besluit van de autoriteiten van het gastland moet beroep openstaan bij een rechterlijke instantie, zodat kan worden onderzocht of het besluit conform het gemeenschapsrecht is. De belangheb-

103 In die zin Kapteyn - VerLoren van Themaat (1989), 429. Zij omschrijven het verschil als 'economically arbitrary and moreover fluid in practice'. Ook zo De Wilde (1994), 793. (Enigszins) anders Stuyck en Geens (1993), 121. En Von der Groeben - Thiesing - Ehlerman (1991), Deel I (art. 59 EG).

14 Zaak 196/87, r.o. 17.

ids Hieruver Roth (1988), $35 \mathrm{v}$.

146 \%aak .340/89, r.o. 15. Vgl. SEW 1992, 644 (M.A. Fierstra). CMLRev. 1992, 635 (Torsten Stein). Deze auteur is van mening dat het arrest in die zin kan worden gelezen, dat deze 'within the traditional interpretation of Article 52 EEC' blijft. Over deze verschillen qua reikwijdte van bet bepaalde in art. 52 EG nog Nachbauer (1991), 470 en Hailbronier - Nuclibauer (1992), 109 en de daar genoemde literatuur. Zie ook zaak C-375/92 (Commissie v. Spanje), r.o. 13. 
bende moet kennis kunnen nemen van de motivering van het jegens hem genomen besluit. ${ }^{107}$. En ook omgekeerde discriminatie is uit den boze $\mathrm{e}^{148}$.

Ook voor de vrijheid van het dienstenverkeer geldt dat niet slechts formele maar ook materiële discriminatie uit den boze is. Met name mag een lidstaat de verrichting van diensten op zijn grondgebied niet afhankelijk stellen van de inachtneming van alle (eigen) nationale vestigingsvoorwaarden, omdat hij daarmee de verdragsbepalingen die het vrije dienstenverkeer moeten verzekeren, ieder nuttig effect zou ontnemen. In het Gullung-arrest $^{149}$ werd herhaald voor artikel 59 EG wat eerder al was geoordeeld in het arrest-Knoors met betrekking tot artikel 52 EG: men kan ook op het terrein van de dienstverlening tegenover de eigen lidstaat in het geweer komen ('omgekeerde discriminatie').

Toch sluit het EG-verdrag het niet uit, dat nationale 'onderscheid-maatregelen' met het verdrag verenigbaar zijn ${ }^{150}$. Dat is het geval wanneer de beperking onder een uitdrukkelijk afwijkende bepaling valt (zoals de artikelen 55 en 56 juncto 66 EG). Dergelijke beperkingen kunnen echter nooit worden ingeroepen om doelstellingen van economische aard (zoals de beperking van concurrentie) na te streven ${ }^{151}$. Volgens artikel 55 EG zijn de artikelen 52 tot en met 58 niet van toepassing op de werkzaamheden ter uitoefening van bet openbaar gezag. Een beroep op artikel $55 \mathrm{EG}$ moet zo worden uitgelegd, dat het niet verder gaat dan wat strikt noodzakelijk is ter vrijwaring van de belangen die het in de lidstaten toestaat te beschermen $^{152}$. De beperkingen in artikel 56, lid 1 EG hebben betrekking op maatregelen die uit hoofde van openbare orde, openbare veiligheid en volksgezondheid gerechtvaardigd zijn.

Wanneer een lidstaat zich op het bepaalde in artikel 56 juncto artikel 66 EG beroept om een regeling die de uitoefening van de vrijheid van dienstverlening kan belemmeren, te rechtvaardigen uit hoofde van de openbare orde, de openbare veiligheid of de volksgezondbeid, moet deze door het gemeenschapsrecht geboden rechtvaardiging worden uitgelegd in het licht van de algemene rechtsbeginselen en met name de fundamentele rechten waarvan het Hof de eerbiediging verzekert. In het arrest Elliniki ${ }^{153}$ heeft het Hof wat dit betreft zijn leer betreffende het toetsen van nationale regelgeving aan communautaire grondrechten nader gepreciseerd. Bekend was al dat het Hof bereid was de communautaire grondrechten binnen de grenzen van de Gemeenschap nagestreefde doelstellingen van algemeen belang te handhaven ${ }^{154}$. Mar in dit arrest gaat het Hof verder ${ }^{155}$. Blijkens het Elliniki-arrest is het Hof niet slechts bereid om die nationale maatregelen te toetsen die zijn vastgesteld ter uitvoering van een communautair voorschrift: ook andere nationale regelgeving, die binnen het domein van het gemeenschapsrecht komt, kan worden

${ }^{147}$ Zie wat dit betreft 's Hofs verwijzing naar zaak 222/86 (Heylens). Hierover AA 1989, 287 (C.W.A. Timmermans).

14 Zaak 115/78, r.o. 20 en 24 (Knoors). Anders dan bij het Auer I-arrest kon Knoors zich beroepen op een richtlijn, waarin de door hem opgebouwde beroepservaring werd erkend. Het verbod op omgekeerde discriminatie volgt dus niet uit artikel 52 EG see. Vgl. Leenen (1985), 544.

149 Zaak 292/86, r.0. 11 (Gullung).

130 Voorbeelden in de sfeer van de overheidsaanbesteding, waar het beroep op artikel 55 en 56 , lid 1 EO faalde zijn zaak C-3/88 (Commissie v. Italiê, Jur. 1989, 4035), waarover Arrowsmith (1992), 83 v. en zaak C-272/91, Commissie v. Italiè, Jur. 1992, 1409, PPLR 1994, CS211 (Jose M. Fernandez Martin).

191 Zie zaak 352/85, r.o. 34 (Bond van Adverteerders), CMLRev. 1990, 371 (Matthijs de Blois). Zie ook zaak C$353 / 89$ (Commissie v. Nederland).

19 Zaak 147/86, r.o. 7 (Commissie v. Griekenland).

193 In het arrest zaak C-260/89 (Elliniki Radiophonia Tileorassi AE/ Dimotiki Etairia Pliroforissis en S. Kouvelas) ging het om het algemene beginsel van vrijheid van meningsuiting in art. 10 EVRM. Zie ook SEW 1993, 400.

is Zaak $5 / 88$, r.o. 18 (Wachauf).

tss Biesheuvel (1988), $666 \mathrm{v}$. had een dergelijke ontwikkeling al vermoed. 
getoetst. Dat betekende dat toepassing van de uitzonderingen in artikel 56 EG op het vrije dienstenverkeer niet mogen indruisen tegen het EVRM. Feenstra wijst er op dat deze conclusie sinds het Gouda-arrest (zaak 288/89) waarschijnlijk cok heeft te gelden voor de algemene belangen die krachtens de rechtspraak van het Hof worden beschermd (waarover hierna) $)^{156}$.

De verdragsbepalingen inzake de vestigingsvrijheid ${ }^{157}$ en het vrij verrichten van dien$\operatorname{sten}^{158}$ zijn pas dan niet van toepassing, wanneer de betrokken activiteit zich in al zijn relevante aspecten binnen één lidstaat afspeelt. Of alle activiteiten zich binnen één lidstaat afspelen is een feitelijke vraag, die ter beoordeling staat aan de nationale rechter.

\section{'Zonder onderscheid'-maatregelen}

De opvatting dat artikel 52 en 59 EG uitsluitend betrekking had op het non-discriminatie naar nationaliteit is achterhaald, door de 'rule of reason'-jurisprudentie, die - ook op de door de beide artikelen bestreken beleidsterreinen - zijn intree heeft gedaan. Daarbij is de ontwikkeling, vanuit een oogpunt van convergentie van de bepalingen inzake de in het verdrag gewaarborgde vrijheden, bij de vrijheid van dienstverlening in artikel 59 EG zelfs al (iets) verder dan de hiervoor geschetste ontwikkelingen bij het vestigingsrecht ${ }^{159}$. En dat, terwijl tot voor kort de dienstenvrijheid "had a rather "shadowy existence" to date for a variety of reasons' ${ }^{\prime 60}$. Hierna wordt onderzocht of deze jurisprudentie noopt tot het stellen van nadere eisen aan de aanvullende voorwaarden.

Rule of reason. Ten aanzien van het vrije goederenverkeer (artikel 30 EG) heeft het Hof de lidstaten een algemeen beperkingsverbod opgelegd behalve wanneer sprake is van een nationale regeling die gerechrvaardigd is door dwingende eisen van algemeen belang. In het Dassonville-arrest ${ }^{161}$ koos het Hof namelijk voor de ruime opvarting inzake artikel $30 \mathrm{EG}$ : handelsbelemmerende effecten zijn verboden. Dat wil zeggen, dat ook al worden nationale en buitenlandse goederen op dezeljde manier behandeld, dan nog kunnen de desbetreffende nationale maatregelen onder het verbod van artikel $30 \mathrm{EG}$ vallen als de intracommunautaire handel als gevolg daarvan al dan niet rechtstreeks, daadwerkelijk of potentieel wordt belemmerd. Om de nationale overheden toch een ontsnappingsmogelijkheid te geven werd naderhand de Dassonville-formule genuanceerd: een nationale maatregel die op zich zelf in de zin van de Dassonville-formule de invoer beperkt, kan gerechtvaardigd zijn voorzover 'dringende behoeften, onder meer verband houdend met de doeltreffendheid van fiscale controles, de bescherming van de volksgezondheid, de eerlijkheid der handelstransacties en de bescherming van consumenten ze noodzakelijk maken"102. Dit is de zogeheten 'rule of reason': een rechtvaardigingsgrond voor handelsbeperkingen voor het geval er geen sprake is van een harmonisatiemaatregel op grond van het verdrag. Deze 'rule of reason'-toets lijkt inmiddels nog wat te zijn bijgesteld, waardoor de nationale overheden nog wat meer beleidsruimte wordt gelaten. De 'rule of reason'-toets hoeft namelijk niet te worden toegepast, indien de nationale regeling de verkoopmethode betreft (i.c. een nationaal

${ }^{136}$ CML.Rev. 1993, 429 (Jaap Feenstra).

157 Zaık 204/87 (Bekaert).

198 Zalak 52/79, r.0. 9 (Debauve).

350 Voor een overzicht van de ontwikkelingen Roth (1988), 35 v. Over de art. 30 EG benadering: Lauwaars Timmermans (1994), 204; De Wilde (1994), 775. Barents - Brinkhorst (1994), 292 v. zijn minder expliciet. Het geval waarbij niet de dienstverrichter maar de ontvanger van de dienst reist, blijft, gelet op het karakter van de aanbesteding, hierna buiten beschouwing. Men zie zaak 286/82 en 26/83 (gevoegd) (Luisi en Carbone). Het Hof concludeerde tot een ruimbartig standpunt: zij die zich op reis begeven (toeristen, patiënten) zijn mede te beschouwen als personen te wier behoeve een dienst wordt verricht. Volgens Timmermans (SEW 1984, 750 v.) laat deze overweging zich lezen als een Dassonville-formule.

169 Roth (1988), 35. In die zin Hailbronner - Nachbaur (1992), 105 v. Leenen (1985), 547 spreekt van een restcategorie.

16. Zaak 8/74, r.o. 5 (Dassonville).

tot Zaak $120 / 78$, r.o. 8 (Cassis de Dijon). 
verbod tot wederinkoop met verlies) en de ingevoerde produkten niet (materieel) worden gediscrimineerd. In plaats van een breed verbod, dat wordt genuanceerd door een rechtvaardigingsgrond, kiest het Hof in het Keck-arrest ${ }^{16}$ voor een beperkter verbod (zonder rechtvaardigingsgrond).

In de marge wil ik er op wijzen dat rechrvaardigingsgronden, zoals het milieubelang, ook een rol lijken te kunnen gaan spelen in de zogenaamde 'onderscheid'-situaties' ${ }^{164}$. Volgens Hailbronner en Nachbaur maakte her Hof ook in het verleden niet steeds een duidelijk onderscheid tussen 'onderscheid' en 'zonder onderscheid'-situaties. Zo ging; het Hof in het Van Wesemael, Webb, Seco-arrest onderzoeken of er wellicht rechtvaardigingsgronden aanwezig. waren terwijl was vastgesteld dat het ging om discriminatoire maatregelen. De Cassis de Dijon-formule wordt dan niet gebruikt om eventuele beperkingen te rechtvaardigen maar om vast te stellen of het gaat om 'onderscheid' of 'zonder onderscheid'-situaties.

CRITERIA ONTLEEND AAN DE VESTIGINGSVRUHEID (ARTIKEL 52 EG). In het Gullung-arrest $^{165}$, ging het Hof ogenschijnlijk een stap verder dan de materiële toetsing in het latere Vlassopoulou-arrest.

Gullung heeft de Frans-Duitse nationaliteit en is als advocaat werkzaam in Duitsland. Hij wilde zich vestigen in Frankrijk waar hem de toegang tot de balie werd ontzegd, kortgezegd omdat hij in het verleden in Frankrijk als notaris tuchtmaatregelen had opgelopen. Hij deed een beroep op de artikelen 52 en 59 EG en richtijn 77/249 (dienstverlening door advocaten).

Overwogen werd dat, nu specifieke gemeenschapsbepalingen ter zake van de vestiging ontbraken, elke lidstaat met betrekking tot de onderdanen van een andere lidstaat zelf regels kan stellen, mits niet van discriminatie ten opzichte de eigen onderdanen sprake is. Dat is op zich niet nieuw ${ }^{106}$. Als voorwaarde stelde het Hof, dat de verplichte inschrijving bij een balie van een lidstaat zonder enige discriminatie voor alle onderdanen van alle lidstaten diende open te staan. Maar het Hof ging verder en overwoog:

'Die verplichting heeft immers met name tot doel, de moraliteit van de advocaat en de naleving van de beroepsregels te waarborgen en het tuchtrechtelijk toezicht op zijn werkzaamheid mogelijk te maken, welk doel alleszins bescherming verdient ${ }^{167}$.

De Wilde ${ }^{168}$ ziet in het toetspunt van het beschermenswaardige doel een aanwijzing dat de 'rule of reason'-toetsing, zoals die op het gebied van het vrije goederenverkeer tot ontwikkeling is gekomen, ook ingang lijkt te vinden op het gebied van het vestigingsrecht.

${ }^{163}$ Zaken C-267/91 en 268/91 (Keck en Mithouard). Vgl. SEW 1994, 115 v. (K. J.M. Mortelmans), CMLRev. 1994, 845 v. (W.-H. Roth). Zie verder Mortelmans (1994), 236 v., Reich (1994), 459 v. en Chalmers (1994), 385 v.

14 Mortelmans (1987), 736 had zich dit afgevraagd. Men zie zaak C-2/90 (Waalse afvalstoffen), SEW 1994, 98 (Sevenster), SEW 1994, 240 (K.J.M. Mortelmans) en CMLRev. 1993, 351 v. (L. Hancher en H. Sevenster).

165 Zaak 292/86, SEW 1988, 390 v. (Peter Jacob).

166 Zie reeds zaak 107/83, 2971 (Klopp).

157 R.o. 29.

164 De Wilde (1994), 787 en 794. Anders P. Behrens, Die Konvergenz der wirtschaftlichen Freiheiten im europäischen Gemeinschaftsrecht, Europarecht. 1992, Heft 2. p. 145 v. waarnaar hij verwijst. 
CRITERIA ONTLEEND AAN HET VRIJE VERKEER VAN DIENSTEN (ARTTKEL 59 V. EG).

Waar op het terrein van het vrije dienstenverkeer harmonisatierichtlijnen (of een 'gelijkwaardigheidsregime') ontbreken, introduceerde het Hof in zijn Webb-arrest ${ }^{169}$, onder verwijzing naar het Van Wesemael-arrest ${ }^{170}$, een met de 'rule of reason' vergelijkbare toets, welke in de loop der tijd verder is gepreciseerd ${ }^{171}$. Een daadwerkelijke eerste toepassing van de 'rule of reason'-rechtspraak op het gebied van de dienstverlening vormt het arrest Commissie v. Duitsland ${ }^{172}$. In latere arresten is deze rechtspraak bevestigd ${ }^{173}$, laatstelijk in het Säger-arrest ${ }^{174}$ en het Schindler-arrest ${ }^{175}$. De redenering van het Hof kan als volgt worden weergegeven.

\section{a. Is artikel 59 EG-verdrag van toepassing?}

Dit wordt aangenomen zodra er sprake is van een beperking van het vrije dienstenverkeer ('beperkingscriterium). Daarvan lijkt snel sprake. Artikel 59 vereist niet enkel de opheffing van elke discriminatie op grond van nationaliteit of vestigingsplaats, maar tevens de opheffing van elke beperking, zelfs indien ze zonder onderscheid van toepassing is op nationale dienstverleners en deze van andere lidstaten ${ }^{176}$. Dat wil niet zeggen dat nationale maatregelen steeds door artikel 59 EG-verdrag volstrekt worden verboden. Er dient te worden onderzocht of de beperking van het vrije dienstenverkeer, die is gelegen in de nationale bepaling, kunnen worden gerechtvaardigd door dwingende redenen van algemeen belang ${ }^{17}$.

\section{b. Wordt deze beperking gerechtvaardigd door dwingende redenen van algemeen belang?}

Het Hof overweegt in het Säger-arrest ten aanzien van deze nationale voorschriften, dat:

'Gelet op de bijzondere aard van de dienstverrichting op het gebied van bepaalde werkzaambeden, kunnen specifieke eisen die aan de dienstverrichter worden gesteld op grond dat de toepassing van de voor de betrokken werkzaamheden geldende regels zulks vereist, niet onverenigbaar met het Verdrag worden geacht. Als grondbeginsel van het Verdrag kan bet vrij verrichten van diensten echter slechts worden beperkt door regelingen die hun rechtvaardiging vinden in dwingende redenen van algemeen belang en die gelden voor iedere persoon of onderneming

109 R.o. 17.

170 Zaak 110-111/78.

[7] In die zin SEW 1993, 669 (M. van Empel).

17 Zaak 205/84, r.o. 27 (Commissie v. Duitsland). Ook zaak 220/83, 3663 v. (Commissie v. Frankrijk), zaak 252/83, 3713 v. (Commissie v. Denemarken), zaak 206/84, 3817 v. (Commissie v. lerland). Vgl. Steenlant Vanhees (1987), 105 v. Aan de vooravond van de arresten zijn Forwood en Clough (Forwood - Clough (1986), 388-389) reeds hoopvol gestemd. Ook positief Lasok (1988), 726. Berr - Groutel (1987), 98, Mortelmans (1987), 725 en Gormley (1989), 10-11. Edward (1987), 231 v. is na het arrest (zaak 205/84) nog niet overtuigd, dat er sprake is van een ander type toersing.

13 Men zie zaak C-154/89, 659 v. (Commissie v. Frankrijk); zaak C-180/89, 709 v. (Commissie v. Italie) en zask C-198/89, 727 v. (Commissie vs. Griekeniand). En zaak 288/89 en in gelijke bewoordingen zaak C.-353/89 (Commissie v. Nederland; Gouda).

194 Zaak C-76/90 (Säger). In die zin De Wilde (1994), 790; SEW 1993, 664 (M. van Empel) en CMLRev. 1993, 145 v. (Wulf-Henning Roth).

175 Zaak C-275/92, r.o. 58-61.

176 Zaak C-76/90 (Säger), r.o. 12.

in Zie de Interpretatieve mededeling van de Commissie inzake het vrij verrichten van diensten over de grenzen heen. Pb C 334/3, 9 december 1993. 
die op het grondgebied van de Lid-Staat van ontvangst werkzaam is, voor zover dit belang niet wordt gewaarborgd door de regels waaraan de dienstverrichter is onderworpen in de Lid-Staat waar hij is gevestigd' (r.o. 15).

Voorbeelden van dergelijke dwingende redenen van algemeen belang zijn naast de in artikel 56 genoemde voorwaarden, de in andere artikelen van het verdrag genoemde vereisten ${ }^{178}$. De Commissie noemt van die andere bepalingen artikel 36 EG-verdrag. Deze artikelen hebben met name betrekking op de openbare zedelijkheid, de consumentenbescherming, werknemersbescherming, de industriële en commerciële eigendom en de bescherming van het nationaal artistiek, historisch of archeologisch bezit. Het Hof laat de lidstaten een ruime beleidsmarge voor wat betreft de keuze van beschermenswaardige belangen. Aan de orde zijn geweest: de beroepsregels ter bescherming van de ontvanger van de dienst ${ }^{179}$, de bescherming van de intellectuele eigendom ${ }^{180}$, de sociale bescherming van werknemers ${ }^{181}$, de bescherming van consumenten ${ }^{182}$, het behoud van het nationale historisch en artistiek bezit ${ }^{183}$, het uitbaten van historische rijkdommen en een betere verspreiding van het historisch, artistiek en cultureel erfgoed ${ }^{184}$, de regels van de beroepsethiek en de eerbaarheid, onafhankelijkheid en de werking van de rechtspraak ${ }^{185}$ en cultuurbeleid dat is gericht op het behoud van de vrijheid van meningsuiting van de diverse maatschappelijke, culturele, godsdienstige en geestelijke stromingen ${ }^{186}$. En blijkens het Schindler-arrest ${ }^{187}$ diende er voldoende beoordelingsvrijheid te zijn voor de nationale autoriteiten ${ }^{188}$, zodat rekening kon worden gehouden met de sociale en culturele bijzonderheden van iedere lidstaat, voor de bescherming van de maatschappelijke orde. Beperkingen kunnen ook gerechtvaardigd worden door overwegingen van sociaal beleid en fraudebestrijding ${ }^{189}$. Verder kon worden gedacht aan zedelijke en religieuze bijzonderheden. Als bekend kunnen doelstellingen van economische aard nooit redenen van openbare orde vormen in de zin van art. $56^{190}$. Hetzelfde geldt voor overwegingen van administratieve aard waarmee bijv. wordt beoogd de werkzaamheden van de autoriteiten van de ontvangende lidstaat te vergemakkelijken ${ }^{191}$.

c. Evenredigheid: dat de beperking gerechtvaardigd moet zijn, veronderstelt drieërlei:

c1. De maatregel moet geschikt zijn om het doel te bereiken. Advocaat-Generaal Van Gerven spreekt in dit verband van het 'relevantiecriterium'.

\footnotetext{
${ }_{178}$ Interpretatieve mededeling van de Commissie, Pb C 334/3, 9 december 1993, m.n. blz. 5 (en noot 26 ).

${ }^{17}$ R.o. 28 (Van Wesemael).

180 Zaak 62/79 (Coditel I).

${ }^{181}$ Zaak 279/80, Webb, r.o. 19; zaken 62-63/81, (Seco), r.o. 10 en 14; zaak 113/89 (Rush Pornguesa), r.o. 18.

180 Zaak 220/83, r.o. 20; zaak 252/83, r.o. 20; zaak 205/84, r.o. 30; zaak 206/84, r.o. 20; zaak C-180/89, r.o. 20; zaak C-198/89, r.o. 21.

100 Zaak C-180/89, r.0. 20.

184 Zaak C-180/89 (Commissie v. Italië), r.o.20; zaak C-154/89 (Commissie v. Frankrijk), r.o. 17; zaak C-198/89, (Commissie v. Griekenland), r.o. 21.

${ }^{185}$ Zaak 33/74, r.o. 12 en 14 (Van Binsbergen).

186 Zaak 288/89, r.o. 23; zaak C-353/89, r.o. 30.

187 Zaak C-275/92 (Schindler).

188 R.0. 61.

${ }^{189}$ R.o. 63 (Schindles).

190 Zaak 288/89, r.0.11.

191 Zaak 205/84, r.0. 54.
} 
Het relevantiecriterium zoals dit gebruikt wordt in de Nederlandse aanbestedingsliteratuur heeft een andere betekenis dan het hier bedoelde beginsel. In zijn proefschrift gebruikt Spier ${ }^{192}$ het om aan te geven dat voor de toepassing van het gelijkheidsbeginsel gezocht moet worden naar 'relevante criteria'. Of zoals Van der Burg ${ }^{193}$ het zei: dat criteria niet 'sachfremd' mogen zijn. Dat wil zeggen dat 'zij hun rechtvaardiging (moeten) kunnen vinden in de aard van de materie'. In die hoedanigheid krijgt het beginsel al snel een politieke inhoud, zoals bij voorbeeld in het vernietigings-KB inzake de Arnhemse boycot: 'voor een goede uitvoering van de opdracht niet relevante aspecten'194. Het Europeesrechtelijke relevantie-criterium leent zich mijns inziens beter als toetssteen voor de aanvaardbaarheid rechrens van een bij de aanbesteding te betrekken beleidsuitgangspunt.

c2. De maatregel mag niet verder gaan dan noodzakelijk is om de beoogde doelstelling te bereiken. In de woorden van Van Gerven: het 'onmisbaarheidscriterium'. De bepalingen moeten voor alle personen en ondernemingen op het eigen grondgebied worden toegepast, voor zover de beoogde belangen niet reeds worden beschermd in de lidstaat van vestiging. Dat betekent dat de door de lidstaat van ontvangst gestelde voorwaarden geen onnodige herhaling mogen zijn van overeenkomstige wettelijke voorwaarden waaraan reeds in de vestigingsstaat is voldaan, en de toezichthoudende autoriteit van eerstbedoelde staat moet rekening houden met de controles en verificaties die al in de vestigingsstaat zijn verricht (het vergelijkbaarheidscriterium) $)^{195}$. Van een onnodige herhaling is sprake wanneer de voorschriften in het vestigingsland materieel gelijke waarborgen bieden voor de bescherming van het algemene belang, geringe verschillen daargelaten. Niet voldoende is dat $\mathrm{zij}$ dezelfde materie regelen ${ }^{196}$.

Van Empel ${ }^{197}$ wijst er in zjn noot onder het Säger-arrest op dat anders dan bij de Cassis de Dijon-formule het Hof er voor het vrije dienstenverkeer geen consequenties aan verbindt dat er voor de omstreden activiteit geen nationale regeling bestond. Van 'Home State control' en 'mutual recognition' zoals bij op artikel 30 gebaseerde 'rule of reason'-jurisprudentic, kon dus geen sprake zijn. Dit bevestigt zijns inziens dat de equivalentie- of relativiteitstest (waarin de regels in de Host State worden vergeleken met die in de Home State) in feite een onderdeel uitmaakt (c.q. een uitwerking is van) van de evenredigheidstoets ${ }^{19 \%}$.

c3. De maatregel moet proportioneel zijn. Dat wil zeggen dat het ermee te bereiken resultaat op moet wegen tegen het nadeel dat aan een ander belang wordt toegebracht. De Moorvan Vugt ${ }^{199}$ wijst er op dat met name in zaken waar fundamentele rechten een rol spelen de evenredigheidstoets zich wat vaker uitstrekt tot de gevolgen voor individuele belangen. De toetsing blijft dan niet beperkt tot de geobjectiveerde noodzakelijkheidstoets.

${ }^{192}$ Spier (1981), nr. 11. Zo is Spier (1993), 126-127. in beginsel ook bereid om de gemeente een ruime marge te laten bij het bepalen van de wenselijkheid van aanbestedingsvoorwaarden. Deze eisen zullen dan wel relevant moeten zijn.

193 Noot onder AB 1987, 273 (Amsterdam/ IKON).

${ }^{194} \mathrm{~KB} 9$ januari 1987, S. 1987, 11 (Arnhem).

198 Zie zaak 205/84, r.o. 47, zaak 110-111/78 (Van Wesemael), r.o. 19.

196 In die zin Van der Esch (1994), 564

19 SEW 1993, 669 (M. van Empel).

19 In die zin SEW 1990, 32 (D.J. Keur): indien een nationale regeling op voorhand een gelijk waardigheidsonderzoek uitsluit, wordt daarmede de mogelijkheid on een beroep te doen op een objectieve rechtvaardigingsgrond voor de (mogelijke) handelsbelemmering verspeeld.

199 De Moor-van Vugt (1993), 30. 
Evenredigheid: ja, maar waartussen?

In zijn bijdrage aan SEW 1992, blz. 751 v. 'Evenredigheid: ja, maar waartussen?' geeft Jans aan dat het evenredigheidsbeginsel een funktie vervult bij de beoordeling van de geoorloofdheid van nationale beperkingen ten aanzien van het vrij verkeer van goederen, personen en diensten ${ }^{200}$. Anders dan Advocaat-Generaal Van Gerven ${ }^{201}$ wil Jans de functie van de evenredigheidstoets beperken tot de keuze van nationale instrumenten. Met name mag het evenredigheidusbeginsel geen rol spelen in het kader van de afweging tussen het beoogde algemene belang en het belang van de vrije (goederen)markt. Jans 'kritiek is dat dit tot gevolg kan hebben dat een maatregel die nodig is om een belang te beschermen dat van hoger orde is dan het vrije goederenverkeer en waarvoor geen minder belemmerende maatregelen voorhanden zijn, toch zou moeten worden nagelaten ${ }^{202}$. Hierna wordt onderzocht op welke wijze het Hof het evenredigheidsbeginsel toepast op het terrein van het vrije dienstenverkeer.

Bepalingen die de werkzaamheden van de dienstenverrichter kunnen beletten of verhinderen zijn in strijd met de artikelen 59 en 60 EG. Maar daarop zijn uitzonderingen mogelijk. In het Seco-arrest $t^{2 n 3}$ overweegt het Hof, dat 'een regeling, waarbij aan werkgevers een sociale bijdrage voor werknemers wordt opgelegd, zonder dat enig sociaal voordeel voor deze werknemers daartegenover staat, (...), redelijkerwijs niet gerechtvaardigd worden geacht uit hoofde van het algemeen belang in verband met de sociale bescherming van de werknemers'. En: 'Een regeling of praktijk, waarbij op algemene wijze een sociale of daarmee verwante last die het vrij verrichten van diensten beperkt, wordt opgelegd aan alle dienstverleners die in een andere lidstaat zijn gevestigd en werknemers uit derde landen in dienst hebben, ongeacht of zij de wetgeving inzake het sociaal minimumloon in de lidstaat waar de dienst wordt verricht hebben nageleefd of niet, kan echter niet als een passend middel worden beschouwd, aangezien een dergelijke algemene maatregel naar haar aard ongeschikt is um die regeling te doen naleven of op enigerlei wijze aan de betrokken werklieden ten goede te laten komen' (r.o. 14). In beide gevallen toetst het Hof of de nationale regeling dienstig is ter bereiking van het ermee beoogde doel (vgl. het 'geschiktheidscriterium').

Wanneer het instrument geschikt is, is daarmee nog niet gezegd dat het ook een noodzakelijk instrument is. Uitgangspunt is dat bepalingen voor alle personen en ondernemingen op het eigen grondgebied moeten worden toegepast, voorzover de beoogde belangen niet reeds: worden beschermd in de lidstaat van vestiging. Dat betekent dat de door de lidstaat van ontvangst gestelde voorwaarden geen onnodige herhaling mogen zijn van overeenkomstige wettelijke voorwaarden waaraan reeds in de vestigingsstaat is voldaan, terwijl de toezicht-

\footnotetext{
${ }^{200}$ Jans (1992), 751, noot 2 wijst voor een eerste aanzet tot toepassing van het evenredigheidsbeginsel naar zaak $7 / 68,589$ (Commissie v, Italie). Het Hof overwoog dat de lidstaten zich slechts van art. 36 mogen bedienen indien zij binnen de bij deze bepaling aangegeven grenzen blijven zowel wat betreft bet te bereiken doel als de aard der te bezigen middelen.

201 Van Gerven spreekt in verband met het evenredigheidsbeginsel van hel evenwichtightidscriterium. Zie W. van Gerven, Het evenredigheidsbeginsel: een beginsel met een groot verleden en een grote toekomst, in: In het nu, wat worden zal. Opstellen aangeboden aan prof.mr. H.C.F. Schoordijk ter gelegenheid van zijn afscheid als hoogleraar aan de Katholieke Universiteit Brabant, Deventer 1991, 75-86 (1.h.b. 77). Zie verder RW 1992, 1244, sub 9.

203 Zaak C-159/90 (Grogan), SEW 1993, 805 v. (S. Prechal).

203 Zaak 62-63/81, r.o. 10.
} 
houdende autoriteit van eerstbedoelde staat rekening moet houden met de controles en verificaties die al in de vestigingsstaat zijn verricht. De 'noodzakelijkheidseis' kunnen we in verschillende vormen tegenkomen.

Reeds in het Van Binsbergen-arrest ${ }^{204}$ werd overwogen, dat in verband met de bijzondere aard van sommige diensten 'specifieke eisen (...) aan de dienstverrichter worden gesteld wegens de toepasselijkheid van beroepsregels die hun grond vinden in het algemeen belang (...) en die voor iedereen gelden die gevestigd is op het grondgebied van de staat waar de dienst wordt verricht, voor zover zulke eisen nodig zijn (cursief van mij) om te voorkomen dat de dienstverrichter door zijn vestiging in een andere lidstaat aan de greep van die regels zou ontsnappen'. Deze regel wordt in het arrest-Van Wesemael ${ }^{205}$ als volgt uitgewerkt: dat de specifieke eisen (...), niet als strijdig met het verdrag moeten worden beschouwd, 'voor zover de dienstverrichter in de staat waar hij is gevestigd, niet aan gelijkaardige ('similar requirements', dat wil zeggen: vergelijkbare voorwaarden; HN) regels is onderworpen'. In zaak 205/84 (Commissie v. Duitsland) ${ }^{206}$ benadrukte het Hof dat om onnodige herhaling te voorkomen, een vergunning moet worden afgegeven aan elke onderneming die in een andere lidstaat is gevestigd en die wetgeving voldoet aan de eisen die in de gaststaat worden geẻist. Wat het vestigingsvereiste betreft, oordeelde het Hof dat dit verder ging dan noadzakelijk was ter verwezenlijking van het beoogde doel (r.o. 20, 27 en 33) ${ }^{207}$. Alleen daar waar het onmisbaar is om een algemeen belang te beschermen kan van de dienstverrichter worden geëist dat hij zich in het gastland vestigt $^{203}$. In de Toeristengidsen-artesten ${ }^{209}$ was het Hof van oordeel dat (r.o. 17) het algemene belang (verspreiding kunst en cultuur) een dwingende reden kon vormen die een beperking van het vrije dienstenverkeer zou kunnen rechtvaardigen. De aan de verspreiding gestelde beperking ging echter verder dan voor de bescherming van dat belang noodzakelijk was. En: bijgevolg (r.o. 21) is de betrokken regeling (...) onevenredig aan het nagestreefde doel. In de Gouda-arrest ${ }^{210}$ overwoog het Hof, dat culturpolitieke doelstellingen erkend worden als behorend tot het algemeen belang, zodat een beperking van het dienstenverkeer gerechtvaardigd zou kunnen zijn. Voor wat betreft de evenredigheidstoets volgde het Hof een nogal strikte benadering (r.0. 25): 'Voorwaarden betreffende de structuur van buitenlandse omroepinstellingen kunnen (..) niet objectief noodzakelijk worden geacht ter verzekering van het algemeen belang van een pluriform landelijk omroepbestel'. En r.o. 24: '(...) Indien de Nederlandse regering dat pluriforme karakter in stand wenst te houden, kan zij er zeer wel mee volstaan, aan het statuut van haar eigen omroepinstellingen een passende vorm te geven'. En recent in het Säger-arrest ${ }^{211}$ besliste het Hof dat de beschermingsregeling a quo dient een algemeen belang, dat de beperking op het vrije dienstenverkeer rechtvaardigt (r.o. 16). Maar de regeling gaat verder dan voor de bescherming van dat algemeen belang noodzakelijk is, indien zij (...) als vereiste stelt, dat de dienstverrichters een heel specifieke beroepskwalificatie bezitten, die onevenredig is aan de behoeften van de ontvangers van de diensten (r.o. 17). Met andere woorden: de eisen zijn onevenredig aan het beogde doel (r.o. 20). En ook in het arrest-Ramrath ${ }^{212}$ en het Schindler-arrest verwees het Hof naar het noodzakelijkheidsvereiste (r.o. 60-6.2).

204 Zaak $33 / 74$ (Van Binsbergen), r.o. 12.

${ }^{205}$ Zaak 110-111/78 r.o. 19 (Van Wesemael). Vgl. CMLRev. 1993, 151-152 (Roth) en SEW 1992, 827 (M.A. Fierstra). Ook zaak 52/79, r.o. 12 (Debauve).

206 Zie ook de overige co-assurantie-arresten zaak 220/83; zaak 252/83, r.o. 17; en zaak 206/84. Alleen voor de Duitse casus speelde nog een rol dat de in Duitsland gevestigde verzekeraars geen verzekeringscontracten konden sluiten met niet in Duitsland gevestigde verzekeringsmaatschappijen.

207 Volgens R.W. Hodgin, in: CMLRev. 1987, 273 volgde zulks reeds uit de arresten in zaak 37/86 (Coenen) en zaak 76/81 (Transporoute).

200 Zie zaak 205/84, r.o. 52. Zie ook zaak 252/83, r.o. 20 (Commissie v. Denemarken).

Zaak C-154/89; xaak C-180/89, r.o. 17; zaak C-198/89. Ook zo zaak C-375/92 (Commissie v. Spanje), r.o. 21.

to Vgl. CMLRev. 1993, 424 v. (Jaap Feenstra). Zie de op dit punt gelijke overwegingen in zaak C-353/89. Zie ook Mortelmans (1992), 41.

I1 Zaak C-76/90, r.o. 15 (Säger).

$2 n$ Zaak 106/91, r.o. 31. Het Hof overwoog: 'Il s' ensuit que ces exigences ne peuvent être considérées comme compatibles avec les dispositions relatives à la libre circulation des personnes que s' il est etabli qu' il existe, dans le domaine de l'acrivité considérée, des raisons impérieuses liées à l' intérét général qui justifient des restrictions a la libre circulation, que cet intérêt n' est pas déjà assuré par des règles de l' Etat ol le ressortissant communautaire est établi et que le même résultat ne peut Etre obtenu par des règles moins contraignantes'. 
De evenredigheidstoets is in zaken waarin het om een bijzonder gevoelige materie gaat zoals bijv. sociaal beleid (Seco, Webb, Beentjes, Rush Portuguesa) minder strikt. Blijkens zaak $113 / 89$, r.o. 12 (Rush Portuguesa) houdt de evenredigheidstoets in feite niet meer in dan een (ruime) discriminatietoets $\mathrm{s}^{213}$. In dat arrest wordt slechts het discriminerende karakter genoemd als grond voor de ongeoorloofdheid van de voorwaarden ten aanzien van het verplaatsen van haar personeel.

Uit het voorafgaande kan worden afgeleid dat het Hof de evenredigheidstoets beperkt tot de keuze van het nationale instrumentarium. Het evenredigheidsbeginsel speelt geen rol in het kader van de afweging tussen het beoogde algemene belang en het belang van de vrije dienstenmarkt (het proportionaliteitsvereiste). Niets wijst in de richting van een zodanige beperking, waar op zich beschermenswaardige doelen achterwege moeten worden gelaten, gelet op de effecten die de beschermende maatregelen met zich meebrengen voor het vrije marktverkeer. Het Hof toetst slechts of het zelfde resultaat kan worden bereikt met minder vergaande middelen. De evenredigheidstoetsing is daarmee allereerst een objectieve noodzakelijkbeidstoetsing. Dit past bij het economisch-rechtelijke karakter van het gemeenschapsrecht, waarop alleen nuancering nodig is wanneer bij de uitvoering van de maatregel fundamentele rechten zijn betrokken. Het is in de eerste plaats de lidstaat zelf die de beschermenswaardige doeleinden (beleidsuitgangspunten) vaststelt, alsmede het daarbij behorende beschermingsniveau (criteria en aanvullende voorwaarden). Mogelijke onevenredigheid moet worden gezocht in de hoogte van het beschermingsniveau, niet in de beschermwaardigheid als zodanig.

\section{Conclusie}

Aan welke eisen moeten de beleidsuitgangspunten voldoen. Beantwoording van deze vraag was de inzet van dit hoofdstuk.

Wat betreft de financiële doelmatigheid: regeling van dit beleidsaspect staat centraal in de nationale aanbestedingsreglementen. Het bepaalde in de Europese aanbestedingsrichtlijn komt tot uidrukking in het UAR-EG 1991. De selectie-eisen uit de UAR-en dienen te voldoen aan eisen van objectiviteit en eenduidigheid, en dienen verder in een redelijke verhouding te staan tot de aard en omvang van het werk ${ }^{214}$. Deze laatste eis kan naar mijn mening worden opgevat als de nadere concretisering van het relevantiecriterium. Van belang is of de selectieeis geschikt is om het doel (de kwaliteitstoetsing) te bereiken. En ook de gunnings-eisen in het UAR en in de richtlijn dienen objectief en strikt relevant te zijn ${ }^{215}$. Kortom: de selectieen gunningscriteria uit het UAR moeten voldoen aan de eisen van relevantie en objectiviteit. De noodzakelijkheid van de criteria moet worden gezocht in de beoogde doelstelling van de aanbestedingsreglementen: het prijs- en kwaliteitsbeleid en de daarmee samenhangende noodzaak om (waar nodig) te selecteren en te gunnen alvorens tot opdrachtverlening kan

\footnotetext{
${ }^{213}$ In die zin SEW 1991, 198-199 (M.A. Fierstra) en SEW 1992, 828 (M.A. Fierstra).

${ }^{214}$ Vergelijk art. 8, lid I UAR 1986 en art. 11, lid 1 UAR-EG 1991.

$215 \mathrm{~Pb} 1987, \mathrm{C} 358$.
} 
worden overgegaan. Deze criteria dienen - vergelijk wat dat betreft het nondiscriminatiebeginsel in de liberalisatie- en coördinatierichtlijn - zonder onderscheid te worden toegepast.

Daarna is onderzocht aan welke eisen de eventuele 'andere' beleidsuitgangspunten (de zogeheten 'aanvullende voorwaarden') zouden moeten voldoen ${ }^{216}$. Net als bij de aanbestedingsreglementering staat het beginsel van non-discriminatie naar nationaliteit voorop. Als harmonisatiemaatregelen ontbreken mogen handelsbelemmerende maatregelen worden genomen, onder de strikte eis dat de maatregel wordt gerechtvaardigd door dwingende eisen van algemeen belang. Het Hof laat de lidstaten wat betreft de keuze van beschermenswaardige belangen een ruime beleidsmarge. Dat de beperking gerechtvaardigd moet zijn veronderstelt dat de maatregel evenredig is. De evenredigheidstoets loopt over drie sporen: de geschiktheidseis, de noodzakelijkheidseis en de proportionaliteitseis. Blijkens de aangehaalde jurisprudentie toetst het Hof met name aan de twee eerste eisen. Dat maatregelen evenredig moeten zijn betekent, dat zij objectief noodzakelijk moeten zijn; de beschermwaardigheid van het betrokken algemeen belang als zodanig staat in de regel niet ter discussie.

Kortom: kennelijk geldt voor alle beleidsuitgangspunten hetzelfde: de eisen waaraan de selectiecriteria, gunningseisen en aanvullende voorwaarden moeten voldoen, kunnen worden herleid tot eisen van objectieve noodzakelijkheid. De proportionaliteit (verhouding algemeen belang tot individueel belang) speelt hoegenaamd geen rol. Daarnaast geldt steeds ook dat de beperkende maatregelen geen onderscheid maken naar nationaliteit. En bovendien eist de aanbestedingregelgeving dat de aanbesteder zijn selectie- en gunningsbeslissingen (achteraf) motiveert. De motivering van de andere beleidsuitgangspunten berust op het nationale recht (waarover hierna in hoofdstuk 5).

\footnotetext{
216 Voor het doel waar het in dit huofusnik om gaat kunnen de verschillen die er bestaan russen de 'rule of reason'toets op het gebied van de vestigingsvrijheid en de dienstenvrijheid worden weggedacht.
} 


\title{
Hoofdstuk 5
}

\section{Grondslagen van aanbestedingsbeleid}

\section{Van privaatrecht naar bestuursrecht}

\section{'No nonsense'-recht: instrumentalisme}

Met het wegvallen van de preventieve toetsing op de onderhandse aanbesteding in 1966 lijkt het er op dat gemeenten voortaan zelf uitsluitend aan het financiële belang dat met de opdracht is gemoeid, zouden moeten toetsen en dus bij voorkeur openbaar zouden moeten aanbesteden, althans uitsluitend de mededinging zouden moeten maximaliseren. Daarmee ontbreekt echter de grond voor toetsing aan andere beleidsuitgangspunten, hoewel die (in de praktijk) wel degelijk een (grote) rol spelen.

\begin{abstract}
De laatste decennia laten namelijk een ontwikkeling zien waarbij plaatselijke opvattingen met betrekking tot algemene maatschappelijke en politieke vraagstukken in het gemeentelijke aanbestedingsbeleid tot uitdrukking worden gebracht. De aanbestedende gemeente treedt dan niet op als een privaatrechtelijke rechtspersoon, maar als een overheid die met privaatrechtelijke middelen sturing beoogt te geven aan maatschappelijk gewenste ontwikkelingen ('social engineering'). De gemeente gebruikt het aanbestedingsrecht dan als een privaatrechtelijk instrument ter realisering van allerlei beleidsuitgangspunten, die heel wat meer kunnen omvatten dan alleen de deskondigheid c.q. de solvabiliteit van de aannemer. Enkele voorbeelden daarvan noemde ik reeds in het eerste hoofdstuk. En ook het eigen onderzoek naar de Euregionale aanbestedingspraktijk liet dat beeld zien.
\end{abstract}

De decentralisatie in 1966 maakte met andere woorden de weg vrij voor een soortgelijk beleidsinstrumenteel gebruik van het privaatrecht als waarvan bij voorbeeld ook bij de gronduitgiftevoorwaarden sprake is. De wetgever heeft onvoldoende beseft dat het preventieve toezicht het gemeentebestuur (oorspronkelijk) dwong tot motivering van een concreet aanbestedingsbesluit, en daarmee van het, in bestuurlijke zin, openbare aanbestedingsbeleid. Het onderscheid tussen de openbare en de onderhandse aanbesteding in artikel 176 gemeentewet had met andere woorden oorspronkelijk niet alleen een procedurele betekenis (in relatie tot de inschrijvers) maar tevens een besturijije. Met het afschaffen van het preventieve toezicht accentueerde de wetgever de - inmiddels uitsluitende - procedurele betekenis van het aanbestedingsbegrip nog eens, door er op te wijzen dat de EG-regelgeving wel zorg zou dragen voor een openbaar aanbestedingsbeleid, dat wil zeggen dat eenieder zou kunnen inschrijven. Het vormde de bevestiging van de praktijk waarin de grondslag voor de keuze van criteria en aanbestedingswijze van een autonome bestuursrechtelijke bevoegdheid allengs in een originaire privaatrechtelijke bevoegdheid was veranderd. Nu gaandeweg de keuze tussen de verschillende aanbestedingsprocedures (zie conclusies hoofdstukken 2 en 3 ) niet of nauwelijks nog aan bestuursrechtelijke criteria werd getoetst, werd de gemeente praktisch in staat gesteld vrijelijk te bepalen met wie al dan niet precontractuele - dat wil zeggen privaatrechtelijke - relaties zouden worden aangegaan. Zo ontstond de mogelijkheid om de

Vgl. De Haan, Drupsteen, Fernhout (1986 a), 19. 
autonome beleidsvrijheid te benutten als ware er sprake van contractsvrijheid. Het leuren vormt daarvan een (minder fraai) voorbeeld ${ }^{2}$. Het beginsel van de openbare aanbesteding herinnert alleen nog in de verte aan de bestuurlijke verhoudingen van weleer: het enige wat de contractsvrijheid beperkt is de gedachte dat er openbaar moet worden aanbesteed. De gemene rechtsleer en later de gemengde rechtsleer legitieme(e)r(d)en dit instrumentele gebruik van het privaatrecht bij de aanbesteding van bouwwerken, zonder dat daarbij tot voor kort enige bestuursrechtelijke grondslag in acht behoefde te worden genomen. Het wekt dan ook geen verbazing om in de feestbundel ter gelegenheid van het afscheid van De Haan te lezen, dat Lubach van mening is dat de bevoegdheidsvraag geen regeling behoeft naast de bestaande regels in de gemeentewet. Het privaatrechtelijke contractenrecht biedt volgens hem een voldoende kader ter beoordeling van de bevoegdheid en de gebondenheid ${ }^{3}$.

De gevolgen van dit instrumentele gebruik van het privaatrecht zijn de in de praktijk aangetroffen ondoorzichtigheid van het gevoerde aanbestedingsbeleid, lokaal protectionisme en uiteindelijk rechtsongelijkheid.

De trend om thans meer dan in het verleden openbaar aan te besteden, wordt primair ingegeven door financiele (doelmatigheids-)argumenten`. Deze openbaarheid heeft betrekking op de mogelijkheid tot inschrijven. Deze openbaarheid heeft echter niets van doen met de bestuurlijke openbaarheid: het verschaffen van inzicht in het gevoerde en te voeren beleid.

De (heersende) gemengde rechtsleer is kennelijk - onder meer blijkens de aangetroffen onderhandse aanbestedingspraktijk - niet in staat tot een bevredigende normering van de beleidsaspecten van overeenkomsten met de overheid. In weerwil van de gedachte dat iedereen gelijke kansen zou moeten hebben op inschrijving, doet zich feitelijk een instrumentele aanbestedingspraktijk voor, die op geen enkele wijze waarborgen schept voor een correcte belangenafweging. De verzuchting van Lubach, die er op neerkomt dat de praktijk zijn eigen gang gaat, spreekt in dit verband boekdelen (zie hoofdstuk 1). Het is precies deze opmerking die de tekortkomingen van de gemene en thans de gemengde rechtsleer bloot legt. Dit is, bezien vanuit een rechtsgeleerd standpunt, uitermate onbevredigend temeer waar de introduktie van de openbare en onderhandse aanbesteding in 1851 juist bedoeld was geweest om de gesloten lokale economieën te doorbreken en onduidelijke gemeentelijke praktijken te voorkomen. Hoezeer ook de voorstanders van de openbare aanbesteding zich de behartiging van het in artikel 1 Grondwet genoemde grondrecht aantrekken, komt het mij voor dat juist het ontbreken van een publiekrechtelijk toetsingskader voor de belangenafweging een onwenselijke aanbestedingspraktijk laat voortduren.

\section{Bestuurstechtelijke normering}

Zonder in dit verband te streven naar iets wat ook maar lijkt op een overzicht van de standpunten over de verhouding tussen publiek- en privaatrecht, wordt hiema het accent gelegd op de ontwikkeling van het eigen standpunt inzake het karakter van het overheidsaanbestculingenrecht.

2 In die zin De Haañ. Drupsteen, Fernhout (1986 b), 80 en noot 200.

3 Lubach (1989), 4!-42.

- O.m. A.J.Chr. Dekkker, Besteding op z'n Europees spaar miljarden guldens, Cobuuw $19 \% 0 \mathrm{nr}, 182$ en Limburg wint miljoenen op openbaar aanbesteden, Cobouw 6 met 1994. 
Uitgangspunt voor het normatieve beleidskader moet naar mijn oordeel zijn dat de overheid op elk moment onderworpen is aan bestuursrechtelijke grondslagen. De Haan c.s. en Jitske de Jong hebben gepleit voor een benadering van de andere kant: 'voor de overheid is het publiekrecht het gemene recht, doch bij wijze van aanvulling daarop kan het privaatrecht ook aan beleidsdoeleinden dienstbaar zijn, mits het daartoe wordt omringd met de nodige bestuursrechtelijke waarborgen'5. Dit uitgangspunt leidt De Haan c.s. vervolgens tot het voorstel om te komen tot een wettelijke formulering van algemene regels voor het overheidscontract. In deze benadering herkent men de instrumentele optiek. Het publiekrechtelijke contractenrecht moet de overheid de basis verschaffen om vervolgens met aan het privaatrecht ontleende middelen doelstellingen te bereiken. Anders dan de hiervoor genoemde opvatting van De Haan gaat het mijns inziens niet alleen of zelfs maar primair om de vraag hoe bepaalde overheidsdoelstellingen kunnen worden bereikt, maar of een bepaald overheidsoptreden publiekrechtelijk toelaatbaar is. Voor de beantwoording van deze vraag zoek ik aansluiting bij de opvatting van Van der Hoeven ${ }^{6}$ dat de omstandigheid dat een handeling deel uitmaakt van de publieke taakvervulling gevolgen heeft voor de inhoud van het recht waardoor die handeling wordt geregeerd onverschillig of dit privaatrecht of publiekrecht in klassieke zin is. Het is de strekking der verrichte handeling die beslissend is voor de inhoud of wijze van hantering der toe te passen norm. Daaruit volgt niet dwingend de thans heersende gemengde rechtsleer, waarbij de publiekrechtelijke en privaatrechtelijke rechtsnormen worden 'gemixt'. De Haan heeft het als volgt kleurrijk omschreven: 'bij alle vervlechting tussen publiek- en privaatrecht zijn steeds de gele lijnen van het privaatrecht duidelijk te onderscheiden van de rode van het publiekrecht, zonder ooit oranje te worden"?

De opvatting dat het (publiek- en privaat)recht een eenheid vormen", gecombineerd met de heersende gemengde rechtsleer, miskent bet principiële verschil dat tussen de beide rechtsgebieden bestaat. Het doet er dan niet langer toe langs welke weg de overheid het nagestreefde resultaat bereikt: het hele recht staat tot haar beschikking, zonder dat er nog veel woorden behoeven te worden vuil gemaakı aan de publiekreehtelijke rechtsbescherming van (derde)belanghebbenden. De recente ontwikkelingen op het gebied van de handhaving van bestuursrechtelijke normen via het privaatrecht geeft wat dat betreft te denken?.

De opvatting van Van der Hoeven betekent dat wanneer de afspraak tussen het bestuur(sorgaan) en de burger betrekking heeft op de behartiging van een algemeen belang, en dus niet alleen op de behartiging van een vermogensrechtelijk belang, daarmee het publiekrechtelijke karakter van de bestuurshandeling is gegeven. Tak ontkent de mogelijkheid voor het bestuur om vermogensrechtelijk te handelen. Hij verdedigt de stelling dat het overheidsoptreden alleen dan toelaatbaar is, indien het voldoet aan alle publiekrechtelijke grond-

\footnotetext{
De Haan, Drupsteen, Fernhout (1986 a), 359. De Jong (1984), 45-46.

Van der Hoeven (1970), $201 \mathrm{v}$.

De Haan (1992), 897. $\mathrm{Vgl}$ in die zin Simon (1993), 9 en 261.

Onder meer Bloembergen (1977)

- HR 22 okt. 1993, AB 1994, 1 (Van der Veen), Gst 6982.3 (Hennekens), AA 1994, 157 (Drupsteen), M\&R 1994, 1 (Kotrenhagen-Edzes), NTBR 1994, 106 (Hartlief/ van Swaaij), BR 1994, 322 (Tjittes), TMA 1994, 75 (Bierbooms) (Staad Magnus) en HR 18 februari 1994, RvdW 1994, 58 C, AB 1994/415 m, nt. G.A. van der Veen (Kabayel) in dit beeld past ook het verlaten van het art. 6:162 BW-belangvereiste: de overheid kan het publiekrecht nu ook afdwingen via het privaatrecht, met als uitsmijter een beroep op de ongerechtvaardigde verrijking (zie HR 14 oktober 1994, RvdW 1994, 202 C, AB 1995, 48 m.nt. G.A. van der Veen (Wrakkenwet)).
} 
slagen. Voor een privaatrechtelijk optreden is ten ene male geen plaats. Zijns inziens handelt de overheid steeds en uitsluitend publiekrechtelijk ${ }^{10}$.

Het gemengde rechtsdenken over het onderscheid tussen privaatrecht en publiekrecht zoals dit in literatuur ${ }^{\prime \prime}$, rechtspraak $^{12}$ en wetgeving ${ }^{13}$ vorm heeft gekregen en nog steeds krijgt, berust volgens Tak op pragmatisne. Gelegenheidsoplossingen, die in het ene geval het overheidshandelen onverkort genormeerd achten door het BW, en in een ander geval overheidscontracten weer volledig toetsen aan publiekrechtelijke criteria ${ }^{14}$, hieden volgens hem geen soelaas voor wat in wezen een maatschappelijk vraagstuk van de eerste orde is. En ook de gemene rechisleer, zoals deze is uitgelegd door Van Praag en Wiarda, krijgt er fors van langs!

De betekenis van deze opvatting is, dat wordt benadrukt dat de overheid bij het gebruik van rechtsfiguren uit het Burgerlijk Wetboek steeds moet aangeven of aan alle publiekrechtelijke eisen is voldaan. Het automatisme (apriorisme) waarmee in de gemengde rechtsleer van handige privaatrechtelijke vormen (een instrumenteel) gebruik wordt gemaakt staat zo principieel ter discussie.

En dat is winst!

Ook Damen plaatst vraagtekens bij de vanzelfsprekendheid waarmee de overheid van het privaatrecht gebruik maakt. Hij wijst er op dat Kobussen zich op geen enkel moment druk maakt of het bestuursrecht niet juist opzettelijk grenzen stelt aan het overheidsoptreden. 'Ongetwijfeld moet zonder gebruik van het privaatrecht soms worden geconcludeerd dat allerlei zaken die mooi zijn voor de 'mensen in het land', niet kunnen, omdat een publiekrechtelijke grondslag ontbreekt. Is het juiste antwoord dan niet: jammer, maar helaas?', aldus Damen, waarmee hij zeer dicht in de buurt van Tak's standpunt staat. Op het punt van de aanbesteding laat hij de overheid echter de privaatrechtelijke weg 'domweg omdat daarvoor niet alleen een bestuursrechtelijke weg niet bestaat, maar ook omdat die weg voor het kopen van potloden niet goed mogelijk is'15. Mijns inziens staat het ontbreken van een bestuursrechtelijke vorm (het contract) er niet aan in de weg dat ook dan een publiekrechtelijke grondslag voor het overheidsoptreden moet worden geëist. Het overheidsoptreden

${ }^{10}$ Tak (1992), 178. Deze opvatting kan op stevige kritiek rekenen uit het kamp van de gemengde rechtsleeraanhangers. Zie ook Van Wijk - Konijnenbelt - Van Male (1994), 476. Konijnenbelt wees in zijn bewerking van het handboek van Van Wijk de beginselen van rechtstaat en demokratie aan als normatief kader voor een beleid dat uitsluitend met privaatrechtelijke middelen kan worden gevoerd (Van Wijk-Konijnenbelt (1991), 315). In de recente bewerking (1994, negende dnuk), samen met Van Male, ontbreekt deze zinsneden op de 'overeenkomende' pagina 480 . Kennelijk zijn de auteurs op dit punt tot andere inzichten gekomen. Het is niet duidelijk of de reden dat het tekstgedeelte ontbreekt moet worden gezocht in de opvatting van beide auteurs dat er een 'ongeschreven, algemeen contractenrecht bestaat dat ook voor de publiekrechtelijke overeenkomst geldt (en dat we, enigszins toegespitst op privaatrechtelijke verhoudingen, herkennen in het BW)' (p. 304). In zijn boekbespreking spreekt Tak (1994), $165 \mathrm{v}$. de hoop uit dat hier wellicht de invullende rechtsleer gloort.

iI Onder verwijzing naar (geschriften van) Lubach, Bloembergen, en Konijnenbelt.

1 Het vasthouden aan het formele BAB-beschikkingsbegrip en de ketentheorie van de Aroh-rechter, de tweewegenleer.

13. Het besluithegrip in art. $3: 1$, lid 2 en arti. $8: 1$ en $8: 3 \mathrm{Awb}$.

14 Respectievelijk HR 27 maart 1987, AB Klassiek nr. 19 (IKON), en 15 maart 1991, NJ 396 (Körfer).

is Damen (1992), 468. 
dient steeds te voldoen aan alle regels van publiekrecht. Hiervoor kan allereerst worden gedacht aan bepalingen inzake de bevoegdheid. Maar ook aan regels inzake legaliteit, het democratiebeginsel, het specialiteitsbeginsel en de exclusiviteit van het algemeen belang als richtsnoer en graadmeter voor alle overheidsoptreden en voor haar bestaan. Het overheidsoptreden wordt steeds beheerst door het publiekrecht, zonder dat er sprake is van een mix met privaatrechtelijke normen. Het ontbreken van dergelijke publiekrechtelijke grondslagen waaraan het overheidsoptreden inzake aanbestedingen moet worden getoetst maakt de tekortkomingen van een louter instrumenteel gebruik van het (privaat)recht, hoe goed ook bedoeld, duidelijk. Een dergelijke benadering zet de deur open naar een onbeperkte bevoegdheidsaanmatiging door het bestuur, hetgeen een bedreiging kan vormen voor de kwaliteit van een democratische samenleving. Wat dat betreft lijkt ook De Haan gevoelig voor het bestuursrechtelijke deficit in de heersende gemengde rechtsleer. In zijn bespreking van de dissertatie van Kobussen, wijst hij op de gevaren van doorkruising van specifieke bevoegdheden en waarborgen van het bestuursrecht door het gebruik van privaatrechtelijke overheidscontracten. Dergelijke doorkruisingen kunnen zich met name voordoen bij overheidsmonopolies. De Haan noemt dan de levering van goederen en diensten door de overheid. Mijns inziens geldt hetzelfde voor de aanbesteding, waar de (gemeentelijke) overheid feitelijk de grootste opdrachtgever is. Daarbij wijst hij op de evidente zwakte van het overheidsprivaatrecht uit een oogpunt van algemene belangenbehartiging. Mede met het oog op deze belangenbehartiging (en belangen van derden) is in het besturssrecht vrijwel steeds een speciale rechtsgrond en ook een specifieke bevoegdheid vereist voor overheidsoptreden en is de uitoefening daarvan met de nodige bestuursrechtelijke waarborgen omgeven. Het privaatrecht mist deze vereisten ${ }^{16}$.

Het is overigens de vraag of de genoemde opvatting van Tak er ook toe dwingt dat, indien de door hem geformuleerde bestuursrechtelijke voorvragen positief zijn beantwoord, de overheid geen vermogensrechtelijke rechtshandelingen zou kunnen verrichten met behulp van privaatrechtelijke rechtsfiguren ${ }^{17}$. Scheltema verwerpt in zijn artikel in het WPNRthemanummer, dat ongeveer tezelfdertijd verscheen als de bijdrage van Tak ${ }^{18}$, het uitgangspunt dat overeenkomsten met de overheid steeds als zijnde privaatrechtelijk zouden moeten worden beschouwd, en dat als vanzelfsprekend de regels van het Burgerlijk Wetboek daarop zouden moeten worden toegepast. Zijns inziens moet naast de privaatrechtelijke overeenkomst de bestuursrechtelijke ('eigensoortige') overeenkomst worden onderscheiden. Hij denkt daarvoor met name aan de overeenkomsten met de overheid die in de sfeer van het bestuur liggen (hij noemt de bevoegdheidsovereenkomst, in het bijzonder de subsidie-overeenkomst). Grondgedachte daarbij is dat het overeenkomstenrecht een aantal regels kent die aan beide delen van het recht gemeen(schappelijk) zijn. Zij het dat de regels niet precies dezelfde behoeven te zijn. Door het vooropstellen van deze bestuursrechtelijke dogmatiek kan de vraag aan de orde komen, in hoeverre er ruimte is voor een overeenkomstige toepassing. Vervolgens legt Scheltema het accent op de verschillen in gebondenheid: hogere publiekrechtelijke belangen kunnen vorderen dat de overheid op de overeenkomst terugkomt. Pu-

16 De Haan (1992), 899.

17 Eerder was Tak (1989), 297 nog wat terughoudender en zag hij naast of na het publiekrecht nog ruimte voor privaatrecbt.

18 Scheltema (1992), 958 v 


\section{Afb. 1: Structuurbeginselen van aanbestedingsbeleid}

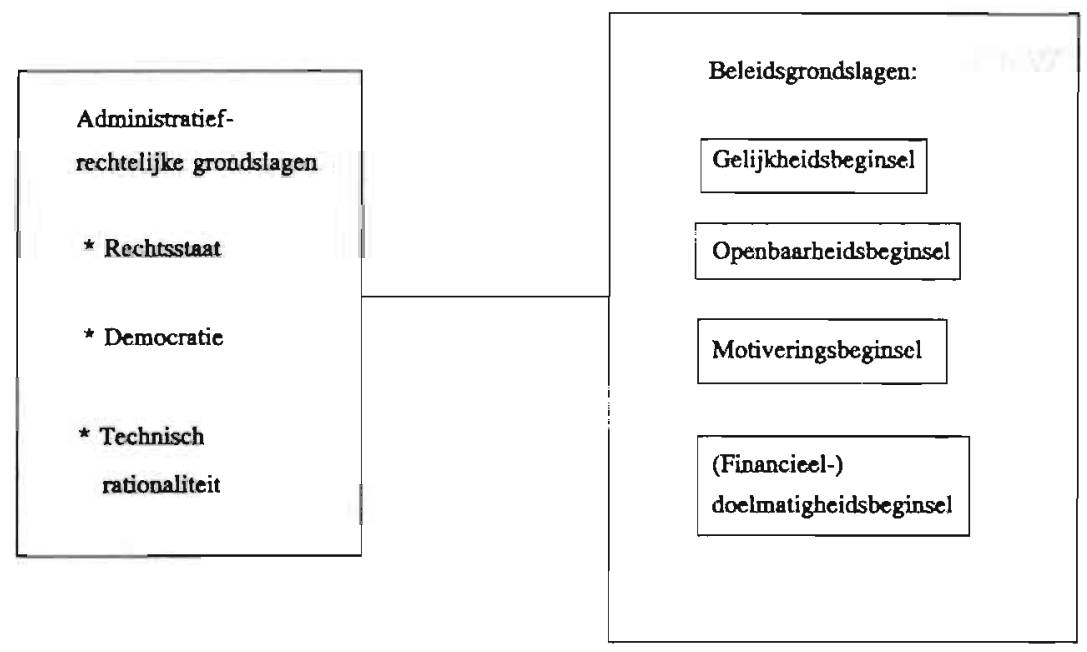

Een van de eisen van rechtsstatelijkheid is de wetmatigheid van het bestuur. Dat wil zeggen dat de overheid steeds zijn bevoegdheid moet kunnen aantonen: willekeur zijdens de overheid moet worden uitgebannen. Dat betekent ook dat gelijke gevallen steeds gelijk zullen moeten worden behandeld, en ongelijke gevallen ongelijk naar de mate waarin zij verschillen. Het in artikel 1 Grondwet opgenomen discriminatieverbod is daar een aspect van ${ }^{25}$. De wetmatigheid van bestuur beoogt bovendien de rechtszekerheid te bevorderen. Het motiveringsbeginsel hangt nauw samen met het gelijkheidsbeginsel in de wijze waarop de beslissingen tot stand komen: het (rationele) besluitvormingsproces. De eis van openbaarheid is de uitdrukking van de eis van demokratie. En in de financiële doelmatigheid herkent men (een aspect van) de technische rationaliteit.

Deze vier grondslagen van aanbestedingsbeleid zijn - meer in het bijzonder - te beschouwen als strucruurbeginselen: rechtsbeginselen, die eisen stellen aan de inhoud van het aanbestedingsbeleid. Deze beginselen moeten worden onderscheiden van de algemene beginselen van behoorlijk bestuur die betrekking hebben op de wijze waarop de besluitvorming tot stand moet komen.

Deze structuurbeginselen zijn te vinden in alle (typen) regelgeving in ons land. En ook daarbuiten, zoals in Belgit, Frankrijk en Duitsland, kan men deze beginselen in de een of andere vorm tegenkomen. In het Europese recht liggen

25 Van Wijk - Konijnenbelt - Van Male (1994), 361. Anders Van den Burg onder het arrest A'dam/ IKON (AB 1987, 273). Ook zo Akkermans (1991), 505. 
de beginselen gezamenlijk ten grondslag aan de coördinatie van het financieel doelmatigheidsbeleid (vergelijk de preambule van richtlijn $71 / 305$ ).

De betekenis ervan is niet beperkt tot besluiten en besluitvorming in de zin van de Awb. Het zijn beginselen die als zodanig ten grondslag liggen aan de besluitvorming inzake de aanbesteding van werken, onafhankelijk van de vraag of de diverse beslissingen ook externe publiekrechtelijke rechtsgevolgen hebben (vergelijk artikel 1:3 Awb). Nu de huidige Gemeentewet hieromtrent geen afzonderlijke regels inhoudt, moet voor deze beslissingen worden teruggegrepen op de systematiek van de oude gemeentewet. Telkens wanneer er in de zin van de gemeentewet een beslissing werd genomen ter voorbereiding van de opdrachtverlening, is er sprake van een beslissing, waarop de vier structuurbeginselen betrekking hebben. Dergelijke beslissingen zijn in elk geval: de vaststelling van het bestek en de besteksvoorwaarden, de beslissing tot aanbesteden en de beslissing tot opdrachtverlening. In wezen gaat het bij dergelijke op de oude gemeentewet gebaseerde beslissingen, steeds om beslissingen die voortvloeien uit de autonome bevoegdheid tot aanbesteden. De vier grondslagen van aanbestedingsbeleid normeren met andere woorden de (uitoefening van de) autonome gemeente(wette)lijke aanbestedingsbevoegdheid voorafgaand aan de feitelijke opdrachtverlening (de overheidsopdracht). Maar ook de beslissingen in het kader van de UAR-aanbestedingsprocedure kunnen worden beschouwd als beslissingen ter voorbereiding van de opdrachtverlening. Van al deze beslissingen kan worden gezegd dat zij een juridisch relevante tussenschakel vormen om tot het resultaat (de opdrachtverlening) te komen.

Van alle voorbereidingsbeslissingen is in ieder geval het besluit tot opdrachtverlening een besluit in de zin van artikel 1:3 Awb. Het besluit tot het aangaan van een (privaatrechtelijke) aannemingsovereenkomst ${ }^{26}$ is door de leer van het acte détachable afscheidbaar van de latere privaatrechtelijke rechtshandeling.

Op dit punt wijkt de systematiek van de Awb dus af van die van de wet Arob. De Arob-rechter paste - ter afbakening yan zijn competentie - de zogeheten keten- of oplostheorie toe, waardoor aan privaatrechtelijke rechtshandelingen voorafgaande besluiten niet afzonderlijk voor toetsing in aanmerking kwamen. De Awb-wetgever heeft de oplostheorie verlaten. Rechtshandelingen worden beschouwd binnen het eigen publiekrechtelijke kader, en dus los van de rechtshandeling waarop zij zijn gericht. Alleen voorzover de rechtsbescherming van de administratieve rechter voor dergelijke losgekoppelde besluiten niet wenselijk of zinvol wordt geacht wordt in Hoofdstuk 8 Awb een uitzondering gemaakt (vergelijk artikel 8:3 Awb). Zie hierna uitvoeriger in paragraaf 5.

Het besluit tot opdrachtverlening moet worden genomen met inachtneming van de in het Derde Hoofdstuk van de Awb gecodificeerde algemene beginselen van behoorlijk bestuur. Aangezien er op dit moment geen adviseur, bij of krachtens een wettelijk voorschrift, is aangewezen (Afdeling 3.3 Awb (advisering)) en wettelijke bepalingen als bedoeld in de artikelen 3:10 (openbare voorbereidingsprocedure) en 3:14 Awb (uitgebreide openbare voorbereidingsprocedure) ontbreken, komt dit neer op de toepasselijkheid van Afdeling 3.2 (zorgvuldigheid en belangenafweging). De beslissingen ter voorbereiding van het besluit tot opdrachtverlening zijn te beschouwen als 'andere handelingen', waarop Afdeling 3.2 Awb van overeenkomstige toepassing is, voor zover de aard yan de handelingen zich daartegen

${ }^{26}$ TK 1988-1989, 21 221, nr. 3, 37 (Memorie van Toelichring bij art. 1:3 Awb), waaruit blijkt dat de ontwerpers van de Awb afstand wilden nemen van de oplos- of ketentheorie. 


\section{Hoofdstuk 5}

niet verzet (vergelijk artikel 3:1, lid 2 Awb). Praktisch betekent dit dat het gehele besluitvormingsproces ter voorbereiding van het besluit tot opdrachtverlening aan de eisen van de tweede Afdeling van het Derde Hoofdstuk moet voldoen.

Samenvatting: De gehele (abstracte en concrete) besluitvorming voorafgaand aan de opdrachtverlening wordt inhoudelijk genormeerd door de vier grondslagen van aanbestedingsbeleid. Overigens zijn op het besluitvormingsproces voorafgaand aan de opdrachtverlening de in Afdeling 2 van het Derde Hoofdstuk van de Awb gecodificeerde algemene beginselen van behoorlijk bestuur steeds van 'overeenkomstige' toepassing.

\section{3. (Bestuursrechtelijke) eisen aan het beleid}

Hieronder worden de vier structuurbeginselen van aanbestedingsbeleid aan een nader onderzoek onderworpen. Het gaat achtereenvolgens om: het gelijkheidsbeginsel, het openbaarheidsbeginsel, het motiveringsbeginsel en het (financieel-)doelmatigheidsbeginsel.

\subsection{Het gelijkheidsbeginsel: eis van beleid}

De eis van beleid maakt het wenselijk dat er vaste beleidslijnen worden ontwikkeld. Duk ${ }^{27}$ formuleert het aldus:

'wat we tegenwoordig rechtens van een bestuursorgaan (...) vergen is: dat het beleid voen bij het gebruik van elke discretionaire bevoegdheid'.

Het is wat Van Kreveld ${ }^{28}$ het consistentiebeginsel noemt. Ook als een bestuursorgaan heschikt over een zekere beslissingsmarge moeten de verschillende beslissingen een vaste lijn vertonen. Inconsistent beleid is niets anders dan willekeurig overheidsoptreden, en dus juridisch ontoelaatbaar. Deze eis van beleid gaat in de opvatting van Duk vooraf aan de toepassing van de algemene beginselen van behoorlijk bestuur, hetgeen betekent dat deze beleidseis steeds via de toepassing van deze algemene beginselen van behoorlijk bestuur moeten worden gerealiseerd. Voor de uitwerking van het op deze beginselen gebaseerde rationele besluitvormingsmodel verwijs ik de lezer naar hetgeen daarover hieronder zal worden opgemerkt.

Het gelijkheidsbeginsel noopt tot argumentatie omtrent de gelijkheidsmaatstaven ${ }^{20}$. Deze maatstaven mogen niet willekeurig zijn. Het is evenwel onvermijdelijk dat deze maatstaven waarde-oordelen inhouden, die in laatste instantie 'logisch en empirisch-theoretisch' willekeurig zijz. De uiteindelijke legitimatiegrond voor de gemaakte keuzen is dan dat er consensus over is bereikt in een rationeel besluitvormingsproces.

\footnotetext{
27 Duk (1978), 564-587. Verfijning door Duk (1981), 233. De jurisprudentie van de administratieve rechter wees uit dat het onthrekeñ van een duidelijke beleidslijn niet zonder consequenties bleef. Zie voor een overzicht van dergelijke uitspraken Versteden (1995), $68 \mathrm{v}$.

28 Van Kreveld (1983), 298.

79 Over deze maatstaven Versteden (1985), $64 \mathrm{v}$
} 
De algemene beginselen van behoorlijk bestuur worden in de literatuur op uiteenlopende wijzen gerubriceerd. Onder meer Wiarda ${ }^{30}$ maakte onderscheid tussen de formele beginselen (beginselen die betrekking hebben op de voorbereiding, inrichting en motivering van besluiten) en materiële beginselen (die van belang zijn voor de inhoud van het besluit). De indeling van Duk is sterk bepaald door de rechterlijke toetsing van vooral beschikkingen. Nicolai ${ }^{31}$ makt onderscheid tussen normen van behoorlijk bestuur waarvan schending een besluit gebrekkig maakt, en normen waarvan schending op zichzelf geen gebrekkig besluit oplevert, omdat zij niet de wijze van bevoegdheidsuitoefening betreffen, maar het daarvan te onderscheiden feitelijke handelen. Ook het indelingsmodel van Konijnenbelt en Van $\mathrm{Male}^{32}$ is in eerste instantie toegesneden op de beschikking, maar laat zich ook gebruiken voor andere besluitvormingsprocessen. $\mathrm{Zij}$ onderscheiden beginselen met betrekking tot het proces van voorbereiding en besluitvorming, met betrekking tot motivering en inrichting van besluiten en met betrekking tot de inhoud van besluiten. De beginselen laten zich overigens niet steeds zo scherp indelen: overlappingen zijn niet uitgesloten. Het model van Konijnenbelt en Van Male wordt hierna tot uitgangspunt genomen, omdat dit het meest direct aansluit op de regeling van de algemene beginselen van behoorlijk bestuur in de Algemene wet bestuursrecht.

\section{Gelijkheid en vertrouwen}

Overheden behoren de hun toegekende bevoegdheden te allen tijde naar behoren uitoefenen. Beleidsvrijheid is niets anders dan een verplichting om de bij het besluit betrokken belangen op rechtens aanvaardbare wijze tegen elkaar af te wegen. Het gelijkheidsbeginsel leidt er in dat verband toe, dat de beleidsuitgangspunten, mede in hun onderlinge verhouding een zekere consistentie en duurzaamheid hebben, waar burgers op kunnen vertrouwen. Voor het aanbestedingsbeleid betekent dit, dat de beleidsuitgangspunten, bij voorkeur worden gerangschikt in een zekere prioriteitsvolgorde en per bouwsector. Naast het gelijkheidsbeginsel treedt het vertrouwensbeginsel dan op, wanneer aannemers bepaalde verwachtingen mogen ontlenen aan het tot dan toe gevoerde overheidsbeleid, waarbij ook valt te denken aan het effect van beleidsregels ${ }^{33}$. Zijn er eenmaal beleidsregels opgesteld en bekend geworden, dan ontleent de burger aan het vertrouwensbeginsel de aanspraak conform de beleidsregel te worden behandeld (behoudens de inherente afwijkingsbevoegdheid). Bij de uitvoering van het beleid kan het zijn dat de algemene beginselen dwingen tot afwijken van het gevoerde beleid. Ten onrechte afwijken van het tot dan toe gevoerde beleid is volgens Duk in strijd met het gelijkheidsbeginsel. Van strijd met het vertrouwensbeginsel is sprake in geval van het niet honoreren van door het beleid gewekte verwachtingen (door het niet nakomen van toezeggingen).

Het gelijkheidsbeginsel betekent vanzelfsprekend niet dat het beleid niet zou kunnen worden gewijzigd: er zal dan in de regel sprake moeten zijn van overgangsmaatregelen. Maar ook is er sprake van een wisselwerking tussen het gelijkheidsbeginsel en het vertrouwensbeginsel. Het vertrouwensbeginsel heeft tezamen met het rechtszekerheidsbeginsel ten doel de rechts-

\footnotetext{
30 Wiarda (1952), 55-94. Uitvoerig hierover Nicolaï (1990), 139-202.

3 Nicolaĩ $(1990), 260$ v. en 326 v.

3.2 Van Wijk - Konijnenbelt - Van Male (1994), 327.

33 Van Wijk - Konijnenbelt - Van Male (1994), 366.
} 
statelijkheid van het overheidsoptreden te bevorderen. Het verlangt dat bestuursorganen gewekt vertrouwen niet beschamen. Of de verwachting door het vertrouwensbeginsel rechtens wordt beschermd hangt af van vier factoren: wie heeft de verwachting gewekt (was dat de bevoegde autoriteit?), hoe is de verwachting gewekt (bij voorbeeld door: eerder gevoerd beleid, een toezegging of een bevoegdhedenovereenkomst), is de betrokkene door op de verwachting af te gaan in een nadeliger positie komen te verkeren (de dispositie-eis), en zijn er redenen die zich tegen het honoreren van het vertrouwen verzetten (contra-indicaties) ? $^{34}$ Konijnenbelt en Van Male ${ }^{35}$ rekenen het gelijkheidsbeginsel en het vertrouwensbeginsel tot de beginselen met betrekking tot de inhoud. Daarnaast behoren ook het (materiële) rechtszekerheidsbeginsel, het verbod van détournement de pouvoir, de materiële zorgvuldigheid en het evenredigheidsbeginsel tot deze categorie. Deze andere beginselen komen hieronder nog afzonderlijk aan de orde bij het rationele besluitvormingsmodel.

\section{Het UAR als gemeentelijke beleidsregel}

Als bekend (vergelijk hoofdstuk 1 ) is de bevoegdheid tot aanbesteden van de rijksoverheid voor de 'nationale' rijksaanbestedingen gebaseerd op het op artikel 34 Comptabiliteitswet gebaseerde Besluit aanbesteding van werken (BAW). Krachtens de laatste wijziging (S. 1994, 379) van artikel 6 BAW is het UAR 1986 van toepassing op werken onder de Europese drempel en is daarboven het UAR-EG 1991 toepasselijk. Het UAR is een ministeriële regeling. Dergelijke regelingen komen tot stand via een lichtere procedure dan andere algemeen verbindende voorschriften: alleen de betrokken minister komt er aan te pas. De regeling in het UAR wordt gesteld krachtens een algemene maatregel van bestuur (het BAW). Anders dan gewoonlijk bij ministeriële regelingen het geval is, is het UAR dus niet rechtstreeks op de wet gebaseerd. De wettelijke basis voor (de wijziging van) het UAR is daarmee kwestieus ${ }^{36}$ : een (toekomstige) wijziging van het UAR kan niet helemaal meer kan worden beschouwd als te zijn gegeven op basis van een bevoegdheid tot regelgeven krachtens de wet. Dat hoeft geen probleem te zijn wanneer er vanuit zou worden gegaan, dat het UAR deel uitmaakt van het BAW. Ik laat dit 'rijks'-probleem hier verder rusten.

In het arrest Staat/ Hasler ${ }^{37}$ oordeelde de Hoge Raad dat het UAR als recht in de zin van artikel 99 Wet op de rechterlijke organisatie kan worden aangemerkt en dus voor cassatie in aanmerking kan komen. De betekenis daarvan is gelegen in de verhoogde rechtsbescherming van gegadigden en inschrijvers, doordat de uitleg van bet reglement en de beoordeling van de juridische kwaliteit aan de Hoge Raad kan worden voorgelegd. De Hoge Raad overwoog daartoe dat het UAR is aan te merken als een naar buiten werkende, voor de rijksoverheid en de bij haar aanbestedingen betrokkenen bindende, regeling, uitgegaan van het openbaar gezag, dat de bevoegdheid daartoe ontleent aan de (Comptabiliteits)wet. Deze binding vloeit voort uit de wijze waarop het UAR tol stand is gekomen. De Hoge Raad wees er op dat het bij de totstandkoming van de Comptabiliteitswet in de bedoeling lag dwingende regels op te

\footnotetext{
* Uitvueriger Van Wijk - Konijnenbelt - Van Male (1994), $351 \mathrm{v}$.

3. Van Wijk - Konijnenhelt - Van Male (1994), 344.

* Noot I.C. van der Vlies onder HR 31 mei 1985, RegelMaat 1986, 75.

3 HR 31 mei 1985, AB 1985, $480 \mathrm{~m} . \mathrm{nt}$. FHvdB, NJ 1985, 648, BR 1985, 788 (Staat/ Hasler). Volgens Blucmhergen (1976), 14, nuot 25 was het UAR 1972 een intem beleidsvoorschrift dat de Stal in acht moet nemen bij het afsluiten van aannemingsovereenkomsten.
} 
stellen met betrekking tot de aanbesteding van werken door de rijksoverheid. De door de Hoge Raad aangenomen binding van de betrokkenen is weinig plausibel ${ }^{38}$. De regeling bevat voorschriften die aan de ministers zijn gericht over de wijze waarop aanbestedingen moeten worden georganiseerd. De regeling zou volgens Van der Vlies eventueel als een instructienorm kunnen worden gezien.

De wetshistorische overwegingen die de Hoge Raad hebben geleid tot het oordeel in het Staat/ Hasler-arrest kunnen niet (vanzelfsprekend) worden herhaald, als grondslag voor de binding van het gemeentebestuur aan het UAR. Van Nouhuys ${ }^{39}$ wil de lagere overheden aan het UAR binden op grond van de algemene beginselen van behoorlijk bestuur in aanvulling op de bepalingen van de coördinatierichtlijn. Dit, gecombineerd met de overwegingen van de Hoge Raad in het eerder genoemde arrest Staat/ Hasler, leidt tot de conclusie, dat het UAR voor gemeenten, die als regel steeds van het UAR gebruik maken, de status van een beleidsregel heeft. In een reeks arresten heeft de Hoge Raad dienaangaande geoordeeld, dat de:

'door een bestuursorgaan binnen zijn bestuursbevoegdheid vastgestelde en behoorlijk bekendgemaakte regels omtrent de uitoefening van zijn beleid, die weliswaar niet kunnen gelden als algemeen verbindende voorschriften omdat zij niet krachtens enige wetgevende bevoegdheid zijn gegeven, maar die het bestuursorgaan wel op grond van enig algemeen beginsel van behoorlijk bestuur binden en die zich naar hun inhoud en strekking ertoe lenen jegens de bij de desbetreffende regeling betrokkenen als rechtsregels te worden toegepast. Daaraan doet niet af dat de aard van de gebondenheid aan een zodanige regel kan meebrengen dat het bestuursorgaan daarvan onder bepaalde omstandigheden kan afwijken'.

Het gemeentebestuur heeft, door in de bekendmaking of het bestek een verwijzing naar het UAR op te nemen, zichzelf vastgelegd op de naleving van de daarin opgenomen bepalingen $^{40}$. Wat het arbitragebeding in artikel 41 UAR 1986 betreft, moet er (vermoedelijk) van worden uit gegaan dat dit inhoudt dat de overheid ervan afziet om bij aanbestedingsgeschillen de burgerlijke rechter te adiëren.

In de derde tranche van de Algemene wet bestuurstecht wordt een afzonderlijke titel (titel 4.4) gewijd aan beleidsregels $^{41}$. De Awb trekt de grenzen van deze rechtsfiguur op diverse fronten heel anders dan tot dusverre werd gedaan. De verschillen zitten dan niet zozeer in de rechtsgevolgen van de beleidsregels als wel in het rechtskarakter ervan. De norspronkelijk door de Commissie-Scheltema voorgestelde bepaling in artikel 4.4.2 Awb, dat een bestuursorgaan dat bij het gebruik van een bevoegdheid tot het nemen van besluiten of bet verrichten van privaatrechtelijke rechtshandelingen een vaste gedragslijn volgt, verplicht is deze in een beleidsregel neer te leggen, tenzij redelijkerwijs kan worden aangenomen dat daaraan geen behoefte bestaat, is door de wetgever niel overgenomen ${ }^{42} \mathrm{Er}$ is wel een beloning voor het bestuur: beleidsregels kunnen de motivering van een besluit vereenvoudigen ${ }^{43}$.

3* In die zin Van Nouhuys (1986), 49.

39. Van Nouhuys (1986), 51.

40 Anders dan de Hoge Raad gaat Van der Vlies (1990), 1149 er van uit dat beleidsregels al uit zichzelf binden.

4 Art. 1:3, lid 4 Awb omschrijft de beleidsregel als volgt: een besluit, niet inhoudende een algemeen verbindend voorschrift, dat een algemene regel geeft omtrent de afweging van belangen, de vaststelling van feiten of de uitleg van wettelijke voorschriften bij het gebruik van een bevoegdheid van een bestuursorgaan.

42 TK 1993-1994, 23 700, nr. 3, 115 (Memorie van Toelichting).

43 Art. 4.4.3 w.o. De Groot - Van der Meulen, Van Rossum (1994), 1197. 
Volgens de Memorie van Toelichting (p. 121) bij artikel 4.4.3 Awb, kan, indien een vaste gedragslijn in een beleidsregel is neergelegd, het bestuursorgaan bij de motivering van met toepassing van die beleidsregel genomen afzonderijke besiuiten naar die beleidsregel verwijzen. Dit betekent dat bij de totstandkoming van het beleid in algemene zin gemaakte keuzen niet steeds opnieuw behoeven te worden gemotiveerd. Dat is immers reeds bij het tot stand brengen van de heleidsregel gebeurd. Bij de motivering van de afzonderlijke besluiten kan dan veelal worden volstaan met een korte verwijzing naar (de motivering van) de toegepaste beleidsregel, alsmede de overweging dat geen sprake is van een bijzonder geval dat tot afwijking van de regel zou kunnen nopen (ook dat ware te motiveren, zie artikel 4.4.5 Awb).

Als beleidsregel is het UAR 'recht' in de zin van artikel $99 \mathrm{RO}$. Op het moment dat er een aanbestedingsovereenkomst ontstaat worden de UAR-bepalingen (algemene) contractsvoorwaarden ${ }^{44}$.

Zo ook volgens de Toelichting ${ }^{43}$ op de voorstellen van de derde tranche Awb. Algemene voorwaarden zoals opgenomen in een beleidsregel zijn onderworpen aan de regels van publiekrech. Pas als deze voorwaarden in een overeenkomst zijn op- of overgenomen binden ze niet langer als beleidsregel maar als een deel van de overeenkomst.

\section{Het rationele besluitvormingsmodel}

De Algemene wet bestuursrecht geeft in het Derde Hoofdstuk een model op basis waarvan rationele besluitvorming mogelijk is. Dit Hoofdstuk is van toepassing op alle besluiten van bestuursorganen, behalve op de algemeen verbindende voorschriften. Het bepaalde in artikel 3:1, lid 2 Awb strekt ertoe, de codificatie en uitwerking van de algemene beginselen van behoorlijk bestuur (in overeenstemming met de jurisprudentie) ook voor privaatrechtelijke en (beslissingen tot het verrichten $v^{4}{ }^{46}$ ) feitelijke handelingen te laten gelden, voorzover de aard van de handelingen zich daartegen niet verzet. Als ratio wordt genoemd, dat 'niet zozeer de vorm van het overheidsoptreden bepalend [dient] te zijn voor het antwoord op de vraag met welke belangen de overheid rekening dient te houden en met welke mate van zorgvuldigheid zij [dient] op te treden, als wel de specifieke situatie waarin van de overheid optreden verlangd wordt, in welke vorm dan ook ${ }^{37}$. Nadat in artikel 3:1 Awb de reikwijdte van het derde hoofdstuk wordt aangegeven, bevat de Tweede Afdeling de codificatie van enige algemene beginselen van behoorlijk bestuur (artikelen 3:2 tot en met 3:4 Awb). Het gaat dan om een aantal in de jurisprudentie ontwikkelde beginselen, zoals het zorgvuldigheidsbeginsel, het verbod van willekeur en het verbod van détournement de pouvoir. De codificatie van de algemene beginselen van behoorlijk bestuur staat er niet aan in de weg dat de rechter zal kunnen blijven toetsen aan het ongeschreven recht ${ }^{48}$. De drie beginselen van behoorlijk bestuur liggen in onderlinge verwevenheid ten grondslag aan het rationele besluitvormingsmodel zoals dit is voorzien in hoofdstuk 3 Awb (zie: afbeelding 2). Gezamenlijk beogen zij de realisering van de eis van (aanbestedings)beleid ${ }^{49}$. In de toekomst zullen de bepalingen van Afdeling 4.1.4 Awb (Motivering) worden verplaatst naar Hoofdstuk 3, titel

4 Zie over algemene voorwaarden ook Van Noubuys (1986), 46. Vgl. voorts HR 10 jan. 1992, AB I992, $282 \mathrm{~m} . \mathrm{nt}$. FHydB, NJ 1992, 670 (Scheffers Bouwmaterialen).

4s TK 1993-1994, 23 700, nr. 3, 112-113 (Memorie van Toelichting).

46 TK 1990-1991, 21 221, ar. 5, 50, punt 2.56 (Memorie van Antwoord).

4 TK 1988-1989, 21 221, nr. 3, 59 (Memorie van Toelichting).

4 TK 1990-1991, 21 221, nr. 5, 52, punt 2.64 (Memorie van Antwoord).

49 In die zin Van Male (1988), 75. 
7, zodat zij voor alle besluiten, en niet slechts voor beschikkingen gelden ${ }^{50}$. Konijnenenbelt en Van Male ${ }^{51}$ rekenen het beginsel van de zorgvuldige voorbereiding, het fair pliny-beginsel en het verbod van détoumement de pouvoir tot de beginselen met betrekking tot de voorbereiding en besluitvorming. Het fair play-beginsel is nog weinig uitgewerkt: de Awb kent alleen het verbod van vooringenomenheid als onderdeel van het fair play-beginsel (artikel 2:4 Awb).

Afb. 2: Het rationele besluitvormingsmodel

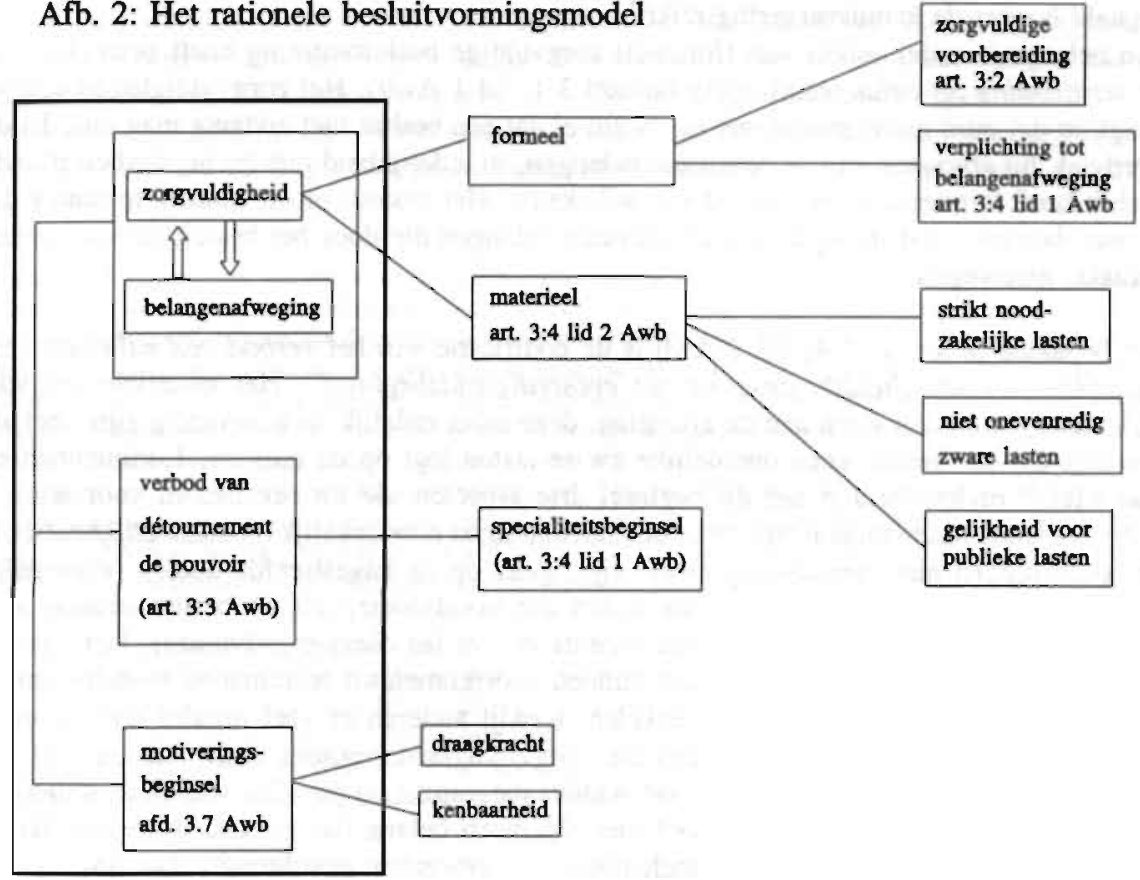

ZORGVULDIGHEID EN BELANGENAFWEGING. Het zorguldigheidsbeginsel heeft zowel betrekking op de voorbereiding van besluiten als op de besluitvorming zelf.

Nicola $\tilde{r}^{2}$ heeft reeds eerder de ontwikkeling van zorgvuldigheidsnormen met betrekking tot het 'nemen' van het bestuit bepleit. Het gaat dan niet alleen om zorgvuldige voorbereiding, maar ook om ten zorgvuldige beshitvorming. De zorgvuldigheid stelt dan eisen aan de beslissingsprocedure en aan de deugdelijkheid van de besluitvorming, dat wil zeggen aan het inhoudelijk nemen van een besluit. Dat kan meebrengen dat ook de positie van derde-belangheb-

so TK 1993-1994, 23 700, nr. 3, 15 (Memorie van Toelichting).

sı Van Wijk - Konijnenenbelt - Van Male (1994), 328.

$s 2$ Nicolaĩ (1990), 292 v. en 301 v. 
benden (andere inschrijvers) bij de voorbereiding en besluitvorming moet worden betrokken. En dat diens belangen bij de afweging van alle betrokken belangen worden meegewogen.

Eén van de (formele) zorgvuldigheidsaspecten is opgenomen in artikel 3:2 Awb: de verplichting om de nodige kennis omtrent de relevante feiten en de af te wegen belangen te vergaren (beginsel van zorgvuldige voorbereiding). De overheid dient zich een goed beeld te vormen van de bij een besluit betrokken belangen. De begrippen 'nodige kennis' en 'de relevante feiten en af te wegen belangen' maken het mogelijk dat per besluit kan worden bepaald hoever de kennisvergaring reik ${ }^{53}$.

Een belangrijk ander aspect van (formeel) zorgvuldige besluitvorming heeft betrekking op de verplichting tot belangenafweging (artikel 3:4, lid $1 \mathrm{Awb}$ ). Het zorgvuldigheidsbeginsel hangt op dat punt nauw samen met het beginsel dat een besluit niet zodanig mag zijn dat de overheid, bij afweging van de betrokken belangen, in redelijkheid niet tot het desbetreffende besluit heeft kunnen komen (verbod van willekeur). Het bestuur moet, binnen de ruimte die de wet daarvoor laat in beginsel alle relevante belangen die door het besluit zullen worden geraakt, meewegen.

Het bepaalde in artikel 3:4, lid $2 \mathrm{Awb}$ is de codificatie van het verbod van willekeur, het materiële zorgvuldigheidsbeginsel en het evenredigheidsbeginsel ${ }^{44}$. Het materiële zorgvuldigheidsbeginsel stelt eisen aan de afweging: deze moet redelijk en zorgvuldig zijn, met als resultaat dat het besluit geen onredelijke zware lasten legt op de burgers. Konijnenbelt en Van Male ${ }^{55}$ onderscheiden aan dit beginsel drie aspecten: de uit een besluit voor iemand voortvloeiende lasten mogen niet zwaarder zijn dan strikt noodzakelijk (noodzakelijkheidseis), de lasten mogen niet onevenredig zwaar zijn, gelet op de nagestreefde doelen (evenredigheidsheginsel) en ten slotte mogen de lasten die voortvloeien uit de besluitvorming niet onevenredig zwaar drukken op enkelen (égalité devant les charges publiques). Het égalitébeginsel waakt ervoor dat de lasten die kunnen voortkomen uit rechtmatige besluitvorming niet onevenredig zwaar drukken op enkelen, terwijl anderen er veel minder door worden geraakt. Op dit punt hangt het materiële zorgvuldigheidsbeginsel nauw samen met het gelijkheidsbeginsel. Het willekeurverbod is aldus toegespitst op gevallen waarin de willekeur bestaat in onevenredigheid tussen doel (het algemeen belang dat in casu in geding is) en middel (met de daaraan voor belanghebbenden verbonden gevolgen) ${ }^{56}$. Daarmee is de wetgever er in geslaagd om het verbod van willekeur als rechterlijke toetsingsnorm om te bouwen naar een beslisnorm voor het bestuur ${ }^{57}$.

"TK 1988-1989, 21221 , nr. 3, 64 (Memorie van Toelichting).

s. TK 1988-1989, 21 221, nr. 3, 69 (Memorie van Toelichting).

ss Van Wijk - Konijnenbelt - Van Male (1994), 370.

36 De evenredigheid in art. 3:4, lid 2 Awb heeft uitdrukkelijk geen betrekking op de verhouding in lastenverdeling tussen de door het besluit getroffen burgers (vgl. het égalite-beginsel) (TK 1990-1991, 21 221, nr. 5,56 (Memorie van Antwoord).

57 Zie over de marginale toetsingswijze nog TK 1990-1991, 21 221, nr. 5, 55, punt 2.72 en 58, punt 2.77 (Memoric van Antwoord). 
De Memorie van Toelichting ${ }^{38}$ wijst in verband met het evenredigheidsvereiste op Europeesrechtelijke ontwikkelingen waarin het evenredigheidsbeginsel in de jurisprudentie van het Europese Hof van Justitie toepassing heeft gevonden in gevallen dat aan belanghebbenden lasten worden opgelegd (zie wat dit betreft vitvoerig Hoofdstuk 4).

Toegepast op het aanbestedingsbeleid betekent rationele besluitvorming dat er een (formeel) zorgvuldig voorbereide belangenafweging moet plaatsvinden. Bovendien moet de afweging tussen de bij de aanbesteding betrokken belangen gelet op de inhoud redelijk en zorgvuldig zijn. Gesteld dat de gemeente bij de opdrachtverlening niet alleen de prijs en kwaliteit in overweging wil nemen, maar ook of de inschrijver in staat zal zijn om langdurig werklozen in dienst te nemen, dan brengt zorgvuldige besluitvorming mee dat de gemeente pas dan de laagste inschrijver zal kunnen passeren, indien na serieuze onderhandelingen met deze inschrijver mocht blijken dat het werkgelegenheidsdoelstelling niet met deze inschrijver is te realiseren. De last (de laagste inschrijver komt niet voor het werk in aanmerking) is dan strikt noodzakelijk.

Anders dan Van den Berg, die een serieuze onderhandelingsplicht wil afleiden uit het UAR, kan naar mijn mening de grondslag voor deze plicht worden afgeleid uit het beginsel van zorgvuldige besluitvorming. Het bestuur heeft hier zwaardere verplichtingen dan de burger. In zijn oratie vroeg Van den Berg zich af, of, wanneer cen aanbesteding niet het gewenste resultaat heeft opgeleverd, de gemeente het werk kan opdragen aan een derde. Zijns inziens kan de aanbesteder pas dan een derde-niet-inschrijver benaderen, nadat hij serieus heeft geprobeerd om via onderhandelingen (op basis van de geldende eisen en criteria) tot overeenstemming te komen met de inschrijver die het meest voor het werk in aanmerking komt ${ }^{59}$. Bij gebreke van een bepaling daaromtrent in het UAR, leidt hij deze onderhandelingsplicht af uit de strekking van dit reglement. Pas nadat is gebleken dat met deze laagste inschrijver geen overeenstemming kan worden bereikt, is de aanbesteder vrij het werk onder én of meer derden aan te besteden (diens noot 39). Van den Berg wijst in dit verband nog op het risico, dat aanbesteders er een gewoonte van kunnen gaan maken de inschrijvingen te beschouwen als een beginpunt van onderhandelingen. Hij verwachtte echter dat, nu het inschrijfcijfer een reële marktprijs vertegenwoordigt, de discussie vooral zal gaan over de mogelijkheden door bezuiniging of alternatieve werkwijzen een prijs te bereiken die binnen het budget van de aanbesteder past ${ }^{50}$. Dat deze onderhandelingsplicht ${ }^{51}$ serieus genomen moeten worden, bleek wel in RvA 19 juni 1992, nr. 15.821, BR 1993, 153. Daarin cordeelde de Raad dat de Staat toerekenbaar tekort was geschoten door niet in te gaan op herhaaldelijke verzoeken van de laagste inschrijver om te overleggen over het nog slechts kleine prijsverschil. Donders ${ }^{2}$ was oorspronkelijk huiverig om een onderhandelingsplicht aan te nemen. Dit zou het machtsevenwicht op de bouwmarkt te zeer ten nadele van de aanbesteder verstoren. Vermoedelijk is hij na de uitspraak van de Europese rechter (zaak 29/92) over het Nederlandse bouwkartel 'om': de gedachte aan een onderhandelingsplicht zou zijns inziens waardevolle uitgangspunten bieden voor het geval dat door een onverhoopte aantasting van de interne door de bedrijfstak zelf opgestelde mededingingsregelingen.

Verder moet het belang van de werkgelegenheid in een niet onevenredige verhouding staan tot het bedrijfseconomische belang van de (gepasseerde) laagste inschrijver, die niet aan deze eis kan voldoen. Wordt de inschrijver gepasseerd dan kan het égalité-beginsel meebrengen

s8 TK 1990-1991, 21 221, nr. 5, 70-71 (Memorie van Antwoord).

so Van den Berg (1991), 13-14. Dooders (1992), 98-99.

6) Van den Berg (1991), 21.

61 Vgl. Jacobsen Jensen n.a.v. discussie over proefschrift van Van den Berg, BR 1990, 416-417. Zie cok Van den Berg (1993 b), 422. Zie ook Van den Berg (1990), nr. 387 v.

62 Donders (1991), 756. In zijn noot onder RvA 16 mei 1991, BR 1991, 799 vraagt Donders zich af of een aanbesteder alvorens aan een derde-niet-inschrijver te gunnen, naar de goede trouw niet verplicht zo moeten worden geacht een voorkeursrecht aan de meest voor het werk in aanmerking komende inschrijver toe te staan. Hij wijst daarbij op het daaraan verbonden bezwaar, dat de aanbesteder gedwongen kan worden om met een inschrijver in zee te gaan die een lagere prijs ontvangt dan zijn oorspronkelijk offerte aangaf. 
dat deze inschrijver wordt gecompenseerd. De gemeente zal er dus voor moeten waken, dat de 'andere' beleidsuitgangspunten voldoende realiteitsgehalte zullen hebben! Overvragen kan belangriike financiële consequenties hebben.

HET VERBOD VAN DÉTOURNEMENT DE POUVOIR. Het verbod van détournement de pouvoir geldt voor alle overheidsoptreden, waardor het verbod een ondersteuning is van het legaliteitsbeginsel (overheidsoptreden alleen op wettelijke grondslag). Volgens artikel 3:4, lid 1 Awb moeten de rechtstreeks bij het besluit betrokken belangen, voor zover niet uit een wettelijk voorschrift of uit de aard van de uit te oefenen bevoegdheid een beperking voortvloeit in de besluitvorming worden betrokken (het specialiteitsbeginsel). Het specialiteitsbeginsel stelt grenzen aan het proces van belangenafweging dat voorafgaat aan de uitoefening van een discretionaire bestuursbevoegdheid. Waar artikel 3:4, lid 1 Awb stipuleert dat de relevante belangen moeten worden meegewogen, maakt artikel 3:3 Awb duidelijk dat andere belangen geen rol mogen spelen $^{63}$. Bepaald wordt dat het bestuursorgaan de bevoegdheid tot het nemen van een besluit niet voor een ander doel mag gebruiken dan waarvoor die bevoegdheid is verleend. Dit is het verbod van détournement de pouvoir: het gaat dan om het oogmerk van de wet. De artikelen 3:4, lid 1 en 3:3 Awb zijn elkaars complement. Waar laatstgenoemde bepaling verbiedt om een beslissingsbevoegdheid te gebruiken voor andere doeleinden of belangen dan waarvoor die bevoegdheid is gegeven, bepaalt artikel 3:4, lid 1 Awb dat alle relevante belangen moeten worden meegewogen, tenzij uit een wettelijk voorschrift of uit de strekking van de bevoegdheid een beperking voortvloeit. Door de toevoeging 'rechtstreeks bij het besluit betrokken' wordt bereikt 'dat een bestuursorgaan geen rekening zal behoeven te houden met belangen die slechts in een meer verwijderd verband door de te nemen beslissing kunnen worden getroffen'64.

In het voorafgaande is veelvuldig melding gemaakt van de mogelijkheid om 'andere' beleidsuitgangspunten in de besluitvorming te betrekken. Als voorbeeld van een dergelijk 'ander' beleidsuitgangspunt werd genoemd de bevordering van werkgelegenheid onder langdurig werklozen (vergelijk het arrest-Beentjes). De Europese Commissie is blijkens haar Mededeling van oordeel dat er daarnaast ook nog wel ruimte is voor andere beleidsuitgangspunten $^{65}$. In het vierde hoofdstuk zijn de aan de diverse beleidsuitgangspunten te stellen eisen in kaart gebracht. Nog niet is onderzocht wèlke belangen (binnen de gegeven marges) bij de aanbesteding mogen worden betrokken. Het specialiteitsbeginsel dwingt er dan toe dat alleen die belangen tegen de belangen van de direct-belanghebbende worden afgewogen die de wet beoogt te beschermen. Het is op dit punt dat de meningen uiteenlopen: welke zijn die belangen, die de wet beoogt te beschermen?

Messer en Heldeweg ${ }^{\text {sit }}$ maken in dil verband een onderscheid tussen 'rekkelijken' en 'preciezen". Een 'precieze' opvatting treffen we aan bij Stellinga", Stroink en De Waard ${ }^{6 *}$. Stellinga wil alleen die belangen bij de afweging

6 TK 1988-1989, 21 221, nr. 3, 62 (Memorie van Toelichting).

6. TK 1988-1989, 21 221, nr, 3, 67-68 (Memorie van Toelichting).

as COM 89(400) def., punt 5 geeft het beleid weer dat de EC voornemens is te voeren (punt 2.1).

46. Messer - Heldeweg (1990), 156-157. Zie voor nog andere standpunten noot Simon onder AR 5 juni 1991, AB 1992, 444.

- Zie zijn annotaties onder KB 28 juli 1976, AB 285, KB 26 okt. 1978, AB 1979, 138, KB 24 maart 1981, AB 1981, 397 en KB 2 febr. 1982, AB 1982, 228. 
betrekken, die de wetgever kennelijk beoogt te beschermen. Stroink en De Waard willen een afweging maken tussen de speciale (wettelijk behartigde) belangen en de belangen van de aanvrager (de direct-belanghebbende gegadigden en inschrijvers). Minder duidelijk is of tot deze belangen ook de belangen van derden moeten worden gerekend. De 'precieze' opvatting legt de nadruk op de relatie met het legaliteitsbeginsel: bestuursbevoegdheden worden toegekend met het oog op bepaalde doelen en mogen alleen daarvoor worden aangewend. Ruimer is de opvatting van Helder en Jue ${ }^{69}: z i j$ willen alleen die belangen niet meewegen die buiten de beleidscontext vallen (d.w.z. belangen die ter' behartiging extra ingrepen vereisen). Tonnater ${ }^{\text {70 }}$ behoort op dit punt tot de 'rekkelijken': het bestuur mag zijns inziens ook de autonome eigen belangen (steeds) meewegen. Gemeenten mogen bij al hun besluiten alle belangen betrekken die het recht aan hun zorg heeft: toevertrouwd. Voor deze integrale belangenafweging zoeken de rekkelijken steun bij het zorgvuldigheidsbeginsel. Welke belangen rechtstreeks bij het aanbestedingsbesluit zijn betrokken wordt dan bepaald door het begrip 'huishouding van de gemeente' (artikel 124 Grondwet en artikel 108 Gemeentewet). Dat daar ook grenzen aan zijn gesteld, moge blijken uit de verschillende KB's waarbij raadsbesluiten werden vernietigd (zie daarover in hoofdstuk 2, par. 3). Bovendien zal het bestuur zich bij de formulering van beleidsuitgangspunten steeds binnen de Europese eis yan non-discriminatie moeten bewegen.

Uitgangspunt moet naar mijn mening zijn, dat aanwijzing van de te behartigen belangen niet aan het bestuur is, maar aan de wetgever (vergelijk de legaliteitseis ${ }^{71}$ ). De Awb-wetgever zegt daarover:

'De vraag of een belang al dan niet een rol mag spelen in een belangenafweging, is een zaak van interpretatie van de wettelijke regeling in kwestie of (bij ontbreken van een wettelijke regeling ) van de aard en strekking van de bevoegdheid zelf. (...) Behoudens aanwijzingen dat bepaalde belangen bij de besluitvorming geen rol mogen spelen, dient overigens voorop te staan dat alle (rechtstreeks betrokken) belangen worden meegewogen'72,

Deze slotzin moet worden gelezen als een negatief geformuleerde interpretatie(vuist)regel ${ }^{73}$. Daaruit zou kunnen worden afgeleid dat slechts het belang van een financieel-doelmatige aanbesteding zou mogen worden gewogen. De wetgever van 1851 en ook de Europese aanbestedingsregelgeving beogen de realisering van juist dit belang. De vraag is of de wetsgeschiedenis van de gemeentewet van 1851 thans nog dwingt tot een afweging waarbij alleen de financiële doelmatigheid een rol mag spelen. Dit algemene belang zou mijns inziens wel moeten worden afgewogen tegen het belang van de aannemer bij een bedrijfseconomisch verantwoorde opdracht. De aannemer mag niet financieel worden 'uitgeknepen'. Of, zoals het CEM-rapport het uitdrukte: 'gerechtvaardigde verlangens van op specifieke markten. werkzame bedrijven op een evenwichtige wijze (...) verzoenen met de eisen, die het. algemeen belang stelt ${ }^{174}$. Bovendien liet het Europese Hof van Justitie ruimte voor een

Stroink - De Waard (1984), 238.

(5) Helder - Jue (1987), $33 \mathrm{v}$.

70 Tonnaer (1982). Zie verder Kooij - Tonnaer (1984), 113

7 Anders Kobussen (1989), 97. Zij concludeert dat een formele legaliteitseis voor alle privaatrechteiijk overheidsoptreden (waartoe zij waarschijolijk ook de aanbesteding rekent) niet zinvol is, omdat het onmogelijk lijkt tot een zinvolle normering voor alle privaatrechtelijk overheidshandelen te komen. Lubach wijst er in zijn NTB-kroniek op (NTB 1989, 330-331) op dat deze conclusie geen antwoord geeft op de vraag wanneer in bijzondere gevallen voor een specifieke wettelijke grondslag wel reden is.

$\pi$ TK 1988-1989, 21 221, nr. 3, 68 (Memorie van Toelichting).

${ }^{73}$ Konijnenbelt (1994), 309 gaat ervan uit dat de wetgever hiermee voor een bepaalde rekkelijke opvatting van het beginsel heeft gekozen.

4 CEM-rapport (1976), 8. 
'ander' (in casu: werkgelegenheids)belang75. Ik zou een ruimere afweging dan enkel op grond van financieel-economische doelmatigheid daarom aanvaardbaar vinden, zij het onder de dwingende voorwaarde dat daarvoor dan een wettelijke basis zou zijn aan te wijzen. Het gevaar is anders niet ondenkbeeldig dat beleidsuitgangspunten oneigenlijk worden ingezet voor een protectionistische en ondoorzichtige aanbestedingspraktijk.

Ook volgens de Europese Commissie kan een louter financieel-doelmatig beleid haaks staan op de noodzaak om bij de overheidsopdrachten ten volle rekening te houden met de sociale en economische samenhang van de Gemeenschap (COM 89(400) def., punt 5).

Het gemeentelijk beleid dient alsdan de verschillende (algemene) en individuele belangen op consistente wijze af te wegen binnen het kader van een rationeel (geobjectiveerd) besluitvormingsproces, op straffe van strijd met het eerder genoemde (materiële) zorgvuldigheidsbeginsel.

Waar een publiekrechtelijke regeling bestaat, dient het gemeentebestuur zich te onthouden van het stellen van 'aanvullende voorwaarden'. Wel zou de gemeente kunnen eisen dat alleen die inschrijvers voor de opdracht in aanmerking kunnen komen indien zij beschikken over bepaalde (bv. milieu-)vergunningen.

MotiveringSBEginSEL. Het ligt in de bedoeling van de Awb-wetgever om de regeling van het motiveringsbeginsel (Afdeling 4.1.4 Awb) te verplaatsen naar een nieuwe Afdeling 3.7. Dat heeft tot gevolg dat de toepassing van deze bepalingen niet langer beperkt zal zijn tot beschikkingen. Ook voor besluiten zal gelden dat deze moeten berusten op een deugdelijke motivering (artikel 4.16 Awb). Konijnenbelt en Van Male ${ }^{76}$ onderscheiden aan het motiveringsbeginsel twee aspecten: draagkracht en kenbaarheid. Het beginsel stelt eisen aan de duidelijkheid van de motivering van de besluiten. Daarnaast behoor tot deze categorie beginselen ook (een aspect van) het rechtszekerheidsbeginsel: de eis dat het besluit duidelijk is geformuleerd en niet voor tweeërlei uitleg vatbaar is (eenduidigheid).

De bepalingen inzake motivering worden volgens de Memorie van Toelichting niet van overeenkomstige toepassing verklaard op andere handelingen van bestuursorganen dan besluiten, zoals privaatrechtelijke rechtshandelingen en feitelijke handelingen. Er worden twee bezwaren genoemd. In de eerste plaats is het de vraag, in hoeverre ook bij privaatrechtelijke rechtshandelingen of feitelijke handelingen van bestuursorganen een motivering kan worden verlangd. Op dit punt wil de Memorie van Toelichting de rechtsontwikkelingen afwachten. Het tweede bezwaar is dat de regels inzake de bekendmaking niet van toepassing zijn op andere handelingen dan besluiten. Gelet op het verband tussen bekendmaking en motivering, lenen de motiveringsbepalingen zich minder goed voor dergelijke niet bekendgemaakte handelingen, aldus de Memorie van Toelichting ${ }^{77}$. Toegespitst op de aanbesteding merkt de Memorie van Antwoord (p. 49) in dat verband op, dat gelet op het bepaalde in de slotzin van

75 Een mogelijke achtergrond voor de overwegingen van het Hof kan geweest zijn, om - gelet op de gebrekkige Europese (demokratische) legitimatie - de lidstaten niet teveel voor de voeten te lopen.

76 Van Wijk - Konijnenbelt - Van Male (1994), 333.

$n$ TK 1993-1994, 23 700, nr. 3, 15 (Memorie van Anrwoord). 
artikel 3:1, lid 2 Awb ('voorzover de aard van de handelingen zich daartegen niet verzet') zulks een genuanceerde toepassing van de algemene beginselen van behoorlijk bestuur bij privaatrechtelijk en feitelijk overheidsoptreden veronderstelt.

'Zo moet de keuze van een bestuursorgaan yoor één bepaalde contractpartner uit vele concurrenten steeds na een zorgvuldige belangenafweging tot stand komen. Irrelevante belangen mogen de voorkeur niet bepalen. Maar het zal duidelijk zijn dat de noodzaak te kiezen nu eenmaal met zich meebrengt, dat bij een vergelijkbare prijskwaliteitverhouding de uiteindelijke belangenafweging nauwelijks aangegeven kan worden. Dit gegeven gevoegd bij het feit dat bestuursorganen bij de keuze van contractspartners een ruime mate van beleidsvrijheid toekomt, zal ertoe leiden dat alleen bij een duidelijk onjuiste belangenafweging de keuze voor een contractpartner als onrechtmatig kan worden gekwalificeerd ${ }^{78}$.

De Memorie van Antwoord weerspiegelt de huidige rechtsopvatting, waarin beslissingen (zoals de gunning) in het kader van de aanbesteding steeds worden opgevat als feitelijke handelingen. Dit hangt ten nauwste samen met de privaatrechtelijke benadering, waarin het sluiten van het contract centraal staat. Beslissingen die worden genomen in de beleidsfase voorafgaand aan het ontstaan van precontractuele verhoudingen en die mogelijk vermogensrechtelijke (rechts)gevolgen hebben voor potentiële gegadigden en inschrijvers tijdens de aanbestedingsprocedure blijven buiten beeld. Alleen het besluit tot opdrachtverlening is een administratiefrechtelijke rechtshandeling; in de toekomst zal in ieder geval voor dit besluit gelden dat het gemotiveerd zal moeten worden.

Met Pront-van Bommel ${ }^{79}$ zou ik willen aannemen dat de ('voor'-)beslissingen ${ }^{20}$ in het kader van de UAR-aanbestedingsprocedure rechtstreeks aan het motiveringsbeginsel worden getoetst. De betekenis daarvan is op dit moment overigens nihil, gelet op de artikelen 6:3 en 8:3 Awb (waarover hierna).

De Awb-wetgever hecht blijkens het hierboven aangehaalde citaat weinig waarde aan de betekenis van het rationele besluitvormingsmodel voor normering van de gemeentelijke beleidsvrijheid bij de aanbesteding van werken. Naar mijn mening kan het besluitvormingsmodel aan zeggingskracht winnen, wanneer de gemeente bij het maken van keuzes wordt gedwongen om aan te geven hoe de diverse beslissingen passen in het in algemene termen geformuleerde beleid. Zoals in België en Frankrijk waar de overheidsaanbesteding tot het administratieve contract wordt gerekend.

Een fraai inkijkje biedt de uitspraak van de Belgische Raad van State van 11 oktoher 1988, Tijđschrift voor Aannemingsrecht, 1991, 126. Na de openbare aanbesteding van een wegennet besloot het bestuur van de opdracht af te zien. Vervolgens ging het bestuur over tot een beperkte heraanbesteding. De aannemer, die bij de oorspronkelijke aanbesteding als laagste inschrijver uit de bus kwam, werd niet uitgenodigd. Deze beslissing werd door de Raad van State vernietigd: de beslissing was niet voldoende gemotiveerd.

\subsection{Het openbaarheidsbeginsel: kenbaarheid van bet beleid}

Het tweede structuurbeginsel is het openbaarheidsbeginsel. Van de eis van beleid zou weinig overblijven wanneer het beleid niet tevens openbaar zou zijn. Openbaar aanbestedingsbeleid

TK 1990-1991, 21 221, nr. 5, 49 (Memorie van Antwoord).

79 Pront-van Bommel (1993), 959.

* De 'voor'-beslissingen komen hierna aan de orde in paragraaf 6.2. 


\section{Hoofdstuk 5}

betekent dan dat het besluitvormingsproces rondom de aanbesteding van werken steeds in de volle openbaarheid moet plaatsvinden. Dat wil allereerst zeggen dat de vaststelling van het beleid in abstracto steeds moet plaatsvinden in een openbare raadsvergadering. De gesloten vergaderingen van $B \& W$ lenen zich uitdrukkelijk niet voor het vaststellen van aanbestedingsbeleid ${ }^{81}$. Het gaat erom dat de diverse beleidskeuzes voorafgaand aan een aanbesteding in het openbaar tot stand komen en aan iedereen bekend kunnen zijn. Deze keuzes kunnen betrekking hebben op het financiële belang van de gemeente (bij de keuze van de aanbestedingsprocedure) en op de deskundigheid en solvabiliteit van de aannemer (bij de keuze van de aannemer). Ook is het denkbaar dat nog 'andere' overwegingen bij de opdrachtverlening worden betrokken. De openbaarheidseis houdt niet alleen in dat het beleid in het openbaar wordt vastgesteld; het veronderstelt tevens dat het beleid in een schriftelijk stuk wordt neergelegd. Mulder en Duk ${ }^{82}$ noemen deze kenbaarheidseis één van de eisen waaraan bet instrumentele gebruik van het recht moet voldoen. De juridische betekenis daarvan ligt in de mogelijkheid de besluiten te toetsen.

De openbare besluitvorming door de raad kan worden beperkt op de gronden genoemd in artikel 23, leden 2, 3 en 4, artikel 24 en artikel 25 Gemeentewet. In dit laatste artikel wordt een relatie gelegd met een belang in artikel 10 van de Wet openbaarheid van besturur (S. 1991, 703). Met name de vaststelling van het budget dat de raad voor de uitwoering van het werk beschikbaar wil stellen is, gelet op de mededinging, geen gegeven dat, voorafgaand aan de opdrachtverlening, in de openbaarheid zou moeten komen.

En ook de uitvoering van het beleid in concreto dient in de volle openbaarheid plaats te hebben. Deze open besluitvorming heeft niet enkel betrekking op het publiek maken van het feit van aanbesteding (de uitnodiging), maar tevens de bekendmaking van de daarbij te hanteren criteria en voorwaarden uitmondend in de keuze voor een aanbestedingsprocedure. Vergelijk op dit punt de openbaarheidseis van het Europese Hof van Justitie in het arrestBeentjes: daar werd geoordeeld dat de ook eventuele 'aanvullende voorwaarden' voorafgaand aan de aanbesteding bekend moesten worden gemaakt.

Open besluitvorming kan helpen voorkomen dat er opnieuw een 'jungle' ontstaat, zowel aan de vraag- als aan de aanbodzijde. Het ontwikkelen van een openbaar aanbestedingsbeleid is een voorwaarde voor een transparante bouwmarktstructuur. Onduidelijkheid (onvoorspelbaarheid) draagt bij aan ongewenste produktiediscontinuïteiten, terwijl het afwentelen van dergelijke risico's het ontstaan van nieuwe aanbestedingsregelingen aan aanbodzijde tot gevolg kan hebben. Het openbaarheidsbeginsel functioneert in dit verband als een soort 'collectieve rechtsbescherming': het recht op openbare besluitvorming.

Openbaar aanbestedingsbeleid brengt niet noodzakelijk mee dat de gemeente in beginsel steeds gebruik zou dienen te maken van de openbare aanbesteding(sprocedure) uit het UAR. Waar het orn gaat is dat de gemeente als regel de aanbesteding in het openbaar bekendmaakt. Er kunnen evenwel gegronde redenen zijn om de inschrijving te beperken. Deze redenen dienen door het gemeentebestuur vooraf en in algemene termen te worden geëxpliciteerd. Hetzelfde geldt voor de aanbesteding in concreto: ook dan zal het bestuur moeten aangeven

t. Anders dan de raadsvergaderingen (artikel 23 Gemeentewet) zijn de vergaderingen van B\&W niet steeds openbaar (artikel 54 Gemeentewet).

2 Mulder-Duk (1985), 26. 
op grond van welke overwegingen zij tot haar besluit is gekomen (zie hierna onder 'motiveringsbeginsel'(als structuurbeginsel)). De openbare aanbesteding wordt wegens haar verwantschap met de licitatie door Hulshof als sterk verouderd beschouwd ${ }^{83}$. Hij pleitte ervoor te zoeken naar andere aanbestedingswijzen (met selectie) ${ }^{84}$. Met onder meer Van den Berg $^{85}$, De Haan c.s. ${ }^{86}$, Koeman ${ }^{87}$ en het CEM-rapport ${ }^{88}$ neem ik aan dat de aanbesteding met voorafgaande selectie een duidelijke voorkeur heeft, als het erom gaat de bedrijfstak van een zekere rentabiliteit te verzekeren. Voor Rozemond ${ }^{89}$ is het vanzelfsprekend dat de onderhandse aanbesteding de voorkeur verdient (alleen de Europese regelgeving gooit roet in het eten), of de aanbesteding met voorafgaande selectie.

Het uitgangspunt van de openbaarheid van de besluitvorming rond de aanbesteding leidt er toe dat onderhandse (d.w.z. niet in het openbaar bekend gemaakte) aanbestedingen tot de zeldzame uitzonderingen behoren. Een onderhandse aanbesteding (na selectie) zoals geregeld wordt in de Uniforme Aanbestedingsreglementen moet daarom in beginsel uitgesloten worden geacht. Alleen in bijzondere, nader te omschrijven, situaties kan er sprake zijn van een onderhandse aanbesteding (eventueel na selectie). Voor dergelijke gevallen zou aansluiting kunnen worden gezocht bij de in het buitenlandse (bij voorbeeld Belgische en Duitse) overheidsaanbestedingsrecht geregelde gevallen. Om te garanderen dat er voldoende aannemers tot de inschrijving worden toegelaten zou wettelijk bepaald moeten worden dat een minimumaantal aannemers wordt uitgenodigd, waardoor de concurrentie is gewaarborgd. In bepaalde, zeer bijzondere gevallen zal de overheid gedwongen kunnen zijn de opdracht enkelvoudig aan te besteden. Ook wat dit betreft zou aansluiting kunnen worden gezocht bij het Belgische en het Duitse recht als ook bij de gevallen bedoeld in artikel 7 richtlijn 93/37 (de zogenaamde 'onderhandelingsprocedures'). Een onderhandse opdracht moet (bij voorbeeld) geoorloofd worden geacht in het geval van spoedeisendheid (vergelijk artikel 7, lid 3, sub c richtlijn 93/37). Deze spoedeisendheid dient dan wel te zijn gerelateerd aan de publiekrechtelijke taakvervulling. Als deze taak onmiddellijke uitvoering eist, kan dit reden zijn voor een ondershandse opdracht. Bij voorbeeld als de gevolgen van buitengewone weersomstandigheden, in het publieke belang, het onmiddellijke herstel van openbare wegen eisen. Het feit dat de gemeente haar taak verzaakt, waardoor op den duur dringend herstel noodzakelijk wordt, is geen reden om tot een onderhandse aanbesteding te besluiten ${ }^{90}$. Watersnoodrampen, zoals in 1993 en 1995, rechtvaardigen daarom naar mijn mening geen ondershandse aanbesteding. Er kan wel worden gedacht aan het gebruik van de versnelde procedure (artikel 14 richtlijn 93/37).

Hulshof (1973), 149.

Hulshof (1973), 153

* Van den Berg (1986), 31. Zie over de nadelen van de openbare ambesteding Van den Berg (1990), 218 en 237 240.

4 De Haan, Drupsteen, Fernhout (1986 b), 82-83.

7) Koeman (1982), 395.

CEM-rapport (1976), 18.

Rozemond (1988), 393.

V Vl. zaak 194/88-R (La Spezia). De President van het Hof beval de lidstaat om alle noodzakelijke maatregelen te nemen om de betwiste aanbesteding uit te stellen tot het moment waarop het Hof zich over de zaak zou hebben uitgesproken. Zie cok zaak C-107/92 (Commissie v. Italiē). 


\subsection{Het motiveringsbeginsel: beredeneerd beleid}

Het motiveringsbeginsel als structuurbeginsel heeft betrekking op de (rationele) argumentatie die ten grondslag liggen aan de blijkens het beleid gemaakte keuzes. Het gaat om vragen zoals: waarom zijn bepaalde beleidsuitgangspunten wel of juist niet bij de aanbesteding betrokken?, wat heeft de keuze van de beleidsuitgangspunten bepaald?, op welke wijze is de prioriteitenstelling ontstaan?, op welke wijze vindt de afweging tussen de beleidsuitgangspunten plaats?, wat is de ratio achter de afweging?, wat bepaalt de keuze voor een bepaalde aanbestedingsprocedure? etcetera. Ook afwijkingen van het beleid moeten worden gemotiveerd. De overheid moet steeds actief en uit eigen beweging en voorafgaand aan en tijdens de eigenlijke aanbesteding gemaakte keuzes motiveren en doorzichtig maken waardoor het aanbestedingsbeleid zowel juridisch als ook politiek toetsbaar wordt.

Het motiveringsbeginsel hangt ten nauwste samen met de 'eis van beleid'. Het bestuur dient op een navolgbare en weloverwogen wijze keuzes te maken: dat wil zeggen op basis van objectieve maatstaven en dus met beleid ${ }^{91}$. In de woorden van Konijnenbelt en Van Male ${ }^{92}$ : 'Het gelijkheidsbeginsel verplicht bestuursorganen, adequate differentiecriteria voor hun beleid vast te stellen en steeds aan te (kunnen) geven dat deze criteria juist zijn toegepast'.

Ook op dit punt is vergelijking met het Belgische recht boeiend. Zo oordeelde de Belgische Raad van State 16 okt. 1990, RW 1991, 813 m.nt. David D'Hooghe, dat verzoekster er een belang bij had om de vernietiging te vorderen van de impliciete weigering om haar toe te laten tot de beperkte aanbesteding. Ook al heeft de overheid een discretionaire bevoegdheid ter zake van de keuze tussen de openbare of beperkte aanbesteding en ter zake van de keirze van de aannemers die zij uitnodigt (vergelijk het 'zwarte gat' in het UAR) tot mededinging bij een beperkte aanbesteding, dan dient deze bevoegdheid niet willekeurig te worden uitgeoefend (eis van beleid). Wanneer in een gegeven geval de omstandigheden zo zijn dat het onbegrijpelijk voorkomt waarom een beperkte en geen openbare aanbesteding werd gehouden of waarom voor een bepaalde aanbesteding een bepaalde aannemer niet werd uitgenodigd, eist het motiveringsbeginsel dat het bestuur dat onbegrijpelijke begrijpelijk maakt en derhalve de redenen van zijn handelwijze doet kennen.

\subsection{Het (financiële) doelmatigheidsbeginsel: prioriteit van het financiële belang}

Naast deze rechtmatigheidseisen staat het bestuurspostulaat: er moet bestuurd worden ${ }^{93}$. Bij het doelmatigheidsbeginsel gaat het om de volgende vragen: a. op welke wijze, en b. met welke middelen kan het gestelde doel (de opdrachtverlening) het best worden bereikt: het grootste resultaat (effectiviteit of doeltreffendheid) tegen de geringste kosten (efficiëntie of doelmatigheid). Dus ook wanneer 'andere' beleidsuitgangspunten hun intrede doen in het aanbestedingsbeleid veronderstelt deze eis van technische rationaliteit, dat de opdrachtverlening steeds de financieel meest doelmatige is. In de prioriteitsvolgorde tussen de diverse bij

91 Duk (1981), 231. Van Kreveld (1983), 185.

92 Van Wijk - Konijnenbeit - Van Male (1994), 361 onder verwijzing naar diverse preadviezen.

93 Konijnenbelt spreekt van technische rátionaliteit. Zie h.o. cok Donner, A.M., Interventie VAR, Geschrift Vereniging vour Administratief Recht LXXXVII, 21. (Onwetmatig bestuur. Verslag van de algemene vergadering gehouden op 5 maart 1981 ter behandeling van het preadvies van mr. F.W. ter Spill en mu. A.Q.C. Tak, Alphen aan den Rijn 1981). Donner merkt op dat er naast het demokratische - en rechtspostulaat ook zou moeten worden uirgegaan van een 'bestuurspostulaat': 'Er moet per slot van rekening ook bestuurd worden!'. Dit besruurspostulaat ontbreekt in Tak (1993), $174 \mathrm{v}$. 
de aanbesteding betrokken belangen, zal het prijs/ kwaliteitsbelang dus steeds bovenaan moeten prijken. De opdracht wordt in beginsel steeds voorwaardelijk verleend aan de laagste inschrijver c.q. de inschrijver met de economisch meest voordelige aanbieding. 'Voorwaardelijk' omdat, wanneer er ook 'andere' belangen bij de opdrachtverlening zijn betrokken, de inschrijver (in beginsel ${ }^{94}$ ) ook aan deze 'aanvullende voorwaarden' zal moeten voldoen alvorens hem het werk wordt opgedragen.

Samenvatting: het gelijkheidsbeginsel (soms in samenhang met het vertrouwensbeginsel), het openbaarheidsbeginsel, het motiveringsbeginsel en het (financieel-)doelmatigheidsbeginsel zijn de 'structuur'-beginselen van aanbestedingsbeleid. Er dient steeds van het bestaan van een openbaar, beredeneerd aanbestedingsbeleid sprake te zijn, waarbij het (gehele) besluitvormingsproces plaatsvindt op basis van een rationeel besluitvormingsmodel, waardoor een financieel-doelmatige opdrachtverlening kan worden gerealiseerd. Door voorafgaand aan de eigenlijke aanbesteding een beleid in abstracto te formuleren wint het rationele besluitvormingsmodel aan zeggingskracht.

\section{Vormgeving van het aanbestedingsbeleid}

Gelet op de eisen die aan het aanbestedingsbeleid ten grondslag liggen is schriftelijkheid noodzakelijk ${ }^{95}$. Dat betekent dat de gemeente op enigerlei wijze haar beleid in abstracto zal moeten vastleggen. Daarvoor kan gedacht worden aan een beleidsnota. Deze beleidsnota zou kunnen worden ontwikkeld op basis van een evaluatie van eerder gevoerd beleid, waardoor de bestuurslasten die daarmee kunnen zijn gemoeid, beperkt kunnen blijven, zeker wanneer deze lasten in geen verhouding staan tot het totaal aan te besteden werken (zoals vermoedelijk bij kleine gemeenten). Het beleidsplan zou moeten worden vastgesteld door het hoogste politieke orgaan: de raad.

De Gemeentewet legt de gemeenten niet in het algemeen de verplichting op tot het vaststellen van een plan of een beleidsverslag (vergelijk de artikelen 110 en 111 Gemeentewet). In de Memorie van Toelichtiug ${ }^{\text {\%o }}$ werd weliswaar de noodzaak van een planmatige aanpak van het gemeentelijk beleid onderstreept, maar werd het niet wenselijk geacht in de wet een verplichting daartoe op te nemen. Het werd aan de gemeentebesturen overgelaten om op eigen wijze, rekening houdend met de beschikbare ambtelijke deskundigheid en financiële mogelijkheden, vorm te geven aan het streven naar een meer planmatig bestuur, aangepast aan de specifieke lokale wensen. Verder werd gedacht aan de mogelijkheid van een betere beleidscoördinatie, aan verbetering van de informaticvoorziening en aan een systematischer prioriteitenstelling?.

De Commissie Wetgevingsvraagstukken ${ }^{98}$ omschrijft de planfiguur aldus:

*4 Vergelijk hetgeen hierover is opgemerkt bij het verbod van détournement de pouvoir.

9 In die zin Mulder - Duk (1985), 26.

\%6 TK 1985-1986, 19 403, nr. 3, 33 (Memorie van Toelichting).

97 Zie cok TK 19 403, 1987-1988, nr. 8, 4-5 (Nota van Wijziging) waar voorgesteld nm ten bepaling op te nemen, die erop is gericht soberheid en terughoudendheid bij het vorderen c.q. vragen van gemeentelijke plannen en beleidsverslagen te bevorderen. Met bet bepaalde in art. 111 Gemeentewet werd tevens gestreefo naar het scheppen van ruimte voor gemeentebesturen om een efficient en planmatig beleid te voren.

* Orde in de regelgeving (Eindrapport 1985). Dit rapport beeft zijn uitwerking niet gemist. Vergelijk de omschrijving van het begrip 'plan' in art. 110, lid 1, sub a Gemeentewet. 
een 'samenhangend geheel van op elkaar afgestemde keuzes omtrent door bestuursorganen te nemen besluiten of te verrichten handelingen, welke ongelijk van inhoud kunnen zijn, teneinde een of meer doelstellingen te bereiken'.

In deze tamelijk orthodoxe visie op het plan en de planning bestaat de funktie van het plan er in om op een rationele wijze een vooraf bepaald doel te bereiken. In die vorm kan er niet of nauwelijks rekening worden gehouden met mogelijk noodzakelijke afwijkingen van het beleid in de toekomst. Een minder rigide planningsvorm is, dat van het plan niet wordt verwacht dat het de toekomst bepaalt, maar dat het op basis daarvan mogelijk wordt verantwoorde keuzes te maken. De aanbestedingsnota zou in dat geval ten minste moeten inhouden welke criteria de gemeente voomemens is te hanteren, de onderlinge volgorde en tot welke aanbestedingsprocedure zulks leidt. Ook de gemaakte afwegingen, prioriteiten e.d. moeten duidelijk uit het plan naarvoren komen. Aan deze beleidsnota kunnen de volgende vier functies worden toegedacht ${ }^{99}$ :

- een politieke beleidsfunktie: het gemeentebestuur levert een toelichting bij het aanbestedingsbeleid. Dit biedt, samen met de begroting een basis voor een algemene beleidsdiscussie en de grondslag voor algemene beleidsuitspraken door de gemeenteraad. De ontwikkeling van het aanbestedingsbeleid kan worden overgelaten aan B\&W. Maar pas nadat het beleid door de raad is vastgesteld, zijn B\&W gelegitimeerd tot de uitvoering van dit beleid. Er zou wat dit betreft door de raad een goedkeuringsprocedure kunnen worden ontwikkeld om voorafgaand aan de vaststelling van het beleid de vinger aan de pols te houden. Dit beleidsstuk kan vervolgens dienen als referentiekader bij de formulering van criteria en voorwaarden, de feitelijke selectie van een aannemer etc. rondom de aanbesteding van een bepaald werk door de overheid.

- een politieke controlefunktie: het is vanuit een demokratisch oogpunt gewenst dat de gemeenteraad voldoende invloed kan doen gelden met betrekking tot uitvoering van het beleid door B\&W. In de praktijk zal daarom regelmatig moeten worden teruggekoppeld naar de raad en de raadscommissies. De aanbestedingsnota geeft de raad een beter houvast bij de uitoefening van haar controlerende taak op het punt van de aanbesteding. Door ook achteraf (bij voorbeeld: jaarlijks) te wijzen op het door haar in algemene termen vastgestelde beleid, wordt de raad in staat gesteld om politieke controle uit te oefenen op de (concrete) uitvoering van het beleid door B\&W.

Door een regelmatige (bij voorbeeld jaarlijkse) evaluatie van de uitvoering van de aanbestedingsbesluiten kan politieke controle plaatsvinden op de ontwikkeling, vaststelling en uitvoering van het beleid, zoals dit onder de verantwoordelijkheid van B\&W plaats heeft.

- een coördinatiefunktie: De bij de aanbesteding betrokken belangen (criteria en voorwaarden) dienen te worden afgestemd. De coördinatie vindt plaats op de grenslijn tussen

99 In die zin, maar dan voor het terein van de volkshuisvesting, C.A. Adriaansens, H. Priemus; met bijdragen van J. van der Schaar, Marges van volkshuisvestingsbeleid: naar een flexibeler juridische vormgeving van een marktgevoelige beleidssector. Voorstudies en achtergronden. Wetenschappelijke Raad voor het Regeringsbeleid, V50, 's-Gravenhage 1986. Deze auteurs doen in hun onderzoek een voorstel voor een 'Staat van de volkshuisvesting'. Dit plan heeft vier funkties: een politieke kontrolefunktie, een indirekte juridische funktie, een koördinatiefunktie en een politieke beleidsfunktie (t.a.p. 133). 
recht en beleid. De regelgeving moet gericht zijn op de expliciete afweging tussen de rechtsbeginselen en de vereiste flexibiliteit van bestuur.

funktie als referentiekader in beroepszaken: een (administratieve) beroepsgang, waarbij kan worden gerefereerd aan een aanbestedingsnota, accentueert de betekenis die moet worden gehecht aan het voeren van een openbaar en gemotiveerd aanbestedingsbeleid, dat voldoet aan het geschreven en ongeschreven regels van besturursrecht. Toetsing van het beleid (de gemaakte keuzes) kan alsdan indirect plaatsvinden door toetsing van het besluit a quo. Evenals de burgerlijke rechter is thans ook de administratieve rechter is in staat om schadevergoedingsvorderingen te beoordelen (vgl. artikel 6:162 BW en artikel 8:73 Awb). De winst van deze bestuursrechtelijke benadering is dat gepasseerde aannemers al tijdens de besluitvorming, dus voorafgaand aan de opdrachtverlening bij de (administratieve) rechter om toetsing kunnen vragen van het door de gemeente gevoerde beleid.

\section{Het besluitvormingsproces; nadere analyse}

In dit hoofdstuk is een aanzet gegeven tot de ontwikkeling van bestuursrechtelijke grondslagen van het besluitvormingsproces inzake de aanbesteding van werken. In de eerste hoofdstuk is de aanbestedingsprocedure uit het UAR eveneens getypeerd als een besluitvormingsproces De vraag is dan: hoe is de verhouding tussen de beide besluitvormingsprocessen? Alvorens op deze vraag in te gaan worden nog even kort de belangrijkste karakteristieken van de beide besluitvormingsprocessen op een rij gezet.

\section{Het UAR-besluitvormingsproces}

De besluitvorming over de financiële doelmatigheid vindt plaats in het kader van één van de in het UAR geregelde aanbestedingsprocedures. Deze procedures zijn gebaseerd op een viertal beginselen: het gelijkheidsbeginsel, het openbaarheidsbeginsel, het motiveringsbeginsel en het beginsel van de financieel-economische doelmatigheid. Het uitlokken van concurrentie is het middel waarmee het doel (opdrachtverlening) wordt bereikt. Het gemeentebestuur zal om dit beleid(saspect) te kunnen realiseren aanbestedingscontracten moeten sluiten met de verschillende mededingers. Als vermogensrechtelijk toerekeningspunt wordt de gemeente dan partij bij deze contracten (vergelijk artikel 2:1 BW).

Het belang van een financieel doelmatige aanbesteding wordt bereikt door in beginsel een ieder gelijke kansen te geven op de inschrijving. Het feitelijke sluiten van het aannemingscontract met de overgebleven aannemer valt buiten de regeling in het aanbestedingsreglement. De aanbesteding wordt in beginsel steeds in het openbaar bekendgemaakt. Het werk wordt: gegund aan de aannemer die voldoet aan de in het bestek en de bekendmaking gestelde geschiktheidseisen, terwijl hij daarnaast redelijkerwijs in staat moet worden geacht het werk vakkundig en op regelmatige wijze uit te voeren. Aan de gunning van het werk kan een afzonderlijke selectieprocedure voorafgaan. De aanbestedingsprocedure resulteert in de regel in de keuze van één aannemer aan wie het werk zal worden opgedragen; er bestaat geen gunningsplicht. Nadat de keuze op een aannemer is gevallen (artikel 24 UAR 1986), eindigt 
de betekenis van het aanbestedingsreglement ${ }^{100}$. Vervolgens moet de raad het besluit tot opdrachtverlening nemen. De betekenis van artikel 25 UAR 1986 moet mijns inziens gezocht worden in de slotzin van het eerste lid: het inschrijvingsbiljet vormt de grondslag van het te sluiten contract: d.w.z. dat ten tijde van de contractssluiting het gunningsresultaat tussen partijen onveranderlijk vaststaat.

\section{Het bestuurlijke besluitvormingsproces}

De bestuurlijke besluitvorming is gebaseerd op een viertal structuurbeginselen: gelijkheid, openbaarheid, motivering en (financiële) doelmatigheid. Dit zijn de beginselen die oorspronkelijk ten grondslag lagen aan autonome bestuursbevoegdheid tot aanbesteden in de gemeentewet (vergelijk hierover hoofdstuk 2). Deze bestuursrechtelijke beginselen stellen eisen aan de inhoud van het aanbestedingsbeleid en gelden met name ook wanneer het aanbestedingsbeleid uitsluitend zou worden gevoerd op basis van financiële doelmatigheidsoverwegingen. Ook dan dient de gemeente beleid te voeren (consistentie), dienen de uitgangspunten kenbaar te zijn en dient de motivering de gemaakte keuzes (met betrekking tot de selectie- en gunningscriteria) te kunnen dragen. Hierin herkent men het bestuursrechtelijke primaat: het aanbestedingsbeleid dient steeds te voldoen aan bestuursrechtelijke eisen: ook tijdens de UAR-aanbestedingsprocedure.

\section{Een bestuurlijke besluitvormingsparaplu: besluitvormingsmodel}

Het bestuursrechtelijke primaat betekent dat de besluitvorming in het kader van de UARaanbestedingsprocedure zich afspeelt binnen een overigens volledig bestuursrechtelijk besluitvormingsproces. De aan het aanbestedingsbeleid te stellen besturssrechtelijke eisen vormen als het ware een besluitvormingsparaplu boven de (beperktere) besluitvorming in het kader van het UAR (zie: afbeelding 3). De bestuursrechtelijke eisen gelden ook tijdens de UARaanbestedingsprocedure. De grondslag voor het bestuurlijke besluitvormingproces moet worden gezocht in de aanbestedingsbevoegdheid van de gemeenten. De besluitvorming in het kader van de UAR-aanbestedingsprocedure vindt plaats op basis van de aanbestedingsovereenkomst; een wederkerig element in de gemeentelijke besluitvorming.

Wanneer er - ter bepaling van de gedachten - van wordt uitgegaan, dat de wetgever bepaald zou hebben, dat er ook 'andere' belangen bij de aanbesteding kunnen worden betrokken, dan wordt zo mogelijk nog duidelijker dat de UAR-procedure een deel vormt van een omvangrijker besluitvormingsproces. De UAR-procedure heeft uitsluitend ten doel vast te stellen welke inschrijver de economisch meest voordelige c.q. de laagste prijs aanbiedt. Maar daarmee is de besluitvorming niet afgerond: de laagste inschrijver moet in beginsel ook in staat zijn te voldoen aan de eventuele aanvullende voorwaarden die de gemeente voorafgaand aan de aanbesteding heeft bekendgemaakt.

Zo bezien zijn de beginselen die aan het UAR ten grondslag liggen 'slechts' de aanbestedingsprocedurele pendanten (species) van de overigens bestuursrechtelijke structuurbeginselen van aanbestedingsbeleid (zie: afbeelding 4). Het gelijkheidsbeginsel in bestuursrechtelijke zin heeft betrekking op de eis van beleid; in procedurele zin op de gelijkheid tussen de gegadigden c.q. de inschrijvers. Het openbaarheidsbeginsel wil in bestuursrechtelijke zin het beleid (keuzes en afwegingen) openbaar doen zijn; in de procedure ziet het (onder meer) op de

to RvA 3 maart 1989, nr. 13.774, BR 1989, 715 m.nt. N.J.M. Donders. 
Afb. 3: Verhouding tussen de beide besluitvormingsprocessen; besluitvormingsparaplu

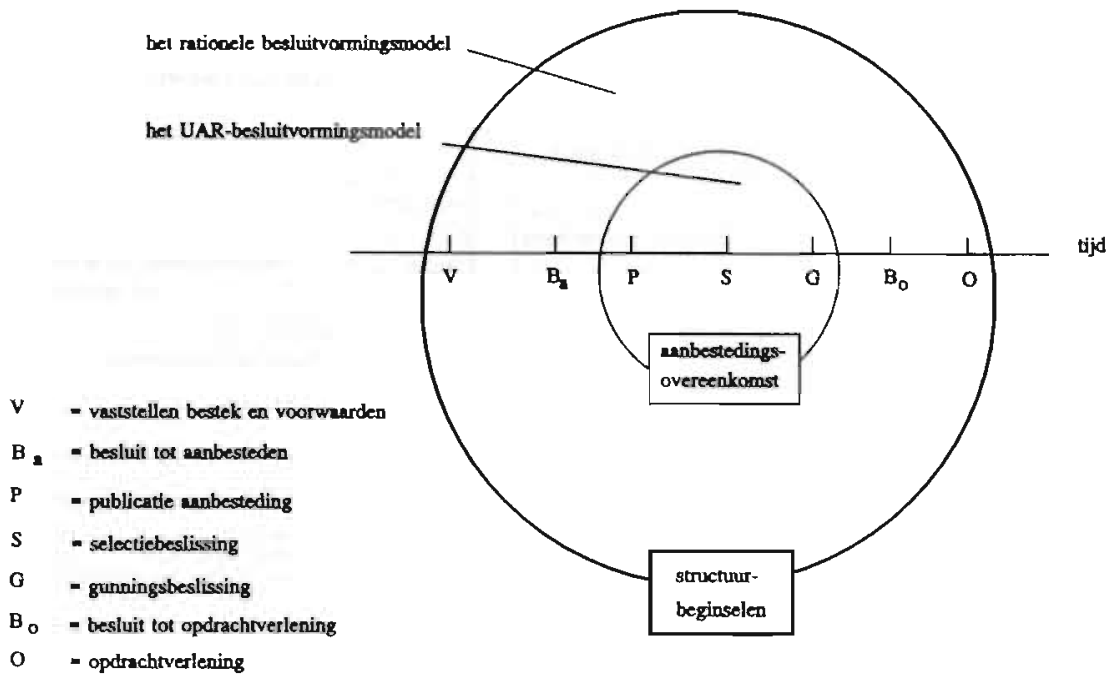

bekendmaking van het feit van aanbesteding. Het motiveringsbeginsel heeft in procedurele zin alleen betrekking op het achteraf aangeven van de redenen waarom de gegadigde niet tot inschrijving is toegelaten danwel waarom hem niet de opdracht is gegund. In bestuursrechtelijke zin gaat de motivering steeds vooraf aan het te voeren beleid. Hetzelfde geldt voor de eisen van relevantie en objectieve noodzakelijkheid. In het UAR zijn deze algemene (communautaire) eisen aan de beleidsuitgangspunten toegesneden op de aard en omvang van het werk.

\section{Het rechtskarakter van de aanbestedingsovereenkomst}

Hierboven is aangegeven dat de aanbestedingsovereenkomst de grondslag vormt voor de besluitvorming met betrekking tot de prijs en kwaliteitsaspecten van de aanbesteding. Daarbij is voorbij gegaan aan het rechtskarakter van de aanbestedingsovereenkomst. De thans heersende opvatting is dat de aanbestedingsovereenkomst een privaatrechtelijke, obligatoire overeenkomst is (vergelijk hoofdstuk 1, paragraaf 5). De overheid beschikt in deze voorstelling a priori over privaatrechtelijke bevoegdheden. Aan het begin van dit hoofdstuk is geconcludeerd, dat de huidige rechtsgeleerde opvatting niet bij machte is om het aanbestedingsbeleid rechtens voldoende te normeren. Ook niet door op de aanbestedingsovereenkomst de algemene beginselen van behoorlijk bestuur van toepassing te verklaren. De gevolgen, die het ontbreken van een voldoende normatief beleidskader heeft, voor de aanbestedingspraktijk zijn beschreven in het praktijkonderzoek (zie: Korte weergave Euregionaal praktijkonderzoek 1986-1988). 
Afb. 4: Grondslagen van aanbesteding

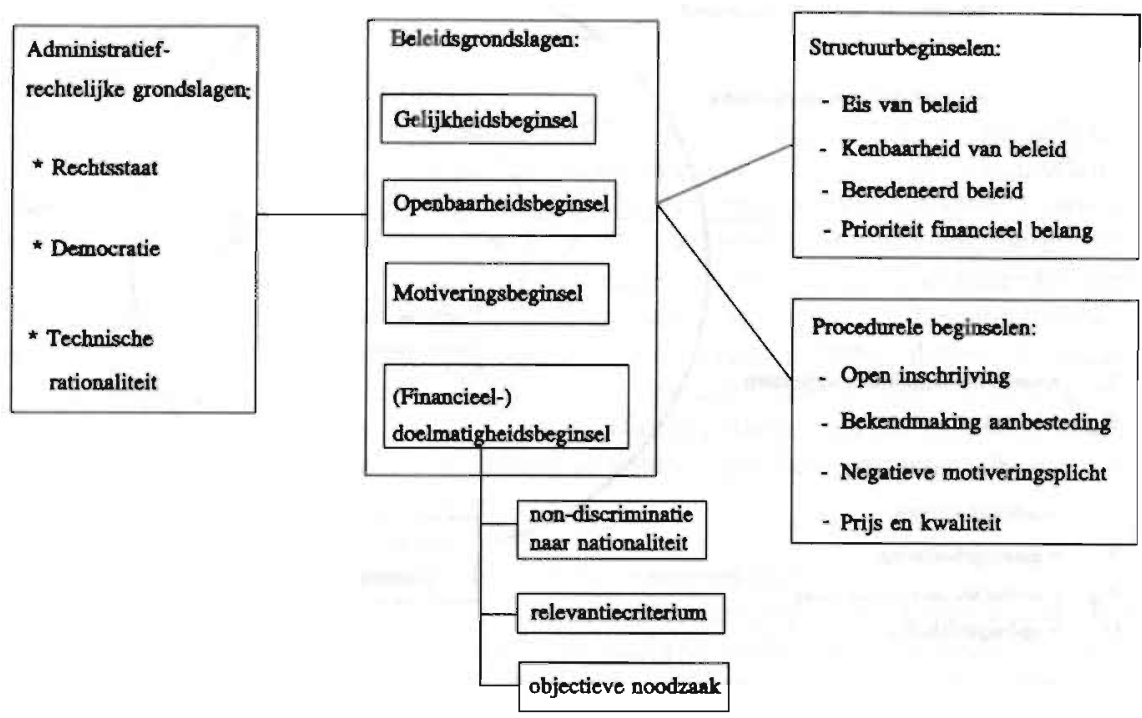

De benadering waarbij de besluitvorming op basis van de aanbestedingsovereenkomst wordt gebracht onder een overigens bestuurlijke besluitvormingsparaplu, maakt het mogelijk de verschillende rechtstheoretische opvattingen over het overheidscontract in één en hetzelfde model onder te brengen; vanzelfsprekend zonder dat daarmee de verschillen tussen de opvattingen verloren zouden gaan. Zo kan een brug worden geslagen tussen de heersende gemengde rechtsleer en de opvatting van bijvoorbeeld Scheltema, Drupsteen en Simon. Deze schrijvers vragen enerzijds steeds naar de legaliteit van het overheidsoptreden, maar sluiten het anderzijds niet uit dat de overheid ter behartiging van het algemeen belang soms gedwongen kan zijn privaatrechtelijke contracten te sluiten. De rechtspersoon gemeente sluit - binnen een overigens bestuursrechtelijke context - dan privaatrechtelijke aanbestedingscontracten. Een dergelijke overeenkomst wordt door Konijnenbelt en Van Male ${ }^{101}$ opgevat als een $b e$ leidsovereenkomst, wanneer daarbij ook 'andere' overwegingen een rol spelen ${ }^{102}$. Zij geven in dit verband het voorbeeld van defensie-aankopen waar tevens overwegingen van werkgelegenheidsbeleid een rol spelen. Daarmee zijn de verschillen tussen de beide rechtsgeleerde opvattingen vanzelfsprekend niet uit de wereld. In de heersende rechtsopvatting wordt het privaatrechtelijke contract tussen de gemeente als aanbesteder en de inschrijvers gemengd met de geschreven en ongeschreven regels van publiekrecht (artikel 3:14 BW). Dit leidt tot een

101 Van Wijk - Konijnenbelt - Van Male (1994), 465.

102 In die zin Zijlstra (1994), 12. 
mix van publiek- en privaatrecht (Lubach, Bloembergen). Van der Hoeven, De Haan, Simon zijn daarentegen van mening dat de publiekrechtelijke en privaatrechtelijke normen afzonderlijk herkenbaar blijven. Overigens lijken de genoemde standpunten elkaar - op het punt van de overheidsaanbesteding - dichter te naderen dan op voorhand zou worden gedacht. In zijn bijdrage aan de Bouwrechtmonografie gaat Bloembergen in op de aanbesteding van werken. Hij schrijft:

'Er begint zich hier een zekere, masr bepaald nog niet helemaal duidelijke lijn af te tekenen. Een aanbod, cen bereidverklaring, een intrekking van een aanbod en een weigering tot het aangaan van een overeenkomst zijn geen beschikkingen als bedoeld in artikel 2 Wet B.A. ${ }^{103}$. Dit is evenwel anders als zo een rechtshandeling mede is verricht op grond van een staats- en administratiefrechtelijk voorschrift, maar dat voorschrift moet dan wel meer zijn dan een interne beleidslijn ${ }^{104}$. Is dat voorschrift meer, zoals in het geval van de Pieterskerk ${ }^{105}$, dan moeten we wellicht aannemen, dat de rechtshandeling een dubbel karakter krijgt: zij brengt, ook krachtens de bedoeling van het overheidslichaam dat de handeling stelt, zowel privaatrechtelijke als administratiefrechtelijke rechtsgevolgen tot stand'.

Kennelijk gaat Bloembergen ervan uit dat de overheid bij de aanbesteding niet alleen maar privaatrechtelijk handelt, maar ook afzonderlijke publiekrechtelijke rechtshandelingen verricht. Ik acht het denkbaar dat het door Bloembergen gesignaleerde 'dubbele' karakter van de overheidsaanbesteding in wezen niets anders is dan het hiervoor door mij beschreven besluitvormingsmodel, waarbij onderscheid wordt gemaakt tussen bestuurlijke en aanbestedingsprocedurele besluitvorming.

De 'invullende' rechtsleer ${ }^{106}$ gaat nog een stap verder. In deze benadering wordt het 'UARaanbestedingscontract' opgevat als een publiekrechtelijke overeenkomst, een 'afspraak' tussen het betrokken bestuursorgaan en de inschrijvers onder de ontbindende voorwaarde van het algemeen belang. Deze publiekrechtelijke overeenkomst komt tot stand door een eenzijdige,

${ }^{109}$ Art. 2, eerste lid Wet B.A.B. luidde: 'Onder beschikking verstaat deze wet de eenzijdige naar buiten gerichte schriftelijke wilsverklaring van een administratief orgaan van de centrale overheid, gegeven krachtens een in enig staats- of administratiefrechtelijk voorschrift vervatte bevoegdheid of verplichting en gericht op de vaststelling. de wijziging of de opheffing van een bestaande rechtsverhouding of het scheppen van een nieuwe rechtsverhouding danwel inhoudende de weigering tot zodanig vaststellen, wijzigen, opheffen of scheppen'.

10. Voor wat betreft het begrip 'staats- en administratiefrechtelijk voorschrift' verwijst Bloembergen naar het Besluit aanbesteding van werken. Het UAR beschouwt hij als een intern beleidsvoorschrift: regels die de Staat in acht moet nemen bij het afsluiten van aannemingsovereenkomsten. Het reglement is evenmin een 'staats- en administratiefrechtelijk voorschrift'.

${ }^{105}$ Het bedoelde Pieterskerk-geval (KB 18 december 1973, AB 1975, 6) betreft de volgende casus: De Hervormde Gemeente te Leiden biedt de Pieterskerk kosteloos aan het Rijk aan, maar het Rijk verklaart dit aanbod niet te aanvaarden, waarop de Hervormde Gemeente een BAB-beroep instelt. De Kroon verwerpe het verweer, dat het niet om een beschikking, maar om een zuiver privaatrechtelijke rechtshandeling zou gaan. Het betrof weliswaar de overdracht van eigendom van onroerend goed, maar - aldus de Kroon - de weigering brengt op grond van een uit 1936 daterende subsidieregeling voor monumenten mee, dat de eigenaar wordt bevrijd van op hem rustende verplichtingen. Daarom moet die weigering gezien worden als een eenzijdige wilsverklaring krachtens een staatsof administratiefrechtelijk voorschrift in de zin van de Wet-BAB.

106 Tak (1993), 175. 
door het publiekrecht beheerste, toezegging ${ }^{107}$ zijdens het bevoegde bestuur en een, door het privaatrecht beheerste, wilsuiting zijdens de belanghebbende inschrijver.

Dit deel van de besluitvorming heeft tot doel de financiële doelmatigheid van de opdrachtverlening te garanderen. Anders dan bij het verlenen van een beschikking aan een belanghebbende, is bij de aanbesteding niet op voorhand bekend wie voor de opdrachtverlening in aanmerking komt. Het gemeentebestuur is daarom gedwongen om 'contracten' aan te gaan met meerdere inschrijvers, waarin partijen afspraken hebben gemaakt omtrent de (UAR-) procedure die (in beginsel) tot gunning van het werk aan één van hen leidt.

Deze publiekrechtelijke afspraak heeft in deze rechtsopvatting niets van doen met een privaatrechtelijk contract. Deze benadering verdient bij de aanbesteding van werken door de overheid mijns inziens de voorkeur. Waar het accent bij de aanbesteding(sovereenkomst) zozeer ligt op het besluitvormingsaspect voorafgaand aan het sluiten van het aannemingscontract, zou ik willen verdedigen dat de aabbestedingsovereenkomst het best ware te typeren als een middel in het kader van de besluitvorming (evenals voorbereidende besluiten, procedurele beslissingen) dat - gelet op de noodzakelijke wederkerigheid - in een aan het Burgerlijk Wetboek ontleende vorm wordt gegoten. In dit besluitvormingsproces is geen sprake van contractsvrijheid, doch van beleidsvrijheid. Bij de uitoefening van deze beleidsvrijheid dient het bestuur de rechtstreeks bij het besluit betrokken belangen af te wegen, voor zover niet uit een wettelijk voorschrift een beperking voortvloeit. En deze afwegingen dienen plaats te vinden op basis van een geobjectiveerd, rationeel besluitvormingsmodel. Vanuit de overheid bezien, moet de aanbestedingsovereenkomst dan worden opgevat als een zuivere publiekrechtelijke overeenkomst. Zijdens de burger is er sprake van een gewone privaatrechtelijke overeenkomst ${ }^{108}$.

\section{Conclusie}

Door bij de aanbesteding van werken te kiezen voor een bestuursrechtelijke benadering is normering van het aanbestedingsbeleid mogelijk. Binnen deze benadering zijn verschillende opvattingen denkbaar over het rechtskarakter van de aanbestedingsovereenkomst. Ondanks de bestaande verschillen kan worden vastgesteld, dat het debat hierover kan plaatsvinden binnen de kaders van het hiervoor geschetste besluitvormingsmodel. Dit vergroot de juridische aanvaardbaarheid van dit 'paraplu'-model en daarmee van de bestuursrechtelijke benadering op het gebied van de aanbesteding van werken door de gemeente.

\footnotetext{
${ }^{107}$ Deze toezegging zijdens het bestuur doet sterk denken aan de acte négocié: formeel een eenzijdig hesluit. Het begrip 'convenant', dat in de literatuur aan een opmars lijkt begonnen, is eveneens een publiekrechtelijke overeenkonst. In de bundel 'Convenanten tussen Overheid en maatschappelijke organisaties', 's-Gravenhage 1993 (F.J. van Ommeren, H.J, de Ru (red.)) wordt het convenant omschreven als 'een schriftelijk ondertekende afspraak van de overheid met een of ineer wederpartijen over de verwezenlijking van overheidsbeleid. Van het aanbestedingsbeleid kan niet worden gezegd dat dit wordt gerealiseerd op basis van afspraken met de gegadigden of inschrijvers. Van een dergelijk afspraak is bij de aanbesteding geen sprake.

103 In die zin Simon (1993), 196
} 


\section{Besluitvorming en bevoegde rechter}

\subsection{De burgerlijke rechter is competent}

\section{Onder de wetten-BAB en Arob}

Het hierboven weergegeven citaat van Bloembergen eindigt met de constatering, dat hij:

'niet [zou] willen uitsluiten, dat dit dubbele karakter leidt tot een dubbele rechterlijke competentie.'

In een noot (noot 25) voegt hij nog het volgende aan dit citaat toe:

'Het Besluit aanbesteding van werken 1973 (K.B. 6 april 1973, Stbl. 202) bevat regels die de Staat in acht moet nemen bij de aanbesteding van werken. Neemt een Minister nu op grond van dit besluit een beslissing over een bepaalde wijze van aanbesteden, dan is dit naar mijn mening een beschikking waartegen beroep op grond van de Wet B.A.B. mogelijk is. Evenmin als in het Pieterskerk-geval, behoeft hier het feit dat aanneming een privaatrechtelijke overeenkomst is eraan in de weg te staan, dat een beslissing van de overheid omtrent het tot stand brengen van die overeenkomst, een beschikking op grond van een staats- of administratiefrechtelijk voorschrift is. (...)'.

Deze uitspraak werd gedaan kort voor de invoering van de Wet Arob. Anders dan bij het B.A.B.-beschikkingsbegrip is het Arob-beschikkingsbegrip niet beperkt tot beschikkingen van de centrale overheid. Ik neem aan, dat Bloembergen ook van beslissingen van het gemeentebestuur over een bepaalde wijze van aanbesteden zou hebben gezegd, dat dit beschikkingen waren, maar dan in de zin van de wet Arob. Bloembergen (of all persons!) merkt in dit verband over het Arob-beschikkingsbegrip op, dat:

'een aanbod tot het aangaan van een overeenkomst, een bereidverklaring daartoe, een intrekking van het aanbod e.d. [ongetwijfeld] rechtshandelingen naar burgerlijk recht [zijn]. Enige aarzeling voel ik wel bij een geval als das van de Pieterskerk: als een rechtshandeling inderdaad een dubbel karakter kan hebben, sluit dan het ook burgerrechtelijke karakter van die handeling het A.R.O.B.-beroep uit? Ik zou ook hier de oude lijn willen voortzetten. De tekst van de wet laat hiervoor ruime: de handeling is niet alleen een rechtshandeling naar burgerlijk recht, maar vooral een administratiefrechtelijke beschikking'.

Ook Meijknecht kiest voor de administratiefrechtelijke oplossing:

'(..) bezien vanuit de tekst van artikel 2 Wet Arob kan er weinig bezwaar tegen hestaan dat de Afdeling zich wel inlaat met precontractuele geschillen: een weigering van de overheid om te contracteren (...) is hoogstens onrechtmatig, maar is zeker geen rechtshandeling naar burgerlijk recht' ${ }^{109}$.

In het verleden zijn heel wat pogingen ondernomen om rechtshandelingen naar burgerlijk recht te laten toetsen door de Arob-rechter ${ }^{110}$. De Arob-rechter bleef echter, net als zijn voorganger, vasthouden aan het formele beschikkingsbegrip. Het besluit tot opdrachtverlening

\footnotetext{
${ }^{109}$ Meijknecht (1979), 195.

${ }^{10}$ Zie Stroink (1979), 391-395 en 423-427; Ten Berge - Stroink (1979), 34-36; Groot (1979), 157-160 en $173-179$. Ook De Jong (1984) 191-192 en noten.
} 


\section{Hoofdstuk 5}

werd opgelost gedacht in de aannemingsovereenkomst ${ }^{111}$. Slechts in enkele bijzondere gevallen achtte de Afdeling rechtspraak zich bevoegd te oordelen over geschillen waarbij burgerlijke rechten waren betrokken ${ }^{112}$. Daarvan is voor dit onderzoek met name van belang de situatie waarin het besluit tot het aangaan van een rechtshandeling tevens publiekrechtelijke gevolgen kan hebben. In dat geval was er volgens de Arob-rechter sprake van zowel een beschikking als van een rechtshandeling naar burgerlijk recht. Wanneer het besluit echter uitsluitend betrekking had op het aangaan van een rechtshandeling naar burgerlijk recht dan verklaarde de Arob-rechter zich onbevoegd ${ }^{113}$. Zoals het besluit van de raad tot het uitgeven van grond in erfpacht. De Afdeling bleek ongevoelig voor de suggesties van De Haan $^{114}$ en Crince le Roy ${ }^{115}$ om contractsweigering bij gronduitgifte door de overheid op te vatten als een beschikking. Volgens deze schrijvers is deze rechtshandeling vanuit beleidsoogpunt in hoge mate vergelijkbaar met de afwijzing van een vergunningsaanvraag. Een opvatting waarin ik mij geheel kan vinden.

\section{Onder de $A w b$}

In de Algemene wet bestuursrecht (Awb) staat het besluit centraal (artikel 1:3 Awb). De Awb-wetgever heeft - oorspronkelijk, in de eerste tranche - voor wat betreft dit besluitbegrip gekozen voor het loslaten van de oplostheorie ${ }^{116}$. Dat kon ook gemakkelijk omdat daaraan geen rechtsbeschermingsaspecten waren verbonden. Dit werd anders met de introduktie van het beroep op de administratieve kamers van de rechtbanken. Deze rechtbankprocedure wordt als regel voorafgegaan door het bezwaar tegen een besluit bij het bestuursorgaan dat de beslissing heeft genomen (vergelijk artikel 6:4 en 7:1 Awb). Wat het bezwaar en beroep betreft, is echter niet het positieve besluitbegrip in artikel 1:3 Awb bepalend, maar een ruimer besluitbegrip. Volgens artikel 6:1 Awb zijn de bepalingen inzake bezwaar en beroep van overeenkomstige toepassing op andere handelingen van bestuursorganen dan besluiten. Ook indien er aanwijsbaar geen rechtsgevolgen zijn is bezwaar of beroep niet steeds uitgesloten (vergelijk artikel 6:2 Awb). De hierna te onderzoeken vraag is of de "ont-'keten'ing" van de voorbereidende besluiten van de latere opdrachtverlening gevolgen heeft of zou moeten hebben voor de competentie inzake aanbestedingsgeschillen van de administratieve rechter.

Belangrijker dan het genoemde artikel 6:2 Awb is voor dit onderzoek artikel 6:3 Awb. Daarin wordt bepaald dat 'een beslissing inzake de procedure ter voorbereiding van een besluit niet vatbaar [is] voor bezwaar of beroep, tenzij de beslissing de belanghebbende los

III Zie AR 11 april 1983, nr. R 01.83.042/s41, ongepubliceerd, geciteerd door Van Nouhuys (1986), 48. Overwogen werd: 'Het besluit tot het gunnen van het werk dient te worden aangemerkt als uitsluitend te zijn gericht op het tot stand komen van een rechtshandeling naar burgerlijk recht, in dit geval het aangaan van een privaatrechtelijke overeenkomst'.

112 'Vroege' voorbeelden van toepassing van de leer van de acte détachables': AR 16 nov. 1984, AB 1985. 384 m. nt. PvB en Rb Haarlem 2 sept 1986, AB 1987, 276 m.nt. PvB, geciteerd bij Van der Does (1987), 1691.

113 Zoals Vz.AR 2 febr. 1978, AB 209 (Ridderborgh BV/ Raad van de gemeente Culemborg).

114 De Haan (1978).

115 Interventie Crince le Roy, BR 1977, 9.

${ }^{116}$ TK 1991-1992, 22 495, nr. 3, 100-101 (Memorie van Toelichting) bij art. 8:3 Awb gaat niet op de ketentheorie in. 
van het voor te bereiden besluit (tot opdrachtverlening) rechtstreeks in zijn belang treft'. De Memorie van Toelichting ${ }^{117}$ zegt hierover:

'Gaat het (...) om een voorbereidingshandeling die op zichzelf reeds voor een of meer belanghebbenden rechtsgevolg heeft, dan is een daartegen gerichte afzonderlijke procedure (...) mogelijk'.

De wetgever heeft met deze bepaling kennelijk niet de bedoeling gehad om de rechtsbescherming die hoofdstuk $8 \mathrm{Awb}$ schept tegen besluiten, uit te breiden tot beslissingen, die geen besluit zijn. Beroep tegen dergelijke voorbereidingsbeslissingen wordt onnodig geacht, omdat eventuele onjuistheden in deze fase van de besluitvorming niet van doorslaggevende invloed behoeven te zijn op het nog te nemen uiteindelijke besluit. In overeenstemming met deze wetsgeschiedenis heeft de Afdeling bestuursrechtspraak ${ }^{118}$ inmiddels geoordeeld dat het beslissingsbegrip moet worden beperkt tot besluiten: dat wil zeggen dat er een rechtsgevolg aanwijsbaar moet zijn. De zinsnede 'los van het voor te bereiden besluit' vormt een veiligheidsklep, voor het geval dat een voorbereidingsbesluit los van het eindresultaat de belanghebbende rechtstreeks in zijn belang treft (vergelijk artikel 1:2 Awb).

Daar is wel eens anders over gedacht. De summiere totstandkomingsgeschiedenis liet de mogelijkheid van een ruimere interpretatie ook toe. Dit hing nauw samen met de ruimere betekenis die dan werd toegekend aan het begrip 'beslissing' boven het begrip 'besluit'. Zie bij voorbeeld Rb. Assen 19 aug. 1994, BR 1994, 921, JB 1994, 203 m.nt. MAH.

Resteert de vraag naar de inhoud van het begrip 'voorbereidingsbeslissing'. Van Male 119 gaat in op de vraag wat onder 'beslissing ter voorbereiding van een besluit' moet worden verstaan. Hij maakt onderscheid tussen al dan niet op rechtsgevolg gerichte beslissingen, waarbij alleen de eerste soort appelabel is ${ }^{120}$. Binnen deze categorie kan het verder gaan om beslissingen die deel uitmaken van een non-contentieuze procedure die moet leiden tot het voor te bereiden besluit en beslissingen welke los van het voor te bereiden besluit deel uitmaken van een keten van connexe besluiten. Wat betreft het eerstgenoemde type beslissingen, geldt dan alleen tegen de uitkomst van de besluitvorming kan worden opgekomen. En dat dit alleen dan anders is, wanneer een eerder besluit de belanghebbende los van het voor te bereiden besluit rechtstreeks in zijn belang raakt. Bij de tweede categorie ligt het complexer.

Heeft artikel 6:3 Awb ook betrekking op besluiten inzake de procedure ter voorbereiding van een (besluit tot het verrichten van een) privaatrechtelijke rechtshandeling. Dat zou betekenen dat van dergelijke voorbereidende besluiten beroep bij de administratieve kamers mogelijk zou zijn, voorzover althans op deze procedurele besluiten de uitzonderingsregel ('tenzij deze beslissing de belanghebbende los van het voor te bereiden besluit rechtstreeks in zijn belang

\footnotetext{
${ }^{117}$ TK 1988-1989, 21 221, nr. 3, 121 (Memorie van Toelichting) bij bet ontwerp-artikel 6.1.4 Awb (ttuns aft. 6:3 Awb).

118 Vz. Abr 14 okt. 1994, JB 1994, 293 m.nt. M.F.J.M.W.

119 Van Male (1992), 50-51.

120 Tak (1993), 189 noemt de eis dat het besluit gericht moet zijn op rechtsgevolg een knieval voor de aan het privaatrecht ontleende notie van rechtshandeling, die tekort doet aan de algemenere en metr ingrijpende consequenties van publiekrechtelijk bandelen.
} 
(reft') van artikel 6:3 Awb van toepassing is. Dit zou leiden tot een dubbele competentie. De wetgever heeft deze consequentie niet gewild: vergelijk artikel 8:3 Awb. In deze meer specifieke bepaling over voorbereidingsbesluiten wordt bepaald dat 'geen beroep kan worden ingesteld tegen een besluit ter voorbereiding van een privaatrechtelijke rechtshandeling'. In dat geval is de gewone rechter bevoegd ${ }^{121}$. Deze besluiten zijn daarmee uitgezonderd van het administratieve beroep. Als het besluit tot opdrachtverlening niet appelabel is op grond van artikel 8:3 Awb, moet a fortiori worden aangenomen dat ook de daaraan voorafgaande voorbereidingsbeslissingen (ex artikel 6:3 Awb) niet appelabel zijn. Toch is leer van de acte détachable niet steeds zonder consequenties voor wat betreft de appelabiliteit van besluiten ter voorbereiding van privaatrechtelijke rechtshandelingen. Vergelijk Pres. Rb 's-Gravenhage 1 juli 1994, JB 1994, 200 m.nt. MAH.

It casu was de gemeente met een projectontwikkelaar overeengekomen, dat laatstgenoemde slechts verkoopovercenkomsten zou sluiten ntet gegadigden aan wie op grond van de gemeentelijke richtlijnen een kavel was toegewezen. Prublemen ontstonden toen een optiehouder door de gemeente van de lijst werd gesehrapt. De rechtbankpresident stelde vast dat het bestreden gemeentelijke besluit was gericht op de totstandkoming van ten koopovereenkomst inzake onroerend goed. Mar nu niet de gemeente, maar de projectontwikkelaar de knopovereenkomst sloot met de optiehouder, ging de president er vanuit dat het bestreden besluit buiten de werkingssfeer was gelegen van artikel 8:3 Awb. Heldeweg is het met deze beslissing eens: 'Nu de overheid geen contractspartner is en hasr rol is beperkt tot de ke'uze van een contractspantner voor de projectontwikkelaar, wenst de president het bestreden besluit buiten de werkingssfeer van artikel 8:3 Awb te laten' (cursief van mij). Heldeweg acht deze zienswijze juist nu het gaat om een contract tussen twee privaatrechtelijke partijen, zodat het is uitgesloten dat zich twee verschillende rechters met dezelfde rechtsvraag gaan bezighouden (vgl. Memorie van Toelichting bij artikel 8:3 Awb, waarnaar de rechtbankpresideat nog verwijst).

\subsection{Naar een bevoegde administratieve rechter}

\section{Criterium}

Het komt mij voor dat het vonnis van de rechtbankpresident ook nog om een andere reden steun verdient. Het mag niet zo zijn dat het enkele feit, dat nu het niet de gemeente is die het contract sluit, zulks op zich reeds voldoende reden is om de voorafgaande gemeentelijke (interne $^{\mathrm{i22}}$ ) besluitvorming niet afzonderlijk te toetsen. Of positiever geformuleerd: als het gemeentebestuur invloed uitoefent op de keuze van de gegadigden, dient de besluitvorming daaromtrent afzonderlijk bij een administratieve rechter ter toetsing te kunnen komen. Het zou anders erg gemakkelijk zijn voor gemeenten om haar (erfpacht)contracten te laten sluiten door bij voorbeeld een projectontwikkelaar. Hetzelfde geldt wat mij betreft voor de aanbesteding.

De belangrijkste reden om de besluiten voorafgaand aan de privaatrechtelijke rechtshandeling niet appelabel te maken, is gelegen in de vrees voor dubbele competentie. Wat betreft

21 De Awb-wetgever wil vooralsnog het privaatrechtelijk handelen door de overheid buiten de administratieve rechtsbescherming houden. Vgl. TK 1991-1992, 22 495, nr. 3, 95-96 (Memorie van Toelichting).

12 Bij voorbeeld: de gemeente besluit tot het al dan niet aangaan van een geldlening. Voor externe beslissingen kan worden gedacht aan de goedkeuring van een rechtshandeling naar burgerlijk reeht. Positieve beslissingen (zoals verlenen van goedkeuring zijn niet appelabel, als intern). Negatieve beslissingen zijn wel appelabel: de civiele en bestuursrechtelijke aspecten zijn goed te scheiden: er gebeurt niets dan nadat de administratieve rechter uitspraak heeft gedaan. Vgl. TK 1991-1992, 22 495, nr.3, 100-101 (Memorie van Toelichting). 
vorderingen uit contract is steeds de burgerlijke rechter competent, ook als de overheid eén der contractspartijen is. Dit uitgangspunt wreekt zich wanneer er in de besluitvorming voorafgaand aan de besluitvorming beslissingen worden genomen, die naderhand niet meer (afzonderlijk) kunnen worden getoetst. Bij de overheidsaanbesteding doet zich dit probleem wel zeer nadrukkelijk voor: de diverse beslissingen voorafgaand aan de opdrachtverlening zijn in de uiteindelijke overheidsopdracht niet meer terug te vinden. Alle beleidselementen zitten in de fase voorafgaand aan de contractssluiting; uitgesloten derden zijn geen belanghebbenden bij het contract. Bovendien is het ook niet wenselijk dat contracten met de overheid steeds door derden zouden kunnen worden opengebroken. Het belang van de derde is dan ook niet het openbreken van een eenmaal gesloten contract: zijn belang is deel te kunnen nemen aan de aanbestedingsprocedure en een faire kans te maken op de opdracht.

Aangezien er alleen een privaatrechtelijke weg is, komt de doorkruisingsleer niet ter tafel. En daarmee evenmin de rechtsbescherming van derden. Zou ter bepaling van de gedachten - met De Haan en Crince le Roy - de contractssluiting worden opgevat als de verlening van een vergunning, dan was onmiddellijk duidelijk geweest, dat voor derden (de overige inschrijvers) beroep openstaat op de administratieve rechter, die via de toetsing van het besluit ook het daaraan ten grondslag liggende beleid zou kunnen toetsen.

Ik zou de competentie van de rechter in dergelijke gevallen - variërend op het thema van artikel 6:3 Awb - willen laten afhangen van het volgende criterium: wanneer het gaat om een onlosmakelijk met een privaatrechtelijke rechtshandeling verbonden besluit, is doorslaggevend voor de administratiefrechterlijke competentie of het besluit los van die privaatrechtelijke rechtshandeling rechtsgevolgen in het leven roept (of juist beoogt te beletten).

Vergelijk de opmerking van M.-A. Flamme en $\mathrm{Ph}$. Flamme ${ }^{123}$ die er op wijzen dat de privaatrechtelijke benadering een doeltreffende rechterlijke controle van de regelmatigheid van de overheidsopdrachten in de weg staat. In die zin Wedekind ${ }^{124}$, die er op wijst dat het zicht op de richtijn Werken voor ons (mede) vertroebeld wordt omdat wij, anders dan in Belgiê en Frankrijk, de overheidsopdrachten vanuit privaatrechtelijk perspectief beziea.

\section{Belgisch model}

Vergelijking met het Belgische recht leert het volgende. De Belgische Raad van State is volgens vaste rechtspraak bevoegd om kennis te nemen van een beroep tot vernietiging van een van het contract afscheidbare eenzijdige rechtshandeling die aan de sluiting van het contract voorafgaat: het zogeheten vernietigingscontentieux. Het beroep moet zijn ingesteld tegen een administratieve rechtshandeling: dit is een eenzijdige en uitvoerbare rechtshandeling van een administratieve overheid. Een uitvoerbare beslissing is 'de handeling waarbij wordt beoogd rechtsgevolgen in het leven te roepen of te beletten dat zij tot stand komen, m.a.w. waarbij wordt beoogd wijzigingen aan te brengen in een bestaande rechtsregel of rechtstoestand, danwel zodanige wijziging te beletten' ${ }^{125}$. De vernietiging heeft terugwerkende kracht. Het bestuur wordt teruggeplaatst in de situatie voorafgaand aan de vernietigde beslissing en moet dan een nieuwe beslissing nemen met inachtneming van het vernietigingsarrest ${ }^{126}$.

\footnotetext{
${ }^{123}$ Flamme - Flamme (1986), 721.

134 Wedekind (1993), 504 noot 6 en 7.

12s D'Hooghe (1993), 592.

${ }^{126}$ D' Hooghe (1993), 587 en 624 v.
} 
Voor dit onderzoek is verder met name het onderscheid tussen voorbereidende handelingen en voorbeslissingen van belang. De voorbereidende handeling wijzigt in beginsel niets aan de bestaande rechtstoestand en laat de overheid vrij in het gevolg dat de voorbereidende maatregel kan hebben. Dergelijke beslissingen zijn niet onmiddellijk aanvechtbaar, hoewel de onwettigheden die erin besloten liggen wel kunnen worden ingeroepen ter ondersteuning van het verzoekschrift tot nietigverklaring. Als voorbeelden van louter voorbereidende handelingen kunnen worden genoemd: machtigingen om een bepaalde gunningsprocedure te volgen, adviezen en voorstellen om het contract aan een welbepaalde inschrijver te gunnen. En ook loutere uitvoeringshandelingen zijn geen administratieve rechtshandelingen (zoals berichten waarbij een reeds kenbaar gemaakte beslissing wordt bevestigd ${ }^{127}$ ).

Een voorbeslissing daarentegen heeft dadelijk gevolg en bepaalt (een deel van) de inhoud van de eindbeslissing. Dergelijke beslissingen kunnen onmiddellijk met een beroep tot vernietiging (vernietigingsberoep) worden bestreden. Het begint al met de beslissing waarbij het bestek wordt vastgesteld of gewijzigd. Deze beslissing kan een onmiddellijk nadeel veroorza$\mathrm{ken}^{128}$. Andere aanvechtbare voorbeslissingen zijn (onder meer) de beslissing over de regelmatigheid van de inschrijvingen, de beslissing over de wijze van gunnen, de beslissing tot vaststelling en eventueel tot wijziging van de gunningsvoorwaarden, de beslissing waarbij het contract wordt opgedragen aan een mede-inschrijver, de beslissing om aan een gunningsprocedure geen gevolg te geven en/ of een nieuwe procedure te beginnen en de beslissingen die in het kader van de uitoefening van het bestuurlijk toezicht worden genomen. De beslissing om de kandidatuur van een bepaalde gegadigde niet in aanmerking te nemen, is weliswaar geen beslissing waarmee de gunningsprocedure wordt afgesloten, maar ten aanzien van de betrokkene gaat het niettemin om een eindbeslissing waartegen dan ook een ontvankelijk vernietigingsberoep kan worden ingesteld ${ }^{129}$.

David D'Hooghe wijst er in zijn noot onder Belgische Raad van State 12 april 1989. TvAan 1990, 140 op, dat het bestek zowel voorbereidende beslissingen als voorbeslissingen inhoudt. Enerzijds bepalingen die betrekking hebben op de wijze waarop het contract zal worden gegund, anderzijds bepalingen die het voorstel van het te sluiten contract omvatten. Nu het bestuur gehouden is tot het eerbiedigen van de voorwaarden in het bestek, kan de beslissing tot vaststelling van het bestek onmiddellijk nadeel berokkenen; een dergelijke beslissing is vatbaar voor vernietigingsberoep. Voorwaarde voor beroep is wel dat de verzoeker belang heeft bij de vernietiging. Dit zal zeker zo zijn, indien hij door de besteksvoorwaarden als mogelijke contractant van het bestuur wordt uitgesloten.

Gelet op het voorafgaande zou ik de diverse ('voor')beslissingen (zijnde rechtshandelingen) in het proces voorafgaand aan het besluit tot opdrachtverlening vatbaar willen achten voor bezwaar en beroep op grond van artikel 6:3 Awb, telkens als de beslissing (middel) een juridisch relevante (en noodzakelijke) tussenschakel vormt om tot dat resultaat (doel) te geraken.

Dat bepaalde beslissingen zijn geregeld in het UAR neemt niet weg, dat de aanbestedingsbevoegdheid steeds berust op de Gemeentewet. Bedacht moet worden dat het UAR voor gemeenten niet verplicht is. Het is wetstechnisch natuurlijk fraaier wanneer de beslissingen in het kader van bet UAR binnen een wettelijk kader worden gebracht. Zie daarover de slotparagraaf.

${ }^{17}$ D'Hooghe (1993), 593 en 595.

123 Zie voorts artikel 2.1.b richulijn 89/665. Zie verder D'Hooghe (1993), 697 e.v.

129 D'Hooghe (1993), 594-595. 
Dat deze voorbeslissingen voor bezwaar en beroep in aanmerking komen, hangt ten nauwste samen met het feit dat bij een aanbesteding de beleidskeuzes rechtsgevolgen hebben voor belanghebbenden in de fase voorafgaand aan het sluiten van het aannemingscontract. Is er eenmaal een contract gesloten, dan is het voor (dan) derde-belanghebbenden via het privaatrecht (vrijwel) onmogelijk om op het gevoerde aanbestedingsbeleid terug te komen. Voor het bestuur is het voordelig, dat al in een vroeg stadium onregelmatigheden kunnen worden hersteld. Dit kan een latere, kostbare, schorsing van de aanbestedingsprocedure voorkomen. Het voordeel voor de burger is dat de onterechte (niet) sluiting van het contract reeds in een vroeg stadium kan worden voorkomen ${ }^{130}$.

\section{Dubbele competentie}

Vooropgesteld dient te worden dat de Belgische Raad van State niet bevoegd is wanneer bijzondere wettelijke bepalingen de regeling van administratieve geschillen opdraagt aan de gewone rechter. Overigens hangt de bevoegdheid van de Raad van State (in navolging van de Franse rechtspraak en rechtsleer) samen met de leer van de acte détachable (afscheidbare akte). De vordering tot vernietiging van het contract - waartoe enkel de gewone rechter bevoegd is - moet worden onderscheiden van de vordering tot vernietiging van de eenzijdige beslissingen die aan de sluiting van het (privaatrechtelijke) contract(=de overheidsopdracht) voorafgaan $^{131}$. De voor de hand liggende vraag is, hoe de bevoegdheid van de Raad van State wordt afgebakend van die van de gewone rechter. De rechtspraak heeft daartoe drie criteria ontwikkeld:

a. het beroep op een subjectief recht. Uit de artikelen 92 en 93 Belgische Grondwet heeft het Hof van Cassatie afgeleid dat de Raad van State niet bevoegd is om kennis te nemen van een beroep tot nietigverklaring waarvan het werkelijk en rechtstreeks voorwerp erin bestaat een geschil op te werpen inzake burgerlijke of politieke rechten (p. 583).

Er zal dus moeten worden nagegaan wat precies met het instellen van het vernietigingsberoep wordt beoogd. Streeft de verzoeker door middel van de instelling van het beroep in werkelijkheid de erkenning van een subjectief recht na, dan is de Raad van State onbevoegd en moet het geschil voor de gewone rechter alanhangig worden gemaakt ${ }^{132}$. Dat de nietigverklaring van de bestreden handeling een weerslag kan hebben op het bestaan of de uitoefening van de subjectieve rechten, brengt echter niet de onbevoegdheid van de Raad van State mee. Wat het (rechtstreeks) eigenlijke voorwerp betreft: daarbij moet volgens de Raad van State niet worden uitgegaan van het subjectieve doel dat de verzoeker nastreeft, maar van het objectieve, direct uit het vernietigingsarrest voortvloeiende rechtsgevolg. Dit kan dus nooit betrekking hebben op de vernietiging van het contract ${ }^{133}$. De Raad van State kan evenmin kennis nemen van een vernietigingsberoep dat is gericht tegen beslissingen die in het kader van de uitvoering van de overeenkomst zijn genomen.

${ }^{130}$ Schorsing heeft niet het effect dat de toewijzing geen verdere doorgang zou vinden. Belgische Raad van State 22 mei 1991, RW 1992, $94 \mathrm{~m} . n t$. David D'Hooghe. De annotator is van mening Jat blijkens deze uitspraak daarvoor toch enige ruimte lijkt te kunnen bestaan.

131 D*Hooghe (1993), 576-577.

110 D'Hooghe (1993), 582-583. De omstandigheid dat het bestuur zich bij de gunningsheslissingen niet a priori in een toestand bevindt waarbij zijn bevoegdheden geheel gebonden is, er niet toe leidt aan de kandidaat-contractanten een subjectief recht op de eerbiediging van het objectieve recht door het bestur kan worden ontzegd.

${ }^{133}$ D'Hooghe (1993), 585-586. 
Deze leer van het werkelijk en rechtstreeks voorwerp biedt in de praktijk niet steeds houvast omdat elk vernietigingsberoep tegen een gunningsbeslissing ook geformuleerd kan worden op een wijze dat eigenlijk het bestaan van een subjectief recht wordt ingeroepen. Uit de rechtspraak van het Hof van Cassatie en de Raad van State blijkt dat met het oog op de bevoegdheidsafbakening niet alleen rekening wordt gehouden met het werkelijk en /eigenlijk voorwerp van het vernietigingsberoep maar ook met het nagestreefde rechtsherstel, evenals met het al dan niet bestaan van enige discretionaire bevoegdheid zijdens het bestuur ${ }^{134}$.

b. Indien de vordering tot vernietiging van het besluit eigenlijk het rechtsherstel beoogt van een op onrechtmatige wijze gekrenkt recht, is de Raad van State eveneens onbevoegd ${ }^{135}$, althans indien de nietigverklaring leidt tot een resultaat dat gelijkwaardig is aan het rechtsherstel door de gewone rechter. Het rechtsherstel dat de gewone rechter biedt heeft betrekking op vernietiging van het contract of op schadevergoeding en is dus van andere aard dan een vernietigingsarrest van de Raad van State.

c. Een derde criterium ter afbakening van de bevoegdheid tussen de Raad van State en de gewone rechtbanken is gelegen in het al dan niet bestaan van enige discretionaire beoordelingsbevoegdheid. Vrij algemeen wordt aangenomen, dat waar het bestuur een zekere discretionaire beoordelingsvrijheid bezit, de Raad van State bevoegd is. Hoewel het bestuur tijdens het gunningsproces beschikt over een zekere discretionaire bevoegdheid, kunnen de wettelijke en reglementaire bepalingen en de algemene beginselen van behoorlijk bestuur ertoe leiden dat het bestuur in een bepaald concreet geval over nagenoeg geen beoordelingbevoegdheid meer beschikt ${ }^{136}$.

Toch blijft al met al lastig te bepalen wanneer een bestreden beslissing steunt op de uitvoering van het contract danwel daarvan is te onderscheiden.

Als voorbeeld noemt D'Hooghe ${ }^{137}$ de eenzijdige bestuursbeslissing om, na de verbreking van de overeenkomst, tot heraunbesteding over te gaan. Deze beslissing kan niet worden bestreden door de inschrijver met wie het contract reeds was gesloten. Deze beslissing vormt slechts de uitvoering van de beslissing om het gesloten contract niet verder uit te voeren. Anderzijds werd het vernietigingsberoep tegen de beslissing om het afgesloten contract, waarvan de toewijzingsbeslissing door de Raad was vernietigd, voort te zetten of an te passen, wel ontvankelijk verkJaard.

\section{Beter: overheidskamer}

Het lijkt weinig zinvol om het aan de ene kant mogelijk te maken dat voorbeslissingen kunnen worden vernietigd, terwijl anderzijds deze vernietiging geen enkel praktisch nut heeft indien, zoals vaak het geval is, het contract reeds is gesloten ${ }^{138}$. Bovendien is het ook niet gewenst dat derden de mogelijkheid hebben om contracten met de overheid door de gewone rechter te laten vernietigen. Het contracteren met de overheid moet niet een al te riskante aangelegenheid worden. De rechtsbescherming moet daarom voorafgaand aan het sluiten van het contract plaatsvinden. Dit brengt D'Hooghe ertoe te concluderen, dat de bestaande duali-

\footnotetext{
${ }^{134}$ D'Hooghe (1993), 584-585.

as D'Hooghe (1993), 586.

136 D'Hooghe (1993), 588-589.

197 D'Hooghe (1993), 590-591.

138 In die zin Van Gerven (1987), 1729: 'pyrrhus-zege' en D'Hooghe (1993), 717-718.
} 
teit van de rechterlijke organisatie weinig voordelen biedt in gevallen waarin de vernietiging van de bestreden beslissing op zichzelf geen rechtsherstel van de benadeelde inhoudt. Hij wijst in dit verband op de pleidooien voor de oprichting van administratieve rechtbanken of administratieve kamers binnen de gewone rechtbanken.

De dualiteitskwestie, die in ons land in de weg staat aan rechtsbescherming door de administratieve rechter, zou verdwijnen, wanneer zou worden overgegaan tot een systeem waarbij alle geschillen betreffende de aanbesteding van overheidscontracten, ongeacht de aard van de handeling of het nagestreefde rechtsherstel, door dezelfde administratieve rechter zouden worden beoordeeld ${ }^{139}$.

\section{Beleidsfasetoetsing}

Tijdens de bespreking van het VAR-preadvies $1994^{1 \text { th }}$ werd gesproken over de taakopvatting van de rechter. Preadviseur (en rechter) Allewijn uitte bedenkingen tegen een meer beleidsmatige taakopvatting van de rechter. Naar zijn oordeel dienen zaken pas bij de rechter te komen als er een individueel rechtsgeschil overblijft ${ }^{141}$. Een heel ander geluid komt van De Moor-van Vugt. Zij wil het in artikel 3:4, lid 2 Awb gecodificeerde evenredigheidsbeginsel een zodanige invulling geven, dat de rechter in staat wordt gesteld om de beleidsfase voorafgaand aan het besluit op zijn rechtmatigheid te beoordelen. Wat houdt deze beleidsfasetoetsing in' De Moor-van Vugt zoekt voor haar benadering aansluiting bij de 'rule of reason'-rechtspraak door het Europese Hof van Justitie.

Zoals hiervoor (in het vierde hoofdstuk) bleek mag een lidstaat een handelsbelemmerende maatregel nemen als harmonisatiemaatregel ontbreekt. Eis is dat de maatregel toegepast wordt zonder onderscheid te maken tussen de eigen onderdanen en die van andere lidstaten. Bovendien moet de maatregel gerechtvaardigd worden door dwingende eisen van algemeen belang (cf. verdragsdoelstellingen). Of dit zo is, is een kwestie van evenredigheid. Deze evenredigheidstoets lnopt over drie sporen. a. de maatregel moet geschiks zijn om de beoogde dvelstelling te bereiken, b. de maatregel mag niet verder gaan dan nootakkelijk is om beoogde doelstelling te brriken, en $\mathrm{c}$. ate maatregel moet proportioneel zijn.

Het Hof waakt over een rechtmatige algemene beleidsvorming, en richt de toetsing met name op de vroegste fases van de belangenafweging, de momenten waarop de beleidskeuzes worden gemaakt voorafgaand aan de uitvoering van het beleid. In verband met de economische achtergronden van het Europese recht ligt het accent in de regel op de geschiktheids- en de noodzakelijkheidstoets (vergelijk wat dit betreft de conclusies in het vierde hoofdstuk $)^{142}$.

Wat het Nederlandse bestuursrecht betreft, concludeert De Moor-van Vugt ${ }^{143}$ dat de Nederlandse administratieve rechter bij de toetsing aan het evenredigheidsbeginsel (buiten het sanctierecht) het accent sterk legt op de verhouding tussen de bij de besluitvorming betrokken belangen, het algemene belang tegenover het individuele belang. De rechter toetst dan of het

\footnotetext{
${ }^{139}$ Scheltema (1992), 958 v. Zie ook Tak (1993), 190.

140 Het nieuwe bestuursprocesrecht; verslag van de algemene vergadering van de Vereniging van Administratief Recht gehouden op 29 april 1994 ter behandeling van de preadviezen van D. Allewijn, M. Schreuder-Vlasblom, Alphen aan den Rijn, 1995 (VAR-reeks 113). Zie voor bespreking van het preadvies J.M. Polak, NJB 1994, 538 en Gerrits-Janssens, NJB 1994, 1142.

141 t.a.p., 118

142 De Moor-van Vugt (1993), 30.

143 De Moor-van Vugt (1993), 35.
} 
individuele belang niet te zeer geraakt wordt in verhouding tot het te dienen algemene belang (proportionaliteit). De geschiktheid noch de noodzakelijkheid van een maatregel in abstracto komen bij de toetsing expliciet aan bod, uitzonderingen daargelaten. Deze wijze van toetsen houdt verband met de opvatting die bestaat over de taak van de rechter: de beoordeling van concrete bestuursbesluiten in hun concrete context.

Wanneer de Nederlandse administratieve rechter tot een objectieve noodzakelijkheidstoetsing zou over gaan, zou dat een verschuiving betekenen van de concrete besluitvorming naar de fase van de beleidsvorming/- bepaling. Deze voorfase zou dan meer in abstracto getoetst gaan worden aan de hand van de ijkpunten (legitieme) doelstelling, geschiktheid en noodzakelijkheid van het toe te passen instrument en de mate waarin individuele belangen getroffen worden door deze toepassing ${ }^{144}$. In dit doel-middelconcept kunnen veel van de materiële algemene beginselen van behoorlijk bestuur ondergebracht worden. Niet alleen het verbod van kennelijke onredelijke belangenafweging, het zorgvuldigheidsbeginsel en het gelijkheidsbeginsel. Ook het vertrouwensbeginsel: het niet-nakomen van een toezegging kan getoetst worden aan het noodzakelijkheidscriterium en aan het proportionaliteitsbeginsel.

Het komt mij voor dat een dergelijke beleidsfasetoetsing geschikt (en gewenst) is voor de rechtmatigheidstoetsing van de besluitvorming ter zake van de aanbesteding van werken. Het gaat er niet alleen om of het individuele belang niet te zeer geraakt wordt in verhouding tot het te dienen algemene belang (proportionaliteit), maar met name om het oordeel of de gemeente terecht die criteria en voorwaarden stelt. Laat men het formuleren van die criteria en voorwaarden over aan de beleidsvrijheid van de gemeente, zonder dat de geschiktheid of de noodzakelijkheid van een maatregel is komen vast te staan, dan zal proportionaliteitstoetsing weinig meer kunnen uitrichten. Door de toetsing van de geschiktheid en noodzakelijkheid van de criteria en aanvullende voorwaarden als zodanig wordt de beleidsvrijheid zelf voorwerp van een administratiefrechtelijke rechtmatigheidstoets.

In het derde hoofdstuk zijn enkele kanttekeningen geplaatst bij de bevoegdheid van de Raad van Arbitrage om kennis te nemen van aanbestedingsgeschillen met de overheid op basis van het UAR-EG 1991. Daaraan kan worden toegevoegd dat de bestuurlijke afwegingen (met name ook buiten het UAR-kader), inclusief de rol van de algemene beginselen van behoorlijk bestuur, mijns inziens beter thuis zijn bij de administratieve rechter. Dit geldt vanzelfsprekend ook voor aanbestedingen op basis van het UAR $1986^{145}$.

\section{Naar een wettelijk kader voor het aanbestedingsbeleid}

Aan het eind gekomen van dit onderzoek naar de grondslagen van het gemeentelijke aanbestedingsbeleid zou ik aan de op basis daarvan getrokken conclusies twee tentatieve opmerkingen willen toevoegen. Tentatief, want er zal nader onderzoek nodig zijn.

\footnotetext{
I4 De Moor-van Vugt (1993), 36-37. Anders Bijloos - Van den Oosterkamp (1990), 861-862.

14s In die zin Adriaansens (1988), 352-353 over oratie Lubach. Anders Pront-van Bommel (1993), $956 \mathrm{v}$.
} 
Afb. 5: Wettelijk kader aanbestedingsbeleid

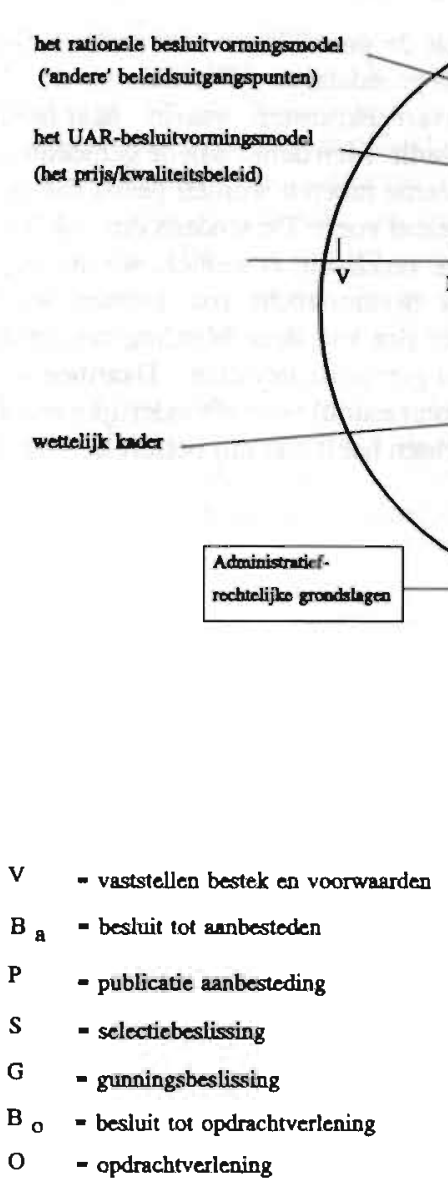

tijd

De eerste opmerking betreft de reikwijdte van het onderzoek. Ik acht het niet nnwaarschijnlijk dat het aanbestedingsbeleid van andere overheden op een vergelijkbare leest zou kunnen worden geschoeid. Dit zou het mogelijk maken te denken aan een Wet op de overbeidsopdrachten, die verder gaat dan het uitsluitend regelen van aanbestedingsprocedurele kwesties (zie: afbeelding 5). Deze 'Wet op de overheidsopdrachten' zou (onder meer) 


\section{Hoofdstuk 5}

bepalingen moeten bevatten over de (gemeentelijke) bevoegdheidsverdeling, het verloop van het besluitvormingsproces (vergelijk het stappenplan), de wijze van vaststelling van het beleid(snota), de te hanteren objectieve selectie- en gunningscriteria, de bij de aanbesteding te betrekken 'andere' belangen, de wijze van opdrachtverlening, mogelijke heraanbesteding, beëindiging van de overeenkomst, een jaarlijkse evaluatieprocedure en de mogelijkheden van bezwaar en beroep voor belanghebbenden tegen het door de overheid gevoerde beleid.

Mijn tweede opmerking is dat ik het denkbaar acht dat de grondslagen van aanbestedingsbeleid een ruimere toepassing zouden kunnen krijgen als grondslagen van andere (in de Algemene wet bestuursrecht te regelen) publiekrechtelijke overeenkomsten, waarin - naar huidige opvattingen - een zeker vermogensrechtelijk element schuilt. Men denke aan de gemeentelijke gronduitgifte-overeenkomst. Ook dan zou van de gemeente moeten worden geëist dat zij op dit beleidsterrein een vooraf kenbaar en gemotiveerd beleid voert. De tendens om ook buiten de sfeer van de aanbesteding het UAR van toepassing te verklaren, is wellicht wat dit betreft een voorteken ${ }^{146}$ ! Aansluiting bij de Algemene wet bestuursrecht zou kunnen worden bereikt door aanpassing van artikel 8:3 Awb. Aan het slot van deze bepaling zou moeten toegevoegd: 'behoudens de in de wet (=in formele zin) geregelde gevallen'. Daarmee wordt bereikt dat de wetgever kan bepalen welk(e) overheidscontract(en) voor afzonderlijke regeling in aanmerking komen. Een Wet op de overheidsopdrachten heeft wat mij betreft de primeur!

${ }^{146}$ Donders (1995), $399 \mathrm{v}$. 


\section{Korte weergave Euregionaal praktijkonderzoek 1986-1988}

\section{Enquête}

\section{Doelstelling}

Begin 1986 werd een begin gemaakt met een onderzoek naar de gemeentelijke aanbestedingspraktijk in de Euregio Maas-Rijn. Dit is het gebied rondom de drie grote steden Maastricht (Zuid-Limburg), Luik (Belgisch Limburg en Luik) en Aken (NordrheinWestfalen). Door niet alleen de Nederlandse Euregionale praktijk te onderzoeken, werd het mogelijk om het Nederlandse gemeentelijke aanbestedingsbeleid in een Europees, dat wil zeggen een grensoverschrijdend, perspectief te plaatsen. Bij aanvang van het onderzoek werd namelijk verondersteld dat het aanbestedingsbeleid van de Zuid-Limburgse gemeenten, door de nabijheid van twee landsgrenzen, moeilijk los kan worden gezien van zijn omgeving. Het doel van het praktijkonderzoek kan daarom als volgt worden omschreven: te onderzoeken welke factoren (binnen- en buitenlands) vorm en inhoud van het gemeentelijk aanbestedingsbeleid bepalen.

Om van de bestaande Euregionale aanbestedingspraktijk een beeld te krijgen werden alle zogeheten Europese Gemeenten in dat gebied aangeschreven en verzocht een enquêteformulier in te vullen en terug te sturen. In Tabel I wordt een overzicht gepresenteerd van het aantal verstuurde en geretourneerde enquêteformulieren.

\section{Tabel I}

Nederland

België

Duitsland

Totaal

$\begin{array}{ll}\text { aantal } & \text { aantal } \\ \text { verstuurde } & \text { geretoumeerde } \\ \text { formulieren } & \text { formulieren }\end{array}$

11

De enquête is gebaseerd op de indelingen zoals deze in het rapport "Naar een ordening op de bouwmarkt ${ }^{2}$ worden onderscheiden. Dat rapport kent een indeling in vier prijsklassen, waarbij dan weer een nader onderscheid wordt gemaakt naar de GWW-sector en de U-bouwsector. Middels een schriftelijke enquête werden de aangeschreven gemeenten gevraagd om, per prijsklasse en per sector, de motieven aan te geven, die een rol spelen bij de selectie en de gunning van een opdracht. De enquête maakte daartoe een onderscheid tussen een negental motieven. Bovendien konden gemeenten een prioriteitsvolgorde tussen de diverse motieven aangeven. De bedoelde motieven zijn achtereenvolgens: de

I Zie ook Nijholt (1987), Verjans (1987) en Nijholt (1988). De (Nederlandse) onderzoeksresultaten lijken in de loop der tijd niets van hun acrualiteit te hebben verloren, getuige recentere onderzoeken door onder meer $\mathrm{L}$. de Boer en J.Telgen van de faculteit der Technische Bedrijfskunde, Universiteit Twente. Voor een kort verslag van hun bevindingen: BB Management 19 juni 1995, p. 2-5, en Vereniging Stadswerk Nederland, nr. 2-95, p. 50-52.

2 Overleggroep Ordeningsthema's Aanbestedingswezen (1982). 
laagste prijs, de betrouwbaarheid van de aannemer, zijn deskundigheid, de vertrouwensrelatie tot de aannemer, de tijdsduur van de aanbestedingsprocedure, het al dan niet voorkómen van opzetregelingen, concurrentie-overwegingen, lokale c.q. regionale werkgelegenheidsoverwegingen en een restcategorie.

\section{Resultaten}

De resultaten van de schriftelijke enquête werden in een vijftal categorieën ondergebracht. Dit zijn: het aantal aanbestedingen per gemeente, de gehanteerde aanbestedingsprocedures, de motieven die bij de aanbesteding een rol spelen, het plaatselijke aanbestedingsbeleid en het vórkomen van contacten met buitenlandse aannemers. Het aantal niet geretourneerde enquêteformulieren bleek aanzienlijk, hetgeen op zichzelf een voldoende reden vormde om daarnaast, door middel van interviews, een nadere oriëntering op de gemeentelijke aanbestedingspraktijk te verkrijgen ${ }^{3}$. In totaal werden daarom nog een vijftiental gemeenten geïnterviewd. Hierna wordt het gecombineerde resultaat van de enquête en de interviews weergegeven. De resultaten hebben betrekking op de periode tussen 1980 en 1985.

NEDERLAND. Uit de schriftelijke resultaten komt, met name bij de kleinere gemeenten, een overduidelijke voorkeur voor de enkelvoudige aanbesteding naar voren. Daarnaast komen ook, voomamelijk bij de wat grotere gemeenten, de onderhandse aanbesteding met of zonder selectie voor. Nog grotere gemeenten dragen in een enkel geval het werk wel eens op na een openbare aanbesteding na selectie. Maar het belangrijkste blijven toch de beide onderhandse aanbestedingsprocedures; en ook enkelvoudige aanbestedingen komen bij grotere gemeenten vaak voor. De openbare aanbestedingsprocedure wordt praktisch niet gehanteerd: het is een marginaal, te verwaarlozen verschijnsel. Deze voorkeur leidt tot een aanbestedingspraktijk waarin de uitnodiging tot inschrijving vrijwel steeds is beperkt tot éen of enkele aannemers uit de eigen gemeente of regio. In het sporadische geval dat er toch openbaar wordt aanbesteed, betekent dat niet meer dan dat een iets grotere groep tot de inschrijving wordt uitgenodigd. In die gevallen gaat het dan gewoonlijk om door de provincie of het Rijk gesubsidieerde aanbestedingen, waarbij dan als extra eis wordt gesteld, dat er een ruimere kring van aannemers in de gelegenheid moet worden gesteld om in te schrijven. Het onderscheid tussen de verschillende sectoren, zoals de GWW-sector en de U-bouwsector, speelt voor deze aanbestedingspraktijk geen noemenswaardige rol.

In de meeste gemeenten is het aanbestedingsbeleid niet in enigerlei vorm vooraf vastgelegd. Gewoonlijk beslissen B\&W over de aanbesteding en is de rol van de raad beperkt tot de vaststelling van het beschikbare krediet. B\&W gaan daarbij in de regel af op het ambtelijk advies van de technische dienst. $B \& W$ brengen hun voorstel vervolgens in de raad. In de meeste gevallen neemt de raad dit voorstel ongewijzigd over (als hamerstuk). Slechts een enkele keer komt het voor dat de raad daarover eerst met B\&W van gedachten wisselt. Maar niet elk aanbestedingsvoorstel behoeft de raad te passeren. Dit kan zich

3 Het verkrijgen van gegevens over de gemeentelijke praktijk blijkt moeilijk. Zie in deze zin rapport A 8640 . Onderzoek Aanbesteding, i.o.v. Ministerie van Economische Zaken, december 1980 en Overleggroep Ordeningsthema's Aanbestedingswezen (1982). 
voordoen als de raad zich in het verleden akkoord heeft verklaard met een beleid waarbij bij voorbeeld de Directeur Gemeentewerken tot een bepaald bedrag gemachtigd is om zelf de aanbestedingsbeslissing te nemen.

BELGIË. Grosso modo geldt dat in de meeste geënquêteerde Belgische gemeenten geen vooraf vastgesteld aanbestedingsbeleid bestaat. Er wordt in België doorgaans gebruik gemaakt van de enkelvoudige of de beperkte aanbesteding. Dit is afhankelijk van de grootte van de opdracht: boven Bfrs. 1.250 .000 wordt in overwegende mate beperkt aanbesteed ${ }^{4}$. Bij de enkelvoudige aanbesteding (ook wel: onderhandse opdracht) ${ }^{5}$ voelen gemeenten zich over het algemeen vrij om diverse criteria in hun gunningsbeslissing mee te wegen. Het gaat daarbij steeds om dezelfde motieven als in het geval een offerteaanvraag wordt gedaan, zoals de prijs, de betrouwbaarheid en de deskundigheid van de aannemer, de kwaliteit, de financiële waarborgen en dergelijke. In het geval van een beperkte aanbesteding ${ }^{6}$ geldt de laagste prijs als het uitsluitende gunningscriterium. De aanbesteding geniet een voorkeur boven de offerte-aanvraag ${ }^{7}$, in welk geval meerdere, vooraf bekendgemaakte, gunningscriteria mogen worden gehanteerd. De financiële grens tussen de beperkte en de openbare aanbesteding ${ }^{8}$ wisselt per gemeente. Factoren die op die grens van invloed zijn, zijn de grootte van de gemeente, de aard van het werk en het beleid van de gemeente. Hoewel de openbare aanbesteding niet vaak voorkomt, vormen de opdrachten in geld gemeten een omvangrijk marktaandeel, doordat het meestal om grote en dure projecten gaat. Het komt, evenals in Nederland, ook voor dat de hogere overheid het openbaar aanbesteden als voorwaarde stelt voor het verkrijgen van een subsidie. De algemene offerte-aanvraag wordt niet of nauwelijks gehanteerd; gezien de daaraan voor de gemeente verbonden nadelen is dat ook niet verwonderlijk (publikatieplicht, er mogen geen lijsten met potentieel geschikte aannemers worden aangelegd, en er dienen gunningscriteria te worden ontwikkeld).

DUITSLAND. In Duitsland wordt onderscheid gemaakt tussen de Tief- und Strassenbau en Hoch- und Zweckbau. De Strassenbau was tijdens de onderzochte periode de grootste sector. Blijkens de schriftelijke enquêteresultaten wordt bij de aanbesteding van bouwwerken in beide sectoren in verreweg de meeste gevallen gebruik gemaakt van de öffentliche Ausschreibung ${ }^{9}$. En in de tweede plaats van de beschränkte Ausschreibung ${ }^{10}$. Alleen in bijzondere situaties wordt de opdracht verleend na een freihändige Vergabe ${ }^{11}$.

Art. 48 KB 22 april 1977 bepaalde dat het gemeentebestuur beneden dit bedrag onderhands mag gurnen.

s Art. 17 Wet van 14 juli 1976: de gunningswijze waarbij de bevoegde overbeid vrij de onderhandelingen aanknoopt die haar nuttig lijken en de opdracht vrij toewijst aan de aannemer die zij gekczen heeft, indien mogelijk na raadpleging van meerdere aannemers.

- Art. 11 Wet van 14 juli 1976: de uitnodiging tot mededinging wordt aan een beperkte groep aannemers gezonden.

' Zie voor de algemene en beperkte offerte-aanvraag: art. 13 Wet 14 juli 1976.

8 Art. 10 Wet 14 juli 1976: deze aanbesteding geschiedt met bekendmaking van de uitnodiging in het door de Staat gepubliceerde bulletin met opening der inschrijving en afkondiging der prijzen in het opesbaar.

- VOB/A 3: voor de uitvoering van werken worden volgens een bepaalde voorgeschreven procedure na openbare bekendmaking een onbeperkt aantal aannemers uitgenodigd om een offerte te doen.

10 VOB/A \$ 3: er worden een beperkt aantal aannemers opgeroepen om een offerte te doen.

"VOB/A \& 3: er wordt zonder formele methode aanbesteed. 
Dit is in overeenstemming met de voorschriften uit de Verdingungsordnung für Bauleistungen, deel A (VOB/A). Blijkens VOB/A $\S 2$, nr. 1 Satz 2 bestaat er - op grond van het gelijkheidsbeginsel - een onderlinge keuzevolgorde tussen de procedures. De overheidsaanbesteder dient telkens, gegeven de specifieke omstandigheden van het geval, te beoordelen welke procedure het meest recht doet aan het gelijke kansenbeginsel, waarbij ook de doelmatigheid een rol speelt.

Het VOB vormt voor alle gemeenten het uitgangspunt. Sommige gemeenten zien daarnaast geen enkele ruimte voor eigen beleid, andere gemeenten daarentegen zijn van mening dat er naast de VOB-hoofdlijnen nog wat (marginale) ruimte bestaat voor een eigen beleid. Dit hangt samen met de vrij strikte onderlinge rangorde tussen de aanbestedingsprocedures. Het te ontwikkelen beleid betreft dan uitsluitend beslissingen over afwijkingen van de normale (d.i. in de VOB-geregelde) gang van zaken, over het aantal te versturen uitnodigingen bij beschränkte Ausschreibung en over eventuele andere details. Met name in de grotere gemeenten zijn regelingen ontwikkeld

over de bevoegdheidsverdeling tussen de Raad, de Bau-Ausschuss en de Stadtdirektor.

\section{Motievenanalyse}

NEDERLAND. De overwegingen achter de enkelvoudige gemeentelijke aanbestedingspraktijk kunnen als volgt worden gekarakteriseerd. De grote werkloosheid in de zwakke regio Zuid-Limburg wordt door de gemeenten aangevoerd ter rechtvaardiging van een sterk lokaal georiënteerde aanbestedingspraktijk. Naast het accent op de lokale en regionale werkgelegenheid speelt de vertrouwensrelatie tussen de gemeente en de aannemer, zeker bij de kleinere werken (tot $f$ 250.000.-), een doorslaggevende rol bij de opdrachtverlening. Ook de betrouwbaarheid van de aannemer wordt wel eens als één van de belangrijkste overwegingen genoemd. Daarnaast kan - zij het wat verder op de achtergrond - de deskundigheid van de aannemer van betekenis zijn voor het verlenen van de opdracht. Dit duidt er op dat de meeste kleinere werken njet een specifieke deskundigheid vergen. Bij de grotere werken zijn het lokale c.q. regionale werkgelegenheidsmotief, de deskundigheid van de aannemer en daarnaast de vertrouwensrelatie gewoonlijk doorslaggevend. Op de achtergrond spelen de prijsvorming en de betrouwbaarheid van de aannemer een rol. De relatieve hoogte van de verschillende aannemingssommen speelt overigens nauwelijks een rol voor de opdrachtverlening. Het prijscriterium is slechts een budgettaire randvoorwaarde: de aannemer dient bij zijn prijsstelling beneden het door de raad gevoteerde krediet te blijven. Voor alle, kleine en grote, werken geldt, dat voor de opdrachtverlening de tijdsduur van de aanbesteding en het uitlokken van concurrentie tijdens de procedure een ondergeschikte rol vervullen. Het makt voor de genoemde resultaten overigens nauwelijks uit of het daarbij gaat om een GWW-werk of om een U-bouwwerk.

BELGIË. Het ad hoc gunningsbeleid is vrijwel steeds overwegend lokaal c.q. regionaal georiënteerd. In de meeste gevallen wordt beperkt of openbaar aanbesteed. Volgens Belgisch recht is bij de aanbesteding alleen het laagste prijscriterium van betekenis voor de gunning van een opdracht. Dit verklaart dat het prijscriterium in België bovenaan de lijst van meest gebruikte gunningscriteria staat. Het onderscheid tussen GWW-sector en 
U-bouwsector speelt geen rol. Toch leidt dit laagste prijscriterium in de praktijk kennelijk niet tot een extra-regionaal beleid.

Uit gesprekken met de ambtelijke diensten kwam naar voren dat de keuze voor de beperkte procedure mede afhankelijk is van de gemeentelijke politieke verhoudingen. Gemeenten die gevoelig zijn voor politieke druk vanuit de plaatselijke bouwwereld of omdat zij bang zijn te worden beschuldigd van vriendjespolitiek, kiezen voor de (beperkte) aanbestedingsprocedure, omdat daar het automatisme van het laagste prijscriterium van toepassing is. Die gemeenten hoeven dan als het ware niet te kiezen, en kunnen voor de gunningsbeslissing verwijzen naar de wettelijke bepalingen. Er zijn daarentegen ook gemeenten die voor de (beperkte) offerte-aanvraag kiezen, waardoor zij (meer) invloed kunnen uitoefenen op de uiteindelijke gunningsbeslissing.

Zijn er lokaal of regionaal voldoende aannemers die over de vereiste deskundigheid beschikken, dan maken gemeenten vrijwel steeds gebruik van de beperkte aanbesteding. Alleen indien lokaal of regionaal de noodzakelijke deskundigheid zou ontbreken, zoals bij voorbeeld bij grote en ingewikkelde bouwprojecten, zou dat voor gemeenten een reden kunnen zijn om openbaar aan te besteden. Maar noch uit de resultaten van de enquète, noch uit de interviews bleek dat zulks vaak voorkwam. Gewoonlijk is de plaatselijke deskundigheid van de bouwbedrijven voldoende om de opdrachten te kunnen uitvoeren.

Ook electorale overwegingen spelen een rol bij het gunningsbeleid, waardoor bet gemeentebestuur bij voorkeur een lokaal c.q. regionaal aanbestedingsbeleid voeren. Aannemers die eerder soortgelijk werk hebben gedaan, genieten soms een zekere voorkeur. Sommige gemeenten gaan daarin zover, dat zij een rouleringssysteem hanteren.

Op papier maakt de Belgische wetgeving een gedegen indruk. Hoe is het mogelijk dat op basis van in de wet genoemde, objectieve criteria Belgische gemeenten vrijwel zonder uitzondering er toch in slagen een lokaal c.q. regionaal voorkeursbeleid to voeren? Ondanks de zeer uitvoerige en gedetailleerde regelgeving is de gemeente vrij in de keuze van de te hanteren gunningswijze. Alleen in het geval dat de gemeente kiest voor de onderhandse opdracht, dient zij te motiveren welk geval ex artikel 17, paragraaf 2 Wet van 1976 van toepassing is ${ }^{12}$. Dit artikel somt limitatief een vijftiental gevallen op, waarin de gemeente van de onderhandse gunningswijze gebruik kan maken. Uit het onderzoek blijkt dat gemeenten met deze motivering geen moeite hebben: de marges zijn voldoende ruim omschreven. Bij de veelvuldig gehanteerde (beperkte) aanbesteding en de (beperkte) offerte-aanvraag behoeft deze beslissing geen verdere motivering. Dit laat gemeenten vrij om een lokaal of regionaal georiënteerd beleid te voeren. Daar komt nog bij dat de gemeente bij een onderhandse opdracht of bij een beperkte procedure ook niet behoeft te publiceren. Bovendien kan de gemeente zelf de samenstelling van de lijstjes bepalen en daarmee welke ondememingen in de beoordeling zullen worden betrokken. Op deze lijsten komen steeds de namen voor van lokale of regionale bouwbedrijven. Opdrachten die de grens van Bfrs. 100.000 niet te boven gaan, mogen aan één aannemer onderhands worden opgedragen.

\footnotetext{
12 Deze motiveringsplicht volgde uit art. 49, par. 3 KB 22 upril 1977.
} 
Ook het bestuurlijke toezicht verandert kennelijk weinig aan deze praktijk. In Belgie is een gemeentelijk besluit waarbij de wijze van opdrachtverlening en de daarbij behorende voorwaarden onderhevig aan de goedkeuring van de provincie, als de opdracht het bedrag van Bfrs. 1,3 miljoen (voor gemeenten met minder dan 5000 inwoners) c.q. van Bfrs. 3,3 miljoen (voor grotere gemeenten) te boven gaat. Veel opdrachten kunnen en worden gegund zonder dat er toezicht is, zoals bij de kleinere opdrachten en wanneer er sprake is van dringende spoed. Het zogenaamde algemene toezicht, dat bij alle opdrachten achteraf plaatsvindt, blijkt in de praktijk voor geen enkele gemeente een obstakel voor een lokaal georiënteerd beleid. Ook het toezicht op de uiteindelijke gunningsbeslissing levert in de praktijk geen problemen op.

Wat de rechterlijke toetsing betreft, lijken de aannemers een zekere terughoudendheid aan de dag te leggen om een zaak aanhangig te maken uit vrees dat men bij volgende opdrachten niet zal worden uitgenodigd. Deze opvatting, die naar voren komt van de zijde van de gemeente lijkt haaks te staan op de opmerking van Flamme. Deze merkt op:

'dat de aannemers (...) niet met cen heilig ontzag opkijken tegen bet aanhangig maken van hun zaak bij de rechter en ook de banbliksems of de geniepige represailles van de openbare kopers niet vrezen'. ${ }^{13}$.

DUTTSLAND. Met betrekking tot de öffentliche Ausschreibung kan, voor de beide bouwsectoren, het volgende worden opgemerkt. In alle prijsklassen is voor de beslissing aan wie het werk wordt gegund het laagste prijscriterium van doorslaggevende betekenis. In de kleinste geënquêteerde gemeente betekent dit, dat het werk alleen dan aan de eigen lokale of regionale aannemer wordt gegund als deze de 'mindestfordernder Bieter' is. In de wat grotere gemeenten wordt gegund aan de 'Preiswertigste Bieter'. Naarmate de gemeentelijke overheid meer ruimte ziet voor het voeren van een eigen beleid, wordt de öffentliche Ausschreibung uitdrukkelijk gehanteerd om een regionale aanbestedingsbeleid te voeren. De betrouwbaarheid van de aannemer en zijn deskundigheid spelen daarnaast ook een zeer belangrijke rol. De overige motieven spelen hoogstens een marginale rol. Het werkgelegenheidsmotief wint aan betekenis, naarmate de aanbestedingssom stijgt.

Ook voor de beschränkte Ausschreibung geldt dat in alle prijsklassen het laagste prijscriterium steeds een doorslaggevende rol speelt. Daarnaast zijn ook de betrouwbaarheid van de aannemer en diens deskundigheid van belang. Bij de kleinere gemeenten speelt, naast de deskundigheid, ook de regionale herkomst van het bedrijf een rol. Gegund wordt aan de aannemer met het 'günstigste Angebot'. Sommige kleine gemeenten voeren uitdrukkelijk een specifiek lokaal/ regionaal aanbestedingsbeleid. In die gemeenten worden kleinere (Hochbau)werken altijd na een beschränkte Ausschreibung gegund aan een plaatselijke aannemer. Maar bij andere kleine gemeenten is dit minder duidelijk; er worden als regel steeds twee buitengemeentelijke aannemers tot de inschrijving uitgenodigd. Door de geringe omvang van de opdrachten zijn het wel veelal uitsluitend lokale c.q. regionale aannemers die inschrijven. Bij de meeste middelgrote gemeenten is de aanbestedingspolitiek lokaal gericht, met een duidelijke regionale invloed. Het beleid wordt mede bepaald door de behoeften van de lokale economie. De overige motieven spelen nauwelijks een rol

13 Flamme (1986), 180. 
van betekenis. Ook hier valt het relatieve belang van het werkgelegenheidsmotief op. Dit belang neemt toe, zeker in de Hoch- und Zweckbau, naarmate de aanbestedingssom groeit.

Het gebruik van de freihändige Vergabe is beperkt tot opdrachten tot 250.000 DM in de Tiefund Strassenbau. Zeer kleine werken (bijv. onderhoud en dergelijke kleiner dan 20.000 DM) worden in de grote gemeente steeds na een freihändige Vergabe gegund aan de lokale aannemers. Dit geldt ook in geval van dringende spoed. In de Hoch- und Zweckbau werd daarvan in de onderzochte periode geen gebruik gemaakt. Geconstateerd kan worden dat bij de freihändige Vergabe de betrouwbaarheid, de laagste prijs, de deskundigheid van de aannemer en lokale/ regionale werkgelegenheidsoverwegingen doorslaggevende motieven zijn. De vertrouwensrelatie tot de aannemer lijkt ook van belang, terwijl de overig denkbare motieven nauwelijks een rol van betekenis lijken te spelen.

In het algemeen geldt dat geen der geënquêteerde gemeenten gebruik maakt van een onderlinge gunningsvolgorde tussen lokale cq. regionale aannemers.

\section{Conclusie}

De Nederlandse en Belgische aanbestedingspraktijk wordt gekenmerkt door een grondige afkeer van de openbare aanbesteding en een even grote voorkeur voor de enkelvoudige, op enige afstand gevolgd door de onderhandse aanbesteding. Deze praktijk wordt met een beroep op de vertrouwensrelatie met de aannemer in combinatie met het plaatselijke werkgelegenheidsbeleid gerechtvaardigd. Het resultaat van deze aanbestedingspraktijk is, dat in vrijwel alle gevallen het werk aan een lokaal of regionaal aannemersbedrijf wordt gegund, waardoor in de praktijk de lokale c.q. regionale, binnenlandse bouwmarkt volledig is afgeschermd. In Duitsland houden gemeenten zich aan de bepalingen van de VOB. Toch slagen de meeste gemeenten erin om de offentliche Ausschreibung te gebruiken voor een eigen veelal specifiek locaal cq regionaal aanbestedingsbeleid. En ook de beide andere aanbestedingsvormen staan niet in de weg aan een lokaal c.q. regionaal aanbestedingsbeleid.

Kennelijk spelen er op plaatselijk niveau andere factoren een rol bij de gunning dan men op grond van de regelgeving zou verwachten. De nauwelijks gereglementeerde Nederlandse aanbestedingsregelgeving leidt in de praktijk niet tot andere resultaten dan de veel uitvoeriger Belgische en Duitse regelgeving. Het accent op het laagste prijscriterium gekoppeld aan een openbare procedure staat kennelijk niet in de weg aan een gemeentelijke wens om, gegeven de plaatselijke omstandigheden, beleid te ontwikkelen. Dit beleid varieert van het opzettelijk ondoorzichtig maken van de gunningsbeslissing tot een expliciet gemaakt regionaal werkgelegenheidsbeleid.

\section{Zuirerheidstoets motieven}

Nadat de schriftelijke enquêteresultaten waren geëvalueerd, deed zich de vraag voor naar de zuiverheid van de aangereikte motieven. Bepaald diende te worden of, en zo ja, in hoeverre de door de gemeenten genoemde motieven voor de opdrachtverlening werden beïnloed door andere, niet uitgesproken overwegingen. Door middel van interviews met 
de voor de uitvoering van het aanbestedingsbeleid verantwoordelijke ambtenaren zou daarover uitsluitsel moeten worden verkregen. De hierna volgende analyse beperkt zich uitdrukkelijk tot het in het Nederlandse deel van de Euregio aangetroffen praktijk.

Uit de schriftelijke enquête kon reeds de conclusie worden getrokken, dat met name het heroep op de vertrouwensrelatie met de aannemer in combinatie met het werkgelegenheidsbeleid het de gemeenten in de praktijk mogelijk maakten om de lokale c.q. regionale, binnenlandse bouwmarkt af te schermen. De hierboven gestelde vraag naar de zuiverheid van de motieven kan daarom als volgt worden geherformuleerd. Welke (achterliggende) omstandigheden leiden er in de dagelijkse praktijk toe, dat aan het vertrouwens- en werkgelegenheidsmotief zo'n doorslaggevende betekenis toekomt voor de opdrachtverlening?

\section{Het vertrouwensmotief}

Achter de vertrouwensrelatie van de gemeente met de plaatselijke en regionale aannemersbedrijven gaat een hele wereld schuil. Hoe dit vertrouwen vorm krijgt, blijkt in de praktijk afhankelijk van de plaatselijke omstandigheden. Daarbij spelen een rol: de grootte van de gemeente, het aantal plaatselijke aannemers, het aantal jaarlijks te vergeven werken en niet in het minst de plaatselijke politieke en bestuurlijke verhoudingen.

Zoals kon worden verwacht, blijkt uit de enquête dat grotere gemeenten over het algemeen meer werken aanbesteden dan kleinere gemeenten. De GWW-sector is daarbij zowel in aantallen als in guldens veruit de grootste sector. Meestal zijn in de grotere gemeenten ook meerdere aannemersbedrijven gevestigd. De wijze waarop deze getalsmatige verschillen leiden tot plaatselijk verschillend aanbestedingsbeleid is afhankelijk van de op een bepaald moment bestaande politieke en bestuurlijke verhoudingen. De vele contacten tussen het bestuur en de aannemers als ook tussen de technische diensten en de aannemers, kunnen variëren van het louter informeren door de aannemer naar toekomstige opdrachten tot - afhankelijk van de plaatselijke omstandigheden - het uitoefenen van een stevige (politieke) druk via een wethouder of gemeenteraadsleden.

Informele contacten tussen de aannemer en de technische dienst kunnen ertoe leiden dat een aannemer als enige op de voordracht aan Burgemeester en Wethouders c.q. de raad voorkomt. Deze diensten hebben in de regel overigens een voorkeur voor de procedure van de open-begrotingsvergelijking. Zij zien daarin een mogelijkheid om door middel van overleg te komen tot een aanvaardbaar prijsniveau. De dienst heeft dan inzage in de afzonderlijke offertes en kan op basis daarvan met de aannemer onderhandelen over de prijs. Op deze wijze kan ook aan een te zware politieke druk worden ontkomen, doordat de dienst de aannemer dan naar de resultaten van de onderhandelingen kan verwijzen. Vervolgens, soms in overleg met de wethouder, doet de dienst dan een voorstel aan het bestuur. Het komt ook voor dat de politieke besluitvorming in de raad of het college van $\mathrm{B} \& W$ wordt gedomineerd door de ambtelijke diensten. Vanuit de aannemerswereld kan ook (politieke) druk worden uitgeoefend op het bestuur om het plaatselijke aanbestedingencircuit gesloten te houden. De politieke druk kan een enkele keer zo groot worden, dat alleen daarom een (defensieve) aanbestedingsnota wordt geschreven. Door te wijzen op het in de aanbestedingsnota aan de hand van geobjectiveerde criteria, geformaliseerde beleid kan het gemeentebestuur, en in haar gevolg ook de technische dienst, zich dan 
tegen een al te grote politieke druk vanuit de plaatselijke aannemerswereld verdedigen. Naarmate het bestuur gevoeliger is voor deze politieke druk, raakt de betekenis van de (technische) prijsvergelijking verder op de achtergrond. Door deze informele contacten en politieke druk blijken plaatselijke en regionale aannemers in staat om een forse claim te leggen op de door de gemeente aan te besteden werken.

Maar anderzijds kunnen ook gemeenten de marktverhoudingen trachten te beïnvloeden, bijvoorbeeld door de aannemers in onzekerheid te laten over de gemeentelijke plannen. Er wordt dan opzettelijk geen aanbestedingsnota ontwikkeld. Of, wanneer het door de raad gevoteerde budget telkenmale wordt overschreden, door het uitvoeren van zogenaamde 'strafexercities'. Er worden dan niet-regionale aannemers uitgenodigd, waardoor de plaatselijke of regionale bouwwereld gedwongen is voor veel lagere (concurrerende) prijzen in te schrijven. Op deze manier weet de gemeente in de praktijk de prijs te drukken. Uit de gesprekken met ambtenaren bleek overigens dat dit drukmiddel niet steeds afdoende is. $\mathrm{Zij}$ wezen op een geval waarin een niet-regionaal bedrijf uitgenodigd werd om in te schrijven. De plaatselijke aannemers slaagden erin deze buitenstaander uit te kopen en berekenden vervolgens deze kosten door in de aanneemsom. In deze drukmiddelen-categorie lijkt ook het dreigen door de gemeente met het gunnen van de opdracht aan een buitenlandse aannemer te kunnen worden geplaatst.

In een aantal geënquêteerde gemeenten is de verhouding tussen het bestuur en de gevestigde aannemerij in een voor beide marktpartijen aanvaardbare vorm gegoten. Deze verhouding tussen het bestuur en de plaatselijke of regionale aannemersbedrijven kan het best worden gekenschetst in termen van 'een wederzijds staakt het vuren'. Een veelvoorkomende manier waarop de beide marktpartijen de wederzijdse afhankelijkheid proberen te kanaliseren is het toerbeurtsysteem. In dit systeem hanteert de gemeente een vooraf bekende volgorde waarop de aannemers voor een werk in aanmerking komen. Voor de verdeling van het werk kunnen per gemeente weer verschillende grondslagen bestaan, zoals de grootte van het werk en de eerdere ervaring met soortgelijk werk. Soms wordt dit systeem aangevuld met een puntensysteem. Het kan ook voorkomen dat het toerbeurtsysteem alleen wordt geactiveerd voor het geval dat een aannemer tijdelijk zonder werk zit. Eveneens afhankelijk van de plaatselijke verhoudingen kunnen ook de aannemers zelf zorgdragen voor een werkverdeling. Het (ad hoc) aanbestedingsbeleid wordt dan als het ware door de aannemers zelf ter hand genomen. Elke aannemer wordt op die manier regelmatig van werk voorzien. Het gevolg van deze werkverdeling is plaatselijk protectionisme, die zowel zijdens de gemeenten als zijdens de aannemers wordt uitgelokt en in stand gehouden.

Het wordt als voordeel van dit toerbeurtsysteem gezien, dat de gemeente ruimte krijgt voor een eigen (werkgelegenheids)beleid en de aannemers duidelijkheid hebben omtrent het gunningsbeleid. Dit toerbeurtsysteem heeft echter als belangrijk nadeel dat er nauwelijks enige prikkel tot innovatie van uitgaat. De prijs is in de praktijk vrijwel steeds gelijk aan het door de raad gebudgetteerde bedrag. Het prijsmotief speelt geen noemenswaardige rol in het uitlokken van concurrentie, hetgeen een verklaring kan vormen voor de geringe betekenis die blijkens de enquête aan het prijs- en concurrentiemotief wordt gehecht. Eventuele prijsopzetten worden door de gemeente voor lief genomen, in ruil voor de vertrouwensrelatie met de aannemer. De aannemer dient dit vertrouwen waar te maken 
door een beperkte directietaak zijdens de gemeente mogelijk te maken, en door een goede nazorg te bieden. Hij dient met andere woorden betrouwbaar te zijn. Strafexercities moeten een excessieve prijsvorming voorkomen. Bij de wat grotere werken kan nog de deskundigheid van de aannemer van belang zijn.

\section{Werkgelegenheidsmotief}

De sterk lokaal georiênteerde aanbestedingspraktijk wordt jegens het hogere bestuur gerechtvaardigd met een beroep op de zorgelijke gemeentelijke werkgelegenheidssituatie. Aangezien het Rijk niet over adequate toezichtsinstrumenten beschikt, is de gemeente in de praktijk gevrijwaard van rijksinmenging in de plaatselijke autonomie.

Voor de verdeling van de subsidiegelden, zoals het PNL-fonds (op basis van de Perspectieven Nota Limburg), wordt het provinciebestuur ingeschakeld. Het provinciale bestuur blijkt in de praktijk echter nauwelijks enige druk op de gemeentebesturen uit te oefenen om de bestaande gemeentelijke aanbestedingspraktijk los te laten. Wanneer (PNL)subsidies worden verleend, slagen gemeenten er in het algemeen in om tijdens gesprekken met de subsidiënt af te geraken van de eis van het houden van een openbare aanbesteding. Gemeenten weten in de regel vast te houden aan het eigen aanbestedingsbeleid. Het resultaat van dergelijk overleg is, dat er bij voorbeeld één regionale aannemer extra tot de inschrijving wordt toegelaten. De strijd om de subsidie tussen de gemeenten onderling wakkert het lokale protectionisme nog verder aan. Als een gemeente er al in slaagt om subsidiegelden binnen te halen, is de gemeente er alles aan gelegen om dit bedrag binnen de eigen gemeentegrenzen te investeren. Ook de plaatselijke bouwbedrijven oefenen druk uit om het werk 'binnenshuis' aan te besteden. Bovendien, zo wordt gesteld, is het gunnen van het werk aan een aannemer buiten de gemeente ook vanuit een electoraal standpunt niet opportuun. Ten slotte wordt er door de gemeenten op gewezen, dat, gegeven de structurele werkloosheid, met name in de bouw, het beslag van de RWWuitkeringen op de gemeentebegroting een rol speelt bij het lokaal aanbesteden van de werken. De gemeente moet ongeveer $10 \%$ van de RWW-kosten zelf dragen; de rest wordt door het Rijk aangevuld.

\section{Conclusie: een afschermingsspiraal}

De hierboven beschreven praktijk komt er, voor wat betreft de onderzochte periode, op neer dat de lokale en regionale bouwmarkt zoveel mogelijk wordt afgeschermd. De voornamelijk enkelvoudige aanbestedingspraktijk komt tot stand onder (politieke) druk van de lokale en regionale bouwwereld, daamaast doordat andere gemeenten ook hun markt gesloten houden en ten slotte als gevolg van electorale overwegingen. Deze praktijk wordt gerechtvaardigd met een beroep op de vertrouwensrelatie en het gemeentelijk werkgelegenheidsbelang. Door het voeren van een gemeentelijk werkgelegenheidsbeleid kan het hogere toezicht op afstand worden gehouden, zodat op lokaal niveau de handen vrij kunnen zijn om toekomstige investeringen binnen de eigen gemeentegrenzen te houden. Het vertrouwensmotief dekt de plaatselijke praktijk van druk en tegendruk tussen het gemeentebestuur, de technische dienst en de bouwwereld af, waardoor een vreedzame coëxistentie mogelijk wordt. Deze vreedzame coëxistentie is bovendien vanuit electoraal standpunt voor beide partijen van belang. Het continueren van de politieke macht vormt een voorwaarde voor het voortduren van de bestaande communicatiekanalen. 
De afscherming dient aldus het belang van de beide marktpartijen. Door deze onderlinge afscherming tussen gemeenten is het, in de onderzochte periode, voor binnenlandse bouwbedrijven nauwelijks mogelijk zich op een andere lokale bouwmarkt te manifesteren. Dit lokale protectionisme heeft dan weer tot gevolg dat de ene lokale protectie de andere protectie uitlokt. Er ontstaat daardoor binnen de regio een afschermings-spiraal, die in stand wordt gehouden door de enkelvoudige aanbesteding.

\section{Europese dimensie}

In deze paragraaf staat met name de wisselwerking tussen het gemeentelijk overheidsopdrachtenbeleid van de drie lidstaten centraal. Nagegaan wordt in hoeverre er van een (lands)grensoverschrijdend beleid sprake is.

\section{Contacten met buitenlandse bouwbedrijven}

NEDERLAND. Contacten met buitenlandse aannemers behoren in de praktijk, zo blijkt uit de enquête, tot de uitzonderingen. Als Belgische of Duitse aannemersbedrijven toch inschrijven, komt dit doordat het niet te vermijden valt, bijvoorbeeld als gevolg van een subsidievoorwaarde. In een enkel geval kan het specialistische karakter van het werk de gemeente noodzaken de landsgrens over te steken, als er in de eigen gemeente of regio geen voldoende deskundigheid voorhanden is. Dit kan de regionale bouwbedrijven ertoe aanzetten zich deze specifieke deskundigheid eigen te maken. Als zij daarin slagen, dan genieten zij ook een duidelijke voorkeur boven de buitenlandse aannemersbedrijven. Een andere reden om grensoverschrijdend aan te besteden, kan zijn gelegen in een (tijdelijk) regionaal capaciteitstekort. Opvallend is echter dat in de onderzochte periode geen enkele opdrachtverlening aan een buitenlands bouwbedrijf plaatsvond. Dit zou kunnen betekenen dat de plaatselijke bedrijven kennelijk steeds over de vereiste deskundigheid beschikken. Het open houden van de mogelijkheid om een buitenlandse aannemer in te schakelen kan dan zijdens de gemeente een drukmiddel zijn om de plaatselijke aannemers tot innovatie of prijsbeheersing aan te zetten.

Er worden in de praktijk ook wel eens werken gesplitst om daardoor onder de Europese drempel te blijven, zodat de Europese richtlijnen niet van toepassing zijn. Het komt verder voor dat bewust publikaties worden achterwege blijven. Daarbij wordt aangetekend dat het aantal aanbestedingen boven de Europese drempelwaarde op gemeentelijk niveau erg klein is, zodat het aantal ontduikingen vrij beperkt zal zijn.

BELGIË. Publikatie van projecten op Europees niveau komt nauwelijks voor, kennelijk, omdat omvangrijke projecten op gemeentelijk niveau uitzonderlijk zijn. Kleinere opdrachten behoeven niet te worden gepubliceerd en dit gebeurt dan ook niet. Bij hoge uitzondering meldt zich een buitenlandse aannemer voor de uitvoering van een opdracht; deze bedrijven zijn dan meestal in België gevestigd. Er is in de geënquêteerde gemeenten echter nog nooit een opdracht aan een buitenlandse aannemer gegund. Toch wordt zulks niet geheel uitgesloten: als het om zeer gespecialiseerd werk gaat waarvoor in België de deskundigheid ontbreekt. Noemenswaard is dat ook de taalgrens in België als zodanig een barrière vormt voor de gunning van opdrachten in het andere landsdeel. Opmerkelijk is 
verder dat in één gemeente, die na de oorlog gedeeltelijk in België en gedeeltelijk in Duitsland kwam te liggen, geen grensoverschrijdend gunningsbeleid wordt gevoerd. Enkele geënquêteerde gemeenten deinzen er evenmin voor terug om een werk in stukken te splitsten om daardoor niet op Europees niveau te hoeven publiceren.

Tot slot dient te worden vermeld dat ook de erkenningsregeling vertragend werkt. Deze erkenning houdt in de vaststelling van een vermoeden dat een aannemer financieel en technisch in staat is overheidsopdrachten van een bepaalde aard en omvang uit te voeren. Voor de erkenning bestaat een uitgebreide procedure, waaraan ook buitenlandse aannemers zich moeten onderwerpen, voordat zij kunnen deelnemen. Buitenlandse bedrijven die inschrijven zijn om die reden dan ook vaak in België gevestigd.

DUITSLAND. De publikatie wordt in de regel bekendgemaakt in de eigen gemeente en het Kreisgebiet. Het gaat hier dus om lokale of regionale bekendmaking. Dit geldt voor alle aanbestedingen tot één miljoen ECU (destijds de 'Europese drempelwaarde', vergelijk artikel 7, lid 1, sub a richtlijn 71/305). Aanbestedingen worden vrijwel nooit in het aangrenzende buitenland bekend gemaakt. $\mathrm{Er}$ is ook nauwelijks sprake van inschrijving door buitenlandse aannemers. Toch komt het een enkele keer voor dat een buitenlandse aannemer inschrijft. Het gaat dan met name om zeer specialistische werken. In een gemeente waar hiervan sprake was, werd in $\pm 2 \%$ van de gevallen de opdracht aan een buitenlandse aannemer gegund. Gunning aan een buitenlandse aannemer behoort ook in Duitsland tot de hoge uitzonderingen. Europese aanbestedingen komen niet of nauwelijks voor. Indien er op Europees niveau wordt gepubliceerd, dan schrijven er ook buitenlandse aannemers in. Of in het verleden in die gevallen ook aan deze buitenlandse aannemers werd gegund blijft onduidelijk. Verwezen wordt dan naar het formele prijscriterium uit de VOB/A: buitenlandse aannemers hebben in de regel minder 'preisgünstige' offertes.

\section{Conclusie}

De op binnenlands-regionaal niveau reeds bestaande afschermingsspiraal krijgt er op het Europese toneel nog een dimensie bij. Door de geringe toegankelijkheid van de verschillende $(\mathrm{Eu})$ regionale markten wordt het protectionisme aan de landsgrenzen aangewakkerd, waardoor dit praktisch niet is te doorbreken.

De gedachte aan een Europees aanbestedingsbeleid leeft niet op gemeentelijk niveau. Zonder dat er steeds sprake is van het opzettelijk ontduiken van de Europese regelgeving of pure onwil, heeft het gemeentebestuur andere prioriteiten. Met de Europese aanbestedingsrichtlijn wordt het dan niet altijd nauw genomen. Ook in de schaarse gevallen dat er wel conform de richtlijn wordt aanbesteed, komt het niet voor dat er aan een buitenlandse aannemer wordt gegund. De selectie speelt zich dan noodgedwongen op het Europese toneel af, maar de binnengemeentelijke verhoudingen en belangen verhinderen een extraregionale gunning. Europees aanbesteden lijkt voornamelijk een pressiemiddel voor de beïnloeding van binnenlandse marktverhoudingen. 


\section{Samenvatting}

\section{Gemeentelijke aanbestedingsbevoegdheid}

Van een overheidsaanbesteding is sprake als een aanbesteder een al dan niet beperkte kring van aannemers uitnodigt tot het doen van een aanbod. De grondslag voor het door de gemeente te voeren aanbestedingsbeleid is gelegen in de Gemeentewet. Deze wet kent, anders dan de oude gemeentewet, geen bijzondere bepalingen over het aanbesteden van werken. Meer in het algemeen geldt dat het gemeentebestuur bevoegd is tot de regeling en bestuur van de huishouding van de gemeente (artikel 108 Gemeentewet).

Historisch onderzoek leert dat de gemeentewetgever in 1851 de bevoegdheden ter zake van de aanbesteding van werken strikt had willen scheiden. De raad was bevoegd tot de keuze tussen de openbare en onderhandse aanbesteding. Burgemeester en Wethouders waren belast met de feitelijke aanbesteding en de gunning. En ook tussen de openbare en onderhandse aanbesteding bestond oorspronkelijk een scherpe scheiding. Alleen de onderhandse aanbesteding stond onder het preventieve toezicht van Gedeputeerde Staten. Deze aanbestedingsregelgeving had de bedoeling het gildesysteem te doorbreken en de (binnenlandse) markt open te stellen. Inmiddels is er van deze strikte scheidingen niets meer over. Er bleken in de praktijk niet alleen veel verschillende opvattingen te bestaan over wat een openbare - danwel onderhandse aanbesteding was, maar er was er ook steeds minder sprake van een duidelijke scheiding van bevoegdheden. Decentralisatie leidde er in 1966 toe dat het preventieve toezicht op de onderhandse aanbesteding werd afgeschaft. Het werd aan het plaatselijk beleid overgelaten of er openbaar dan wel onderhands zou worden aanbesteed. Het uitgangspunt van de openbare aanbesteding dat dan nog onverkort in de gemeentewet staat, is dan praktisch al een dode letter. En daarmee was de facto de keuze van de aannemer afhankelijk van de 'plaatselijke omstandigheden' (behoudens de mogelijkheid tot (achteraf) repressief toezicht door de Kroon). De wetgever motiveerde deze vergaande decentralisatie met een beroep op de EEG-aanbestedingsregelgeving, waardoor de aanbesteding vaak in het openbaar zou worden aangekondigd.

\section{De Europese dimensie}

Het aanbesteden van (bouw)werken door de overheid is al lang niet meer een zaak van louter nationale aard. Het terrein van de overheidsaanbesteding vormt een speerpunt in de (verdere) ontwikkeling van de Europese (interne) markt. Daartoe zijn al in de jaren zeventig een aantal richtlijnen ontwikkeld. De liberalisatierichtijn (71/304) beoogt de verdere openstelling van de bouwmarkt, door het verbod van non-discriminatie naar nationaliteit. De coördinatierichtlijn (93/37) beoogt de afstemming van het aanbestedingsbeleid der lidstaten, voorzover dat is gericht op de optimalisering van de verhouding tussen prijs en kwaliteit. Het middel daartoe vormt de harmonisatie van de nationale aanbestedingsprocedures. Voor de keuze van een aanbestedingsprocedure is het nationale recht bepalend. Centraal staat de verbetering van de informatievoorziening, waardoor de bouwmarkt aan transparantie wint in het belang van de aannemers. Tot het midden van de jaren tachtig had de coördinatierichtlijn nauwelijks praktische betekenis. Gedwongen door de economische omstandigheden werd het openstellen van de nationale markten opportuun. Dit leidde tot een aanscherping en een uitbreiding van de werkingssfeer van de richtlijnbepalingen. Sinds 1989 is het Europese richtlijnenarsenaal verrijkt met een rechtsmiddelenrichtlijn, die voorziet in een procedure waardoor op de inachtneming van 
de bepaalde in de coördinatierichtlijn gemeenschappelijk toezicht kan worden uitgeoefend.

\section{De nationale aanbestedingsireglementering}

De wijze waarop gegađigden worden geselecteerd en aan het werk vervolgens aan één der inschrijvers wordt gegund is op het nationale niveau geregeld in een tweetal Uniforme aanbestedingsreglementen (UAR). Het UAR 1986 dat het UAR 1972 vervangt, beoogt een bijdrage te leveren aan een betere marktordening. De machtsverhoudingen op de bouwmarkt kunnen er namelijk gemakkelijk toe leiden dat aannemers tegen elkaar worden uitgespeeld ('leuren'). Iedere aannemer moet gelijke kansen worden geboden op inschrijving. Door het verstrekken van duidelijke informatie moet de aannemer in staat worden gesteld te beoordelen of hij voor het werk zal inschrijven. Het UAR 1986 regelt de verschillende aanbestedingsprocedures voor werken onder 5 miljoen Ecu, de zogenaamde 'Europese drempel'. Daarboven is het speciaal voor Europese aanbesteding ontwikkelde UAR-EG 1991 toepasselijk, waarvan inhoud en systematiek zoveel mogelijk gelijk zijn aan het UAR 1986, zij het dat daarin de aanpassingen die voortvloeien uit de gewijzigde coördinatierichtlijn zijn verwerkt. Hoewel zij daartoe niet zijn verplicht, maken gemeenten in de praktijk vrijwel altijd gebruik van deze aanbestedingsreglementen.

\section{Werkhypothese}

Evenals de Europese richtlijnen gaan de aanbestedingsreglementen uit van de openbare aanbesteding(sprocedure). De vraag is wat de betekenis daarvan is, zolang de formele wetgever nalaat expliciet aan te geven 'hoe' er moet worden aanbesteed en de gemeente de vrijheid wordt gelaten om een andere aanbestedingsprocedure te kiezen. Met het wegvallen van de preventieve toetsing op de onderhandse aanbesteding in 1966 lijkt het erop dat gemeenten voortaan zelf uitsluitend aan het financiële belang dat met de opdracht is gemoeid, zouden moeten toetsen en dus bij voorkeur openbaar zouden moeten aanbesteden. Daarmee ontbreekt echter de grond voor toetsing aan andere beleidsuitgangspunten, hoewel die in de praktijk wel degelijk een grote rol spelen. De decentralisatie in 1966 maakte met andere woorden de weg vrij voor een soortgelijk beleidsinstrumenteel gebruik van het privaatrecht als waarvan bij voorbeeld ook bij de gronduitgiftevoorwaarden sprake is. Gemeenten kunnen zo vrijelijk gebruik maken van die UAR-procedure die hun - als marktpartij - het beste uitkomt. Sommige schrijvers erkennen echter dat bij de aanbesteding van werken problemen kunnen ontstaan in verband met het beginsel van de rechtsgelijkheid, dat speciaal de overheid bij de opdrachtverlening in acht zou moeten nemen. Dit leidt tot de werkhypothese, dat er kennelijk behoefte is aan 'zoiets als een aanbestedingsbeleid', waarbij de gemeente een zekere ordening aanbrengt in het scala van beleidsuitgangspunten ter gelegenheid van een aanbesteding. Een dergelijk beleid bestaat in de afweging tussen de mogelijk bij de opdrachtverlening te betrekken beleidsuitgangspunten, met als sequeel de keuze van een bepaalde aanbestedingsprocedure. Met deze werkhypothese hangt de volgende probleemstelling samen: welke eisen moeten worden gesteld aan een gemeentelijk aanbestedingsbeleid?

\section{Eisen aan de beleidsuitgangspunten}

De regeling van het belang van een financiële doelmatige aanbesteding staat centraal in de nationale aanbestedingsreglementen en de Europese coördinatierichtlijn. In het vierde hoofdstuk wordt onderzocht welke eisen de nationale en Europese aanbestedingsregelge- 
ving stellen aan de selectie- en gunningscriteria. Een tweede kwestie die met name aandacht verdient is of er, ter gelegenheid van de opdrachtverlening, ook ruimte is voor andere beleidsuitgangspunten. Voor dit laatste zou gedacht kunnen worden aan het lokale werkgelegenheidsbeleid. Mag een dergelijke overweging worden meegewogen in de uiteindelijke opdrachtverlening?

a. Op het nationale niveau. Anders dan in het UAR 1972 zijn in het UAR 1986 de selectie- en gunningscriteria verregaand geobjectiveerd, waardoor de doorzichtigheid van de procedures kon worden verbeterd. Door de objectivering van de selectie- en gunningscriteria moest worden bereikt dat beoordelingsvrijheid van de aanbesteder werd gerelateerd aan de in het bestek of in de bekendmaking vermelde eisen en criteria. Deze objectivering is overigens beperkt tot de openbare aanbesteding en de aanbesteding met voorafgaande selectie. Bovendien introduceert het UAR 1986 de Raad van Arbitrage voor de Bouwbedrijven als geschillenbeslechter op het gebied van de (overheids)aanbesteding.

Naast de algemene maatschappelijke geschiktheidseisen (zoals het bezit van een vestigingsvergunning), kan de aanbesteder het bewijs vragen van de financiële, economische en technische capaciteit van de aannemer. De eisen moeten objectief en eenduidig zijn, alsmede in redelijke verhouding staan tot het werk (evenredigheidsbeginsel). De eisen van objectiviteit en eenduidigheid beogen de transparantie van de bouwmarkt te vergroten en de concurrentie te beperken tot min of meer gelijkwaardige bedrijven. Ten dele dienen zij het belang van de inschrijver: deze moet kunnen beoordelen of zijn onderneming voor gunning in aanmerking komt. Anderzijds moet het ontwerpen van een profielschets, waaraan de inschrijver moet voldoen, worden overgelaten aan het beleid van de aanbesteder. Arbiters toetsen de voorwaarden die aan de geschiktheidseisen worden gesteld daarom terecht marginaal. Het evenredigheidsbeginsel beoogt de bevordering van een gezonde concurrentie door het aantal aspirant-inschrijvers tot min of meer gelijkwaardige bedrijven te beperken. Het gaat hier om het marktbeleid van de aanbesteder. Ook daarbij past een wat terughoudender arbitrale toetsing.

De gunningscriteria betreffen de aan het werk te stellen eisen. In beginsel geldt het criterium van de laagste prijs. Maar er kunnen ook andere gunningscriteria worden gehanteerd.

Of de aannemer voor gunning in aanmerking komt is van twee vragen afhankelijk. Ten eerste dient hij aan de bekendgemaakte geschiktheidseisen te voldoen, en verder moet hij redelijkerwijs in staat worden geacht het werk vakkundig en op regelmatige wijze uit te voeren. Met name deze tweede toets bedreigt de objectiviteit. Bovendien hoeft de aanbesteder na een aanbesteding na selectie niet alle gegadigden, die voldoen aan de gestelde geschiktheidseisen, de kans te geven om in te schrijven. Dit staat bekend als 'het zwarte gat': het moment waarop de aanbesteder een nagenoeg onbeperkte en oncontroleerbare discretionaire bevoegdheid kan uitoefenen. De vraag of een inschrijver voldoet aan de gestelde geschiktheidseisen, dient 'vol' te worden getoetst met een zeker respect voor de beleidsvrijheid van de aanbesteder. Het gaat erom, of de inschrijver in beginsel in aanmerking komt voor gunning, waarbij de beleidsvrijheid van de aanbesteder klein moet worden geacht. Pas als de inschrijver aan de volledige profielschets voldoet, komt hij 
voor de opdracht in aanmerking. Hoewel de aanbesteder niet kan worden verplicht om het werk op te dragen, moet in enkele gevallen een gunningsplicht worden aangenomen.

Naast de objectivering van de criteria introduceerde het UAR 1986 een bescheiden motiveringsplicht: de aanbesteder moet achteraf begrijpelijk maken waarom de gegadigde niet tot de inschrijving is toegelaten c.q. waarom het werk hem niet is opgedragen. Het UAR-EG 1991 trekt de in het UAR 1986 uitgezette lijnen door. Het 'zwarte gat' lijkt geëlimineerd, doordat een andere systematiek is gekozen. En bovendien zijn er motiveringsplichten bij gekomen; ook voor de aannemer.

b. Op het Europese niveau. Het op het nationale niveau gevoerde prijs/ kwaliteitsbeleid wordt op Europees niveau gecoördineerd. De coördinatierichtlijn onderscheidt tussen algemene geschiktheidseisen, selectie-eisen (dat wil zeggen: bijzondere geschiktheidseisen) en gunningscriteria. Voor de vaststelling van de algemene geschiktheid noemt de richtlijn een aantal inhoudelijke criteria. Voor de specifieke capaciteiten geeft de richtlijn referenties en geschiktheidscriteria. Deze criteria houden verband met economische en financiële draagkracht en technische bekwaamheid. De publikatievoorschriften hebben betrekking op de te verlangen referenties. Door de aanbesteder te verplichten voorafgaand aan de aanbestedingsprocedure de deelnemingscriteria bekend te maken wordt de transparantie van de bouwmarkt bevorderd. Hetgeen nog wordt versterkt door de in de gewijzigde richtlijn opgenomen wederzijdse motiveringsplichten. De inhoud van de selectie-eisen wordt bepaald op basis van het nationale recht: het UAR.

De overheid heeft bij de gunning op basis van de economisch voordeligste aanbieding een discretionaire beslissingsruimte, zij het dat de gunningscriteria objectief en strikt relevant moeten zijn met betrekking tot het werk en uniform van toepassing voor alle aannemers ongeacht hun nationaliteit. Uit 's Hofs jurisprudentie komt naar voren, dat de bepalingen inzake de deelneming tot doel hebhen te voorkomen dat de gegadigden zijn overgeleverd aan de willekeur van de aanbesteder.

Met de gewijzigde richtlijn wordt op communautair niveau het motiveringsbeginsel geintroduceerd in de relatie tussen aanbesteder en gegadigden c.q. inschrijvers: de aanbesteder zal meer dan voorheen zijn handelen moeten motiveren.

Het Hof en de Europese Commissie achten het verder mogelijk dat er naast de eisen en criteria in de richtlijn nog aanvullende voorwaarden worden geformuleerd, die een rol kunnen spelen bij het verlenen van de opdracht. Selectie-eisen en gunningscriteria moeten principieel worden onderscheiden van deze 'aanvullende voorwaarden': deze voorwaarden mogen niet gaan fungeren als verkapte selectie- of gunningscriteria. Onderzocht is aan welke eisen de eventuele 'andere' beleidsuitgangspunten (de zogeheten 'aanvullende voorwaarden') zouden moeten voldoen. Een 'aanvullende voorwaarde' kan gerechtvaardigd worden door 'dwingende eisen van algemeen belang' (wanneer er althans geen harmonisatiemaatregelen bestaan). Het Hof laat de lidstaten wat betreft de keuze van beschermenswaardige belangen een ruime beleidsmarge. Dat de beperking gerechtvaardigd moet zijn veronderstelt dat de 'aanvullende voorwaarde' evenredig moet zijn aan de te bereiken doelstelling (het beschermenswaardige belang). De evenredigheidstoets loopt over drie sporen: de geschiktheidseis, de noodzakelijkheidseis en de proportionaliteitseis. Blijkens de aangehaalde jurisprudentie toetst het Hof met name aan de twee eerste eisen. 
Dat maatregelen evenredig moeten zijn betekent, dat zij objectief noodzakelijk moeten zijn.

Wat de publikatie betreft, heeft het Hof overwogen, dat bij een aanvullende voorwaarde alle procedurevoorschriften van de richtlijn moeten worden nageleefd. Dat betekent dat een dergelijke uitsluitingsgrond in de aankondiging van de opdracht moet worden vermeld, opdat de aannemers van het bestaan ervan kennis kunnen nemen.

\section{Grondslagen van aanbestedingsbeleid}

Wanneer eenmaal de marges zijn verkend waarbinnen de gemeente beleidsuitgangspunten kan formuleren, rest nog de vraag naar de grondslagen van aanbestedingsbeleid. Aan welke eisen dient het aanbestedingsbeleid te voldoen? Bepleit wordt om de huidige privaatrechtelijke benadering te vervangen door een bestuursrechtelijke. In weerwil van de gedachte dat iedereen gelijke kansen zou moeten hebben op inschrijving, doet zich feitelijk een instrumentele aanbestedingspraktijk voor, die op geen enkele wijze waarborgen schept voor een correcte belangenafweging. Uitgangspunt voor het normatieve beleidskader moet naar mijn oordeel zijn dat de overheid op elk moment onderworpen is aan bestuursrechtelijke grondslagen. Daarbij gaat het met name om de vraag of een bepaald overheidsoptreden publiekrechtelijk toelaatbaar is. Dit primaat van het bestuursrecht dient naar mijn mening het primaat van de openbare aanbesteding te vervangen. In het bijzonder is er geen sprake van contractsvrijheid aan de zijde van de overheid. In plaats van contractsvrijheid is sprake van een nader te normeren beleidsvrijheid: de plicht tot het afwegen van belangen. En deze afwegingen dienen plaats te vinden op basis van een geobjectiveerd, rationeel besluitvormingsmodel.

De eisen die aan het aanbestedingsbeleid moeten worden gesteld, zijn de eisen die ten grondslag liggen aan de bevoegdheid tot aanbesteden. Het gaat dan om een viertal beginselen: het gelijkheidsbeginsel, het openbaarheidsbeginsel, het motiveringsbeginsel en het beginsel van een (financieel-)doelmatige aanbesteding. Deze eisen zijn te beschouwen als de nadere uitwerking van de algemene bestuursrechtelijke grondslagen: rechtsstaat, demokratie en technische rationaliteit. Meer in het bijzonder zijn deze beginselen te beschouwen als structuurbeginselen: rechtsbeginselen, die eisen stellen aan de inhoud van het aanbestedingsbeleid. Het zijn beginselen die als zodanig ten grondslag liggen aan de besluitvorming inzake de aanbesteding van werken, onafhankelijk van de vraag of de diverse beslissingen ook externe publiekrechtelijke rechtsgevolgen hebben.

Het gelijkheidsbeginsel stipuleert de eis van beleid. Het is wenselijk dat er vaste beleidslijnen worden ontwikkeld. Soms treedt naast het gelijkheidsbeginsel nog het vertrouwensbeginsel op, namelijk wanneer aannemers bepaalde verwachtingen mogen ontlenen aan het tot dan toe gevoerde overheidsbeleid, waarbij ook valt te denken aan het effect van beleidsregels (zoals het UAR). Van de eis van beleid zou weinig overblijven wanneer het beleid niet tevens openbaar zou zijn. Openbaar aanbestedingsbeleid betekent dan dat het besluitvormingsproces rondom de aanbesteding van werken steeds in de volle openbaarheid moet plaatsvinden. Het veronderstelt tevens dat het beleid in een schriftelijk stuk (beleidsnota) wordt neergelegd. Aan deze beleidsnota kunnen de volgende vier functies worden toegedacht: een politieke beleidsfunktie, een politieke controlefunktie, een coördinatiefunktie en een funktie als referentiekader in beroepszaken. Het uitgangspunt 
van de openbaarheid van de besluitvorming rond de aanbesteding leidt er toe dat onderhandse (d.w.z. niet in het openbaar bekend gemaakte) aanbestedingen tot de zeldzame uitzonderingen behoren. Het motiveringsbeginsel heeft betrekking op de (rationele) argumentatie die ten grondslag liggen aan de blijkens het beleid gemaakte keuzes, en hangt ten nauwste samen met de 'eis van beleid'. Naast deze rechtmatigheidseisen staat het bestuurspostulaat: er moet bestuurd worden (het doelmatigheidsbeginsel).

Het bestuursrechtelijke primaat betekent dat de besluitvorming in het kader van de UARaanbestedingsprocedure zich afspeelt binnen een overigens volledig bestuursrechtelijk besluitvormingsproces. De aan het aanbestedingsbeleid te stellen bestuursrechtelijke eisen vormen als het ware een besluitvormingsparaplu boven de (beperktere) besluitvorming in het kader van het UAR. De bestuursrechtelijke eisen gelden ook tijdens de UAR-aanbestedingsprocedure. De grondslag voor het bestuurlijke besluitvormingproces moet worden gezocht in de aanbestedingsbevoegdheid van de gemeenten. De besluitvorming in het kader van de UAR-aanbestedingsprocedure vindt plaats op basis van de aanbestedingsovereenkomst; een wederkerig element in de gemeentelijke besluitvorming. Waar het accent bij de aanbesteding(sovereenkomst) zozeer ligt op het besluitvormingsaspect voorafgaand aan het sluiten van het aannemingscontract, zou ik willen verdedigen dat de aanbestedingsovereenkomst het best ware te typeren als een publiekrechtelijke overeenkomst: een middel in het kader van de besluitvorming (evenals voorbereidende besluiten, procedurele beslissingen) dat - gelet op de noodzakelijke wederkerigheid - in een aan het Burgerlijk Wetboek ontleende vorm wordt gegoten. Zo bezien zijn de beginselen die aan het UAR ten grondslag liggen 'slechts' de aanbestedingsprocedurele pendanten (species) van de overigens bestuursrechtelijke structuurbeginselen van aanbestedingsbeleid.

Passend bij deze bestuursrechtelijke benadering bepleit ik een systeem waarbij alle geschillen betreffende de aanbesteding van overheidscontracten, ongeacht de aard van de handeling of het nagestreefde rechtsherstel, door dezelfde administratieve rechter zouden worden beoordeeld. Bovendien zou de administratieve rechter zich dan niet moeten beperken tot de vraag of het individuele belang niet te zeer geraakt wordt in verhouding tot het te dienen algemene belang (proportionaliteit). Hij zou moeten overgaan tot een objectieve noodzakelijkheidstoetsing. Dat zou een verschuiving betekenen van de concrete besluitvorming naar de fase van de beleidsvorming/- bepaling. Het komt mij voor dat een dergelijke beleidsfasetoetsing geschikt (en gewenst) is voor de rechtmatigheidstoetsing van de besluitvorming ter zake van de aanbesteding van werken. Het gaat er niet slechts om of het individuele belang niet te zeer geraakt wordt in verhouding tot het te dienen algemene belang (proportionaliteit), maar met name ook of de gemeente terecht bepaalde criteria en (aanvullende) voorwaarden stelt. Laat men het formuleren van die criteria en voorwaarden over aan de beleidsvrijheid van de gemeente, zonder dat de geschiktheid of de noodzakelijkheid van een maatregel is komen vast te staan, dan zal proportionaliteitstoetsing weinig meer kunnen uitrichten. Door de toetsing van de geschiktheid en noodzakelijkheid van de criteria en aanvullende voorwaarden wordt de beleidsvrijheid zelf voorwerp van een administratiefrechtelijke rechtmatigheidstoets.

Het onderzoek eindigt met een pleidooi voor een Wet op de overheidsopdrachten, die verder gaat dan het uitsluitend regelen van aanbestedingsprocedurele kwesties. Aansluiting 
bij de Algemene wet bestuursrecht zou kunnen worden bereikt door aanpassing van artikel 8:3 Awb. Aan het slot van deze bepaling zou moeten toegevoegd: 'behoudens de in de wet (=in formele zin) geregelde gevallen'. Daarmee wordt bereikt dat de wetgever kan bepalen welk(e) overheidscontract(en) voor afzonderlijke regeling in aanmerking komen. 



\section{Powers of local authorities to put out work to tender}

It is possible to speak of public procurement if a local authority offering work to tender invites a restricted or unrestricted number of contractors to tender an offer. The basis of the policy to be conducted by the local authority regarding the putting of work out to tender is laid down in the Local Authority Act (Gemeentewet). In contrast to the former Local Authority Act, this new act does not contain any provision regulating the putting of work out to tender. In general the rule applies that the local authority executive is empowered to provide for and administer the running of the local community (Article 108 Local Authority Act).

Historical research shows that the legislator of the Local Authority Act 1851 wanted to keep a strict separation of the powers regarding the putting of work out to tender. The council was empowered to make a choice between the open and the restricted form of putting out work to tender. The mayor and aldermen were charged with actually putting the work out to tender and with the allocation of the contract. Furthermore, there was originally a sharp distinction between the open and restricted procurement procedures. Only the restricted tender procedure was subject to the preventative supervision of the Provincial Executive. These legislative provisions on public procurement purported to break through the guild system and to secure openness of the (domestic) market. These days nothing remains of these strict separations. It appeared that, in practice, not only were there many differences of opinion as to when putting work out to tender was open or restricted, but there was, moreover, less and less talk of a clear separation of powers. Decentralisation led in 1966 to the abolition of the preventative supervision of the restricted procurement procedure. It was left up to local policy to determine whether work was put out by open or restricted form. The assumption, then still expressed in the Local Authority Act, that work is, in principle, to be put out by the open form, is thus in practice a dead letter. Accordingly, (apart from the possibility of repressive supervision (after the event) by the Crown), the choice of contractor depended upon "local conditions'. The legislator explained this far-reaching decentralisation by reference to the EEC legislation on public procurement, according to which the putting of work out to tender is often announced in public.

\section{The European dimension}

The putting out to tender of (construction) work by the government is not an exclusively domestic matter. The field of public procurement forms a spearhead in the (further) development of the European (internal) market. Already in the 1970s a number of directives were developed to this end. The Liberalisation Directive (71/304) strives, through the prohibition of discrimination according to nationality, for further opening up of the construction market. The Coordination Directive (93/37) tries to secure, insofar as is conducive to optimisation of the relationship between price and quality, that the policies in the various Member States regarding public procurement are geared up to one another. The mechanism for pursuing this goal is the harmonisation of the national procurement procedures. Domestic law determines the procedure for putting work out to tender. The central concern is the improvement of the flow of information, by which, in the interests of potential contractors, the construction market gains transparency. Until mid-way in the 1980 s the Coordination Directive had almost no practical significance. Under pressure of economic circumstances, the advantages of opening up the national markets became apparent. This led to a refinenent of definition and 
extending of the field of operation of the provisions of the Directive. Since 1989 the European arsenal of directives includes a legal remedy directive, which provides for a procedure by which the community can supervise compliance with the provisions of the Coordination Directive.

\section{National provisions on putting work out to tender}

The way in which candidates are selected and the work is subsequently allocated to one of the applicants is regulated at national level in two Uniform Public Procurement Regulations (UPPR; Uniform aanbestedingsreglement). The UPPR 1986, which replaces the UPPR 1972, purports to make a contribution to better organisation of the market. The power relationships in the construction market make it possible for the authority putting the work out to tender to play the contractors off against one another ('hawking'). Each contractor should be given an equal chance of making a tender. Through the provision of unambiguous information each contractor should be placed in a position to consider whether he will make a tender for the work. The UPPR 1986 regulates the various procurement procedures when the contract is worth less than 5 million ECU, the so-called 'European threshold'. Additionally the EECUPPR 1991 (Uniform aanbestedingsreglement-EG 1991), specially designed for public procurement in the European market, is applicable, the content and structure of which is so far as possible like that of the UPPR 1986, albeit that the 1991 directive, but not the 1986 directive, contains adjustments flowing from the Coordination Directive. Local authorities, although not obliged to do so, in practice nearly always use these public procurement regulations.

\section{Working hypothesis}

Just like the European directive, the Uniform Public Procurement Regulations use the open procurement procedure as a starting-point. The question is, as long as the legislator fails to indicate explicitly 'how' work must be put out to tender and the local authority is given the freedom to choose another procedure for putting work out to tender, as to the significance of this starting-point. Once the preventative supervision of the restricted form of putting work out to tender was abolished in 1966, it seemed as if local authorities should forthwith themselves scrutinise exclusively the financial implications of the commission of work and therefore should by preference use the open form of putting work out to tender. In these conditions there is no basis for scrutiny in the light of other policy considerations, notwithstanding that such other considerations play a large role in practice. In other words the decentralisation in 1966 paved the way for a sort of policy-orientated application of private law such as, for example, is to be found in the conditions attached to dispositions of land. Local authorities can thus make free use of the UPPR-procedure which works out the best for the authority as a party in the open market. Some writers recognise that, in putting out work for tender, problems can arise in connection with the principle of equality before the law, of which principle in particular the government should take account when commissioning the work. This leads to the working hypothesis that there is evidently a need for 'something like a public procurement policy', according to which the local authority brings a certain order in its scale of policy considerations bearing upon putting work out to tender. Such policy is inherent in the attainment of a balance of possible policy considerations pertaining to the commissioning of the work, with the sequel of the choice for a certain procurement procedure. 
The following question is connected with this working hypothesis: to which requirements should a local authority's policy regarding the putting of work out to tender be subject'?

\section{Requirements of the policy considerations}

The regulation of the interest in a financially efficient putting out of work to tender is of central concern in the national regulations on public procurement and in the European Coordination Directive. In the fourth chapter the requirements imposed by national and European legislation on the selection and allocation aspects of public procurement are scrutinised. A second question which especially requires attention is whether in the event of commissioning the work there is also room for other policy considerations. An example of the latter would be local policy on employment opportunities. May such consideration be taken account of in the final commissioning of work?

a. At national level. In contrast to the position in the UPPR 1972 the UPPR 1986 renders objective to a far-reaching extent the selection and allocation procedures, with the result that it has become possible to make the procedures easier to oversee. The purpose of rendering the selection and allocation criteria objective was to harness the freedom of choice of the local authority putting the work out to tender to criteria mentioned in the specification of work or announcement. This process of rendering objective is restricted to the open public procurement procedure and to the open public procedure with prior selection.

Furthermore the UPPR 1986 introduced the Council of Arbitration for Construction Firms to resolve disputes in the field of (government) procurement.

In addition to the general requirements as to suitability (such as being in possession of a licence permitting establishment), the local authority putting the work out to tender may request evidence of the contractor's financial, economic and technical abilities. The require-ments must be objective and unambiguous, moreover they must be of relevance to the work which is to be performed (proportionality principle). The requirements of being objective and unambiguous aim to enhance the transparency of the construction market and to secure that competition for any given procurement of public work takes place between firms of more or less equal value. The requirements serve partly the interests of the contractor registering an interest in the work: such contractor should be placed in a position to assess whether or not his firm is eligible for allocation. Partly the specification of the profile of the desired contractor must be left up to the policy of the local authority putting the work out to tender. Arbitrators therefore rightly subject the requirements relating to suitability to an only marginal scrutiny. The proporionality principle aims to achieve a healthy competition by restricting the number of aspirant-contractors to firms of more-or-less equal value. One is here concerned with the marketing policy of the authority putting the work out to tender. Also in this matter restraint by arbitrators is called for.

The allocation-criteria concern the requirements to be imposed upon the work. In principle the criterium of the lowest price applies. But other allocation-criteria may be applied.

Whether a contractor is eligible for allocation turns upon the answer to two questions. First, he must satisfy the publicised requirements pertaining to suitability, and moreover it must be reasonably apparent that he is in a position to perform the work skilfully and with regularity. In particular this second test poses a threat to objectivity of the requirements. Fur- 
thermore the local authority putting work out to tender is not required, after putting work out to tender, to give all candidates satisfying the specified suitability requirements the chance to submit a tender. 'This is well-known as the 'black hole'; the moment at which the local authority putting work out to tender can exercise an almost unlimited and uncontrollable discretionary power. The question whether a contractor who has submitted a tender satisfies the specified requirements as to suitability should be 'fully' tested with a certain respect for the freedom of the local authority putting the work out to tender to determine policy. The issue is whether the firm which has submitted the tender is in principle eligible for allocation, an issue in relation to which the right to determine policy of the local authority putting work out to tender only has a limited bearing. Only when the contractor who has submitted the tender entirely fulfils the desired profile can he be considered eligible for the commission of work. Although the local authority putting the work out to tender cannot be obliged to commission the work, an obligation to allocate must in any case be taken to be established. In addition to rendering the criteria objective, the UPPR 1986 introduced a modest obligation to give reasons; the local authority putting the work out to tender must subsequently be able to explain why the candidate was not permitted to submit a tender, or, when applicable, why he was not commissioned to do the work. The EEC-UPPR 1991 takes the principles in the UPPR 1986 a step further. The 'black hole' appears, through the choice of another system, to have been eradicated. Moreover new obligations to give reasons are established, also for the contractor.

b. At European level. The policy operating at national level regarding price and quality is coordinated at European level. The Coordination Directive distinguishes general requirements as to suitability, selection requirements (i.e.: special requirements as to suitability) and allocation criteria. In order to determine suitability in general the directive itemises a number of substantive criteria. Regarding the specific criteria the directive lays down recommendations and criteria as to suitability. These criteria concern economic and financial capacity and technical ability. The publication specifications concem the recommendations to be required. By requiring the local authority putting work out to tender to specify in advance of the procedure of putting the work out to tender the criteria determining participation, the transparency of the construction market is enhanced. This transparency is further enhanced by the mutual obligations, specified in the amended directive, to give reasons. The contents of the selection-requirements are determined on the basis of national law: the UPPR.

The government has a discretionary power of decision in the allocation on the basis of the most economically advantageous offer, albeit that the criteria of allocation must be objective and strictly relevant to the work and must be uniformly applied to all contractors regardless of their nationality. It is apparent from case law that the provisions on participation aim to avoid candidates being subject to the whim of the local authority putting out work to tender. Through the amended directive the principle that reasons be given in the relationship between the local authority putting work out to tender and candidates, or, as applicable, authority making a tender is introduced at Community level: more than formerly the local authority putting out work to tender will have to give reasons for decisions.

The Court and the European Commission consider it furthermore possible that, in addition to the requirements and criteria in the directive, further 'supplementary conditions' could be imposed, which could play a role in the commissioning of work. Selection requirements and 
allocation criteria must, as a matter of principle, be distinguished from these 'supplementary conditions'; such conditions must not be deployed as attenuated selection or allocation criteria. The requirements which these 'other' policy considerations (the so-called 'supplementary conditions' should satisfy is examined. A 'supplementary condition' can be justified by 'urgent requirements of general interest' (at any rate when there are no harmonisation provisions applicable). The Court permits the Member States a broad margin of appreciation when determining the choice of interests deserving of protection. The requirement that the restriction must be justified pre-supposes that the 'supplementary condition' must be in proportion to the aim pursued (the interest deserving protection). This proportionality test encapsulates three elements: the requirement that the measure is appropriate; the requirement that the measure is necessary and the requirement that the measure is in proportion to the aim pursued. The case law referred to shows that the Court tests, in particular, compliance with the first two requirements. The requirement that measures must be proportionate means that they must be objectively necessary.

On the subject of publicity, the Court has held that, where a 'supplementary condition' is concerned, all procedural requirements imposed by the directive must be complied with. That means that such condition justifying exclusion must be mentioned in the announcement of the commission of work, in order that contractors are informed of the existence of such condition.

\section{Principles of public procurement policy}

Once the parameters are established within which the local authority can formulate policy considerations, there remains the question of the principles of public procurement policy. What are the requirements which the policy regarding the putting of work out to tender should fulfil? It is contended that the present private law approach should be replaced with an administrative law approach. Notwithstanding the ideal that everyone ought to have an equal chance of submitting a tender, in reality work is put out to tender according to an instrumentalist practice which in no respect provides guarantees for a correct balancing of interests. In my view the starting-point for the normative policy-framework should be that the government is at all times subject to the principles of administrative law. In particular the issue is whether an action by the government is, in a public law sense, permissible. This primacy of administrative law should, in my opinion, replace the primacy of the open form of putting work out to tender. In particular it cannot be said that there is freedom of contract on the side of the government. Instead of freedom of contract it is appropriate to speak of a freedom - which requires to be more closely specified - to determine policy: the obligation to weigh up interests. And this weighing up of interests should take place on the basis of an objectively sound, rational decision-making model.

The requirements which the policies regarding the putting of work out to tender should be required to fulfil are the requirements which lie at the foundations of the power to put work out to tender. There are four principles: the principle of equality, the principle of publicity, the principle requiring reasons to be given and the principle that putting work out to tender should be (financially) effective. These requirements should be regarded as specific consequences of the general principles of administrative law: the rule of law, democracy and technical rationality. More particularly these principles should be regarded as structure principles: legal principles which impose requirements regarding the contents of public procurement 
policy. They are principles which as such form the foundation of decision-making in respect of putting work out to tender, quite irrespective of the question whether the various decisions also have external public law effects.

The principle of equality specifies that there must be a policy. It is highly desirable that fixed policy rules are developed. Sometimes, in addition to the principle of equality, the principle of good faith is operative; namely, whenever contractors are entitled, having regard to the government policy developed on putting work out to tender - including the effect of such policy rules as the UPPR -, to have certain expectations. There would not be much left of the requirement that a policy be developed without the additional requirement of publicity. A public procurement policy means that the decision-making process concerning the putting of work out to tender must always take place in full public view. Furthermore it is necessary that the policy is laid down in a written document (policy document). Such policy document fulfils the following four functions: a political policy function, a political check function, a coordination function and a function as point of reference in appeal cases. The basic proposition of publicity of decision-making when putting work out to tender leads to the result that restricted (i.e. not announced in public) putting of work out to tender becomes a rare exception. The principle that reasons should be given pertains to the (rational) argument which lies at the basis of the choices made in formation of the policy, and is closely linked to the 'requirement that there be a policy'. In addition to these requirements of legality there is the requirement that administration be effective.

The primacy of administrative law means that decision-making in relation to the UPPR procedure for putting work out to tender takes place within an entirely administrative law decision-making process. The requirements imposed by administrative law upon the policy on putting work out to tender comprise, as it were, a decision-making umbrella above the more limited decision-making within the context of the UPPR. The administrative law requirements apply throughout the UPPR procurement procedure. The foundation of the administrative law decision-making process must be sought in the powers of local authorities to put work out to tender. Decision-making in the context of the UPPR public procurement procedure takes place on the basis of a contract to put work out to tender: a reciprocal element in the local authority's decision-making. Where the accent in the case of the contract to put work out to tender so evidently lies upon the decision-making element which precedes the conclusion of a contract commissioning work, I would propound the view that the contract to put work out to tender should be treated as a public low contract: a mechanism in the context of decision-making (just like preparatory resolutions, procedural decisions) which in the light of the necessary reciprocity - will be expressed in the form of one of the contracts of the Civil Law Code. When regarded in this light the principles underlying the UPPR form 'merely' the procedural incidents (species) within the structural principles of administrative law governing the formation of policy on putting work out to tender.

In accordance with this administrative law approach I argue for a system in which all disputes concerning the putting out of work to tender of government contracts, regardless of the type of transaction or the legal remedy sought, should be adjudicated by the same administrative law judge. Furthermore the administrative law judge should not confine his attention to the question whether the individual interest is not too seriously affected in relation to the general interest which is pursued (proportionality). He should engage in an examination of the 
objective necessity of the measure. That would mean there would be a shift of attention from the concrete decision-making towards the phase of formation of policy. It seems to me that such judicial scrutiny at the policy phase is conducive (and desirable) to achieve judicial scrutiny of the legality of decision-making on putting work out to tender. It is not only the issue whether the individual interest is not too seriously affected in relation to the general interest pursued (proportionality), but, namely, also whether the local authority is right to insist upon fulfilment of certain criteria and (supplementary) conditions. If one leaves the formulation of the criteria and conditions over to the local authority's freedom to make policy, without scrutinising the aptness or the necessity of a measure, then the proportionality test will achieve little. By testing the aptness and the necessity of the criteria and supplementary conditions the freedom to make policy itself can be scrutinised for its legality according to the principles of administrative law.

This research concludes with a plea for a Public Procurement Act (Wet op de overheidsopdrachten), which Act would go further than merely regulating the procedural questions arising from putting work out to tender. A link to the Administrative Law Act (Algemene wet bestuursrecht) could be found by application of Article 8:3 Administrative Law Act. At the conclusion of this provision could be added: 'apart from the cases provided for by law (i.e. primary legislation)'. In this way the legislature is given the opportunity to determine which government contracts should be provided for separately. 

ABAR (1984), Rapport van de commissie inzake algemene bepalingen van administratief recht, vijfde geheel herziene druk, Alphen aan den Rijn 1984

. Ackermans-Wijn (1989), J.C.E., Contracten met de overheid. Een onderzoek naar de contractsvrijheid van publiekrechtelijke rechtspersonen en het toepasselijke materiële recht, ac.prft. Katholieke Universiteit Nijmegen, Deventer 1989

. Admiraal (1993), P.H., Een economische visie op de reglementering van aanbestedingen, Bouwrecht 1993, 582-587

Adriaansens (1981), C.A. Aanbesteding van overheidswerken en aanbestedingsbeleid van lagere overheden, Bouwrecht 1981, 171-177

Adriaansens (1988), C.A., "Over grenzen van het bouwrecht", Inaugurele rede van Prof.Mr. D.A. Lubach, Bouwrecht 1988, 352-353

. Van Agtmaal (1970), P.A.Th., E.E.G.-richtlijnen betreffende het plaatsen van overheidsopdrachten voor het uitvoeren van werken, Bouwrecht 1970, 796-799

Van Agtmaal (1971), P.A.Th., Oplossing van de problemen rond de EEG-richtlijnen betreffende het plaatsen van de overheidsopdrachten voor de uitvoering van werken, Bouwrecht 1971, 737-742

Akkermans (1988), P.W.C., Amsterdam-Ikon arrest, AA 1988, 111-114

. Akkermans (1991), P.W.C., Beleid en (on)gelijke behandeling, HR 26 oktober 1990, nr. 7756, AB 1991, nr. 90, AA 1991, 502-507

. Arrowsmith, (1992), Sue, Public Procurement in the European Community: Volume II, Winteringham 1992

- Arrowsmith (1994), Sue, The Award of Interim Measures in Procurement Cases: Implications of the Recent Order in the Wallonia Buses Case, PPLRev. 1994, CS130CS136

. Asser-Harkamp II (1993), Mr. C. Asser's Handleiding tot de beofening van het Nederands burgerlijk recht, deel 4-II, Algemene leer der overeenkomsten, Zwolle 1993

Asser-Coehorst-De Leede-Thunnissen (1983), Mr. C. Asser's Handleiding tot de beoefening van het Nederlands burgerlijk recht, deel 5-III, Bijzondere overeenkomsten, Overeenkomst van opdracht, arbeidsovereenkomst, aanneming van werk, door P.J.M.G.

Coehorst, L.J.M. de Leede, H.O. Thunnissen, Zwolle 1983

- Asser-Kortmann-De Leede-Thunnissen (1994), Mr. C. Asser's Handleiding tot de beoefening van het Nederlands burgerlijk recht, deel 5-III, Bijzondere overeenkomsten. Overeenkomst van opdracht, arbeidsovereenkomst, aanneming van werk, Zwolle 1994

Atkins (1988), W.S. Management Consultants, The Cost of non-Europe in Public Sector Procurement, Brussel 1988

Balk (1985), A., Prijsvorming en Ordening in de bouw, Gemeentewerken 1985, 99-105

Van Baren (1977), R., Aanbestedingsbeleid: mogelijk of niet?, Bondsblad 1977, 1093 1099

. Barents - Brinkhorst (1994), R. Barents en L.J. Brinkhorst, Grondlijnen van Europees Recht, Alphen aan den Rijn 1994

Van den Berg (1986), M.A.M.C., Bespreking van J. Spier, Overeenkomsten met de overheid, dissertatie Leiden, 1981, Bouwrecht 1986, 31-35 
- Van den Berg (1987 a), A.J., De Gewijzigde Statuten (1987) van de Raad van Arbitrage voor de Bouwbedrijven in Nederland, Bouwrecht 1987, 709-730

. Van den Berg (1987 b), M.A.M.C., in: Beraadslagingen over het preadvies van Mr. J.W. van Nouhuys, Bouwrecht 1987, 92-101

. Van den Berg (1990), M.A.M.C., Samenwerkingsvormen in de bouw, ac.prft. Katholieke Universiteit Brabant, Bouwrecht monografiën, Geschrift nr. 8, Deventer 1990

- Van den Berg (1991), M.A.M.C., Een faire kans. Het UAR als waarborg voor een eerlijke aanbesteding, inaugurale rede Rijksuniversiteit Leiden, 15 maart 1991, Deventer 1991

. Van den Berg (1993), a M.A.M.C., Verticale aanbestedingsregeling: een wenkend alternatief, Bouwrecht 1993, 32-44

. Van den Berg (1993 b), M.A.M.C., Plas-Valburg in de toekomende tijd, Bouwrecht $1993,417-424$

. Ten Berge - Stroink (1979), J.B.J.M. ten Berge en F.A.M. Stroink, Kroniek AROBjurisprudentie, TvO 1979, 34-36

. Berr - Groutel (1987), Claude J. Berr et Hubert Groutel, Droit européen des assurances:

Liberté de prestation de service et coassurance, RTDE 1987, 83-104

. Biegman-Hartogh (1972), A.M., Kostenvergoeding bij precontractuele verhoudingen in de bouw, Bouwrecht 1972, 157-165

. Biesheuvel (1988), M.B.W., Artikel 6 van de Europese Conventie voor de Rechten van de Mens en het gemeenschapsrecht, Preadvies voor de Nederlandse Vereniging voor Europees Recht 1988, SEW 1988, 659-705

. Bleeker (1993), R.G.T., Een completer UAR, Bouwrecht 1993, 54-60

Bloembergen (1976), A.R. en W.J. Slagter, Contracten met de overheid in het bijzonder in de bouw, Bouwrecht Monografiën nr. 3, Deventer 1976

. Bloembergen (1977), A.R., De eenheid van privaatrecht en administratief recht, WPNR 5372 (1977), 1-5, WPNR 5373 (1977), 17-23, WPNR 5374 (1977), 33-36, WPNR 5375 (1977), 49-54

Bloembergen (1992), A.R., Overheidsprivaatrecht: schets van een algemeen deel, WPNR 6074 (1992), 950-957

Boissevain (1867), J.H.G., De gemeentewet opgehelderd door eene aantekening, geput uit de officiële, bij de wetgevende macht gewisselde stukken en door verwijzing naar de verwante wetsbepalingen, ter verklaring van het verband waarin de artikelen der wet, zoo onderling, als met de algemeene wetgeving staan, aangevuld met eene geschiedenis harer toepassing door G. van Oosterwijk, Arnhem 1867

Boncompagni (1990), G., Les principales caracteristiques des Directives Communautaires, Bouwrecht 1990, 322-324

. Boonstra (1981), Tj.H., Prijsvormingsregels bij de aanbesteding, Bouwrecht 1981, 178 194

. Bovis (1993), Chris, Extra-territorial Effects in the Application of EC Legislation on Public Procurement, LIEI 1993, 83-93

. Braakman (1993), A.J., De SPO-regeling vanuit het perspectief van het kartelrecht, Bouwrecht 1993, 1-12

. Brederveld (1990), E., De nieuwe gemeentewet. Beroep van door ambtenaren krachtens delegatie genomen besluiten, Gst 6908 (1990), 417-420 
. Brederveld (1992), E., Herten en voor vernietiging vatbare gevolgen. Het parochiehuis Woerden revisited, Gst 6944 (1992), 288-290

. Bregman (1993), A.G., De richtlijn werken en publiek-private samenwerking, Bouwrecht $1993,499-503$

- Burger (1971), B., F.A. Helmstrijd, A.J. Nieuwenhuizen, A. Zadel, Nederlands Gemeenterecht, Alphen aan den Rijn 1971

. Burger (1983), B., A.J. Nieuwenhuizen, J.C. Schroot, J.H. Sikkes, Schets van het Nederlands Gemeenterecht, Alphen aan den Rijn/ 's-Gravenhage 1983

Buriks (1955), A., Gemeenterecht II, Alphen aan den Rijn, 1955

Van Buuren (1991), P.J.J., De twee-wegenleer is niet van de baan, NJB 1991, 15011503

. Buys, (1887), J.T., De Grondwet. Toelichting en Kritiek. Tweede Deel, Arnhem 1887

- Bijloos- Van den Oosterkamp (1990), A.W.M. Bijloos, J.S. van den Oosterkamp, De verhouding van de algemene beginselen van het gemeenschapsrecht tot de Algemene wet bestuursrecht, SEW 1990, 853-867

. CEM-rapport (1976), Commissie economische mededinging, Aanbestedingsregelingen, Advies aan de Minister van Economische Zaken, 1 december 1975, 's-Gravenhage juni 1976

. Chalmers (1994), Damian, Repacking the Internal Market - The Ramifications of the Keck Judgement, European Law Review 1994, 385-403

COB/ SER (1989), Commissie Ontwikkeling Bedrijven COB/SER, Onderzoek Overheidsopdrachten in de interne markt EG. Verslag van een onderzoek naar de marktaspecten en internationale concurrentiepositie van Nederlandse bedrijven in een viertal sectoren. Bijlage bij het SER-advies: $89 / 10$ (Overheidsopdrachten in de interne markt EG), januari 1989

. Coleman en Margue (1989), R.J. Coleman en T.-L. Margue, L'action de la Communauté visant le respect des règles communautaires en matière de passation des marchés publics de fournitures et de travaux: problèmes et perspectives, RMC 1989, 546-553

Commissie Wetgevingsvraagstukken (1985), Eindrapport, 's-Gravenhage 10 december 1985

Cox (1993), Andrew, The Single Market Rules and the Enforcement Regime After 1992. Public Procurement in the European Community: Volume I, Winteringham 1993

. CPB (1989), Centraal Planbureau, Nederland en Europa 1992. Liberalisering van de EG-markt voor overheidsaankopen, Werkdocument nr. 33, 's-Gravenhage november 1989

. Crince le Roy (1975), R., Het repressieve toezicht en de publiekrechtelijke rechtsbescherming van de burger, Bouwrecht 1975, 397-410

. Damen (1992), L.J.A., Mariëtte Kobussen, De vrijheid van de overheid, RM Themis 1992, 465-471

- Van der Does (1987), J.A.E., Overeenkomsten met de overheid, Tijdschrift voor Privaatrecht 1987, 1677-1708

Donders (1991), N.J.M., Een faire kans, Oratie Prof. Mr. M.A.M.C. van den Berg. Kluwer - Deventer - 1991, Bouwrecht 1991, 754-757

Donders (1992), N.J.M., Achtergronden van het nieuwe aanbestedingsrecht. Bouwrecht 1992, 93-99 
. Donders (1994), N.J.M., Toetsing van het ervaringsvereiste bij aanbestedingen, Bouwrecht 1994, 114-119

. Donders (1995), N.J.M., De Raad van Arbitrage op vreemd terrein, Bouwrecht 1995, 399-402

. Droogleever Fortuyn (1970), E., De overheid en de standaardcontracten, WPNR 5067 (1970), 33-39

. Droogleever Fortuyn (1979), E., Congruentie van privaatrechtelijke en administratiefrechtelijke begrippen, in: Non sine causa (Van Opstall-bundel), Zwolle 1979, 39-47

- Drupsteen (1990), Th.G., De Pina-Helmond; het einde van de twee-wegenleer, AA 1990, 840-845

. Drupsteen (1994), Th.G., Staat/ Magnus; nog éénmaal twee-wegen, AA 1994, 157-165

. Duk (1978), W. De zachte kern van het bestuursrecht, RM Themis 1978, 564-587

. Duk (1981), W., Maatstaven voor beoordeling van sancties, AA 1981, 231-238

. Van Dunné (1985), J.M., Verbintenissenrecht in ontwikkeling. Op de grenzen van geldend en wordend recht, Deventer 1985

. Dijkhuis (1973), N., Richtlijn van de Raad van de Europese Gemeenschappen betreffende de coördinatie van procedures voor het plaatsen van overheidsopdrachten voor de uitvoering van werken, Bouwrecht 1973, 72-75

Dijksma (1981), E.R., Wijziging Erecode verdient geen ereprijs, Woningraad 13 februari 1981, 9

. Edward (1987), David, Establishment and Services: An Analysis of the Insurance Cases, European Law Review 1987, 231-256

. Elsen (1967), G.L., Wat veranderde er door het vervallen van artikel 213 gemeentewet?, De Nederlandse Gemeente 1967, 428

. Elzinga (1979), D.J., Politieke controle in de lokale demokratie, Deventer 1979

. Van Erp (1990), J.H.M., Contract als rechtsbetrekking: een rechtsvergelijkende studie, ac.prft. Katholieke Universiteit Brabant, Zwolle 1990

. Van der Esch (1994), B., De voltooiing van de interne markt voor goederen en diensten volgens art. 8A EEG en het Witboek van 1985; enkele juridische kanttekeningen, SEW $1994,559-578$

- Everwijn (1897), J.C.A., Het samentreffen van preventief en repressief toezicht op lagere besturen, Leiden 1897

. Fernhout (1989), R., Instrument en norm, in: Rechtsvorming in de sociale rechtsstaat, Bundel opstellen aangeboden aan prof. mr. P. De Haan ter gelegenheid van zijn afscheid van de Technische Universiteit Delft en de Vrije Universiteit Amsterdam, Deventer 1989, 23-36

. Flamme (1990), M.A., La réglementation des marchés publics en Belgique, en France et au Grand-Dûche de Luxemburg, Bouwrecht 1990, 332-337

. Flamme - Flamme (1986), M.-A. Flamme en Ph. Flamme, De abnormaal lage prijzen bij overheidsopdrachten, gisteren nog aangemoedigd, vandaag te verwerpen, Bouwrecht 1986, 717-728

- Flamme - Flamme (1988), Flamme, M.A. en Ph. Flamme, Flamme, M.-A., Ph. Flamme, Vers l'Europe des marchés publics? (a propos de la directive "fournitures" du 22 mars 1988) RMC 1988, 455-479 
Forwoord - Clough (1986), Nicolas Forwood and Mark Clough, The Single European Act and Free Movement. Legal Implications of the Provisions for the Completion of the Internal Market, European Law Review 1986, 383-408

McGee en Weatherill (1990), McGee Andrew and Stephen Weatherill, The evolution of the Single Market - Harmonisation or Liberalisation, MLRev 1990, 578-596

Gerven - Wyckaert (1987), Gerven, W. van en M. Wyckaert, Overeenkomsten met de overheid, TvP 1987, 1709-1754

Glazener (1990), P., Openbare aanbesteding. De richtlijnen inzake openbare aanbesteding in Nederlands perspectief, Adv.bl. 1990 (Europa-special), 613-617

Glazener, Pijnacker Hordijk en Van der Riet (1990), P. Glazener, E.H. Pijnacker Hordijk en E.M.A. van der Riet, Application in the Netherlands of the Directives on Public Procurement, Report of the Netherlands Association for European Law for the FIDE Congress 1990, Madrid 1990, SEW 1990, 194-222

Goorden (1990), C.P.J., Komend gemeenterecht: de nieuwe Gemeentewet en de Algemene wet bestuursrecht, NTB 90/10, 301-311

Gormley (1989), Laurence W., Some reflections on the internal market and free movement of goods, LIEI 1989, 9-20

Gormley (1992), L.W., Openbare aanbesteding: Inleiding tot het EG-beleid, Bouwrecht $1992,85-93$

Gormley (1994), Laurence, Public Procurement, in: 1993, the European market: myth or reality?/ editors, Dennis Campbell, Charles Flint, Deventer 1994, 151-167

Goudsmit (1973), J.J., Enkele opmerkingen over de Richtlijn van de Raad van de Europese Gemeenschappen betreffende de coördinatie van procedures, voor het plaatsen van overheidsopdrachten voor de uitvoering van werken, Bouwrecht 1973, 69-72

Goudsmit (1974), J.J., Reglementen in het precontractuele stadium, NJB 1974, 229-234

Goudsmit (1989), J.J., in: W.J.P. Bakens, J.J. Goudsmit, F.H. van den Bercken, De veranderende bouwopgave, Preadviezen voor de Vereniging voor Bouwrecht, nr. 17, Deventer 1989, 29-62

Van der Grinten (1953), W.C.L., Opzetregelingen, NV 1953-1954, 41-44

Von der Groeben - Thiesing - Ehlerman (1991), H. von der Groeben, H. von Boeck, J. Thiesing, Kommentar zum EWG-Vertrag, 2 delen, 2e Auflage, Baden-Baden 1974

Groen (1952), K., Is het opzetcontract een geoorloofde overeenkomst? (I en II, slot), SEW 1952, 235-240 en 262-270

Groot (1979), M., Bestuursrecht en planning, TvO 1979, 157-160 en 173-179

De Groot - Van der Meulen - Van Rossum (1994), G.R.J. de Groot, B.M.J. van der Meulen, A.A. van Rossum, Subsidies, beleidsregels, bestuursorganen. Het wetsvoorstel derde tranche van de Algemene wet bestuursrecht, NJB 1994, 1193-1200

. De Haan (1978), P., De gemeenten en de grondpolitiek, Bestuursforum 1978, 117-120, 153-158

De Haan (1990), P., De drie dimensies van het bestuursrecht, NJB 1990, 344-348

De Haan (1992), P., Vrijheid en aansprakelijkheid van de overheid. een vijftal proefschriften over de verhouding publiek-/privaatrecht, Bouwrecht 1992, 893-903

- De Haan, Drupsteen, Fermhout (1986 a), P. de Haan, Th.G. Drupsteen, R. Fernhout, Bestuursrecht in de sociale rechtsstaat, Deel I, Deventer 1986 


\section{Literatuur}

. De Haan, Drupsteen, Fermhout (1986 b), P. de Haan, Th.G. Drupsteen, R. Fernhout, Bestuurstecht in de sociale rechtsstaat, Deel II, Deventer 1986

. Hailbronner - Nachbaur (1992), Kay Hailbronner und Nachbaur, Andreas, Die Dienstleistungsfreiheit in der Rechtsprechung des EuGH, EuZW 1992, 105-113

. Hancher - Ottervanger - Slot (1993), Leigh Hancher, Tom Ottervanger, Piet Jan Slot, EC State Aids, Chancery/ Wiley 1993

. Hum (1994), A.D. Op weg naar een nieuwe Wet economische mededinging, SEW 1994, 492-508

Hartelust (1988), A.M., De vergaderprocedure volgens het nieuwe Uniform Prijsregelend Reglement (UPR), Bouwrecht 1988, 274-277

Heiermann (1990), W., The EC-Directive concerning coordination of procedures for the award of public works contracts, Bouwrecht 1990, 325-331

Helder-Jue (1987), E. Helder, R.J. Jue, Belangenafweging in het bestuursrecht, Bestuurswetenschappen 1987, 25-42

Hendriks (1957), A., De prijsvorming in het bouwbedrijf, ac.prft. Technische Hogeschool Delft, Rotterdam, 1957

Hennekens (1987), H.Ph.J.A.M., Artikel 1 Grondwet: geen passe-partout, De Nederlandse Gemeente 1987, 201-202

- Hennekens (1994), Beroep op de administratieve rechter in relatie tot bestuurlijk toezicht, Gst 6991 (1994), 345-355

. Heringa - Zwart (1993), Heringa, A.W. en T. Zwart, De Nederlandse Grondwet, Zwolle 1993

. Van der Hoeven (1970), J., De magische lijn. Verkenningen op de grens van publieken privaatrecht, in: Honderd Jaar Rechtsleven, NJV 1870-1970, 201-219

Hogerzeil (1982), J.P., De aanbesteder: van heer en meester tot structurele underdog, in: Vijfenzeventig jaar Bouwarbitrage, 1907 - 11 april - 1982, Gedenkboek van de Raad van Arbitrage voor de Bouwbedrijven in Nederland, Zwolle 1982, 124-165

. Holterman (1987 a), Th., Vredesbeleid ook gemeentelijk beleid, TvO 1987, 335-337

. Holterman (1987 b), Th. en B.C. Vis, Reactie op 'Arnhem: dorp aan de rivier?', AA $1987,451-452$

. Hoogerwerf (1989), A. (red.) Overheidsbeleid, Alphen aan den Rijn 1989

D'Hooghe (1993), David, De gunning van overheidscontracten en overheidsopdrachten en het toezicht door de Raad van State en de gewone rechtbanken, Brugge 1993

Hulshof (1973), H., Doel en Funktie van de Reglementaire Opzetcontracten in de Bouwnijverheid, Deventer 1973

Huygen (1991), W.G., Aansprakelijkheid van de overheid. Graadmeter voor de verhouding tussen publiek- en privaatrecht, ac.prft. Rijksuniversiteit Leiden, Deventer 1991

. Ingenstau - Korbion (198), Heinz Ingenstau und Hermann Korbion, Verdingungsordnung für Bauleistungen, Teile A und B; DIN 1960/61 (Fassung 1979); Kommentar, Düsseldorf 1989

. Jacobs (1952), J.H., Het opzetcontract, SEW 1952, 48-51

. Jacobsen Jensen (1993), J.N., Figuurzagen in het UPR met een Brussels kantje. Mogelijke civielrechtelijke gevolgen van de EC-beschikking, Bouwrecht 1993, 25-32 
Jak (1976), W.B., Het advies van de Commissie economische mededinging over Aanbestedingsregelingen, Bouwrecht 1976, 841-860

Jalles (1990), Isabel, Das Urteil des EuGH in der Sache "Rush Portuguesa" - eine Anmerkung, EuZW 1990, 310-311

Jans (1992), J.H., Evenredigheid: ja, maar waartussen? Fen aantal opmerkingen over de toepassing van het proportionaliteitsbeginsel in het kader van de art. 30, 34 en 36 E(E)G-Verdrag, SEW 1992, 751-770

Janssen (1993), J.G.J., Laat Brussel nog enige vrijheid beleidsovereenkomsten te sluiten?, Bouwrecht 1993, 493-499

Johnson - O'Keefe (1994), Esther Johnson, David O'Keeffe, From Discrimination to Obstacles to Free Movement: Recent Developments Conceming the Free Movement of Workers 1989-1994, CMLRev. 1994, 1313-1346

De Jong (1984), J., Gemeentelijke gronduitgifte, ac.prft. Rijksuniversiteit Utrecht, Deventer 1984

Kan (1951), J.M., Toezicht en controle, in: Gedenkboek gemeentewet 1851-1951, Gedenkboek ter gelegengenheid van het honderdjarig bestaan van de gemeentewet uitgegeven door de Vereniging van Nederlandse Gemeenten, 's-Gravenhage 1951, 168-226

. Kan (1986), J.M., Het toezicht in het wetsontwerp voor de nieuwe Gemeentewet, Gst 6812 (1986), 184-187

. Kapteyn - VerLoren van Themaat (1987), P.J.G. Kapteyn en P. Verloren van Themaat, Inleiding tot het recht van de Europese Gemeenschappen, Deventer, 1987

. Kapteyn - VerLoren van Themaat (1989), P.J.G. Kapteyn en P. Verloren van Themaat, Introduction to the law of the European Communities: after the coming into force of the Single European Act, Deventer 1989

. Kindt (1979), J.I.R., Continuiteit in de bouw mythe of mogelijkheid. Moeilijkheden, mogelijkheden en wenselijkheid van een taakstellend bouwprogramma van lagere overheden, 's-Gravenhage, januari 1979

. De Kluiver (1992), Harm-Jan, Onderhandelen en privaatrecht, ac.prft. Vrije Universiteit Amsterdam, Deventer 1992

De Kluiver en Mac Lean (1987). De Kluiver, H.J. en M.M. Mac Lean, De Voorovereenkomst (I en II). Een beschouwing in rechtsvergelijkend perspectief, RM Themis 1987 , 6-23 en 60-75. Klijn en Koolma (1985), E.H. Klijn en H.M. Koolma, Deregulering op de bouwmarkt: een vergeten issue, S\&V 1985, 433-438

Kobussen (1989), M., Een privaatrechtelijke legaliteitseis? De wissel(werking) tussen het legaliteitsbeginsel en het ongeschreven recht bij privaatrechtelijk overheidshandelen, NTB 89/4, 97-10

Kobussen (1991), Mariëtte, De vrijheid van de overheid. Een vergelijking van de privaatrechtelijke en bestursrechtelijke beoordelingskaders, om te komen tot een beantwoording van de vraag, en in hoeverre het privaatrecht voor de overheid remplaçant kan zijn voor het bestuursrecht, ac.prft. Katholieke universiteit Brabant, Zwolle 1991

Kocken (1973), M.J.A.V., Van stads- en plattelandsbestuur naar gemeentebestuur, Proeve van een geschiedenis van ontstaan en ontwikkeling van het Nederlandse gemeentebestuur tot en met de Gemeentewet van 1851, 's-Gravenhage 1973

. Koeman (1982), N.S.J., J. Spier/ Overeenkomst met de overheid, RM Themis 1982, 395-399 


\section{Literatuur}

Konijnenbelt (1989 a), Willem, Provinciale en gemeentelijke autonomie en gedogend beleid, NTB 89/7, 211-219

. Konijnenbelt (1989 b), W., Rechtsvorming door het bestuur, Bouwrecht 1989, 496-505

Konijnenbelt (1994), W., Het specialiteitsbeginsel in het Nederlandse en Franse administratieve recht, NTB 94/10, 305-312

- Kooij - Tonnaer (1984), Chr. Kooij en F.P.C.L. Tonnaer, Vergunningverlening in stroomversnelling, preadviezen, Geschriften van de VAR XCII, Alphen aan den Rijn 1984

. Kortmann (1987), C.A.J.M., De Grondwetsherzieningen 1983 en 1987, Deventer 1987

Kortmann (1990), S.C.J.J., LOTA-gemeenten aansprakelijk voor schade door voorkeursbeleid, NV 1990, 69-75

Kraan, (1990), D.J., De beslechting van bestuursgeschillen; preadviezen uitgebracht door prof. mr. Th.G. Drupsteen en mr. K.J. Kraan voor de algemene vergadering van de Nederlandse vereniging voor Administratief Recht op 11 mei 1990, VAR-reeks 104, Alphen aan den Rijn 1990

Kranenburg (1951), R., Het Nederlandsch Staatsrecht, Haarlem 1951

Van Kreveld (1983), J.H., Beleidsregels in het recht, ac.prft. Rijksuniversiteit Groningen, Deventer 1983

. Kuizinga - Tak (1975), Kuizinga, W. en A.Q.C. Tak, "Het preventieve toezicht", Bouwrecht 1975, 374-397

. De Laat de Kanter (1892), Ph.S., De bevoegdheid van de burgemeester om gemeenteraadsbesluiten voor vemietiging voor te dragen, ac.prft. Rijksuniversiteit Leiden 1892

. Van de Laken (1985), F.R., Hoger beroep in bouwarbitrage gewenst?, TvA 85/1, 1-9

Lasok (1988), K.P.E., Freedom to provide insurance services in the light of the "coinsurance cases", MLRev 1988, 706-734

De Laubadère (1990), Laubadère, André, Jean Claude Venezia en Yves Gaudemet, Traité de droit administratif, Paris 1990, Tome I

. Laus (1966), L., Het opzetcontract en de normen, waardoor deze overeenkomst wordt beheerst, AA 1966, 95-107

Lawwaars - Timmermans (1994), R.H. Lauwaars, C.W.A. Timmermans, Europees Gemeenschapsrecht in kort bestek, Groningen 1994

. Leenen (1985), A.Th.S., Recente ontwikkelingen op het terrein van de vrijheid van vestiging en de vrijheid van dienstverlening binnen de EEG, SEW 1985, 543-563

. Lion (1851), Iz.J., Wet, regelende de zamenstelling, inrigting en bevoegdheid der gemeentebesturen; verklaard en toegelicht, tot een handleiding voor de gemeentebesturen en kiezers, en voorafgegaan van een overzigt van de Hoofdbeginselen der nieuwe Gemeentewet, vergeleken met de tot dusver bestaande Gemeentewetgeving, 's-Gravenhage 1851

. Van Loenen (z.j.), De gemeentewet en haar toepassing, onder eindred. van M. van Troostwijk; bew. door G.W.J. Boxelaar, J.L. Buysse en J.W.A.A. Kruijsse. Oorspronkelijk bewerkt door J.W.A.C. van Loenen (losbladige), Alphen aan den Rijn, 1959- ...

. Van der Loo (1969), W.P.M., Enkele problemen in de pre-contractuele fase van de aanneming van werk, Bouwrecht 1969, 655-666

Lubach (1981), D.A., Precontractuele verhoudingen bij beleidsovereenkomsten, Bouwrecht 1981, 146-153 
Lubach (1982), D.A., Beleidsovereenkomsten, ac.prft. Rijksuniversiteit Groningen, Deventer 1982

. Lubach (1986), D.A., De verhouding privaat-publiekrecht in het licht van het NBW, in: Bestuursrecht en (nieuw) burgerlijk recht, Preadviezen VAR XCIV, Alphen aan den Rijn 1986, 9-64

. Lubach (1987), D.A., Overeenkomsten met de overheid en algemene beginselen van behoorlijk bestuur, AA 1987, 343-349

. Lubach (1988), D.A., Bouwcontracten op de grens van privaat- en publiekrecht; enkele meer algemene opmerkingen aan de hand van de projectontwikkeling, Bouwrecht 1988, 423-430

. Lubach (1989), D.A., Rechtsvorming ten aanzien van overeenkomsten in de Algemene wet bestuursrecht, in: Rechtsvorming in de sociale rechtsstaat, Bundel opstellen aangeboden aan prof. mr. P. De Haan ter gelegenheid van zijn afscheid van de Technische Universiteit Delft en de Vrije Universiteit Amsterdam, Deventer 1989, 37-50

Van Male (1988), R.M., Beredeneerd besluiten. Plaats, funktie en betekenis van het motiveringsbeginsel in het Nederlandse bestuursrecht, NTB 88/3, 75-79

Van Male (1992), R.M., Enkele aspecten van het begrip belanghebbende in de Algemene wet bestuursrecht, in: De belanghebbende, Preadvies, VAR-reeks 108, Alphen aan den Rijn 1992, 7-100

- Martin (1993 a), José Maria Fernández, The European Commission's Centralised Enforcement of Public Procurement Rules: A Critical View, PPLRev. 1993, 40-66

Martin (1993 b), José M. Fernandez, Case C-243/89, Commission v. Denmark (The Storebaelt Case), Judgement of June 22, 1993, PPLRev 1993, CS153-CS156

. Martin en Stehmann (1991), José M. Fernandez Martin en Oliver Stehmann, Product Market Integration versus Regional Cohesion in the Community, European Law Review, 216-243

. Mattera (1990), Alfonso, Le marché unique européen. Ses règles, son fonctionnement, Paris 1990

- Van de Meent (1991), G.M.A., Rechtsbescheming bij overheidsaanbestedingen in de bouw, TvA 91/4, 123-132

- Van de Meent (1993), Gert-Wim, New Legislation on Procurement in The Netherlands: Raamwet EEG-voorschriften aanbestedingen (Framework Law on the EEC Procurement Rules); Besluit aanbestedingen nutssector (Royal Decree implementing Directive 90/531 on Utilities); and Besluit overheidsaanbestedingen (Royal Decree implementing Directive 92/50 on Services), PPLRev. 1993, CS136-CS139

. Van de Meent (1994), Gert-Wim, Restoring the Pecking Order: New Dutch Competition Law on Collusive Tendering. The Netherlands, PPLRev. 1994, CS143-CS148

. Messer-Heldeweg (1990), E.A. Messer en M.A. Heldeweg, Bestuurscompensatie en het specialiteitsbeginsel. Een beschouwing over juridische spraakverwarring, rekkelijken versus preciezen en enkele cryptische wetsartikelen, RM Themis 1990, 147-166

Meijknecht (1979), P.A.M., Planverbintenissen: vormgeving aan privaatrechtelijke verbintenissen in het bijzonder ten dienste van het economisch beleid, mede bezien tegen de achtergrond van het Poolse recht, ac.prft. Vrije Universiteit Amsterdam, Zwolle 1979

. Mok (1983), M.R., Het paard achter de wagen. Deregulering en kartelrecht, SEW 1983, 666-678 
Mok (1987), M.R., Toepassing WEM, TVVS 1987, 46-49

. Mok (1994), M.R., Voortgaande verscherping nationaal kartelbeleid in Nederland: twee nieuwe generieke maatregelen, SEW 1994, 467-480

. De Monchy (1947), S.J.R., Handboek voor het Nederlands Provincierecht, Haarlem 1947

. De Moor-van Vugt (1993), A.J.C., Symbiose van evenredigheidstoetsen?, NTB 93/1, 26-37

. Mortelmans (1987), K.J.M., Het vrije verkeer van diensten in de verzekeringssector, AA $1987,725-737$

Mortelmans (1992), K.J.M., De Mediawet en het EEG-Verdrag, AA 1992, 41-52

. Mortelmans (1994), K.J.M., De interne markt en het facettenbeleid na het Keck-arrest: nationaal beleid, vrij verkeer of harmonisatie, SEW 1994, 236-250

. Mulder - Duk (1985), A. Mulder, R.A.A. Duk, Schets van het sociaal-economisch recht in Nederland, Zwolle 1985

. Nachbaur (1991), Andreas, Art. 52 EWG - Mehr als nur ein Diskriminierungsverbot? Anmerkung zur Entscheidung des EuGH vom 7.5.1991 in der Rs C-340/89, EuZW 1991, 470-472

. Nicolaï (1990), P., Beginselen van behoorlijk bestuur, ac.prft. Universiteit van Amsterdam, Amsterdam 1990

. Nieskens-Isphording (1986), B.W.M., De gemeente en contractuele goede trouw, Gst 6820 (1986), 329-332

. Niemeyer (1993), Hans-Jörg, Recent Developments in EC State Aid Law, EuZW 1993, 273-279

. Van Nouhuys (1986), J.W., Aspecten van aanbestedingsrecht, in: J.W. van Nouhuys, W.J. Slagter. M.-A. Flamme, Aanbestedings- en mededingingsrecht in de bouw, Preadvies voor de Vereniging voor Bouwrecht, ur. 14, Deventer 1986, 3-53

. Van Nouhuys (1987), J.W., Wijzigingsvoorstel Coördinatierichtlijn, Bouwrecht 1987, $416-420$

. Nijenhuis en Boland-de Vries (1977), J. Nijenhuis en M. Boland-de Vries (1977), Een kwantitatief onderzoek naar de vernietigingsbesluiten van de Kroon (I), (II) en (slot), TvO $1977,391-393,410-414$ en 437-441

- Nijholt (1987), H., Aanbestedingsrecht en aanbestedingspraktijk in de Nederlandse Euregio, Delft 1987

. Nijholt (1988), H., Aanbestedingsrecht en aanbestedingspraktijk in de Duitse Euregio, Delft 1988

. Nijholt (1989), H. De gevolgen van de gewijzigde EG-coördinatierichtlijn voor het Nederlandse aanbestedingsrecht, Maastricht/ 's-Gravenhage 1989

. Nijholt (1990), H., Het Uniforme Aanbestedingsreglement 1990. De artikelen in het UAR 1990 en de toelichting daarop, Maastricht 1990

Nijholt (1991), H., Het voorontwerp uniform aanbestedingsreglement-EG, Bouwrecht $1991,594-600$

Van Oppen - Van Oppen (1895), Eug. van Oppen en L. van Oppen, Nederlandse Pasicrisie, bevattende in alphabetische methode den zakelijken inhoud van alle in Nederland gewezen rechterlijke beslissingen en de chronologische lijst dier beslissingen, 
met opgave van al de verzamelingen van rechtspraak waarin zij gevonden werden, bewerkt door L.J. Veerman, Heusden 1895

Oppenheim, (1928 a), J., 'Het Nederlandsch Gemeenterecht', bewerkt door C.W. van der Pot Bzn., Deel I, Haarlem 1928

- Oppenheim $(1928 \mathrm{~b})$, J., 'Het Nederlandsch Gemeenterecht', bewerkt door C.W. van der Pot Bzn., Deel II, Haarlem 1928

Ottervanger en Nijhuis (1994), Ottervanger, T.R. en M.T. Nijhuis, Wijziging Wet economische mededinging ter vergroting van de effectiiteit, SEW 1994, 481-491

. Oud (1956), P.J. Oud, Handboek voor het Nederlands gemeenterecht, Deel I. Zwolle 1956

. Oud (1959), P.J., Gemeenterecht, Deel II, Zwolle 1959

. Oud (1970), P.J., Het constitutioneel recht van het Koninkrijk der Nederlanden, Deel II, Zwolle 1970

- Overleggroep Ordeningsthema's Aanbestedingswezen (1982), Naar een ordening op de bouwmarkt, Staatsuitgeverij, 's-Gravenhage 23 juni 1982

. Padoa-Schioppa (1987), Tommaso, Efficiency, Stability and Equity: a Report, New York 1987

. Pelganta (1981), R.J., De afstandsverklaring: erecode aangepast, Woningraad 23 januari 1981,9

. Polak (1952), J.M., Het opzetcontract, SEW 1952, 51-55

- Poortinga (1987), E., De scheiding tussen publiek- en privaatrecht bij Johan Rudolph Thorbecke (1798-1872). Theorie en toepassing, ac.prft. Rijksuniversiteit Utrecht, Nijmegen 1987

Pop, (1970), J.J.H., Inzicht in toezicht? Over goedkeuring van delegatiebesluiten, De Nederlandse Gemeente 1970, 213-215

. Van Praag (1966), M.M., Bouwrecht, Amsterdam 1966

- Pickup (1986), David M.W., Reverse Discrimination and Freedom of Movement for Workers, CMLRev. 1986, 135-156

. Pront-van Bommel (1993), S., Toetsen aan de beginselen van behoorlijk bestuur in arbitrage, in het bijzonder inzake aanbestedingsgeschillen, Bouwrecht 1993, 956-963

. Pijnacker Hordijk (1992 a), E.H., Tenuitvoerlegging van de nieuwe EG-richtlijnen inzake overheidsaanbestedingen binnen de Nederlandse rechtsorde, Bouwrecht 1992, 99117

Pijnacker Hordijk (1992 b), E.H., Wetsvoorstel Raamwet EEG-Voorschriften Aanbestedingen, Bouwrecht 1992, 678-680

Pijnacker Hordijk - Bel (1993), E.H. Pijnacker Hordijk - N.A.J. Bel, Jurisprudentiekroniek Hof van Justitie EG, Bouwrecht 1993, 685-694

Pijnacker Hordijk - Bel (1994), E.H. Pijnacker Hordijk - N.A.J. Bel, Jurisprudentiekroniek Hof van Justitie EG, Bouwrecht 1994, 656-664

. Randeraat (1994), Nico, 'Aantekening' op de gedecentralieerde eenheidsstaat, Bestuurswetenschappen 1994, 476-482

Rees (1994), Peter, Public Procurement in the Construction Industry, in: 1993, the European market: myth or reality?/ editors, Dennis Campbell, Charles Flint, Deventer $1994,169-188$ 
. Reich (1994), Norbert, The "November Revolution" of the European Court of Justice: Keck, Meng and Audi Revisited, CMLRev 1994, 459-492

. Van der Riet (1992), E.M.A., Rechtsbescherming voor aannemers onder het Europese aanbestedingsrecht, Bouwrecht 1992, 117-123

. Roth (1988), Wulf-Henning, The European Economic Community's Law on Services: Harmonisation, CMLRev. (1988), 35-94

. Rozemond (1976), J., Vormen van arbitrage en bindend advies en van burgerlijke, tuchten strafrechtspraak in de bouw, in: J.M. Polak, Th.G. Drupsteen, J. Rozemond, Vormen en beginselen van rechtspraak, zowel in het algemeen als in het bijzonder met betrekking tot het bouwrecht, Publikatie van de Vereniging voor Bouwrecht, nr. 4, Deventer 1976, 85-139

. Rozemond (1982), J., De emancipatie van de aannemer als contractspartij, in: Vijfenzeventig jaar Bouwarbitrage, 1907- 11 april - 1982, Gedenkboek van de Raad van Arbitrage voor de Bouwbedrijven in Nederland, Zwolle 1982, 89-120

. Rozemond (1984), J. Rozemond, Waarom geen hoger beroep in arbitrage?, TvA 84/5, 129-134

. Rozemond (1987), J. in: Beraadslagingen over het preadvies van J.W. van Nouhuys, Bouwrecht 1987, 92-101

Rozemond (1988), J., Het aannemings- en onderaannemingscontract, Bouwrecht 1988, 393-402

Rozemond (1989), J., Eenzijdige opzegging door de opdrachtgever onbeperkt mogelijk?, Bouwrecht 1989, 236-239

Sanders (1991), P., Overheidsopdrachten en arbitrage, TvA 91/6, 202-205

- Santen (1988), A.H.M., Aanbod en aanvaarding bij het kopen van een woning, Oratie Universiteit van Amsterdam 26 januari 1988, Deventer 1988

Van Schaick (1980), W.L., Het (sociaal) vestigingsbeleid van de gemeente Rotterdam. De praktijk van hantering van vestigingscriteria en van ons vergunningensysteem. Gst 6599 (1980), 159-160

. Scheltema (1982), M., Bestuursrecht: Is het bestuur wetgever in eigen zaak?, in: W.F. de Gaay Fortman, Problemen van wetgeving, Deventer 1982, 131-143

. Scheltema (1992), M., Een bijzondere positie voor de overheid in het overeenkomstenrecht? of: aandacht voor de bestuursrechtelijke overeenkomst?, WPNR 6074 (1992), 958-963

- Schlangen (1989), J.A.M., Overheidsopdrachten voor de uitvoering van werken, doct. sriptie Rijksuniversiteit Utrecht, Ministerie van Economische Zaken, 's-Gravenhage augustus 1989

Schroot (1979), J.C., M. van Vliet, N. Wijma, Begrip van de Nederlandse Gemeente, Deel III, Alphen aan den Rijn 1979

Schroot (1980), J.C., M. van Vliet, N. Wijma, Begrip van de Nederlandse Gemeente, Deel IV, Alphen aan den Rijn 1980

. Simon (1988), H.J., De directe toetsing getoetst, over publieke normen in het privaatrecht, Bouwrecht 1988, 2-12

. Simon (1992), H.J., De behartiging van het publieke belang door de overheid via de uitoefening van privaatrechtelijke bevoegdheden, in: Overheid en burgerlijk recht. De 
stand van zaken en perspectieven (F.J. van Ommeren, H.J. de Ru, H.J. Simon, B. Wessels), Zwolle 1992, 1-65

. Simon (1993), Henk, Publiekrecht of privaatrecht? een geschiktheidsonderzoek aan de hand van het nutsmaximalisatiebeginsel toegespitst op het gebruik van het privaatrecht door het bestuur, ac. prft. Vrije Universiteit Amsterdam, Zwolle 1993

Sikkes (1967), J.H., Beknopt leerboek voor het gemeenterecht, bew. door A. Zadel en F.A. Helmstrijd, Alphen aan den Rijn, 1967

. Slagter (1975 a), W.J., Mededingingsrecht in de bouw!, Bouwrecht 1975, 230-257

Slagter (1975 b), W.J., Mededingingsrecht in de bouw (II), Bouwrecht 1975, 571-585

Slagter (1986), W.J., Aanbestedings- en mededingingsrecht in de bouw, in: J.W. van Nouhuys, W.J. Slagter. M.-A. Flamme, Aanbestedings- en mededingingsrecht in de bouw, Preadvies voor de Vereniging voor Bouwrecht, nr. 14, Deventer 1986, 57-155

. Slagter (1987), W.J., Beantwoording door Prof. Mr. W.J. Slagter, in: Beraadslagingen over het preadvies van Prof. Mr. W.J. Slagter, Bouwrecht 1987, 101-109

- Slagter (1988), W.J., Het uniform prijsregelend reglement voor onderhandse prijsaanbiedingen en voor prijsaanbieding bij openbare aanbesteding, Bouwrecht 1988, 161-170

- Slagter (1993), W.J. Alternatieven voor een verboden prijsregeling in de bouw, Bouwrecht 1993, 13-25

. Smit (1977), D.H., Interventie, Bouwrecht 1977, 13-15

Smit - Herzog (1976), Smit, Hans and Peter Herzog, The law of the European Community: A commentary on the EEC Treaty, Deel I, New York 1976 -.. (losbl.)

Snijders (1988), W., Artikel 3.1.1.15 NBW en de schakelbepalingen nader bezien, Bestuursrecht en Nieuw BW, Juvat-bundel 1988, 49-69

- Spier (1981), J., Overeenkomsten met de overheid, ac.prft. Rijksuniversiteit Leiden, Deventer 1981

. Spier (1993), J., Hoe bijzonder is (de positie van) de overheid? HR 24 april 1992, NJ 1993, 232 MS (Zeeland/ Hoondert), NTBR 1993, 125-127

Stam, G.S., Boycotacties tegen bouw rakettenbasis onhoudbaar, De Nederlandse Gemeente 1986, 734-735

Steenbeek (1958), J.G., Rechtshandeling en rechtsgevolg in het staats- en administratiefrecht, ac.prft. Rijksuniversiteit Utrecht, Arnhem 1958

Steenlant - Vanhees (1978), J. Steenlant en H. Vanhees, Vrije vestiging en dienstverlening in de verzekeringssector. De arresten van 28 januari en 4 december 1986 van het Hof van Justitie, RW 1987-1988, 105-118

Stroink (1979), F.A.M., Rechtshandeling naar burgerlijk recht en/ of AROB-beschikking?, TvO 1979, 391-395 en 423-427

Stroink (1987), F.A.M., Bestuursrecht in de sociale rechtsstaat door Prof. Mr. P. de Haan, Prof. Mr. Th.G. Drupsteen en Mr. R. Fernhout m.m.v. Mw. Mr. C.S. Valkenburg. Bespreking van deel II, Bestuurshandelingen en waarborgen, Bouwrecht 1987, 280282

Stuyck - Geens (1993), Stuyck, J. en K. Geens, Vrij verkeer van advocaten in de EEG, SEW 1993, 111-139

Stroink - De Waard (1984), F.A.M. Stroink en B.W.N. de Waard, Het specialiteitsbeginsel, in: M.C.B. Burkens, R. Crince Le Roy (red.), Burger en overheid. Opstellen bij het afscheid van prof. mr. J.G. Steenbeek als hoogleraar aan de Utrechtse Rechtenfaculteit, 's-Gravenhage 1984, 231-256 
- Swann (1992), The Single Market and Beyond, A Study of the Wider Implications of the Single Market (Dennis Swann ed.), London 1992

. Tak (1989), A.Q.C., Terugtocht van twee-wegen, NTB 89/9/10, 297-314

. Tak (1993), A.Q.C., Overheid en Burgerlijk Wetboek. Naar een invullende rechtsleer, Recht en Kritiek 1993, 174-190

. Tak (1994), A.Q.C., De nieuwe van Wijk/ Konijnenbelt, NTB 94/6, 165-177

Van der Tang-van Loenen (1990), P.H., Inventarisatie spontane vernietigingsbesluiten van de Kroon, 1987-1988-1989, Gst 6912 (1990), 525-529

. Van der Tang-van Loenen (1993), P.H., Inventarisatie spontane vernietigingsbesluiten van de Kroon 1990-1991-1992, Gst 6966 (1993), 277-283

. Thorbecke (1843), J.R., Aanteekening op de Grondwet, tweede deel, tweede uitgave, Amsterdam 1843

. Thunnissen (1982), H.O., Vijfenzeventig jaar Bouwarbitrage 1907 - 11 april - 1982. Gedenkboek van de Raad van Arbitrage voor de Bouwbedrijven in Nederland, Bouwrecht $1982,468-472$

. Timmermans (1980), C.W.A., EEG-harmonisatie en Nederlands recht: een beeld van bewogen beweging, RM Themis 1980, 406 e.v.

. Tonnaer (1982), F.P.C.L., Wikken en beschikken, Zwolle 1982

- Verhey (1987). N., Onrechtmatige overheidsdaad en beginselen van behoorlijk bestuur: de Hoge Raad toetst eindelijk rechtstreeks, NJB 1987, 1309-1315

- Verjans (1987), J., Aanbestedingsrecht en aanbestedingspraktijk in de Belgische Euregio, Delft 1987

. VerLoren van Themaat (1975), P., EEG en bouwbedrijf, Bouwrecht 1975, 261-272

Verplanke (1987), C.J., Nationale taken voor gemeenten?, De Nederlandse Gemeente $1987,72-73$

. Versteden (1985), C.J.N., Het falende gelijkheidsbeginsel, in: Het gelijkheidsbeginsel in het administratieve recht, VAR XC.II, Alphen aan den Rijn, 57-99

- Vervaele (1993), Bestuursrechtelijke toepassing en handhaving van gemeenschapsrecht in Nederland, onder red. van: J.A.E. Vervaele, Deventer 1993 (Europese monografiën; 41)

. Vignes (1990), Daniel, The Harmonisation of National Legislation and the EEC, European Law Review 1990, 358-374

- Vis (1980), B.C., m.m.v. J.J.A. Woldring, Naar één gemeentewet, Uniformerende regelingen 1798-1850 voorafgaande aan de Gemeentewet 1851, Zwolle 1980

- Visser (1986), B.L.W., Toezicht in bestuurlijke rechtsverhoudingen, ac.prft. Rijksuniversiteit Groningen, Deventer 1986

. Van der Vlies (1990), I.C., Meer recht in de zin van art. 99 Wet RO, NJB 1990, 11471151

. Vreugdenhil (1982), J.J., Wijziging Erecode AVBB kan woningbouw vertragen, De Nederlandse Gemeente 1982, 203-204

. De Vries (1931), C.W. en G.A. van Poelje, Bronnen tot de kennis van de gemeentewet verzameld en ingeleid door prof.mr. C.W. de Vries en van aanteekening voorzien door prof.mr. G.A. van Poelje, Rotterdam 1931

- De Vries (1990), G.J.P., De opzegging van obligatoire overeenkomsten, ac,prft. Universiteit van Amsterdam, Zwolle 1990 
Van Vugt (1984), P.A., Paternalisme gemeentebesturen. Uitsluiten vin hedrijven strijdig met de Grondwet, Binnenlands bestuur 4 mei 1984, 27

Van Wassenaer (1990), A.G.J., Hoe de aanbesteding is geregeld. Een kwestie van vraag, aanbod en aanvaarding. Beschouwingen over de invloed van aanhestedingsprocedures op precontractuele verhoudingen en de contracteervrijheid, Reeks Studiekring Drion, Geschrift no. 9, Deventer 1990

Van Wassenaer (1993 a), A.G.J., The day after the battle of Brittan ... of Horizontale wegen naar een alternatief mededingingsstelsel?, Bouwrecht 1993, 44-54

. Van Wassenaer (1993 b), A.G.J., De ontwikkelende overheid en de bouw na de richtlijn werken (71/305/EEG) en de EG-richtlijn diensten (92/50/EEG). Naschrift bij "De Reikwijdte van de EEG-Richtlijn 71/305", Bouwrecht 1993, 588-594

Wedekind (1990 a), W., Bouwrecht op weg naar "1992", Bouwrecht 1990, 811-821

Wedekind $(1990 \mathrm{~b}), \mathrm{W}$., Een interessante casus betreffende overheidsopdrachten in de EEG: de zaak commissie VS Denemarken (zaak 243/89R), Bouwrecht 1990, 14-17

Wedekind (1992), W., Enige hoofdzaken van de richtlijn "werken" vergeleken met de richtlijn "uitgesloten sectoren" en de interpretatie-problematiek daarbij, Bouwrecht 1992. 87-93

. Wedekind (1993), W., Zwart, wit of grijs bij overheidsopdrachten voor de uitvoering van werken, Bouwrecht 1993, 503-509

- Weiss (1993), Friedl, Public Procurement in European community law (European Community law series; 4), London 1993

Van Werven (1985), D.E., Berechting van aanbestedingsgeschillen door de Raad van Arbitrage voor de Bouwbedrijven? Het voorontwerp Uniform Aanbestedingsreglement 1985, TvA $85 / 2,42-49$

Van Werven (1986), D.E., Uniform Aanbestedingsreglement 1986, Bouwrecht 1986, 658-661

- Van Werven (1992), D.E., Aanbestedings- en mededingingsrecht, in: Bouwrecht in kort bestek, P. de Haan, M.A. van Voorst van Beest, A.G. Bregman (red.), Deventer 1992, 216-233

Wessel (1977), J., Beleidsovereenkomsten en andere afspraken in de publieke sfeer, in: Beleidsakkoorden, Staatsrechtconferentie 12 februari 1977 (preadvies), Utrecht, 233-313

Wessels (1994), B., Juridische aspecten van opdrachtneming in de bouwpraktijk, Bouwrecht 1994, 909-913

Wiarda (1952), G.J., Algemene beginselen van behoorlijk bestuur, Geschriften van de Vereniging voor Administratief Recht XXIV, Haarlem 1952, 55-94

De Wilde (1994), E.L.H., Modemisering van het Nederlandse vestigingsheleid. Is het gemodemiseerde beleid Europeesrechtelijk gezien, wel modern genoeg?, SEW 1994, 775799

Winter (1981), J.A., Nationale steunmaatregelen en het gemeenschapsrecht: een onderzoek naar de uitlegging en toepassing van de artikelen $92 \mathrm{t} / \mathrm{m} 94$ van het EEGverdrag, ac.prft. Rijksuniversiteit Leiden, Europese Monografiën nr. 29, Deventer 1981

Winter (1991), Jan A., Public procurement in the EEC, CMLRev 1991, 741-782

Winter (1992), J.A., Aanbestedingen in Nederland in Europees perspectief, in: De BV Nederland op de interne markt, 's-Gravenhage 1992, 26-36 


\section{Literatuur}

. Van Wijk/ Konijnenbelt (1991), H.D. van Wijk, Hoofdstukken van administratief recht, bewerkt door Willem Konijnenbelt, Utrecht, 1991

- Van Wijk - Konijnenbelt - Van Male (1994), H.D. van Wijk, Hoofdstukken van administratief recht, bewerkt door Willem Konijnenbelt en Ron M. van Male, Utrecht, 1994

- Van Wijngaarden (1985), M.A., Het Voorontwerp Uniform Aanbestedingsreglement 1985, Bouwrecht 1985, 261-270

. Van Wijngaarden (1986), M.A., Wijziging van de statuten van de Raad van Arbitrage in verband met de inwerkingtreding van het Uniform Aanbestedingsreglement 1986, Bouwrecht 1986, 728-732

. Van Wijngaarden (1989), M.A., Een hele verbouwing: veranderingen in het bouwrecht in de tweede helft van de jaren '80. Afscheidscollege Rijksuniversiteit Leiden, Zwolle 1989

. Wijzenbroek (1988), Willy, Kunnen gemeenten zelfstandig buitenlands beleid voeren?, Bestuur 1988, 48-52

. Wyatt - Dashwood (1993), Wyatt, D. and A. Dashwood, European Community Law, London 1993

Zonderland (1959), P., Het aanbestedingswezen, SEW 1959, 66-82

. Zonderland (1974), P., Methode van het privaatrecht, Amsterdam 1974

Zonderland (1975), P., Precontractuele verhoudingen in de bouw en het z.g. economisch bouwrecht, Bouwrecht 1975, 257-261

Zijlstra (1994), S.E., Convenanten, Preadvies voor de Vereniging voor de vergelijkende studie van het recht in België en Nederland, Zwolle 1994 


\section{Jurisprudentieregister}

\section{Europees Hof van Justitie}

\begin{tabular}{|c|c|}
\hline $26 / 62$ & 5 februari 1963, Jur. 1963, 5 (Van Gend \& Loos) 17 \\
\hline $75 / 63$ & 19 maart 1964, Jur. 1964, 177 (Hoekstra) 133 \\
\hline 90 en $91 / 63$ & 13 november 1964, Jur 1964, 1277 (Zuivelprodukten) 17 \\
\hline $6 / 64$ & 15 juni 1964, Jur 1964, 1203 (m.n. 1218) (Costa/ENEL) 17 \\
\hline $7 / 68$ & 10 december 1968, Jur. 1968, 589 (Commissie v. Italië) 147 \\
\hline en $11 / 69$ & $\begin{array}{l}10 \text { december 1969, Jur. 1969, } 523 \text { (Frans preferentieel herdisconto- } \\
\text { tarief) } 137\end{array}$ \\
\hline 170 & $\begin{array}{l}17 \text { december } 1970 \text {, Jur. 1970, } 1125 \text { v. (Internationale Handels- } \\
\text { gesellschaft) } 134\end{array}$ \\
\hline 74 & 21 juni 1974, Jur. 1974, 631 (Reyners) 139 \\
\hline 74 & 11 juli 1974 , Jur. 1974, 837 v. (Dassonville) 138,142 \\
\hline$/ 74$ & 3 december 1974, Jur. 1974, 1299 (Van Binsbergen) 139, 145, 148 \\
\hline 174 & 4 december 1974, Jur. 1974, 1337 (Van Duyn) 134 \\
\hline$/ 75$ & 28 oktober 1975, Jur. 1975, 1219 (Rutili) 134 \\
\hline 1775 & 8 april 1976, Jur. 1976, 455 (Defrenne II) 18 \\
\hline 176 & 28 april 1977 , Jur. 1977,765 (Thieffry) 18 \\
\hline$/ 77$ & 27 oktober 1977, Jur. 1977, 1999 (Bouchereau) 134 \\
\hline $0-111 / 78$ & 18 januari 1979 , Jur. 1979,35 (Van Wesemael) $143,144,148$ \\
\hline $5 / 78$ & 7 februari 1979, Jur. 1979, 399 (Knoors) 141 \\
\hline $0 / 78$ & $\begin{array}{l}20 \text { februari 1979, Jur. 1979, } 649 \text { (Cassis de Dijon; Rewe) 142, } 143 . \\
146\end{array}$ \\
\hline $8 / 78$ & 5 april 1979 , Jur. 1979,1629 (Ratti) 88 \\
\hline 179 & 18 maart 1980, Jur. 1980, 833 (Debauve; Teledistributie) 142 \\
\hline 179 & 18 maart 1980, Jur. 1980, 881 (Coditel I) 145 \\
\hline $9 / 80$ & 17 december 1981, Jur. 1981, 3305 (Webb) 143, 144, 145, 149 \\
\hline$-63 / 81$ & 3 februari 1982, Jur 1982, 223 (Seco) 145, 143, 147, 149 \\
\hline 181 & $\begin{array}{l}10 \text { februari 1982, Jur. 1982, } 417 \text { (Transporoute) 17, 120, 123, 129, } \\
148\end{array}$ \\
\hline $16 / 81$ & 18 mei 1982 , Jur. 1982,1665 (Adoui) 134 \\
\hline $7-178 / 82$ & 5 april 1984, Jur. 1984, 1797 (Van de Haar) 138 \\
\hline $6 / 82$ en $26 / 83$ & 31 januari 1984, Jur. 1984, 377 (gevoegd) (Luisi en Carbone) 142 \\
\hline $7 / 83$ & 12 juli 1984, Jur. 1984, 2971 (Klopp) 143 \\
\hline $0 / 83$ & $\begin{array}{l}4 \text { december 1986, Jur. 1986, } 3663 \text { (Commissie vs. Frankrijk) } 144 \text {, } \\
145,148\end{array}$ \\
\hline $252 / 83$ & $\begin{array}{l}4 \text { december 1986, Jur. 1986, } 3713 \text { (Commissie vs. Denemarken) } 144 \text {, } \\
145,148\end{array}$ \\
\hline $269 / 83$ & 14 maart 1985, Jur. 1985, 837 (Commissie v. Frankrijk) 138 \\
\hline $74 / 83$ & 28 maart 1985, Jur. 1985, 1077 (Commissie v. Italië) 123 \\
\hline $103 / 84$ & 5 juni 1986, Jur. 1986 (1759) (Commissie v. Italië) 137, 138 \\
\hline $205 / 84$ & $\begin{array}{l}4 \text { december 1986, Jur. 1986, } 3755 \text { (Commissie v. Duitsland) } 144 \text {, } \\
145,146,148\end{array}$ \\
\hline
\end{tabular}


$206 / 84$

$298 / 84$

$199 / 85$

$352 / 85$

$27-29 / 86$

$37 / 86$

$147 / 86$

222/86

292/86

$31 / 87$

$45 / 87$

$196 / 87$

204/87

C. $-3 / 88$

$5 / 88$

C- $21 / 88$

103/88

C- $351 / 88$

113/89

C- $154 / 89$

C- $180 / 89$

198/89

C- $243 / 89$

C-260/89

C. $-288 / 89$

$295 / 89$

$340 / 89$

C- $353 / 89$

C $-360 / 89$

C- $2 / 90$

C-76/90
4 december 1986, Jur. 1986, 3817 (Commissie v. Ierland) 144, 145, 148

23 januari 1986, Jur. 1986, 247 (Iorio Paolo v. Azienda Autonome della Ferrovie dello Stato) 134

10 maart 1987, Jur. 1987, 1039 (Commissie v. Italië) 95

26 april 1988, Jur. 1988, 2085 (Bond van Adverteerders) 141

9 juli 1987, Jur. 1987, 3347 (CEI en Bellini) 119, 120, 121, 122, $127-128$

24 september 1987, Jur. 1987, 3589148

15 maart 1988, Jur. 1988, 1637 (Commissie v. Griekenland) 141

15 oktober 1987, Jur. 1987, 4097 (Heylens) 141

19 januari 1988, Jur. 1988, 131 (Gullung) 141, 143

20 september 1988, Jur. 1988, 4635 (Gebroeders Beentjes BV/ Nederland) $17,119,121,122,124,126,127,128,129,131,132$, $133,139,149$

22 september 1988, Jur. 1988, 4929 (Dundalk) 92, 93, 94, 95, 138

5 oktober 1988, Jur. 1988, 6159 (Steymann) 140

20 april 1988, Jur. 1988, 2029 (Bekaert) 142

5 december 1989, Jur. 1989, 4035 (Commissie v. Italië) 141

13 juli 1989, Jur. 1989, 2609 (Wachauf) 141

20 maart 1990, Jur. 1990, 889 (Du Pont de Nemours) 130, 138

22 juni 1989, Jur. 1989, 1839 (Fratelli Costanzo) 123

11 juli 1991, Jur. 1991, 3641 (Laboratori Bruneau) 138

27 maart 1990, Jur. 1990, 1417 (Rush Portugesa Lda/ Office national d'immigration) $135,139,145,148,149$

26 februari 1991, Jur. 1991, 659 (Commissie v. Frankrijk; toeristengidsen) $135,144,145,148$

26 februari 1991, Jur. 1991, 709 (Commissie v. Italië; toeristengidsen) $135,144,145,148$

26 februari 1991, Jur. 1991, 727 (Commissie v. Griekenland; toeristengidsen) $135,144,145,148$

22 juni 1993, Jur. 1993, 3385 (Commissie v. Denemarken; Storebaelt) 93

18 juni 1991, Jur. 1991, 2925 (Elliniki Radiophonia Tileorassi AE/ Dimotiki Etairia Pliroforissis en S. Kouvelas) 141

25 juli 1991, Jur. 1991, 4007 (Stichting Collectieve Antennevoorziening Gouda e.a./ Commissariaat voor de Media) 142, 144, 145

18 juni 1991, Jur. 1991, 2967 (Impresa Dona Alfonso \& Figli s.n.c.t. Corsorcione per lo sviluppo industrale del Commune di Malfacone (CSI) e.a.) 123

7 mei 1991, Jur. 1991, 2357 (Vlassopoulou) 140

25 juli 1991, Jur. 1991, 4069 (Mediawet; Commissie v. Nederland) $141,144,145,148$

3 juni 1992, Jur. 1992, 3401 (Commissie v. Italiē) 129-131

9 juli 1992, Jur. 1992, 4431 (Waalse afvalstoffen) 143

25 juli 1991, Jur. 1991, 4221 (Säger) $144,146,148$ 
C- $159 / 90$

C- $362 / 90$

C-24/91

106/91

C-267 en 268/91

C-272/91

C-71/92

C-107/92

C- $275 / 92$

C-296/92

$331 / 92$

C- $375 / 92$

$389 / 92$

C-43/93
4 oktober 1991 Jur. 1991, 4685 (Grogan) 147

31 maart 1992, Jur. 1990, 2353 (Commissie v. Italië) 121

18 maart 1992, Jur. 1992, 1989 (Commissie v. Spanje) 95, 96

20 mei 1992, Jur. 1992, 3351 (Ramrath) 148

(gevoegd) 24 november 1993, Jur. 1993, 6097 (Keck en Mithouard) 143

26 april 1994, Jur. 1992, 1409 (Commissie v. Italië) 99, 141

17 november 1993, Jur. 1993, 5923 (Commissie v. Spanje) 92, 120. 121,129

2 augustus 1993, Jur. 1993, 4655 (Commissie v. Italië) 95, 96, 173

24 maart 1994, Jur. 1994, 1039 (Schindler) 144, 145

12 januari 1994, Jur. 1994, 1 (Commissie v. Italië) 95

19 apri] 1994, Jur. 1994, 1329 (Gestión Hotelera Internacional SA v.

Communidad Autónoma de Canarias c.s.) 92

22 maart 1994, Jur. 1994, 923 (Commissie v. Spanje) 140, 148

14 april 1994, Jur. 1994, 1289 (Ballast Nedam Groep v. België) 5

9 augustus 1994, Jur. nog niet gebonden (Vander Elst v. Office des migrations internationales) 135

President van het Europees Hof van Justitie

45/87-R 13 maart 1987, Jur. 1987, 1369 (Dundalk) 96

194/88-R 27 september 1988, Jur. 1988, 5647 (Commissie v. Italië; La Spezia) 95, 173

C-87/94-R 22 april 1994, Jur. 1994, 1395 (Commissie v. België; Waalse bussen) 94

(President) Gerecht van Eerste Aanleg

T-29/92-R $\quad 16$ juli 1992, Jur. 1992, 216115

T 29/92 21 februari 1995, BR 1995, 333 (SPO/ Europese Commissie) 15, 167

Europese Commissie

5 februari $1992 \quad$ IV/31.572 en 32.571 - Bouwnijverheid in Nederland, Pb 7 april 1992. Nr. L $92 / 1$ (92/204), BR 1992, 4767,15

Koninklijke Besluiten

1 oktober 1856 ,

25 augustus 1881

9 september 1881

6 november 1882

4 augustus 1886

2 juli 1890

13 juni 1891
S. 1856,9166

S. 1881,15244

S. 1881,154 (Veere) 55

nr. 17 , WBA 1883,175856

nr. 1657

WBA 1890,215455

nr. 25, WBA 1891, 221056 
Jurisprudentie

26 mei 1909

Gst 1909, 301357

22 april 1924

Gst 1924, 3795 57, 58

26 oktober 1951

nr. 14, ARB 1952, p. 15259

18 december 1973

nr. $18, A B$ 1975, 6 (Pieterskerk) 181

28 juli 1976

nr. 68, AB 285168

26 oktober 1978

24 maart 1981

nr. 33, AB 1979, 138168

2 februari 1982

nr. 9, AB 1981, 397168

9 januari 1987

nr. 7, AB 1982, 228168

22 december 1988

17 januari 1990

S. 1987,11 (Arnhem) 32, 33, 68-69, 71, 146

15 mei 1990

S. $675, \mathrm{AB} 1989,490$, Gst 1989, 6871 (Hilversum) 69

28 december 1990

S. 1990 , nrs. $65-7869$

S. 1990 , nrs. $309-31469$

3 maart 1992

1991, nrs. 23-37 69-70

S. 1992,122 (Herten) 67

(Voorzitter) Afdeling Rechtspraak van de Raad van State

2 februari 1978 AB 209 (Ridderborgh BV/ Raad van de gemeente Culemborg) 184

11 april 1983 nr. R 01.83.042/s41 184

16 november 1984 AB 1985, 384184

5 juni 1991

AB 1992, 444168

(Voorzitter) Afdeling bestuursrechtspraak van de Raad van State

14 oktober 1994 Jb 1994, 293185

\section{Hoge Raad}

14 mei $1856 \quad$ W. 1857,187164

7 juni $1864 \quad$ W. 1864,259966

22 november 1918 NJ 1919, p. 4211

8 juni 1923

NJ 1923, p. 1031 (Foppe Kalt/ Prins) 11

1 mei 1924

NJ 1924, p. 85611

13 januari 1927

NJ 1927, p. 279 (Gembo/ Prins) 11

4 november 1927

14 januari 1949

NJ 1928, p. 25411

25 februari 1949

31 maart 1953

NJ 1949, 557 (Zandvoortse woonruimtevordering) 30

15 november 1957 NJ 1958, 67 (Baris/ Riezenkamp) 26, 31

4 januari $1963 \quad$ NJ 1964, 202-204 (Landsmeer) 30

19 december 1969 NJ 1970, 154 (Lindeboom/ Amsterdam) 2

28 februari 1975 NJ 1975, 423 (Parochiehuis Woerden) 67

16 januari 1981

NJ 1981,42630

13 maart 1981

NJ 1981, 346 (Den Haag/ Van Beveren) 31

15 juni 1981

NJ 1982, 85 (Stuyvers' Beheer/ Eugster) 27

18 juni 1982

NJ 1983, 723 (Plas/ Valburg) 30 
31 mei 1985

27 maart 1987

23 oktober 1987

12 januari 1990

15 maart 1991

10 januari 1992

24 april 1992

5 februari 1993

22 oktober 1993

18 februari 1994

14 oktober 1994

Gerechtshoven

Arnhem

's-Gravenhage

Den Bosch

's-Hertogenbosch
NJ 1985, 648 (Staat/ Hasler) 26-27, 77, 82, 84, 162, 163

NJ 1987, 727 (Amsterdam/Ikon) 30, 32, 70, 146, 154, 158

NJ 1988, 1017 (VSH/ Shell) 27

NJ 1990, 766 (Staat/ Appels) 30

NJ 1991, 396 (Körfer/ Heerlen) 30, 32, 154

NJ 1992, 670 (Scheffers Bouwmaterialen) 164

NJ 1993, 232 (Zeeland/ Hoondert) 31-32

AB 1993, 23973

AB 1994, 1 (Staat/ Magnus) 153

AB 1994, 415 (Kabayel) 153

AB 1995, 48 (Wrakkenwet) 153

Arrondissementsrechtbanken

Heerenveen 26 juni 1861, W. 1861, 230939

's-Hertogenbosch 29 januari 1892, W. 1892, 614156

Middelburg 29 februari 1888, W. 1888561439,40

Breda $\quad 18$ mei 1976, BR 1978,15110

Zuthpen 18 oktober 1979, BR 1980, 3610

Haarlem 2 september 1986, AB 1987, 276184

Maastricht 24 december 1987, BR 1988, 389 (gem. Meerssen/ Kunicon) 93

Rotterdam 23 oktober 1992, BR 1993, 8415

Assen 19 augustus 1994, BR 1994, 921185

\section{President arrondissementsrechtbank}

's-Gravenhage

Roermond

Leeuwarden

's-Gravenhage

Middelburg

's-Gravenhage

's-Gravenhage
26 januari 1983, BR 1986, 788 30, 84, 104, 114

18 augustus 1983, BR 1984, 162, KG 1983, nr. 27230

5 oktober 1983, BR 1984, 74115

22 januari 1986, AB 1987, 85 (Stassen/ Delft) 32

8 november 1990, BR 1991, 40831

16 juli 1993, BR 1993, 92883

1 juli 1994, Jb 1994, 200186

Raad van Arbitrage voor de Bouwbedrijven in Nederland

25 oktober 1973 BR 1973, 124-12680 
1 maart 1984

31 maart 1987, nr. 12.753

26 mei 1987 , nr. 12.820

28 juli 1987, nr. 12.927

20 november 1987 , nr. 13.079

11 maart 1988, pr. 13.221

27 juni 1988, nr. 12.930

29 juni 1988, nr. 13.092

14 juli 1988 , nr. 13.444

9 januari 1989, nr. 13.693

26 januari 1989 , nrs. 13.074 en 13.713 (gevoegd)

3 maart 1989, nr. 13.774

23 maart 1989, nr. 13.509

26 mei 1989 , nr. 13.900

26 mei 1989, nr. 13.902

2 juni 1989, nr. 13.359

1 augustus 1989 , nr. 14.011

17 oktober 1989 , nr. 12,930

7 november 1989 , nr. 13.932

8 november 1989 , nr. 13.743

9 november 1989 , nr. 14.077

16 januari 1990 , nr. 13.665

14 maart 1990, nr. 14.377

2 mei 1990 , nr. 14.468

5 juli 1990 , nr. 14.563

31 juli 1990 , nr. 14.615

25 oktober 1990 , nr. 13.540

11 januari $1991, \mathrm{nr} .14 .786$

1 februari 1991, nr. 70.023 (appèl)

11 februari 1991, nrs. 14.903

en 14.904

12 februari 1991 , nr. 14.876

9 april 1991, nr. 15.008

18 april 1991, nr. 15.045

16 mei 1991 , nr. 70.010 (appè)

21 mei 1991, nr. 14.661

19 juli 1991, nr. 15.201

8 augustus 1991, nr. 15.215

15 oktober 1991, nr. 70.029 (appèl)

4 december 1991, nr. 15.494
BR 1989, 8592,80

BR 1987, $55025,26,109$

BR 1987, $623107,111,112$

BR 1987, 79381

BR 1989, 483 105, 108

BR 1988, 787111

BR 1989, $7126,81,112$

BR 1989, 86289

BR 1988, 790107,108

BR 1989, 55081,111

BR 1989, 552 81, 82, 111

BR 1989, $71581,83,113,115,178$

BR 1989, $718106,111,116$

BR 1989, 720113

BR 1989, 722113

BR 1989, 865106,111

BR 1990, 6325,82

BR 1990, 22826

BR 1990, 312 109, 111

BR 1990, 314107,111

BR 1990, 230113

BR 1990, $64425,81,85$

BR 1990, 566107,110

BR 1990, $783107,109,110,111$

BR 1991, 23881,114

BR 1991, 314111

BR 1991, 316111

BR 1991, 561111

BR 1991, 49581,111

BR 1991, 644107,108

BR 1991, 49981

BR 1991, 79884

BR 1991, 564107

BR 1991, $799113,114,167$

BR 1991, 802114

BR 1991, 804111

BR 1992, 243111

BR 1992, 160111

BR 1992, 341116 
8 januari 1992, nr. 15.419

22 januari 1992, nrs. 70.030 en 70.032

23 januari 1992, nr. 70.038

11 februari 1992 , nr. 14.857

4 maart 1992, nr. 14.940

12 mei 1992 , nr. 15.775

2 juni 1992, nr. 15.780

2 juni 1992, nr. 15.782

8 juli 1992, nr. 15.881

19 juni 1992 , nr. 15.821

15 juli 1992, nr. 15.798

7 april 1993, nr. 15.982

6 juli 1993, nr. 16.599

13 juli 1993, nr. 16.472

16 juli 1993, nr. 16.549

10 augustus 1993 , nr. 16.686

12 augustus 1993 , nr. 16.695

17 augustus 1993 , nr. 16.696

29 oktober 1993, nr. 16.839

10 november 1993 , nr. 15.674

25 april 1994, nr. 17.113

28 april 1994, nr. 17.106

20 juni 1994, or. 17.264

23 september 1994, nr. 17.422

10 oktober 1994, nr. 17.458

16 maart 1995, nr. 17.776

Belgische Raad van State

4 juni 1986

12 april 1989

11 oktober 1988

16 oktober 1990

22 mei 1991

1 oktober 1991

19 mei 1992
BR 1992, 879108

BR 1992, 422 106, 107, 111

BR 1992, 881107

BR 1992, 887108

BR 1993, 152 107, 108

BR 1992, 94483,106

BR 1992, 794 81, 105

BR 1992, 796115

BR 1993, 156106

BR 1993, 153167

BR 1993, 15785

BR 1993, 1006107

BR 1994, 155106,117

BR 1994, 157108

BR 1993, 1007107

BR 1994, 1044107

BR 1993, 92981

BR 1993, 100981,107

BR 1994, 8388

BR 1994, 354 110, 111

BR 1994, 70787

BR 1994, 710108

BR 1994, 104684

BR 1995, 622117

BR 1995, 166108

BR 1995, 796109

TvAan. 1989, 143123

TvAan 1990, 140188

TvAan. 1991, 126171

RW 1991, 813174

RW 1992, 94189

TvAan. 1992, 23685

TvAan. 1992, 24285 



\section{Trefwoordenregister}

verwezen wordt naar pagina's

\section{Aanbestedingsbegrip 36}

$\approx$ besluitkarakter 181

in de gemeentewet $47,52,57 v ., 61-62$

v. opdrachtverlening 1

v. openbaar aanbod 2

v. overheidsopdrachten voor de uitvoering van werken 3,97

v. uitgifte van bouwwerken 3

Aanbestedingsbeleid 29, 34v., $157 v$.

$\approx-$ en algemene beginselen van behoorlijk bestuur $32 \mathrm{v} ., 116,156,179$

$\approx-$ en derden 156

$\approx$ algemeen belang-toets 155

$\approx$ beleidsgrondslag $47 \mathrm{v} ., 59,151 \mathrm{v}, 157 \mathrm{v}$.

$\approx$ bestuursrechtelijk uitgangspunt $33,152 \mathrm{v}$., $177 \mathrm{v}$.

$\approx$ Europese beleidscoördinatie $119 \mathrm{v}$.

$\approx$ marktbeleid 107

$\approx$ normatief beleidskader $153 \mathrm{v} ., 157,171,179$

$\approx$ plaatselijke omstandigheden 60

$\approx$ regionale en sociale aspecten overheidsaanbesteding $132 \mathrm{v}$.,

147

$\approx$ schorsing en vernietiging door de Kroon $65-67$

$\approx$ structuurbeginselen $158 \mathrm{v}$., $160 \mathrm{v}$

$\approx$ toetsing door arbiters $106 \mathrm{v}$.

$\approx$ vaste beleidslijnen; beleidsregels $160 \mathrm{v} ., 172$

$\approx$ werkgelegenheid en 'andere' beleidsuitgangspunten $32,34,65,70-72,128 \mathrm{v} ., 132$, $134,147,168$

$\approx$ zie ook: aanbestedingsovereenkomst

$\approx$ zie ook: Aanvullende voorwaarde

$\approx$ zie ook: Bouwmarktstructuur

Aanbestedingsbevoegdheid 37v., 63, $155 v$.

$\approx$ ontwerp-De Kempenaer 38, 49-50, 52, 53

$\approx$ stedelijke en plattelandsreglementen $48-49$

Aanbestedingsovereenkomst

$\approx$ beleidsaspecten 29

$\approx$ beleidsinstrument $35,151 \mathrm{v}, 154$

$\approx$ inhoud 4

$\approx$ ontstaan 28

$\approx$ rechtskarakter $25 \mathrm{v}, 29,179 \mathrm{v}$.

Aanbestedingspraktijk 61, 92

$\approx$ behoefte aan aanbestedingsbeleid 34,179

$\approx$ beperkte aanbesteding 58-59 


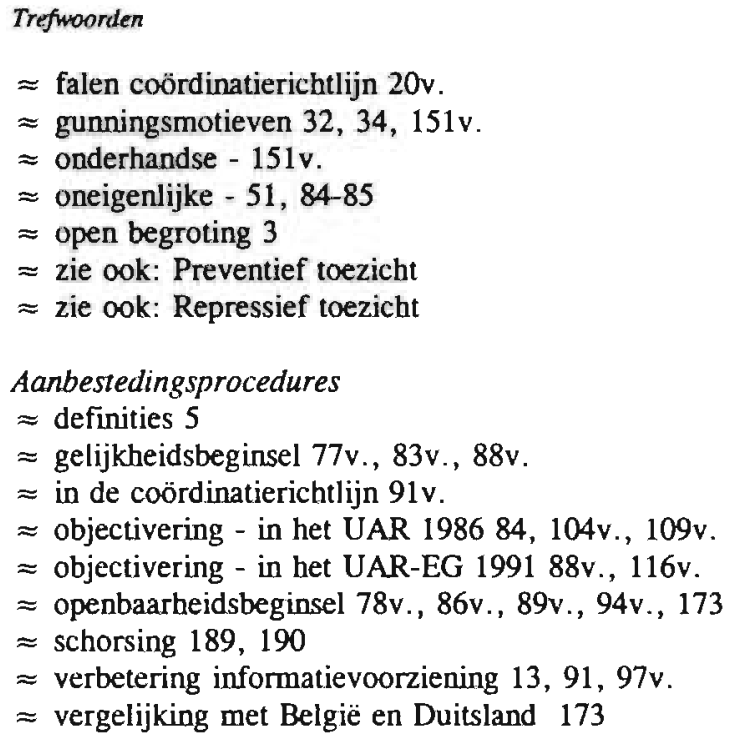

Aanvullende voonwaarde 157, 168, 170

$\approx$ eisen aan - 139v.

$\approx$ gesloten kwalificatiesysteem coördinatierichtlijn 126v., 133

$\approx$ milieuvergunning 170

$\approx$ publikatie -131

$\approx$ regionale en sociale aspecten overheidsaanbesteding $132 \mathrm{v}$.

$\approx$ steunverleningsbeleid Europese Commissie $135 \mathrm{v}$.

Abnormaal lage prijzen 118, 123, 124-125

Acte détachabele 159, 186

Afstandsverklaring 79,88

Alternatieve aambieding 89, 115, 117

Arbitragebeding 1, 80-83, 163

Asfaltkartels 8

Belangenafweging 152, 165v., 170, 174, 192

Beleidsuitgangspunten $32,34,126 \mathrm{v}$.

$\approx$ 'andere' beleidsuitgangspunten, zie: aanvullende voorwaarde

$\approx$ eisen aan - 103v.

Beleidsvrijheid 171 
$\approx$ gemeentebestuur 56, 59, 107, 109v., 112, 129, 157

$\approx$ verbod van détournement de pouvoir 168

Belgische gemeentewet van 1836

$\approx$ bevoegdheidsverdeling 38

$\approx$ preventief toezicht 53

Benelux Unie-verdrag

$\approx$ openbare aanbesteding 60

Beoordelingsnimte 111, 123

Beperkte aanbesteding 58

Beroepsregister 93

Besluit aanbesteding van werken 28

Besluit mededingingsregelingen aanbestedingen 1, 13

Besluit mededingingsregelingen in de Bouwsector 2, 10, 13

Besluit voor de horizontale prijsregeling 14

Besluitbegrip 170v.

$\approx$ - en motivering 171

$\approx$ - en rechterlijke competentie $183 \mathrm{v}$.

$\approx$ 'voor'-beslissing 171,188

$\approx$ 'voorbereidingsbeslissing' $185 \mathrm{v}$.

$\approx$ voorbereidende handelingen 188

Besluitvormingsproces $177 v$.

$\approx$ (funktie van) aanbestedingsovereenkomst 182

$\approx$ (funkties van) beleidsnota $172,175 \mathrm{v}$.

$\approx$ besluitvormingsparaplu $178 \mathrm{v} ., 180$

$\approx$ rationeel besluitvormingsmodel $157,160,162,164 \mathrm{v} ., 170$

$\approx$ voorbereiding in abstracto 157,172

$\approx$ voorbereiding in concreto 157,172

\section{Besmet werk 59}

\section{Bestuursbevoegdheid 155}

$\approx$ omgekeerde delegatie 39,41

$\approx$ verdeling over de gemeentelijke bestuursorganen $37 \mathrm{v} ., 44 \mathrm{v} ., 57 \mathrm{v}$.

$\approx$ voorbehoud ex art. 176 gemeentewet (oud) 40,42 
Trefwoorden

Betrokkenen in art. 41 UAR 198681

\section{Bouwinitiatief 1}

Bouwmarktstructuur 7v.

$\approx$ misstandenbeleid 12

$\approx$ ordeningsaspecten aanbestedingsbeleid 16,121

$\approx$ standaardisering 104

$\approx$ transparantie 91, 104, 106, 172

$\approx$ tweesporenbeleid $12,78 \mathrm{v}$.

Bouwparticipanten

$\approx$ definities 5

Bolnteam 4

Classificatie 122

Combinatie 107

Competente rechter $183 v$.

$\approx$ beleidsfase-toetsing 189, 191-192

$\approx$ Belgisch model $187 \mathrm{v}$.

$\approx$ dubbele competentie 186v., 189-191

$\approx$ oplostheorie 184

Concessieverlening 4

Contractsurijheid 30, 33, 156, 171

$\approx$ apriorisme $154 \mathrm{v} ., 179$

$\approx$ gunningsplicht $112 \mathrm{v}$.

$\approx$ rechtsgeleerde standpunten $152 \mathrm{v},, 180$

Contractsweigering 30,32

Coördinatierichtlijn 19v., 119v.

$\approx$ - en steunverleningsbeleid $135 \mathrm{v}$.

$\approx$ - en UAR-EG $199187 \mathrm{v}$.

$\approx$ financiële drempel 97, 100,114

$\approx$ non-discriminatiebeginsel 91,92

$\approx$ openbaarheidsbeginsel $91,92,94 \mathrm{v}$.

$\approx$ wijzigingsvoorstellen 23,97

'de minimis'-uitzondering 137

$\approx$ standpunt Europese Hof van Justitie 137v. 
Decentralisatie $60 v ., 63,66$

$\approx$ aanbestedingsbegrip $60,151 \mathrm{v}$.

Demokratiebeginsel 155v., 157

Dualisme 45

Eenduidigheid 106, 107, 111, 117, 118, 170

Eigen beheer

$\approx \mathrm{v}$. aanbesteding 40,49-51, 113

Erkenningsregeling 121

Europese bekendmaking 117

Europese Commissie

$\approx$ betekenis aanvullende voorwaarde $132 \mathrm{v}$.

$\approx$ steunverleningsbeleid $135 \mathrm{v}$.

Europese technische norm 98, 99

Evenredigheidsbeginsel 65

$\approx$ 'rule of reason' jurisprudentie 145-149, 191

$\approx$ als algemeen beginsel van behoorlijk bestuur $162,166 \mathrm{v}$

$\approx$ beleidsfase-toetsing 191-192

$\approx$ in de aanbestedingsreglementen $106 \mathrm{v}, 117$

Exclusief-verkeersafspraken 10

Exécution active 44

Exécution délibérative 44

Fair play-beginsel 32, 165

Financiële doelmatigheid $174 \mathrm{v}$.

$\approx$ aanvullende voorwaarde $126 \mathrm{v}$.

$\approx$ arbitrale toetsing $106 \mathrm{v}$.

$\approx$ beginsel van openbare aanbesteding in de gemeentewet $51,151 \mathrm{v} ., 157 \mathrm{v} ., 169$

$\approx$ gunningscriteria 104v., 116v., 122v., 124v.

$\approx$ het subjectieve oordeel van de opdrachtgever $103 \mathrm{v}, 114$

$\approx$ keuze aanbestedingsprocedure 33,152

$\approx$ preventief toezicht door Gedeputeerde Staten 52, 56-57, 61, $151 \mathrm{v}$.

$\approx$ selectie-eisen $104 \mathrm{v}$., $116 \mathrm{v}$.

$\approx$ technische rationaliteit 157 
Gelijkheidsbeginsel $32 v$.

$\approx-$ en motiveringsbeginsel 174

$\approx-$ en openbaarheidsbeginsel $171 \mathrm{v}$.

$\approx-$ en vertrouwensbeginsel 161,192

$\approx$ art. 1 Grondwet 71

$\approx$ beginsel van openbare aanbesteding in de gemeentewet $51,151 \mathrm{v}, 157,178$

$\approx$ égalité devant les charges publiques $166 \mathrm{v}$.

$\approx$ eis van beleid; consistentiebeginsel $160 \mathrm{v} ., 170$

$\approx$ in het UAR $197277 \mathrm{v}$.

$\approx$ in het UAR $198683 \mathrm{v} ., 178$

$\approx$ in het UAR-EG $199188 \mathrm{v} ., 178$

$\approx$ relevantiecriterium 70

Gemeenschappelijke markt 16

$\approx$ coördinatie nationale markten 17,119

$\approx$ negatieve $\mathrm{v}$. positieve integratie 18

$\approx$ tegenvallende resultaten 20

Gemene rechtsleer 152, 154

Gemengde rechtsleer 152v., 155, 180

Geobjectiveerde noodzakelijkheidstoets 146, 148v., 166, 179, 192

\section{Geschiktheidseisen}

$\approx$ - en aanvullende voorwaarde $126 \mathrm{v}$.

$\approx$ arbitrale toetsing 106

$\approx$ eisen aan $-106 \mathrm{v} ., 116 \mathrm{v} ., 120 \mathrm{v} ., 124 \mathrm{v} ., 179$

$\approx$ publikatie $86 \mathrm{v} ., 89,94 \mathrm{v} ., 109,117,120,122,124$

\section{Gestanddoeningstermijn 8485}

Gronduitgifte 151v., 184, 186, 194

\section{Gunning}

$\approx$ abnormaal lage prijzen 118,123

$\approx$ afzien van - 125

$\approx$ alternatieve aanbieding 115,117

$\approx$ eisen aan -scriteria 109v., 117, 122v., 124-125., 179

$\approx$ gunningsplicht $112 \mathrm{v}$.

$\approx$ laagste prijscriterium 105,117

$\approx$ publikatie $-\operatorname{seisen} 86 \mathrm{v} ., 89 \mathrm{v} ., 105,122 \mathrm{v} ., 125$

$\approx$ uitvoering raadsbesluit $41 \mathrm{v}$. 
Handhavingsrichtlijn 89/665/EEG 24, 97v.

Heraanbesteding 114, 125

Inschrijving

$\approx$ intrekken -3

Interne markt 21

Invullende rechtsleer 181

Laagste inschrijver

$\approx$ gunningsbesluit B\&W 43

$\approx$ gunningsplicht $112 \mathrm{v}$.

$\approx$ motiveringseis 116,123

$\approx$ waarschuwingsplicht aanbesteder 112

Laagste prijscriterium 105

$\approx$ abnormaal lage prijzen 118

$\approx$ publikatie $86 \mathrm{v} ., 89,124$

Legaliteitsbeginsel 155v., 169, 180

Leuren 6, 9, 27, 78, 79, 113,152

Licitatie 76, 173

Malafiditeit 105

Management-overeenkomst 4

Materiële discriminatie 140

Monisme 45

Motiveringsbeginsel 32, 164, 174

$\approx$ 'bijzondere redenen' in art. 176 gemeentewet (oud) 50-51, 56

$\approx$ algemeen beginsel van behoorlijk bestuur 116,170

$\approx$ beginsel van openbare aanbesteding in de gemeentewet $51,151 \mathrm{v} ., 157,179 \approx$ het subjectieve oordeel van de opdrachtgever $103 \mathrm{v} ., 115$

$\approx$ in de coördinatierichtlijn $98,123,125-126$

$\approx$ in het UAR $1986115 \mathrm{v} ., 179$

$\approx$ in het UAR-EG $1991117 \mathrm{v} ., 179$

$\approx$ prioriteitenstelling 174

$\approx$ zie ook: Preventief toezicht 


\section{Trefwaorden}

Non-discriminatie naar nationaliteit 18, 127, 133, 143

$\approx-$ en aanvullende voorwaarde $139 \mathrm{v}$.

$\approx-$ en steunverleningsbeleid $136 \mathrm{v}$.

$\approx$ Benelux Unie-verdrag 60

$\approx$ Coördinatierichtlijn 61, 91v., 98, 99, 124

$\approx$ Liberalisatierichtlijn 71/304/EEG 19, 28, $91 v$.

Omgekeerde discriminatie 141

$\approx$ uitvoering richtlijnbepalingen 18

Onderaanneming 107, 110,126, 129

Onderhandelen 167

$\approx$ aanvullende voorwaarde 133

$\approx$ bezwaren 6

$\approx$ voorkomen leurgedrag $27,113 \mathrm{v}$.

Onderhandelingsplicht 27

₹ toepasselijkheid UAR 27

Onderhandelingsprocedure 5

$\approx$ regeling in coördinatierichtlijn 98,100

$\approx$ regeling in het UAR-EG $19916,87-90,117 \mathrm{v}$.

Onderhandse aanbesteding

$\approx$ in de gemeentewet $47,50-51,61$

$\approx$ ontwerp-De Kempenaer 49

Oneigenlijke aanneming 110

Onmisbaarheidscriterium

$\approx$ zie: Verdragsvrijheidsbeperkende maatregelen, noodzakelijkheidseis

Onrechtmatige bedrijfsuitoefening 105

Ontwerp-De Kempenaer 49

$\approx$ bevoegdheidsverdeling 38

$\approx$ preventief toezicht 52

Opdrachtverlening

$\approx$ aan derden na aanbesteding 114

$\approx$ door B\&W 44

$\approx$ gesloten kwalificatiesysteem coōrdinatierichtlijn $126 \mathrm{v}$, , 133

$\approx$ juridisch relevante beslissingen voorafgaand aan -159 
Open begroting 3

\section{Openbaarheidsbeginsel}

$\approx$ beginsel van openbare aanbesteding in de gemeentewet $51,61,151 \mathrm{v} ., 157,178$

$\approx$ bestuurlijke openheid; kenbaarheidseis $156,171 \mathrm{v}$.

$\approx$ in de coördinatierichtlijn $91,92,94,99-100$

$\approx$ in het UAR $197278 \mathrm{v}$.

$\approx$ in het UAR $198686 \mathrm{v} ., 178$

$\approx$ in het UAR-EG $199189 \mathrm{v}, 178$

$\approx$ inbreuken op publiciteitseis $95 \mathrm{v}$.

$\approx$ openbare raadsvergadering $40,41,43,47$

\section{Openbare aanbesteding}

$\approx$ beginselen van -51

$\approx$ doorbreking gildesysteem 50-51

$\approx$ Europese coördinatierichtlijn 60

$\approx$ grondslagen 29

$\approx$ in de gemeentewet $47,50-51,151 \mathrm{v}$.

$\approx$ Ontwerp-De Kempenaer 49

$\approx$ primaat van het bestuursrecht 156

$\approx$ primaat van de $-29,75,90$

$\approx$ zie ook: Aanbestedingspraktijk

Oplostheorie 154, 184

Opzetpraktijk 10-12, 15

Osmose 33

Overeenkomstenrecht

$\approx$ bestuursrecht en - 30

Overheidscontract 153v., $180 \mathrm{v}$.

$\approx$ beleidsovereenkomst 29,180

$\approx$ bevoegdhedenovereenkomst 155

$\approx$ gebondenheid 155-156

$\approx$ publiekrechtelijk karakter 182

$\approx$ subsidie-overeenkomst 155

\section{Positief toezicht 64}

\section{Prestatiebestek 89}

Preventief toezicht Gedeputeerde Staten 52v.

$\approx$ aanbestedingsbesluiten 43

$\approx$ begrotingstoezicht 42,61 
$\approx$ beperkte aanbesteding 58-59

$\approx$ burgerrechtelijke rechtshandelingen $48,52,54-56,58,60$

$\approx$ decentralisatie $60-61,151 \mathrm{v}$.

$\approx$ marginale toetsing 56

$\approx$ onderhandse aanbesteding 49,61

$\approx$ ontwerp-De Kempenaer 49-50

$\approx$ stedelijke en plattelandsreglementen $48-49$

$\approx$ toetsingspraktijk 54, 57-58

Projectontwikkelingsovereenkomst 4, 186

Protectionisme 58, 152

Prijsafspraken $8 v$.

$\approx$ civiele jurispnudentie 11-12

'Rule of reason'-jurisprudentie $142 v$.

$\approx$ - en rechterlijke beleidsfase-toetsing 191-192

Raamwet EEG-voorschriften aanbestedingen 28

Rechtsbescherming

$\approx$ bij burgerlijke rechter 163

$\approx$ onredelijke belangenafweging 29

$\approx$ toetsing aan algemene beginselen van behoorlijk bestuur $29 v$.

Rechtsstaat 157

₹ zie: Aanbestedingsbevoegdheid

Rechtszekerheidsbeginsel 162, 170

Referenties 109, 111, 117, 120v., 128

Registratie in Handelsregister 120

Relevantiecriterium (communautair)

z zie: Verdragsvrijheidsbeperkende maatregelen, geschiktheidseis

Repressief toezicht $63 \mathrm{v}$.

$\approx$ administratiefrechtelijke rechtsbescherming 72-74

$\approx$ gevolgen van de vernietiging 67

$\approx$ opvattingen in literatuur en rechtspraak $70-72$

$\approx$ toetsingspraktijk $68-70$

\section{Richtlijn}

$\approx$ rechtstreekse werking richtlijnbepalingen 17,18 
$\approx$ toepassing door overheden 19

\section{Shortlisten 7}

Toepasselijkheid UAR 27

$\approx$ gebondenheid partijen 28

$\approx$ grondslag 28

Toetsing aan algemene beginselen van behoorlijk bestuur $\approx$ privaatrechtelijk overheidsoptreden $30 \mathrm{v}$.

\section{Tumkey-contract 4}

Uniform Aanbestedingsreglement (algemeen)

$\approx$ binding gemeentebestuur aan - 163

$\approx$ gemeentelijke beleidsregel $162 \mathrm{v}$.

$\approx$ instructienorm 163

$\approx$ recht in de zin van art. $99 \mathrm{RO} 27$

$\approx$ strekking; onderhandelingsplicht 167

$\approx$ toepasselijkheid - 27

$\approx$ uniformering $75 \mathrm{v}$.

Uniform Aanbestedingsreglement 1972

$\approx$ het gelijkheidsbeginsel $77 \mathrm{v}$.

$\approx$ het openbaarheidsbeginsel $78 \mathrm{v}$.

Uniform Aanbestedingsreglement 1986

$\approx$ het gelijkheidsbeginsel $83 \mathrm{v}$.

$\approx$ het openbaarheidsbeginsel $86 \mathrm{v}$.

$\approx$ zie ook: Financiële doelmatigheid

$\approx$ zie ook: Motiveringsbeginsel

Uniform Aanbestedingsreglement-EG 1991

$\approx$ het gelijkheidsbeginsel $88 \mathrm{v}$.

$\approx$ het openbaarheidsbeginsel $89 \mathrm{v}$.

$\approx$ zie ook: Financiële doelmatigheid

$\approx$ zie ook: Motiveringsbeginsel

Uitgesloten sectoren 23, 92

Uitnodiging tot het doen van een aanbod 1 $\approx$ toepasselijkheid UAR 28

\section{Vangnet 117}

$\approx$ art. 24, lid 2 UAR 1986 109v. 
Trefumorden

\section{Varianten 98}

Verbod van détoumement de pouvoir 162, 164-165, $168 \mathrm{v}$.

$\approx$ specialiteitsbeginsel 155,168

\section{Verbodstelsel}

$\approx$ Europees kartelrecht 15

$\approx$ ontheffing 14

Verdragswrijheidsbeperkende maatregelen

$\approx$ beperkingscriterium $144 \mathrm{v}$.

$\approx$ geschiktheidseis $134,145-146,147,179,191$

$\approx$ noodzakelijkheidseis $134,141,146,148 \mathrm{v}, 166 \mathrm{v} ., 179,191-192$

$\approx$ proportionaliteitseis $146,191-192$

$\approx$ 'rule of reason'-jurisprudentie $142 v$.

Vergelijkbaarheidscriterium

$\approx$ zie: Verdragsvrijheidsbeperkende maatregelen, noodzakelijkheidseis

Versnelde procedure in de coördinatierichtlijn 96

Vestigingsvrijheid 18v., 139v., $143 v$.

$\approx$ 'Beentjes'-criterium 127, 131

$\approx$ 'rule of reason'-jurisprudentie $143 \mathrm{v}$.

$\approx$ vestigingsvergunning 105

$V O B / A 113,173$

Voorbereidingsbeslissingen 159

Voorinformatieprocedure

$\approx$ in de coördinatierichtlijn 98-100

$\approx$ in het UAR-EG 199190

Voorrangsbeginsel 17

Vrij dienstenverkeer $18 \mathrm{v} ., 135$

$\approx$ 'Beentjes'-criterium 127, 131

$\approx$ 'rule of reason'-jurisprudentie $144 \mathrm{v}$.

$\approx$ criteria voor beperking $-139 v$.

Vrij goederenverkeer

$\approx$ 'rule of reason'-jurisprudentie 142-143

Vrij wenknemersverkeer 133v., 139

$\approx$ criteria voor beperking - 134 
$\approx$ Wet economische mededinging 15-16

Willekeur 158, 160, $164 v$.

Zorgvuldigheidsbeginsel 32, 162, $164 v$.

$\approx$ - en belangenafweging $165,170,192$

$\approx$ onderhandelingsplicht 167

'Zwarte gat' in art. 30, lid 1 UAR 1986112 


\section{Curriculum vitae}

Hylke Nijholt werd op 20 juli 1953 geboren te Ten Boer (Groningen). Nadat hij het Mulo-A examen had gedaan, behaalde hij - in de avonduren - het diploma Atheneum-B aan het Van Maerlant-College te Eindhoven (1975). Na twee jaar bedrijfskunde te hebben gestudeerd aan de Technische Hogeschool Eindhoven, begon hij in 1977 aan de rechtenstudie aan de Rijksuniversiteit Leiden. Na een onderbreking van een jaar, waarin hij werkzaam was bij de Eindhovense belastinginspectie, voltooide hij zijn studie in $1984 \mathrm{met}$ een doctoraal-examen Nederlands Recht, privaatrechtelijke richting. Sinds 1985 is hij werkzaam aan de Rijksuniversiteit Limburg. Eerst als wetenschappelijk assistent, thans als universitair docent privaatrecht. 

